"Estudos conformacionais de seqüências

hidrofóbicas de domínios de receptores acoplados a proteínas G (GPCR) e da proteína G. Um estudo de CD e espectroscopia de fluorescência”.

\title{
FÁBIO CASALLANOVO
}

Tese de doutorado apresentada ao

Departamento de Bioquímica do Instituto de Química da Universidade de São Paulo.

Orientadora: Profa. Dra. Shirley Schreier

São Paulo, 12 de abril de 2004. 
“Estudos conformacionais de seqủências hidrofóbicas de domínios de receptores acoplados a proteínas G (GPCR) e da proteína G. Um estudo de CD e espectroscopia de fluorescência”

\section{FABIO CASALLANOVO}

Tese de Doutorado submetida ao Instituto de Química da Universidade de São Paulo como parte dos requisitos necessários à obtenção do grau de Doutor em Ciências - Área: Bioquímica.

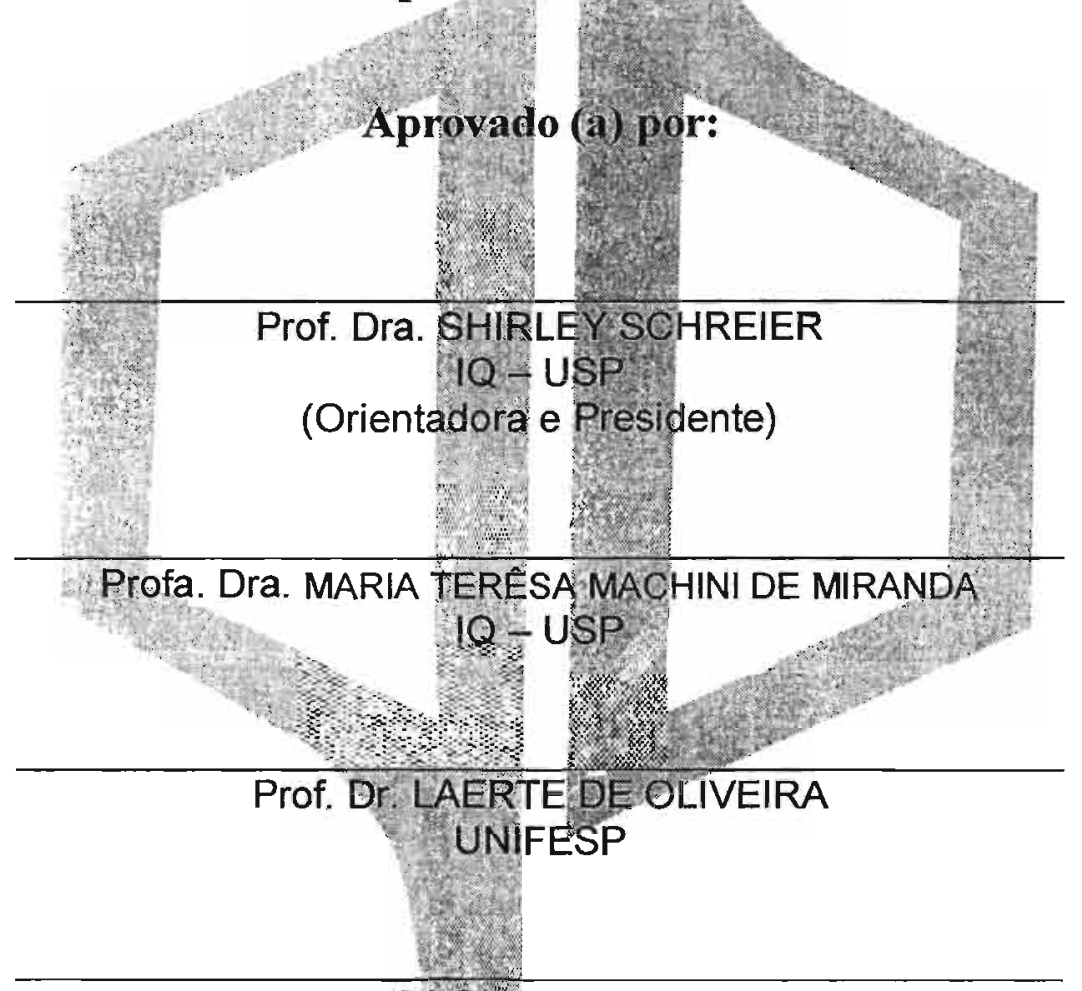

\footnotetext{
Prof. Dr. WALETR FIIGUEIRA DE AZEVEDO JUNIOR IB - UNESP - São José do Rio Preto

Prof. Dr. AMANDO SIUITI ITO

FFCLRP - USP
}

SÃO PAULO

28 de JUNHO 2004 
...chemists are a strange class of mortals, impelled by an almost insane impulse to seek their pleasure among smoke and vapor, soot and flame, poisons and poverty, yet among all these evils I seem to live so sweetly, that [I'd die before I'd] change places with the Persian King. Johann Joachim Becher $1635-1682$ 
Aos meus pais, Fúlvio e Maria Antônia, e ao meu irmão Fúlvio, que contribuíram muito para a realização do meu doutorado. 


\section{Agradecimentos}

Ao pessoal do laboratório, Salay, Felipe, Myriam, Fábio Dyszy, Tatiana e Marcelo, obrigado pela paciência e pela ajuda.

À Aninha, obrigado pelos papos, discussões e pelo apoio.

Ao Carlos Àlvares, que me ajudou muito nos momentos finais.

Ao pessoal que passou pelo LBE, Raquel, Berê, Noboru, Roberto Salinas, Goretti, Thelma e Mercedes.

Ã Renata Fischer, pela amizade.

Ao Claúdio S. Shida, que me ajudou muito em vários momentos, obrigado pelos conselhos e pela amizade.

Aos meus amigos Eroc, Paulo, Luís Mayer e Luiz, obrigado pelo apoio e por me agüentar nos momentos mais dificeis.

À Lua, que é uma pessoa que eu gosto muito e com a qual tive uma ótima amizade desde o primeiro dia em que entrei no laboratório como aluno de iniciação científica. Obrigado pelos conselhos e pelos momentos de alegria.

À Dra. Shirley, que é uma pessoa muito especial. Poucas pessoas sabem contar estórias e atrair a admiração dos outros como você. Com você aprendi muito, sempre admirei sua postura e inteligência. Você também soube ser muito compreensiva nos momentos mais dificeis.

À Fapesp e ao CNPq, obrigado pelo apoio finaceiro. 


\section{Índice}

Lista de abreviações. iv

Resumo y

Abstract vii

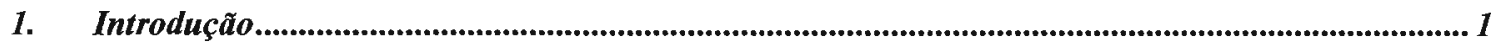

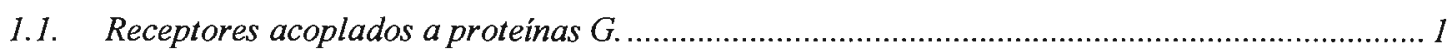

1.1.1. Estrutura dos GPCRs da familia da rodopsina ........................................................ 3

1.1.2. Estudo conformacional de fragmentos de GPCRs ..................................................... 8

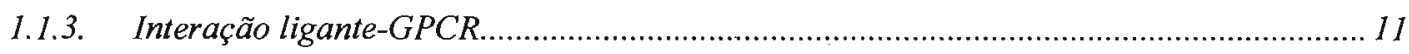

1.1.4. Mecanismos envolvidos na ativação do receptor e sua interação com a proteína G.........11

1.1.4.1. Ativação do receptor ...................................................................................... 11

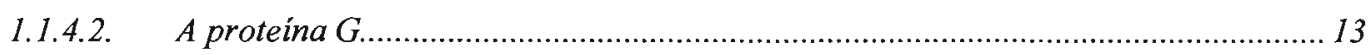

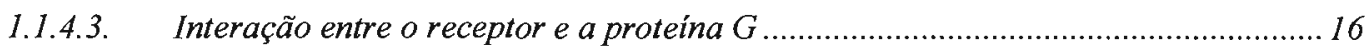

1.2. Receptor do hormônio luteinizante e ativação constitutiva..................................................... 18

1.2.1. Estrutura do receptor do hormônio luteinizante ...................................................... 18

1.2.2. Mecanismo de ativaç̧̃o constitutiva

1.2.3. Vias de transdução de sinal ativadas pelo LHR ........................................................... 24

1.3. O receptor $A T_{I A}$ de angiotensina II e a interação com a proteina $G$.........................................2 24

1.3.1. O receptor $A T_{I A}$ de angiotensina II ........................................................................... 24

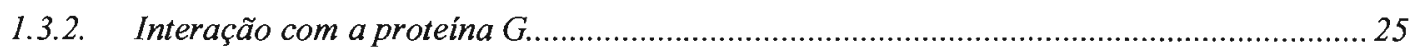

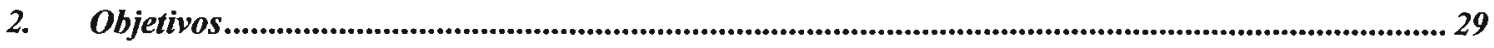

3. Materiais e Métodos.................................................................................................................. 30

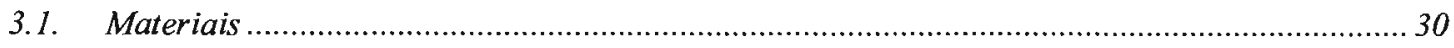

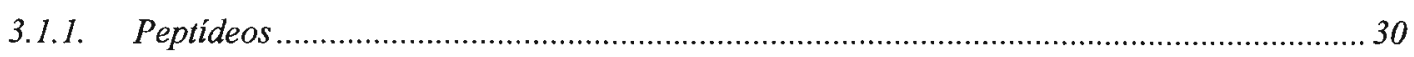

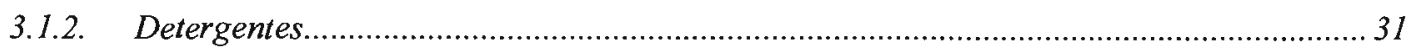

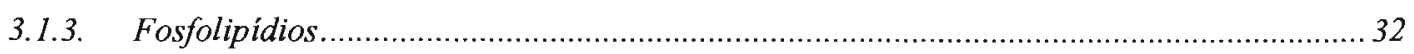

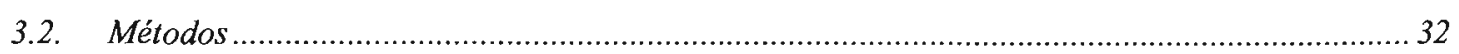

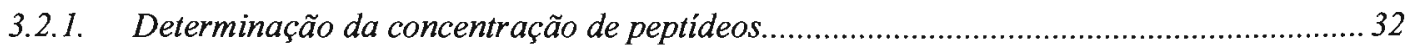

3.2.2. f-CT, CG, Ni3 e i2 na presença de detergentes. ............................................................. 33

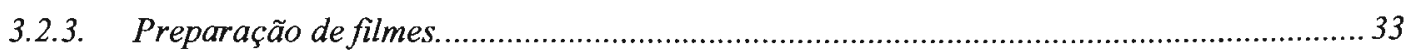

3.2.4. Preparação de bicamadas fosfolipidicas.................................................................... 33

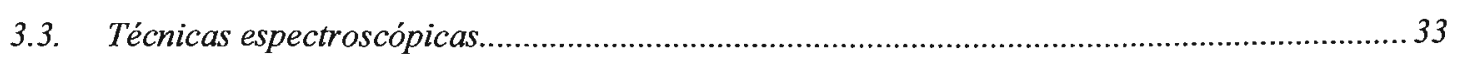

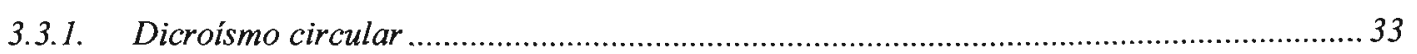

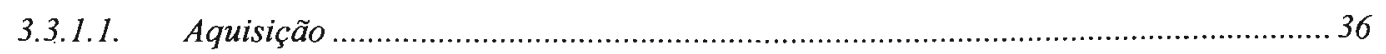

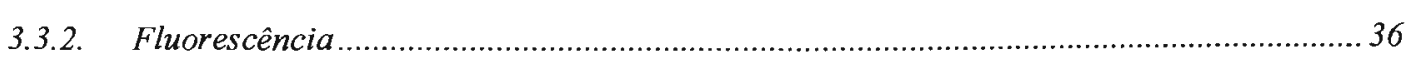

3.3.2.1. Supressão da intensidade de fluorescência......................................................... 38

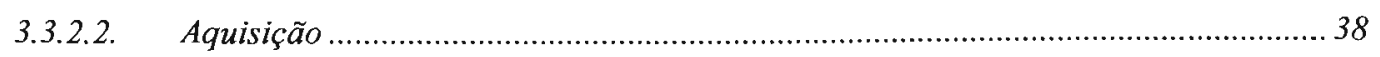


4.1. Estudo conformacional da TM6 do LHR e de seus mutantes envolvidos em FMPP............... 39

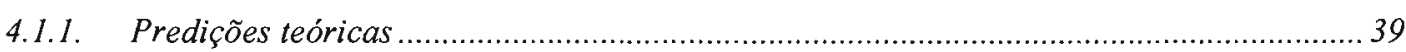

4.1.2. Estudos em solução aquosa e na presença de TFE ....................................................... 39

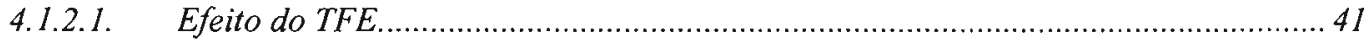

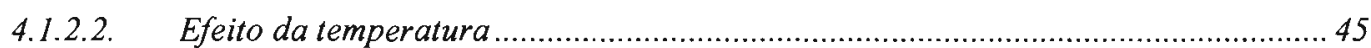

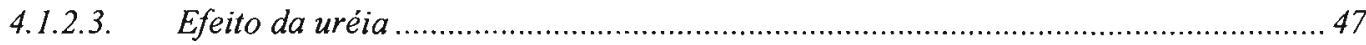

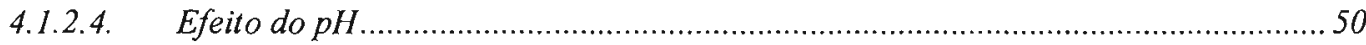

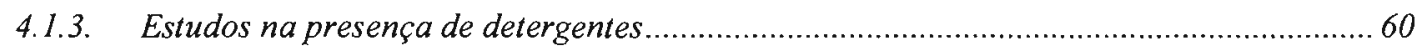

4.1.3.1. Estudos na presença de HPS .................................................................... 61

4.1.3.2. Estudos na presença de LPC .................................................................... 75

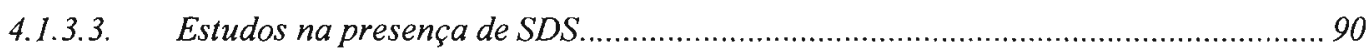

4.1.3.4. Hidratação dos filmes dos peptídeos na presença de detergentes....................... 103

4.1.3.4.1. Efeito do $\mathrm{pH}$ sobre I em presença de detergentes........................................... 105

4.1.3.4.2. Efeito do $\mathrm{pH}$ sobre II em presença de detergentes. ........................................ 107

4.1.3.4.3. Efeito do $\mathrm{pH}$ sobre III em presença de detergentes...................................... 116

4.1.4. Estudos na presença de vesículas fosfolipidicas ................................................ 124

4.1.4.1. Efeito do $\mathrm{pH}$ sobre I em presença de vesículas fosfolipídicas .............................. 126

4.1.4.2. Efeito do $\mathrm{pH}$ sobre 11 em presença de vesiculas fosfolipídicas ............................. 133

4.1.4.3. Efeito do pH sobre III em presença de vesículas fosfolipídicas............................. 139

4.1.5. Supressão da intensidade de fluorescência por acrilamida ........................................ 15I

4.2. Estudo conformacional de CG e sua interação com fragmentos do receptor $A T_{I A}$ de angiotensina 11

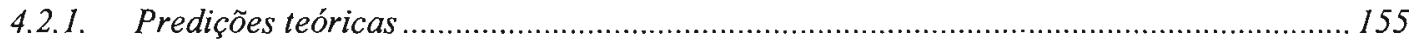

4.2.2. Estudos em solução aquosa e na presença de TFE.................................................. 155

4.2.2.1. Efeito do trifluoroetanol .......................................................................... 157

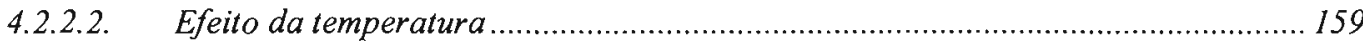

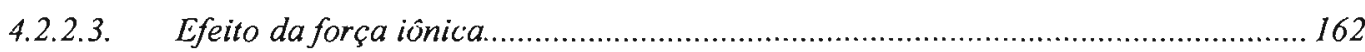

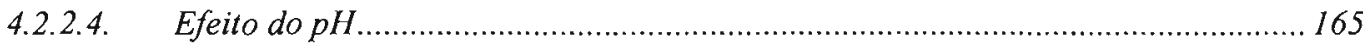

4.2.3. Estudos na presença de membranas modelo.................................................... 170

4.2.3.1. Estudos na presença de HPS. .................................................................... 170

4.2.3.2. Estudos na presença de LPC ....................................................... 184

4.2.3.3. Estudos na presença de SDS....................................................................... 198

4.2.4. Supressão da intensidade de fluorescência ................................................................. 208

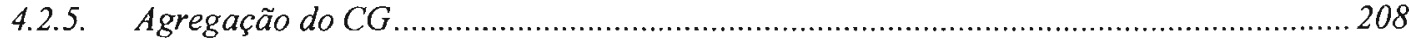

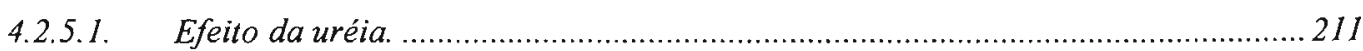

4.2.5.2. Efeito do $\mathrm{pH}$ e de detergentes. ....................................................................... 213

4.2.6. Interação entre $C G$ e fragmentos do receptor $A T_{I A}$ de angiotensina $I I$........................2 217

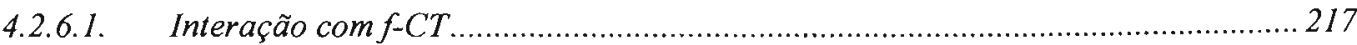

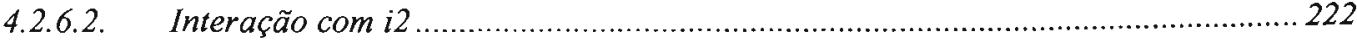

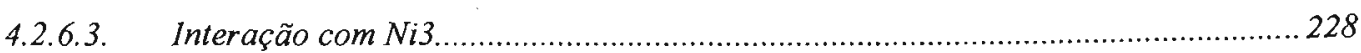




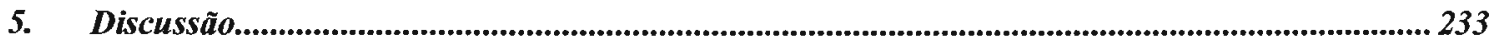

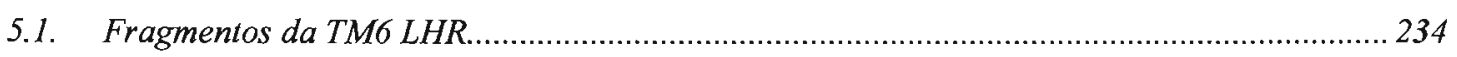

5.1.1. Estudo conformacional dos peptídeos derivados da TM6 do hLHR .............................. 234

5.1.2. Estudos na presença de membranas modelo..........................................................240

5.1.3. Possíveis implicações biológicas............................................................................ 244

5.2. CG e sua interação com fragmentos do receptor $A T_{1 A}$ de angiotensina II.............................. 246

5.2.1. Estudos em solução aquosa e na presença de TFE ................................................... 246

5.2.2. Estudos na presença de detergentes..................................................................... 249

5.2.3. Interação do CG com fragmentos do receptor $A T_{1 A}$ de angiotensina $11 \ldots \ldots \ldots \ldots \ldots \ldots \ldots \ldots . . . . . . . . . . . .250$

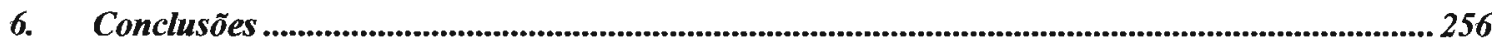

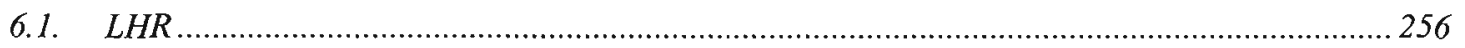

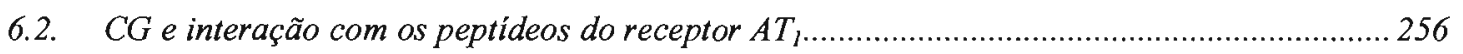

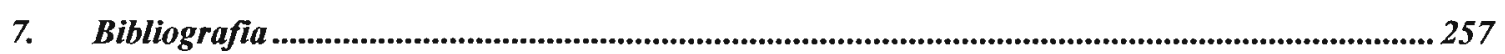

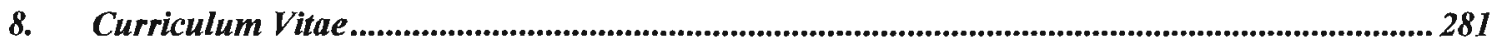

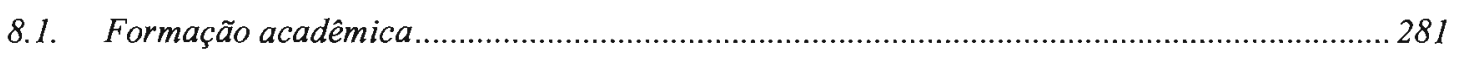

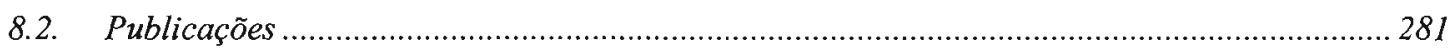




\section{Lista de abreviações}

I

peptídeo correspondente a porção N-terminal da sexta hélice transmembranar do receptor do hormônio luteinizante

II

análogo de I, D578G

U

análogo de I, D578Y

cAMP

AMP cíclico (adenosina-2', 3'-fosfato)

$\mathrm{CD}$

dicroísmo circular

$\mathrm{cmc}$

concentração micelar crítica

CG

fragmento C-terminal da subunidade $\alpha$ da proteína $\mathrm{G}$.

e

alça extracelular

$f$-CT

peptídeo correspondente à porção $\mathrm{N}$-terminal do domínio C-

terminal do receptor $\mathrm{AT}_{\mathrm{IA}}$ de angiotensina $\mathrm{II}$.

FMPP

síndrome da puberdade precoce masculina familiar

GDP

guanosina-5'-difosfato

GPCR

receptores acoplados a proteínas $\mathrm{G}$

GTP

guanosina-5'-trifosfato

HPS

$\mathrm{N}$-hexadecil-N,N-dimetil-3-amônio-1-propanosulfonato

i

alça intracelular

i2

peptídeo correspondente à segunda alça intracelular do

receptor $\mathrm{AT}_{1 \mathrm{~A}}$ de angiotensina II

LH

hormônio luteinizante

LHR

receptor do hormônio luteinizante

LPC

lisofosfatidilcolina

LUV

vesículas unilamelares grandes

$\mathrm{Ni3}$

peptídeo correspondente à porção $\mathrm{N}$-terminal da i3 do receptor

$\mathrm{AT}_{1 \mathrm{~A}}$ de angiotensina II

PLC

fosfolipase $\mathrm{C}$

POPC

1-palmitoil-2-oleil-fosfatidilcolina

$\mathrm{PBC}$

tampão fosfato-borato-citrato

POPG

1-palmitoil-2-oleil-fosfatidilglicerol

SDS

dodecilsulfato de sódio

TM

hélice transmembranar

TFE

2,2,2 - trifluoroetanol 


\section{Resumo}

O trabalho desenvolvido nesta tese doutorado enfocou dois projetos: O primeiro envolveu o estudo conformacional de um peptídeo correspondente à região $\mathrm{N}$-terminal da TM6 do LHR (KMAILIFTDFT, resíduos 570-580) e de dois análogos (D578G e D578Y) envolvidos na síndrome da puberdade precoce masculina familiar (FMPP). A substituição do resíduo de $\mathrm{Asp}^{578}$ por outros aminoácidos como Gly ou Tyr provoca a ativação constitutiva do receptor, levando à FMPP.

Os peptídeos foram estudados por CD e fluorescência em solução aquosa, na presença de TFE e na presença de membranas-modelo. Observou-se que os três peptídeos agregavam em solução aquosa e na presença de membranas. Apesar disso, foi possível observar um comportamento diferente dos três peptídeos em solução aquosa em função do $\mathrm{pH}$, na presença de TFE e em presença de detergentes e vesículas fosfolipídicas. De todos peptídeos, aquele que apresentou maior propensão à aquisição de estrutura $\alpha$-helicoidal foi o análogo D578G, tanto em solução aquosa quanto nos outros sistemas estudados. $\mathrm{Na}$ presença de detergentes, observou-se que os peptídeos eram capazes de se ligar às diferentes interfaces estudadas, principalmente com carga líquida negativa. $\mathrm{Na}$ presença de membranas fosfolipídicas, tanto o peptídeo nativo quanto os análogos adquiriram estrutura em folha $\beta$.

Para estudar o efeito da agregação, também foram realizados experimentos na presença de agentes desnaturantes, como uréia, e em função da temperatura. Os resultados obtidos indicam que mesmo na presença de altas concentrações de agentes desnaturantes e em altas temperaturas, estes fragmentos continuavam agregados. Outra abordagem para contornar o efeito da agregação foi a ressuspensão de filmes dos peptídeos com soluções de detergentes; essa metodologia mostrou que em condições adequadas os peptídeos tendem a formar estrutura $\alpha$-helicoidal.

Apesar da alta propensão dos peptídeos à agregação, foi possível observar experimentalmente que uma única mutação é capaz de provocar mudanças conformacionais significativas; estas mudanças podem estar relacionadas à ativação constitutiva do receptor e levar à FMPP. A propensão a agregação poderia ter relevância biológica, uma vez que na literatura tem sido observado que muitos GPCRs sofrem dimerização. 
O segundo projeto enfocou o estudo conformacional de um fragmento correspondente à região $\mathrm{C}$-terminal da subunidade $\alpha$ da proteína $\mathrm{G}(\mathrm{CG})$, assim como sua possível interação com fragmentos correspondentes ao C-terminal, à i2 e à porção $\mathrm{N}$-terminal da $\mathrm{i} 3$ do receptor $\mathrm{AT}_{1 \mathrm{~A}}$ de angiotensina II.

$\mathrm{O}$ peptídeo estudado mostrou-se muito sensível à força iônica, $\mathrm{pH}$ e TFE, observando-se mudança de estrutura ao acaso para $\alpha$-hélice em alguns pHs e na presença de TFE e para folha $\beta$ com o aumento da força iônica.

$\mathrm{Na}$ presença de detergentes, observou-se que o peptídeo era capaz de ligar-se tanto a interfaces com carga líquida zero (HPS e LPC) quanto com carga líquida negativa. Observou-se também que o CG tem maior afinidade por LPC do que por HPS.

O estudo do CG em diferentes condições forneceu subsídios para investigarmos a interação deste fragmento com regiões do receptor $\mathrm{AT}_{1 \mathrm{~A}}$ de angiotensina II que estão envolvidas com a ativação da proteína $\mathrm{G}$.

Foram feitos estudos em solução aquosa e na presença de LPC com CG na presença de $f$-CT, $\mathrm{Ni} 3$ e i2. Os resultados mostram que $\mathrm{CG}$ interage com os fragmentos do receptor $\mathrm{AT}_{1}$ na presença de micelas de LPC. Esses resultados mostram pela primeira vez por CD a interação de domínios de um GPCR com um domínio de sua respectiva proteína $\mathrm{G}$. 


\section{Abstract}

The work presented here focused on two projects: The first involved the conformational study of a peptide corresponding to the N-terminal region of the LHR TM6 (KMAILIFTDFT, residues 570-580) and of two analogs (D578G and D578Y) involved in familial male precocious puberty (FMPP). The substitution of the Asp ${ }^{578}$ residue for other amino-acids such as Gly or Tyr leads to receptor constitutive activation, causing FMPP.

The peptides were studied by means of CD and fluorescence spectroscopy in aqueous solution, in the presence of TFE, and in the presence of model membranes. We observed that the peptides aggregate in aqueous solution an in the presence of modelmembranes. However, each peptide had a different behavior in aqueous solution as a function of $\mathrm{pH}$ and in the presence of detergents and phospholipid vesicles. The D578G analog displayed the highest propensity to acquire $\alpha$-helical conformation in the presence of TFE and in aqueous solution.

In the presence of detergents we observed that the peptides were able to bind to different interfaces, especially negatively charged ones. In the presence of phospholipid membranes, all peptides displayed $\beta$-sheet conformation.

In order to study the effect of aggregation, we performed experiments in the presence of denaturing agents such as urea and as a function of temperature. Even in the presence of high urea concentrations and at higher temperatures, the fragments remained aggregated. This result led us to another approach, where peptide films were hydrated in the presence of detergents. Using this methodology it was observed that the fragments were less aggregated, indicating that under adequate conditions the peptides tend to adopt $\alpha$-helical conformation.

In summary, it was possible to observe experimentally that one single point mutation in a short peptide is capable of inducing significant conformational changes, which might be related to constitutive activity and FMPP. The observed aggregation properties could have a biological role, since it has been found that GPCRs are capable of forming dimers.

The second project involved the conformational study of a fragment corresponding to the C-terminal region of the $G$ protein $G_{\alpha}$ subunit (CG) and its 
interaction with fragments corresponding to the C-terminal, i2 and the $\mathrm{N}$-terminal region of $\mathrm{i} 3$ of the angiotensin $\Pi \mathrm{AT}_{1 \mathrm{~A}}$ receptor.

The conformation of $\mathrm{CG}$ is very sensitive to $\mathrm{pH}$, ionic strength, and TFE. In aqueous solution, at higher pHs an increase of CG secondary structure was observed. In the presence of TFE, CG displayed $\alpha$-helical conformation. The increase of ionic strength led to the acquisition of $\beta$-sheet conformation. In the presence of detergents, CG is able to interact with zwitterionic (HPS and LPC) and negatively charged interfaces. CG has a greater affinity for LPC than HPS.

The conformational study of CG under different conditions provided insights to investigate the interaction of this peptide with fragments of the angiotensin $\Pi \mathrm{AT}_{1 \mathrm{~A}}$ receptor involved in $G$ protein activation. Several studies were performed in the presence of LPC micelles, either with CG or with CG in the presence of $f$-CT, i2, and Ni3. The results demonstrated for the first time the interaction of a G-protein domain with domains of a GPCR. 


\section{Introdução}

\subsection{Receptores acoplados a proteinas $G$.}

Sinais disparados por agentes extracelulares, como neurotransmissores, neuromoduladores, hormônios, íons, etc., controlam a atividade de cada célula. Estes sinais são transmitidos para o interior da célula através de uma grande variedade de receptores de membrana, dentre os quais os receptores acoplados a proteínas G (GPCR). Os GPCRs são proteínas que compreendem uma das maiores famílias de receptores encontradas na natureza, sendo que até o momento perto de 5000 seqüências de GPCRs, constituindo cerca de 305 famílias, estão depositadas no banco de dados de GPCRs (http://www.gpcr.org/7tm) ${ }^{(1)}$.

Uma variedade significativa de ligantes como hormônios (glucagon, hormônio luteinizante, adrenalina), neurotransmissores (acetilcolina, dopamina, serotonina), quemoquinas (por exemplo, interleucina-8), mediadores locais (prostaglandinas, tromboxanas), nucleotídeos, etc., agem através dos $\operatorname{GPCRs}{ }^{(2,3)}$, os quais regulam por exemplo, enzimas metabólicas, canais iônicos e fatores de transcrição (Fig. 1). Dessa forma os GPCRs estão envolvidos no controle de diversas funções sistêmicas como o desenvolvimento embrionário, homeostase, desenvolvimento das gônadas, aprendizado e memória ${ }^{(2)}$. Também estão envolvidos em estímulos sensoriais como visão, odor e gustação $^{(3)}$.

Os GPCRs podem ser classificados de duas maneiras: (a) com base na estrutura do ligante e (b) com base na homologia da seqüência de aminoácidos e suas propriedades de ligação a proteínas G. Com base nesse último critério, os GPCRs podem ser classificados em quatro grandes grupos ou famílias ${ }^{(3,4)}$ :

(i) receptores da família da rodopsina (família A);

(ii) receptores da família do glucagon/secretina (família B);

(iii) receptores da família metabotrópica de glutamato/sensor de cálcio (família C);

(iv) receptores da familia de feromônios "Gi-vomeronasais" (família D).

Apesar da enorme diversidade de ligantes e processos mediados por esses receptores, em comum todos os membros da família de GPCRs possuem apenas uma única cadeia polipeptídica, que apresenta sete segmentos transmembranares, conectados 
por três alças externas e três alças citossólicas, um domínio $\mathrm{N}$-terminal extracelular e um domínio C-terminal intracelular ${ }^{(3,4)}$ (Fig. 2).

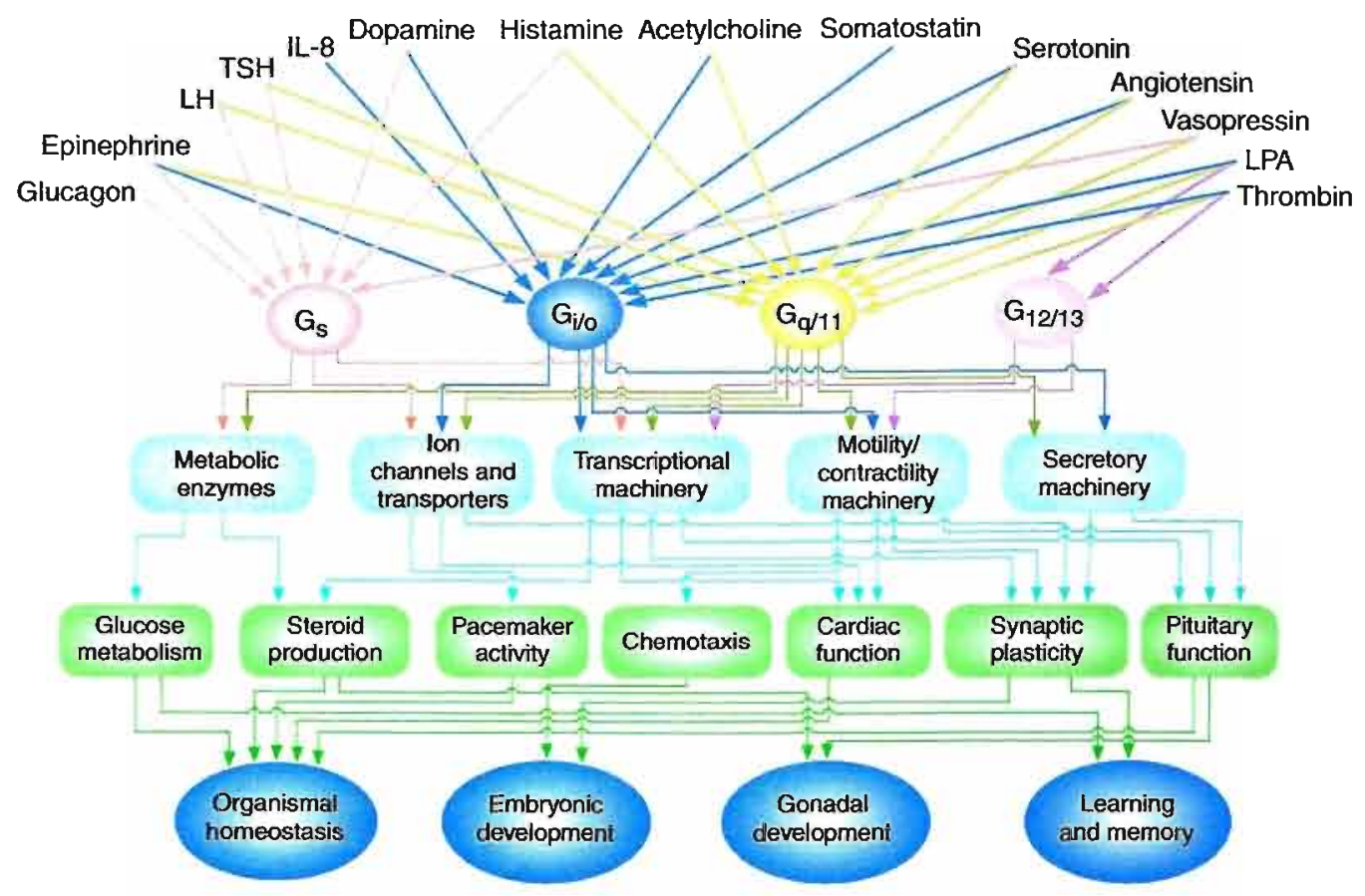

Figura 1 - Representação esquemática de como várias vias de transdução de sinal são reguladas por GPCRS. O esquema ilustra como ligantes diferentes atuam sobre as quatro subfamílias de proteínas $\mathrm{G}$ e através delas regulam a atividade de vários efetores (enzimas, canais iônicos, fatores de transcrição,etc.) resultando na produção de respostas fisiológicas ${ }^{(2)}$.

\section{Extra-celular}

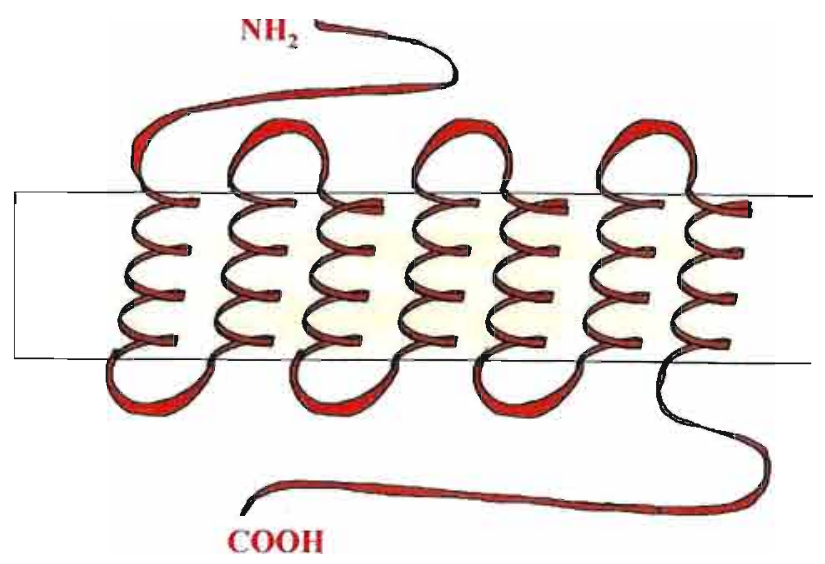

\section{Citossol}

Figura 2 - Representação esquemática de um receptor acoplado à proteína G. 


\subsubsection{Estrutura dos GPCRs da família da rodopsina}

Os receptores da família da rodopsina constituem uma das maiores famílias de GPCRs. Além da própria rodopsina, ela inclui receptores de hormônios glicoproteicos (folículo estimulante, FSH, luteinizante, LH, tireotropina, TSH), de hormônios peptídicos (angiotensina, bradicinina, vasopressina), de aminas biogênicas (receptor muscarínico de acetilcolina, dopamina, adrenalina) entre outros (leucotrienos, prostanóides, purinas) ${ }^{(4)}$. A homologia entre os membros da família da rodopsina é baixa e se restringe a alguns resíduos importantes altamente conservados, localizados principalmente nas TMs (Fig. 3). Na justaposição entre a TM3 e a i2 existe uma seqüência de aminoácidos, D/ERY, onde o resíduo de Arg é conservado em todos os membros da família da rodopsina ${ }^{(4)}$. Além disso, existe também um resíduo de Cys na região C-terminal do receptor, que é palmitoilado na maioria dos GPCRs da família da rodopsina (Fig. 3).

Devido a dificuldades de obtenção de cristais de proteínas de membrana, existem poucas informações estruturais de alta resolução para os GPCRs ${ }^{(5)}$. Foi obtida uma estrutura de alta resolução para o cristal de uma fotoproteína (bomba de prótons) extraída da membrana púrpura do procarioto Halobacterium halobium, a bacteriorrodopsina ${ }^{(6)}$. Esta proteína não é um GPCR, porém, assim como a rodopsina, esta proteína possui retinal como cromóforo e portanto é considerada como homólogo bacteriano da rodopsina. O cristal da bacteriorodopsina mostrou que esta proteína possui sete segmentos transmembranares $\alpha$-helicoidais. Dessa forma, a bacteriorodopsina foi utilizada como molde para modelos estruturais tridimensionais para os GPCRs ${ }^{(7-10)}$. Contudo, essa abordagem é considerada obsoleta atualmente ${ }^{(4)}$, uma vez que a bacteriodopsina não possui a menor homologia seqüencial com qualquer GPCR.

A rodopsina constitui um dos receptores mais estudados, em parte devido a sua obtenção relativamente fácil (11). Utilizando a técnica de criomicroscopia eletrônica, Schertler et al. (12-14) obtiveram estruturas de baixa resolução a partir de cristais bidimensionais da rodopsina. A partir da análise dos mapas de densidade eletrônica desses cristais e dos resultados de difração de raios X para cristais tridimensionais da bacteriorodopsina ${ }^{(15)}$, foi deduzida a topografia do core transmembranar dessas proteínas, onde se confirmou a presença de sete segmentos transmembranares ${ }^{(12-14)}$. 


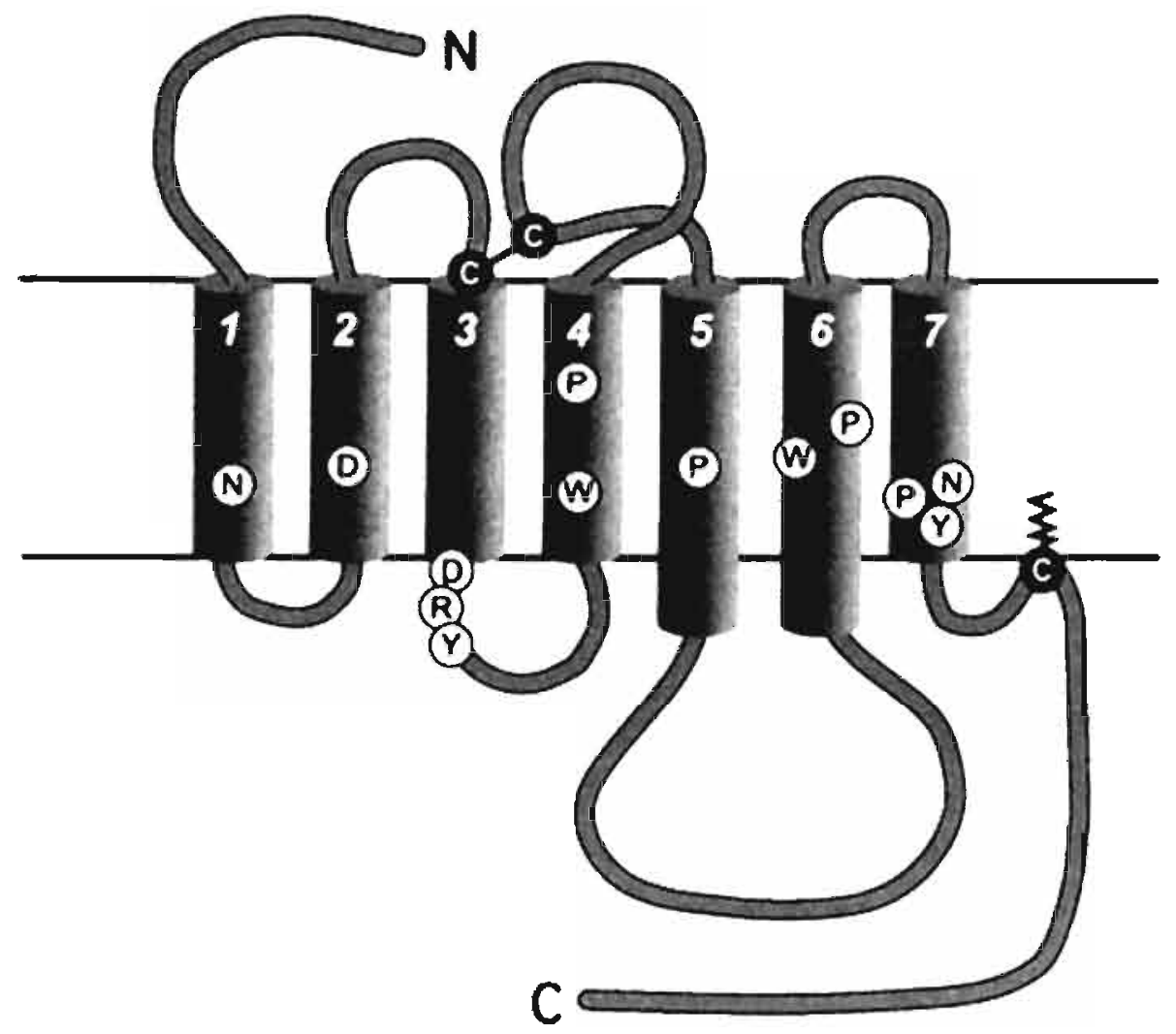

Figura 3 - Os círculos brancos mostram resíduos altamente conservados nos GPCRs da família da rodopsina. A maioria dos receptores possui uma ponte dissulfeto entre e 2 e e3 e um sítio de palmitoilação (círculo negro) na região C-terminal, formando uma quarta alça intracelular ${ }^{(4)}$. 
A partir desses resultados, Baldwin et al. ${ }^{(16)}$ propuseram um modelo para a orientação das TMs na rodopsina. De acordo com esse modelo, as sete TMs helicoidais estariam arranjadas de modo seqüencial e orientadas no sentido anti-horário, visto a partir do lado extracelular, formando um conjunto de hélices fortemente empacotadas. O empacotamento das TMs é mantido por uma rede de pontes de hidrogênio e por pontes salinas.

Um modelo de baixa resolução da rodopsina obtido através da técnica de microscopia eletrônica mostrou que as sete TMs estão empacotadas mais densamente na face citoplasmática do que no lado extracelular ${ }^{(17)}$. Como resultado, a área ocupada pelas TMs é $25 \%$ menor no lado citoplasmátco do que no lado extracelular. Com base neste mapa de densidade eletrônica e na análise da seqüência de mais de 500 GPCRs, Baldwin et al. ${ }^{(18)}$ propuseram um modelo mais refinado para a família de receptores da rodopsina, onde as TMs 4, 6 e 7 estão orientadas quase que perpendicularmente ao plano da membrana (Fig. 4). As hélices 1, 2, 3 e 5 estão inclinadas cerca de $25^{\circ}$ em relação à normal da membrana. Baldwin et al. ${ }^{(18)}$ também estimaram o comprimento aproximado das diferentes hélices e o quanto elas se estendem para o lado intra e extracelular. De acordo com esse modelo, a TM3 é a maior das hélices e as TMs 4 e 7 são as menores. Baldwin et al. ${ }^{(18)}$ também previram que as hélices mais expostas à membrana lipídica são TM1, TM4 e TM5. A TM3 estaria enterrada mais profundamente dentro do receptor, onde faria contatos com TM2, TM4, TM5 e TM6. Verificou-se que o modelo proposto para o receptor era consistente com resultados experimentais ${ }^{(3,19-22)}$.

Nessa área, houve um grande avanço recentemente com a obtenção da estrutura de alta resolução da rodopsina ${ }^{(5)}$ (Fig. 5). A estrutura obtida confirmou os resultados obtidos a partir dos dados de criomicroscopia e os modelos gerados a partir deles. A estrutura cristalina também apresentou fatos novos; a presença de prolinas na TM1, TM4, TM6 e TM7 causa dobras, assim como os resíduos de Gly na TM2. O grupo de Javitch ${ }^{(23)}$ já havia observado no receptor $\mathrm{D}_{2}$ de dopamina a presença de dobras nas TM6 e 7 causadas pela presença de Pro. Apesar disso, Javitch et al. ${ }^{(23)}$ concluiram que as TMs formavam $\alpha$-hélices regulares. No entanto, a estrutura cristalina da rodopsina revelou que as TMs não formam $\alpha$-hélices regulares, na verdade contém segmentos com hélices $3_{10}$ ou $\pi^{(24)}$. Visiers et al. ${ }^{(25)}$ propuseram que essas dobras podem ser 

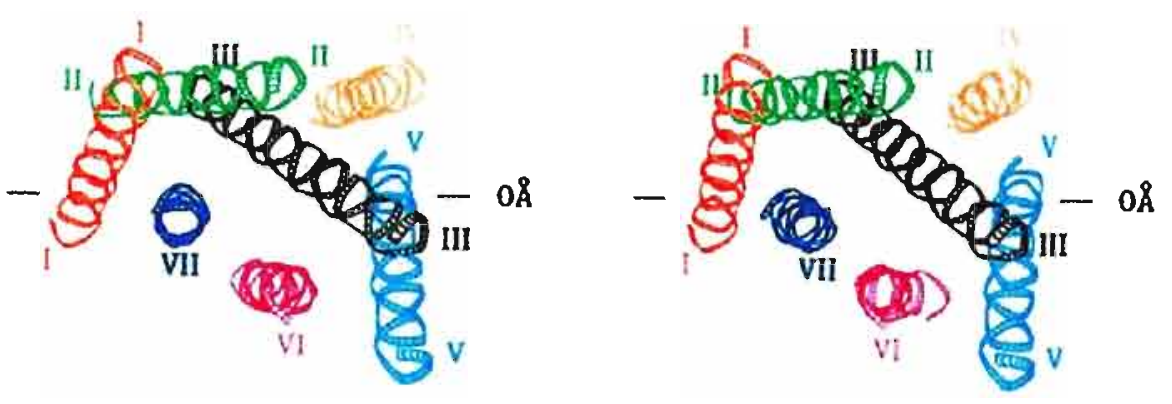

(a)

(a)

(b)

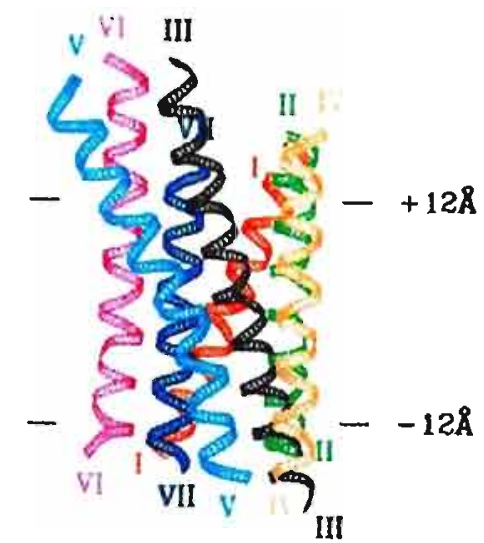

(b)

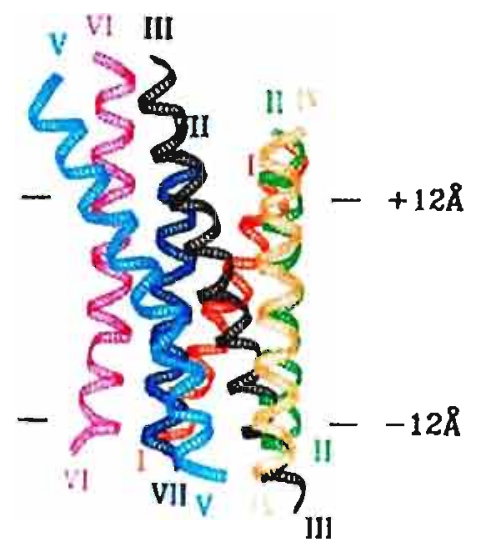

(c)

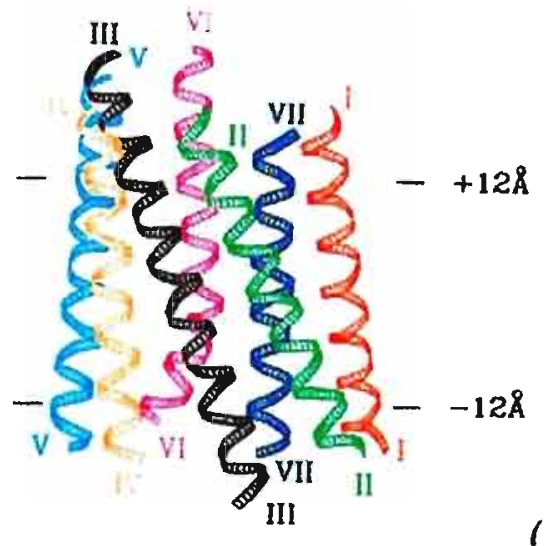

(c)

Figura 4 - Três modelos para as hélices transmembranares da ropdopsina construídos a partir das posições do carbono alfa segundo Baldwin et al. ${ }^{(18)}$. (a) Visão do lado intracelular da membrana, onde o centro da bicamada é indicado por $0 \AA$. (b) Visão a partir do interior da membrana observando-se a partir da TM5. (c) Visão a partir do interior da membrana observando-se a partir da TM2 e da TM4. Em (b) e (c) o lado intracelular está localizado no topo da figura; $12 \AA \mathrm{e}-12 \AA$ representam a distância a partir do centro da bicamada. 


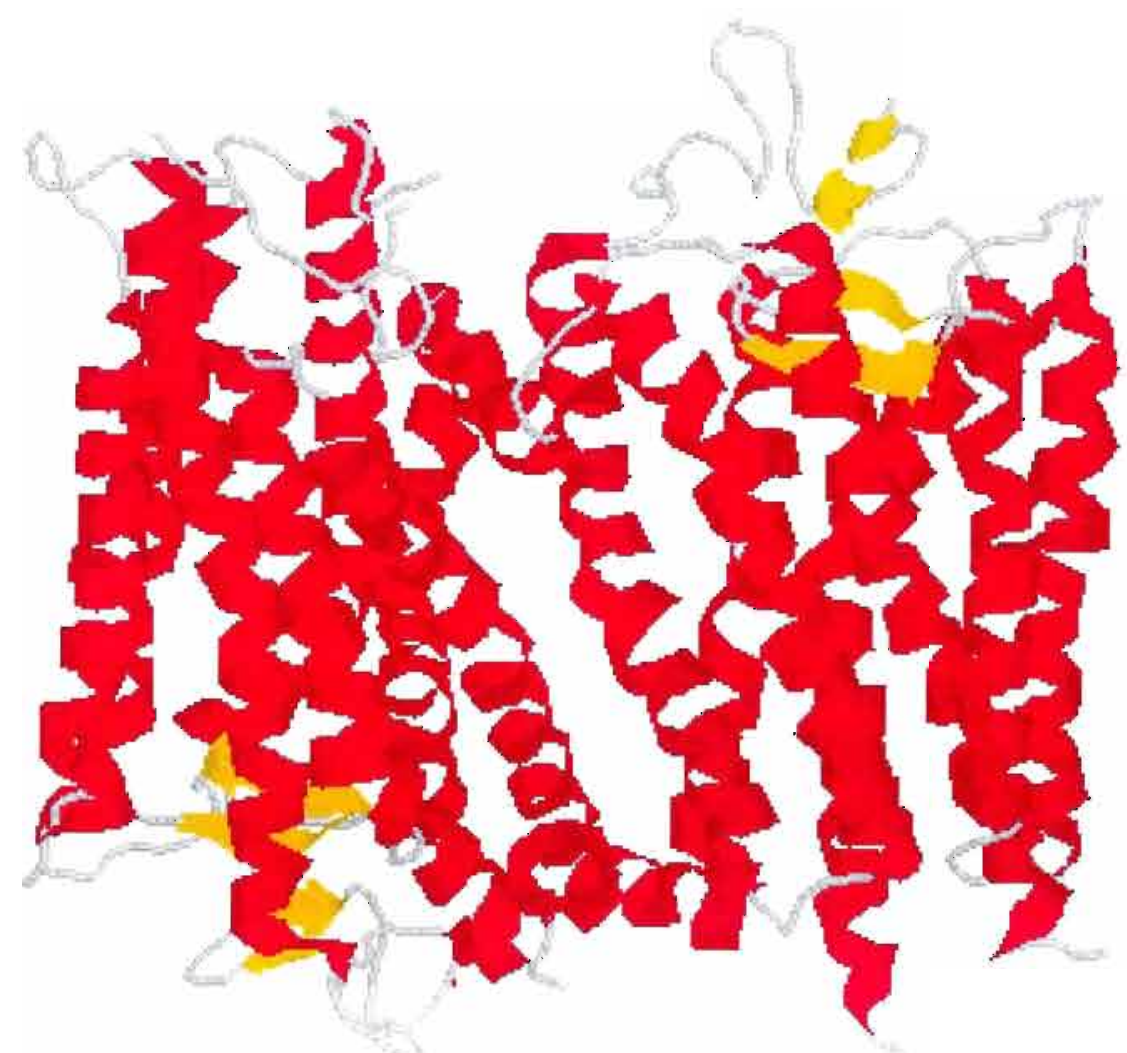

Figura 5 - Estrutura cristalina da rodopsina resolvida por Palczewski et al. ${ }^{(5)}$. Em vermelho estão representadas as regiões transmembranares (TM), em cinza as alças extra e intracelulares e amarelo folhas $\beta$. Código de acesso no PDB: 3F88. 
importantes para as mudanças conformacionais associadas com a ativação dos GPCRs (24). Além disso, a estrutura mostrou pela primeira vez o N-terminal, as três alças externas e as três alças citossólicas, assim como o domínio C-terminal ${ }^{(5)}$.

\subsubsection{Estudo conformacional de fragmentos de GPCRs}

Para estudar a conformação de proteínas e investigar detalhes sobre seu mecanismo de enovelamento, uma das abordagens utilizadas é o estudo de fragmentos de proteínas. Uma das preocupações sobre a validade dessa é proposta é se a conformação adquirida por um fragmento corresponderia a sua conformação nativa na proteína intacta.

$\mathrm{Na}$ literatura, há pelo menos três décadas foi observado que peptídeos correspondentes a porções de proteínas globulares possuem as mesmas propriedades conformacionais que aquelas observadas na proteína nativa ${ }^{(26-28)}$. Uma das proteínas mais estudadas através dessa abordagem foi a termolisina, uma proteína hemolítica encontrada em Bacillus thermoproteolyticus. Fontana et al. (29-32) têm estudado sistematicamente porções correspondentes a domínios dessa proteína através de várias técnicas (CD, NMR, calorimetria), as quais forneceram detalhes sobre o mecanismo de enovelamento e interação com membranas. Estudos conformacionais de fragmentos de outras proteínas globulares também têm ajudado a entender detalhes sobre sua função (33-34).

No caso de proteínas de membrana, dadas as dificuldades de determinação de sua estrutura por técnicas espectroscópicas, como NMR, e difração de raios X, o estudo de fragmentos também tem sido empregado estudar a função de várias proteínas de membrana, como canais de sódio ${ }^{(35)}$, canais de potássio ${ }^{(36)}$, a glicoforina $\mathrm{A}^{(37)}$ e a bacteriorodopsina ${ }^{(38)}$.

Com relação aos GPCRs, essa abordagem foi utilizada para estudar tanto fragmentos de domínios extra e intracelulares, como de porções transmembranares ${ }^{(43-}$ ${ }^{67)}$. Nesse campo, nosso laboratório foi um dos primeiros a publicar trabalhos enfocando o estudo conformacional de fragmentos de GPCRs, tanto em solução aquosa como na presença de modelos de membrana.

Com relação à região extracelular, existem poucos estudos espectroscópicos (NMR, CD, fluorescência) na literatura ${ }^{(39-45)}$. Para a maioria dos GPCRs, as alças extracelulares são pequenas e inicialmente considerava-se que não possuíam estrutura secundária ${ }^{(46)}$. No entanto foi observado que fragmentos sintéticos correspondentes a 
alças extracelulares de GPCRs possuíam estrutura secundária definida na presença de um agente indutor de estrutura secundária (TFE) e de membranas-modelo ${ }^{(40)}$. A estrutura cristalográfica da rodopsina revelou que essa região forma uma estrutura compacta entre o domínio $\mathrm{N}$-terminal e as alças extracelulares. Além disso, foi observada a presença de uma dobra $\beta$ na e 2 estabilizada por uma ponte dissulfeto entre o resíduo Cys110 na TM3 e o resíduo Cys187 na e2. Essa ponte dissulfeto é altamente conservada entre os GPCRs ${ }^{(5)}$.

Com relação às alças citossólicas (i) e o domínio C-terminal (CT), essa região foi extensivamente estudada por várias técnicas espectroscópicas como $\mathrm{NMR}, \mathrm{CD}$, fluorescência e por spin-label sítio-dirigido, empregando-se fragmentos sintéticos correspondentes às alças citossólicas e ao domínio C-terminal ${ }^{(47-59)}$. Estes estudos revelaram que esses fragmentos possuem estrutura secundária definida. Yeagle e col. ${ }^{(51-}$ ${ }^{54)}$ mostraram que a i1 e a i2 da rodopsina formam dobras $\beta^{(52)}$, enquanto que a i3 e a região proximal do CT formam estruturas $\alpha$-helicoidais ${ }^{(51,53,54)}$. Isto também foi observado por Jung et al. ao estudar o receptor $\beta$-adrenérgico ${ }^{(60)}$. Este trabalho e do grupo de Yeagle mostraram que a região que se estende entre a TM7 e o sítio de palmitoilação do receptor nas Cys 322 e 323 forma um $\alpha$-hélice putativa, chamada de i4 ${ }^{(53)}$. Yeagle et al. ${ }^{(51)}$ construíram um modelo tridimensional para a superfície intracelular da rodopsina ajustando os resultados obtidos experimentalmente para as regiões i1-i4 com o modelo proposto por Baldwin ${ }^{(16)}$. Um fato interessante foi que o modelo proposto está de acordo com os resultados obtidos através da técnica de marcador de spin sítio-dirigido (SDSL), onde foi possível medir as distâncias entre sítios específicos da rodopsina ${ }^{(55-59)}$. Os resultados obtidos por SDSL apoiam fortemente a idéia de que a região proximal e distal da i3 (Ni3 e Ci3, respectivamente) representam extensões $\alpha$-helicoidais das TM5 e TM6 ${ }^{(58)}$. Também foi observado que a porção correspondente à junção TM3 e i2 forma uma $\alpha$-hélice ${ }^{(59)}$.

Foi ainda verificado por $\mathrm{CD}$ e NMR que fragmentos sintéticos correspondentes à $\mathrm{Ni3}$ e CT do receptor $\mathrm{AT}_{1 \mathrm{~A}}$ de angiotensina II adquirem estrutura $\alpha$-helicoidal em solução aquosa em função do $\mathrm{pH}$ e em TFE ${ }^{(48-50)} \mathrm{e}$ na presença de detergentes (Dra. T.A. Pertinhez, tese de doutoramento, 1998). A mesma abordagem levou a resultados similares para a i3 do receptor do hormônio da paratireóide/proteína relacionda ao hormônio da paratireóide ${ }^{(61)}$. 
Alguns grupos também enfocaram o estudo de fragmentos sintéticos correspondentes a regiões transmembranares de GPCRs. Foi observado por CD que um peptídeo correspondente à TM2 do receptor BKB2 de bradicinina adquire conformação $\alpha$-helicoidal na presença de TFE e em solução aquosa na presença de membranasmodelo ${ }^{(62,63)}$. O mesmo grupo também observou por espectroscopia de fluorescência que esse peptídeo era capaz de atravessar a membrana ${ }^{(63)}$,

O grupo de Naider et al. ${ }^{(64-67)}$ também têm tido uma contribuição relevante na literatura ao estudar fragmentos sintéticos correspondentes a TMs de um GPCR de Saccharomyces cerevisiae. Esse grupo observou que com exceção das TMs 3 e 6 na presença de modelos de membrana, todos os outros peptídeos adotaram conformação $\alpha$ helicoidal na presença de TFE, misturas de TFE-água e na presença de micelas de detergentes e de vesículas fosfolipídicas ${ }^{(64)}$. As outras TMs adotaram conformação em folha $\beta$ na presença de SDS e de vesículas de dimiristoilfosfatidilcolina (DMPC) e possuíam tendência à agregação ${ }^{(64)}$. Estudos de espectroscopia de infra-vermelho por transformada de Fourier desses peptídeos na presença de vesículas de DMPC também mostraram que a TM3 e a TM6 adotam conformação em folha $\beta^{(65)}$, sendo que para a TM6 resultados de NMR do estado sólido mostraram que sua porção C-terminal forma uma $\alpha$-hélice e que esse fragmento encontra-se inclinado em relação à normal da membrana ${ }^{(66)}$. Estudos de NMR da TM6 e TM7 na presença de TFE mostraram que as $\alpha$-hélices formadas por esses fragmentos possuem dobras (kinks) ao redor dos resíduos de prolina ${ }^{(67)}$. Albert et al. ${ }^{(68)}$ também observaram a presença de dobras ao redor do resíduo de prolina na TM6 da rodopsina.

Antes da obtenção de um cristal da rodopsina que difratasse com alta resolução, os resultados descritos até então contribuíram de maneira significativa para a elaboração de modelos dos GPCRs, tanto no que concerne a sua estrutura quanto ao mecanismo de transdução de sinal. A estrutura cristalina da rodopsina revelou que geralmente os modelos assumidos para essa proteína estavam corretos; ela confirmou a presença da chamada hélice VIII no i4, paralela ao plano da membrana e perpendicular a TM7.

A obtenção do cristal da rodopsina abre perspectivas quanto à ativação da própria rodopsina e a obtenção de modelos $3 \mathrm{D}$ de outros receptores, tendo por molde a rodopsina ${ }^{(24,69-72)}$. No entanto, essa abordagem não é consenso na literatura ${ }^{(69,70)}$. Acredita-se que o refinamento desses modelos para outros GPCRs também deva se basear em resultados experimentais que validem esses modelos ${ }^{(70)}$. 


\subsubsection{Interação ligante-GPCR}

$\mathrm{Na}$ literatura, foram feitos vários estudos para identificar o sítio de ligação de vários ligantes a seus respectivos receptores, sendo os receptores adrenérgicos os melhor caracterizados ${ }^{(73-76)}$.

Dependendo do tipo de ligante, as regiões envolvidas com a ligação do ligante são diferentes. No caso de receptores de moléculas pequenas como aminas biogênicas (epinefrina, norepinefrina, dopamina, serotonina, histamina e acetilcolina), o sítio de ligação é formado pelas TMs ${ }^{(4)}$. Para o receptor $\beta_{2}$ adrenérgico por exemplo, observouse através da técnica de espectroscopia de fluorescência que o sítio de ligação encontrava-se profundamente enterrado no receptor ${ }^{(77)}$.

Para receptores de ligantes peptídicos, foi observado que os domínios extracelulares são importantes para a ligação do peptídeo. Para muitos receptores existem evidências de interações com a região $\mathrm{N}$-terminal e com as alças extracelulares. Esse tipo de observação foi visto para os receptores de angiotensina II ${ }^{(78-80)}$, neuropeptídeo $\mathrm{Y}^{(81)}$, interleucina ${ }^{(82)}$, vasopressina ${ }^{(83)}$ e $\mathrm{GnRH}$ (hormônio liberador de gonadotropina) ${ }^{(84)}$. No caso dos receptores de angiotensina $\Pi{ }^{(85,86)}$, opióides ${ }^{(87)}$ e de bradicinina ${ }^{(88)}$ há indícios de alguns pontos de interação localizados nos domínios transmembranares.

Quanto aos receptores de hormônios glicoproteícos como o LH, FSH e TSH, observou-se que estes receptores possuem domínios $\mathrm{N}$-terminais relativamente grandes para acomodar o ligante ${ }^{(73,89-94)}$. A interação entre receptor e ligante leva a mudanças conformacionais, que causam a ativação do receptor ${ }^{(73)}$.

\subsubsection{Mecanismos envolvidos na ativação do receptor e sua interação com a proteína $G$}

\subsubsection{Ativação do receptor}

O mecanismo proposto na literatura para ativação dos GPCRs envolve a ligação do ligante ao receptor, sendo que este evento desencadeia uma série de mudanças conformacionais propagadas pelas TMs, induzindo mudanças conformacionais nas alças citossólicas e no C-terminal levando a ativação da proteína G.

$\mathrm{Na}$ tentativa de entender a interação do ligante com o receptor, foram propostos alguns modelos na literatura ${ }^{(95-98)}$. O modelo mais simples é o modelo de dois estados 
ou modelo ternário ${ }^{(95)}$, no qual propõe-se que o receptor pode existir em dois estados: o estado inativo $(R)$ e o estado ativo $\left(R^{*}\right)$, os quais encontram-se em equilíbrio. Postula-se que a forma inativa do receptor é mantida por uma rede de interações intramoleculares, como pontes de hidrogênio e interações eletrostáticas ${ }^{(96)}$. Quando essas interações são rompidas, ocorre a isomerização do estado $\mathrm{R}$ para o estado $\mathrm{R}^{*}$. De acordo como esse modelo, a isomerização pode ocorrer de forma espontânea ou pode ser induzida pelo agonista. Na ausência do agonista, prevalece o estado $\mathrm{R}$; no entanto, a barreira energética entre os dois estados é pequena, de forma que uma pequena fração assume espontaneamente o estado $R^{*}$. Propõe-se que os agonistas liguem com maior afinidade ao estado $\mathrm{R}^{*}$, deslocando o equilíbrio nessa direção; antagonistas inversos ligam-se com maior afinidade ao estado $\mathrm{R}$ e antagonistas neutros ligam-se com a mesma afinidade aos dois estados ${ }^{(95)}$. A ocorrência de mutações em resíduos que são importantes para manter o receptor na forma $\mathrm{R}$ pode eliminar essas interações, deslocando o equilíbrio para a forma ativa do receptor ${ }^{(95,97)}$. Nesses casos, ocorre ativação constitutiva do receptor, que é definida como ativação na ausência do ligante.

No entanto, resultados experimentais demonstraram que esse modelo não é suficiente para explicar o comportamento complexo dos GPCRs; surgiram evidências de que na verdade o receptor pode existir em vários estados ${ }^{(98,99)}$. Experimentos com os receptores $\alpha_{1 \mathrm{~B}}$ e $\beta_{2}$-adrenérgicos apóiam a idéia de que o receptor pode existir em vários estados na forma ativa ${ }^{(100,101)}$. Schwartz et al. ${ }^{(102)}$ propõem que o receptor pode alternar espontaneamente entre várias conformações, tanto no estado ativo, quanto no inativo. Segundo esse grupo, a resposta biológica é desencadeada pela preferência do ligante por uma determinada conformação pela qual possui maior afinidade. Se esta conformação é reconhecida pela proteína $\mathrm{G}$ como ativa, o ligante comporta-se como um agonista; se a conformação preferida é a inativa, o ligante comporta-se como antagonista inverso.

A descoberta de que algumas mutações causavam ativação constitutiva, ajudou a descobrir resíduos que são importantes para manter o receptor na forma inativa ${ }^{(95,97,103-}$ ${ }^{105)}$. Muitas das mutações foram inicialmente descobertas na porção C-terminal da i3 dos receptores adrenérgicos ${ }^{(83,85,92,93)}$. Depois foram descobertas várias mutações nas TMs dos receptores de hormônios glicoproteícos, principalmente na TM6 ${ }^{(106,107)}$. Allen et al. ${ }^{(105)}$ descobriram que a substituição de um resíduo de Ala na i3 do receptor $\alpha$ adrenérgico por qualquer outro aminoácido era capaz de causar forte ativação do receptor na ausência do ligante. Esse resultado foi interpretado como evidência de que interações intramoleculares mantém o receptor em sua forma inativa. O rompimento 
dessas interações, seja pela ligação do ligante, seja por mutação, seria capaz de causar alterações conformacionais levando à exposição de resíduos importantes na superfície intracelular para a interação com a proteína $\mathrm{G}$.

Estudos com os receptores dos hormônios LH e FSH também mostraram que a TM5 e a TM6 desempenham um papel importante na manutenção do estado inativo do receptor ${ }^{(108)}$. Papel semelhante para a TM6 também foi observado para o receptor M5 muscarínico ${ }^{(109)}$ e para o receptor do feromônio fator $\alpha^{(110)}$. No caso da rodopsina, existem evidências de que uma metionina na TM6 e o motivo conservado NPXXY na TM7, assim como uma ponte salina entre um resíduo de Lys ${ }^{293}$ na TM7 e de Glu na TM3 são importantes para manter o receptor na forma inativa ${ }^{(107)}$; é interessante observar que a Lys ${ }^{293}$ da TM7 é o sítio de ligação do retinal. Também foram observadas interações estabilizantes entre a TM3 e 7 para o receptor de angiotensina $\Pi^{(112)}$ e o receptor $\alpha$-adrenérgico ${ }^{(113)}$.

Outro fator que parece ser importante para ativação do receptor é a protonação do resíduo de Asp ou Glu no motivo D/E-R-Y na i2. Observou-se que a substituição de Asp ou Glu por Asn ou Gln levava à ativação constitutiva do receptor $\beta_{2}$-adrenérgico (114); resultados semelhantes foram observados para o receptor GnRH (hormônio liberador de gonadotropina) ${ }^{(115)}$ e para o receptor muscarínico M1 ${ }^{(116)}$. Sakmar et al. (117) obtiveram evidências de que a protonação do resíduo de Glu ${ }^{134}$ acompanha a formação da metarodopsina II, o qual é o estado ativo da rodopsina. Outro fato observado é que ativação do receptor é acompanhada por um rearranjo da posição relativa das $\mathrm{TMS}^{(118)}$.

Com relação à rodopsina, vários estudos espectroscópicos e biofísicos demonstraram experimentalmente a diferença entre a conformação da forma ativa e a forma inativa do receptor ${ }^{(56-59,119-121)}$. Até o momento, não se dispõe de uma estrutura cristalina de alta resolução para a forma ativa do receptor.

\subsubsection{A proteina $G$}

A proteína $\mathrm{G}$ é uma proteína heterotrimérica, composta pelas subunidades $\alpha, \beta \mathrm{e}$ $\gamma$ (Fig. 6). No entanto, vários genes codificam para cada subunidade. Foram identificados 20 tipos de subunidade $\alpha, 6$ de $\beta$ e12 de $\gamma^{(3,122)}$. As proteínas G podem ser classificadas em quatro classes com base na homologia da sequiência de aminoácidos da 


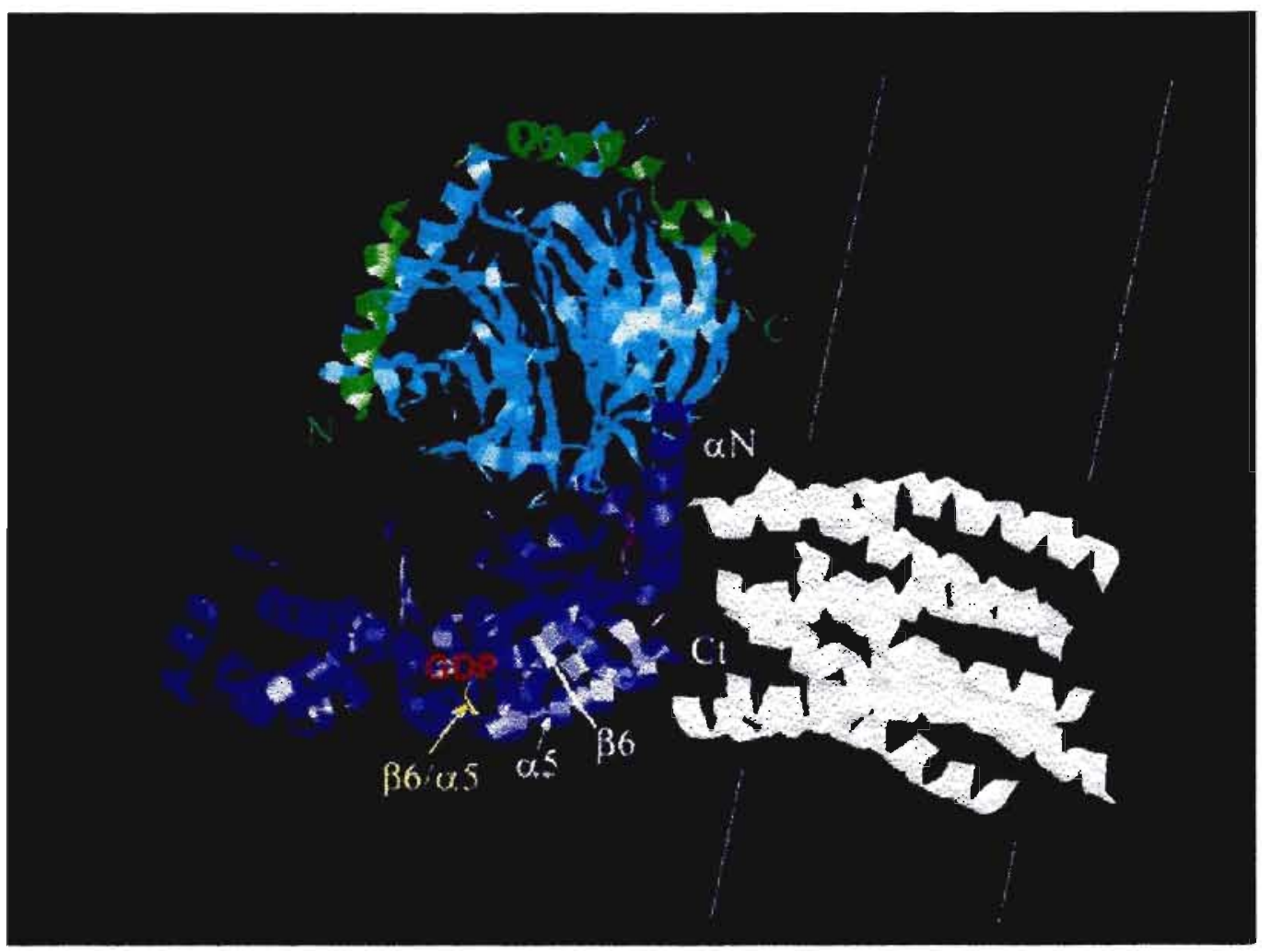

Figura 6 - Modelo do complexo receptor/proteína $G$ de acordo com a estrutura cristalina publicada por Lambright et al. ${ }^{(128)}$. A região púrpura corresponde à subunidade $\alpha$, a região turquesa à subunidade $\beta$ e a região verde à subunidade $\gamma$. Em branco está mostrado o receptor, sendo que as linhas brancas correspondem aos limites da membrana plasmática. Em amarelo mostra-se o sitio de ligação de GDP na subunidade $\alpha$, que é contactado pela alça entre a folha $\beta 6$ e a $\alpha$-hélice $\alpha 5$. 
subunidade $\alpha^{(123,124)}: G_{\mathrm{s}}$, responsável pela ativação da adenilato ciclase, $G_{i}$ e $G_{0}$; que inibem a adenilato ciclase; $G_{q}$; que ativa a fosfolipase $C$ e $G_{12}$ e $G_{13}$ com função desconhecida ${ }^{(125)}$. Com relação às outras subunidades, a subunidade $\beta$ possui alto grau de homologia seqüencial, enquanto que a subunidade $\gamma$ não possui ${ }^{(122)}$.

$\mathrm{Na}$ sua forma inativa, a proteína G forma um heterotrímero e possui GDP ligado à subunidade $\alpha^{(3,122,123)}$. Quando ocorre a ativação da proteína $\mathrm{G}$ pelo receptor, ocorre a troca de GDP por GTP na subunidade $\alpha$. A ligação de GTP diminui a afinidade da subunidade $\alpha$ pelas outras subunidades, promovendo a dissociação de G $\alpha$-GTP do

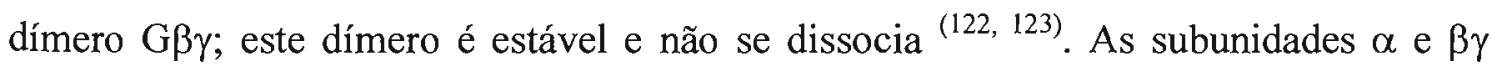
ativam uma enorme variedade de efetores, elas estimulam ou inibem enzimas como a adenilato ciclase e as fosfolipases $\mathrm{A}, \mathrm{C}$ e $\mathrm{D}$, além de ativar canais de $\mathrm{Ca}^{2+}$ e $\mathrm{K}^{+}$. A ativação/inibição dessas enzimas leva à produção de segundos mensageiros, desencadeando uma cascata de reações intracelulares, levando à produção de respostas fisiológicas em tecidos ${ }^{(126)}$.

Tanto a subunidade $\alpha$ quanto $\beta \gamma$ interagem seletivamente com as moléculas efetoras ${ }^{(123,124)}$. Por exemplo, $\alpha_{\mathrm{s}}$ e $\alpha_{\mathrm{i}}$ controlam os níveis de cAMP ao ativar e inibir, respectivamente, diferentes isoformas da adenilato ciclase ${ }^{(115,116)}$. A desativação da proteína G ocorre quando Ga hidrolisa GTP a GDP, levando novamente a formação do heterotrímero ${ }^{(123-125)}$.

A estrutura tridimensional de proteínas $\mathrm{G}$ foi determinada por difração de raios$\mathrm{X}$ por alguns grupos $(127,128)$ e ajudou a descobrir detalhes sobre o mecanismo de interação com seus receptores. De acordo com essas estruturas, a subunidade $\alpha$ consiste de dois domínios, sendo que o nucleotídeo de guanina encontra-se profundamente enterrado ${ }^{(127,128)}$.

Um dos domínios corresponde ao domínio GTPase e sua estrutura consiste de seis dobras $\beta$ ( $\beta 1-\beta 6)$, as quais são rodeados por seis $\alpha$-hélices, $\alpha 1-\alpha 5$ e $\alpha \mathrm{G}$. O outro domínio consiste de uma $\alpha$-hélice central ( $\alpha \mathrm{A}$ ) rodeada por cinco $\alpha$-hélices menores $(\alpha B-\alpha F)$. Um fato interessante é que na subunidade $\alpha$ livre, o domínio $N$-terminal encontra-se desordenado, enquanto que no heterotrímero este segmento adota conformação $\alpha$-helicoidal. Essa diferença é atribuída a interações entre a subunidade $\alpha$ e a subunidade $\beta^{(127,128)}$. 
Quanto à subunidade $\beta$, sua porção $N$-terminal adota estrutura $\alpha$-helicoidal. Essa subunidade também possui sete folhas $\beta$, sendo que cada uma é composta por quatro fitas $\beta$ antiparalelas formando uma estrutura chamada de " $\beta$ propeller" (127-129).

Com relação à subunidade $\gamma$, uma de suas faces liga-se ao $\beta$ propeller da subunidade $\beta$ em uma conformação estendida ${ }^{(127-129)}$. Seu domínio N-terminal adquire uma conformação em $\alpha$-hélice, que forma um "coiled-coil" com a $\alpha$-hélice $N$-terminal de $G \beta$. A estrutura do dímero $G \beta \gamma$ livre é idêntica àquela encontrada no heterotrímero; dessa forma como apenas G $\beta \gamma$ livre pode interagir "downstream" com outros efetores (127-128), a subunidade $\alpha$ pode ser considerada um regulador negativo da função de G $\beta \gamma$.

Tanto a subunidade $\alpha$ quanto a $\gamma$ possuem modificações lipídicas, que são importantes para seu ancoramento à membrana plasmática ${ }^{(130)}$. A subunidade $\alpha$ pode ser tanto miristoilada quanto palmitoilada em sua porção N-terminal. A subunidade $\gamma$, por outro lado, é farnesilada no domínio C-terminal ${ }^{(125)}$. A estrutura cristalina mostra que os sítios de acilação estão relativamente próximos, o que sugere que eles se localizam em um mesmo sítio na membrana plasmática ${ }^{(128)}$.

\subsubsection{Interação entre o receptor e a proteína $G$}

$\mathrm{Na}$ maioria dos casos, quando ativados pelo ligante, os GPCRs acoplam-se seletivamente a proteínas G. Nesta área foram feitos vários estudos, utilizando quimeras, mutações e peptídeos sintéticos com a intenção de elucidar elementos estruturais importantes para a interação de receptores com suas respectivas proteínas $G$ $(3,46,84,85,131,132)$. Foi observado que 12 , i3 e em alguns receptores, a parte proximal do

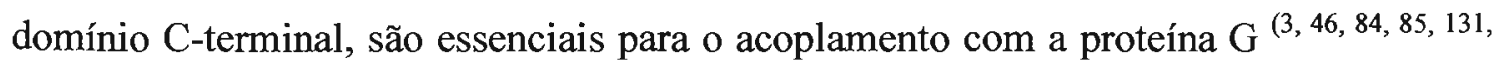
132).

No receptor muscarínico e no adrenérgico foi demonstrado que a i3 possui papel vital para a especificidade do acoplamento entre diferentes subunidades $\alpha$ da proteína $\mathrm{G}$ $(3,84,132)$. A i2, no entanto, é menos importante para determinar a especificidade, porém é importante para a eficiência da ativação da proteína $\mathrm{G}^{(3,15,132)}$.

Presume-se que a região proximal da i2 possua uma $\alpha$-hélice que se estende a partir da TM3. No receptor muscarínico M5 foi observado através de mutações que a substituição de resíduos agrupados na região $\mathrm{N}$-terminal da alça causavam ativação constitutiva do receptor, enquanto que substituições no lado oposto comprometiam o 
acoplamento da proteína $G^{(133)}$. Com base nesses resultados, acredita-se que a i2 funcione como uma ponte que permite o acoplamento com a proteína $\mathrm{G}^{(133)}$. Na região proximal da i2, junto à TM3, existe o motivo DRY, o qual é altamente conservado entre os GPCRs ${ }^{(134)}$. A hipótese formulada com os resultados obtidos para o receptor muscarínico é consistente com o papel postulado na transdução de sinal para o motivo DRY ${ }^{(103,114,116)}$ e com a mudança de orientação da TM3 em relação à TM6 quando da ligação do ligante ${ }^{(135,136)}$.

Apesar da enorme quantidade de trabalhos publicados, ainda se sabe relativamente pouco sobre os pontos de contato entre o receptor e a proteína $\mathrm{G}$ ou como essas duas proteínas estão orientadas em relação à outra. Propõe-se que o domínio de ligação do nucleotídeo guanina da subunidade $\alpha$ esteja $30 \AA$ distante da membrana ${ }^{(124,}$ 125, 137). Dessa forma, o receptor deveria induzir a liberação de GDP da subunidade $\alpha$ sem interagir diretamente com o domínio de ligação do nucleotídeo.

Especula-se que os movimentos preditos da TM3 e TM6 para longe uma da outra durante a ativação do receptor poderiam permitir que o $\mathrm{C}$-terminal da subunidade $\alpha$ se inserisse dentro da cavidade formada pelas sete hélices transmembranares ${ }^{(137)}$. Este evento poderia disparar mudanças estruturais na $\alpha$-hélice 5 e também na folha $\beta 6$ da subunidade $\alpha$, os quais seriam transmitidos para o domínio de ligação do nucleotídeo através da alça $\alpha 5 / \beta 6$, localizada na vizinhança do nucleotídeo ${ }^{(137)}$.

Kisselev et al. ${ }^{(138)}$ estudaram por NMR a conformação de um fragmento sintético correspondente à porção C-terminal da subunidade $\alpha$ da transducina $\left(\mathrm{G}_{\mathrm{t} \alpha}\right.$, resíduos 340-350) ligada ao estado excitado da rodopsina. Os resultados mostraram que a ativação da rodopsina provoca uma mudança significativa em $G_{t \alpha}$, que muda de estrutura ao acaso para uma conformação $\alpha$-helicoidal seguida de uma dobra reversa centrada no resíduo de $\mathrm{Gly}^{348}$. A estrutura de $\mathrm{G}_{\mathrm{t} \alpha}$ determinada por NMR foi superposta à estrutura cristalina de $\mathrm{G}_{\mathrm{t} \alpha}$ ligada à GDP (Fig. 7). Os resultados mostraram que a excitação da rodopsina promove a formação de uma $\alpha$-hélice contínua entre os resíduos 325 e 346, na qual a parte distal de $G_{t a}$ possui um cluster formado pelas cadeias laterais dos resíduos hidrofóbicos. Os autores propõem que a interação entre esse cluster e o receptor é importante para a ativação da proteína G. Esse resultado foi contestado pelo grupo de Aris et al. ${ }^{(139)}$, que alegaram que os resultados de NMR foram interpretados erroneamente. No entanto, no mesmo artigo o grupo postulou que a 


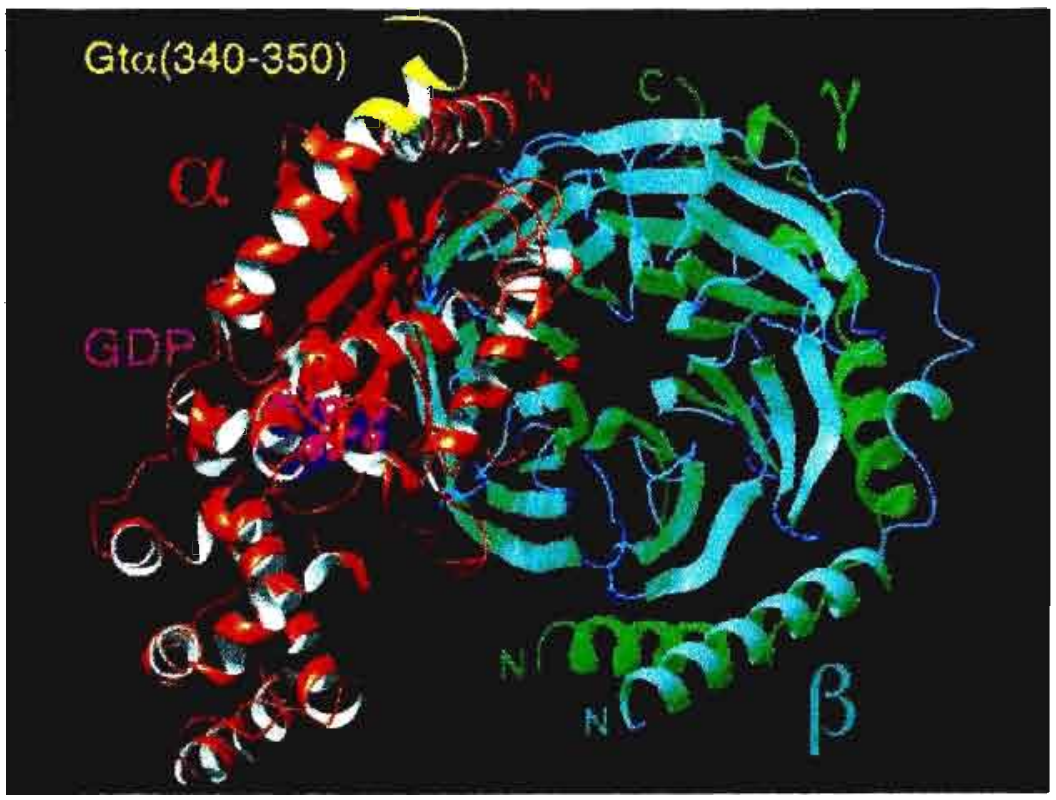

Figura 7 - Conformação de $\mathrm{G}_{1 \alpha}$ ligado ao estado ativado da rodopsina (amarelo) superposta a estrutura da transducina ligada a GDP (magenta) determinada por difração de raio-X, segundo modelagem feita por Kisselev et al. ${ }^{(138)}$. Número de acesso no PDB: 1GOT.

interação hidrofóbica entre $G_{t \alpha}$ e o sítio de ligação no receptor no estado excitado é a principal força que controla essa interação.

\subsection{Receptor do hormônio luteinizante e ativação constitutiva}

\subsubsection{Estrutura do receptor do hormônio luteinizante}

O receptor do hormônio luteinizante/gonadotropina coriônica (LHR) está presente nas células de Leydig ou células intersticiais, localizadas nos testículos, e em células ovarianas como as células luteais, células granulosas e células da teca ${ }^{(128)}$. Em machos e em fêmeas fora do período gestacional, o receptor fica exposto à ação do hormônio luteinizante $(\mathrm{LH})$, resultando na produção de testosterona. Nas fềmeas, durante a gravidez, o receptor fica exposto à ação da gonadotropina coriônica (CG), resultando na produção de progesterona ${ }^{(140)}$.

Tanto o LH quanto o CG são hormônios glicoproteícos constituídos de duas subunidades, $\alpha$ e $\beta$. A subunidade $\alpha$ é idêntica para ambos os hormônios e a subunidade $\beta$ é responsável pela especificidade de ligação. Foi observado experimentalmente que tanto o LH quanto a CG são capazes de se ligar ao receptor com igual afinidade ${ }^{(140)}$. 
O LHR pertence à família dos GPCRs, sendo classificado como membro da família dos receptores da rodopsina; o LHR humano (hLHR) é constituído de 675 aminoácidos (Fig. 8) ${ }^{(140)}$. Dentro dessa família da rodopsina, o LHR é classificado como pertencendo à subfamília de receptores de hormônios glicoproteícos, assim como o receptor do hormônio folículo estimulante (FSHR) e o receptor da tireotropina (TSHR), os quais possuem alto grau de homologia e um domínio N-terminal grande, que no caso do LHR possui cerca de 340 resíduos ${ }^{(140)}$. A presença de um domínio desse tamanho é importante para acomodar o ligante, que possui cerca de $40 \mathrm{kDa}$.

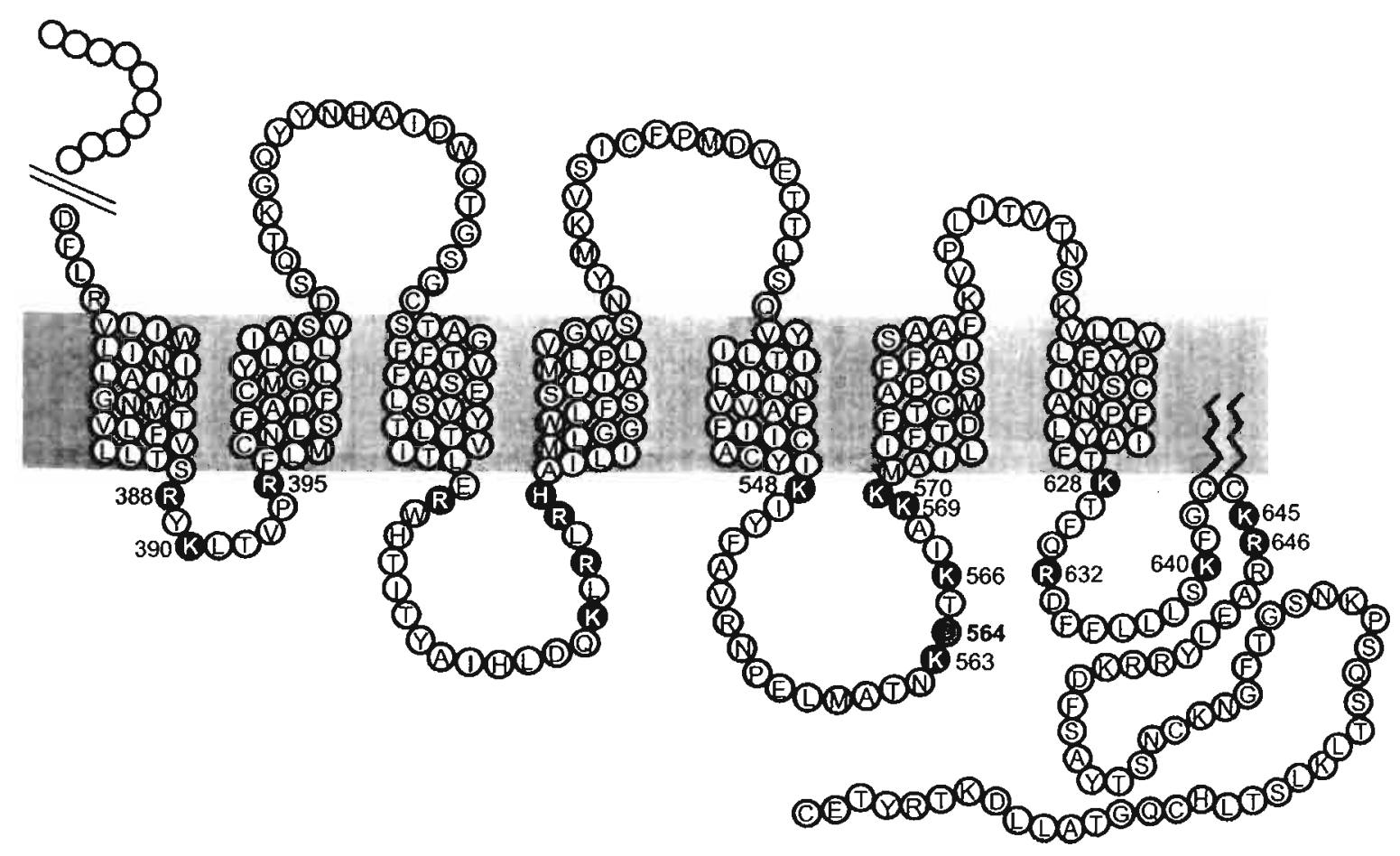

Figura 8 - Modelo em serpentina do LHR publicado por Schöneberg et al. ${ }^{(156)}$ Os aminoácidos em letras brancas e com fundo preto representam os aminoácidos básicos conservados no LHR. A figura também mostra dois sítios de palmitoilação nos resíduos de $\mathrm{Cys}^{643}$ e $\mathrm{Cys}^{644}$. 
Observou-se experimentalmente que o ligante era capaz de ligar-se com igual afinidade ao receptor intacto e a um mutante onde apenas o domínio $\mathrm{N}$-terminal foi expresso, o que demonstrou que apenas esse domínio é importante para a interação com o ligante ${ }^{(141)}$. Esse domínio também é responsável tanto pela especificidade quanto pela ligação do hormônio ${ }^{(93,142-144)}$. Estudos com quimeras do LHR/FSHR, onde foram expressos receptores contendo o $\mathrm{N}$-terminal com a sequiência de aminoácidos ora do LHR ora do FSHR, demonstraram que a ligação do hormônio é regulada pela identidade da região N-terminal ${ }^{(92,144)}$.

O domínio $\mathrm{N}$-terminal possui seis sítios de glicosilação, duas regiões ricas em cisteínas, localizadas na parte proximal e distal, e nove domínios ricos em aminoácidos hidrofóbicos, chamados de repetições ricas em leucina; LRR ${ }^{(140)}$. Os sítios de glicosilação parecem não ser importantes para a interação do receptor com o ligante ${ }^{(140,}$ 145); através de experimentos onde os carboidratos foram clivados enzimaticamente ou onde foram expressos mutantes sem esses sítios não foi verificada a diminuição da afinidade do receptor pelo $\mathrm{LH}^{(92,146)}$. Também foi observado que os glicosídeos não são importantes para o enovelamento correto do receptor, embora se especule que eles possam facilitar esse processo ${ }^{(145)}$.

Quanto às outras regiões, observou-se que a deleção de uma porção do domínio $\mathrm{N}$-terminal correspondente à região rica em cisteínas e aos sete primeiros LRRs aboliam a ligação da CG humana (hCG), mostrando que essa região é essencial para a ligação do ligante ${ }^{(92)}$. Vários estudos mostraram que a deleção da parte distal do domínio Nterminal não afeta a afinidade da hCG pelo receptor e nem a transdução de sinal ${ }^{(92,142,}$ 147, 148).

A ligação do $\mathrm{LH} / \mathrm{CG}$ ao domínio extracelular resulta em mudanças conformacionais, que causam o rearranjo das TMs e que culminam na ativação da proteína G. No entanto, até o momento esse processo é pouco compreendido. Estudos de mutagênese demonstraram que vários resíduos localizados na parte distal do domínio N-terminal ${ }^{(149-151)}$ e na e ${ }^{(152,153)}$ são essenciais para ativação da proteína G. Também foi observado que resíduos localizados na e2 são importantes para a transdução de sinal ${ }^{(154)}$. Segaloff et al. ${ }^{(140)}$, propuseram três modelos para ligação do ligante ao receptor e sua ativação, sendo que em todos os casos existem evidências experimentais que apóiam os três modelos, que são descritos abaixo: 
a. O ligante poderia ligar-se ao domínio extracelular do LHR e o hormônio ligado a este domínio seria capaz de interagir com as TMs, provocando sua ativação.

b. O ligante poderia ligar-se ao domínio extracelular do LHR, provocando mudanças conformacionais que resultem na ativação das TMs.

c. O domínio extracelular do LHR mantém o receptor em sua forma inativa; a ligação do ligante ao domínio extracelular ativaria as TMs ao relaxar essa interação.

Além da ligação do ligante, vários estudos bioquímicos, através de mutagênese sítio-dirigida e ensaios com peptídeos sintéticos têm enfocado o papel das TMs e das alças citossólicas para a ativação e acoplamento à proteína $\mathrm{G}^{(108,155,156)}$. Foi observado que fragmentos sintéticos correspondentes à justaposição entre as TMs 4, 5, 6 e 7 e as alças citossólicas correspondentes eram capazes de ativar $\mathrm{G}_{\mathrm{s}}{ }^{(155)}$. O mesmo grupo também observou que um fragmento correspondente à porção C-terminal da i3 e Nterminal da TM6 era mais eficaz ao ativar a proteína $G$ do que um fragmento correspondente apenas ao N-terminal da TM6, evidenciando o papel da i3 do LHR no acoplamento com a proteína $\mathrm{G}^{\left({ }^{(15)}\right)}$. Estudos de mutagênese sítio-dirigida também demonstraram que a i3 é importante nesse processo; esses estudos mostraram ainda que interações entre TM5 e TM6 são importantes para manter o receptor em sua forma inativa $^{(108,156)}$.

Utilizando-se da mesma técnica e de modelagem molecular, Angelova et al. ${ }^{(157)}$ demonstraram que a TM7 também possui um papel importante na ativação do receptor, principalmente os resíduos de $\mathrm{Asn}^{593}$ e $\mathrm{Asn}^{597}$. Segundo esses resultados, a interação desses resíduos com a TM6 é importante para manter o receptor em sua forma inativa.

\subsubsection{Mecanismo de ativação constitutiva}

Uma das características mais importantes dos GPCRs é a atividade constitutiva, a qual pode ser definida como sinalização independente de ligante. Esta característica foi observada pela primeira vez em um mutante do receptor $\alpha_{1 \mathrm{~B}}$-adrenérgico ${ }^{(158)}$ e pode ajudar a revelar detalhes sobre o mecanismo de transdução de sinal e ativação da

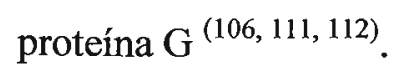

Descobriu-se que mutações responsáveis por algumas doenças humanas causam ativação constitutiva dos GPCRs, dentre as quais algumas formas de puberdade precoce masculina familiar (FMPP), ou testoxicose, que estão associadas com mutações na 
quinta e sexta hélices transmembranares (TM5 e TM6) e na porção C-terminal da i3 do LHR humano ${ }^{(106,108,159)}$. Indivíduos do sexo masculino afetados por FMPP apresentam níveis elevados de testosterona e hiperplasia das células de Leydig; sinais da puberdade aparecem geralmente aos 4 anos de idade ${ }^{(73,108,159)}$.

É postulado que a conformação do receptor inativo é mantida por uma rede de interações entre as hélices transmembranares ${ }^{(3,4)}$. As mudanças conformacionais induzidas pela ligação do agonista romperiam estas interações, levando à ativação da proteína $\mathrm{G}^{(3,4)}$. Mutações nas hélices transmembranares podem mimetizar a situação de ocupação do ligante, causando mudanças no empacotamento das mesmas e/ou de domínios intra-celulares, e resultar na ativação constitutiva do receptor ${ }^{(108,155,160,161)}$. Observou-se na rodopsina que uma ponte salina entre a TM3 e TM7 é importante para manter o receptor no estado inativo; uma mutação que enfraqueça ou rompa esta interação ativa constitutivamente o receptor ${ }^{(160)}$. Experimentos de mutação sítiodirigida do LHR indicaram que interações entre a TM5 e TM6 têm um papel importante no mecanismo de ativação do receptor ${ }^{(108)}$. Pearlstein et al. ${ }^{(161)}$ construíram um modelo baseado num mapa $2 \mathrm{D}$ de densidade eletrônica do receptor da rodopsina bovina para $o$ LHR nativo e para alguns mutantes que ocorrem naturalmente, o qual sugere que um aglomerado hidrofóbico altamente empacotado entre as metades superiores da TM5 e da TM6 e uma rede de pontes de hidrogênio entre as partes centrais da TM6 e da TM7 são críticos para estabilizar a forma nativa do receptor e que uma única mutação é capaz de romper estas interações.

A mutação mais freqüentemente encontrada no LHR é Asp578Gly. Kosugi et al. (162) observaram que este resíduo, altamente conservado, é importante para manter a conformação inativa do receptor. Os resultados por eles obtidos sugerem que a habilidade de $\mathrm{Asp}^{578}$ de servir como um aceptor de pontes de hidrogênio adequadamente posicionado é mais importante para estabilizar o estado inativo do que sua carga negativa. Mutações por resíduos menores (Gly) ou de tamanho similar (Leu) são capazes de ativar a via de c-AMP. Por outro lado, mutações por resíduos volumosos, como os que possuem cadeias laterais aromáticas, também são capazes de ativar a via da fosfolipase $\mathrm{C}$, o que pode ser devido a um rompimento adicional do empacotamento inter-helicoidal ${ }^{(162)}$. Estas observações estão de acordo com o modelo proposto por Pearlstein, onde $\mathrm{Asp}^{578}$ é posicionado em direção à TM7 e é capaz de formar pontes de hidrogênio com $\operatorname{Asn}^{615}$ e Asn ${ }^{617}{ }^{(161)}$. A mutação de Asp por Gly implicaria numa perda dessas duas pontes de hidrogênio assim como na diminuição do empacotamento entre 
TM5 e TM6. Ainda, a mutação de Asp por Tyr interferiria com o resíduo de Ser $^{616}$ devido à cadeia lateral volumosa da Tyr ${ }^{(159,161)}$.

Além de Pearlstein et al. ${ }^{(161)}$, dois outros modelos do hLHR foram publicados respectivamente por Fanelli et al. ${ }^{(163)}$ e por Shinozaki et al. ${ }^{(164)}$, sendo que este último utiliza como molde a estrutura cristalina de alta resolução da rodopsina. Ambos os modelos mostram que os sítios do hLHR suscetíveis a mutações constitutivas estão próximos a aminoácidos altamente conservados na família dos receptores da rodopsina. Esses modelos também sugerem interações entre a TM6 e a TM7, entre a TM3 e a TM7 e que as TMs 6 e 7 desempenham um papel fundamental para estabilizar a estrutura inativa do hLHR, corroborando estudos de mutagênese ${ }^{(108,152,153)}$.

As estruturas preditas por esses modelos sugerem que as mutações introduzem modificações estruturais na superfície entre as TM3 e 6 e o citossol ${ }^{(163,164)}$. Dentre essas mutações, uma delas envolve o resíduo de $\mathrm{Arg}^{464}$ do hLHR, presente no motivo E/DRY. Propõe-se que o resíduo $\mathrm{Arg}^{464}$ forme uma ponte salina com dois outros resíduos, Glu ${ }^{463}$, adjacente ao primeiro, e também $\mathrm{Asp}^{564}$, localizado na i3. Com relação a este último resíduo, foi observado que várias mutações nessa posição provocam ativação constitutiva do receptor ${ }^{(156,159,165)}$.

É proposto que a substituição de $\mathrm{Arg}^{464}$ por outro resíduo implicaria na perda da das interações com um ou com ambos os resíduos mencionados acima ${ }^{(163-165)}$. De acordo com o modelo proposto por Fanelli et al. ${ }^{(163)}$, a interação $\mathrm{Arg}^{464}-\mathrm{Asp}^{564}$ contribui significativamente para a manutenção do estado inativo do hLHR. A quebra dessa interação resultaria na exposição maior ao solvente de resíduos da TM3 e da TM6 que se localizam na interface entre a membrana e o citossol. Essa hipótese está de acordo com estudos que demonstram que o rearranjo relativo da TM3 e da TM6 é essencial

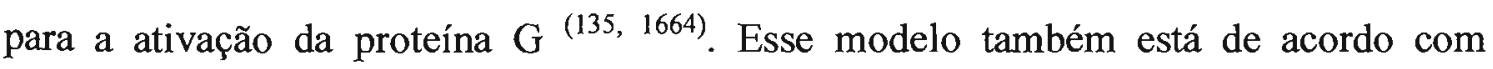
resultados que mostram que a TM5, a TM6 e a i3 estão envolvidos na ativação da proteína $\mathrm{G}^{(108,167)}$.

Shinozaki et al. ${ }^{(165)}$ também mostraram em seu modelo que a substituição de Leu $^{457}$ na TM3 por um resíduo catiônico causa ativação constitutiva do receptor. A substituição por um resíduo catiônico, como Lys, Arg ou His, resulta em interações novas com o resíduo de $\mathrm{Asp}^{578}$ na TM6, que são capazes de estabilizar a forma ativa do receptor. Esse estudo demonstra que a ativação constitutiva não resulta apenas da quebra de interações que estabilizam a forma inativa do receptor, mas também do aparecimento de interações novas que estabilizam a forma ativa. 
$\mathrm{Na}$ ausência de um cristal de alta resolução de outros GPCRs, estudos com mutantes constitutivamente ativos contribuem significativamente para elucidar o mecanismo de transdução de sinal.

\subsubsection{Vias de transdução de sinal ativadas pelo LHR}

O LHR foi um dos primeiros GPCRs para o qual se demonstrou a ativação independente de duas vias de transdução de sinal, a via de adenilato ciclase, resultando na produção de cAMP e a da fosfolipase C (PLC), resultando na produção de inositol trifosfato $\left(\mathrm{IP}_{3}\right)^{(168,169)}$.

É consenso na literatura que a primeira via ocorre através do acoplamento do receptor com $G_{s}(170,171)$. No entanto, a identidade das outras proteínas $G$ que são ativadas pelo LHR e quais delas resultam na produção de $\mathrm{IP}_{3}$ é controversa. Existem resultados que mostram que o LHR de rato é capaz de ativar $G_{s}$ e $G_{i 2}$, porém não ativa $\mathrm{G}_{\mathrm{q} / 11}, \mathrm{G}_{12}$ e/ou $\mathrm{G}_{13}{ }^{(172)}$. Outro grupo por sua vez, mostrou que o LHR porcino ativa $\mathrm{G}_{\mathrm{s}}$, $\mathrm{G}_{\mathrm{i}}, \mathrm{G}_{13}$ e $\mathrm{G}_{\mathrm{q} / 11}{ }^{(170,171)}$. Quanto à subunidade da proteína $\mathrm{G}$ que ativa a PLC os dados são conflitantes; alguns autores mostraram que a ativação da PLC pelo LHR é mediada pela subunidade $\beta \gamma$ liberada após a ativação de $G_{\mathrm{i} 2}$ e talvez $G_{\mathrm{s}}{ }^{(172)}$, enquanto outros mostraram que a PLC pode ser ativada pela subunidade $\mathrm{G} \alpha_{\mathrm{q}}$ liberada após a ativação de $\mathrm{G}_{\mathrm{q}}{ }^{(173)}$.

Enquanto o papel do cAMP como mediador da esteroidogênese é bem documentado na literatura, pouco se sabe sobre os processos mediados pela PLC quando da ativação pelo LHR. Foi observado que a ativação da PLC requer altas concentrações do hormônio ${ }^{(168)}$; por causa disso, foi proposto que esta via é importante durante o pico da produção de LH no ciclo pré-menstrual ou durante a gravidez ${ }^{(169)}$.

\subsection{O receptor $A T_{1 A}$ de angiotensina II e a interação com a proteina $G$.}

\subsubsection{O receptor $A T_{1 A}$ de angiotensina II}

A angiotensina II (DRVYIHPF) é um hormônio peptídico envolvido na regulação da pressão sangüínea e na homeostase de cálcio ${ }^{(174)}$. Esse peptídeo é formado a partir de uma proteína precurssora, o angiotensinogênio. $O$ angiotensinogênio é clivado por duas enzimas, a renina e a enzima conversora da angiotensina para dar origem à angiotensina II. 
Através de estudos farmacológicos envolvendo antagonistas não peptídicos postulou-se a existência de vários subtipos de receptores de angiotensina II ${ }^{(175,176)}$. Foram caracterizados farmacologicamente dois subtipos de receptores com alta

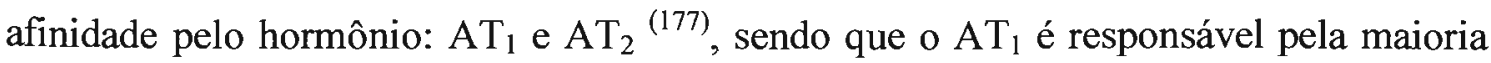
das respostas conhecidas ${ }^{(178)}$. Em algumas espécies, como humanos e ratos, o receptor $\mathrm{AT}_{1}$ possui duas isoformas, $\mathrm{AT}_{1 \mathrm{~A}}$ e $\mathrm{AT}_{1 \mathrm{~B}}$, com $95 \%$ de homologia e propriedades semelhantes ${ }^{(179)}$.

Assim como o LHR, o receptor $\mathrm{AT}_{1 \mathrm{~A}}$ de angiotensina II pertence à superfamília de receptores acoplados à proteína $\mathrm{G}$; a clonagem do receptor de rato revelou que este possui 359 aminoácidos (Fig. 9) ${ }^{(180)}$. Na região $\mathrm{N}$-terminal e na e2 são encontrados sítios de glicosilação que no entanto, parecem não ser importantes para a ligação do agonista, mas sim para o enovelamento correto do receptor ${ }^{(181)}$.

Seu domínio C-terminal possui vários resíduos de Ser, Thr e Tyr, sendo que alguns deles são fosforilados. Esses resíduos possuem um papel importante na internalização do receptor ${ }^{(182)}$.

A AngII possui alta afinidade pelo receptor $\mathrm{AT}_{1}{ }^{(183)}$. A ligação do hormônio ao receptor envolve a interação entre as cadeias laterais de resíduos de AngII e de resíduos localizados nas alças extracelulares e nas TMs. O resíduo de Lys ${ }^{199}$, localizado na TM5 do receptor interage com o grupo $\alpha$-carboxílico da $\mathrm{Phe}^{8}$ da AngII ${ }^{(78,184)}$. Outros resíduos também são importantes para a ligação da AngII e ativação do receptor, como a His ${ }^{256}$ que interagiria com $\mathrm{Phe}^{8}$ da AngII ${ }^{(185)} ; \mathrm{Asp}^{281}$ na TM7 que interagiria com $\mathrm{Arg}^{2}$ da AngII (185). Também foi observada que a interação entre $\mathrm{Tyr}^{4}$ da AngII com $\operatorname{Asn}^{111}$ na TM3 é importante para a ativação do receptor ${ }^{(112,186)}$. Outros estudos demonstraram que resíduos localizados na TM7, como Tyr ${ }^{292}$, são importantes para a ligação de AngII ao receptor e sua ativação ${ }^{(12,186-188)}$.

\subsubsection{Interação com a proteína $G$}

Conforme discutido anteriormente, foi observado que as regiões correspondentes às alças citossólicas e o domínio C-terminal dos GPCRs são importantes para o acoplamento com a proteína $\mathrm{G}^{(3,4)}$.

No caso do receptor $\mathrm{AT}_{1 \mathrm{~A}}$, o domínio C-terminal (CT) foi estudado por mutações dos resíduos carregados positivamente ${ }^{(189)}$, por deleção parcial ou total desse domínio ${ }^{(190)}$, pela produção de receptores quiméricos ${ }^{(191)}$ e através de peptídeos

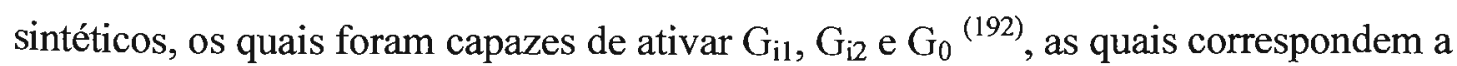




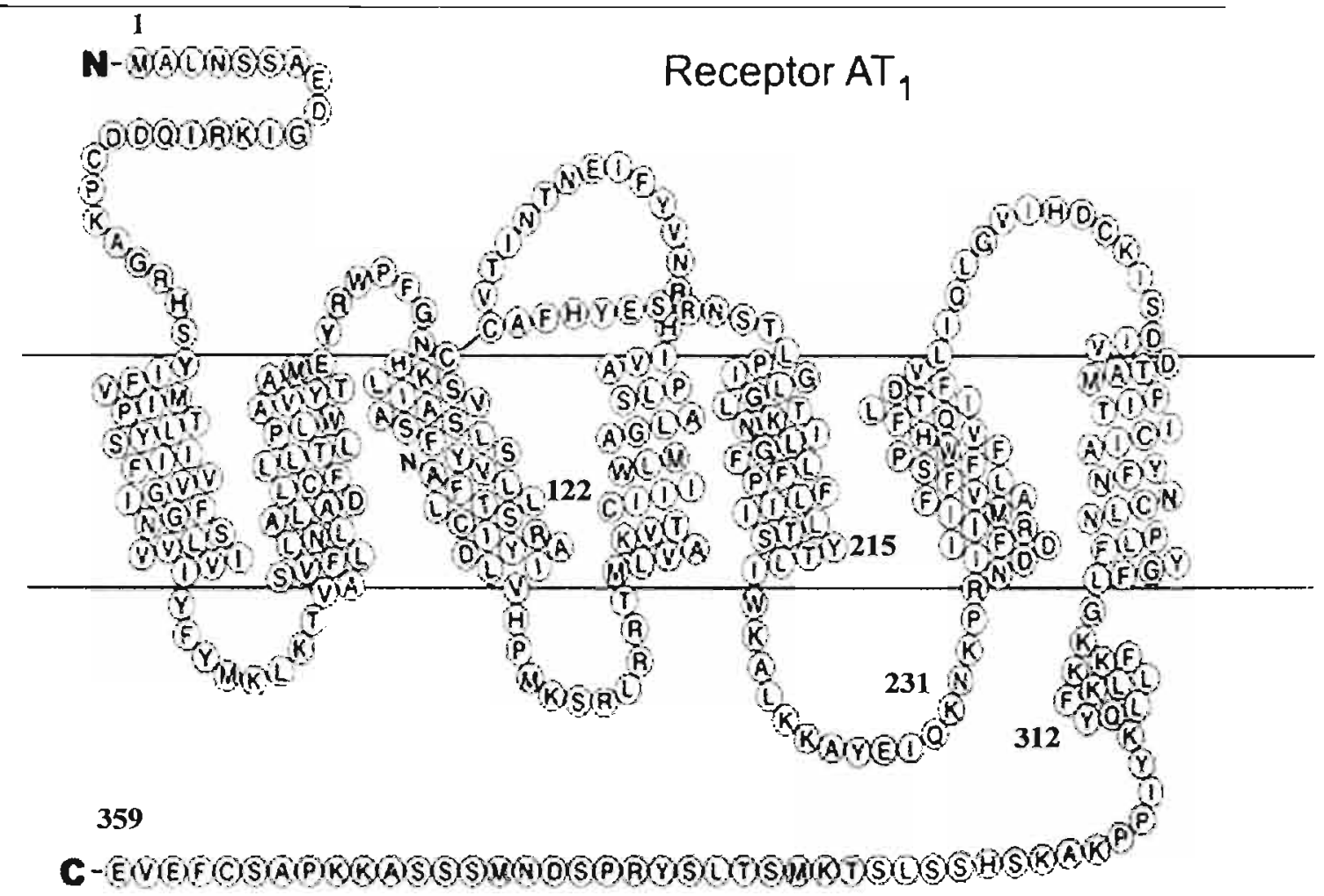

Figura 9 - Seqüência de aminoácidos e topografia do receptor $\mathrm{AT}_{1 \mathrm{~A}}$ do receptor de angiotensina II. A Figura mostra uma ponte dissulfeto entre os resíduos de Cys101 e Cys180 localizados respectivamente na TM3 e na e2 do receptor.

subespécies de proteína G. Os resultados experimentais mostraram que o CT é importante para o acoplamento e ativação da proteína $\mathrm{G}$ e que os resíduos $\mathrm{Tyr}^{312}$, $\mathrm{Phe}^{313}$ $\mathrm{e} \mathrm{Leu}^{314}$ desempenham um papel fundamental no mecanismo de ativação ${ }^{(193)}$.

Em nosso grupo, a Dra. T.A. Pertinhez (tese de doutoramento, 1998) mostrou experimentalmente por $\mathrm{CD}$ que um peptídeo correspondente à região proximal do domínio C-terminal do receptor $\mathrm{AT}_{\mathrm{IA}}$ de angiotensina II $(f-\mathrm{CT})$ possui tendência à formação de $\alpha$-hélice com o aumento da concentração do peptídeo, do $\mathrm{pH}$, da força iônica, da porcentagem de TFE, com a diminuição da temperatura e ainda na presença de micelas micelas de detergentes, tanto com carga superficial zero quanto com carga negativa. A estrutura deste fragmento foi determinada por NMR ${ }^{(48)}$ e os resultados estão de acordo com os dados de CD e de predições teóricas de que esse domínio forma uma $\alpha$-hélice anfipática.

A localização predita para o $f$-CT é no final da TM7, próximo à interface membrana-água. É proposto que a TM7 é um domínio do receptor que sofre deslocamento após a ligação do agonista ${ }^{(194)}$. Este rearranjo de sua posição poderia ser 
suficiente para deslocar o $f$-CT para uma região que favoreça a aquisição e/ou exposição da estrutura de hélice anfipática necessária para a interação com a com a proteína $\mathrm{G}^{(195)}$.

Quanto ao sítio de ligação na proteína $\mathrm{G}$, é proposto que o mesmo se localizaria na subunidade $\mathrm{G}_{\alpha}{ }^{\left({ }^{196)}\right.}$ e que incluiria as regiões $\mathrm{N}$-terminal e C-terminal ${ }^{(197)}$ dessa subunidade. Foi mostrado experimentalmente que essas regiões são importantes para a troca de GDP por GTP ${ }^{(125)}$. Oliveira et $a l^{(197)}$ propuseram que o acoplamento do $f$-CT com a subunidade $\alpha$ da proteína $\mathrm{G}$ se daria por uma interação entre múltiplas $\alpha$-hélices, ou seja, que haveria uma interação entre a $\alpha$-hélice anfipática formada pelo $f$-CT, uma porção $\alpha$-helicoidal do C-terminal (CG) e uma porção, também em $\alpha$-hélice, do Nterminal da proteína $\mathrm{G}$.

Outras regiões importantes para o acoplamento com a proteína $\mathrm{G}$ são as regiões $\mathrm{N}$ - e C-terminais da i3 ${ }^{(198,199)}$. Estudos de mutagênese mostraram que os resíduos 219 a 225 no N-terminal da i3 (Ni3) do receptor $\mathrm{AT}_{1 \mathrm{~A}}$ é importante para o acoplamento com a proteína $\mathrm{G}^{(199)}$. Também foi observado que peptídeos sintéticos correspondentes a esse domínio foram capazes de ativar a proteína $\mathrm{G}^{(192,199)}$. O mesmo não foi verificado para um fragmento correspondente à porção C-terminal da i3 $(\mathrm{Ci} 3)$ do receptor $\mathrm{AT}_{1 \mathrm{~A}}{ }^{(193,200)}$, embora tenha sido observado na literatura que os resíduos 232 a 235 da Ci3 são importantes para ativar a proteína $\mathrm{G}^{(199)}$.

Franzoni et al. ${ }^{(49)}$ observaram por NMR que o fragmento Ni3 é capaz de formar uma $\alpha$-hélice anfipática em água-30\% TFE, enquanto que o fragmento $\mathrm{Ci} 3$ possui baixa propensão à formação de estrutura $\alpha$-helicoidal; essas diferenças podem estar relacionadas com a capacidade de cada peptídeo de ativar a proteína $G$.

Outra região importante para ativação da proteina $\mathrm{G}$ é a correspondente a i2 ${ }^{(190)}$. É proposto que a seqüência Asp-Arg-Tyr (DRY, resíduos 125-127) na porção Nterminal da i2 é essencial para o acoplamento com $G_{q}{ }^{(201)}$ e importante para o acoplamento com outras proteínas $\mathrm{G}^{(202)}$. Essa seqüência é altamente conservada entre os GPCRs ${ }^{(201)}$. Inagami et al ${ }^{(203)}$ mostraram que o resíduo $\mathrm{Asp}^{125}$ é essencial para o acoplamento com a proteína $\mathrm{G}, \operatorname{Arg}^{126}$ é essencial para o acoplamento com $\mathrm{G}_{\mathbf{q}}$, porém não para outras proteínas $\mathrm{G}$ e que $\mathrm{Tyr}^{127}$ não é importante para o acoplamento com a proteína G.

Observou-se por CD que um fragmento correspondente a i2 (resíduos 122-146) do receptor $\mathrm{AT}_{1 \mathrm{~A}}$ possui estrutura ao acaso em solução e possui tendência à formação 
de $\alpha$-hélice em concentrações crescentes de TFE e na presença de membranas modelo com carga líquida negativa (Dr. C.S. Shida, trabalhos não publicados).

Esses resultados estão de acordo com a proposta de Griendling et al ${ }^{(134)}$, que propõe que essas regiões (i2, i3 e CT) formam uma superfície de ligação do receptor $\mathrm{AT}_{1 \mathrm{~A}}$ com a proteína $\mathrm{G}$. 


\section{Objetivos}

O trabalho desenvolvido durante esta tese consistiu de dois projetos. O primeiro consistiu no estudo das propriedades conformacionais de um fragmento correspondente à porção proximal da TM6 do hLHR, compreendendo os resíduos 570-580, cuja seqüência é KMAILIFTDFT. Além da seqüência nativa, estudou-se a conformação de dois peptídeos contendo mutações relacionadas com FMPP, a saber, KMAILIFTGFT (II) e KMAILIFTYFT (III). Estudando-se a conformação desses fragmentos, procurouse entender como a troca de apenas um aminoácido é capaz de provocar ativação constitutiva.

Para tal, investigaram-se as propriedades conformacionais de I, II e III em solução aquosa em função do $\mathrm{pH}$, estudou-se o efeito de um agente indutor de estrutura secundária (trifluoroetanol, TFE) e a conformação desses fragmentos na presença de modelos de membrana, tanto detergentes quanto vesículas fosfolipídicas. Esses estudos foram realizados por dicroísmo circular (CD) para os peptídeos I e II e por CD e fluorescência para III, uma vez que este último é o único fragmento que possui um aminoácido fluorescente.

A segunda parte desta parte deste trabalho consistiu no estudo das propriedades conformacionais de um peptídeo correspondente à porção C-terminal da subunidade $\alpha$ da proteína $\mathrm{G}(\mathrm{CG})$, em solução aquosa e na presença de membranas modelo. Para tal, foi sintetizado um peptídeo correspondente aos resíduos 341-359 de $\mathrm{G}_{\mathrm{q} \alpha}$, cuja seqüência é FAAVKDTILQLNLKEYNLV. Os estudos em solução aquosa foram feitos em função do $\mathrm{pH}$, força iônica e temperatura, assim como o efeito do TFE. Na presença de membranas modelo, estudou-se a conformação de CG na presença de micelas de HPS, LPC e SDS.

Os estudos com CG serviram como base para realizar outra parte deste projeto, que consistiu no estudo da interação entre esse fragmento e fragmentos do receptor $\mathrm{AT}_{1 \mathrm{~A}}$ de angiotensina II, a saber, a porção $\mathrm{N}$-terminal da região C-terminal (LFYGFLGKKFKKYFLQLLKYI, resíduos 300-321, $f$-CT), a porção N-terminal da terceira alça intra-celular (TSYTLIWKALKKAYEIQKN, resíduos 213-231, Ni3) e a segunda alça intracelular (LIDRYLAIVHPMKSRLRRTMLVAK, resíduos 122-146, i2). 


\section{Materiais e Métodos}

\subsection{Materiais}

\subsubsection{Peptídeos}

Os peptídeos correspondentes à porção N-terminal da TM6 do LHR foram fornecidos pela Dra. Deborah Segaloff (Tabela 1), os quais foram sintetizados pela empresa Multiple Peptide Systems, San Diego, CA. Os peptídeos foram sintetizados na forma de amida C-terminal pelo método de síntese em fase sólida de Merrifield ${ }^{(204,205)}$ e purificados por HPLC de fase reversa, sendo que os peptídeos possuem grau de pureza maior que $95 \%$. A solução estoque dos peptídeos foi preparada em TFE, pois os mesmos são muito pouco solúveis em água.

Os peptídeos correspondentes ao do domínio C-terminal da subunidade $\alpha$ da proteína $\mathrm{G}(\mathrm{CG})$ e às porções $\mathrm{C}$-terminal e a i2 do receptor $\mathrm{AT}_{1 \mathrm{~A}}$ (Tabela 1) foram sintetizados no Departamento de Biofísica da Universidade Federal de São Paulo, pela equipe do Dr. Clóvis R. Nakaie, na forma de amida C-terminal pelo método de síntese em fase sólida fazendo uso da estratégia t-Boc para o $\alpha$-amino grupo ${ }^{(204,205)}$. O peptídeo foi purificado por HPLC de fase reversa, obtendo-se um grau de pureza maior que $95 \%$. Para tal, utilizou-se um equipamento da Waters, modelo Delta Prep 4000, acoplado a um detector UV-Vis (modelo 486), coletor de frações LKB-Frac-200 da Pharmacia e registrador Servogor 120. De um modo geral, utilizam-se colunas semi-preparativas ou preparativas Vydac $\mathrm{C}_{18}(10 \times 250$ e $25 \times 250 \mathrm{~mm}$, respectivamente, diâmetro dos poros de 300 $\AA$ e diâmetro dos grãos da resina de $15-20 \mu \mathrm{m}$ ). A identidade do peptídeo foi confirmada por análise de aminoácidos e por espectrometria de massa em um sistema LCMS da Waters, o qual é constituído por um módulo de separação Alliance, modelo 2690; detector photo diode array, modelo 996; injetor automático, com capacidade de 120 amostras e espectrômetro de Micromass, modelo VMD. O sistema é controlado por uma Workstation Compaq, modelo AP-200.

No caso do CG, uma solução estoque do peptídeo foi preparada dissolvendo-o em $100 \%$ TFE, pois o mesmo é pouco solúvel em água. Os outros peptídeos (f-CT, Ni3 e i2) 
são aquossolúveis, dessa forma estes foram dissolvidos em água Milli-Q para preparar soluções estoque.

Tabela 1. - Seqüências dos peptídeos utilizados neste estudo.

\begin{tabular}{cc}
\hline Peptídeo & Seqüência \\
\hline Fragmentos da TM6 do LHR & resíduos 570-580 \\
I & KMAILIFTDFT-NH ${ }_{2}$ \\
II & KMAILIFTGFT-NH ${ }_{2}$ \\
III & KMAILIFTYFT-NH ${ }_{2}$ \\
\hline
\end{tabular}

Fragmentos do receptor $\mathrm{AT}_{1 \mathrm{~A}}$ de angiotensina II

$\begin{array}{cc}f \text {-CT } & \text { LFYGFLGKKFKKYFLQLLKYI-NH } \\ \text { i2 } & \text { resíduos 300-321 } \\ & \text { LSIDRYLAIVHPMKSRLRRTMLVAK-NH } \\ & 122-146 \\ \mathrm{Ni} 3 & \text { TSYTLIÍduos } \\ \end{array}$

Fragmento C-terminal da

subunidade $\alpha$ da proteína $\mathrm{G}$

CG $\quad$ FAAVKDTILQLNLKEYNLV-NH ${ }_{2}$, resíduos 341-359

\subsubsection{Detergentes}

A interação dos peptídeos com micelas foi realizada utilizando-se detergentes zwitteriônicos, a saber, N-hexadecil-N,N-dimetil-3-amônio-1-propano-sulfonato (HPS) e 1palmitoil-2-hidroxi-lisofosfatidilcolina (LPC), e um detergente carregado negativamente, dodecil-sulfato de sódio (SDS) (Fig. 10); a cmc de HPS, LPC e SDS é de 5,0 × $10^{-5} \mathrm{M}, 7,0$ $\times 10^{-6} \mathrm{M} \mathrm{e} 8,0 \times 10^{-3} \mathrm{M}$, respectivamente ${ }^{(206-208)}$. Os estudos foram realizados nos $\mathrm{pHs} 3,0$, $4,0,7,0$ e 10,0 .

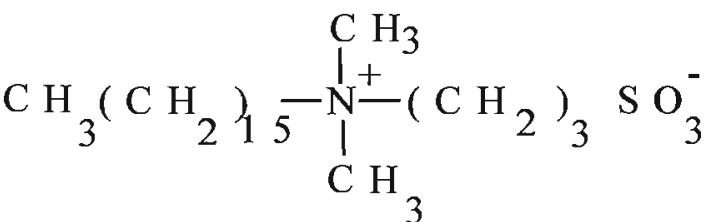

(a)

$$
\mathrm{CH}_{3}-\left(\mathrm{CH}_{2}\right)-\mathrm{SO}_{4}^{-} \mathrm{Na}^{+}
$$

(b)<smiles>CCCCCCCCCCCCCCCC(=O)OCC(O)COP(=O)([O-])OCC[N+](C)(C)C</smiles>

(c)

Figura 10. - Estrutura química dos detergentes utilizados. (a) HPS, (b) SDS e (c) LPC. 


\subsubsection{Fosfolipídios}

A interação dos peptídeos com fosfolipídios foi estudada preparando-se vesículas contendo fosfolipídios com carga líquida neutra, 1-palmitoil-2-oleil-fosfatidilcolina (POPC) e com vesículas contendo POPC e um fosfolipídio com carga líquida negativa, 1-palmitoil2-oleil-fosfatidilglicerol (POPG) na proporção 9:1, mol:mol (Fig. 11).
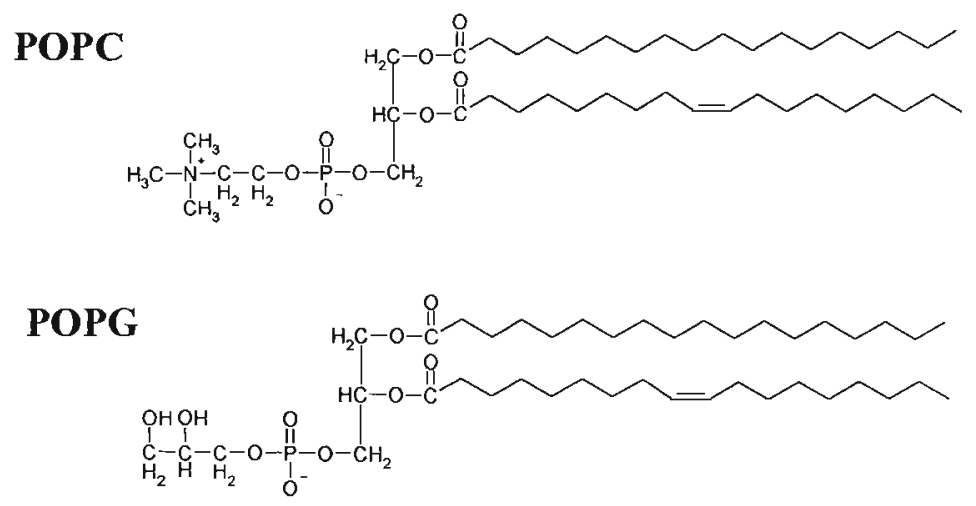

Figura 11 - Estrutura química dos fosfolipídios utilizados nesse estudo.

\subsection{Métodos}

\subsubsection{Determinação da concentração de peptídeos}

A concentração dos peptídeos derivados do LHR em solução foi determinada lendose a absorbância a $257 \mathrm{~nm}$ para I e II e a $275 \mathrm{~nm}$ para III em um espectrofotômetro Hitachi U-2010. Os coeficiente de extinção molar $(\varepsilon)$ utilizados foram $\varepsilon_{257}=394 \mathrm{M}^{-1} \mathrm{~cm}^{-1}$ para I e II, e $\varepsilon_{275}=1420 \mathrm{M}^{-1} \mathrm{~cm}^{-1}$ para III ${ }^{(209)}$.

Com relação aos peptídeos do receptor de angiotensina e ao $\mathrm{CG}$, a concentração foi determinada lendo-se a absorbância em 275 nm. Os coeficientes de extinção molar foram $\varepsilon_{275}=1420 \mathrm{M}^{-1} \mathrm{~cm}^{-1}$ para o CG e para o i2, $\varepsilon_{280}=8440 \mathrm{M}^{-1} \mathrm{~cm}^{-1}$ para o Ni3 e $\varepsilon_{275}=$ $4260 \mathrm{M}^{-1} \mathrm{~cm}^{-1}$ para of $-\mathrm{CT}^{(209)}$.

Para os experimentos onde foi feito um filme do peptídeo, não foi possível determinar a concentração por absorbância, uma vez que na presença de grandes quantidades de detergente ocorre significativo espalhamento de luz. A concentração 
indicada nos experimentos é baseada na diluição a partir da solução estoque dos peptídeos em TFE.

\subsection{2. $f-C T, C G, N i 3$ e i2 na presença de detergentes.}

$\mathrm{O}$ estudo dos peptídeos na presença de detergentes foi realizado de duas maneiras. Para facilitar a redação da tese, estes serão chamados respectivamente de método a e método $\mathbf{b}$.

Método a: uma alíquota dos detergentes foi adicionada à solução aquosa contendo o peptídeo a ser estudado.

Método b: uma solução contendo os detergentes foi adicionada a um filme do peptídeo obtido por evaporação do solvente da solução estoque (TFE). O recipiente foi agitado por vórtex durante 20 minutos. Além disso, o recipiente foi aquecido em banhomaria por pequenos intervalos durante a agitação para facilitar a captação dos peptídeos.

\subsubsection{Preparação de filmes.}

Filmes de peptídeos foram feitos retirando-se alíquotas das soluções estoque para um tubo de ensaio, as amostras foram secas com nitrogênio e submetidas a vácuo por 30 minutos. Em seguida, os filmes foram hidratados conforme descrito no método b.

\subsubsection{Preparação de bicamadas fosfolipídicas}

Filmes de fosfolipídios foram preparados a partir de soluções clorofórmicas dos mesmos. As amostras foram secas com nitrogênio e em seguida submetidas à vácuo por 2 horas para garantir que todo o solvente tivesse sido evaporado. Em seguida, os filmes foram hidratados com água Milli-Q e extrudados em membranas de policarbonato com poro de $100 \mathrm{~nm}$ de diâmetro a fim de obter vesículas unilamelares grandes (LUV).

\subsection{Técnicas espectroscópicas}

\subsubsection{Dicroísmo circular}

A técnica de dicroísmo circular (CD) detecta a atividade óptica de moléculas quirais originada pela interação de centros assimétricos com a luz circularmente polarizada. Este fenômeno é representado pela diferença de absorção entre a luz polarizada à direita e à esquerda. Em proteínas e em peptídeos os cromóforos responsáveis pelo espectro de $\mathrm{CD}$ 
são a ligação amida, os resíduos aromáticos de triptofano, tirosina e fenilalanina, e as pontes dissulfeto ${ }^{(210)}$.

A rotação ao redor da ligação $\mathrm{O}=\mathrm{C}-\mathrm{NH}$ da amida peptídica é restrita devido ao caráter de dupla ligação resultante da coplanaridade dos átomos CONH. Existem apenas duas ligações cuja rotação é permitida: $\mathrm{C} \alpha-\mathrm{NH}$, cujo ângulo de rotação é $\phi$ e $\mathrm{CO}-\alpha-\mathrm{NH}$, cujo ângulo de rotação é $\Psi$. Os ângulos específicos $\phi$ e $\Psi$ são os responsáveis pelo espectro de CD característico das estruturas secundárias, $\alpha$-hélice, folha $\beta$ paralela e anti-paralela, vários tipos de dobras $\beta$ e estrutura randômica. $O$ cromóforo amida apresenta as transições : $\mathrm{n} \rightarrow \pi^{*}$, centrada próximo a $220 \mathrm{~nm}$, com energia de transição menor, e $\pi \rightarrow \pi^{*}$ centrada em $190 \mathrm{~nm}^{(211)}$.

Quando a proteína está enovelada, o arranjo tridimensional dos cromóforos afeta a estrutura eletrônica e, em conseqüência, o espectro da proteína ou peptídeo. Para as proteínas com estrutura ao acaso, as interações de longa distância são mínimas e seu espectro é composto das duas bandas, $n \rightarrow \pi^{*}$ e $\pi \rightarrow \pi^{*}$. A estrutura $\beta$ apresenta uma banda $\mathrm{n} \rightarrow \pi^{*}$ centrada em $215 \mathrm{~nm}$ e uma banda $\pi \rightarrow \pi^{*}$ centrada em $196 \mathrm{~nm}$, as quais são originadas pelos elétrons desemparelhados do oxigênio da carbonila. $O$ espectro de uma $\alpha$ hélice possui essas mesmas bandas. Contudo, ele é mais complicado pois nele a transição $\pi \rightarrow \pi^{*}$ é desdobrada em $\pi \rightarrow \pi^{*}(\perp)$, centrada em $191 \mathrm{~nm}$, e $\pi \rightarrow \pi^{*}(/ /)$ centrada em $208 \mathrm{~nm}$. A transição $n \rightarrow \pi^{*}$ é deslocada para menor energia, centrada em $222 \mathrm{~nm}{ }^{(212)}$. A Figura abaixo apresenta espectros característicos de CD das estruturas secundárias acima mencionadas. 


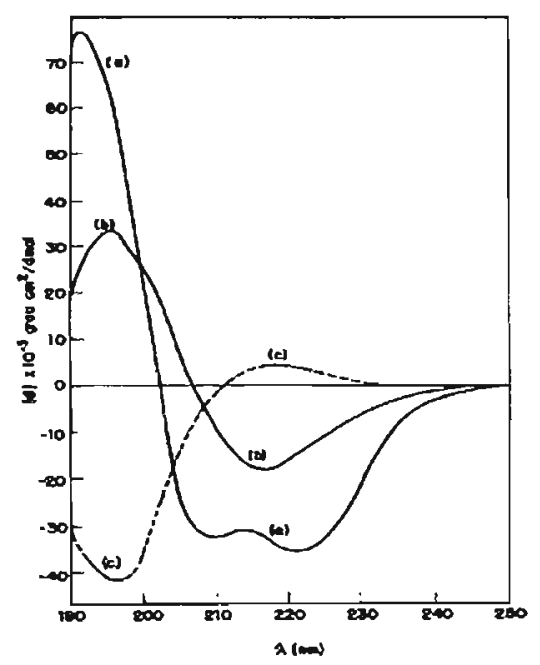

Figura 12 - Espectros de CD característicos das estruturas secundárias (a) $\alpha$-hélice, (b) folha $\beta$ pregueada e (c) estrutura randômica ${ }^{(213)}$.

Com relação a estrutura $\alpha$-helicoidal, a intensidade do espectro de $\mathrm{CD}$ depende do número de resíduos na cadeia polipeptídica que participam desse tipo de estrutura. $\mathrm{Na}$ literatura, Chen et al. ${ }^{(214)}$ desenvolveram uma equação para estimar o conteúdo de $\alpha$-hélice em proteínas, que leva em consideração o valor de elipticidade molar residual em $222 \mathrm{~nm}$ e o tamanho da cadeia polipeptídica. Essa equação está descrita abaixo:

$$
[\theta]_{\lambda}=\left(f_{\mathrm{H}}-i k / N\right)[\theta]_{\mathrm{H} \infty}(1)
$$

onde $[\theta]_{\lambda}$ é a elipticidade molar residual no comprimento de onda $\lambda,[\theta]_{H_{\infty}}$ é o máximo de elipticidade molar residual para uma hélice de tamanho infinito, $f_{\mathrm{H}}$ é a fração de hélice na molécula, $i$ corresponde ao número de segmentos helicoidais, $N$ corresponde ao número de resíduos e k é uma constante que depende de $\lambda$, no caso equivale a 2,57 em $222 \mathrm{~nm}$.

Além da equação acima, existe outra equação desenvolvida por Baldwin et al. ${ }^{(215)}$ utilizada para estimar o conteúdo de estrutura secundária em peptídeos. Essa equação também se baseia no valor de elipticidade molar residual em $222 \mathrm{~nm}\left([\theta]_{222}\right)$ e leva em consideração a contribuição de resíduos ao acaso tanto no $\mathrm{N}$ - como no C-terminal e a temperatura. A equação está descrita abaixo:

$$
[\theta]_{222}=\left[f_{\mathrm{H}} \theta_{\mathrm{H}}\left(f_{\mathrm{H}}-x / N_{r}\right)\right]+\left[\left(1-f_{\mathrm{H}}\right) \theta_{\mathrm{C}}\right](2) ;
$$

onde $\theta_{\mathrm{C}}=640-45 \mathrm{~T}, \theta_{\mathrm{H}}=42500+125 \mathrm{~T}$; sendo que $\mathrm{T}$ é a temperatura em graus Celcius; $\theta_{\mathrm{C}}$ e $\theta_{\mathrm{H}}$ correspondem, respectivamente, ao valor de elipticidade molar residual para um peptídeo de tamanho infinito ao acaso e completamente helicoidal; $\mathrm{x}$ é o parâmetro de 
correção para o tamanho da cadeia, que no caso de um peptídeo amidado no C-terminal equivale a $3 ; \mathrm{N}_{\mathrm{r}}$ corresponde ao número de resíduos na cadeia.

\subsubsection{Aquisição}

Os espectros de CD foram adquiridos em um espectropolarímetro CD6 Jobin-Yvon, em celas de $1,0 \mathrm{~mm}$ de caminho óptico. $\mathrm{O}$ número de varreduras variou de acordo com o experimento. Em geral, utilizamos 4 varreduras por espectro com tempo de integração de 3 $\mathrm{s}$ por ponto. Para todos os experimentos a leitura foi feita a cada $0,5 \mathrm{~nm}$. O aparelho foi calibrado com ácido-(+)-10-canforsulfônico, conforme o manual do equipamento.

\subsubsection{Fluorescência ${ }^{(216)}$}

O fenômeno da fluorescência é observado quando um elétron retorna do estado singlete excitado $\left(S_{1}\right)$, de maior energia, para o estado singlete fundamental, de menor energia $\left(S_{0}\right)$, resultando na emissão de um fóton. Substâncias que apresentam fluorescência significativa geralmente possuem elétrons delocalizados presentes em ligações duplas conjugadas. Ao incidir-se um feixe de luz, o fluoróforo absorve o quantum de energia adequado em $\mathrm{S}_{0}$, resultando na promoção instantânea $\left(10^{-15} \mathrm{~s}\right)$ para níveis eletrônicos de maior energia $S_{1}$ ou $S_{2}$. Com raras exceções, moléculas em fases condensadas, como em solução aquosa, rapidamente relaxam para o nível de energia vibracional mais baixo em $S_{1}$. Este processo é chamado de conversão interna e ocorre em torno de $10^{-12} \mathrm{~s}$. A volta ao estado fundamental ocorre a partir daí para vários níveis vibracionais de $\mathrm{S}_{0}$. Outros processos podem ocorrer, como decaimento não-radioativo, onde a molécula relaxa para o estado fundamental sem emitir fótons. Ainda, moléculas no estado $S_{1}$ podem sofrer conversão para o primeiro estado triplete $\left(T_{1}\right)$, chamado de cruzamento entre sistemas. A transição de $\mathrm{T}_{1}$ para o nível fundamental em $\mathrm{S}_{0}$ é proibida, e como resultado a constante de velocidade para tal emissão é várias ordens de grandeza menor do que para fluorescência. A emissão a partir de $T_{1}$ é chamada de fosforescência e seus tempos de vida são da ordem de $10^{-6} \mathrm{~s}$ a mais de $1 \mathrm{~s}$. Esses processos estão representados no diagrama de Jablonski (Fig. 13). 


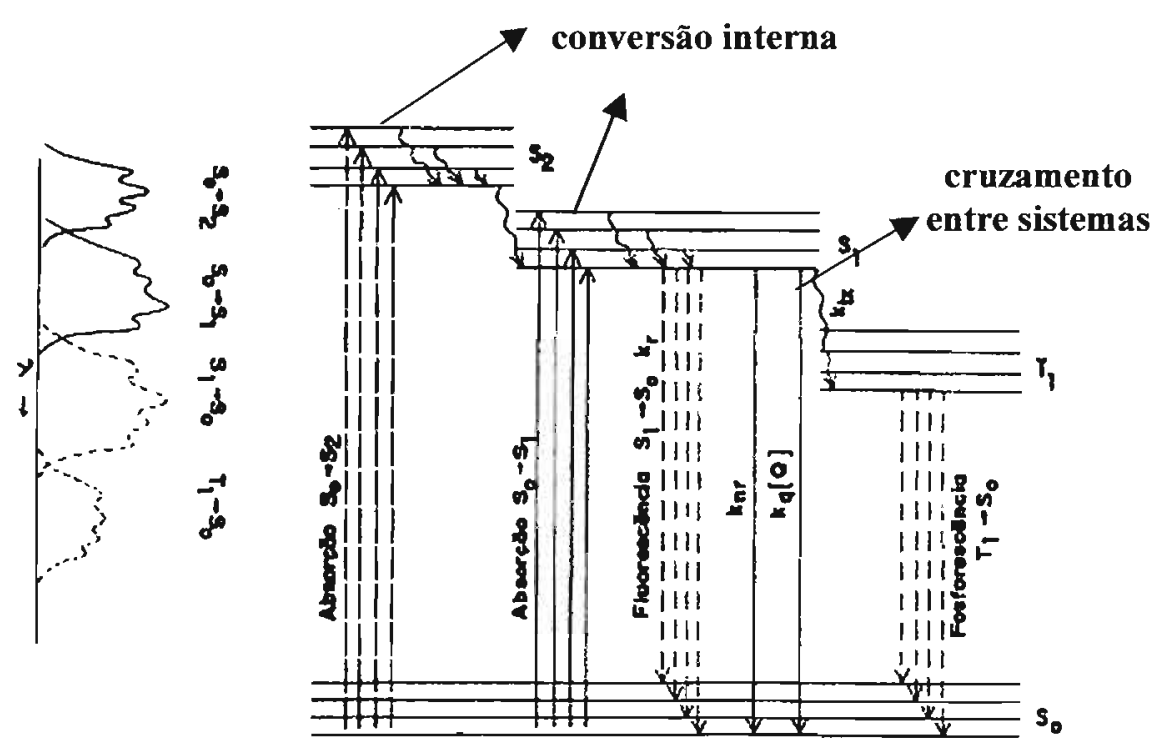

Figura 13 - Diagrama de Jablonski para a absorção de fótons do estado fundamental $\left(\mathrm{S}_{0}\right)$ para os estados singlete excitados $\left(\mathrm{S}_{1}\right.$ e $\left.\mathrm{S}_{2}\right) \cdot \mathrm{T}_{1}$ é o primeiro estado triplete excitado. Espectros para as várias transições apresentados a esquerda ${ }^{(217)}$.

A fluorescência de proteínas e peptideos se origina dos resíduos aromáticos de triptofano e tirosina. A fenilalanina possui um rendimento quântico muito baixo e por isso a emissão deste resíduo raramente é observada. Geralmente, os experimentos de fluorescência de proteínas são feitos excitando-se no comprimento de onda do máximo de absorção, em torno de $280 \mathrm{~nm}$, onde o espectro de emissão se deve à contribuição tanto de Tyr como de Trp. Contudo, é possível excitar-se seletivamente o Trp entre 295 e $305 \mathrm{~nm}$. Nessa região pode-se excitar também o tirosinato, que apresenta emissão em torno de 345 nm. $\mathrm{O} \mathrm{pK}$ a do grupo hidroxila da tirosina é perto de 10,5; contudo, este valor pode decrescer a 4,0 ou menos ao excitar-se, e mesmo a ionização do estado fundamental pode ocorrer até em pH neutro. A emissão de tirosinato geralmente é fraca devido ao seu baixo rendimento quântico. Contudo, assim como no caso do Trp, a emissão do tirosinato pode servir como uma sonda para estudar o ambiente em torno da proteína. Os fluoróforos são sensiveis ao ambiente que os circunda; a interação destes com moléculas do solvente altera a energia do estado excitado e, consequentemente, a freqüência de emissão. Assim, propriedades como comprimento de onda do máximo de emissão $\left(\lambda_{\text {máx }}\right)$, rendimento quântico $\left(\phi_{\mathrm{F}}\right)$, tempo de vida do fluoróforo $\left(\tau_{\mathrm{F}}\right)$, e propriedades de polarização podem ser utilizadas para caracterizar propriedades estruturais das proteínas. 


\subsubsection{Supressão da intensidade de fluorescência ${ }^{(216)}$}

A supressão da fluorescência refere-se a qualquer processo que resulte na diminuição da intensidade de fluorescência de uma dada substância, os quais incluem: reações no estado excitado, transferência de energia, formação de complexos, ou supressão estática, e supressão colisional, também chamada de supressão dinâmica. A supressão colisional da fluorescência é descrita pela equação de Stern-Volmer:

$$
\mathrm{F}_{0} / \mathrm{F}=1+k_{\mathrm{q}} \tau_{0}[\mathrm{Q}]=1+K_{\mathrm{SV}}[\mathrm{Q}]
$$

onde $\mathrm{F}_{0}$ e $\mathrm{F}$ são as intensidades de fluorescência na ausência e na presença de supressor, $k_{\mathrm{q}}$ é a constante de supressão bimolecular e $\tau_{0}$ é o tempo de vida do fluoróforo na ausência do supressor, Q. $K_{\mathrm{SV}}=k_{\mathrm{q}} \tau_{0}$ é a constante de Stern-Volmer.

Devido à grande absorção da acrilamida, particularmente no comprimento de onda usado para excitação, a intensidade de fluorescência foi corrigida de acordo com:

$$
\mathrm{I}(\lambda)_{\text {corr }}=\mathrm{I}(\lambda)_{0} \mathrm{e}^{2,3 \text { Aexc } 1 / 2 \mathrm{D}} \mathrm{e}^{2,3 \text { Aem } 1 / 2 \mathrm{D}^{\prime}}
$$

onde $I(\lambda)_{0}$ e $I(\lambda)_{\text {corr }}$ são, respectivamente, as intensidades de fluorescência medida e corrigida em dado comprimento de onda. $A_{\text {exc }}$ e $A_{e m}$ são, respectivamente, os valores de absorção nos comprimentos de onda de excitação e de máximo de emissão da amostra. D e D'são os caminhos ópticos das celas usadas para excitação e emissão respectivamente.

\subsubsection{Aquisição}

Os espectros de fluorescência foram adquiridos em um fluorímetro Hitachi F-4500 em celas de 1,0 cm de caminho óptico. As amostras foram excitadas em $275 \mathrm{~nm}$ e os espectros de emissão de Tyr foram adquiridos entre 285 e $500 \mathrm{~nm}$. A titulação do grupo fenol da cadeia lateral da tirosina também foi acompanhada por fluorescência. Para observar o espectro de emissão de fenolato, as amostras foram excitadas em $292 \mathrm{~nm}$ e os espectros adquiridos entre 300 e $500 \mathrm{~nm}$. Todos os espectros tiveram a linha de base subtraída. 


\section{Resultados}

\subsection{Estudo conformacional da TM6 do LHR e de seus mutantes envolvidos em FMPP}

\subsubsection{Predições teóricas}

O conteúdo de estrutura secundária do peptídeo nativo (I) e de seus análogos (II e III), resíduos 570-580, foi estimado empregando-se o método de redes neurais desenvolvidos por Rost et al. ${ }^{(218)}$ (Fig. 14). A predição teórica foi feita para a região que corresponde aos resíduos 564-604 do LHR, que engloba a porção C-terminal da i3 e a toda a TM6 do LHR.

Os resultados obtidos indicam que a região que compreende o peptídeo nativo não possui propensão significativa a adquirir $\alpha$-hélice (Fig. 14a). Observa-se que a região compreendida entre a porção C-terminal da i3 e N-terminal da TM6 possui em média $50 \%$ de conteúdo $\alpha$-helicoidal, enquanto que a região que corresponde a parte central da TM6 possui propensão maior, em torno de $70 \%$. De acordo com a predição, a região C-terminal deste fragmento, $\mathrm{Val}^{596}-\mathrm{Ser}^{604}$, estaria ao acaso. Na literatura foi observado por NMR que um fragmento que corresponde a porção C-terminal da i3 e N-terminal da TM6, resíduos $560-585$, forma $\alpha$-hélice em solução na presença de $50 \%$ TFE ${ }^{(219)}$. Segundo esses resultados, os resíduos que fazem parte da hélice correspondem a porção $\mathrm{N}$-terminal da TM6, o que corrobora a predição teórica.

Com relação aos peptídeos análogos, observa-se que a substituição de $\mathrm{Asp}^{578}$ por Gly (II) ou Tyr (III) (Fig. 14b e 14c) induz um aumento significativo do conteúdo de estrutura $\alpha$-helicoidal, principalmente na região N-terminal. A substituição por esses aminoácidos poderia resultar em um aumento das interações entre as cadeias laterais dos aminoácidos que poderia resultar em um aumento do conteúdo de estrutura secundária.

\subsubsection{Estudos em solução aquosa e na presença de TFE}

Em solução aquosa, observou-se que os peptídeos estudados possuem forte tendência à agregação, mesmo em concentrações baixas. A agregação provavelmente está relacionada com o fato de que esses fragmentos possuem um conteúdo significativo de resíduos hidrofóbicos. 
(a)
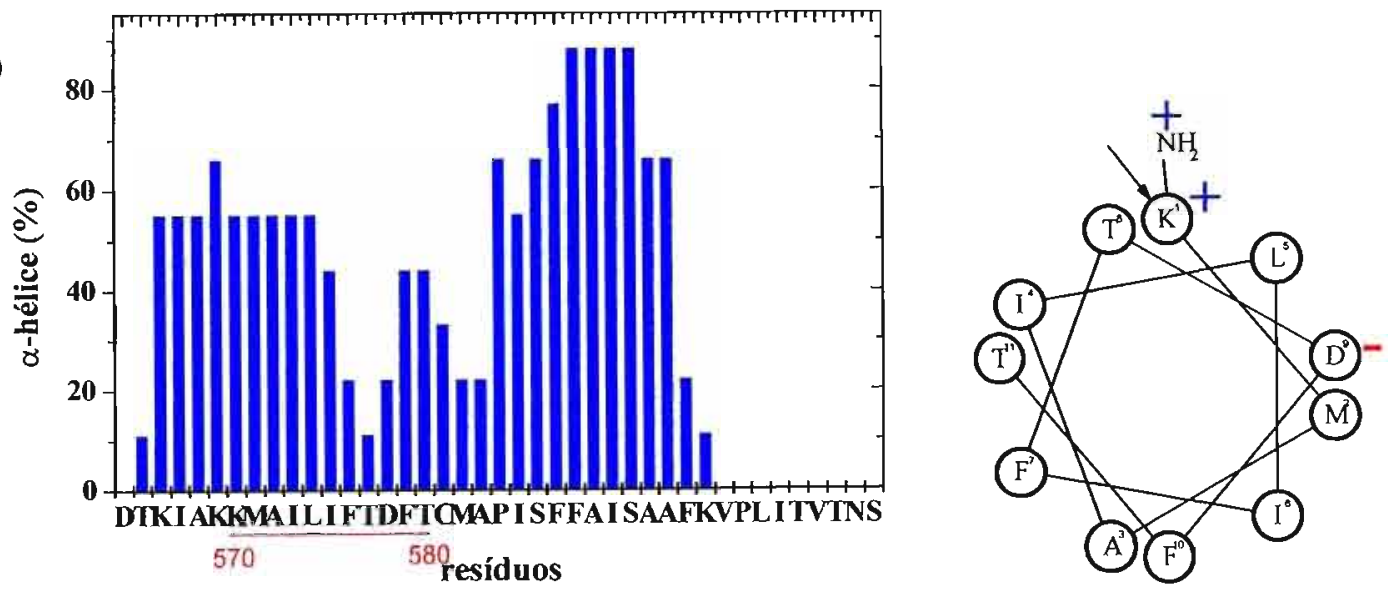

(b)
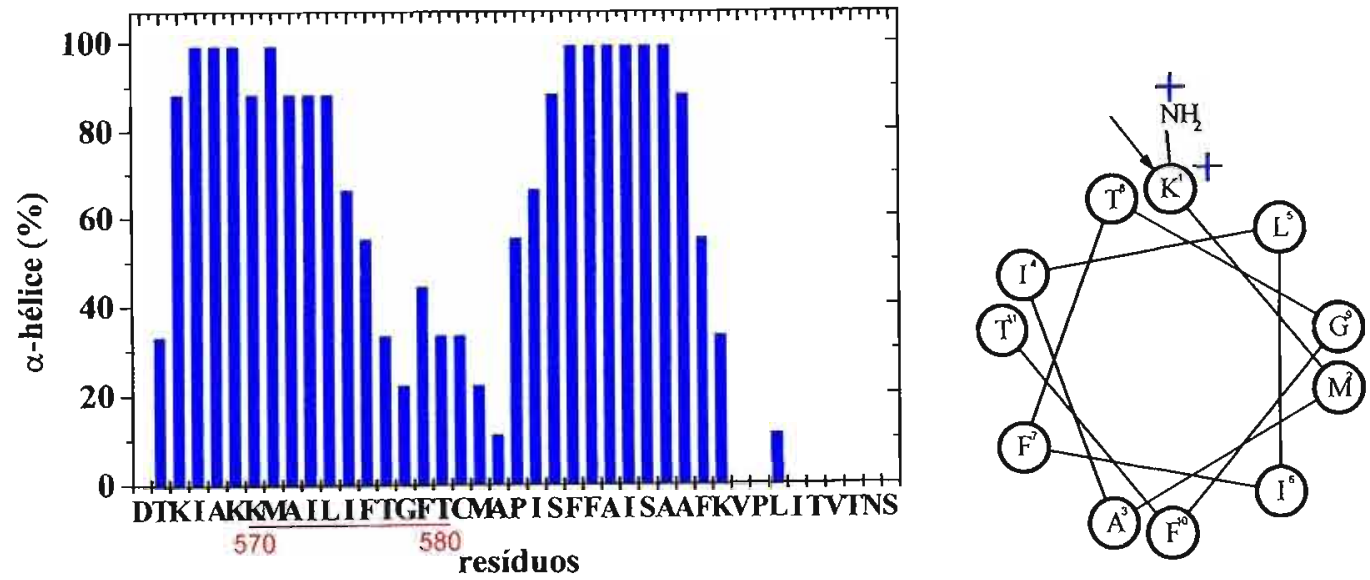

(c)
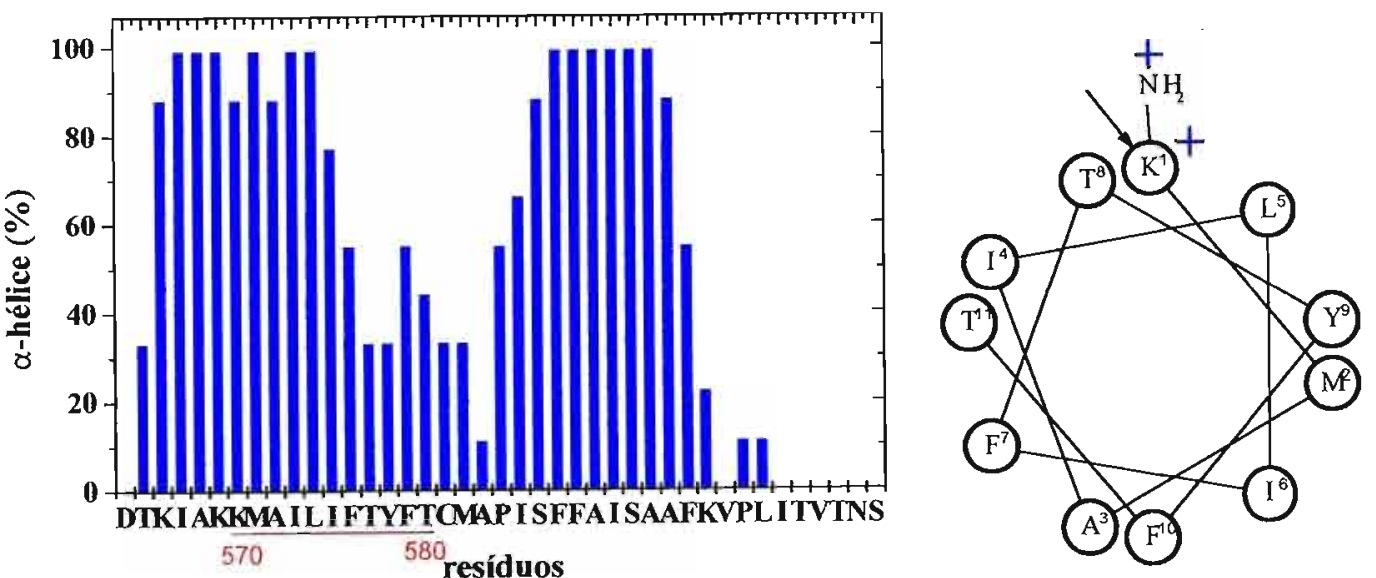

Figura 14 - Predição teórica e diagrama de Schiffer-Edmundson ${ }^{(220)}$ para um fragmento correspondente à porção C-terminal da i3 e a TM6 do LHR (resíduos 564704) (a) e de seus análogos Asp578Gly(b) e Asp578Tyr (c). 
Para contornar o problema da agregação foram realizadas várias abordagens como o efeito de agentes desnaturantes e da temperatura sobre a conformação dos peptídeos, assim como a variação do conteúdo de um solvente orgânico, TFE, o qual atua como agente indutor de estrutura secundária. Além disso, estudou-se o efeito do $\mathrm{pH}$ sobre as propriedades conformacionais dos peptídeos. Esses resultados estão descritos a seguir.

\subsubsection{Efeito do TFE}

Em solução aquosa em pH 4,0, o espectro de CD de I (Fig. 15a) indica que este peptídeo adota conformação em folha $\beta$. O espectro apresenta um máximo em torno de 202 nm e um mínimo em torno de 220 nm (Tabela 2), o que mostra que o espectro está deslocado para o vermelho. O deslocamento do espectro de CD para comprimentos de onda maiores é indicativo de agregação. Com o aumento da concentração de TFE, observa-se um deslocamento gradual da posição dos máximos e mínimos para comprimentos de onda mais baixos. Na presença de $20 \%$ TFE o espectro de CD de I apresenta uma banda positiva contendo um ombro, o que poderia ser devido a contribuição de populações diferentes de I, com diferentes graus de agregação.

Tabela 2 - Comprimento de onda $(\lambda, \mathrm{nm})$ máximo e mínimo nos espectros de CD dos peptídeos I, II e III e respectivos valores de elipticidade molar $\left([\theta], 10^{3}\right.$ deg.cm $\left.\mathrm{dmol}^{-1}\right)$

\begin{tabular}{ccccc|cccc|cccc}
\multicolumn{1}{c}{ I } & \multicolumn{1}{c}{ I } & \multicolumn{6}{c}{ UI } \\
\hline $\begin{array}{ccccc}\text { TFE } \\
(\%)\end{array}$ & $\lambda_{\max }$ & {$[\theta]$} & $\lambda_{\min }$ & {$[\theta]$} & $\lambda_{\max }$ & {$[\theta]$} & $\lambda_{\min }$ & {$[\theta]$} & $\lambda_{\max }$ & {$[\theta]$} & $\lambda_{\min }$ & {$[\theta]$} \\
\hline 2 & 202 & 3,13 & 220 & $-1,68$ & - & - & 198 & $-8,79$ & 201 & 11,2 & 218 & $-1,39$ \\
20 & 192 & 5,61 & 215 & $-3,92$ & -- & - & 202 & $-4,96$ & 197 & 19,7 & 217 & $-4,6$ \\
& 200 & 3,86 & & & & & 219 & $-2,75$ & & & & \\
60 & 193 & 2,41 & 205 & $-4,57$ & 190 & 2,94 & 204 & 5,64 & 194 & 12,3 & 208 & $-7,02$ \\
& & & 222 & $-3,57$ & & & 220 & $-3,45$ & & & & \\
100 & 191 & 6,21 & 207 & $-7,06$ & 190 & & 205 & $-6,79$ & 192 & 15,0 & 208 & $-9,42$ \\
& & & 216 & $-7,53$ & & & 217 & $-5,60$ & & & & \\
\hline
\end{tabular}

Acima de 40 \% TFE, a banda positiva apresenta um máximo centrado em 192 $\mathrm{nm}$ e a banda negativa, um mínimo ao redor de $206 \mathrm{~nm}$ e outro ao redor de $220 \mathrm{~nm}$. Em $100 \%$ TFE, a posição do último mínimo está em cerca de 216 nm. 
(a)

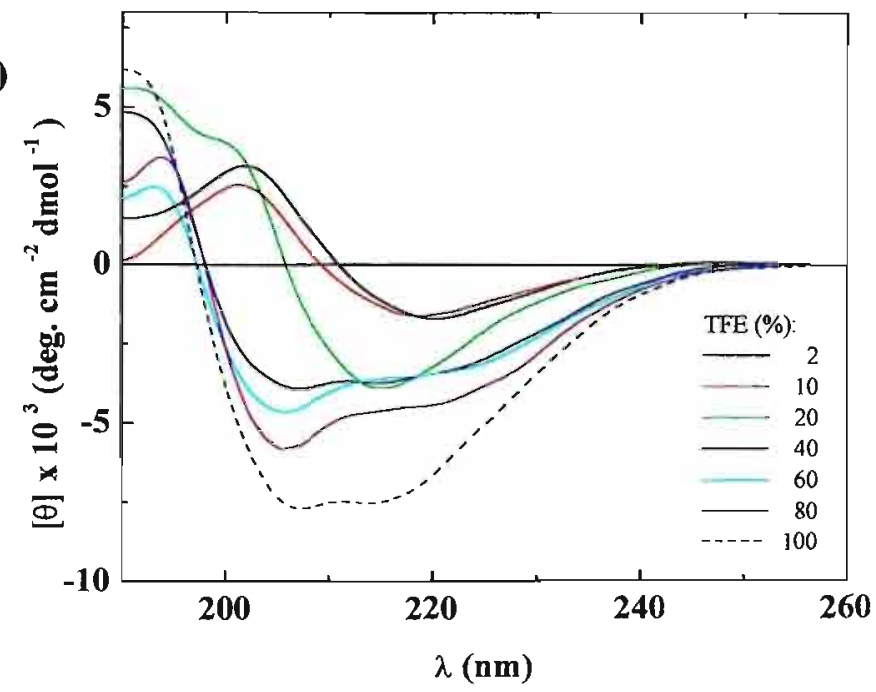

(b)

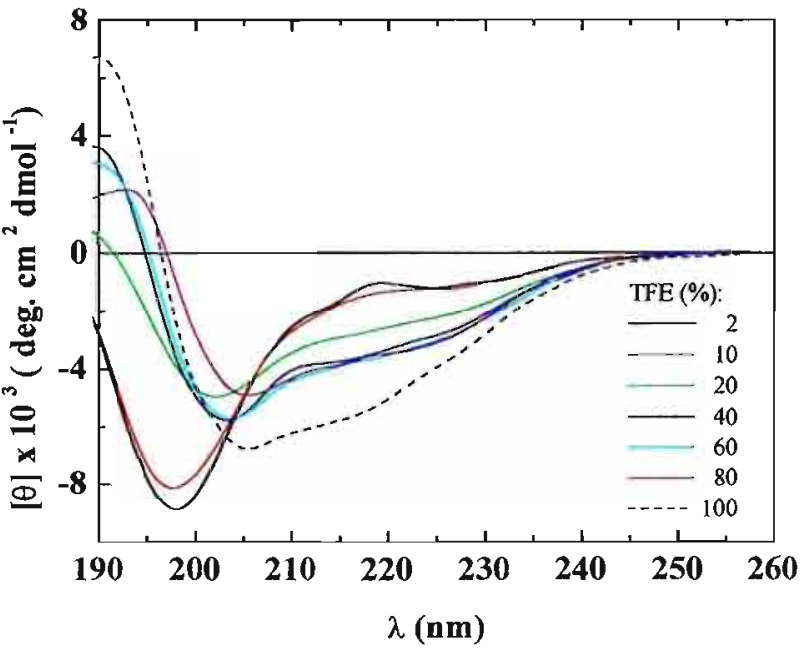

(c)

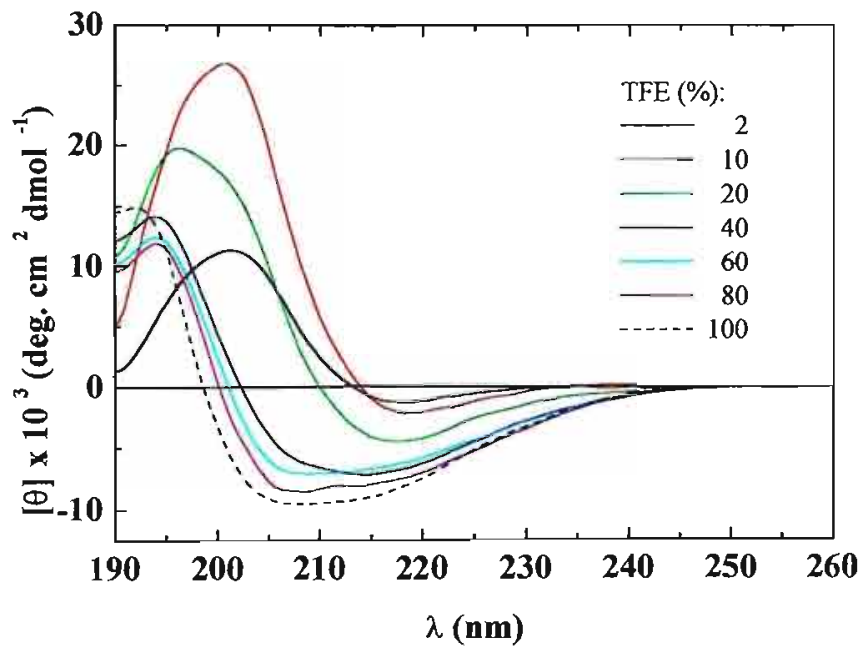

Figura 15 - Espectros de CD dos peptídeos I (a), II (b) e III (c) em função da concentração de TFE. $[$ peptídeo] $=80 \mu \mathrm{M}$. 
Esses resultados mostram que o TFE é capaz de reduzir o grau de agregação de I ao promover a mudança de um espectro indicativo de folha $\beta$ em solução aquosa para um indicativo de estrutura $\alpha$-helicoidal acima de $40 \%$ TFE. No entanto é importante ressaltar que a intensidade do espectro é pequena, o que indica um conteúdo relativamente baixo de $\alpha$-hélice. Isso pode estar relacionado com o tamanho do fragmento de apenas 11 aminoácidos. Peptídeos pequenos possuem estrutura flexível, o que pode resultar na aquisição de um menor conteúdo de estrutura secundária .

$\mathrm{O}$ espectro de $\mathrm{CD}$ de $\Pi$ (Fig. 15b) em solução aquosa em pH 4,0 mostra que o peptídeo adquire estrutura ao acaso, com uma banda negativa centrada ao redor de 198 nm (Tabela 2); isto indica que o análogo II é relativamente mais solúvel do que I. A substituição de $\mathrm{Asp}^{578}$ por Gly provavelmente torna o peptídeo mais flexível em relação ao fragmento nativo. O resíduo de Gly é freqüentemente encontrado em dobras e pouco encontrado em $\alpha$-hélices. ${ }^{(209)}$

Com o aumento do conteúdo de TFE, a conformação de II muda de ao acaso para $\alpha$-hélice. A partir de $20 \%$ TFE, o espectro de CD do peptídeo apresenta uma banda com dois mínimos, um ao redor de $205 \mathrm{~nm}$ e outro ao redor de $220 \mathrm{~nm}$ (Tabela 2). Acima de $40 \%$ TFE também é possível observar uma banda positiva em torno de $190 \mathrm{~nm}$. Assim como observado para o fragmento nativo, a intensidade do espectro de $\mathrm{CD}$ é relativamente baixa.

Para o análogo III (Fig. 15c), o espectro de CD em solução aquosa indica a formação de folha $\beta$. Assim como para I, este espectro apresenta-se deslocado para o vermelho, com uma banda positiva em $203 \mathrm{~nm}$ e uma banda negativa em $218 \mathrm{~nm}$, o que indica que III também está agregado em solução aquosa. No entanto, é possível notar que o espectro de CD de III difere do espectro de I, sendo que o espectro do primeiro apresenta uma banda positiva significativamente mais intensa do que a banda negativa. Isto sugere que os peptídeos I e III adotam conformações diferentes em solução aquosa. Com o aumento do conteúdo de TFE, os espectros de CD mostram que este mutante muda gradualmente de folha $\beta$ em solução aquosa para $\alpha$-hélice em $100 \%$ TFE. Entre 40 e $80 \%$ TFE observa-se que a banda positiva do espectro situa-se ao redor de $195 \mathrm{~nm}$, sendo que e em $100 \%$ TFE este sedesloca ainda mais para o azul, situando-se em torno de $193 \mathrm{~nm}$. Esses resultados indicam que na presença de altas concentrações do solvente orgânico ocorre diminuição do grau de agregação de III. 
Comparando-se a variação de elipticidade molar em 222 nm (Tabela 3), observamse intensidades baixas e relativamente parecidas para os três peptídeos, o que deve estar relacionado com o tamanho dos fragmentos e a sua solubilidade. Como discutido acima, abaixo de $20 \%$ TFE, os peptídeos I e III adotam folha $\beta$, enquanto que II adota estrutura ao acaso. Espectros com características de estrutura $\alpha$-helicoidal foram obtidos para os peptídeos na presença de concentrações de TFE superiores a $40 \%$.

Tabela 3- Elipticidade molar ([0]) a $222 \mathrm{~nm}$ nos espectros de CD de I, II e III em função da concentração de TFE

\begin{tabular}{|c|c|c|c|}
\hline \multirow[t]{2}{*}{ Peptídeo } & \multicolumn{3}{|c|}{$\left[\left.\theta\right|_{222} \times 10^{3}\left(\right.\right.$ deg. $\left.\mathrm{cm}^{-2} \mathrm{dmol}^{-1}\right)$} \\
\hline & $2 \%$ TFE & $60 \%$ TFE & $100 \%$ TFE \\
\hline I & $-1,6$ & $-3,4$ & $-6,0$ \\
\hline ПI & $-1,1$ & $-3,3$ & $-4,6$ \\
\hline III & $-0,9$ & $-5,3$ & $-6,6$ \\
\hline
\end{tabular}

Utilizamos as equações de Chen et al. ${ }^{(214)}$ e de Baldwin et al. ${ }^{(215)}$ para medir o conteúdo de $\alpha$-hélice para os peptídios (Tabela 4). Oberva-se que pelo método de Chen 0 conteúdo de estrutura secundária é significativamente maior na presença de baixas concentrações de TFE em relação ao método de Baldwin, o que está relacionado com os parâmetros utilizados por cada equação (ver Materiais e Métodos). No entanto, esses valores convergem na presença de concentrações mais altas de TFE, que corresponde à condição onde os espectros dos peptídeos são indicativos de estrutura $\alpha$-helicoidal. De modo geral, o conteúdo de $\alpha$-hélice na presença de $100 \%$ TFE não é muito alto, em torno de $40 \%$ para todos os fragmentos; esse resultado era esperado, uma vez que os fragmentos possuem apenas 11 resíduos.

Tabela 4 - Conteúdo de estrutura $\alpha$-helicoidal para os peptídeos I, II e III em função da concentração de TFE.

\begin{tabular}{|c|c|c|c|c|c|c|}
\hline \multicolumn{7}{|c|}{$\% \alpha$-hélice } \\
\hline \multirow[b]{2}{*}{ TFE (\%) } & \multicolumn{2}{|c|}{ I } & \multicolumn{2}{|c|}{ II } & \multicolumn{2}{|c|}{ III } \\
\hline & Baldwin $^{a}$ & Chen $^{a}$ & Baldwin $^{a}$ & Chen $^{\mathrm{a}}$ & Baldwin ${ }^{a}$ & Chen $^{\mathrm{a}}$ \\
\hline 2 & 18 & 27 & 14 & 25 & 12 & 26 \\
\hline 10 & 17 & 27 & 15 & 26 & 19 & 28 \\
\hline 20 & 25 & 30 & 23 & 29 & 29 & 34 \\
\hline 40 & 27 & 31 & 26 & 30 & 36 & 39 \\
\hline 60 & 27 & 31 & 27 & 31 & 36 & 38 \\
\hline 80 & 31 & 34 & 27 & 31 & 39 & 40 \\
\hline 100 & 38 & 38 & 31 & 35 & 40 & 42 \\
\hline
\end{tabular}


O análogo II adquire um conteúdo de estrutura $\alpha$-helicoidal menor que os demais. Isso pode estar relacionado com a presença do resíduo de Gly, o qual não possui cadeia lateral e é capaz de induzir dobras em peptídeos ${ }^{(209)}$, tornando-os mais flexíveis.

\subsubsection{Efeito da temperatura}

Outra abordagem para contornar o efeito da agregação dos peptídeos foi estudar o efeito da variação da temperatura sobre os espectros de CD de I e seus análogos (Fig. 16). Os estudos foram efeitos em solução aquosa em pH 7,0.

$\mathrm{O}$ espectro de $\mathrm{CD}$ de I (Fig. 16a) à temperatura ambiente $\left(20^{\circ} \mathrm{C}\right)$ apresenta uma banda positiva em torno de $195 \mathrm{~nm}$ e uma banda negativa centrada em $216 \mathrm{~nm}$ (Tabela 5), o que como já mencionado, indica a formação de folha $\beta$. Com o aumento da temperatura, observa-se acima de $40{ }^{\circ} \mathrm{C}$ diminuição da intensidade da banda positiva, enquanto os valores de elipticidade molar para a banda negativa diminuem acima de $70{ }^{\circ} \mathrm{C}$, causando achatamento do espectro.

Com o aumento da temperatura observa-se um pequeno deslocamento da posição de $\lambda_{\text {mín }}$ para comprimentos de onda maiores (Tabela 5). Esses espectros poderiam ser indicativos de conformação em folha $\beta$ ou de dobra $\beta^{(221)}$. Foi observado visualmente que a solução ficou límpida com o aumento da temperatura e que após abaixar a mesma para temperatura ambiente, houve a formação de precipitados fibrosos. Dessa forma, pode-se inferir que o aumento da temperatura resultou no aumento da solubilidade de I e que em temperaturas mais altas o peptídeo poderia adotar conformação em dobra $\beta$.

Tabela 5 - Comprimento de onda máximo $\left(\lambda_{\text {max }}\right)$ e mínimo $\left(\lambda_{\text {min }}\right)$ nos espectros de CD dos peptídeos I, II e III em função da temperatura, $\mathrm{pH} \mathrm{7,0}$

\begin{tabular}{ccccccc}
\hline & & \multicolumn{3}{c}{ II } & \multicolumn{2}{c}{ III } \\
\hline Temperatura $\left(\mathbf{C}^{\circ}\right)$ & $\lambda_{\text {máx }}$ & $\lambda_{\min }$ & $\lambda_{\max }$ & $\lambda_{\min }$ & $\lambda_{\text {máx }}$ & $\lambda_{\min }$ \\
20 & 194 & 216 & 191 & 206,216 & 195 & 219 \\
40 & 193 & 219 & 192 & 206,217 & 191 & 220 \\
60 & 194 & 218 & 192 & 206,217 & 194 & 220 \\
80 & 192 & 222 & 191 & 206,217 & 192 & 220 \\
\hline
\end{tabular}

O espectro de CD de II (Fig. 16b) mostra uma banda positiva abaixo de $195 \mathrm{~nm}$ e uma banda negativa com mínimos ao redor de 206 e 218 nm (Tabela 5). Nessa condição, o espectro de CD de II foi interpretado como sendo de estrutura $\alpha$-helicoidal, apesar da posição dos mínimos estar deslocada para comprimentos de onda mais baixos. 
(a)

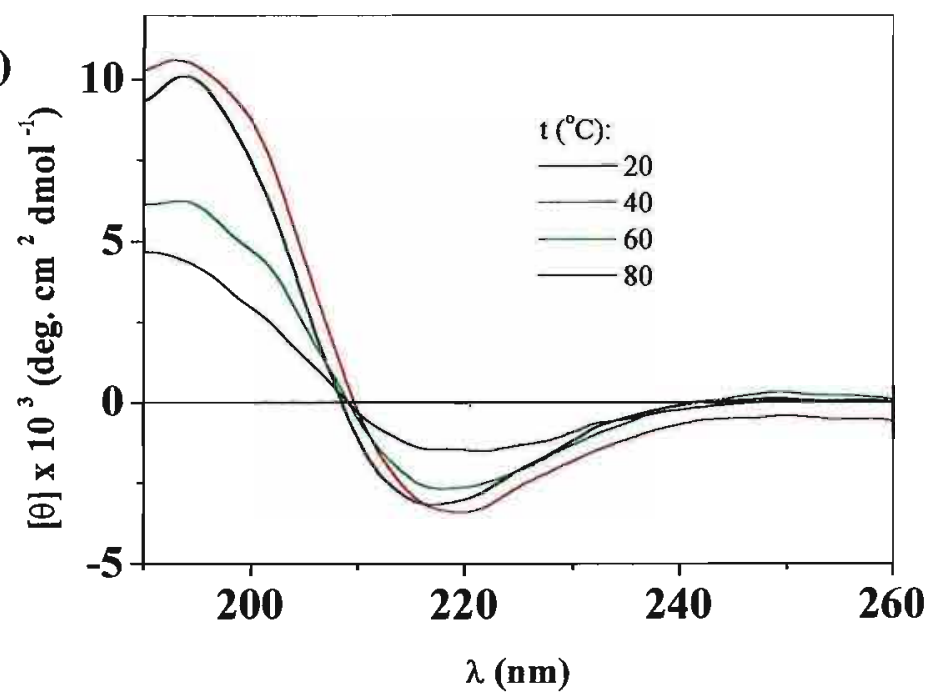

(b)

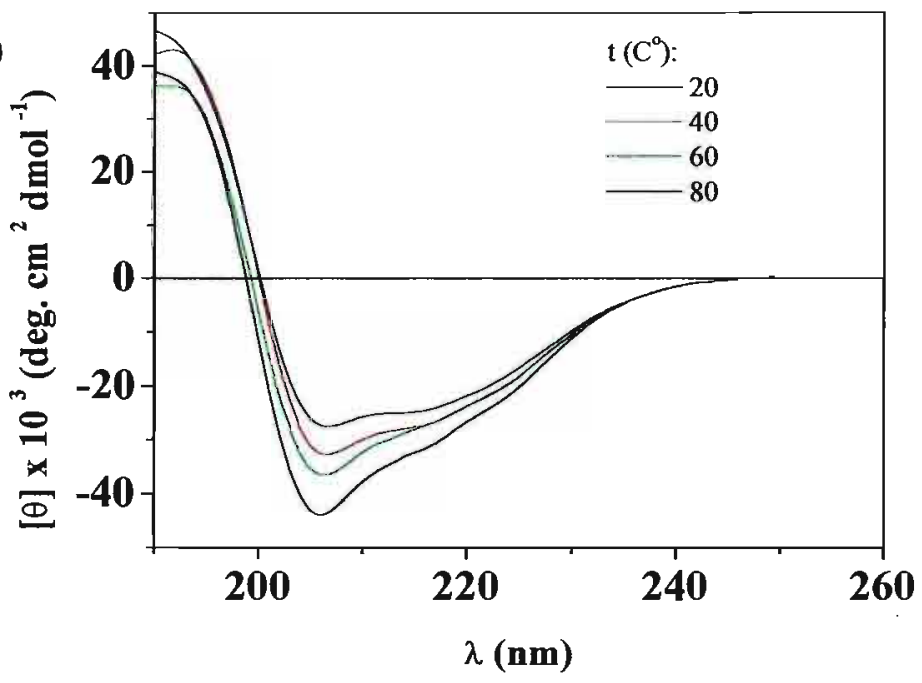

(c)

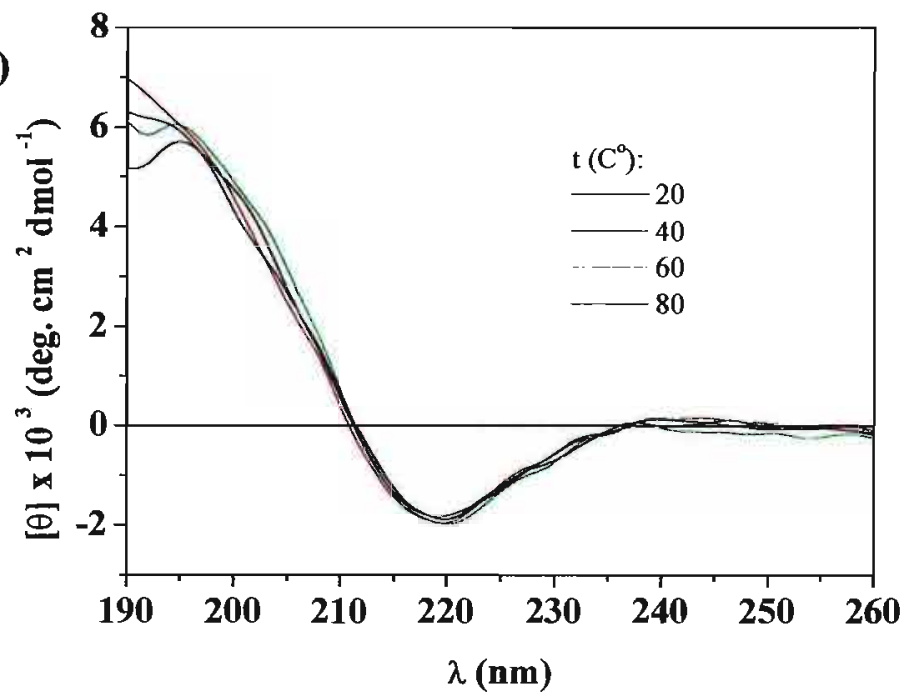

Figura 16 - Espectros de CD de I, II e III em solução aquosa em função temperatura, pH 7,0. [peptídeo] $=80 \mu \mathrm{M}$. 
$\mathrm{O}$ aumento da temperatura não provocou um deslocamento da posição dos máximos e mínimos, nem achatamento do espectro. Foi observada apenas uma pequena diminuição da elipticidade molar em $206 \mathrm{~nm}$. Em comparação com o peptídeo nativo, esses resultados sugerem que o mutante II é menos sensível ao efeito da temperatura do que I.

Com relação ao peptídeo III, o espectro de CD (Fig. 16c) apresenta uma banda positiva em $195 \mathrm{~nm}$ e uma banda negativa ao redor de $220 \mathrm{~nm}$ (Tabela 5), o que indica estrutura em folha $\beta$. Com o aumento da temperatura, não foram observadas mudanças significativas nos espectros de CD, o que indica que III é pouco sensível ao efeito da temperatura. Comparando-se com os resultados obtidos para os outros peptídeos, podese inferir que III apresenta-se mais fortemente agregado. A presença do resíduo de Tyr pode contribuir para o aumento de interações inter-moleculares, resultando em maior tendência à agregação.

\subsubsection{Efeito da uréia}

A uréia é sabidamente um forte agente desnaturante e muito utilizada para estudar o enovelamento de proteínas e peptídeos. Dessa forma, resolvemos investigar o efeito da uréia sobre a conformação dos peptídeos I, II e III numa tentativa de diminuir seu grau de agregação.

Na Figura 17 mostra-se o efeito de diferentes concentrações de uréia sobre os espectros de CD dos peptídeos estudados. As amostras foram preparadas a partir de uma solução estoque do peptídeo em uréia $6 \mathrm{M}, \mathrm{pH}$ 7,0 a partir da qual foram feitas diluições para obter concentrações menores de uréia. Para comparação, a Figura 17a mostra os espectros de I, II e III em solução aquosa, $\mathrm{pH}$ 7,0. Devido ao fato de que a uréia absorve fortemente abaixo de $210 \mathrm{~nm}$, os espectros de CD na presença de uréia foram adquiridos na faixa entre $210-260 \mathrm{~nm}$.

Os espectros de CD de I (Fig. 17b) na presença de diferentes concentrações de uréia não apresentaram um comportamento em comum, alguns espectros possuem bandas negativas alargadas, enquanto que outros apresentaram bandas mais estreitas, com múnimo ao redor de $215 \mathrm{~nm}$. Observou-se que os valores de [ $\theta$ ] tanto em 215 quanto em $222 \mathrm{~nm}$ aumentam com a concentração de uréia. Para efeito comparativo, a Tabela 6 abaixo mostra a variação de elipticidade molar em 215 e $222 \mathrm{~nm}$ em função da concentração de uréia. 

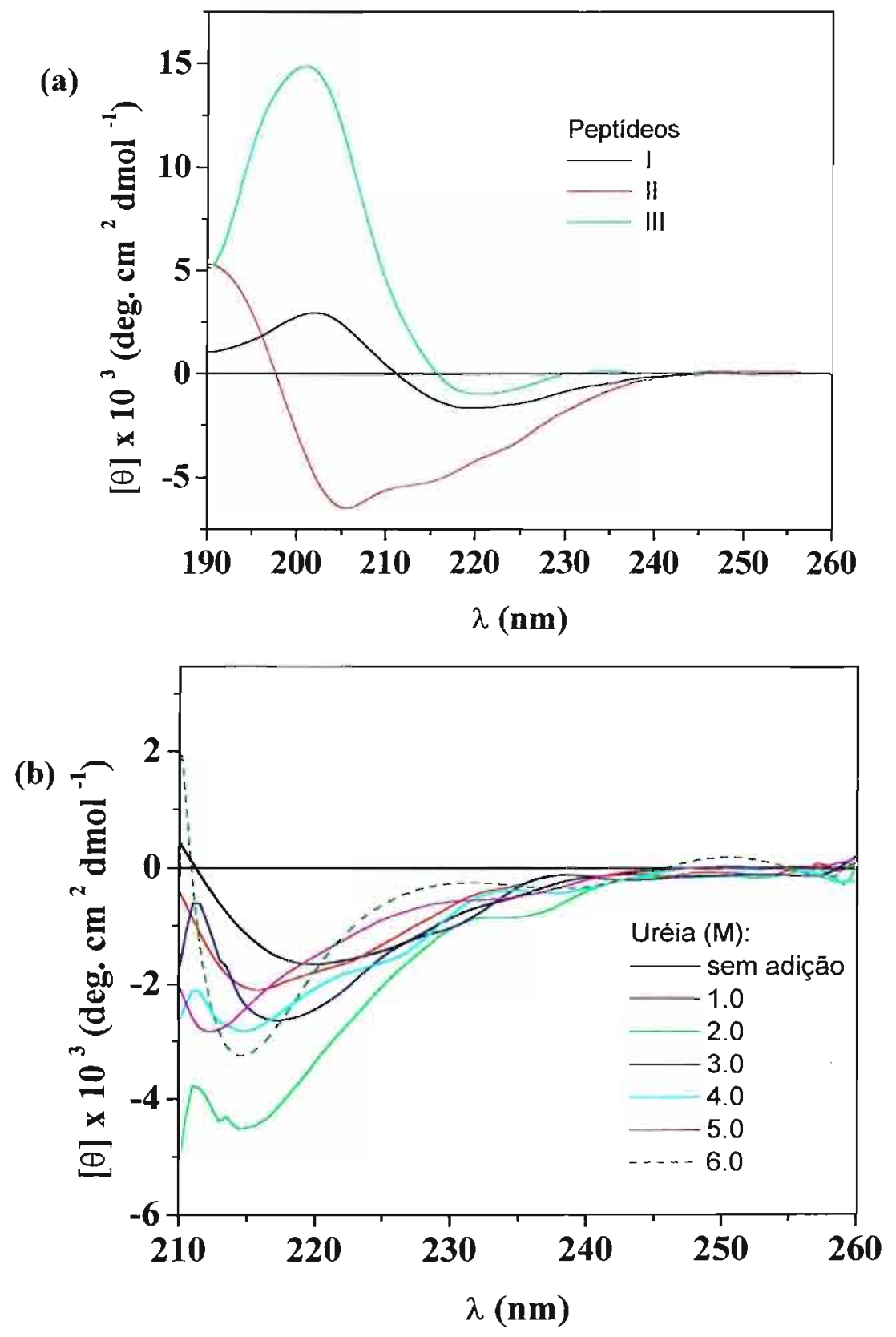

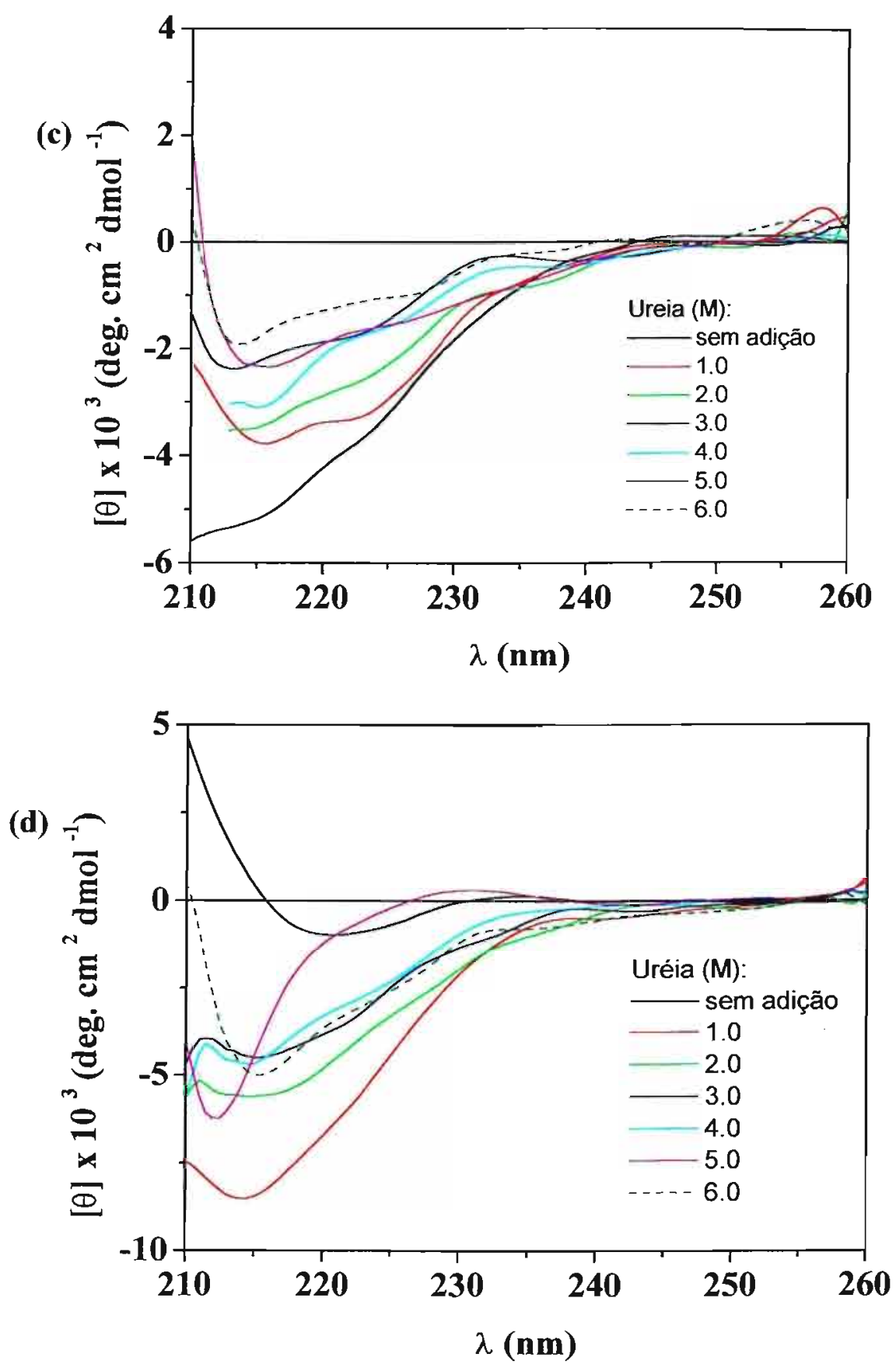

Figura 17 - Espectros de CD de I, II e III em solução aquosa, pH 7,0 (a). Espectros de de I (b), II (c) e III (d) em função da concentração de uréia, pH 7,0, à temperatura ambiente. $[$ peptídeo] $=70 \mu \mathrm{M}$. 


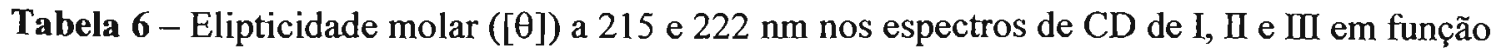
da concentração de uréia, pH 7,0. [peptídeo] $=70 \mu \mathrm{M}$.

\begin{tabular}{ccccccc}
\hline Uréia (M) & \multicolumn{3}{c}{$[\theta]_{215}$} & \multicolumn{3}{c}{$[\theta]_{222}$} \\
\hline 0 & I & II & III & I & II & III \\
1 & -1153 & -5174 & 411 & -1590 & -3848 & -920 \\
2 & -2067 & -3738 & -8441 & -1655 & -3316 & -5895 \\
3 & -4487 & -3467 & -5693 & -2785 & -2676 & -4182 \\
4 & -2397 & -2237 & -4497 & -2112 & -1769 & -3431 \\
5 & -2821 & -3089 & -4681 & -1833 & -1816 & -2922 \\
6 & -2394 & -2316 & -4460 & -1245 & -1696 & -733 \\
& -3220 & -1796 & -4976 & -1179 & -1158 & -3187 \\
\hline
\end{tabular}

Para o peptídeo II (Fig. 17c), observa-se que quanto maior a concentração de uréia, menor o conteúdo de estrutura secundária, visto pelo decréscimo da elipticidade molar tanto em 215 quanto em $222 \mathrm{~nm}$ (Tabela 6). A diminuição no conteúdo de estrutura secundária sugere que a uréia seja capaz de promover pelo menos uma desagregação parcial do peptídeo.

Os espectros de CD de III (Fig. 17d) também mostram que a banda negativa do espectro diminui de intensidade em função da concentração de uréia. Em torno de $3 \mathrm{M}$ uréia a intensidade cai à aproximadamente metade em relação a $1 \mathrm{M}$ uréia; em seguida ocorre praticamente uma estabilização da elipticidade molar. Esse efeito acima de $3 \mathrm{M}$ uréia também é observado para os peptídeos I e II.

\subsubsection{Efeito do $\mathrm{pH}$}

As propriedades conformacionais dos peptídeos I, II e III foram estudas em solução aquosa em função do pH por $\mathrm{CD}$ e por fluorescência (III). Além do grupo Nterminal, os peptídeos estudados têm os seguintes resíduos com grupos ionizáveis nas cadeias laterais: Lys, Asp (I) e Tyr (III). Efeitos de polaridade ou vizinhança de cargas podem levar a alterações dos pKs desses grupos ${ }^{(222)}$. A carga líquida dos peptídeos em solução em vários pHs, sem levar em conta os efeitos mencionados acima, está mostrada na Figura 18. 


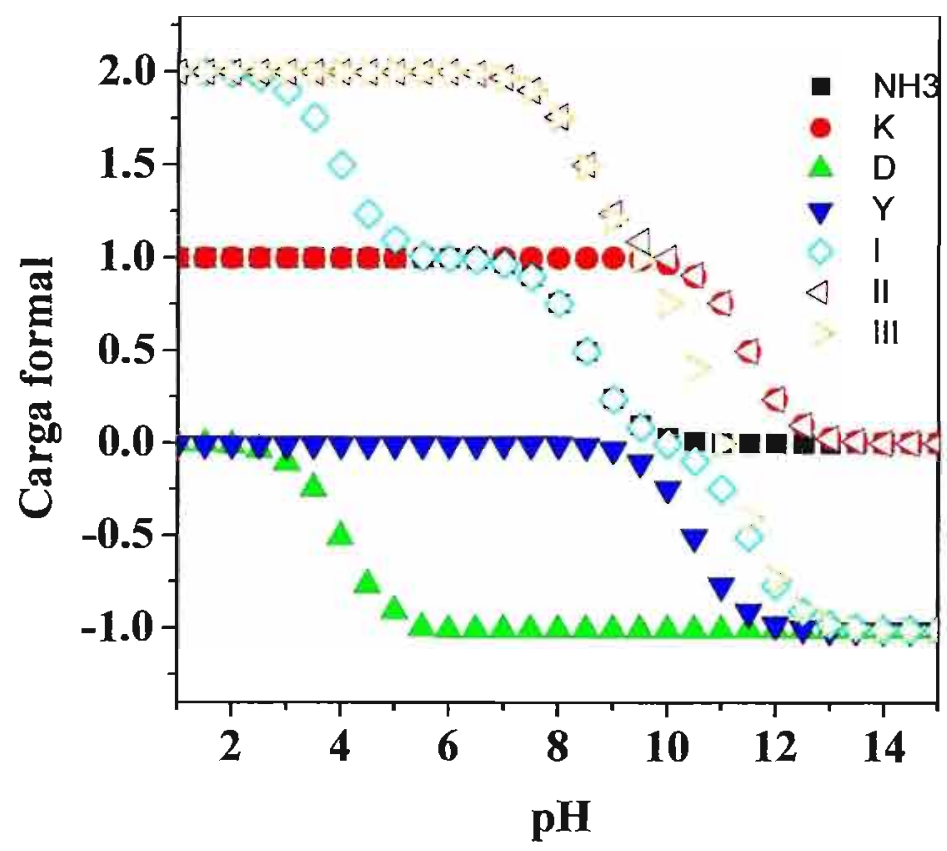

Figura 18 - Variação da carga teórica dos aminoácidos presentes nos peptídeos I, II e III e de suas respectivas cargas formais em função do $\mathrm{pH}$. $\mathrm{pK}_{\mathrm{a}}$ dos grupos ionizáveis: $\mathrm{N}$ terrminal:8,5; Asp: 4,0; Tyr: 10,5 e Lys:11,0 ${ }^{(223)}$. 
A Figura 19 mostra o efeito do pH para o peptídeo I. Em pH 3,0 o espectro de I apresenta uma banda positiva em torno de $202,5 \mathrm{~nm}$ e uma banda negativa ao redor de $216 \mathrm{~nm}$ (Tabela 7), este espectro poderia ser atribuído ao de uma estrutura em folha $\beta$ (Fig. 19a), no entanto a posição do máximo encontra-se deslocado para o vermelho ${ }^{(224)}$. Segundo Hollósi et al. ${ }^{(221)}$, espectros com essas características correspondem a dobras $\beta$. Com o aumento do $\mathrm{pH}$, o mínimo da banda negativa se desloca para $220 \mathrm{~nm}$; observa-se ainda que as bandas positiva e negativa na maioria dos pHs são proporcionais. Espectros de CD com características similares a essas também foram atribuídos a dobras $\beta^{(221)}$.

Tabela 7 - Comprimento de onda máximo $\left(\lambda_{\operatorname{máx}}\right)$ e mínimo $\left(\lambda_{\min }\right)$ nos espectros de CD dos peptídeos I, II e III em função do pH.

\begin{tabular}{ccccccc}
\hline & & $\mathrm{I}$ & \multicolumn{2}{c}{ II } & \multicolumn{2}{c}{ III } \\
\hline $\mathrm{pH}$ & $\lambda_{\text {máx }}$ & $\lambda_{\min }$ & $\lambda_{\text {máx }}$ & $\lambda_{\min }$ & $\lambda_{\text {máx }}$ & $\lambda_{\min }$ \\
4,0 & 202 & 220 & - & 197 & 202 & 218 \\
7,0 & 202 & 220 & 191 & 205,217 & 202 & 222 \\
10,0 & 202 & 220 & 194 & 206,217 & 201 & 224 \\
\hline
\end{tabular}

A Figura 19b mostra a variação da elipticidade molar em 202,5 e em 220 nm em função do pH. Inicialmente, observamos um aumento da elipticidade molar em 202,5 nm entre pH 3 e 4, atingindo um máximo em pH 6,0; a partir daí a intensidade diminui. Vários eventos podem estar acontecendo; o aumento inicial de intensidade em $\mathrm{pH}$ ácido pode estar refletindo a desprotonação do resíduo de Asp. Em seguida, a queda da elipticidade molar acima de pH 6,0 pode ser devida a dois fatores: a diminuição da solubilidade do peptídeo, o que facilita sua agregação e mesmo precipitação, e a desprotonação do grupo $\mathrm{N}$-terminal e do grupo $\varepsilon-\mathrm{NH}_{2}$ da cadeia lateral da Lys. Apesar dos $\mathrm{pK}_{\mathrm{a}} \mathrm{s}$ desses grupos serem da ordem de 8,5 e 11,0 respectivamente ${ }^{(223)}$, é necessário levar em conta a vizinhança onde se encontra o peptídeo. Dessa forma, é possível que por causa de efeitos de carga ou polaridade, o $\mathrm{pK}_{\mathrm{a}}$ de um desses grupos, ou talvez dos dois, tenha baixado e por isso observamos o decréscimo dos valores de elipticidade molar em 202,5 $\mathrm{nm}$ a partir de $\mathrm{pH} 7,0$.

Observou-se visualmente em pHs mais alcalinos, principalmente de $\mathrm{pH}$ 10,0 em diante, o aparecimento de precipitados em solução. Além disso, também se verificou aumento do ruído no espectro de CD. Não foi possível adquirir o espectro de I em $\mathrm{pH}$ 12,0 devido justamente ao aumento do ruído e também à precipitação. Nestas condições o peptídeo torna-se extremamente hidrofóbico, sendo energeticamente desfavorável sua permanência em solução. $O$ fato de que $I$ não adquire estrutura 
(a)

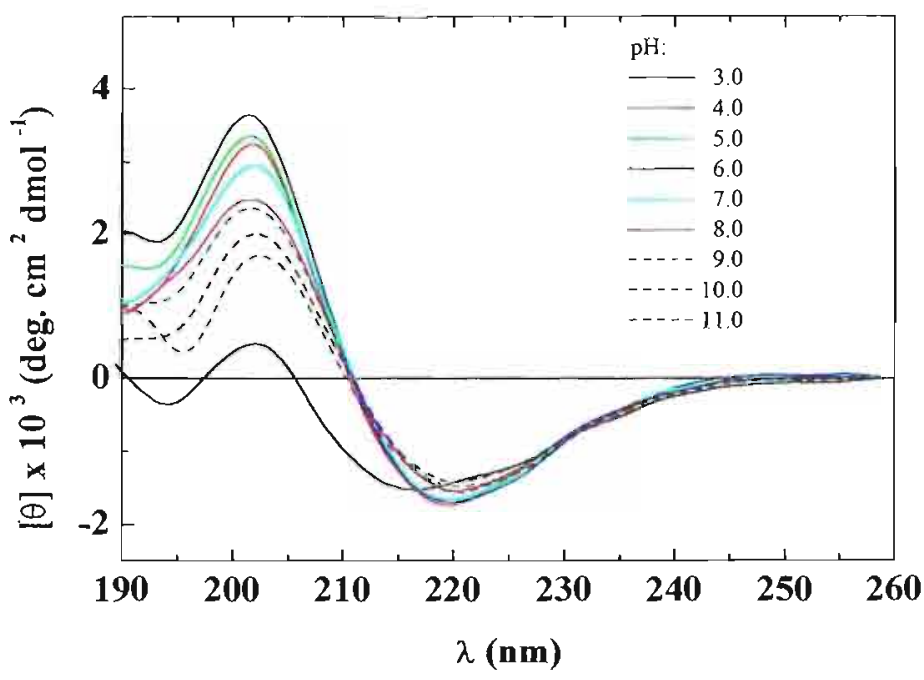

(b)

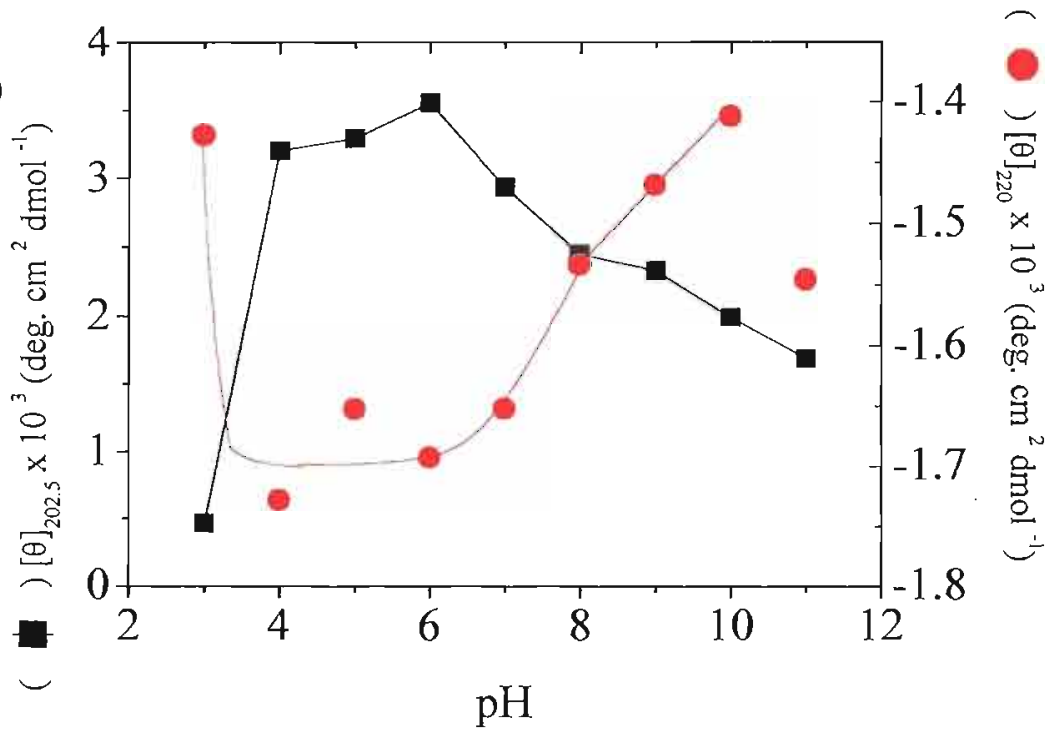

Figura 19 - (a) Efeito da variação do pH sobre os espectros de CD de $100 \mu \mathrm{M}$ de I em solução contendo $2 \%$ de TFE. (b) variação da elipticidade molar [ $\theta]$ em 202,5 (ש) e 220 nm (*) em função do $\mathrm{pH}$. 
helicoidal em solução pode estar relacionado com sua solubilidade ou com o seu tamanho.

Para o análogo II (Fig. 20a), ao contrário de I, observa-se que até pH 6,0 o peptídeo possui conformação ao acaso. Nesta faixa de $\mathrm{pH}$, II não possui nenhum grupo ionizável, e como pode ser observado na Fig. 20b, os valores de elipticidade molar tanto em 195 quanto em 222 nm não variam muito até pH 6,0. A partir de $\mathrm{pH}$ 7,0, o espectro de CD de II mostra que a conformação deste peptídeo muda de ao acaso para $\alpha$-hélice. $O$ espectro de II apresenta uma banda positiva ao redor de $190 \mathrm{~nm}$ e uma banda negativa com dois mínimos, o primeiro em torno de $205 \mathrm{~nm}$ e o segundo ao redor de $216 \mathrm{~nm}$ (Fig. 20a). Com a mudança de $\mathrm{pH}$ de 7,0 para 8,0, observa-se um aumento de intensidade significativo. De $\mathrm{pH} 9,0 \mathrm{em}$ diante, os espectros tornam-se mais achatados, o que indica que II estaria agregando. Este evento pode estar relacionando com a desprotonação do grupo amino terminal e da cadeia lateral de Lys. Na Tabela 8 mostra-se a relação $[\theta]_{208} /[\theta]_{222}$ para II em alguns pHs. Essa relação pode ser utilizada para indicar se um determinado segmento helicoidal é monomérico ou não ${ }^{(225)}$. Em estruturas $\alpha$-helicoidais monoméricas a banda em $208 \mathrm{~nm}$ é mais intensa do que em $222 \mathrm{~nm}$. Esse parâmetro não foi calculado para II em pHs abaixo de 7,0 porque nessa faixa de $\mathrm{pH}$ o peptídeo encontra-se ao acaso (Figura 20a). Pode-se observar que acima de pH 9,0 a banda em $222 \mathrm{~nm}$ é mais intensa do que em $208 \mathrm{~nm}$, o que sugere que nesses pHs ocorre agregação.

Tabela 8 - Razão entre a elipticidade molar [ $\theta]$ medida em 208 e 222 nm nos espectros de $\mathrm{CD}$ de II em função do $\mathrm{pH}$.

\begin{tabular}{cc}
\hline $\mathrm{pH}$ & {$[0]_{208} /[\theta]_{222}$} \\
\hline 7,0 & 1,56 \\
8,0 & 1,33 \\
9,0 & 0,84 \\
10,0 & 0,81 \\
11,0 & 0,79 \\
\hline
\end{tabular}

A Figura 20b mostra a variação de elipticidade molar em função $\mathrm{pH}$. Observa-se que o aumento de elipticidade molar tanto em 195 quanto em $220 \mathrm{~nm}$ se inicia a partir de $\mathrm{pH} 5,0$, portanto bem abaixo dos $\mathrm{pK}_{\mathrm{a}} \mathrm{s}$ dos grupos ionizáveis de II, o que sugere que os $\mathrm{pK}_{\mathrm{a}} \mathrm{s}$ desses grupos tenham baixado. Com o aumento do $\mathrm{pH}$ observou-se um aumento de turbidez da amostra e, assim como no caso do peptídeo I, não foi possível adquirir o espectro acima de $\mathrm{pH} 12,0$. 
(a)

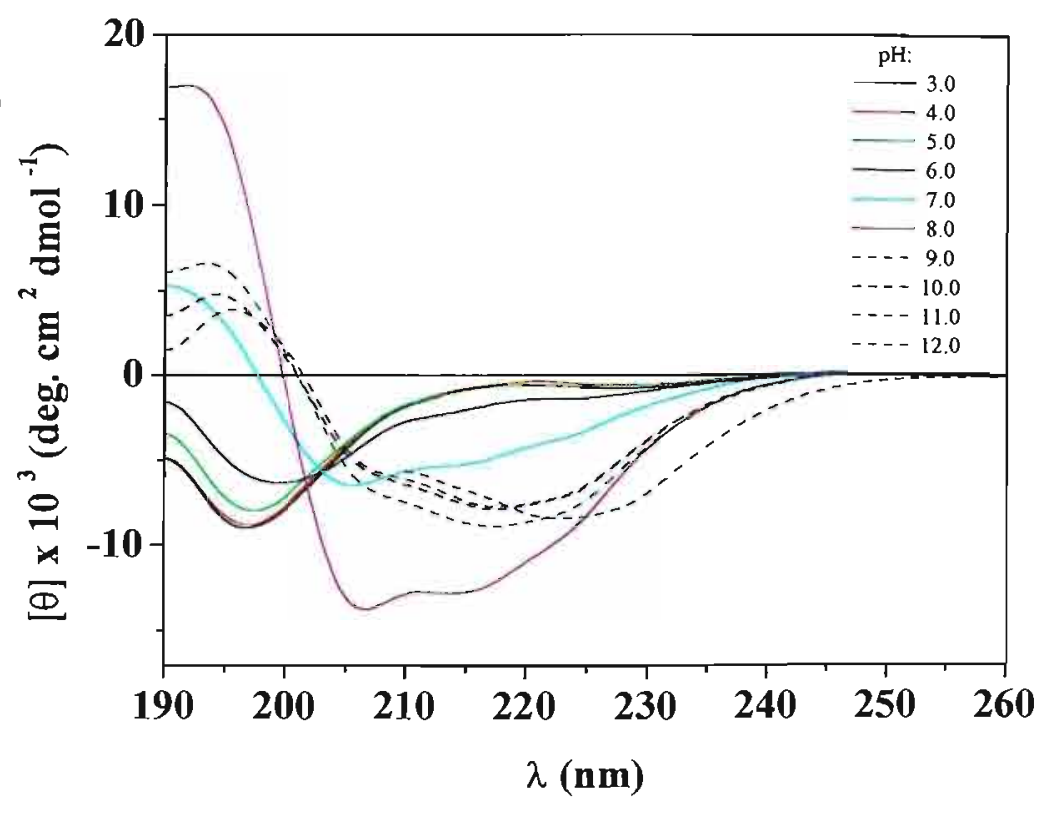

(b)

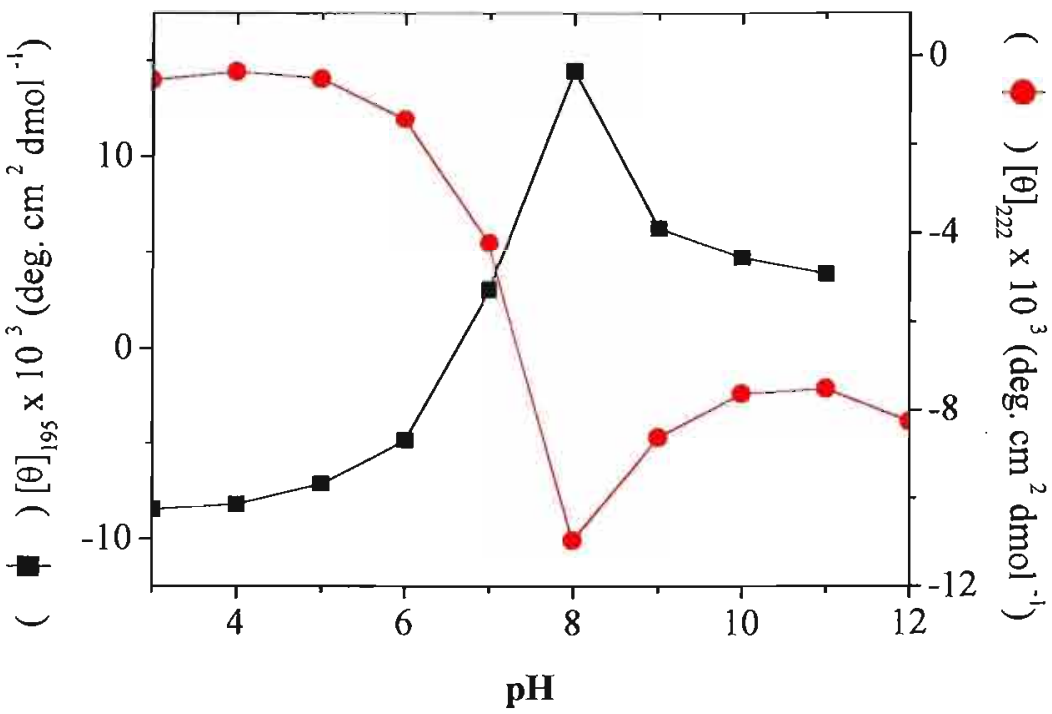

Figura 20 - (a) Efeito da variação do pH sobre os espectros de CD de $100 \mu \mathrm{M}$ II em solução contendo $2 \%$ de TFE. (b) variação da elipticidade molar [ $\theta$ ] em 195 (ロ) e 222 $\mathrm{nm}(\bullet)$ em função do pH. 
O espectro do análogo III em pH 3,0 (Fig. 21a) encontra-se deslocado para o vermelho, apresentando uma banda positiva com máximo em $203 \mathrm{~nm}$ e uma banda negativa com mínimo em $217 \mathrm{~nm}$, o que sugere que III adota conformação em dobra $\beta^{(221)}$ nesse $\mathrm{pH}$. Com o aumento do $\mathrm{pH}$ observa-se um aumento significativo de intensidade para a banda positiva, enquanto que a intensidade da banda negativa centrada em $217 \mathrm{~nm}$ varia pouco. Isto pode ser observado na Figura $21 \mathrm{~b}$, onde se mostra a variação da elipticidade molar em 201 e em $220 \mathrm{~nm}$.

Acompanhando-se a variação da elipticidade molar em 201 nm (Fig. 21b), observase uma curva em forma de sino, atingindo um máximo em $\mathrm{pH}$ 6,0 e diminuindo logo em seguida. A variação de elipticidade molar em $220 \mathrm{~nm}$ também mostra um ponto de inflexão em torno de $\mathrm{pH} 6,0$; III não possui nenhum grupo ionizável $\mathrm{em} \mathrm{pH}$ ácido, portanto, este comportamento sugere o abaixamento do $\mathrm{pK}_{\mathrm{a}}$ desses grupos. De $\mathrm{pH}$ 8,0 em diante, a elipticidade molar praticamente não varia mais, o que também sugere o abaixamento significativo do $\mathrm{pK}_{\mathrm{a}}$. É possível que efeitos de vizinhança sejam responsáveis por esse evento.

É interessante notar que os espectros de CD do análogo III também são diferentes daqueles obtidos pelo peptídeo nativo. Na literatura, espectros parecidos com àqueles obtidos com peptídeo III, com o máximo da banda positiva centrado um pouco acima de $200 \mathrm{~nm}$ e o mínimo acima de $220 \mathrm{~nm}$, foram atribuídos à conformação em folha $\beta$ paralela (224). Nesses espectros também se pode observar que a banda positiva do espectro é proporcionalmente muito mais intensa do que a banda negativa. Essas características são similares os espectros de III na faixa de pH entre 4,0 e 7,0. Quanto ao espectro de III nos pHs acima de 8,0, observa-se que a banda negativa do espectro desloca-se para comprimentos de onda mais altos, em torno de $224 \mathrm{~nm}$, que são característicos de dobra $\beta^{(221)}$. Esses resultados indicam que a variação do $\mathrm{pH}$ provoca mudanças conformacionais em III.

$\mathrm{O}$ análogo III possui um resíduo de Tyr, o que permitiu realizar estudos por espectroscopia de fluorescência (Fig. 22). O espectro de emissão de III foi obtido excitando-se a amostra em 275 nm, sendo que em pH 3,0 observa-se um máximo em 302 nm. Ao prosseguirmos com a titulação a intensidade de fluorescência decai com o pH, mesmo em pHs ácidos. Este comportamento é inesperado, pois como mencionado 

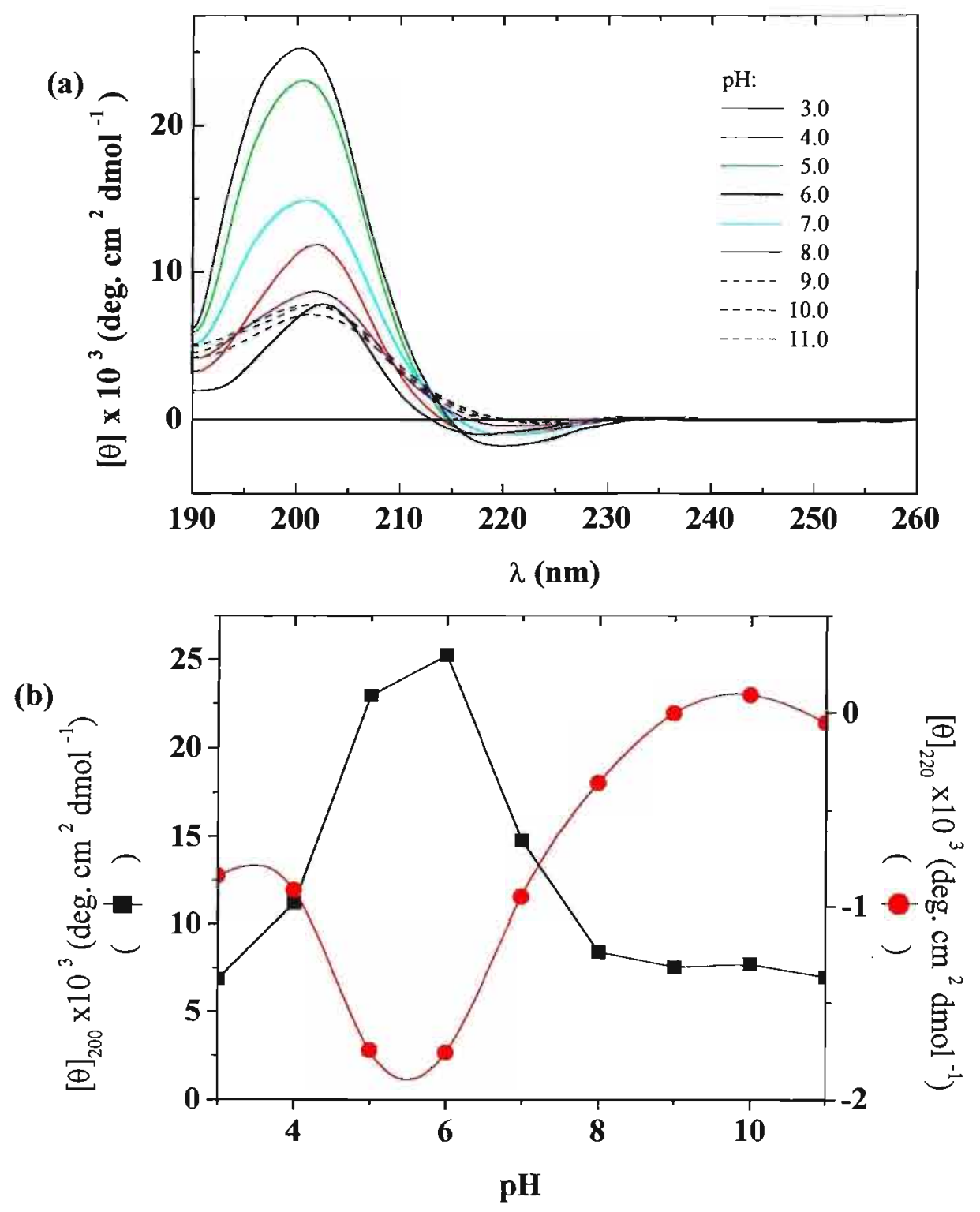

Figura 21 - (a) Efeito da variação do pH sobre os espectros de CD de $100 \mu \mathrm{M}$ III em solução contendo $2 \%$ de TFE. (b) variação da elipticidade molar [ $\theta$ ] em 200 (ロ) e $220 \mathrm{~nm}$ (•) em função do $\mathrm{pH}$. 

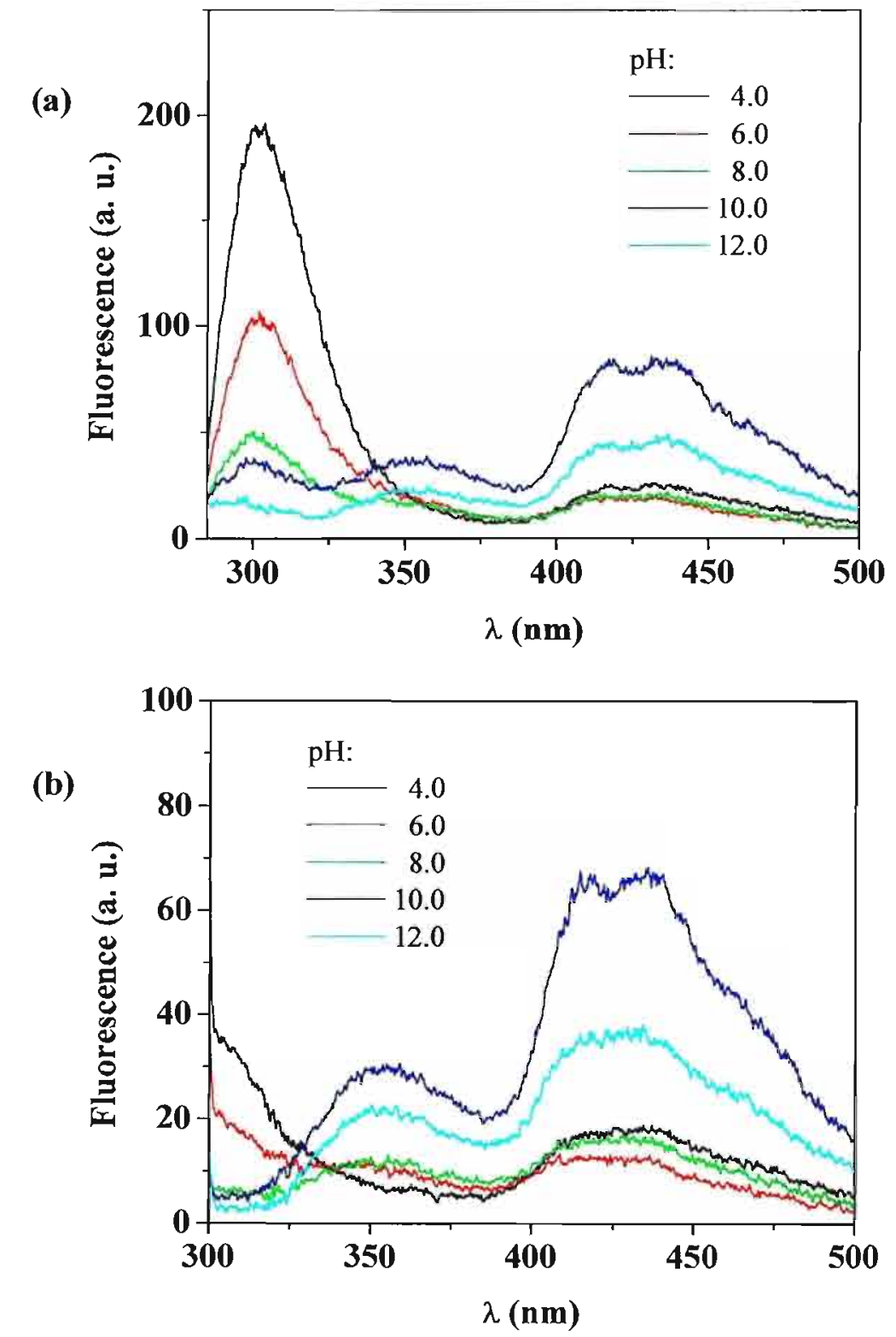

Figura 22 - Espectros de fluorescência de III $30 \mu \mathrm{M}$ em função do pH. Excitação em 275 (a) e $292 \mathrm{~nm}$ (b). 
anteriormente, III não possui nenhum grupo titulável nesta faixa de $\mathrm{pH}$. Esperávamos que a intensidade se mantivesse constante até pH alcalino e então começasse a cair devido à desprotonação da tirosina, formando tirosinato, como observado pela variação da carga teórica de III. Uma das possibilidades é de que a desprotonação da tirosina está ocorrendo no estado excitado, onde o $\mathrm{pK}_{\mathrm{a}}$ cai para $4,0^{(216)}$. Contudo, conforme observado nos dados de $\mathrm{CD}$, esta não é a única possibilidade, também pode ter o ocorrido o abaixamento do $\mathrm{pK}_{\mathrm{a}}$ da Tyr. A Figura 23 mostra a variação da intensidade de fluorescência em $302 \mathrm{~nm}$ com o pH. Pode-se observar um decréscimo acentuado até pH 7,0, e depois uma diminuição mais suave da intensidade.

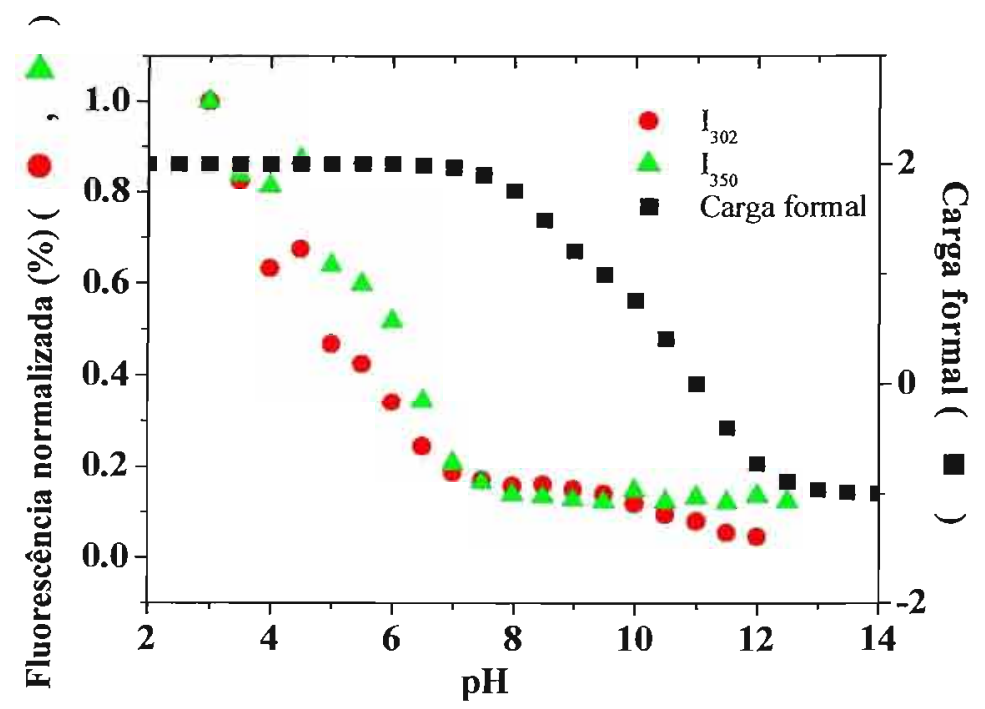

Fig. 23 - Variação da carga líquida e da intensidade de fluorescência de $30 \mu \mathrm{M}$ de III em função do pH. A amostra foi excitada em 275 (•) e 292 ( ) nm.

À medida que aumentamos o pH, a partir de $\mathrm{pH}$ 9,0 observou-se o aparecimento da banda característica da emissão de tirosinato, com máximo em $355 \mathrm{~nm}$. O tirosinato possui comprimento de onda de excitação em $292 \mathrm{~nm}$, dessa forma a amostra também foi excitada nesse comprimento de onda (Fig. 22b). Nesse caso, foi possível observar o aparecimento de uma banda correspondente ao tirosinato a partir de $\mathrm{pH}$ 7,0 e um aumento mais pronunciado da intensidade de fluorescência a partir de $\mathrm{pH}$ 8,0. A intensidade atinge um valor máximo em pH 10,0 e volta a cair, o que provavelmente se deve à precipitação do peptídeo em pHs mais elevados, uma vez que é possível observar em solução a presença de partículas em pHs mais elevados. 
Caso estivéssemos observando apenas a desprotonação da Tyr, seria de se esperar que ao mesmo tempo a banda de fenol diminuísse e a banda de fenolato aumentasse. No entanto, o que ocorre é que a banda de fenolato começa a aumentar só depois que a banda de fenol diminui. Na Figura 22b, observa-se que o comportamento da variação da intensidade de fluorescência em $350 \mathrm{~nm}$ é similar ao observado em $302 \mathrm{~nm}$. Esses resultados também sugerem alteração do $\mathrm{pK}_{\mathrm{a}}$ da tirosina.

Inesperadamente, foi observado o aparecimento de uma banda acima de $400 \mathrm{~nm}$, que em alguns pHs apresenta dois picos centrados ao redor de 420 e $430 \mathrm{~nm}$, respectivamente. Essa banda foi observada tanto ao se excitar a amostra em $275 \mathrm{~nm}$ como em $292 \mathrm{~nm}$. Inicialmente pensamos que esta banda se deveria à presença de alguma contaminação ou produto de degradação do peptídeo, contudo, repetindo o experimento com outra solução estoque, continuamos a observá-la. Além disso, a intensidade dessa banda é sensível ao pH; esse resultado indicou que a banda era real.

Uma das possibilidades é que a agregação em $\mathrm{pH}$ alcalino promova interação intermolecular entre os anéis aromáticos de tirosina e de fenilalanina ou ainda intermolecular entre as tirosinas. Na literatura ${ }^{(226)}$, bandas como aqui observadas são também características de bitirosina. Geralmente esse dímero covalente se forma a partir de condições oxidantes ${ }^{(227)}$, porém sua formação por ação de luz também foi descrita ${ }^{(228)}$. Dessa forma, a agregação e a incidência de luz sobre a amostra podem levar à formação de bitirosina

\subsubsection{Estudos na presença de detergentes}

Para estudar a conformação dos peptídeos em ambientes que mimetizem aquele encontrado na membrana biológica, estudamos o efeito de detergentes sobre a conformação dos peptídeos I, II e III. Para tal utilizamos detergentes com carga líquida zero (HPS e LPC) e com carga líquida negativa (SDS).

Nesse estudo foram feitas duas abordagens:

a) a uma solução aquosa contendo o peptídeo na concentração desejada, foram adicionadas concentrações crescentes de detergente. Esse estudo foi feito em três pHs diferentes: $4,0,7,0$ e 10,0 .

b) um filme do peptídeo foi ressuspenso na presença de uma solução aquosa contendo o detergente em altas concentrações e em seguida variou-se o pH. 


\subsubsection{Estudos na presença de HPS}

Em pH 4,0 (Fig. 24a), o aumento da concentração de HPS causa o deslocamento do mínimo do espectro de CD de I de 218 para $221 \mathrm{~nm}$ (Tabela 9) e o achatamento do espectro. A Figura 23b mostra a variação de elipticidade molar em função de HPS; é possível observar que acima de 0,2 mM HPS a valor de elipticidade tende a se estabilizar, o que indica que o peptídeo I está praticamente todo ligado ao detergente. A partir dessa concentração de HPS, a banda positiva do espectro encontra-se significativamente achatada, o que provavelmente está relacionado com o espalhamento de luz.

Nos pHs 7,0 e 10,0 (Fig. 25a e 26a, respectivamente) foi observado um efeito semelhante, embora o achatamento dos espectros nesses pHs não tenha sido tão pronunciado quanto em $\mathrm{pH} 4,0$. Em pH 7,0 ocorre um pequeno deslocamento para o azul do máximo do espectro de 201 para $197 \mathrm{~nm}$; enquanto que em pH 10,0 observa-se aumento da elipticidade molar com a adição de HPS; o que sugere que I é capaz de interagir com o detergente nesses pHs. Assim com o observado em pH 4,0, variação de elipticidade molar indica que acima de 0,2 mM HPS o peptídeo I está praticamente todo ligado ao detergente (Fig. 25b e 26b).

Tabela 9- Posição do comprimento de onda máximo $\left(\lambda_{\operatorname{mix}}\right)$ e mínimo $\left(\lambda_{\min }\right)$ nos espectros de CD de I em presença de concentrações crescentes de HPS em função do $\mathrm{pH}$.

\begin{tabular}{|c|c|c|c|c|c|c|}
\hline \multicolumn{7}{|c|}{$\lambda(\mathrm{nm})$} \\
\hline [HPS] (mM) & & & & & & \\
\hline & $\lambda_{\max }$ & $\lambda_{\min }$ & $\lambda_{\max }$ & $\lambda_{\min }$ & $\lambda_{\max }$ & $\lambda_{\min }$ \\
\hline sem adição & 200 & 218 & 201 & 219 & 202 & 218 \\
\hline 0,1 & 196 & 220 & 197 & 219 & 201 & 218 \\
\hline 0,5 & 200 & 221 & 197 & 219 & 201 & 217 \\
\hline
\end{tabular}

A Figura 27 mostra a interação do peptídeo II com HPS. Em pH 4,0 (Fig. 27a) o detergente provoca pouca ou nenhuma mudança conformacional. Nesse $\mathrm{pH}$, a conformação de II encontra-se ao acaso, com uma banda negativa centrada em $198 \mathrm{~nm}$ (Tabela 10); na presença de HPS observa-se um pequeno aumento na intensidade dessa banda, o que sugere que II se liga ao detergente. A Figura $27 \mathrm{~b}$ mostra que a variação da elipticidade molar é 


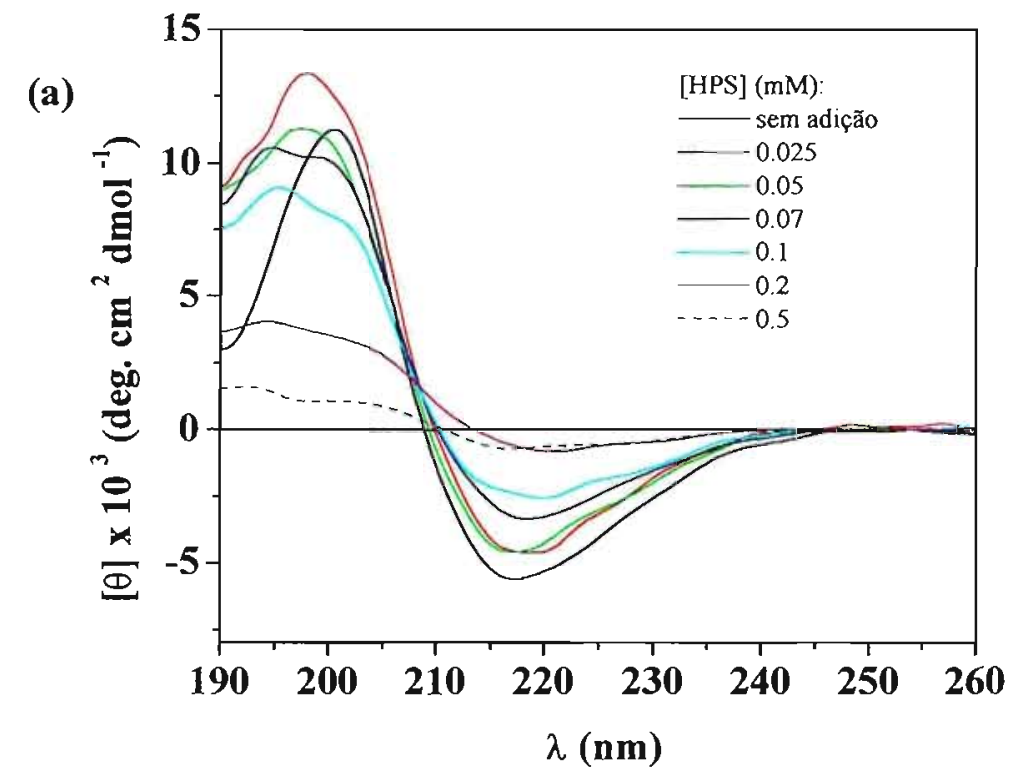

(b)

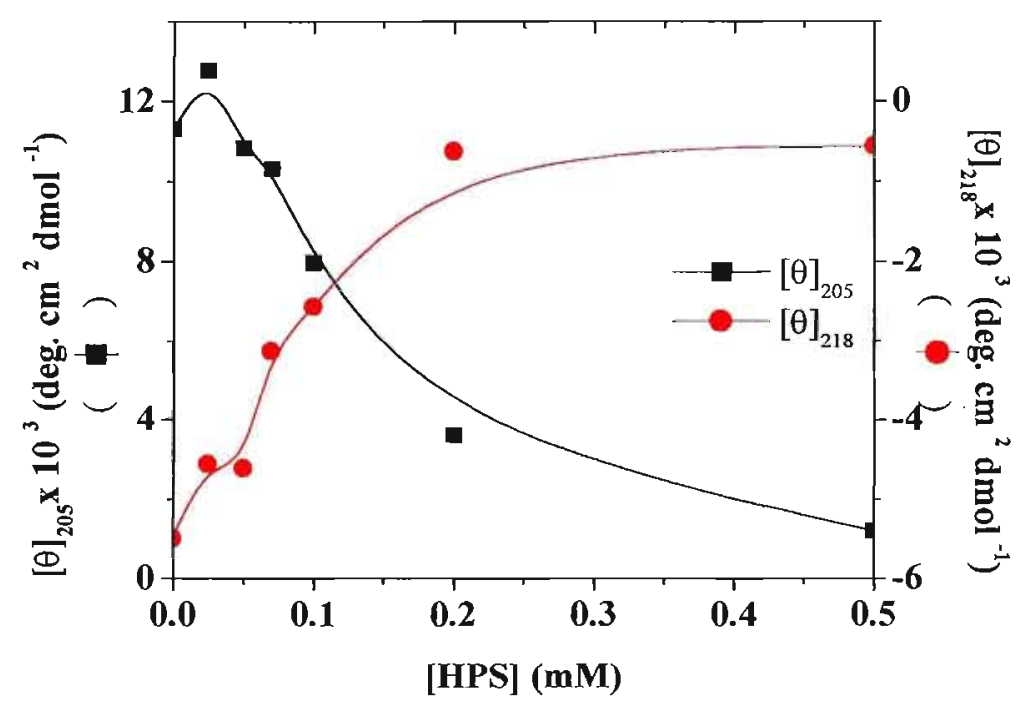

Figura 24 - Espectros de CD (a) e variação da elipticidade molar em 205 e 218 nm (b) de $70 \mu \mathrm{M}$ de I em função da concentração de HPS, pH 4,0. 
(a)

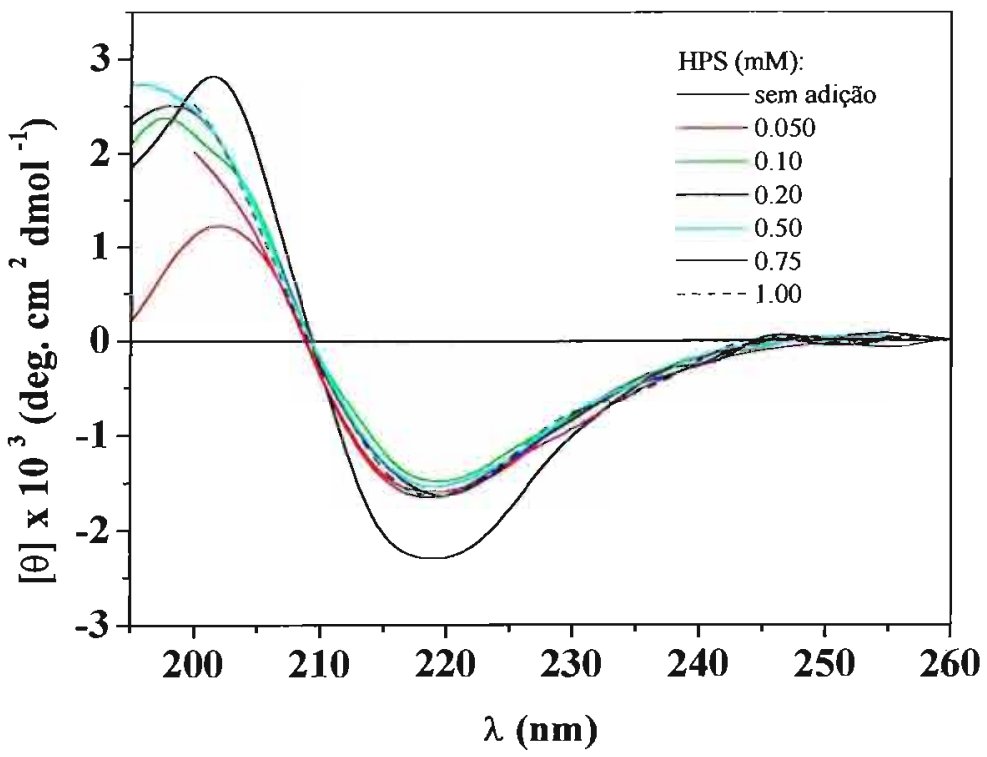

(b)

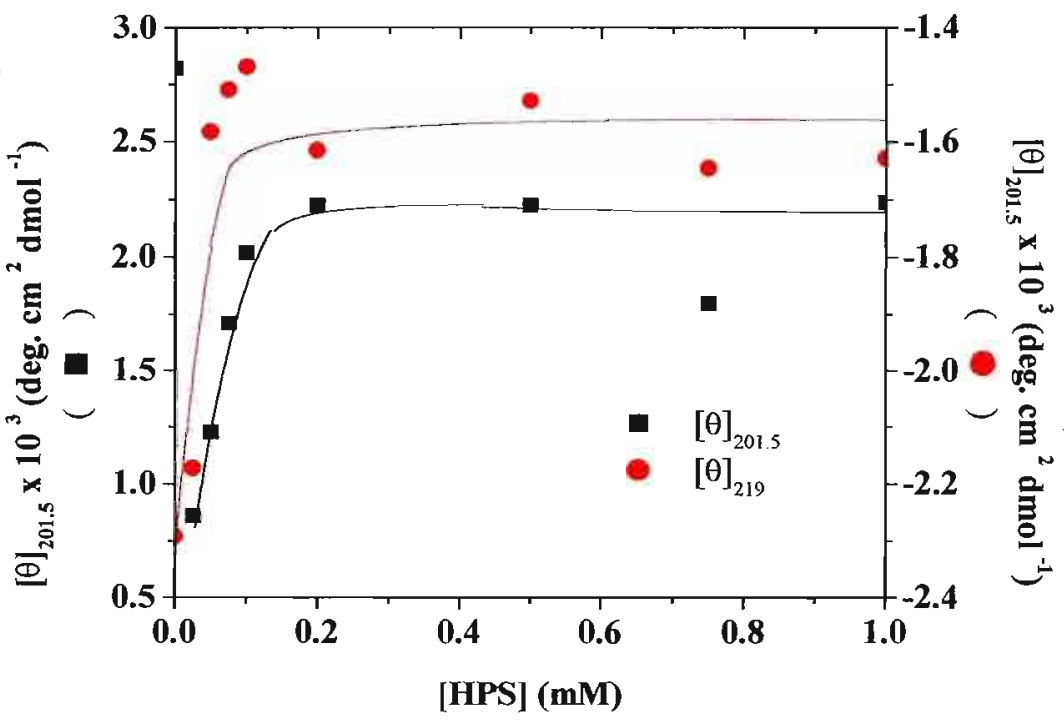

Figura 25 - Espectros de CD (a) e variação da elipticidade molar em 201 e 219 nm (b) de $70 \mu \mathrm{M}$ de I em função da concentração de HPS, pH 7,0. 
(a)

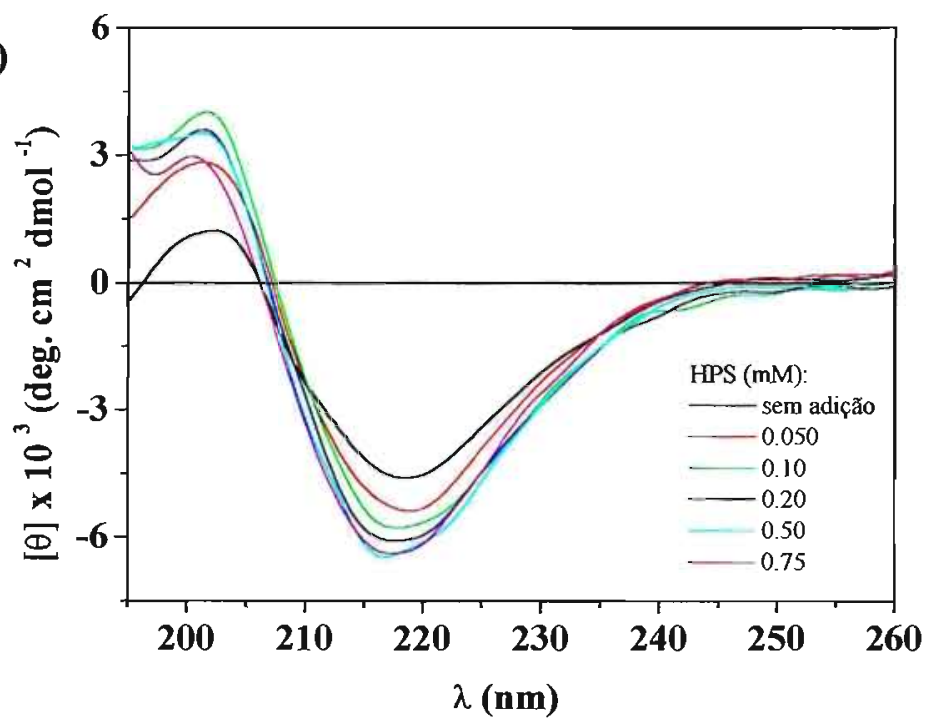

(b)

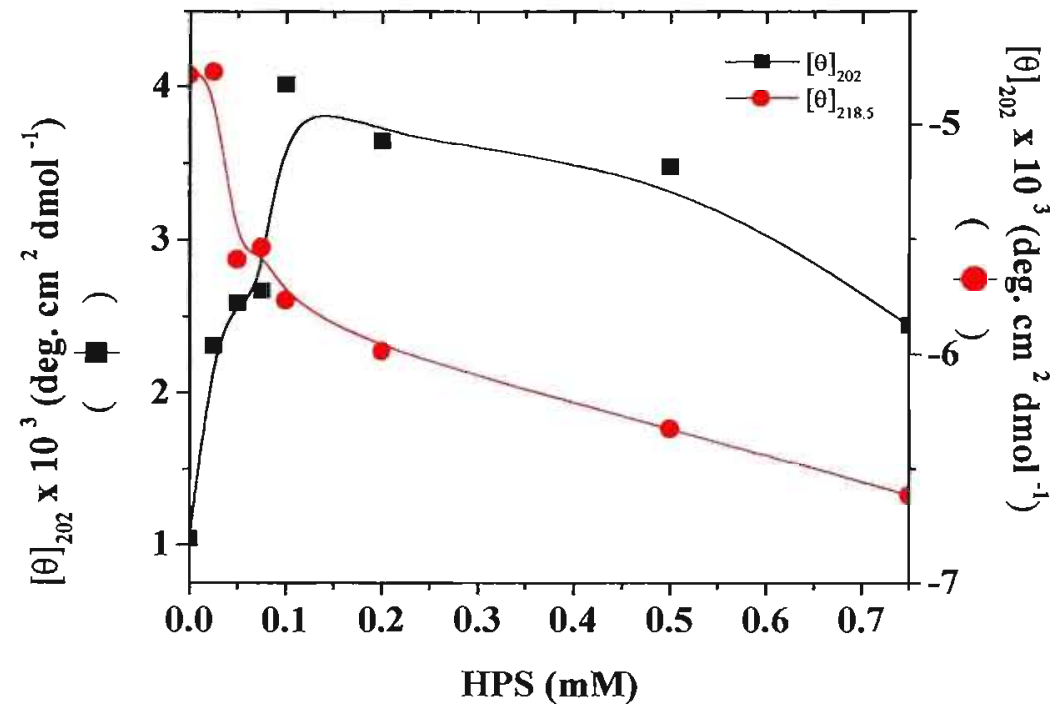

Figura 26 - Espectros de CD (a) e variação da elipticidade molar em 205 e 218 nm (b) de $70 \mu \mathrm{M}$ de I em função da concentração de HPS, pH 10,0. 

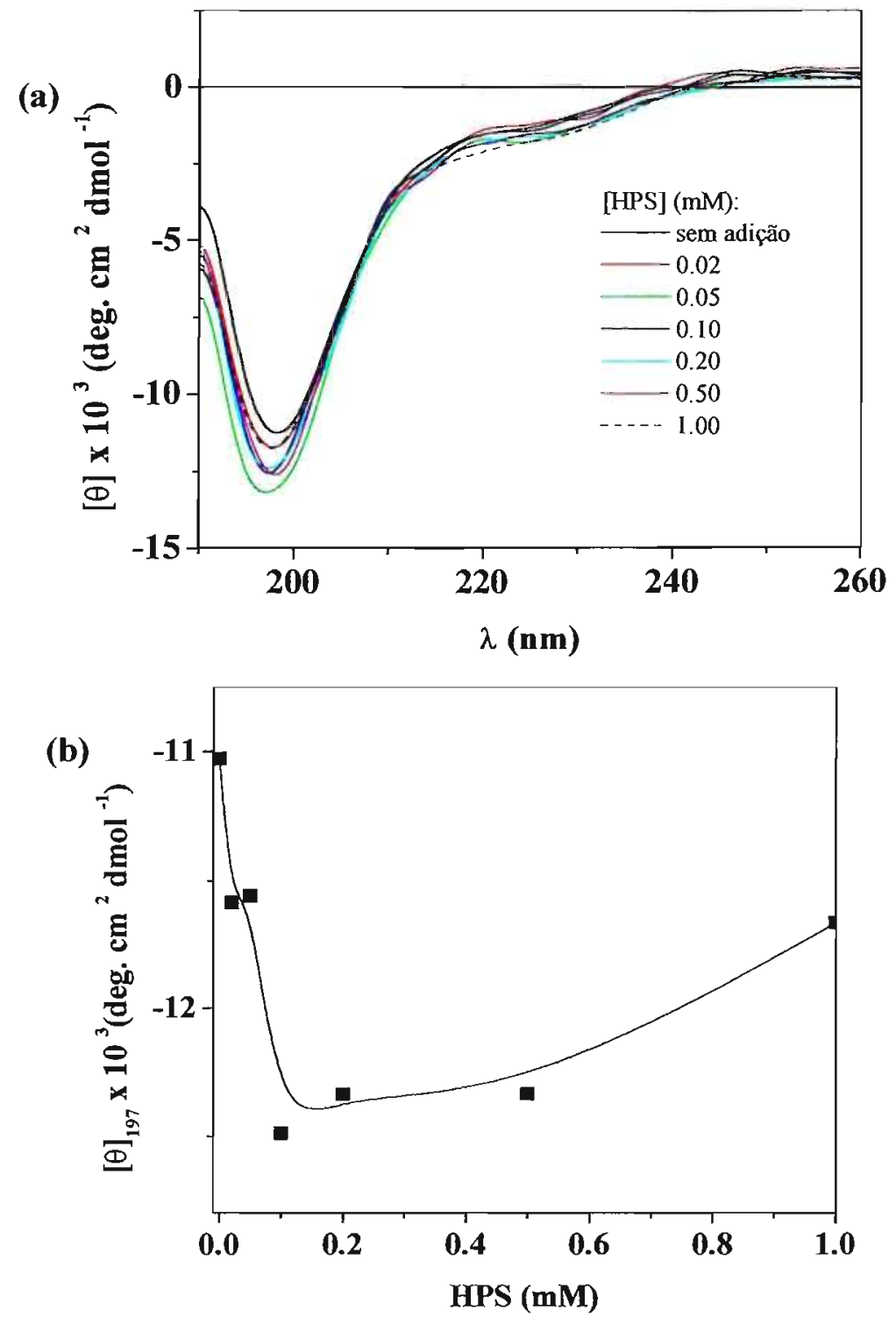

Figura 27 - Espectros de CD (a) e variação da elipticidade molar em 197 nm (b) de $70 \mu \mathrm{M}$ de II em função da concentração de HPS, pH 4,0. 
pequena, mudando pouco entre 0,1 e $0,5 \mathrm{mM}$ de HPS. A diminuição de $[\theta]_{198} \mathrm{em} 1 \mathrm{mM}$ poderia ser devida ao espalhamento de luz.

Tabela 10 - Posição do comprimento de onda máximo $\left(\lambda_{\max }\right)$ e mínimo $\left(\lambda_{\min }\right)$ nos espectros de CD de II em presença de concentrações crescentes de HPS função do pH.

\begin{tabular}{ccccccc}
\hline \multicolumn{7}{c}{$\lambda(\mathrm{nm})$} \\
\hline [HPS] $(\mathrm{mM})$ & & $\mathrm{pH} \mathrm{4,0}$ & \multicolumn{2}{c}{$\mathrm{pH} \mathrm{7,0}$} & \multicolumn{2}{c}{$\mathrm{pH} \mathrm{10,0}$} \\
\hline & $\lambda_{\max }$ & $\lambda_{\min }$ & $\lambda_{\max }$ & $\lambda_{\min }$ & $\lambda_{\max }$ & $\lambda_{\min }$ \\
sem adição & - & 198 & 193 & 216 & 190 & 215 \\
0,1 & - & 197 & 191 & 216 & 191 & 217 \\
0,5 & - & 197 & 190 & 215 & 191 & 217 \\
\hline
\end{tabular}

Em pH 7,0 (Fig. 28a) II adota conformação $\alpha$-helicoidal, apresentado uma banda positiva ao redor de $193 \mathrm{~nm}$ e duas bandas negativas centradas em 206 e $216 \mathrm{~nm}$, respectivamente. Com o aumento da concentração de HPS, inicialmente observa-se um aumento da intensidade do espectro (Fig. 28b); no entanto, acima de 0,1 mM HPS observa-se seu achatamento. O aumento inicial da elipticidade molar indica que II interage com o surfactante. Nota-se também o deslocamento da banda positiva para 190 nm e do primeiro mínimo de 206 para 204 nm (Tabela 10), o que sugere que II sofre mudanças conformacionais ao interagir com HPS. É possível observar que acima de 0,5 mM HPS, o fragmento II encontra-se praticamente todo ligado ao detergente.

Em pH 10,0 (Fig. 29a) após a adição de HPS ocorre uma mudança significativa na forma do espectro. Em solução aquosa, II apresenta um espectro indicativo de uma $\alpha$-hélice agregada, sua banda negativa apresenta $\lambda_{\min }$ ao redor de 204 e $216 \mathrm{~nm}$. Com a adição do detergente, o primeiro mínimo praticamente desaparece, tornando-se um ombro e o segundo mínimo é deslocado para redor de $217 \mathrm{~nm}$, indicando a formação de folha $\beta$. Adições posteriores do detergente não causam mudanças significativas no espectro; acima de 0,2 mM HPS a elipticidade molar ao redor de $216 \mathrm{~nm}$ permanece constante (Fig. 29b).

Esses resultados indicam que II é capaz de se ligar ao detergente, sofrendo mudanças conformacionais significativas nos $\mathrm{pHs} 7,0$ e 10,0. Nesses dois pHs o detergente estabiliza uma folha $\beta$, no entanto a forma dos espectros de $\mathrm{CD}$ indica que o detergente estabiliza conformações diferentes.

O espectro de CD de III na presença de HPS em pH 4,0 (Fig. 30a) apresenta um deslocamento significativo do vermelho para o azul e um aumento da intensidade com a adição do detergente. A banda positiva centrada ao redor de $203 \mathrm{~nm}$ desloca-se para 193 $\mathrm{nm}$, enquanto que o $\lambda_{\min }$ da banda negativa permanece praticamente inalterado, ao redor 
(a)

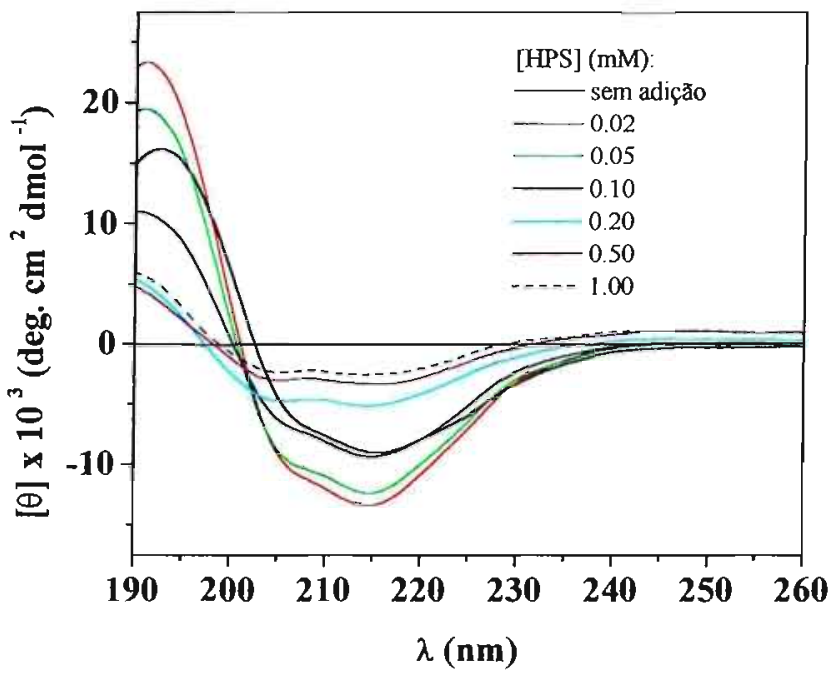

(b)

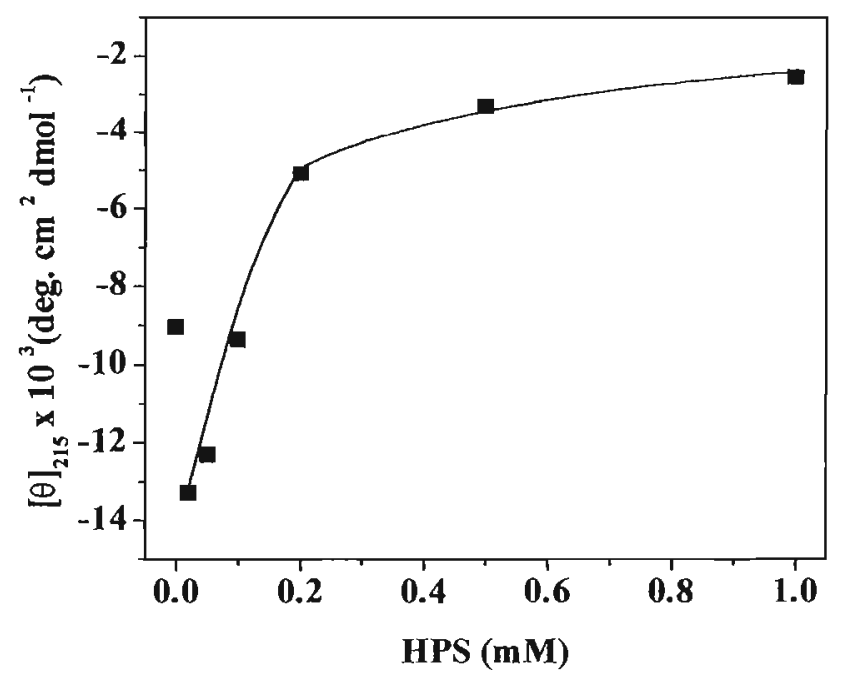

(c)

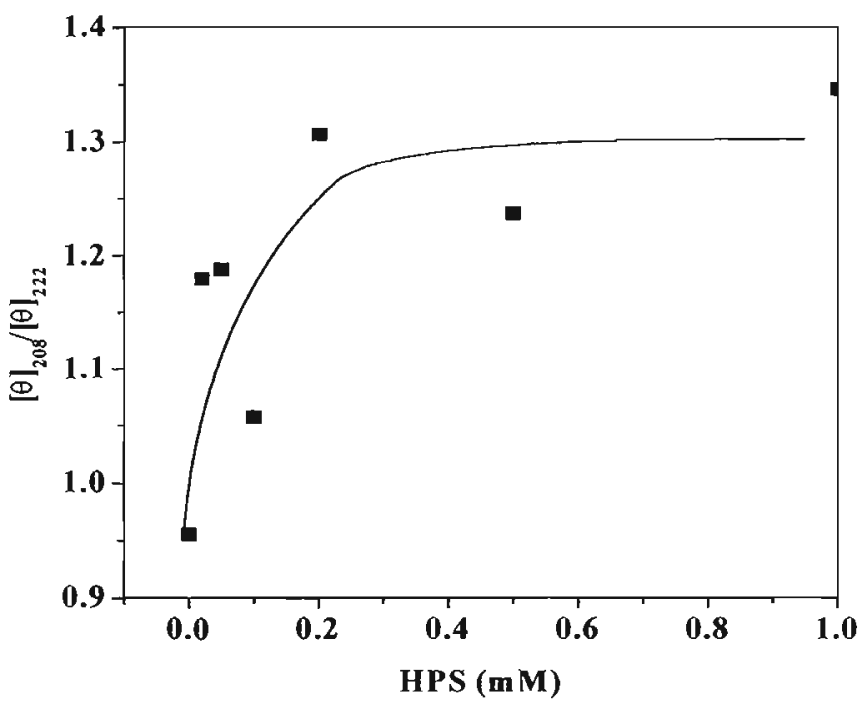

Figura 28 - Espectros de CD (a), variação da elipticidade molar em 215 nm (b) e razão entre a elipticidade molar em 208 e $222 \mathrm{~nm}$ de $70 \mu \mathrm{M}$ de $\Pi$ em função da concentração de HPS, pH 7,0. 
(a)

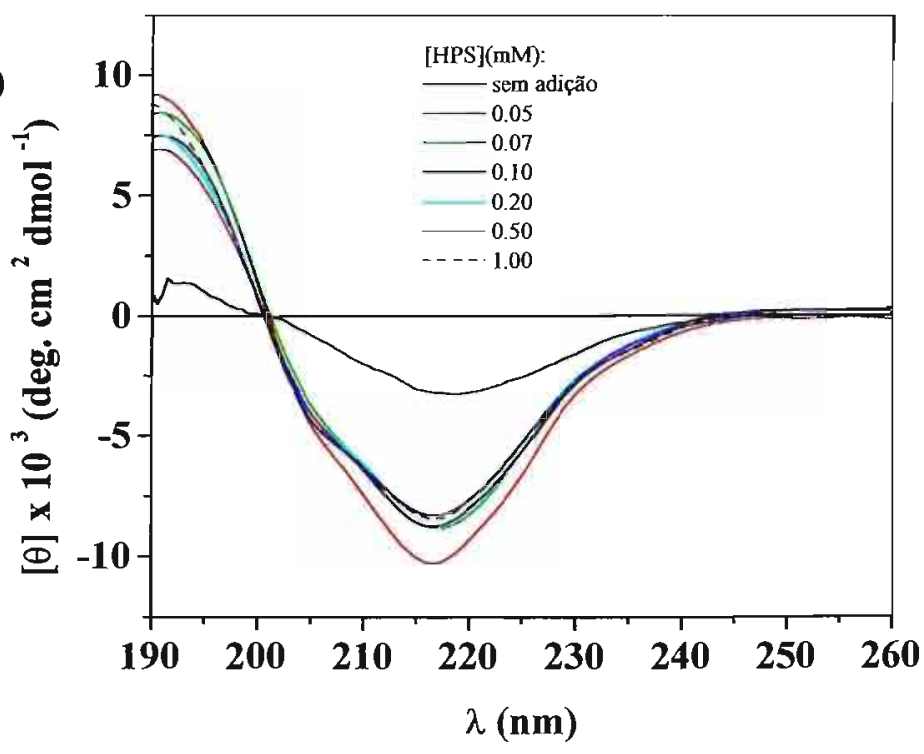

(b)

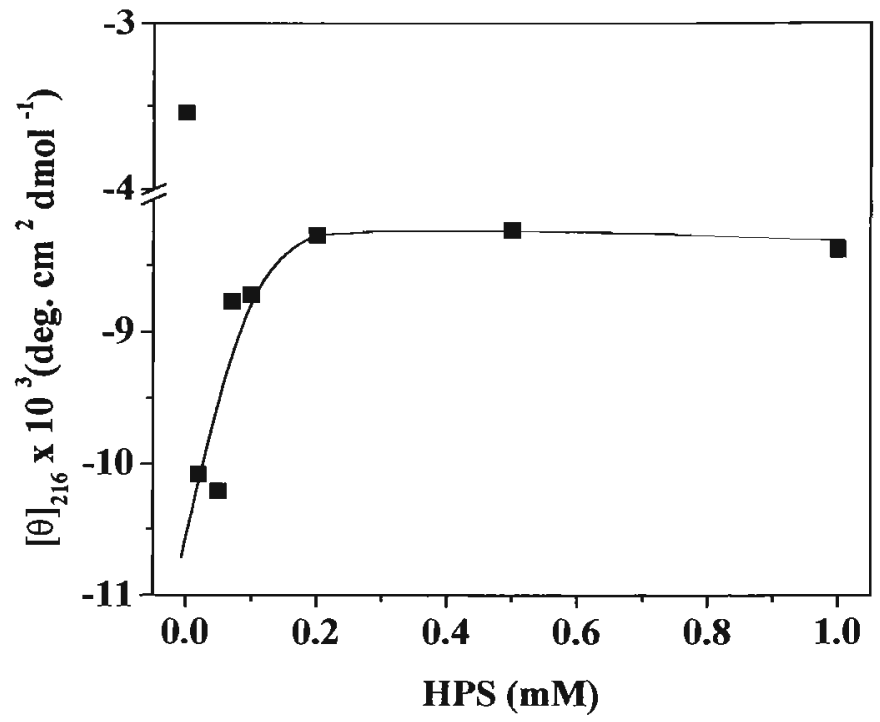

Figura 29 - Espectros de CD (a) e variação da elipticidade molar em 197 nm (b) de 70 $\mu \mathrm{M}$ de II em função da concentração de HPS, pH 10,0. 
(a)
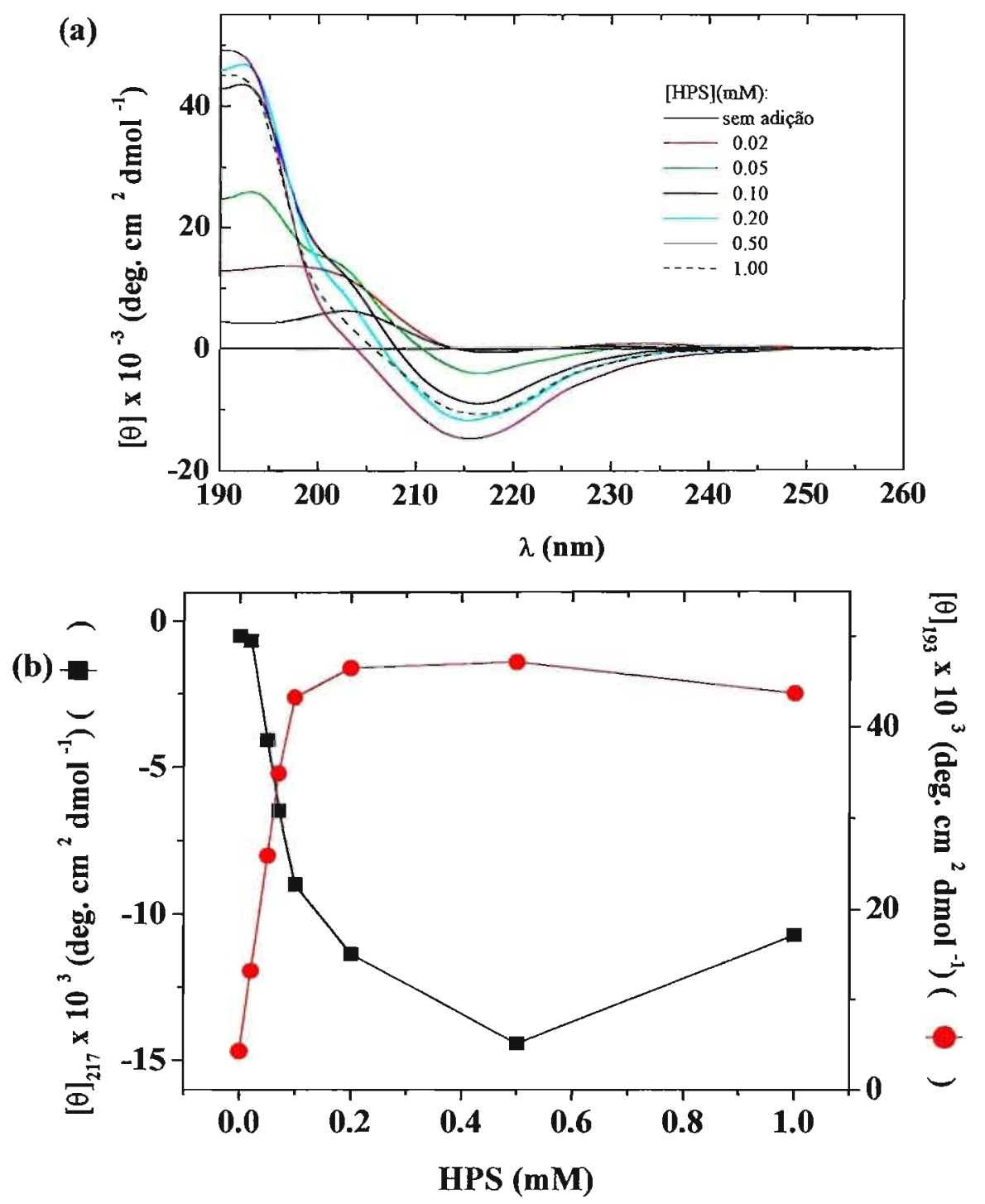

Figura 30 - Espectros de CD (a) e variação da elipticidade molar em 193 e 217 nm (b) de $70 \mu \mathrm{M}$ de III em função da concentração de HPS, pH 4,0. 
de $217 \mathrm{~nm}$ (Tabela 11). Esse resultado indica que III interage com o detergente nesse pH e evidencia uma mudança conformacional de III com o aumento da concentração de detergente; essa mudança conformacional sugere que HPS é capaz de diminuir o grau de agregação de III.

Tabela 11 - Posição do comprimento de onda máximo $\left(\lambda_{\max }\right)$ e mínimo $\left(\lambda_{\min }\right)$ nos espectros de CD de III em presença de concentrações crescentes de HPS em função do $\mathrm{pH}$.

\begin{tabular}{ccccccc}
\hline \multicolumn{7}{c}{$\lambda(\mathrm{nm})$} \\
\hline [HPS] $(\mathrm{mM})$ & \multicolumn{7}{c}{$\mathrm{pH} \mathrm{4,0} 7,0$} & \multicolumn{2}{c}{$\mathrm{pH} \mathrm{10,0}$} \\
\hline & $\lambda_{\max }$ & $\lambda_{\min }$ & $\lambda_{\max }$ & $\lambda_{\min }$ & $\lambda_{\max }$ & $\lambda_{\min }$ \\
sem adição & 203 & 216 & 202 & 219 & 205 & 218 \\
0,1 & 193 & 217 & 195 & 220 & 204 & 219 \\
0,5 & 191 & 216 & 197 & 219 & 203 & 218 \\
\hline
\end{tabular}

Nos outros pHs, III parece ter uma afinidade menor por HPS. Nos pHs 7,0 e 10,0 (Fig. 31a e 32a, respectivamente) observa-se um alargamento das bandas positivas e negativas do espectro de $\mathrm{CD}$, enquanto que a intensidade do espectro de III nesses $\mathrm{pHs}$ não muda significativamente com o aumento da concentração do detergente (Fig. 31b e $32 \mathrm{~b}$, respectivamente). É interessante notar que em ambos os pHs a interação com a micela parece se estabilizar ao redor de 0,2 mM HPS. Em pH 7,0, assim como observado em pHs mais baixos, o máximo da banda positiva é deslocado para comprimentos de onda mais baixos (Tabela 11), enquanto que em $\mathrm{pH}$ mais alcalino o deslocamento de $\lambda_{\text {máx }}$ é pequeno.

A interação do peptídeo III com micelas também foi estudada por fluorescência. É possível observar um grande aumento da intensidade de fluorescência em todos os pHs estudados (Figuras 33 e 34) após as primeiras adições de detergente, indicando que III apresenta uma forte interação com HPS, mesmo quando este ainda está na forma monomérica (cmc 5,0 ×10 ${ }^{-5} \mathrm{M}$, ref. 205). Observando-se a variação de intensidade de fluorescência em $302 \mathrm{~nm}$ em função de HPS (Fig. 34), nota-se que acima de 0,2 mM HPS, a intensidade de fluorescência praticamente não aumenta mais, o que sugere que III estaria praticamente todo ligado à micela. A interação significativa de III com HPS provavelmente se deve à natureza hidrofóbica do peptídeo. Esses resultados são consistentes com àqueles observados por $\mathrm{CD}$.

Ao excitarmos a amostra em $275 \mathrm{~nm}$ em pH 10,0 é possível observar tanto o aumento da intensidade de fluorescência em $302 \mathrm{~nm}$, que é relativa à tirosina, quanto em $350 \mathrm{~nm}$, relativa a tirosinato, o que indica a contribuição das duas espécies. $O$ aumento da intensidade em $302 \mathrm{~nm}$ pode ser interpretado como um indício do 


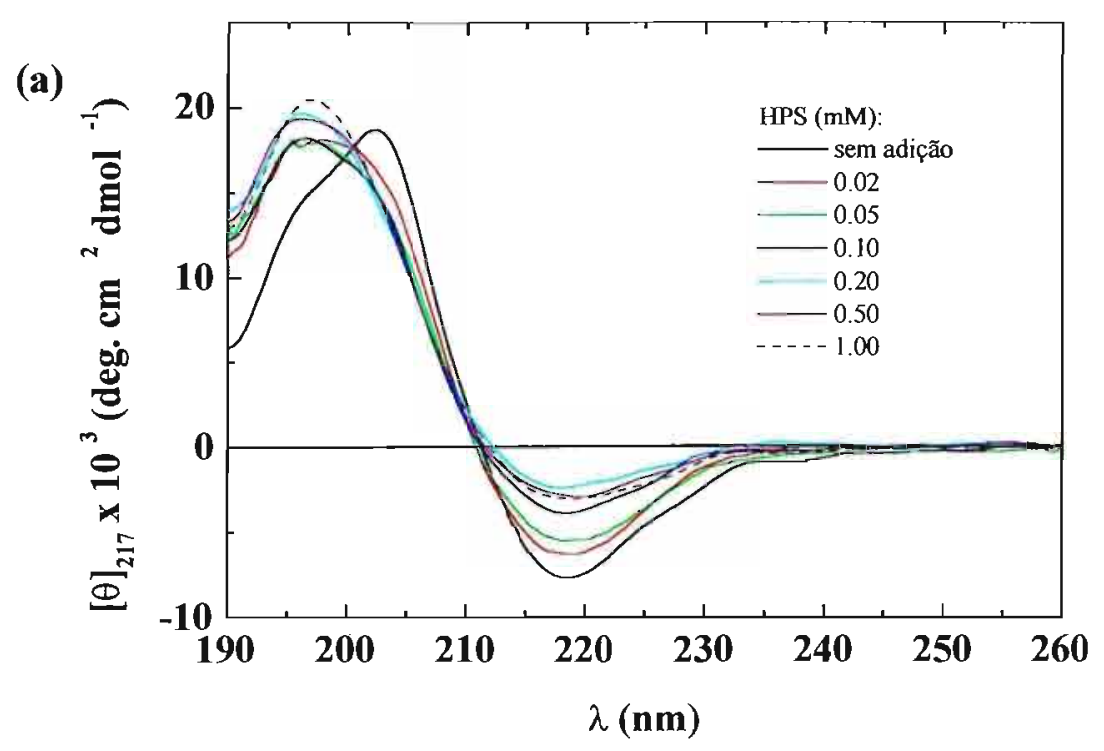

(b)

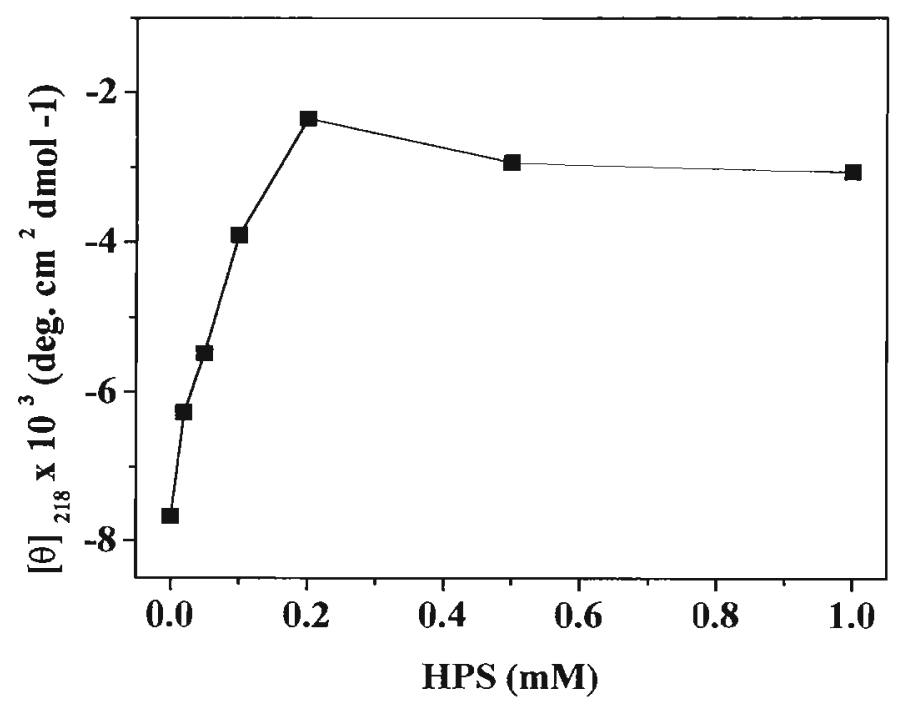

Figura 31 - Espectros de CD (a) e variação da elipticidade molar em 218 nm (b) de 70 $\mu \mathrm{M}$ de III em função da concentração de HPS, pH 7,0. 


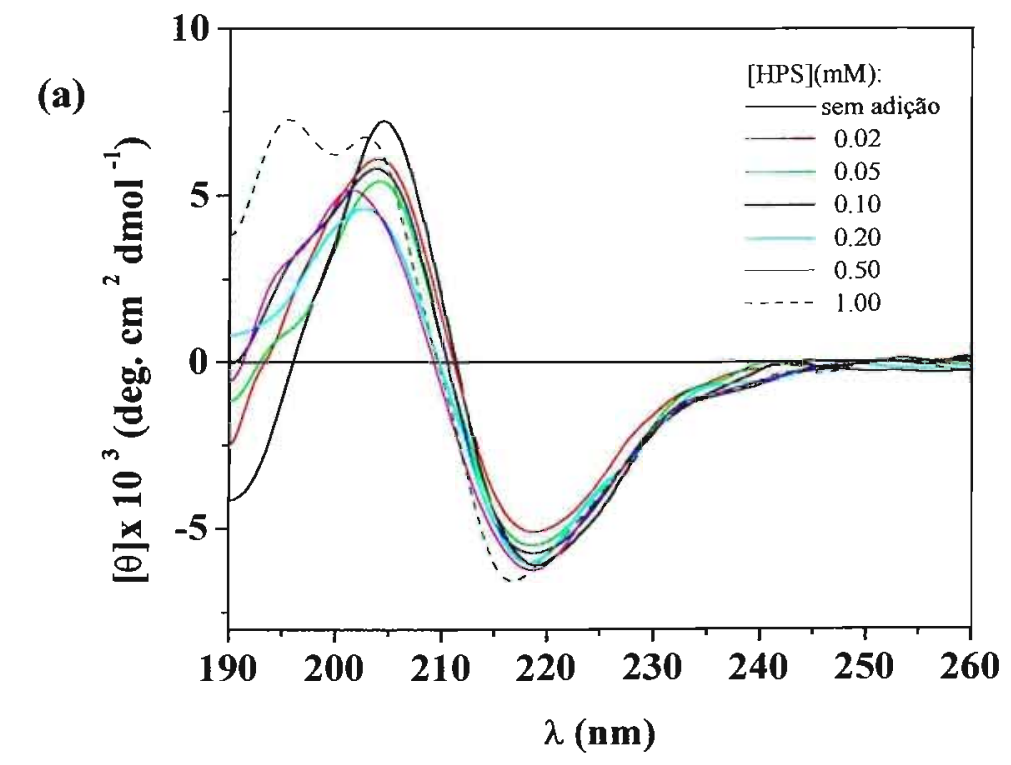

(b)

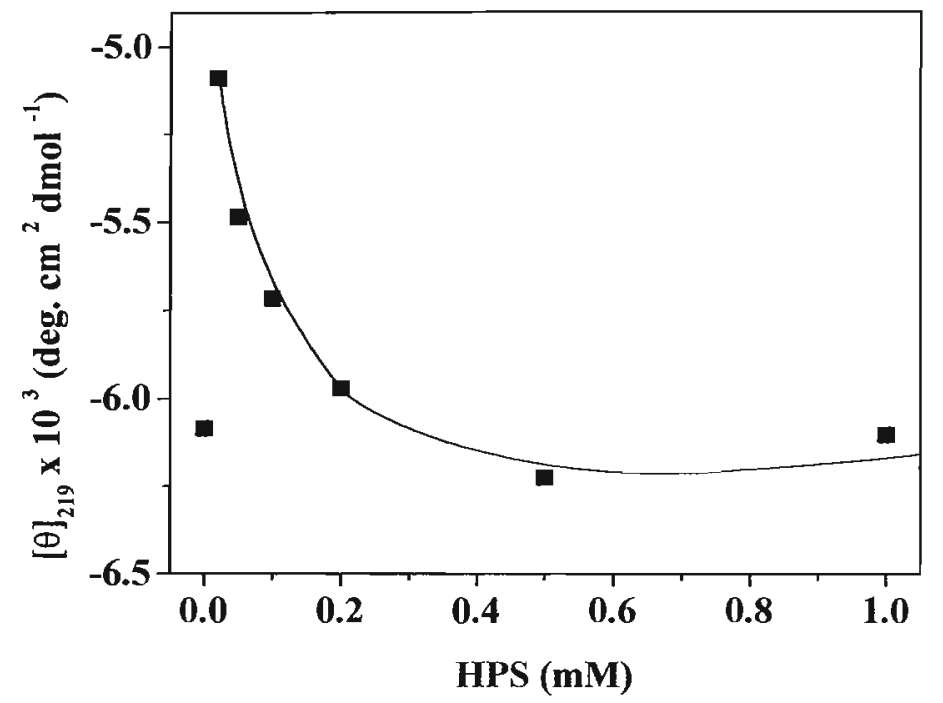

Figura 32 - Espectros de CD (a) e variação da elipticidade molar em 219 nm (b) de 70 $\mu \mathrm{M}$ de III em função da concentração de HPS, pH 10,0. 
(a)

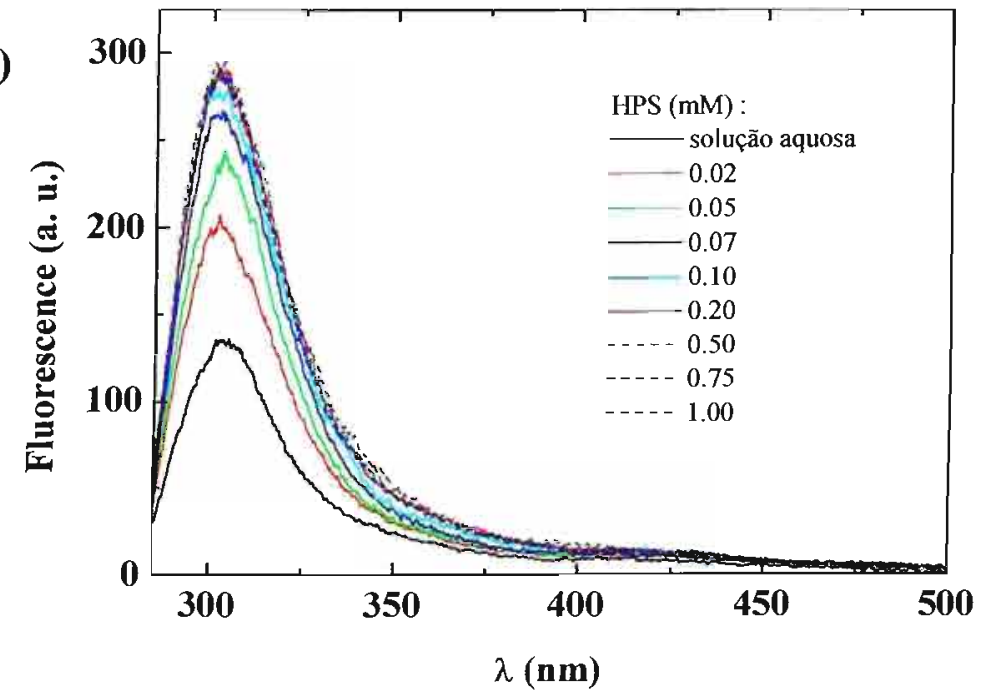

(b)
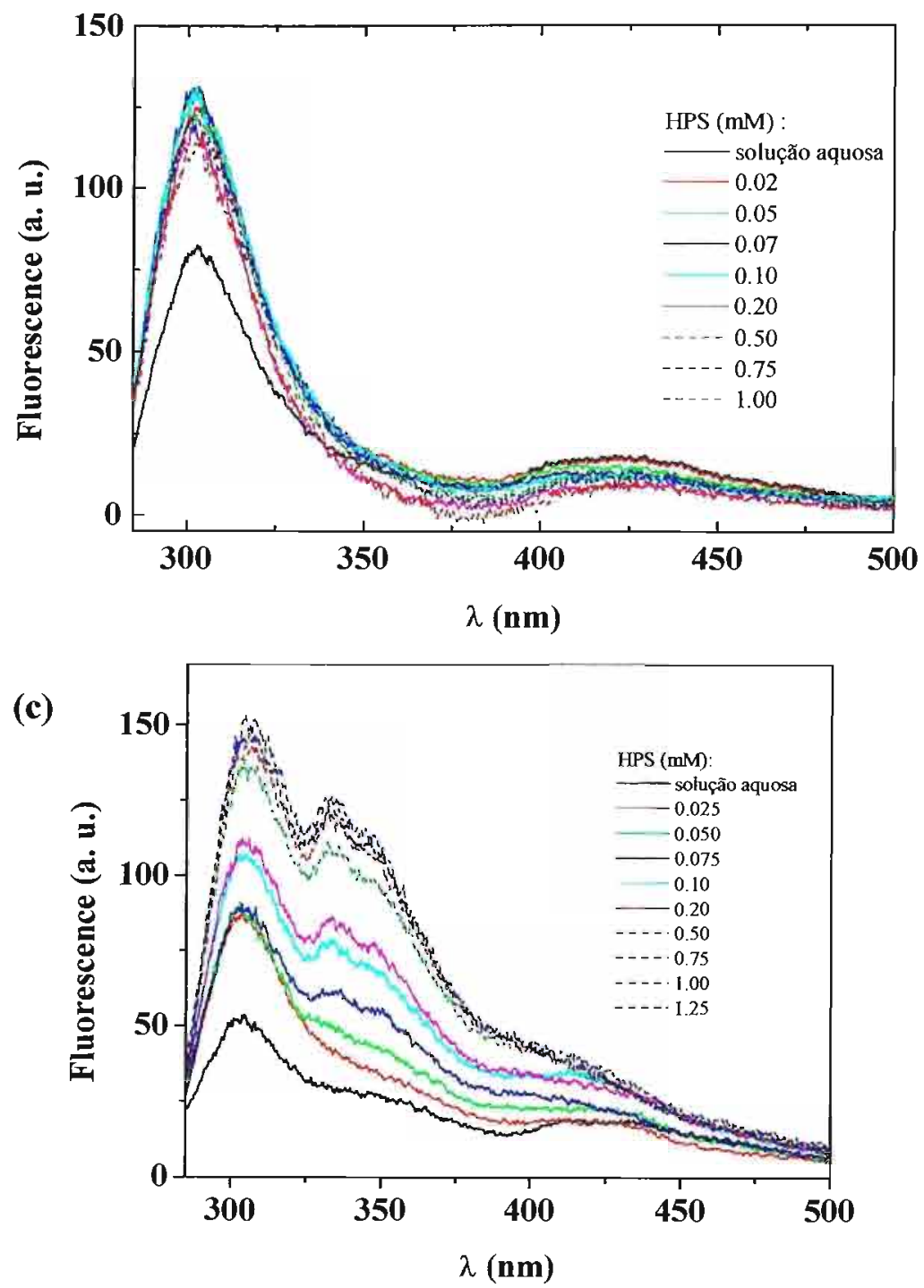

Figura 33 - Espectros de fluorescência de $30 \mu \mathrm{M}$ de III em função da concentração de HPS. pH: 4,0 (a); 7,0 (b) e 10,0 (c). $\lambda_{\text {exc }}=275 \mathrm{~nm}$. 


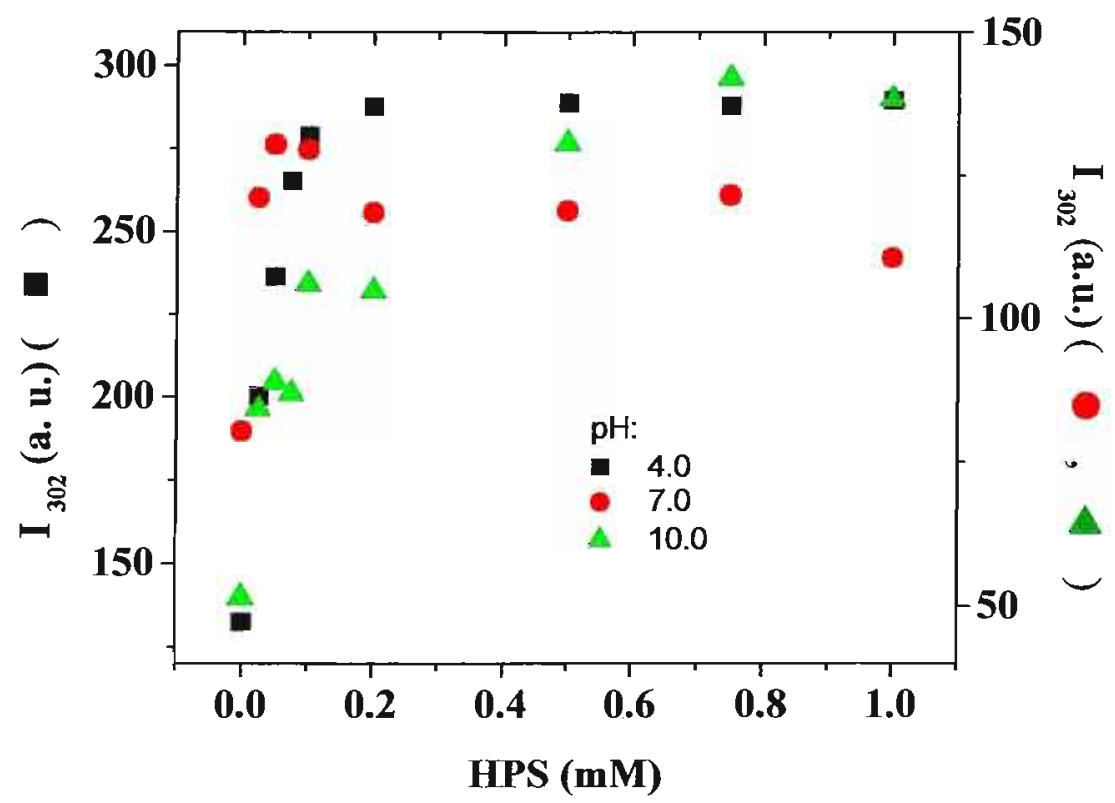

Figura 34 - Variação da intensidade de fluorescência em $302 \mathrm{~nm}$ de $30 \mu \mathrm{M}$ de III em

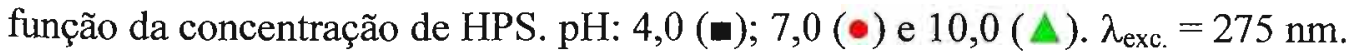


do abaixamento do $\mathrm{pK}_{\mathrm{a}}$ da Tyr na presença de HPS. Segundo Lakowicz ${ }^{(216)}$, a Tyr no seu estado excitado possui $\mathrm{pK}_{\mathrm{a}}$ em torno de 4,0; portanto, é possível que essa espécie seja estabilizada na presença do detergente.

O experimento de fluorescência mostra que III interage com HPS nos pHs 7,0 e 10,0 (Fig. 33b e 33c, respectivamente), o que não fica claro no experimento de $C D$, principalmente em pH 10,0 (Fig. 32). No nosso grupo observamos que a técnica de CD é mais sensível a mudanças conformacionais, enquanto que a fluorescência é capaz de mostrar mais claramente a ligação de uma espécie a uma interface e a titulação de um grupo ionizável.

Outro fato relevante é que a banda atribuída a bitirosina, entre 400 e $450 \mathrm{~nm}$, que aparece claramente quando da titulação do peptídeo em solução aquosa, não é muito pronunciada na presença de HPS nos pHs 7,0 e 10,0. Isto sugere que na presença do detergente, ocorre uma diminuição do grau de agregação de III. A presença ou não da banda de bitirosinato nos espectros de fluorescência foi utilizada nesse e nos experimentos posteriores com um indicativo do grau de agregação de III.

\subsubsection{Estudos na presença de LPC}

As propriedades conformacionais de I e dos análogos II e III foram estudadas por CD na presença do detergente lisofosfatidilcolina (LPC) em três pHs diferentes. Quantidades crescentes de LPC foram adicionadas a soluções contendo os peptídeos estudados.

Assim como o HPS, a LPC também é um detergente zwitteriônico. Contudo, a LPC possui uma cabeça polar com um dipolo semelhante ao da cabeça polar da fosfatidilcolina ${ }^{(229)}$, enquanto que o HPS não. Resultados anteriores obtidos com outros peptídeos estudados no nosso laboratório, haviam demonstrado que essa diferença pode levar a resultados diferentes ao estudar-se a ligação de um peptídeo com os dois detergentes.

A Figura 35a mostra os espectros de CD de I em função de concentrações crescentes de LPC, a pH 4,0. Os espectros na presença do detergente apresentam características de estrutura em folha $\beta$, sendo que com a adição do detergente ocorreram mudanças consideráveis de intensidade (Fig. 35b), provavelmente por causa da interação do peptídeo com o detergente. Em solução aquosa em pH 4,0, o espectro de CD de I apresenta uma banda com máximo centrado em $200 \mathrm{~nm}$ e mínimo em $219 \mathrm{~nm}$ 
(a)

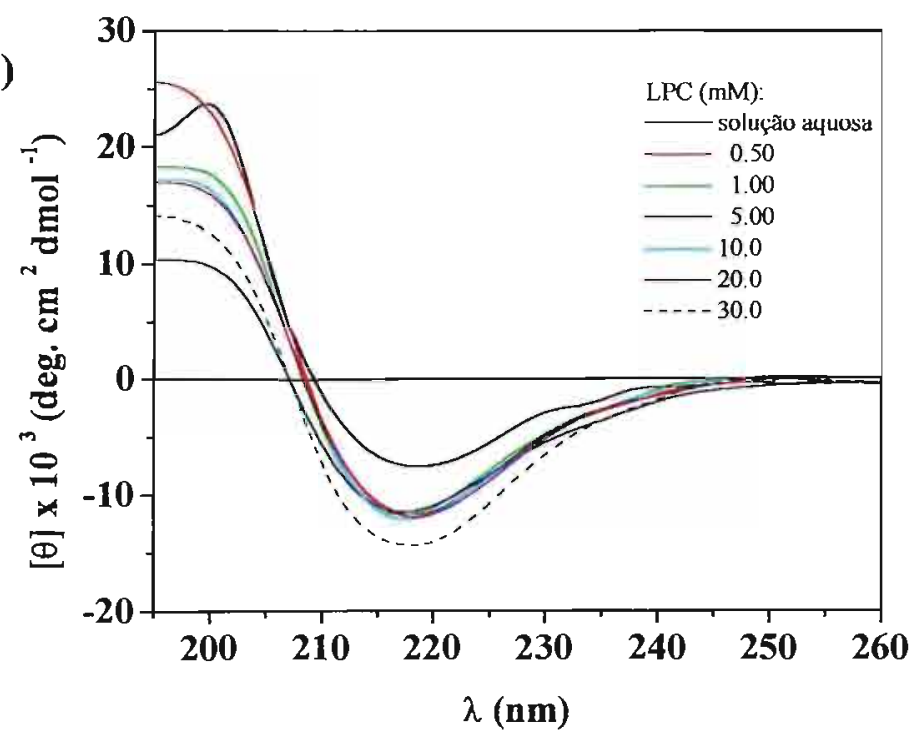

(b)

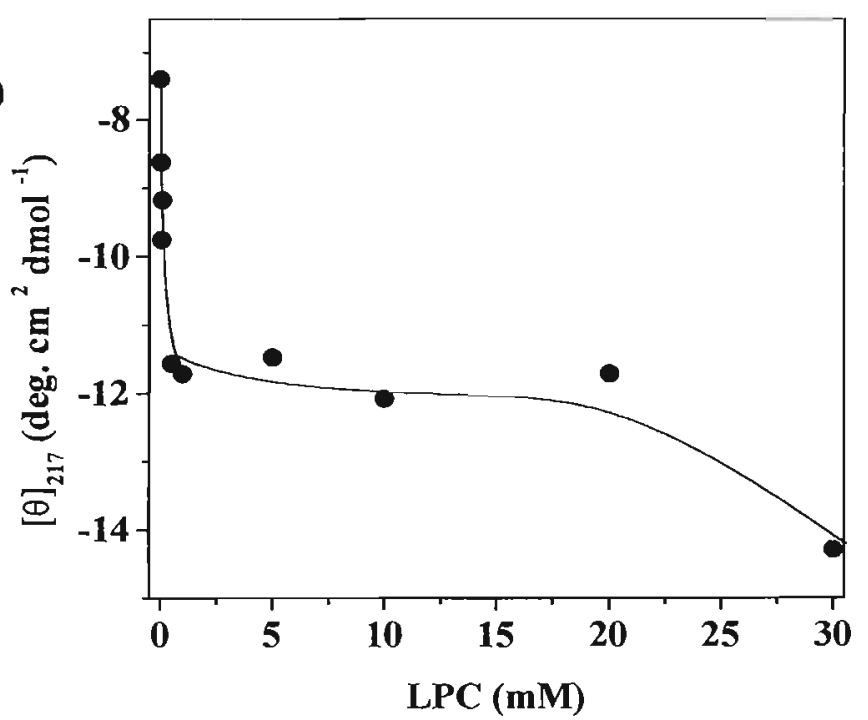

Figura 35 - Espectros de CD (a) e variação da elipticidade molar em 217 nm (b) de 70 $\mu \mathrm{M}$ de I em função da concentração de LPC, pH 4,0. 
(Tabela 12), um espectro com essas características foi atribuído a uma folha $\beta$ paralela (221)

Tabela 12 - Comprimento de onda máximo $\left(\lambda_{\max }\right)$ e mínimo $\left(\lambda_{\min }\right)$ nos espectros de CD de I na presença de concentrações crescentes de LPC em função do $\mathrm{pH}$.

\begin{tabular}{ccccccc}
\hline \multicolumn{7}{c}{$[\theta] \times 10^{3}$ deg. $\mathrm{cm}^{2} \mathrm{dmol}^{-1}$} \\
\hline [LPC] $(\mathrm{mM})$ & \multicolumn{7}{c}{$\mathrm{pH} \mathrm{4,0}$} & \multicolumn{2}{c}{$\mathrm{pH} 7,0$} & \multicolumn{2}{c}{$\mathrm{pH} \mathrm{10,0}$} \\
\hline & $\lambda_{\max }$ & $\lambda_{\min }$ & $\lambda_{\max }$ & $\lambda_{\min }$ & $\lambda_{\max }$ & $\lambda_{\min }$ \\
sem adição & 200 & 219 & 203 & 222 & $195,204^{*}$ & 222 \\
0,1 & 198 & 218 & 201 & 220 & 202 & 219 \\
0,5 & 195 & 218 & 200 & 220 & 202 & 219 \\
1,0 & 198 & 217 & 201 & 219 & 202 & 219 \\
5,0 & 198 & 217 & $196,202^{*}$ & 219 & 202 & 218 \\
10,0 & 198 & 217 & 199 & 218 & 202 & 219 \\
20,0 & 197 & 218 & 201 & 220 & 202 & 220 \\
30,0 & 197 & 218 & 198 & 220 & 201 & 219 \\
\hline * & 197 &
\end{tabular}

Com o aumento de LPC, observa-se uma mudança da posição dos máximos e mínimo para comprimentos de onda mais baixos, sendo que essa mudança é maior para o $\lambda_{\text {máx }}$; esse resultado indica que I interage com LPC. Observa-se também que a banda positiva do espectro sofre achatamento acima de $1 \mathrm{mM}$ LPC. Esses resultados sugerem que I pode sofrer mudanças conformacionais na presença de LPC nesse $\mathrm{pH}$.

Em pH 7,0 (Fig. 36), ocorrem mudanças semelhantes com a adição de LPC, principalmente quanto à banda negativa dos espectros, a qual apresenta um aumento significativo de intensidade (Fig. 36b). Observa-se também um pequeno deslocamento para o azul do mínimo do espectro de 222 para $219 \mathrm{~nm}$ com a adição de quantidades crescentes do detergente (Fig. 36a). O espectro em solução aquosa nesse pH corresponde ao espectro de uma dobra $\beta$, o deslocamento para o azul do $\lambda_{\max }$ e do $\lambda_{\min }$ sugere que a conformação do peptídeo muda para a de uma folha $\beta$.

Em pH 10,0 (Fig. 37), assim como em pH 7,0, também observou-se um aumento de intensidade da banda negativa do espectro e deslocamento de seu mínimo para o azul (Tabela 12) (Fig. 37a). O espectro de I em solução aquosa nesse pH apresenta um máximo ao redor de $195 \mathrm{~nm}$ e um mínimo em torno de $222 \mathrm{~nm}$; no espectro também é possível observar um ombro ao redor de $204 \mathrm{~nm}$, espectros com características similares foram atribuídos a uma dobra $\beta^{(221)}$. Na presença do detergente, a posição do máximo é deslocada para $202 \mathrm{~nm}$, essa posição permanece constante em todas as concentrações de LPC. Quanto ao mínimo, na presença de LPC situa-se ao redor de $219 \mathrm{~nm}$. Os espectros de dobra $\beta$ que possuem um mínimo ao redor de $220 \mathrm{~nm}{ }^{(221)}$, geralmente possuem 
(a)

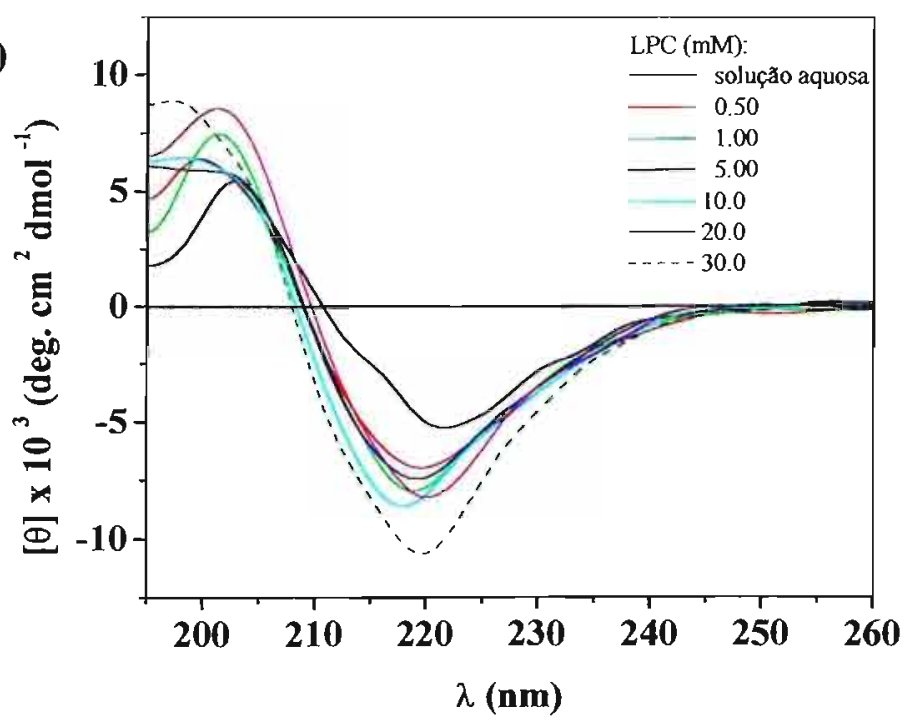

(b)

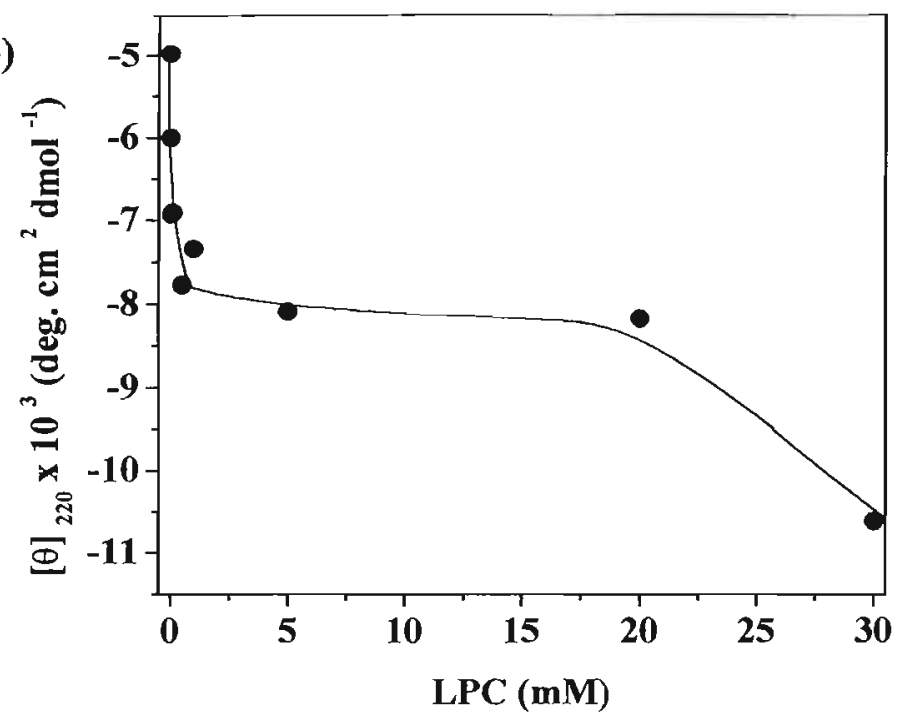

Figura 36 - Espectros de CD (a) e variação da elipticidade molar em 220 nm (b) de 70 $\mu \mathrm{M}$ de I em função da concentração de LPC, pH 7,0. 
(a)

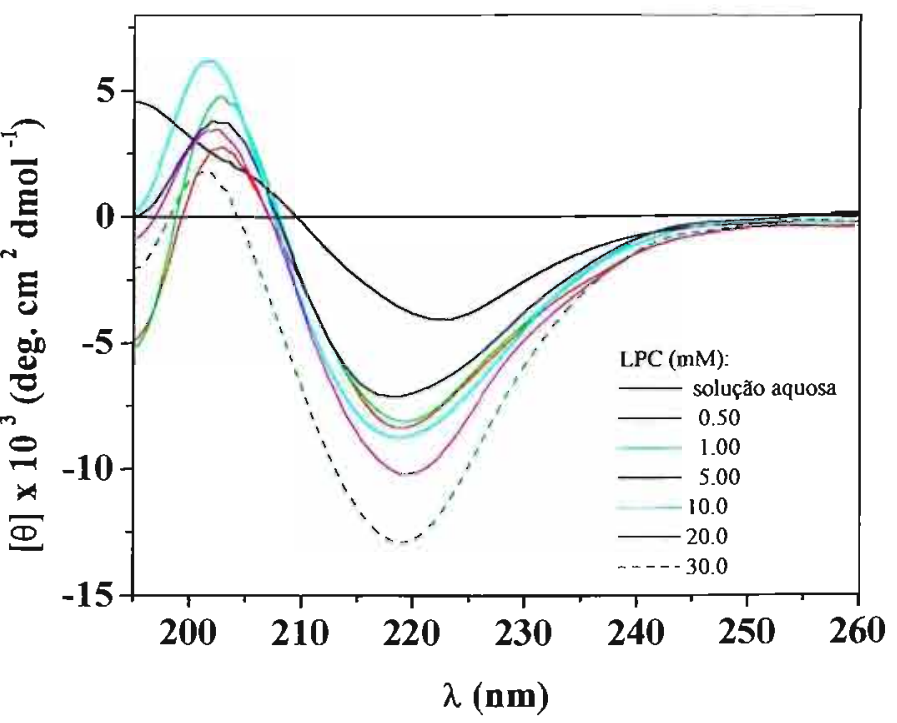

(b)

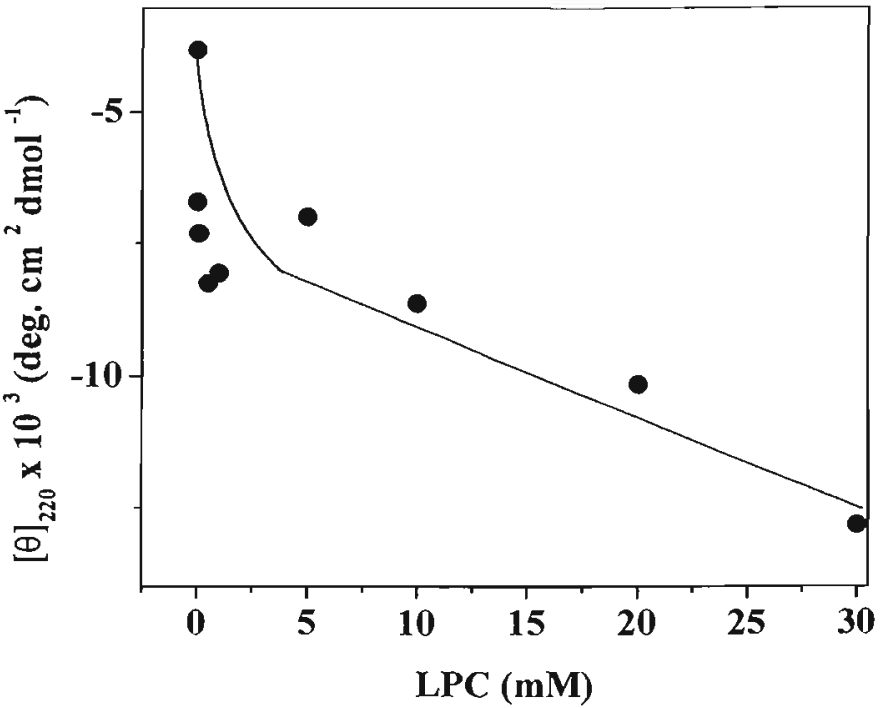

Figura 37 - Espectros de CD (a) e variação da elipticidade molar em $220 \mathrm{~nm}$ (b) de 70 $\mu \mathrm{M}$ de I em função da concentração de LPC, pH 10,0. 
máximo abaixo de $200 \mathrm{~nm}$, enquanto que espectros atribuídos a folhas $\beta$ paralelas possuem máximo ao redor de $200 \mathrm{~nm}$ e mínimo próximo a $220 \mathrm{~nm}{ }^{(224)}$. Dessa forma, optamos por concluir que a presença de LPC induziu uma mudança de dobra para folha $\beta$.

Para o peptídeo II em $\mathrm{pH}$ 4,0 (Fig. 38) foram observadas mudanças conformacionais significativas com a adição de quantidades crescentes do detergente. Em solução (Fig. 38a) II adota uma conformação ao acaso; com a adição de detergente, os espectros indicam que o peptídeo continua com estrutura ao acaso até $0,5 \mathrm{mM}$ LPC. Os espectros de CD entre 1 e $5 \mathrm{mM}$ LPC parecem ter a contribuição de diferentes populações, visto pelo deslocamento do mínimo para ao redor de $202 \mathrm{~nm}$ e o aparecimento de um segundo mínimo em $218 \mathrm{~nm}$ (Tabela 13). Acima de $5 \mathrm{mM}$ LPC, as características do espectro são indicativas de conformação em dobra $\beta$. Observa-se um aumento da elipticidade molar em 215 nm (Fig. 38b). Resultados anteriores com HPS, mostraram que o peptídeo não muda de conformação na presença do detergente nesse $\mathrm{pH}$, permanecendo ao acaso.

Tabela 13 - Comprimento de onda máximo $\left(\lambda_{\max }\right)$ e mínimo $\left(\lambda_{\min }\right)$ nos espectros de CD de II na presença de concentrações crescentes de LPC em função do $\mathrm{pH}$.

\begin{tabular}{|c|c|c|c|c|c|c|}
\hline \multicolumn{7}{|c|}{$[\theta] \times 10^{3}$ deg. $\mathrm{cm}^{2} \mathrm{dmol}^{-1}$} \\
\hline$[\mathrm{LPC}](\mathrm{mM})$ & \multicolumn{2}{|c|}{$\mathrm{pH} \mathrm{4,0}$} & \multicolumn{2}{|c|}{$\mathrm{pH} \mathrm{7,0}$} & \multicolumn{2}{|c|}{$\mathrm{pH} 10,0$} \\
\hline & $\lambda_{\max }$ & $\lambda_{\text {min }}$ & $\lambda_{\max }$ & $\lambda_{\min }$ & $\lambda_{\max }$ & $\lambda_{\min }$ \\
\hline sem adição & -- & 195 & -- & 208,222 & 198 & 219 \\
\hline 0,1 & -- & 195 & 195 & 217 & 196 & 211,220 \\
\hline 0,5 & - & 195 & 195 & 217 & -- & $206^{*}, 218$ \\
\hline 1,0 & -- & 202,218 & 195 & 219 & 195 & 216 \\
\hline 5,0 & 195 & $203^{*}, 214$ & 195 & $205^{*}, 216$ & 195 & $204^{*}, 215$ \\
\hline 10,0 & 195 & $203^{*}, 214$ & 195 & $205^{*}, 216$ & 196 & 217 \\
\hline 20,0 & 195 & 204,220 & 195 & $205 *, 217$ & 195 & $205^{*}, 219$ \\
\hline 30,0 & 195 & 205,217 & 195 & $204 *, 219$ & 195 & $204^{*}, 218$ \\
\hline
\end{tabular}

* ombro

Em solução, foi observado que o conteúdo de estrutura secundária do peptídeo tende a aumentar com o pH (Fig. 18b), adquirindo estrutura $\alpha$-helicoidal entre $\mathrm{pH} 7$ e 8 , ocorrendo agregação em pHs maiores devido à desprotonação dos grupos ionizáveis da cadeia lateral da Lys e do $\mathrm{N}$-terminal.

Em pH 7,0 (Fig. 39), o espectro em solução aquosa apresenta um mínimo centrado em 208 nm e outro em 222 nm, embora o espectro esteja achatado, essas características são as de uma conformação $\alpha$-helicoidal. Com a adição de LPC observase um grande aumento de intensidade e a presença de apenas um mínimo por volta de $217 \mathrm{~nm}$ e o aparecimento de um máximo centrado em $195 \mathrm{~nm}$ (Tabela 13) (Fig. 39a), o que indica que a conformação de II muda para folha $\beta$ com adição do detergente. 
(a)
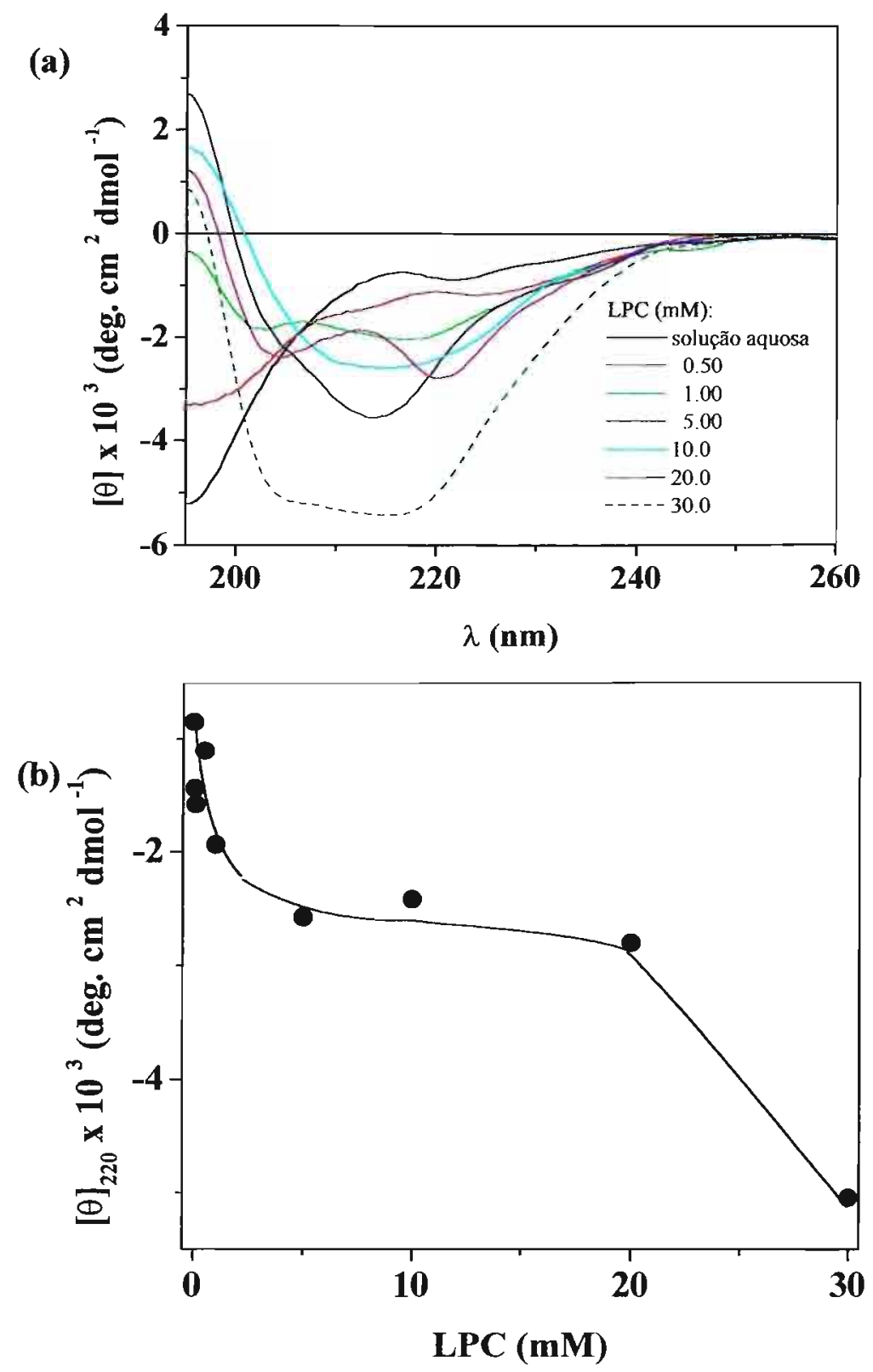

Figura 38 - Espectros de CD (a) e variação da elipticidade molar em 220 nm (b) de 70 $\mu \mathrm{M}$ de II em função da concentração de LPC, pH 4,0. 

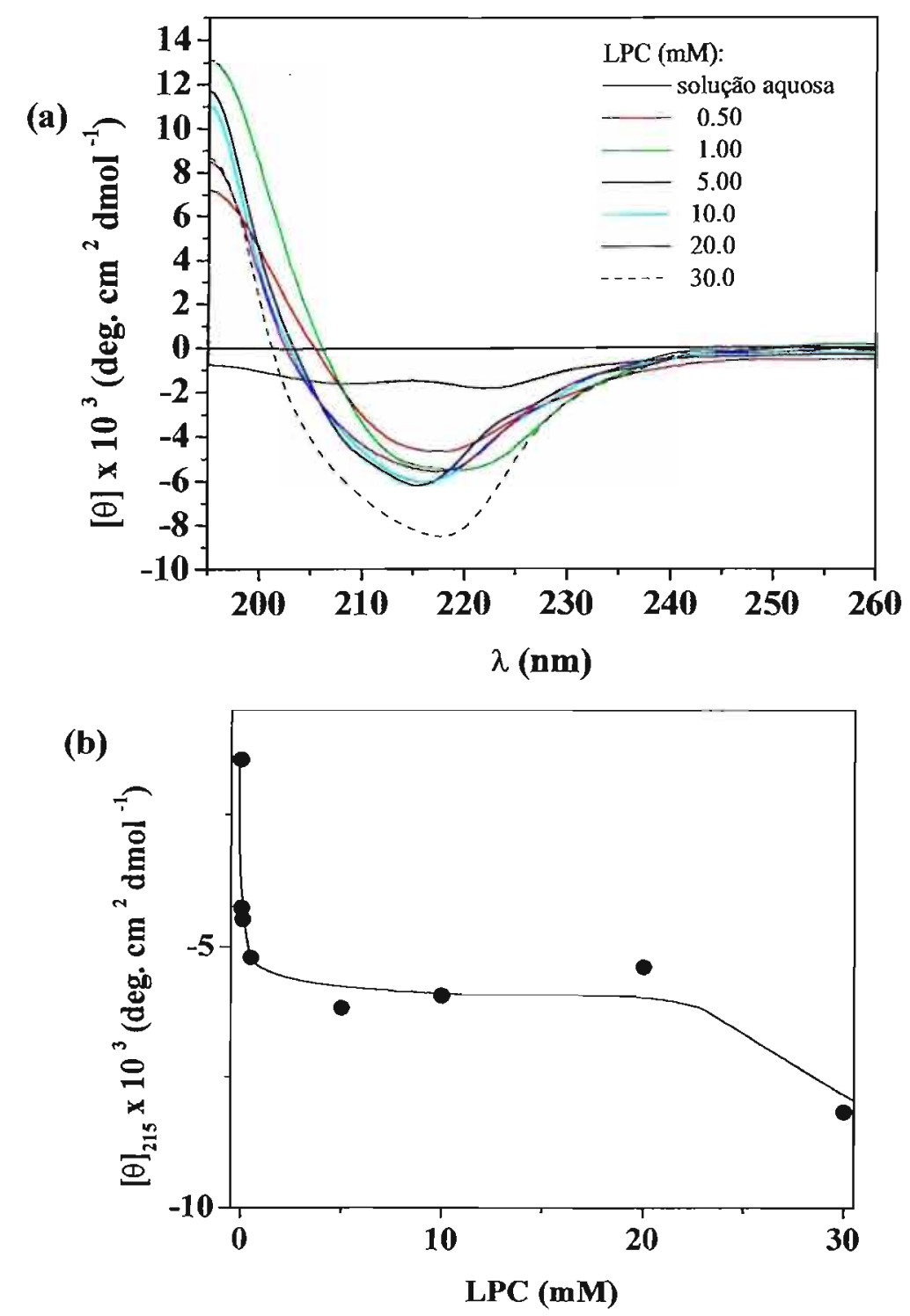

Figura 39 - Espectros de CD (a) e variação da elipticidade molar em 215 nm (b) de $70 \mu \mathrm{M}$ de II em função da concentração de LPC, pH 7,0. 
A Fig. 39b mostra a variação de elipticidade molar em $215 \mathrm{~nm}$, na qual é possível perceber que acima de $5 \mathrm{mM} L P C[\theta]$ varia pouco.

Em pH 10,0 (Fig. 40), o espectro em solução de II (Fig. 40a) apresenta uma banda positiva alargada com máximo ao redor de $198 \mathrm{~nm}$ e uma banda negativa com mínimo centrado em $219 \mathrm{~nm}$, o que indica que II adota conformação em folha $\beta$. O alargamento da banda positiva provavelmente seria devido ao espalhamento de luz, o que indica que II estaria agregado em solução. Com a adição de LPC, ocorre um aumento de intensidade da banda negativa do espectro (Fig. 40b), a posição do máximo é deslocada para comprimentos de onda mais baixos, situando-se ao redor de $195 \mathrm{~nm}$. Também é possível observar o aparecimento de um ombro ao redor de $205 \mathrm{~nm}$ em quase todos os espectros acima de $0,5 \mathrm{mM}$ LPC. Com relação ao mínimo, cada espectro apresenta um $\lambda_{\min }$ em uma posição diferente, na faixa entre 215 e $220 \mathrm{~nm}$. Essas alterações poderiam estar relacionadas com espalhamento de luz ou com a presença de diferentes populações, que poderiam ser atribuídas ora a dobras ora a folhas $\beta^{(221)}$. A primeira para comprimentos de onda ao redor de $215 \mathrm{~nm}$ e a segunda para comprimentos de onda em torno de $219 \mathrm{~nm}$, respectivamente.

Em solução os espectros de CD (Fig. 19c) mostraram que o peptídeo III adota conformação em folha $\beta$, com uma banda positiva larga, cuja intensidade varia com o $\mathrm{pH}$ e uma banda negativa de baixa intensidade. Na presença de LPC em pH 4,0 (Fig. 41), ocorre um aumento de intensidade com a adição do detergente e um deslocamento das bandas positivas e negativas para o azul, para $195 \mathrm{~nm}$ e para ao redor de $215 \mathrm{~nm}$ respectivamente (Fig. 41a) (Tabela 14), que são atribuídos a uma folha $\beta$ paralela ${ }^{(224)}$. A Fig. 41 b mostra uma variação significativa de elipticidade molar em $218 \mathrm{~nm}$ abaixo de $1 \mathrm{mM}$ LPC, acima dessa concentração a variação de intensidade é gradual, o que sugere que a adição de quantidades maiores de detergente não resulta em mudanças conformacionais significativas.

Em pH 7,0, observou-se que a adição de LPC provoca mudanças pouco significativas nos espectros de CD até $1 \mathrm{mM}$ LPC (Fig. 42); com o aumento da concentração do detergente, há um aumento de intensidade da banda negativa do espectro e um pequeno deslocamento do $\lambda_{\operatorname{máx}}$ de 197 para $195 \mathrm{~nm}$ e do $\lambda_{\min }$ de 218 para $216 \mathrm{~nm}$ (Tabela 14), no entanto os espectros de CD continuam sendo indicativos de folha $\beta$. 
(a)

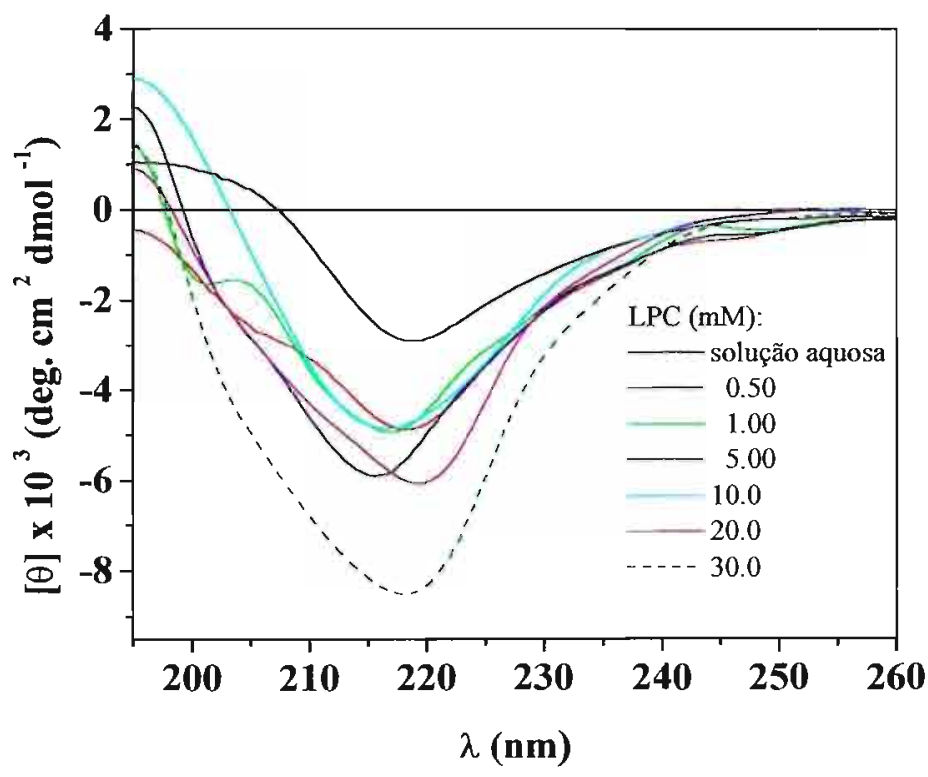

(b)

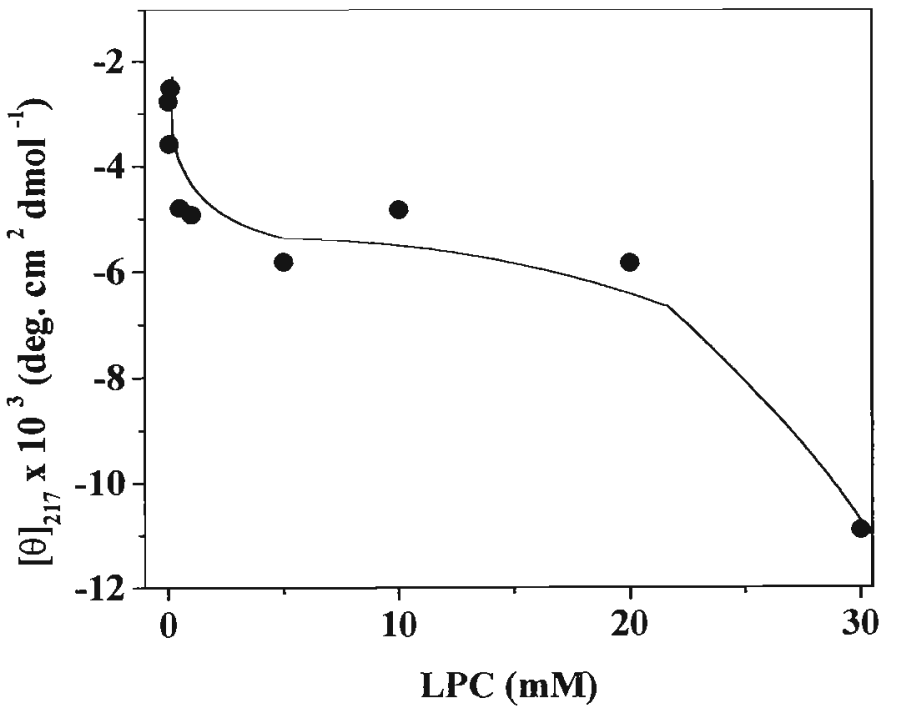

Figura 40 - Espectros de CD (a) e variação da elipticidade molar em 217 nm (b) de 70 $\mu \mathrm{M}$ de $\Pi$ em função da concentração de LPC, $\mathrm{pH}$ 10,0. 
(a)

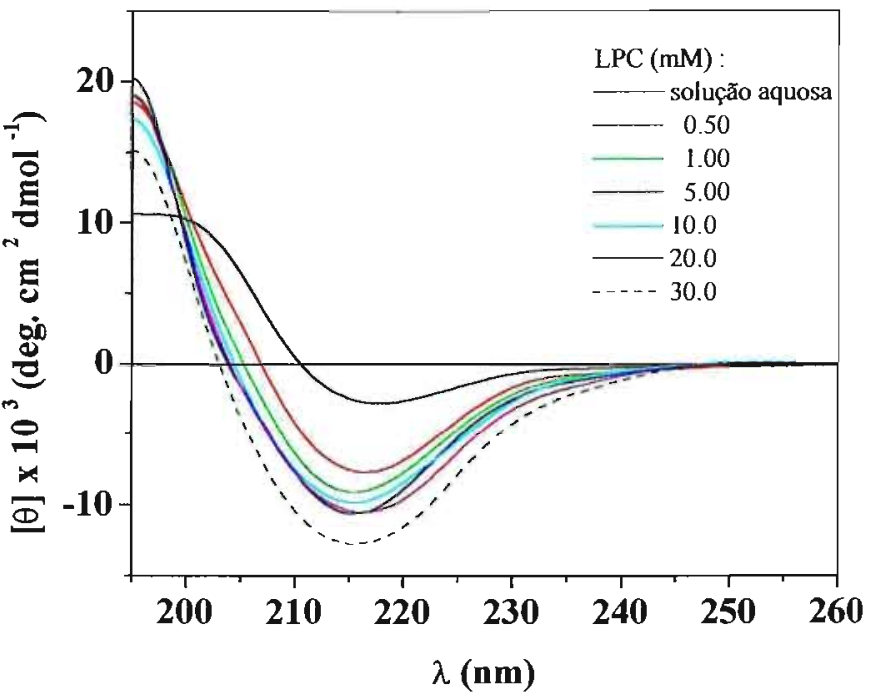

(b)

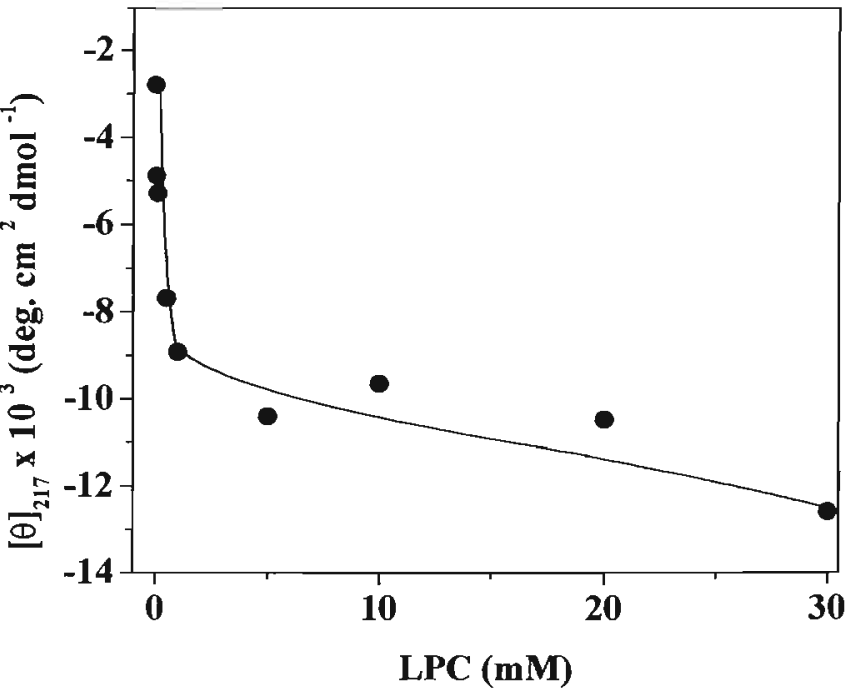

Figura 41- Espectros de CD (a) e variação da elipticidade molar em 217 nm (b) de $70 \mu \mathrm{M}$ de III em função da concentração de LPC, pH 4,0. 
(a)

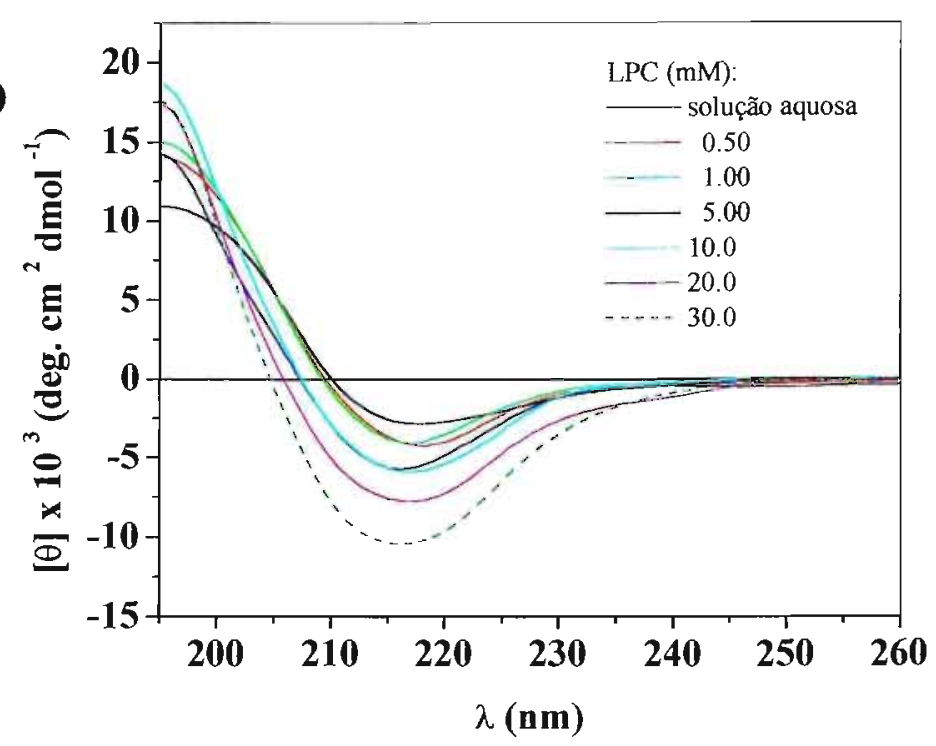

(b)

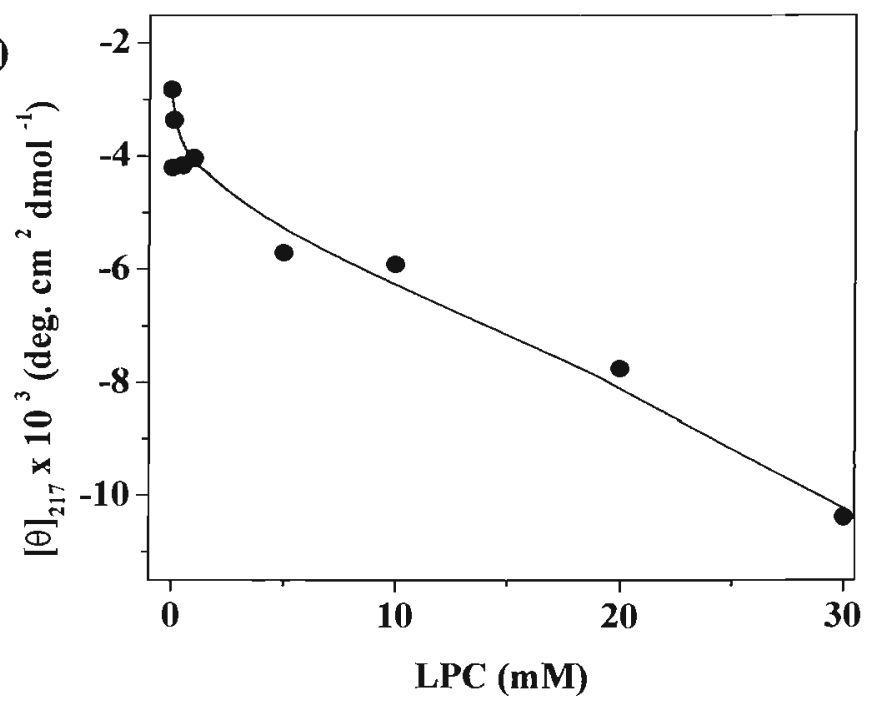

Figura 42 - Espectros de CD (a) e variação da elipticidade molar em $217 \mathrm{~nm}$ (b) de $70 \mu \mathrm{M}$ de III em função da concentração de LPC, pH 7,0. 
Tabela 14 - Comprimento de onda máximo $\left(\lambda_{\max }\right)$ e mínimo $\left(\lambda_{\min }\right)$ nos espectros de CD de $\mathrm{III}$ na presença de concentrações crescentes de LPC em função do $\mathrm{pH}$.

\begin{tabular}{ccccccc}
\hline \multicolumn{7}{c}{$[\theta] \times 10^{3}$ deg. $\mathrm{cm}^{2} \mathrm{dmol}^{-1}$} \\
\hline [LPC] $(\mathrm{mM})$ & \multicolumn{7}{c}{$\mathrm{pH} \mathrm{7,0}$} & \multicolumn{2}{c}{$\mathrm{pH} \mathrm{10,0}$} \\
\hline & $\lambda_{\max }$ & $\lambda_{\min }$ & $\lambda_{\max }$ & $\lambda_{\min }$ & $\lambda_{\max }$ & $\lambda_{\min }$ \\
sem adição & 200 & 218 & 197 & 218 & 201 & 220 \\
0,1 & 195 & 217 & 197 & 218 & 196 & 219 \\
0,5 & 195 & 216 & 195 & 218 & 201 & 220 \\
1,0 & 195 & 215 & 195 & 218 & 195 & 220 \\
5,0 & 195 & 215 & 195 & 216 & 195 & 217 \\
10,0 & 195 & 216 & 195 & 216 & 200 & 219 \\
20,0 & 195 & 216 & 195 & 217 & 195 & 220 \\
30,0 & 195 & 215 & 195 & 216 & 197 & 218 \\
\hline
\end{tabular}

O espectro de CD de III em solução aquosa em pH 10,0 (Fig. 43a) apresenta bandas achatadas, devido ao espalhamento de luz causado pela agregação do peptídeo. Observa-se um aumento gradual de intensidade na região de 215-220 nm com a adição do detergente, assim como observado nos pHs 4,0 e 7,0. Na Fig. 43b mostra-se a variação de elipticidade molar em $217 \mathrm{~nm}$ em função da concentração de LPC. Observa-se que entre 1 e $30 \mathrm{mM}$ LPC, a variação de intensidade é pequena. Os espectros de CD do peptídeo nessas concentrações mostram mudanças pouco significativas. As posições do máximo e mínimo das bandas positiva e negativa variam pouco, o que indica que o detergente estabiliza um conformação em folha $\beta$ nesse $\mathrm{pH}$. Na presença de concentrações maiores do detergente ocorre um aumento considerável da banda negativa do espectro, o que sugere desagregação.

Os resultados de fluorescência mostram a interação de III com o detergente em $\mathrm{pH}$ 4,0 (Fig. 44a). Acima de 10 mM LPC (Fig. 45), a intensidade de fluorescência na região de $300 \mathrm{~nm}$ praticamente não aumenta mais, sugerindo que acima dessa concentração III já está praticamente todo ligado ao detergente.

Em pH 7,0 (Fig. 44b), a intensidade de fluorescência de ПI praticamente não varia até $10 \mathrm{mM}$ LPC. É possível que a baixa interação com III nessas condições esteja relacionada com a carga líquida do peptídeo nesse pH. Acima dessa concentração houve um aumento abrupto da intensidade de fluorescência e o aparecimento de uma banda entre 320 e $400 \mathrm{~nm}$, que pode ser devida à contribuição de tirosinato.

Em pH 10,0 (Fig. 44c), o espectro de fluorescência de III em solução apresenta baixa intensidade. A partir da adição de quantidades crescentes de LPC ocorre um aumento gradual da intensidade de fluorescência em $302 \mathrm{~nm}\left(\mathrm{I}_{302}\right)$ até $20 \mathrm{mM} \mathrm{LPC} \mathrm{(Fig.} \mathrm{45).} \mathrm{Para}$ 
(a)
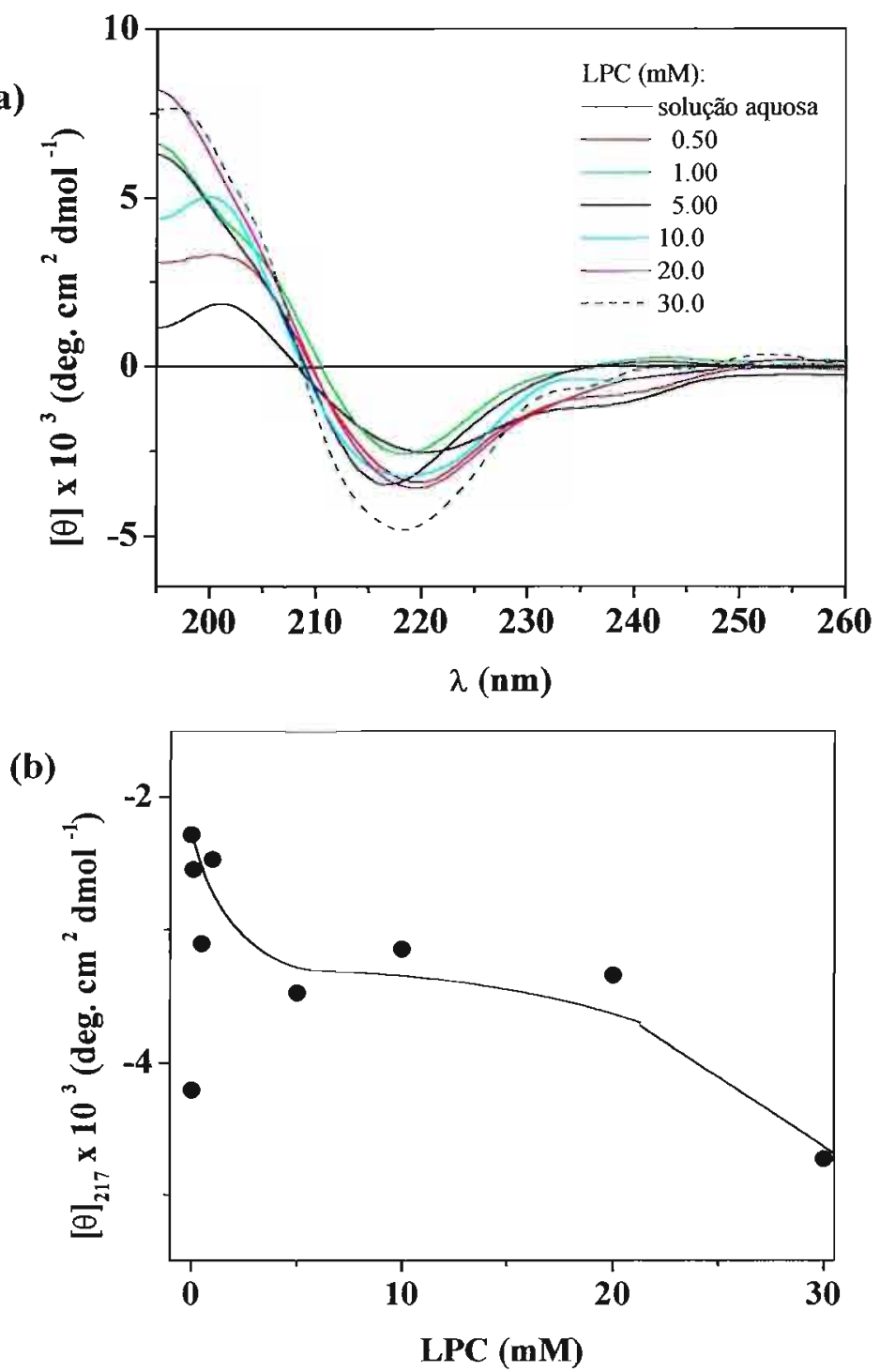

Figura 43- Espectros de CD (a) e variação da elipticidade molar em $217 \mathrm{~nm}$ (b) de $70 \mu \mathrm{M}$ de III em função da concentração de LPC, pH 10,0. 

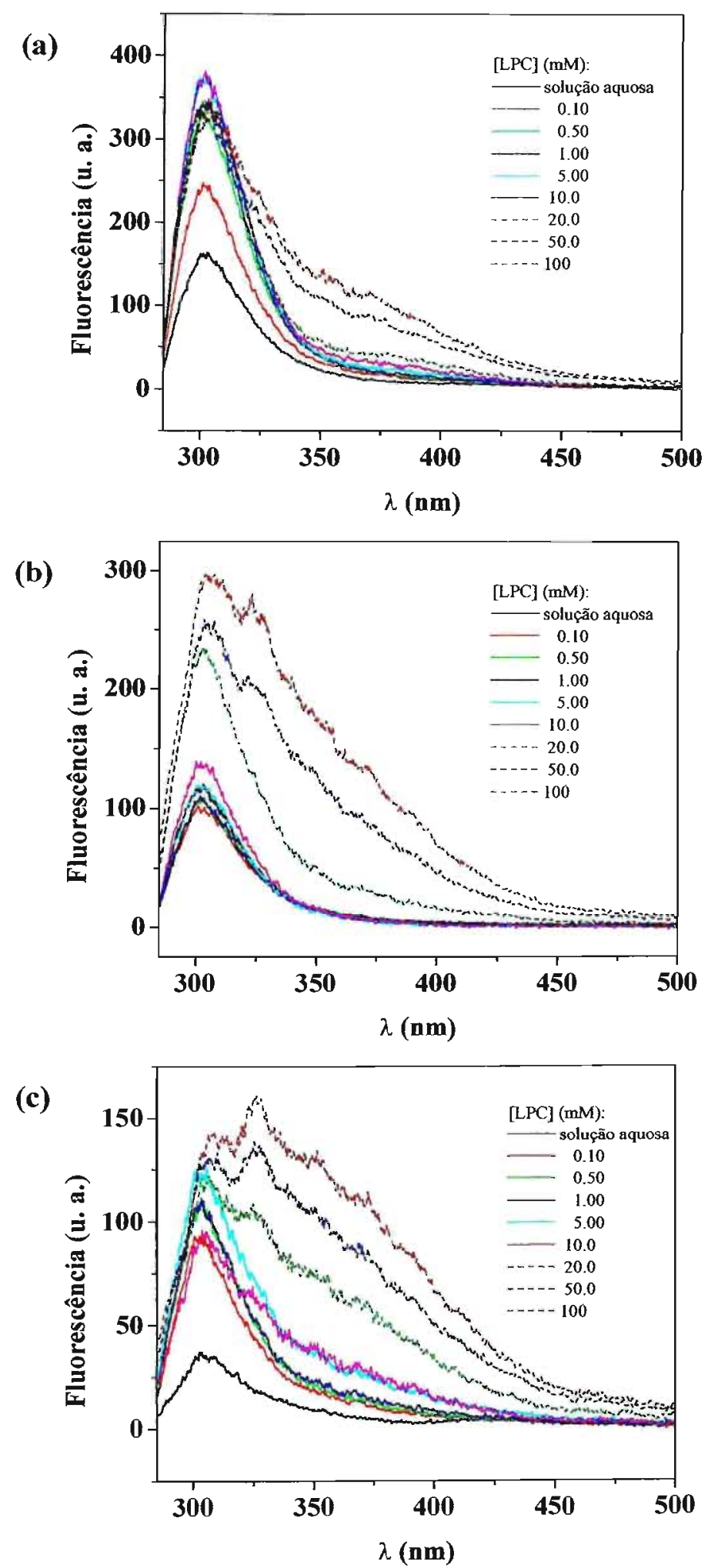

Figura 44 - Espectros de fluorescência de $30 \mu \mathrm{M}$ de III em função da concentração de LPC. pH: 4,0 (a); 7,0 (b) e 10,0 (c). $\lambda_{\mathrm{exc}}=275 \mathrm{~nm}$. 


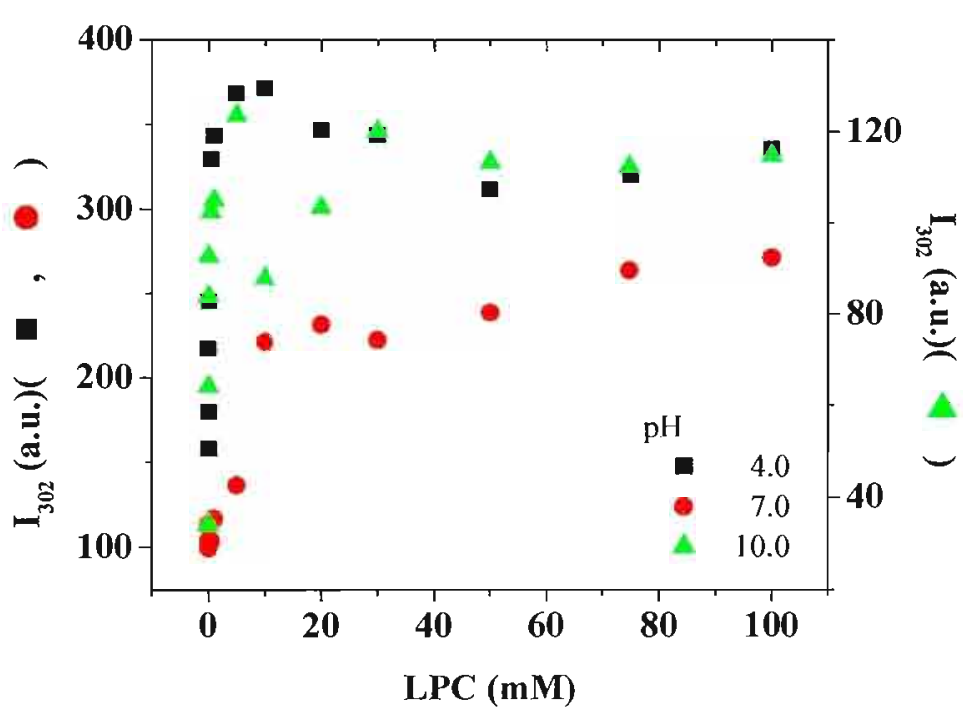

Figura 45 - Variação da intensidade de fluorescência em $302 \mathrm{~nm}$ de $30 \mu \mathrm{M}$ de III em

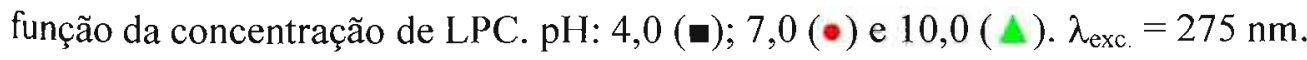

concentrações maiores do detergente a intensidade de fluorescência varia muito pouco, indicando que acima dessa concentração a maior parte do peptídeo deve estar ligada ao detergente. $\mathrm{O}$ aumento $\mathrm{I}_{302}$ com a concentração do detergente pode ser devido ao aumento do pKa da Tyr. Observa-se o aparecimento de uma outra banda de fluorescência, acima de $320 \mathrm{~nm}$, cuja intensidade aumenta com o aumento da concentração de detergente. Nesse $\mathrm{pH}$, ocorre a emissão de tirosinato com $\lambda_{\text {máx }}$ em $350 \mathrm{~nm}^{(216)}$.

\subsubsection{Estudos na presença de SDS}

A Figura 46 mostra os espectros de CD de I em função da concentração de detergente. Nos pHs 4,0 e 7,0 (Fig. 46a e 47a, respectivamente) os espectros não apresentam mudanças significativas. Em pH 4,0, na ausência de detergente, observa-se um espectro característico de folha $\beta$, com uma banda positiva centrada em $199 \mathrm{~nm}$ e uma banda negativa centrada em $219 \mathrm{~nm}$. Com a adição de SDS, a posição dos máximos e mínimos permanece praticamente igual e ocorre um pequeno aumento da intensidade dos espectros (Fig. 46b), que pode ser devido à interação do peptídeo com o detergente. Esse resultado também mostra que o SDS estabiliza a conformação em folha $\beta$ de I.

Em pH 7,0 (Fig. 47a), observa-se um deslocamento da banda positiva do espectro para o azul, de 202 para $196 \mathrm{~nm}$, enquanto que a posição do mínimo mantém-se inalterada. 
(a)

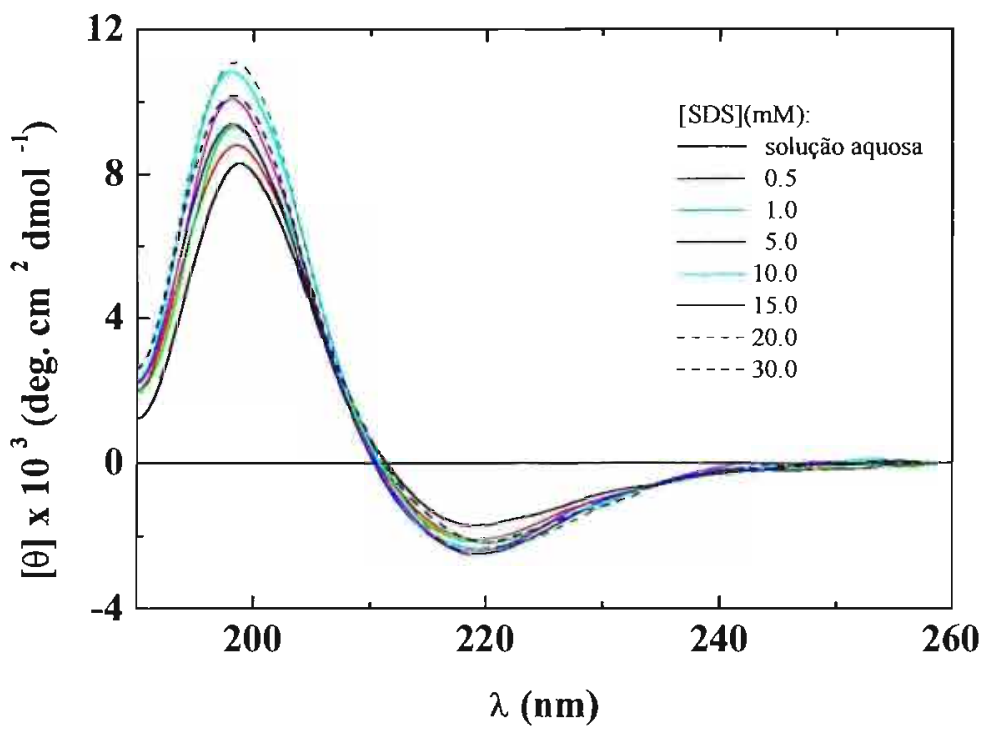

(b)

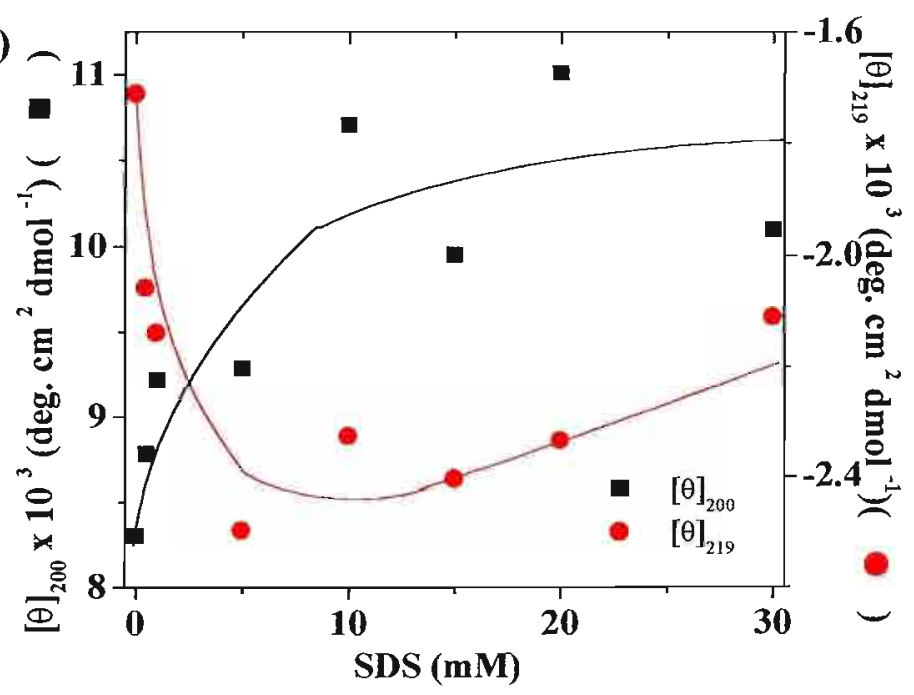

Figura 46- Espectros de CD (a) e variação da elipticidade molar em 200 e 219 nm (b) de $70 \mu \mathrm{M}$ de I em função da concentração de SDS, pH 4,0. 
(a)

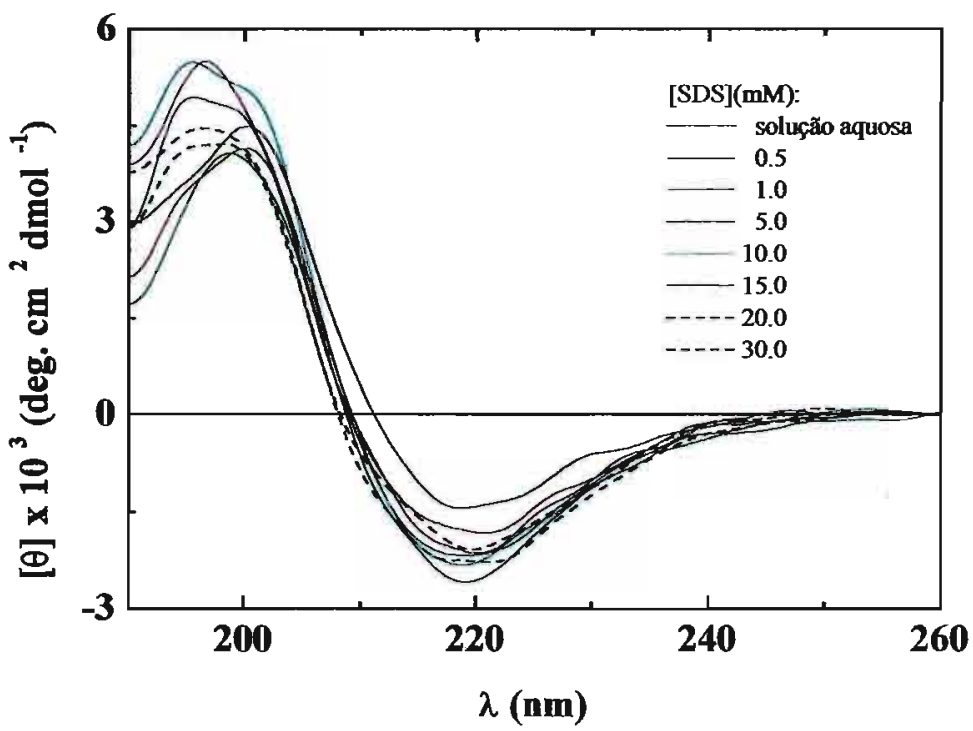

(b)

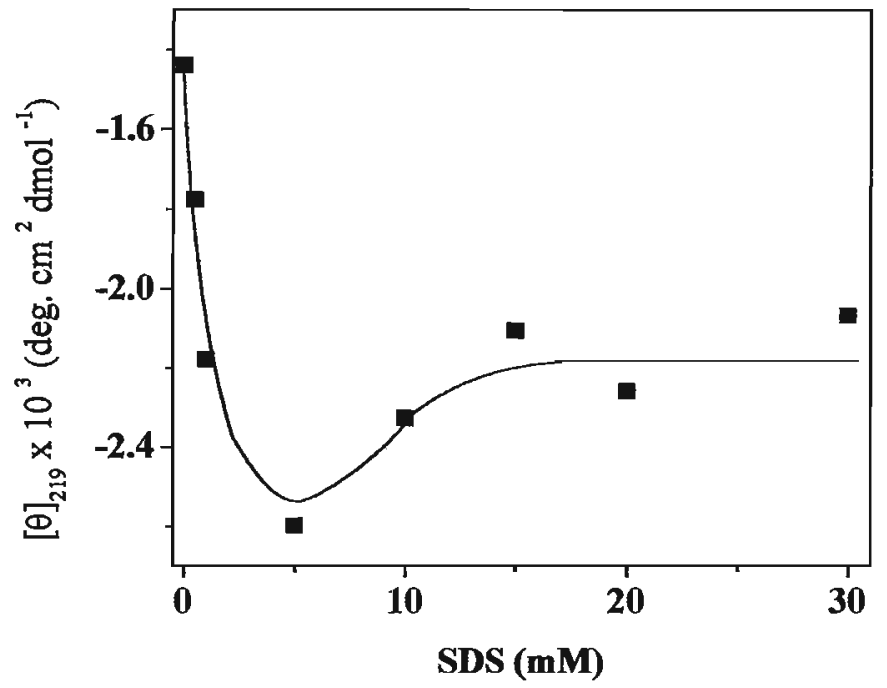

Figura 47- Espectros de CD (a) e variação da elipticidade molar em 219 nm (b) de $70 \mu \mathrm{M}$ de I em função da concentração de SDS, pH 7,0. 
O deslocamento da banda positiva do espectro para comprimentos de ondas mais baixos indica que a conformação de I muda de dobra para folha $\beta$. A intensidade do espectro de CD de I varia pouco com a adição de detergente (Fig. 47b), acima de $15 \mathrm{mM}$ de SDS I parece estar praticamente todo ligado ao detergente.

Tabela 15 - Comprimento de onda máximo $\left(\lambda_{\max }\right)$ e mínimo $\left(\lambda_{\min }\right)$ nos espectros de CD de I na presença de concentrações crescentes de SDS em função do $\mathrm{pH}$.

\begin{tabular}{ccccccc}
\hline [SDS] (mM) & \multicolumn{2}{c}{$\mathrm{pH} \mathrm{4,0}$} & & $\mathrm{pH} \mathrm{7,0}$ & \multicolumn{2}{c}{$\mathrm{pH} \mathrm{10,0}$} \\
\hline & $\lambda_{\max }$ & $\lambda_{\min }$ & $\lambda_{\max }$ & $\lambda_{\min }$ & $\lambda_{\max }$ & $\lambda_{\min }$ \\
sem adição & 199 & 219 & 202 & 220 & 200 & 218 \\
5 & 198 & 219 & 196 & 219 & $194,199^{*}$ & 217 \\
10 & 198 & 220 & 196 & 219 & $191,198 *$ & 216 \\
20 & 198 & 219 & 197 & 219 & 193 & 216 \\
30 & 198 & 220 & 196 & 220 & 191 & 215 \\
\hline *ombro & & & & & &
\end{tabular}

Em $\mathrm{pH} 10,0$ (Fig. 48a) foram observadas as mudanças mais significativas nos espectros de CD de III; à medida que se aumenta a concentração do detergente; observamse espectros largos, apresentando ombros, o que pode ser indicativo de um equilíbrio de populações, uma vez que na presença de $50 \mathrm{mM}$ SDS o máximo da banda positiva do espectro desloca-se para o azul, de $200 \mathrm{~nm}$ em solução aquosa para cerca de $191 \mathrm{~nm}$ (Tabela 15), o que indica mudança de uma conformação em dobra $\beta$ para folha $\beta$.

Para o peptídeo II, em todos os pHs houve mudanças significativas nos espectros, principalmente em pH 4,0 (Fig. 49a). O espectro de II nesse pH muda de conformação ao acaso para uma conformação indicativa de folha $\beta$ assim que SDS é adicionado à solução com o peptídeo; o espectro na presença de SDS apresenta uma banda positiva com máximo ao redor de $195 \mathrm{~nm}$ e uma banda negativa com mínimo ao redor de $216 \mathrm{~nm}$ (Tabela 16). Com o aumento da concentração de SDS, a posição desses máximos e mínimos mantém-se constante, assim como a intensidade da banda positiva do espectro, o que indica que a conformação adotada pelo peptídeo ao interagir com os monômeros de SDS não muda acima da cmc do detergente, em torno de $8 \mathrm{mM}^{(207)}$.

$\mathrm{Na}$ Figura 49b apresenta-se a variação da elipticidade molar em $219 \mathrm{~nm}$, uma vez que ao redor de $195 \mathrm{~nm}$, os valores de elipticidade molar flutuam bastante e não é possível observar nenhuma tendência. Essa Figura também mostra que abaixo da cmc o peptídeo II está praticamente todo ligado ao surfactante. A interação significativa do análogo II com 
(a)

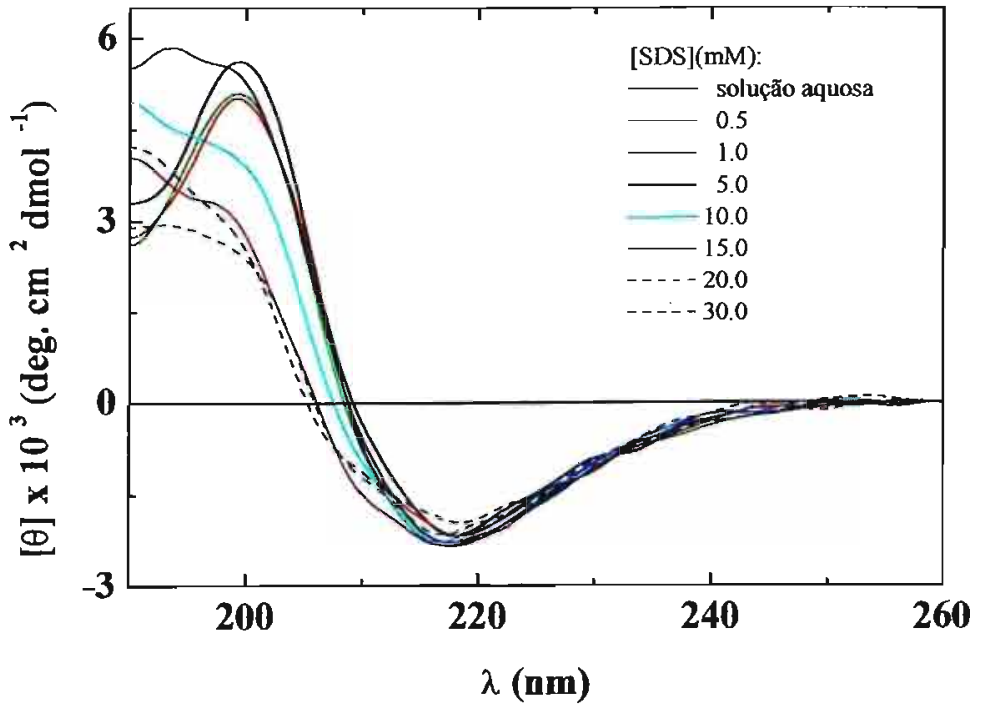

(b)

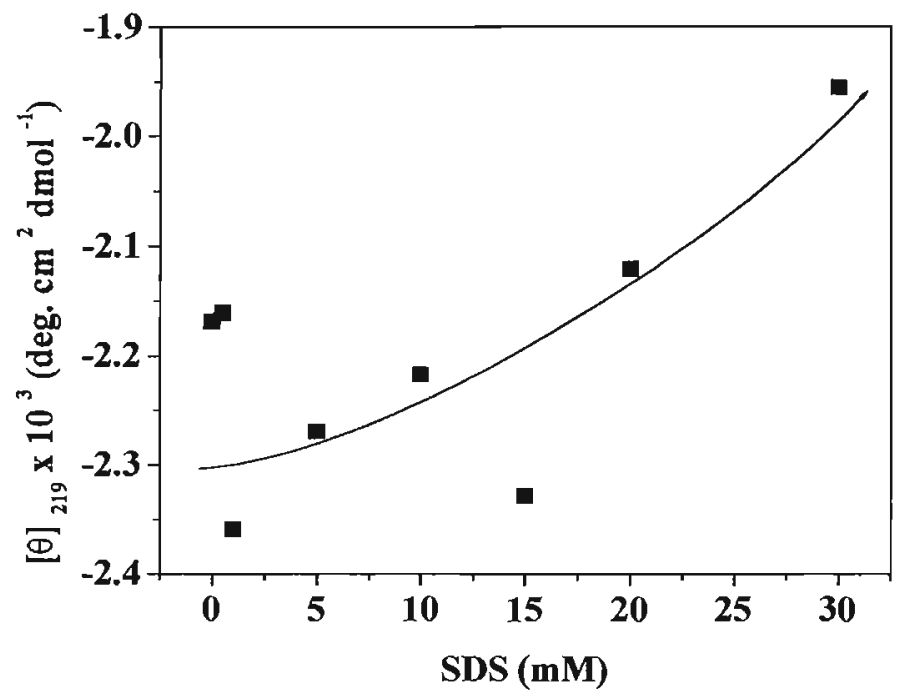

Figura 48- Espectros de CD (a) e variação da elipticidade molar em 219 nm (b) de $70 \mu \mathrm{M}$ de I em função da concentração de SDS, pH 10,0. 
(a)

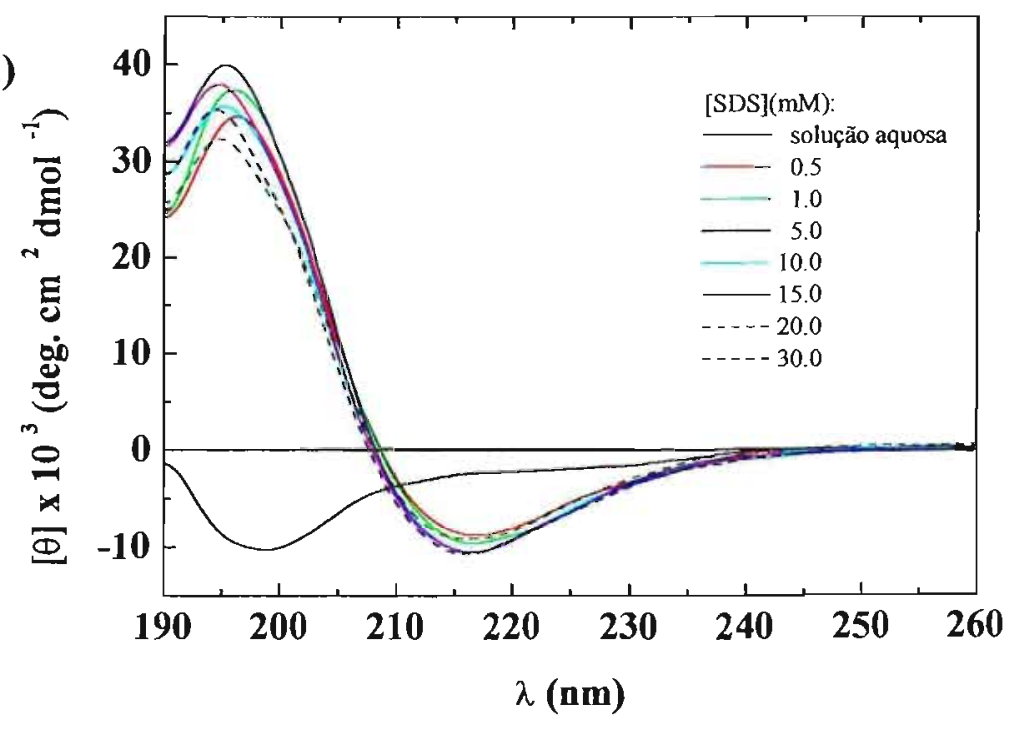

(b)

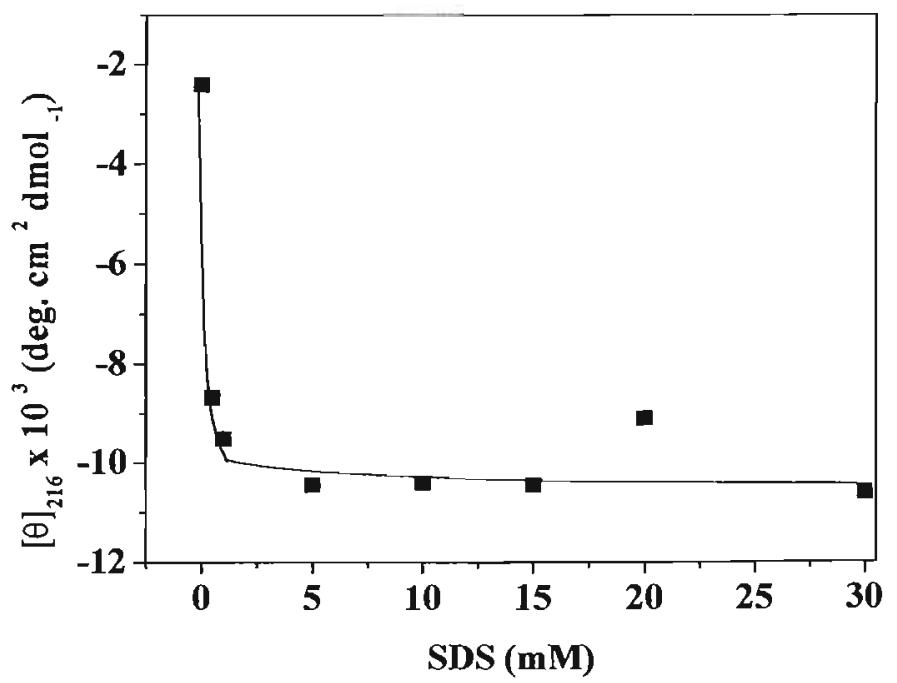

Figura 49- Espectros de CD (a) e variação da elipticidade molar em 216 nm (b) de $70 \mu \mathrm{M}$ de II em função da concentração de SDS, pH 4,0. 
SDS nesse $\mathrm{pH}$ pode estar relacionada com o fato de que II é mais solúvel em solução aquosa do que os outros peptídeos, o que facilitaria a interação com o surfactante.

Tabela 16 - Comprimento de onda máximo $\left(\lambda_{\max }\right)$ e mínimo $\left(\lambda_{\min }\right)$ nos espectros de CD de II na presença de concentrações crescentes de SDS em função do $\mathrm{pH}$.

\begin{tabular}{ccccccc}
\hline [SDS] $(\mathrm{mM})$ & \multicolumn{2}{c}{$\mathrm{pH} \mathrm{4,0}$} & \multicolumn{2}{c}{$\mathrm{pH} \mathrm{7,0}$} & \multicolumn{2}{c}{$\mathrm{pH} \mathrm{10,0}$} \\
\hline & $\lambda_{\max }$ & $\lambda_{\min }$ & $\lambda_{\max }$ & $\lambda_{\min }$ & $\lambda_{\max }$ & $\lambda_{\min }$ \\
sem adição & -- & 198 & 190 & 205,221 & 194 & 217 \\
5 & 195 & 216 & 196 & 217 & 194 & 217 \\
10 & 195 & 216 & 195 & 217 & 194 & 217 \\
20 & 195 & 216 & 195 & 217 & 193 & 217 \\
30 & 194 & 216 & 195 & 217 & 193 & 217 \\
\hline
\end{tabular}

Em pH 7,0 uma efeito similar foi observado. Em solução aquosa o espectro de II (Fig. 50a) possui uma conformação do tipo $\alpha$-helicoidal, com duas bandas negativas, uma centrada em $205 \mathrm{~nm}$ e a outra ao redor de $221 \mathrm{~nm}$ (Tabela 16). Com a adição do surfactante, essa conformação muda para uma sugestiva de folha $\beta$. Nos espectros de CD é possível observar apenas uma banda negativa ao redor de $217 \mathrm{~nm}$ e a banda positiva do espectro desloca-se de $190 \mathrm{~nm}$ para ao redor de $195 \mathrm{~nm}$. A posição dessas bandas permanece constante com o aumento da concentração do detergente, sendo que a intensidade destas varia pouco, como pode ser observado na Figura 50b. No entanto, assim como observado para $\mathrm{pH} 4,0$, esses resultados também indicam que II interage com SDS abaixo da $\mathrm{cmc}$ em $\mathrm{pH}$ neutro.

Em pH 10,0 (Fig. 51a), o efeito da adição SDS é menor. Em solução aquosa o espectro de CD de II apresenta uma banda positiva achatada e uma banda negativa com mínimo centrado ao redor de $217 \mathrm{~nm}$ (Tabela 16), o que indica conformação em folha $\beta$. Com o aumento da concentração de SDS, observa-se um pequeno aumento da intensidade da banda positiva do espectro, sendo que esta se torna menos achatada. A Figura 51b mostra a variação de elipticidade molar em $194 \mathrm{~nm}$ em função da concentração de detergente; é possível observar que acima de $15 \mathrm{mM}$ SDS II está praticamente todo ligado ao surfactante. Os resultados mostram que a conformação de II não muda com a adição de SDS.

No caso do peptídeo III, os estudos foram feitos por CD e por fluorescência. Por $\mathrm{CD}$ o efeito mais pronunciado é observado em pH 4,0 (Fig. 52a). Na ausência de SDS, o espectro de III apresenta-se achatado com um máximo ao redor de $204 \mathrm{~nm}$ e um mínimo centrado em $215 \mathrm{~nm}$, o que indica conformação em folha $\beta$. Logo após a adição de SDS, ocorre um aumento significativo da intensidade e um deslocamento da posição do 
(a)

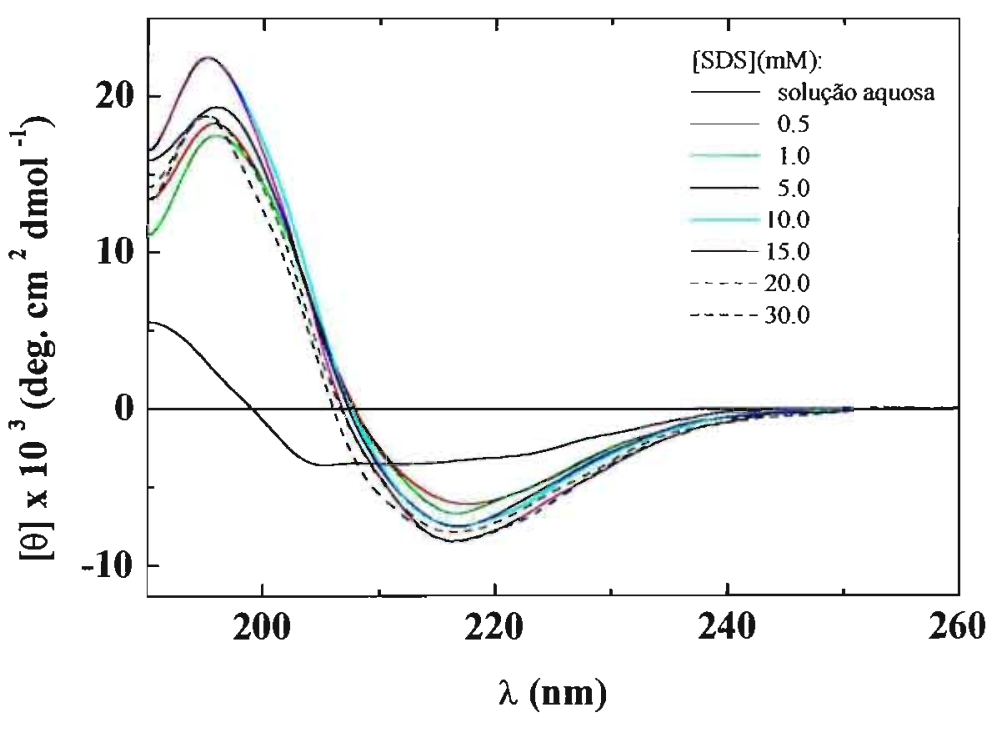

(b)

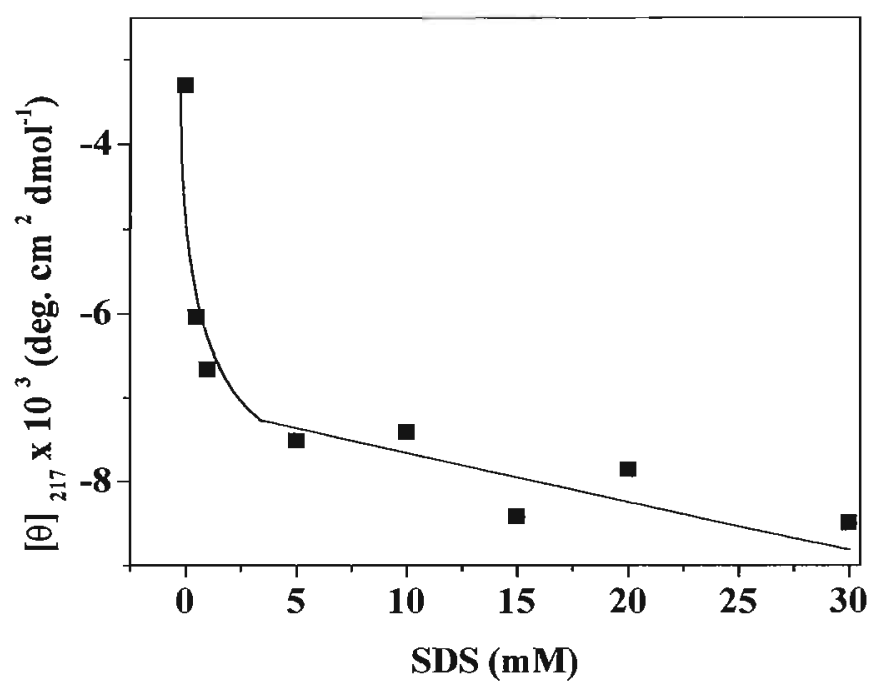

Figura 50- Espectros de CD (a) e variação da elipticidade molar em $217 \mathrm{~nm}$ (b) de $70 \mu \mathrm{M}$ de II em função da concentração de SDS, pH 7,0. 


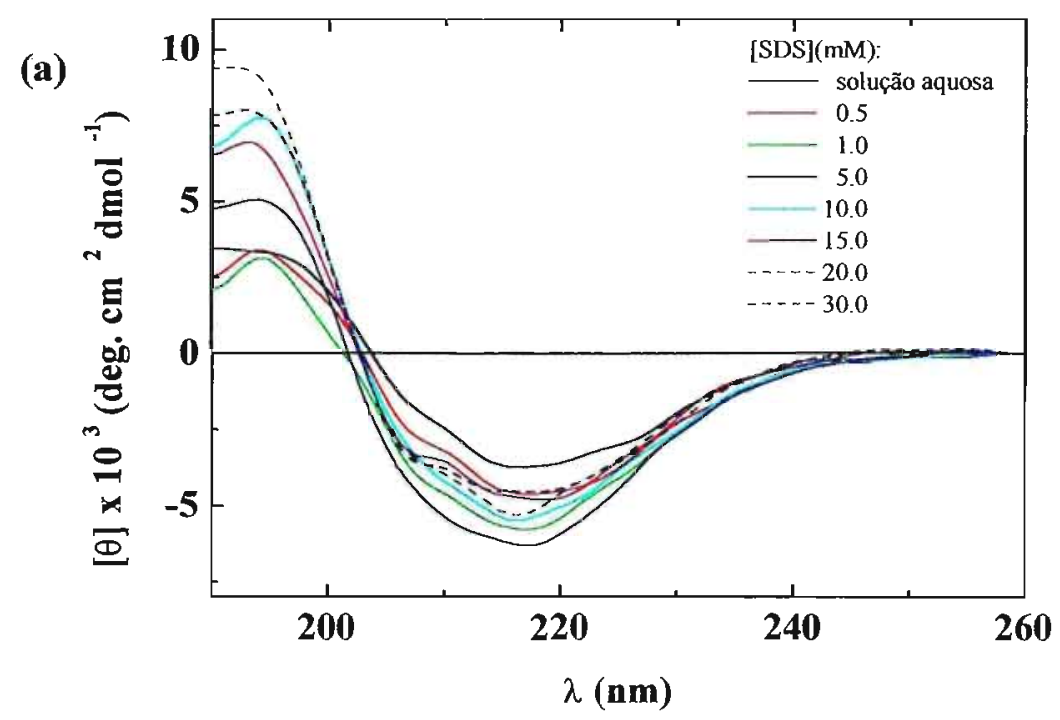

(b)

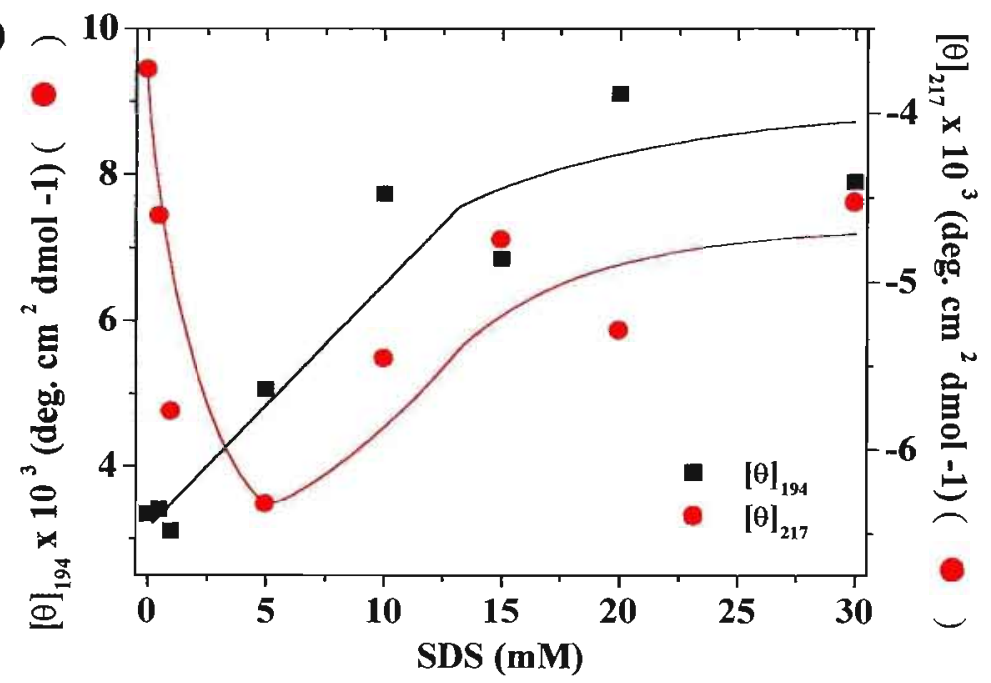

Figura 51 - Espectros de CD (a) e variação da elipticidade molar em 194 e 217 nm (b) de $70 \mu \mathrm{M}$ de II em função da concentração de SDS, pH 10,0. 
(a)

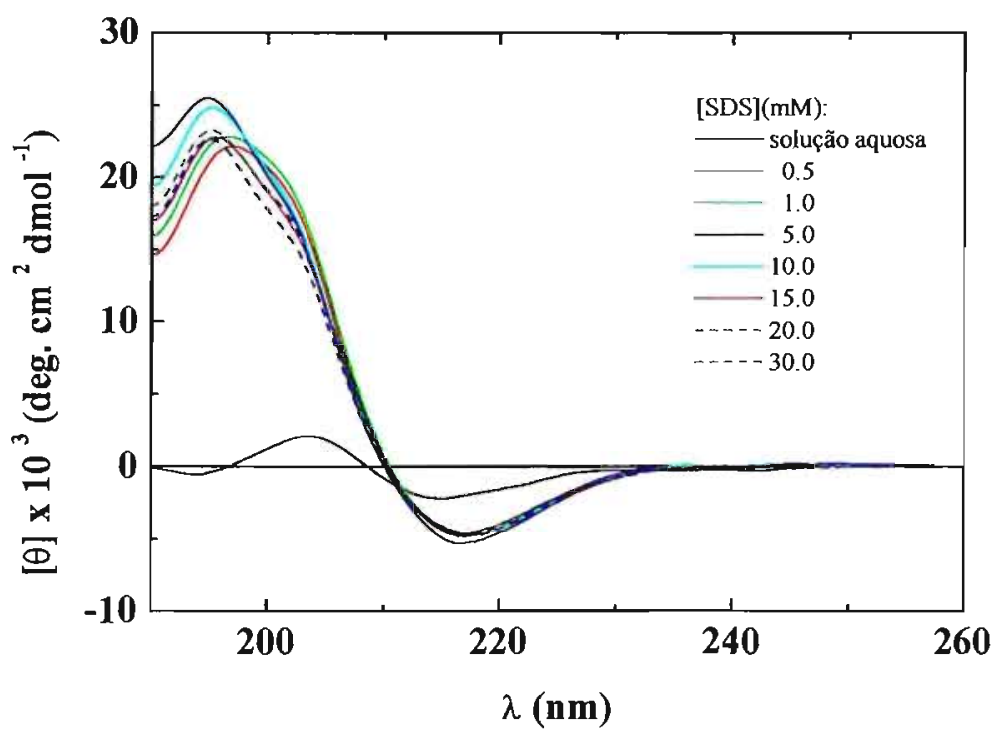

(b)

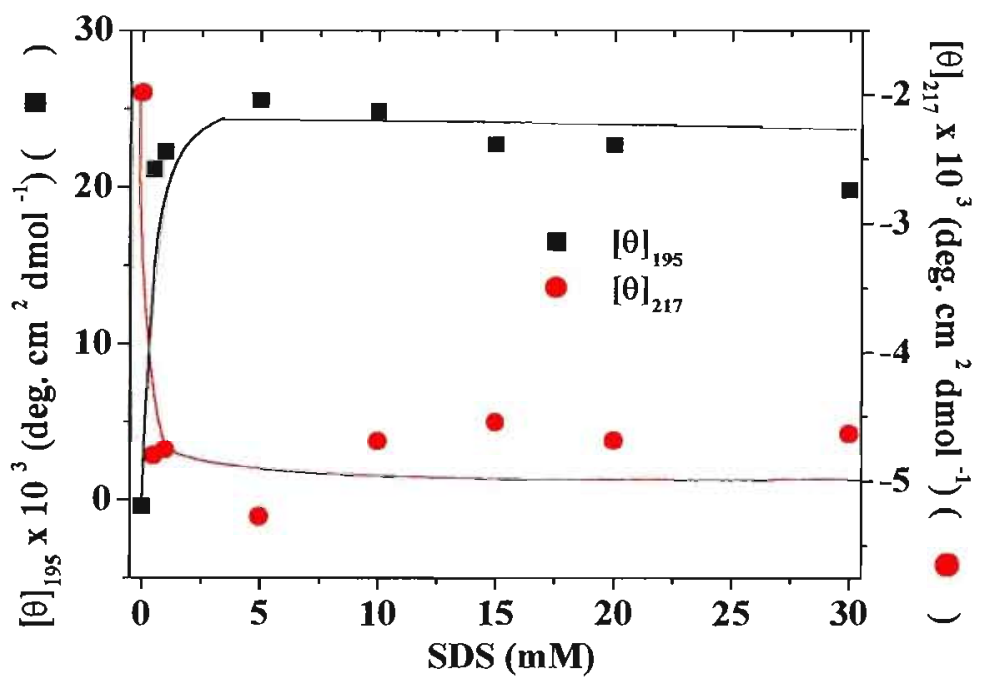

Figura 52 - Espectros de CD (a) e variação da elipticidade molar em 195 e 217 nm (b) de $70 \mu \mathrm{M}$ de III em função da concentração de SDS, pH 4,0. 
máximo e mínimo para 195 e $217 \mathrm{~nm}$ respectivamente (Tabela 17), o que indica que III liga-se fortemente ao detergente, porém continua adotar conformação sugestiva de folha $\beta$. A presença de um ombro ao redor de $201 \mathrm{~nm}$ na banda positiva do espectro pode ser devido ao equilíbrio de diferentes populações. A adição de maiores quantidades de surfactante não resulta em aumento significativo de $[\theta]_{195}$ (Fig. 52b), o que indica que III já estaria praticamente todo ligado a SDS abaixo de sua cmc.

Tabela 17 - Comprimento de onda máximo $\left(\lambda_{\max }\right)$ e mínimo $\left(\lambda_{\min }\right)$ nos espectros de $\mathrm{CD}$ de $\mathrm{III}$ na presença de concentrações crescentes de SDS em função do $\mathrm{pH}$.

\begin{tabular}{ccccccc}
\hline \multicolumn{7}{c}{$\lambda(\mathrm{nm})$} \\
\hline [SDS] $(\mathrm{mM})$ & \multicolumn{2}{c}{$\mathrm{pH} 4,0$} & $\mathrm{pH} \mathrm{7,0}$ & $\mathrm{pH} \mathrm{10,0}$ \\
\hline & $\lambda_{\max }$ & $\lambda_{\min }$ & $\lambda_{\max }$ & $\lambda_{\min }$ & $\lambda_{\max }$ & $\lambda_{\min }$ \\
sem adição & 204 & 215 & 196 & 217 & 198 & 219 \\
5 & $195,201^{*}$ & 217 & 196 & 217 & $194,202^{*}$ & 217 \\
10 & $195,201^{*}$ & 218 & 196 & 218 & $194,202^{*}$ & 217 \\
20 & $195,201^{*}$ & 218 & 196 & 218 & 195 & 217 \\
50 & $195,202^{*}$ & 217 & 196 & 217 & $195,200^{*}$ & 217 \\
\hline *ombro & & & & & &
\end{tabular}

Em pH 7,0 (Fig. 53a) o efeito é menos pronunciado, observando-se mudanças espectrais menos significativas. Após a adição do detergente, num primeiro momento ocorre um achatamento do espectro; à medida que aumentou-se a concentração do detergente, a intensidade do espectro voltou a aumentar, atingindo os valores iniciais. A posição do $\lambda_{\max }$ da banda positva e do $\lambda_{\min }$ da banda negativa do espectro $\mathrm{CD}$ de III permanece constante com a adição do detergente (Tabela 17). Os espectros obtidos nesse pH são interpretados como de conformação em folha $\beta$. No entanto, a presença de um ombro na banda positiva em torno de $202 \mathrm{~nm}$ sugere um equilíbrio entre populações. É possível que se formem diferentes tipos de folha $\beta$ (paralela e anti-paralela) ${ }^{(224)}$.

Em pH 10,0 (Fig. 54a), o espectro inicial em solução aquosa está achatado. Com a adição de SDS há um progressivo aumento da intensidade da banda positiva e da banda negativa do espectro, como pode ser observado na Figura $54 \mathrm{~b}$, onde se mostra a variação de $[\theta]_{218}$ em função da concentração do detergente. Ocorre um pequeno deslocamento de $\lambda_{\text {máx }}$ e $\lambda_{\min }$ para comprimentos de onda mais baixos (Tabela 17), assim como o aparecimento de um ombro na banda positiva centrado em torno de $202 \mathrm{~nm}$; em altas concentrações do detergente este ombro torna-se menos pronunciado. A presença desse 
(a)

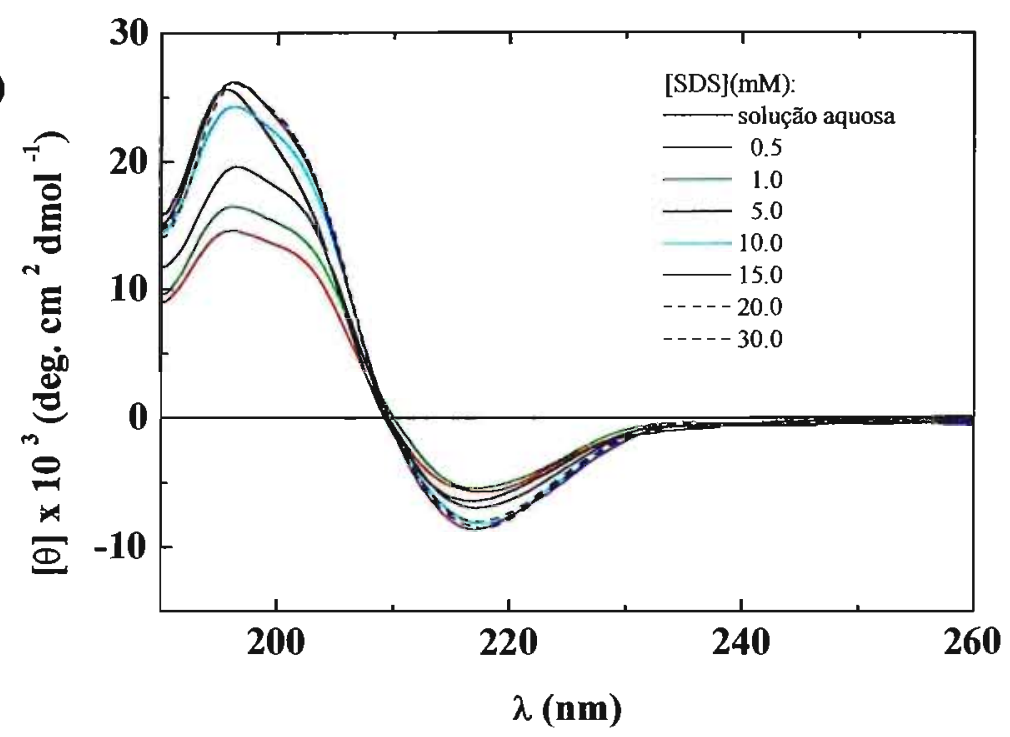

(b)

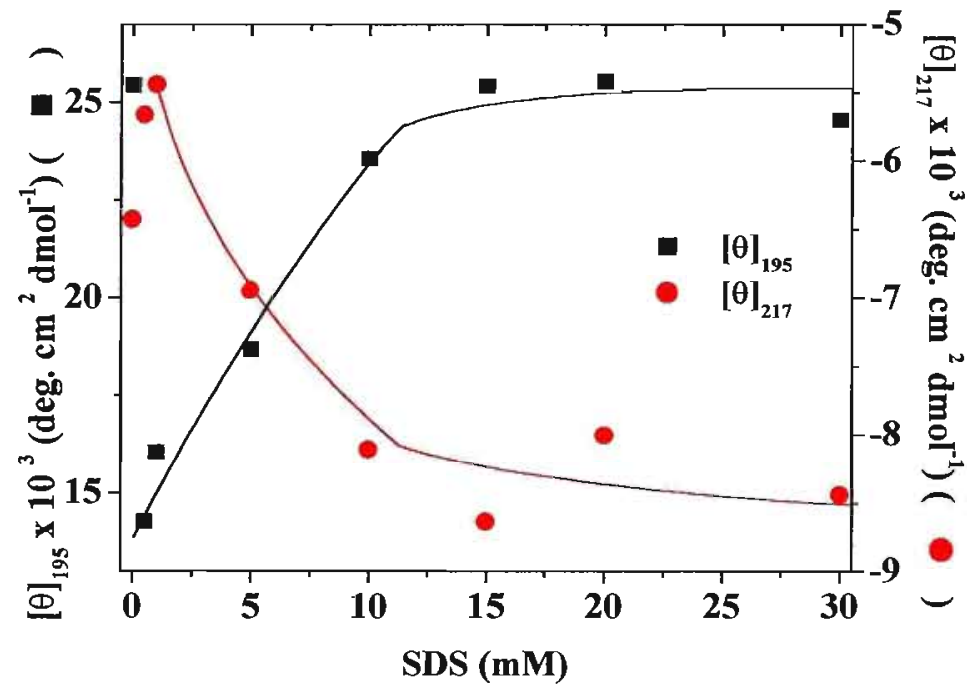

Figura 53 - Espectros de CD (a) e variação da elipticidade molar em 195 e 217 nm (b) de $70 \mu \mathrm{M}$ de III em função da concentração de SDS, pH 7,0. 
(a)
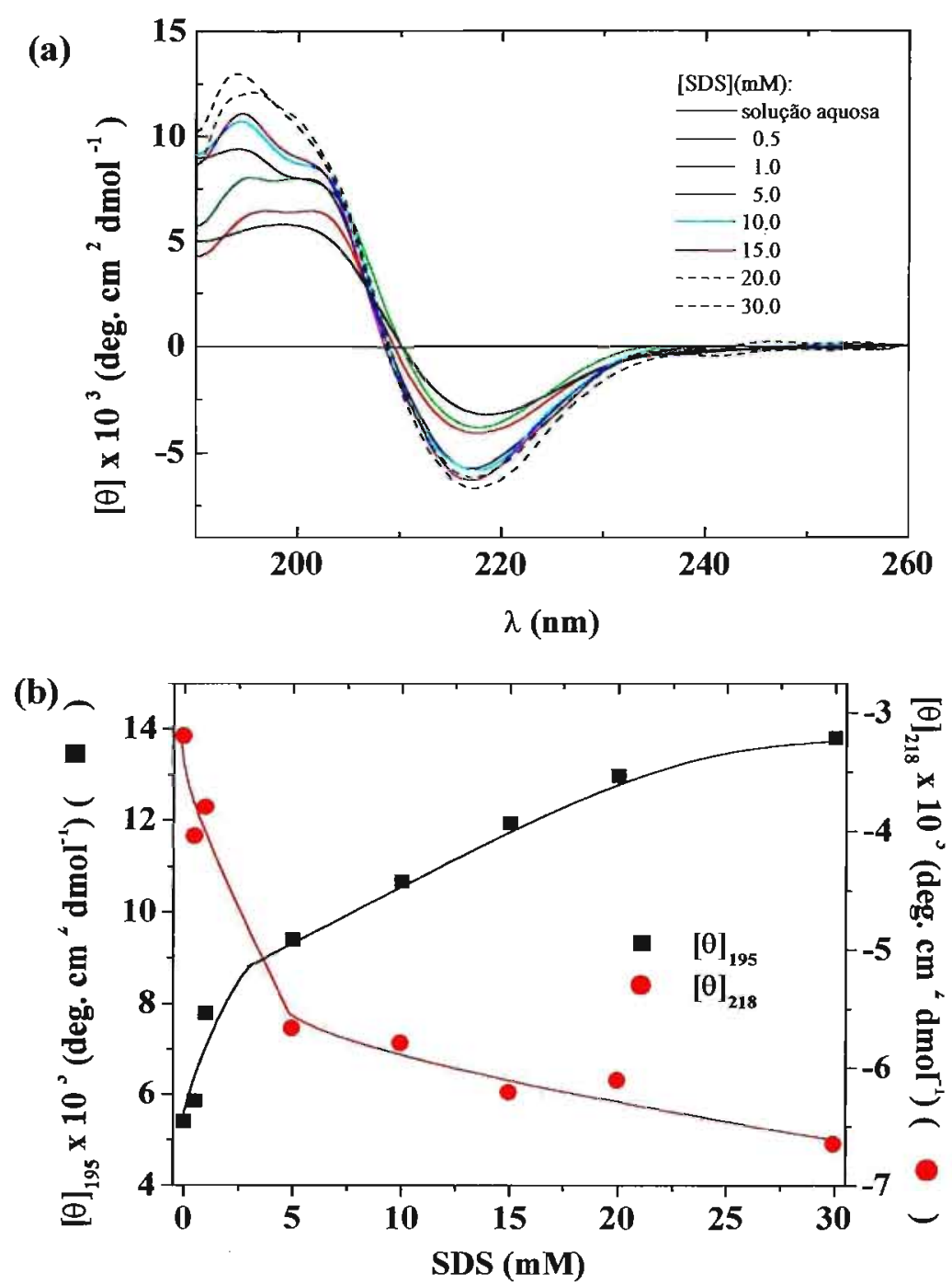

Figura 54 - Espectros de CD (a) e variação da elipticidade molar em 195 e 218 nm (b) de $70 \mu \mathrm{M}$ de III em função da concentração de SDS, pH 10,0. 
ombro pode ser interpretada com um equilíbrio de populações conforme descrito acima para III em $\mathrm{pH} 7,0$.

Os resultados de fluorescência também mostraram que III interage com SDS (Fig. 55). Em pH 4,0 (Fig. 55a) observou-se um aumento significativo da intensidade de fluorescência na presença de concentrações relativamente baixas do detergente. A variação da intensidade de fluorescência em 302 nm (Fig. 56) mostra que acima de 0,1 mM SDS, portanto bem abaixo da $\mathrm{cmc}$, III encontra-se quase que totalmente ligado ao surfactante, 0 que corrobora o experimento de $\mathrm{CD}$.

Nos outros pHs (Fig. 55b e 55c), também foi observado que III interage com o surfactante, porém o aumento da intensidade de fluorescência é gradual e não abrupto como observado em pH ácido. Isto provavelmente se deve à contribuição da interação eletrostática entre o peptídeo e o surfactante nesse $\mathrm{pH}$.

Nos pHs mais altos a carga líquida positiva de III é menor, portanto diminui a contribuição das interações eletrostáticas entre o peptídeo e o detergente. Observa-se ainda que em pH 10,0 o aumento relativo da intensidade de fluorescência é maior do que em $\mathrm{pH}$ 7,0 (Fig. 55b e 55c); a intensidade de fluorescência final em pH 7,0 é duas vezes maior que a inicial, enquanto que para $\mathrm{pH} 10,0$ ela é quase quatro vezes maior que a inicial. É possível que em pHs mais alcalinos a contribuição da hidrofobicidade do peptídeo para a interação com o detergente seja maior.

Também não foi observado o aparecimento da banda relativa ao tirosinato em $\mathrm{pH}$ 10,0. É possível que na presença de SDS o $\mathrm{pK}_{\mathrm{a}}$ da Tyr tenha aumentado. Também não foi observada a banda de emissão relativa à bitirosina (entre 400 e $450 \mathrm{~nm}$ ). Como mencionado anteriormente, a bitirosina pode ser formada como resultado de interações intermoleculares; portanto a ausência dessa banda pode indicar que o grau de agregação de III na presença de SDS é menor do que em solução aquosa. Nesse $\mathrm{pH}$, o experimento de $\mathrm{CD}$ mostrou um pequeno deslocamento da banda positiva do espectro para comprimentos de onda menores, o que também pode estar relacionado com um grau menor de agregação.

\subsubsection{Hidratação dos filmes dos peptideos na presença de detergentes.}

Uma vez que os peptídeos possuem tendência de agregarem-se em solução aquosa e mesmo na presença de detergentes, procuramos outra abordagem para diminuir o grau de agregação destes fragmentos. Assim sendo, optamos por fazer um filme dos mesmos 
(a)

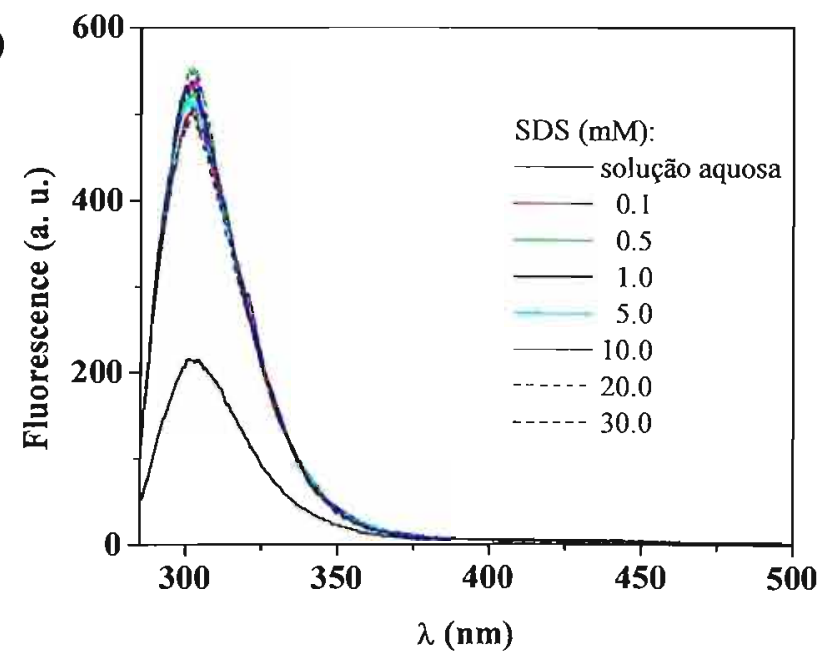

(b)

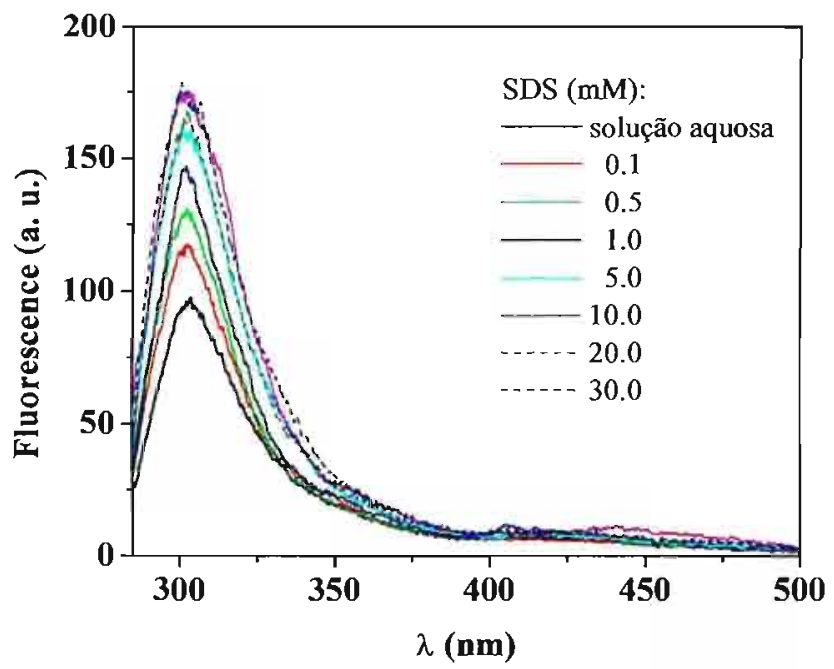

(c)

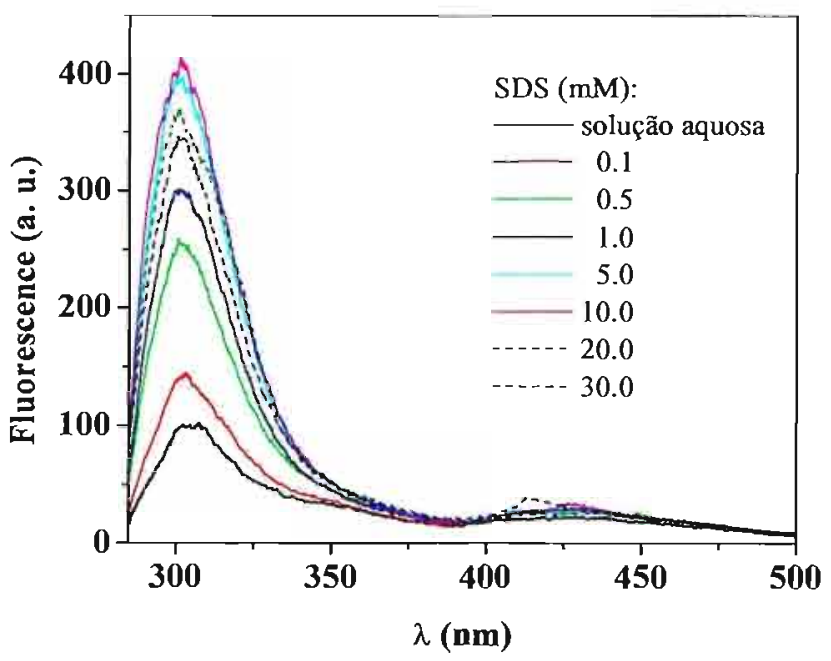

Figura 55 - Espectros de fluorescência de $30 \mu \mathrm{M}$ de UI em função da concentração de SDS. pH: 4,0 (a); 7,0 (b) e 10,0 (c). $\lambda_{\text {exc }}=275 \mathrm{~nm}$. 


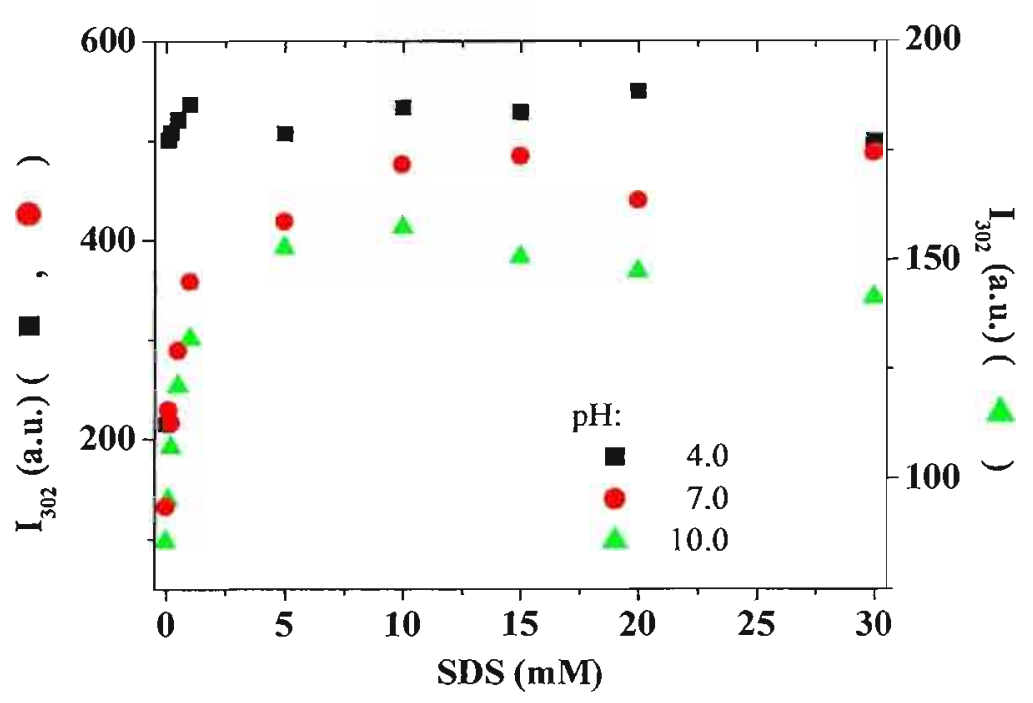

Figura 56 - Variação da intensidade de fluorescência em $302 \mathrm{~nm}$ de $30 \mu \mathrm{M}$ de III em

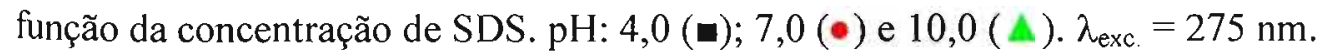

(vide Materiais e Métodos) e ressuspendê-los na presença de soluções contendo os detergentes HPS, LPC e SDS. Escolhemos concentrações do surfactante correspondentes àquelas em que os resultados anteriormente descritos mostraram que os fragmentos estavam ligados às micelas dos surfactantes ( 1 mM HPS, 20 mM LPC e 20 mM SDS). Para maximizar o efeito dos detergentes, também realizamos esses experimentos na presença de concentrações maiores de surfactantes (50 mM HPS, 50 mM SDS e 100 mM SDS).

\subsection{Efeito do pH sobre I em presença de detergentes.}

A Figura 57 apresenta o efeito da variação do $\mathrm{pH}$ sobre os espectros do peptídeo nativo e seus mutantes na presença de $1 \mathrm{mM}$ e $50 \mathrm{mM}$ de HPS (Fig. 57a e 57b, respectivamente). Observa-se nos dois casos que I apresenta bandas alargadas, sendo que na presença de $1 \mathrm{mM}$ HPS (Fig. 57a), observa-se um progressivo deslocamento banda negativa ao redor de $224 \mathrm{~nm}$ em pH 4,0 para $216 \mathrm{~nm}$ e da banda positiva centrada em torno de $206 \mathrm{~nm}$ para $198 \mathrm{~nm}$. O espectro obtido em $\mathrm{pH}$ baixo corresponde ao de uma dobra $\beta$; com o aumento do $\mathrm{pH}$ ocorre uma mudança para folha $\beta$. De maneira geral, na presença de 50 mM HPS (Fig. 57b) não foi observado um deslocamento significativo da posição da banda positiva e negativa, o que indica que I não mudou de conformação com o aumento do $\mathrm{pH}$. 

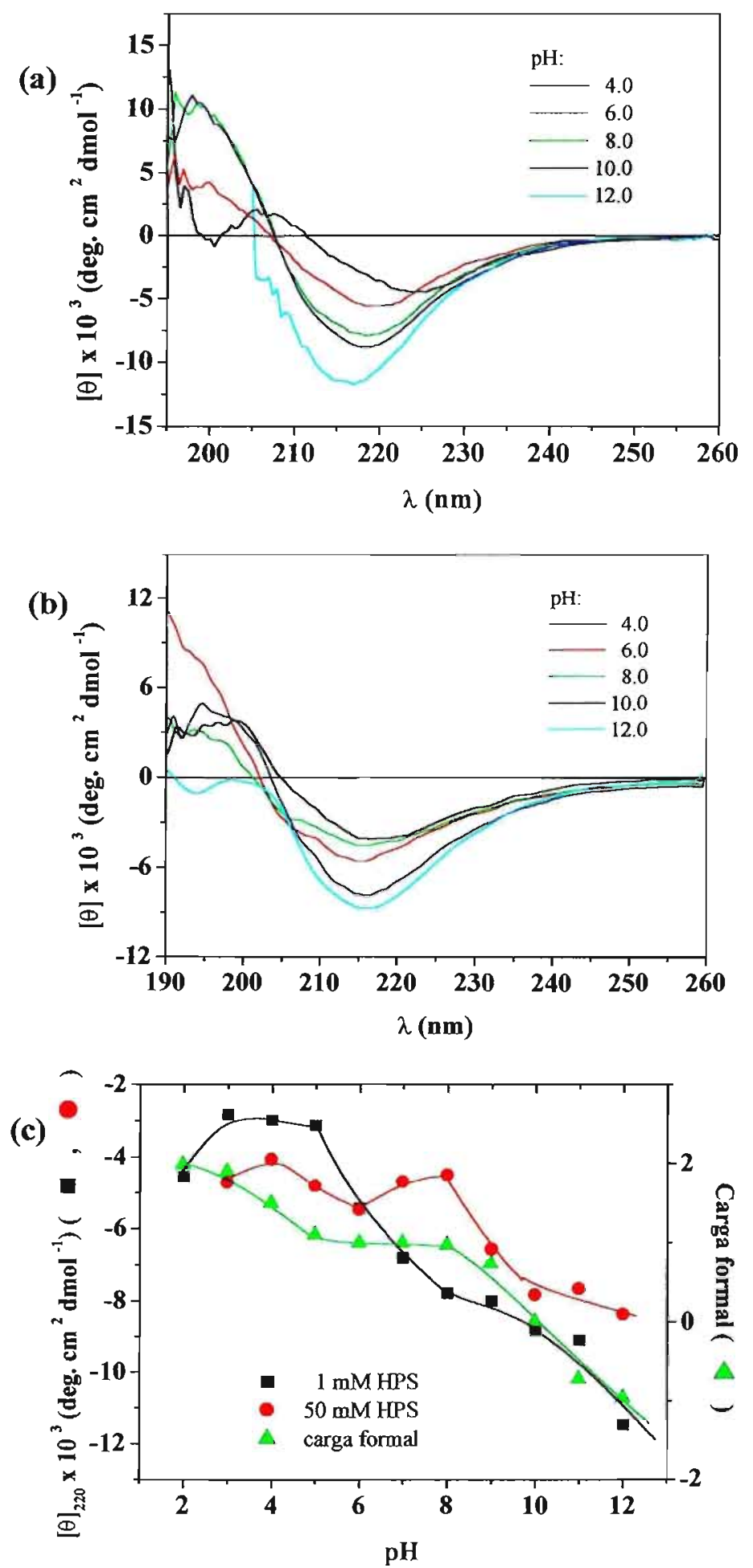

Figura 57 - Espectros de CD de um filme de $80 \mu \mathrm{M}$ de I suspenso na presença de uma solução aquosa de $1 \mathrm{mM}$ (a) e $50 \mathrm{mM}$ HPS (b) em função do pH. Variação da elipticidade molar em 220 nm e variação da carga líquida de I em função do pH. 
A Figura 57c mostra a variação da carga teórica do peptídeo e a variação da elipticidade molar de I na presença de HPS em função do $\mathrm{pH}$. Na presença de $50 \mathrm{mM}$ HPS a variação da elipticidade molar é similar à variação da carga teórica. Em $1 \mathrm{mM}$ HPS não é possível observar uma variação abrupta da elipticidade molar a partir de $\mathrm{pH}$ 5,0, o que pode estar refletindo a desprotonação dos grupos ionizáveis de $\mathrm{I}$, como o grupo amino terminal e em pHs mais alcalinos a desprotonação da cadeia lateral de Lys.

Na presença de 20 e $50 \mathrm{mM}$ LPC (Fig. 58) também foi possível observar um pequeno deslocamento da banda negativa do espectro de $\mathrm{CD}$ em pHs baixos para comprimentos de onda menores. Na presença de $20 \mathrm{mM}$ LPC (Fig. 58a), o espectro de CD de I apresenta um mínimo ao redor de $220 \mathrm{~nm}$ em pH baixo, o qual se desloca para $217 \mathrm{~nm}$ em pHs mais altos. Na presença de $50 \mathrm{mM}$ LPc observa-se um deslocamento do mínimo do espectro de $219 \mathrm{~nm}$ para $217 \mathrm{~nm}$. Em abos os casos os espectros de CD de I são similares, os espectros de CD indica que em ambos os caos I adquire estrutura em folha $\beta$.

$\mathrm{Na}$ Figura 58c, a variação da elipticidade molar em função do $\mathrm{pH}$ mostra que em ambos os casos não foi observado um patamar entre pHs 5,0 e 8,0. É possível que esse comportamento reflita o abaixamento do $\mathrm{pK}_{\mathrm{a}}$ do grupo $\mathrm{N}$-terminal do peptídeo.

Na presença de SDS (Fig. 59) observa-se uma diferença significativa nos espectros de CD de I na presença de 20 e 100 mM SDS. No priemeiro caso (Fig. 59a), os espectros de $\mathrm{CD}$ apresentam bandas deslocadas para o vermelho; abaixo de $\mathrm{pH} 8,0$ os espectros são relativamente parecidos e apresentam uma banda positiva alargada, o que indica adota conformação em folha $\beta$. A partir de $\mathrm{pH}$ 10,0 observa-se uma mudança nesses espectros; em $\mathrm{pH}$ 12,0, o espectro de CD sugere que I adota conformação $\alpha$-helicoidal. Na presença de concentrações maiores de SDS observa-se em praticamente toda faixa de $\mathrm{pH}$ espectros de CD que sugerem que I adota conformação $\alpha$-helicoidal. Tanto na presença de $20 \mathrm{mM}$ quanto em $100 \mathrm{mM}$ SDS a variação da elipticidade molar é similar à variação da carga teórica de I (Fig. 59c).

\subsection{Efeito do $\mathrm{pH}$ sobre II em presença de detergentes.}

A Figura 60 mostra os espectros de CD de II na presença de $1 \mathrm{mM}$ (Fig.60a) e 50 mM HPS (Fig.60b) em função do pH. Na presença de 1mM HPS observa-se que em pHs 

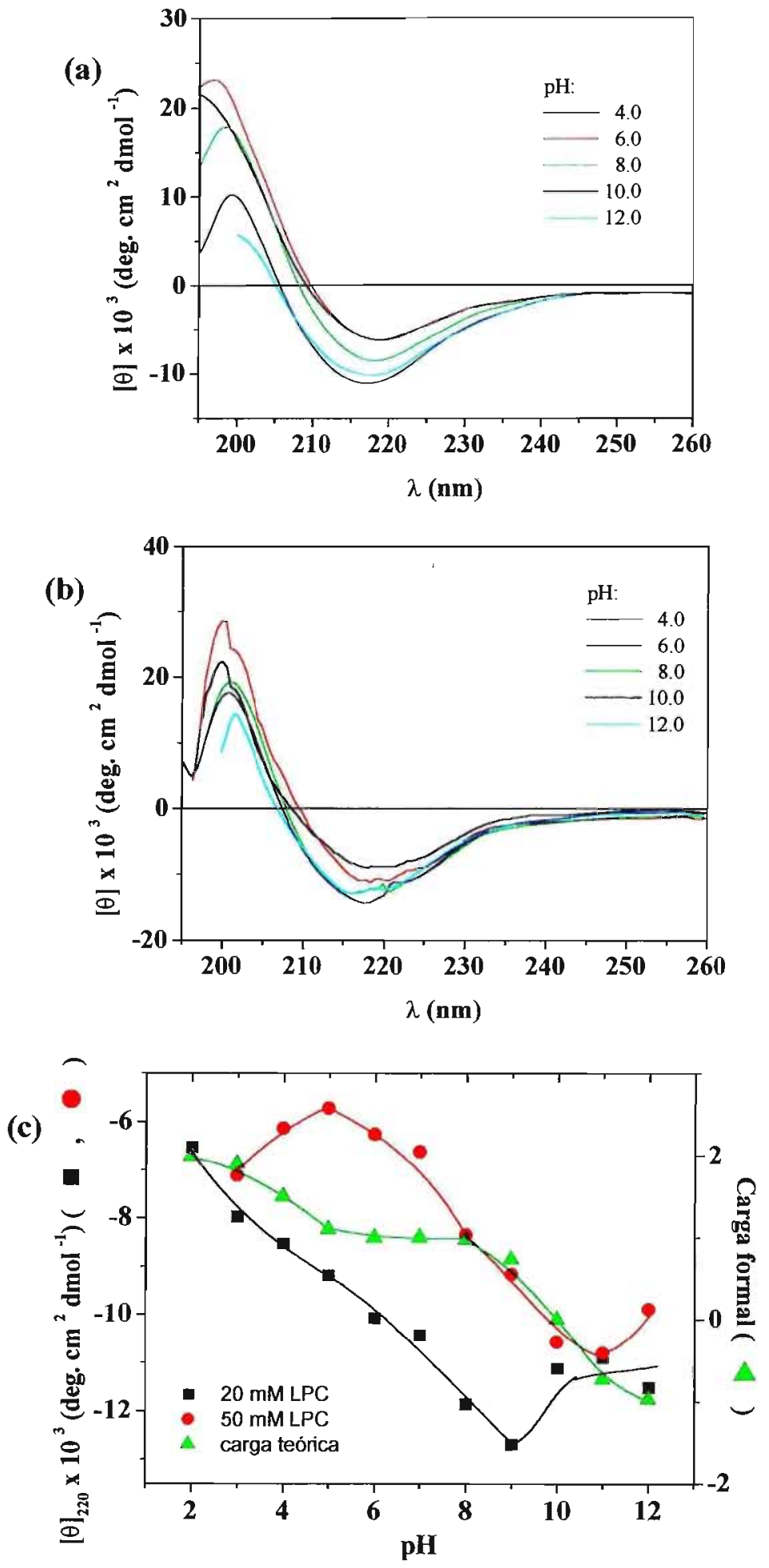

Figura 58 - Espectros de CD de um filme de $80 \mu \mathrm{M}$ de I suspenso na presença de uma solução aquosa de $20 \mathrm{mM}$ (a) e $50 \mathrm{mM}$ LPC (b) em função do pH. Variação da elipticidade molar em 220 nm e variação da carga líquida de I em função do pH. 

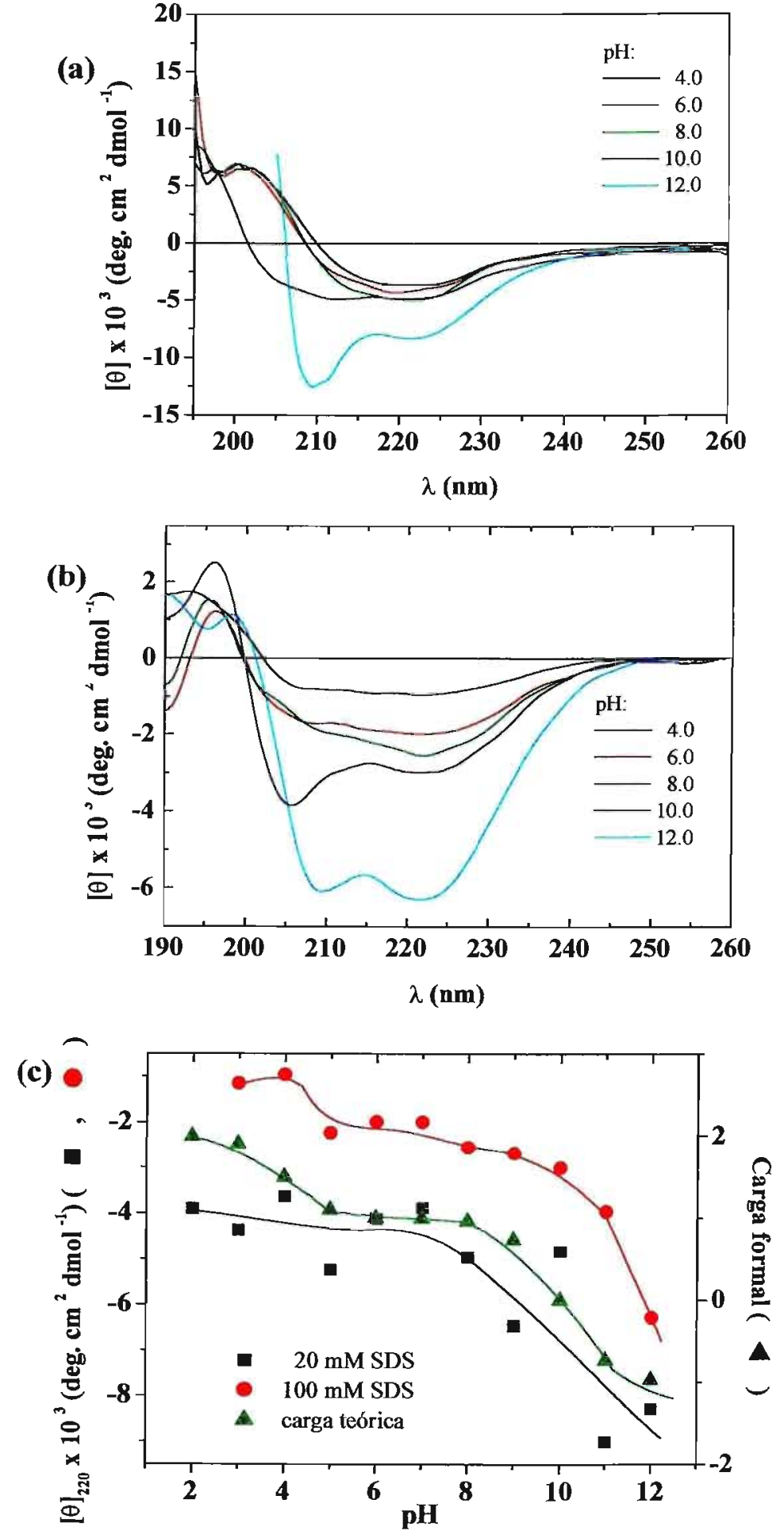

Figura 59 - Espectros de CD de um filme de $80 \mu \mathrm{M}$ de I suspenso na presença de uma solução aquosa de $20 \mathrm{mM}$ (a) e $100 \mathrm{mM}$ SDS (b) em função do pH. Variação da elipticidade molar em 220 nm e variação da carga líquida de I em função do pH. 

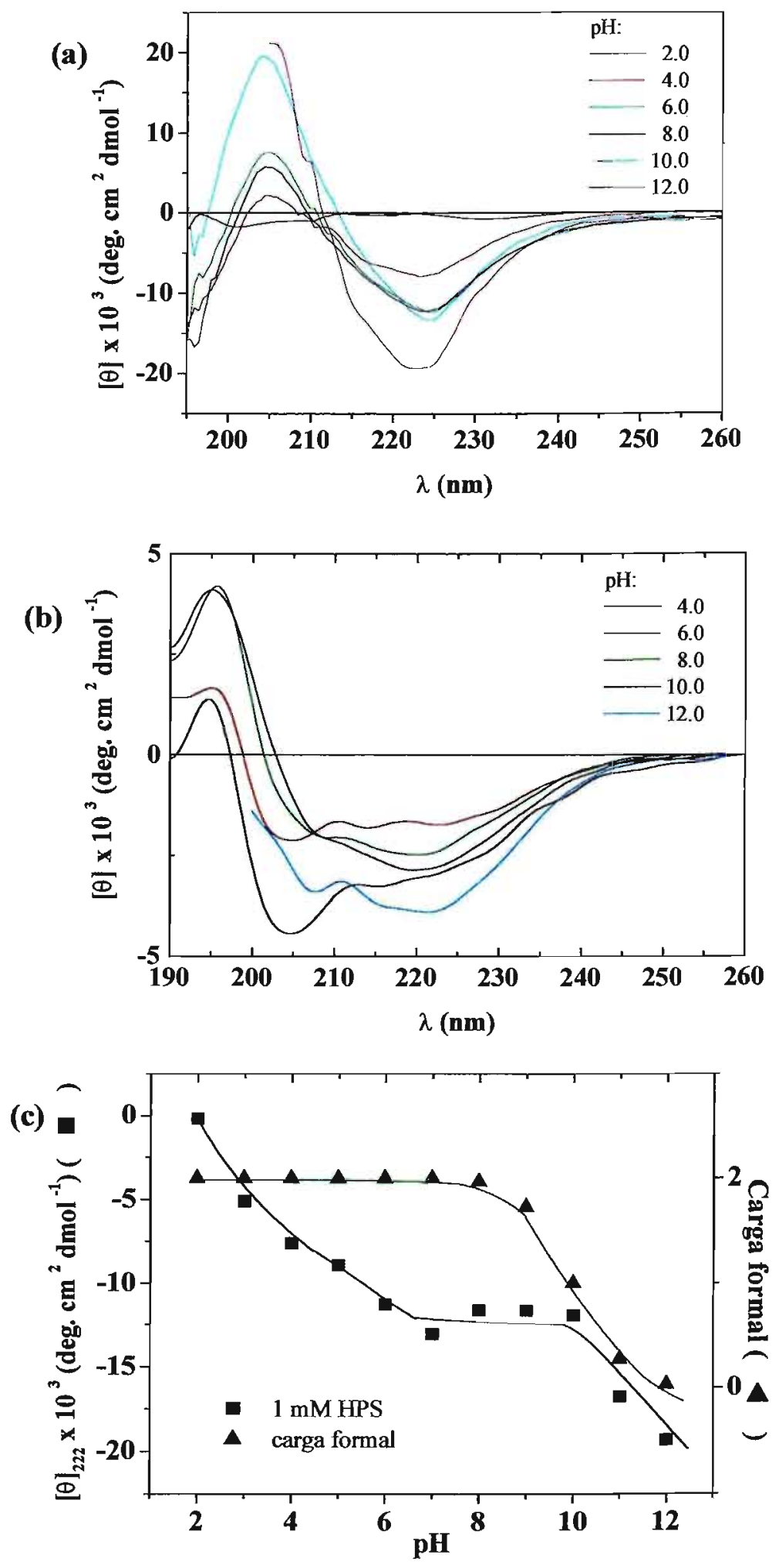


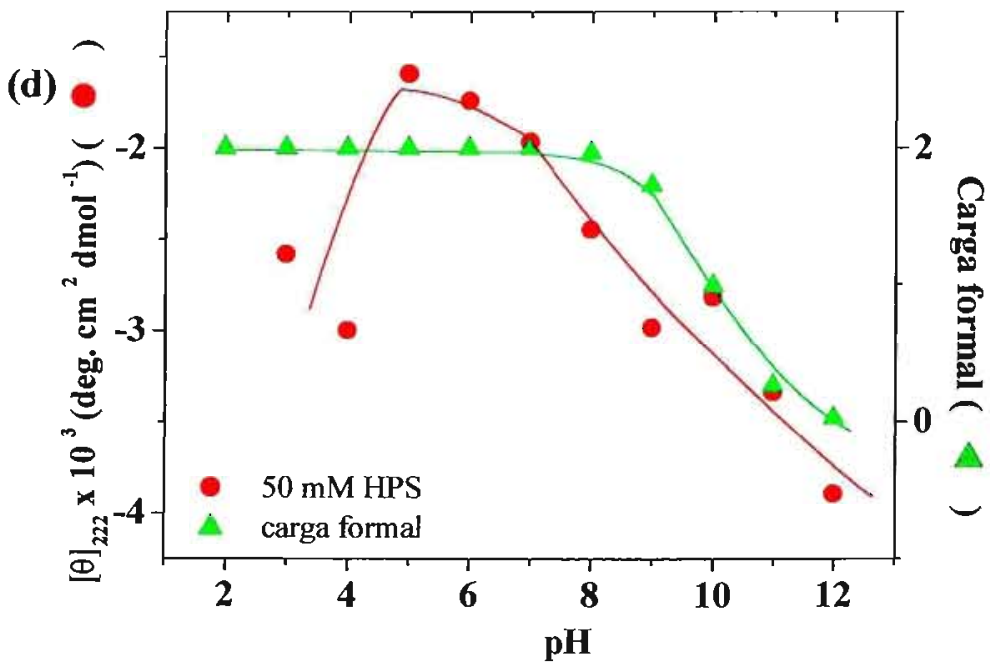

Figura 60 - Espectros de CD de um filme de $80 \mu \mathrm{M}$ de II suspenso na presença de uma solução aquosa de 1 mM (a) e 50 mM HPS (b) em função do pH. Variação da carga líquida de II e da elipticidade molar em $222 \mathrm{~nm}$ em função do $\mathrm{pH}$ na presença de $1 \mathrm{mM}$ (c) e 50 $\mathrm{mM} \operatorname{HPS}(\mathrm{d})$. 
baixos o espectro de CD de II apresenta uma pequena banda positiva centrada ao redor de $205 \mathrm{~nm}$ e uma banda negativa com mínimo em torno de $223 \mathrm{~nm}$. Com o aumento do pH, observa-se o aumento da intensidade do espectro de $\mathrm{CD}$, porém a posição dos máximos e mínimos nos espectros de II mantém-se praticamente inalterada.

Em 50 mM HPS (Fig. 60b) os espectros de CD de II indicam que o peptídeo adota conformação $\alpha$-helicoidal na faixa de pH estudada. Em pHs baixos II apresenta uma banda negativa ao redor de $205 \mathrm{~nm}$ e outra ao redor de $222 \mathrm{~nm}$. Com o aumento do $\mathrm{pH}$, a primeira banda negativa desloca-se para $207 \mathrm{~nm}$.

$\mathrm{Na}$ presença de $1 \mathrm{mM}$ de HPS observa-se uma diferença significativa entre a variação da carga teórica e a variação da elipticidade molar (Fig. 60c). O peptídeo possui apenas dois grupos ionizáveis, o grupo $\mathrm{N}$-terminal e o grupo $\varepsilon-\mathrm{NH}_{2}$ na cadeia lateral do resíduo de Lys. Esses grupamentos possuem $\mathrm{pK}_{\mathrm{a}}$ em torno de 8,5 e 11,0, respectivamente. Observa-se um decréscimo significativo da elipticidade molar na faixa de $\mathrm{pH}$ entre $2,0 \mathrm{e}$ 6,0 , o que sugere o abaixamento do $\mathrm{pK}_{\mathrm{a}}$ do grupo amino terminal. Na presença de $50 \mathrm{mM}$ HPS a variação da elipticidade molar também sugere o abaixamento do $\mathrm{pK}_{\mathrm{a}}$ desse grupo.

Na presença de LPC (Fig. 61) os espectros de CD de II na presença de $20 \mathrm{mM} \mathrm{LPC}$ apresentam duas bandas negativas, em torno de 214 e $222 \mathrm{~nm}$ respectivamente e uma banda positiva cujo máximo se desloca de $199 \mathrm{~nm}$ em pH 4,0 para $201 \mathrm{~nm}$ acima de pH 6,0. Não foram observadas mudanças significativas do espectro de II em função do $\mathrm{pH}$. Em presença de $50 \mathrm{mM}$ LPC (Fig. 61 b) nota-se que os espectros de CD são diferentes daqueles obtidos e na presença de concentrações mais baixas do detergente. Os espectros apresentam um mínimo ao redor de 220 e um máximo abaixo de $195 \mathrm{~nm}$.

A Figura 61c mostra que o comportamento da variação de elipticidade molar em $222 \mathrm{~nm}$ foi parecido na presença das duas concentrações de detergentes. Em ambos os casos, os resultados sugerem alteração do $\mathrm{pKa}$ dos grupos ionizáveis de $\Pi$, o grupo amino terminal e a cadeia lateral da Lys.

$\mathrm{Na}$ presença de $20 \mathrm{mM}$ SDS (Fig.62a) os resultados indicam que II sofre uma mudança conformacional com o aumento do $\mathrm{pH}$. Em pH 4,0 II apresenta um espectro com uma banda positiva em torno de $200 \mathrm{~nm}$ e uma banda negativa ao redor de $219 \mathrm{~nm}$, indicativa de conformação em folha $\beta$. Com o aumento do $\mathrm{pH}$, observa-se o aparecimento 
(a)
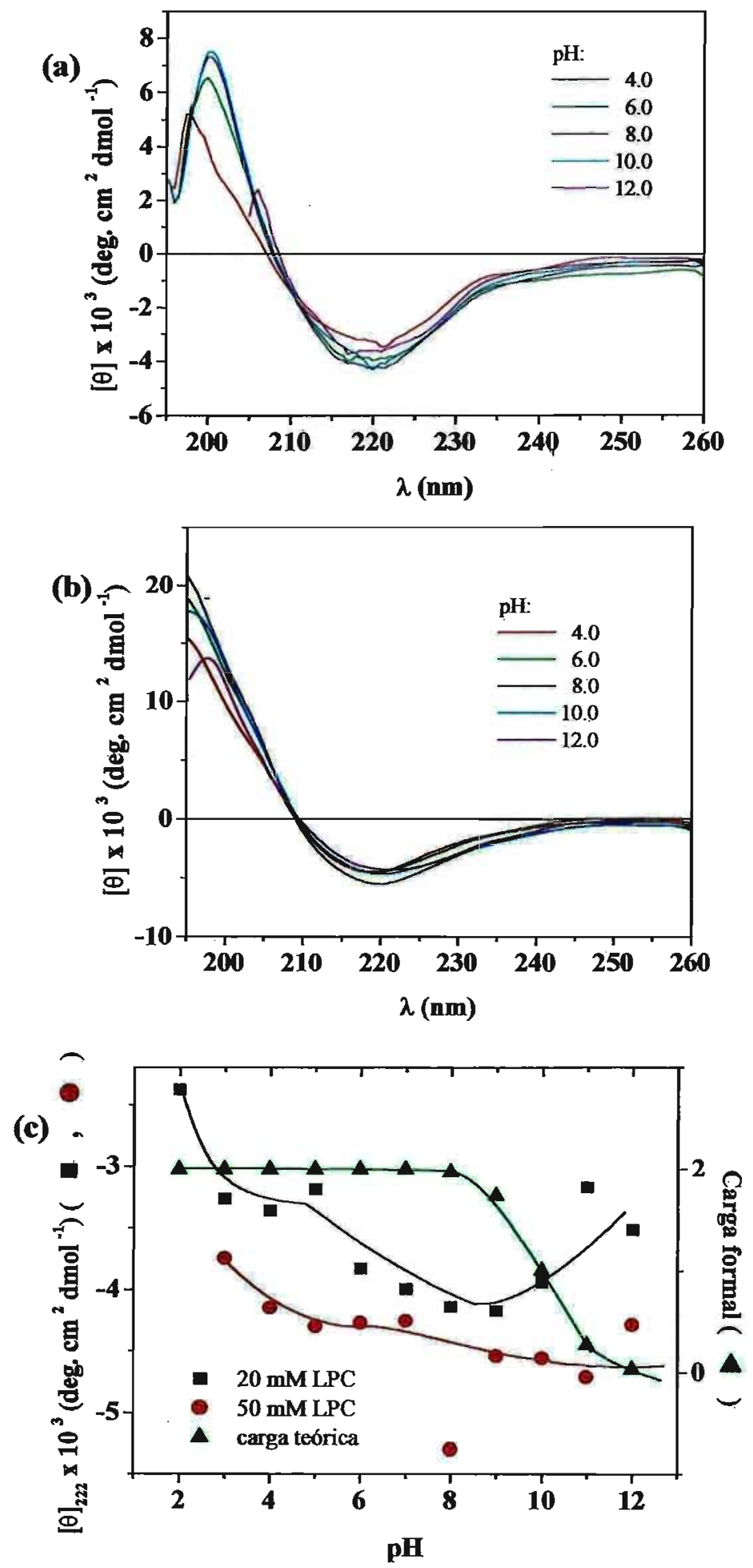

Figura 61 - Espectros de CD de um filme de $80 \mu \mathrm{M}$ de II suspenso na presença de uma solução aquosa de $20 \mathrm{mM}$ (a) e $50 \mathrm{mM}$ LPC (b) em função do pH. Variação da carga líquida de II e da elipticidade molar em 222 nm em função do pH (c). 
(a)
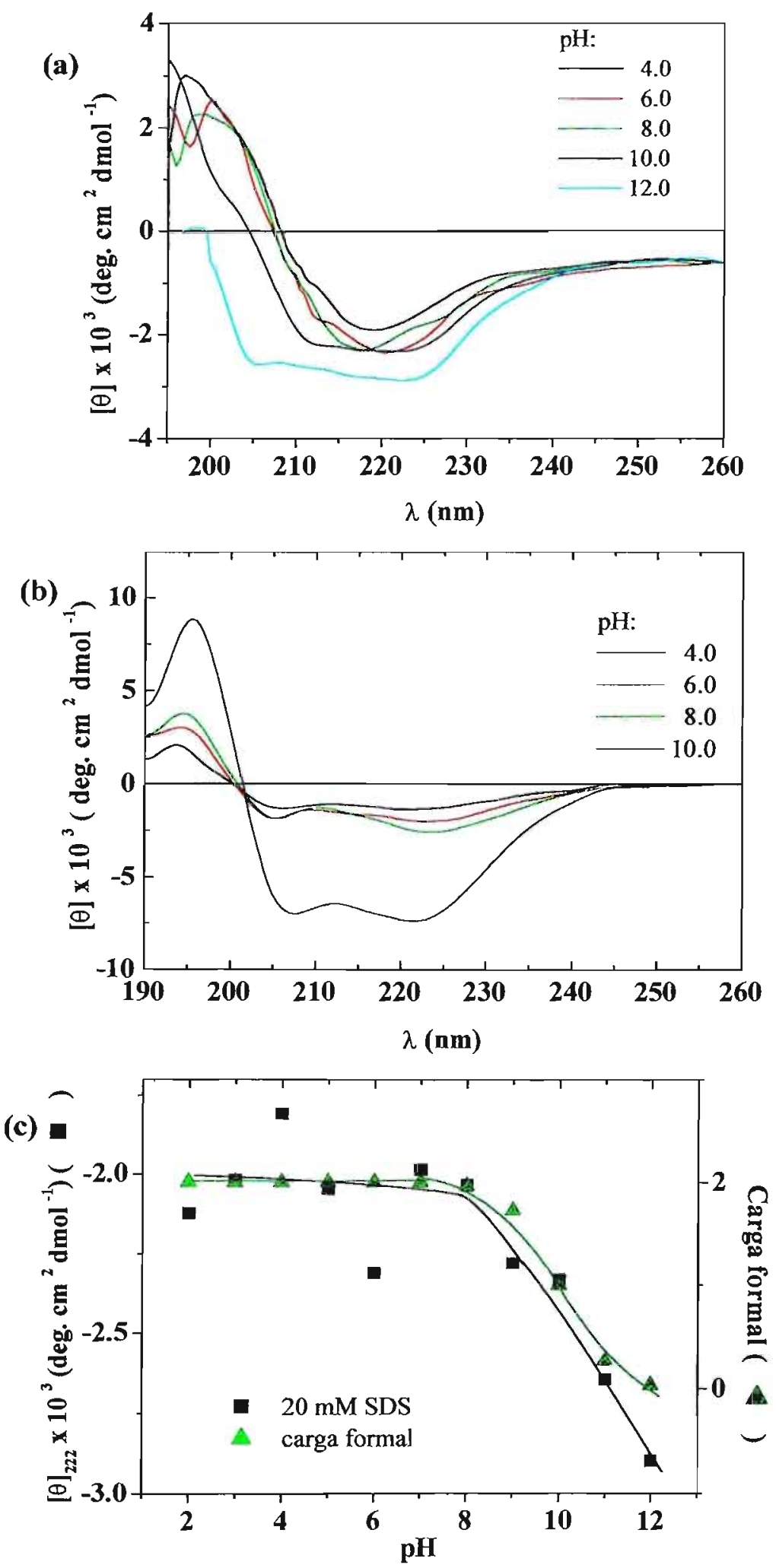


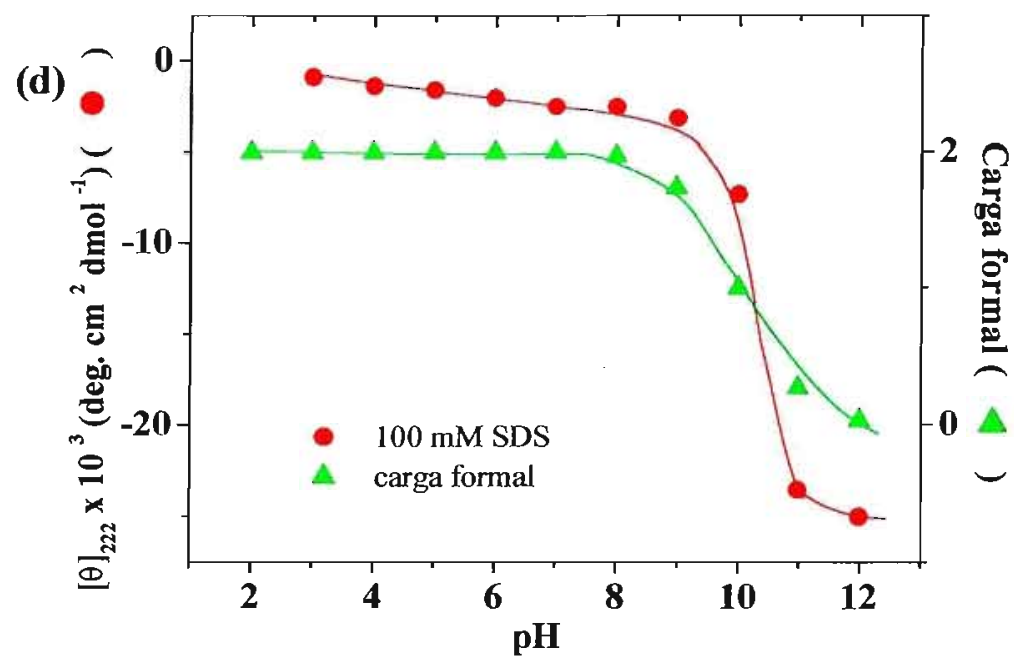

Figura 62 - Espectros de CD de um filme de $80 \mu \mathrm{M}$ de II suspenso na presença de uma solução aquosa de $20 \mathrm{mM}$ (a) e $100 \mathrm{mM}$ SDS (b) em função do pH. Variação da elipticidade molar em $222 \mathrm{~nm}$ e variação da carga líquida de II em função do pH (c) e (d). 
de duas bandas negativas, ao redor de $212 \mathrm{~nm}$ e acima de $222 \mathrm{~nm}$, enquanto que ocorre um deslocamento da banda positiva para comprimentos de onda mais baixos.

Os espectros de CD do filme de II na presença de 100 mM SDS (Fig.62b) indicam que este adota conformação $\alpha$-helicoidal em quase toda a faixa $\mathrm{pH}$. Acima de $\mathrm{pH} 8,0$ ocorre um grande aumento da intensidade do espectro de CD. Na Figura não estão mostrados os espectros acima de $\mathrm{pH}$ 10,0. Nessa condição observou-se um aumento significativo da banda negativa do espectro, o qual a partir desse $\mathrm{pH}$ deixa de ser indicativo de estrutura $\alpha$ helicoidal. Também foi observado que tanto na presença de $20 \mathrm{mM}$ (Fig. 62c) quanto na presença de 100 mM SDS (Fig. 62d) a variação da elipticidade molar é similar a variação da carga teórica de II.

\subsection{Efeito do pH sobre III em presença de detergentes.}

A Figura 63 mostra os espectros de CD de um filme de III na presença de HPS. Na presença de $1 \mathrm{mM}$ de HPS (Fig.63a), os espectros de CD apresentaram um ruído significativo, o que pode estar relacionado com espalhamento de luz. Nessa condição os espectros de III apresentam um $\lambda_{\text {máx }}$ baixo de $200 \mathrm{~nm}$ e um $\lambda_{\min }$ ao redor de $217 \mathrm{~nm}$, sendo indicativos de conformação em folha $\beta$. Na maioria da faixa de $\mathrm{pH}$ estudada não foi observada uma mudança significativa na posição desses comprimentos de onda, o que indica que II continua a adotar folha $\beta$ ao longo de toda a faixa de $\mathrm{pH}$ estudada.

Ao suspender o filme de III na presença de 50 mM HPS (Fig. 63b), observou-se que o peptídeo adota conformação $\alpha$-helicoidal em todos os $\mathrm{pH}$. Os espectros apresentam duas bandas negativas, a primeira ao redor de $210 \mathrm{~nm}$ e a segunda em torno de $222 \mathrm{~nm}$. A Figura 63c mostra que na presença das duas concentrações de HPS, a variação da elipticidade molar em $222 \mathrm{~nm}$ é similar a da carga teórica de III.

Esse experimento também foi feito por fluorescência na presença de $50 \mathrm{mM}$ HPS (Fig. 64), onde a amostra foi excitada em 275 (Fig. 64a) e 292 nm (Fig. 64b). A Figura 64a mostra que ocorre diminuição da intensidade de fluorescência com o aumento do $\mathrm{pH}$, o que reflete a desprotonação do grupo fenol da tirosina. Observa-se o aparecimento do espectro de emissão de fenolato a partir de pH 10 . Essa banda, centrada ao redor de $350 \mathrm{~nm}$, torna-se nítida no espectro de III em pH 12,0. 

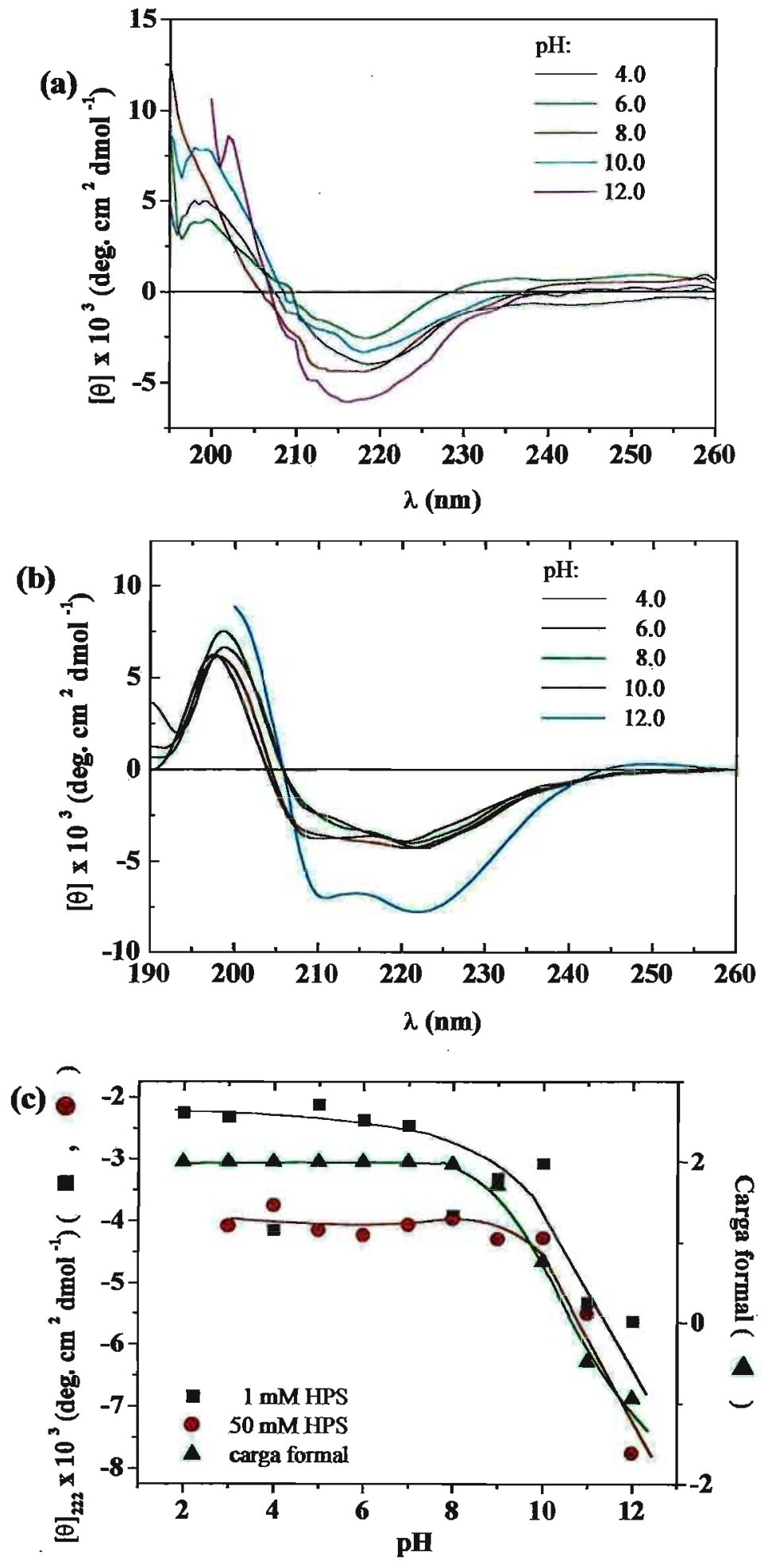

Figura 63 - Espectros de CD de um filme de $80 \mu \mathrm{M}$ de III suspenso na presença de uma solução aquosa de $1 \mathrm{mM}$ (a) e $50 \mathrm{mM}$ HPS (b) em função do pH. Variação da elipticidade molar em $222 \mathrm{~nm}$ e variação da carga líquida de III em função do pH (c). 

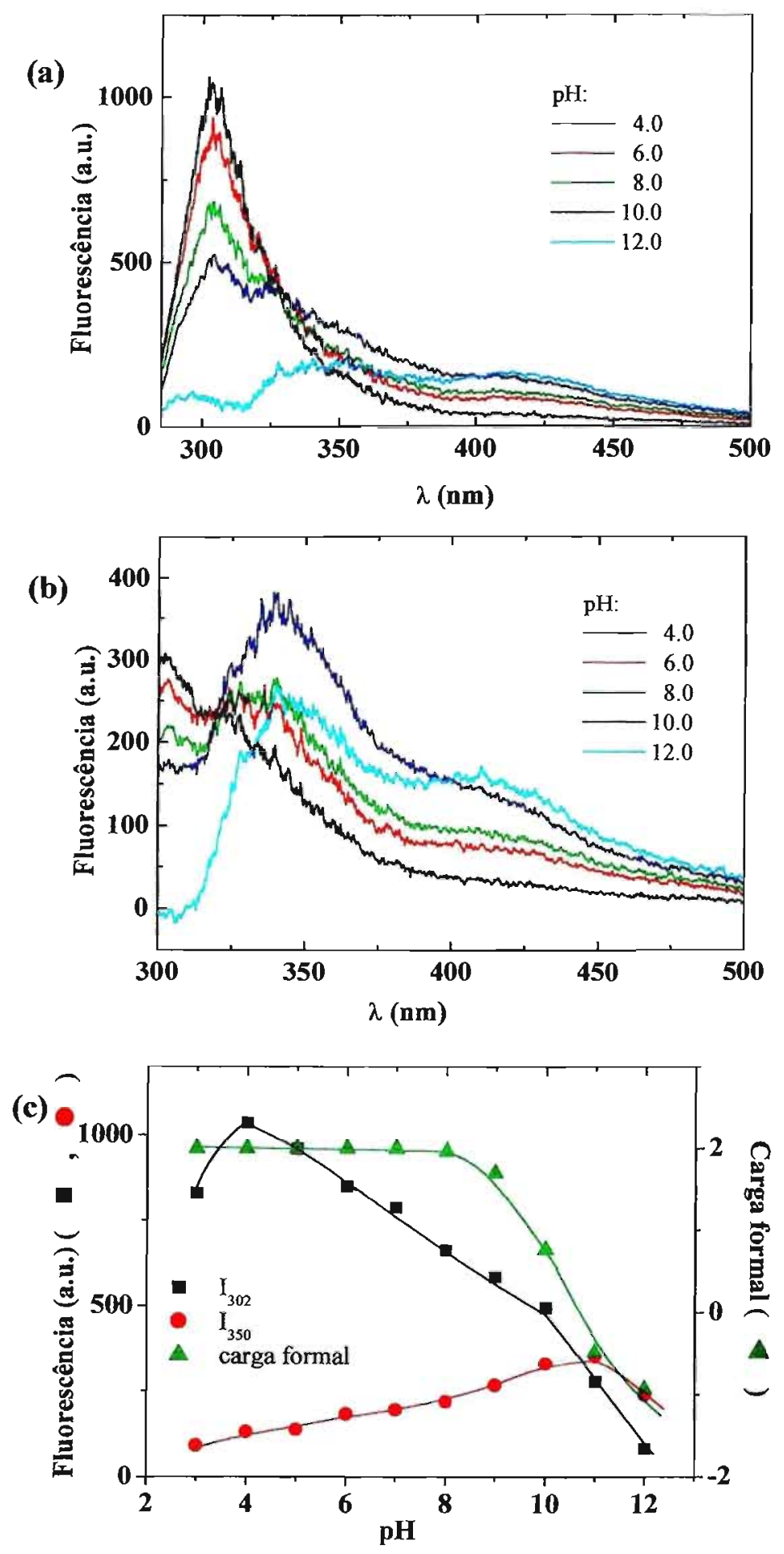

Figura 64 - Espectros de fluorescência de um filme de $30 \mu \mathrm{M}$ de III suspenso na presença de uma solução aquosa de $1 \mathrm{mM}$ (a) e $50 \mathrm{mM}$ HPS (b) em função do pH. Variação da intensidade de fluorescência em 302 e $350 \mathrm{~nm}$ e variação da carga líquida de III em função do $\mathrm{pH}(\mathrm{c})$. 
Na Figura 64b também é possível observar o aparecimento da banda relativa à emissão de fenolato com o aumento do $\mathrm{pH}$ a partir de $\mathrm{pH}$ 6,0. Com exceção do espectro de III em pH 12,0, não foi possível observar nitidamente a presença da banda atribuída a bitirosina, acima de $400 \mathrm{~nm}$. Isto sugere que houve diminuição do grau de agregação de III na presença de altas concentrações de HPS.

A Figura $64 \mathrm{c}$ mostra a variação da carga teórica e a variação da intensidade de fluorescência de III em 302 e $350 \mathrm{~nm}$ em função do pH. Como mencionado acima, observase uma diminuição de $\mathrm{I}_{302}$ a partir de $\mathrm{pH} 4,0$. Esse poderia sugerir que houve diminuição do $\mathrm{pK}_{\mathrm{a}}$ do grupo fenol, o que não foi possível observar no experimento de CD. Deve-se levar em conta que o experimento de fluorescência é mais sensível aos eventos que acontecem com o resíduo de tirosina. È possível que a queda da intensidade de fluorescência em pHs baixos reflita a desprotonação de Tyr no estado excitado.

Na presença de LPC (Fig. 65), os espectros de CD de III na presença de $20 \mathrm{mM}$ (Fig. 65a) e principalmente em $50 \mathrm{mM} \mathrm{LPC} \mathrm{(Fig.} \mathrm{65b)} \mathrm{mostram} \mathrm{poucas} \mathrm{mudanças} \mathrm{em}$ função do pH. De modo geral, em ambos os casos os espectros são indicativos de estrutura em folha $\beta$.

Comparando-se a variação da elipticidade molar em $222 \mathrm{~nm}$ em função do pH (Fig. 65c) observa-se um comportamento diferente na presença das duas concentrações de LPC. Em $20 \mathrm{mM} \mathrm{LPC}[\theta]_{222}$ muda pouco entre os pHs 3,0 e 8,0, enquanto que em $50 \mathrm{mM} \mathrm{LPC}$ observa-se uma queda gradual da elipticidade molar nesse comprimento de onda.

Por fluorescência (Fig. 66), na presença de $50 \mathrm{mM}$ LPC observa-se uma queda da intensidade de fluorescência de $\mathrm{II}$ em $302 \mathrm{~nm}$ (Fig. 66a e 66c) a partir de pH 5,0, o que pode estar refletindo a desprotonação do grupo fenol possível observar a banda de emissão de fenolato a partir de pH 6,0. A intensidade de fluorescência dessa banda é maior do que àquela observada na presença de HPS, o que poderia ser explicado pelo aumento do rendimento quântico do fenolato na presença de LPC.

$\mathrm{Na}$ presença de SDS, os espectros de CD também mostram que os melhores resultados foram obtidos na presença de altas concentrações do detergente (Fig. 67). Na presença de $20 \mathrm{mM}$ SDS (Fig. 67a), o espectro em pH apresenta duas bandas negativas centradas em 209 e $222 \mathrm{~nm}$ respectivamente. Com o aumento do $\mathrm{pH}$, a primeira banda 

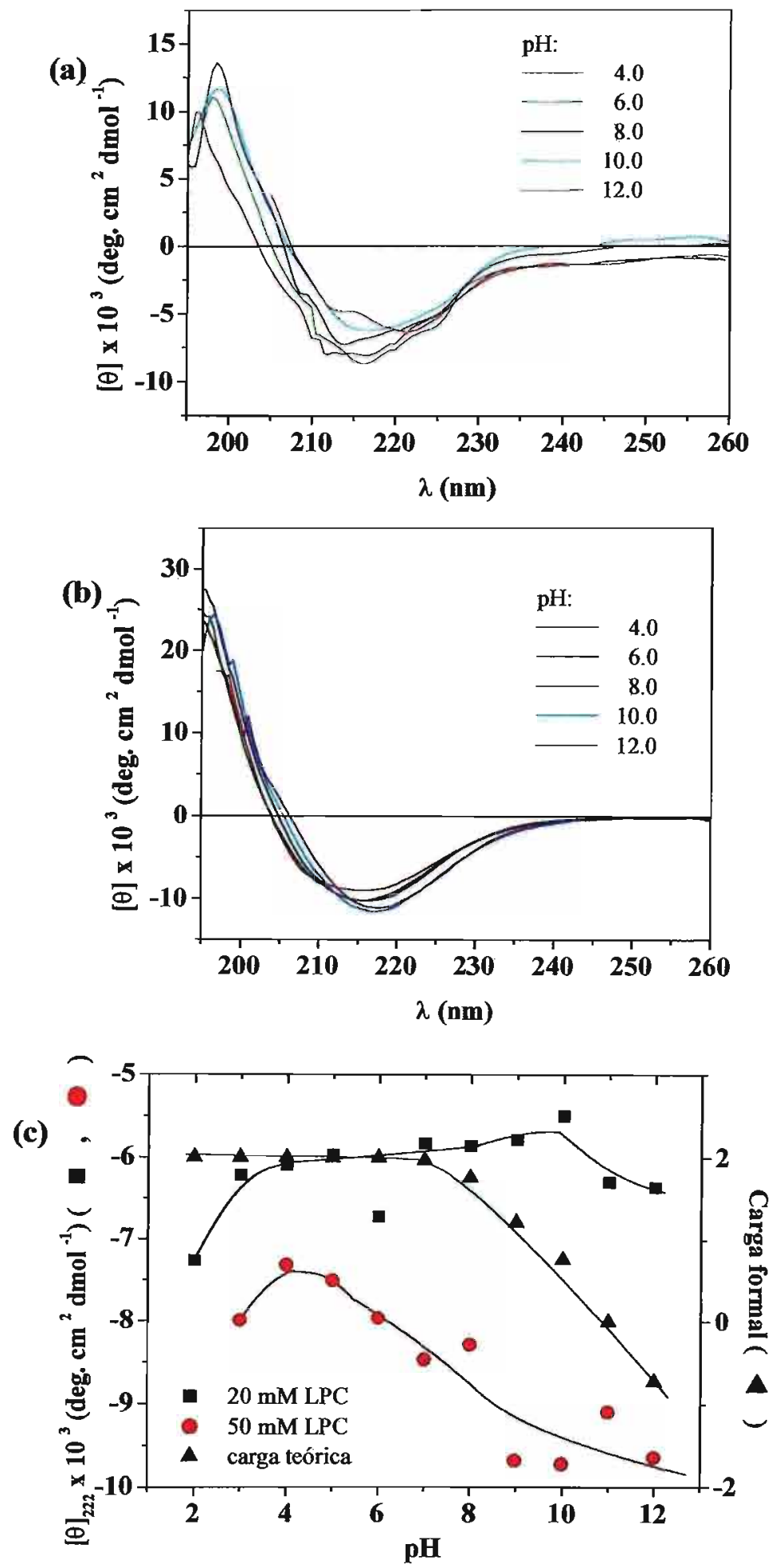

Figura 65 - Espectros de CD de um filme de $80 \mu \mathrm{M}$ de III suspenso na presença de uma solução aquosa de $20 \mathrm{mM}$ (a) e $50 \mathrm{mM}$ LPC (b) em função do pH. Variação da elipticidade molar em 222 nm e variação da carga líquida de III em função do pH (c). 

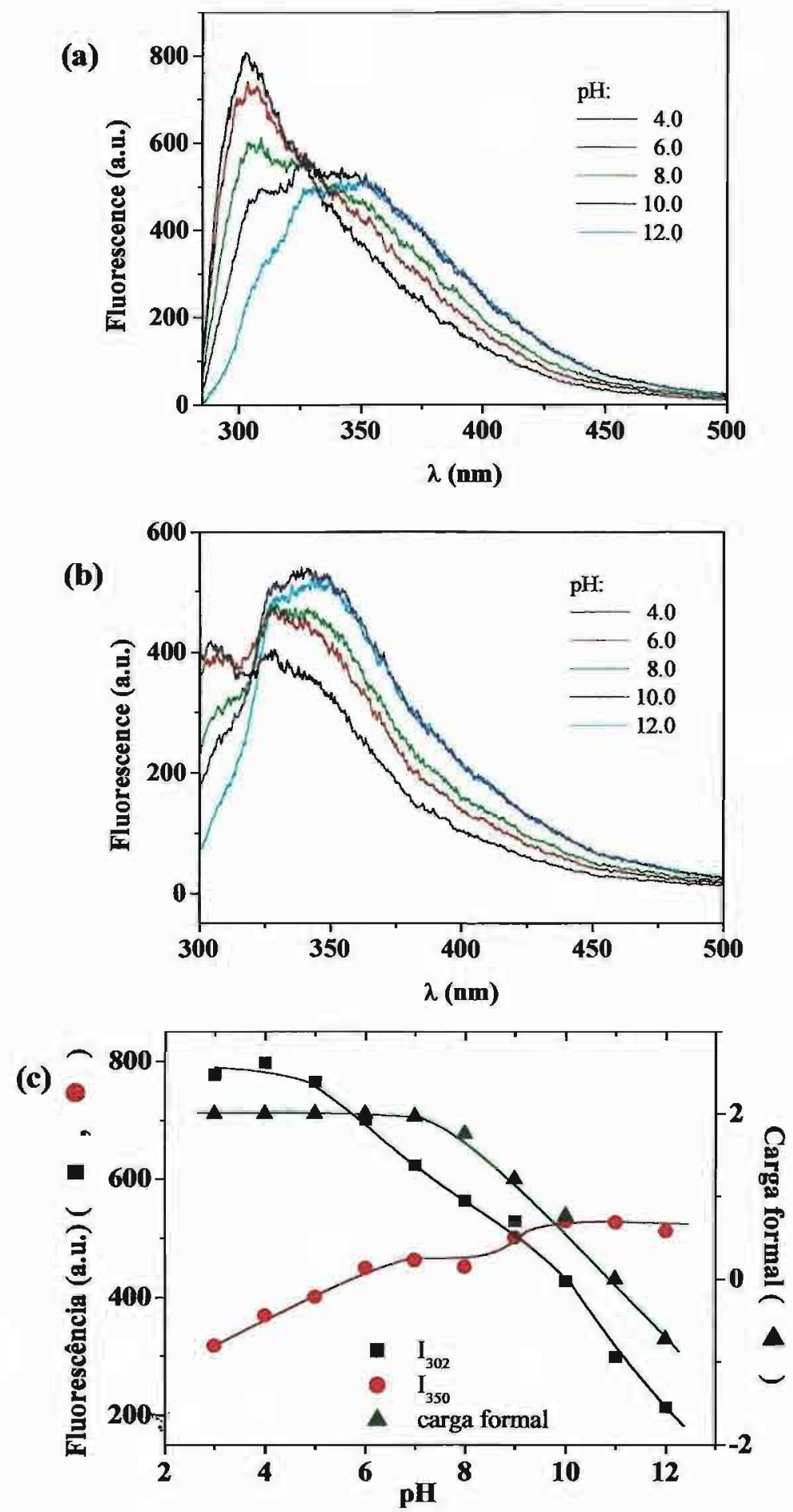

Figura 66 - Espectros de fluorescência de um filme de $30 \mu \mathrm{M}$ de $\mathrm{III}$ suspenso na presença de uma solução aquosa de $20 \mathrm{mM}$ (a) e $50 \mathrm{mM}$ LPC (b) em função do pH. Variação da intensidade de fluorescência em 302 e $350 \mathrm{~nm}$ e variação da carga líquida de III em função do $\mathrm{pH}(\mathrm{c})$. 

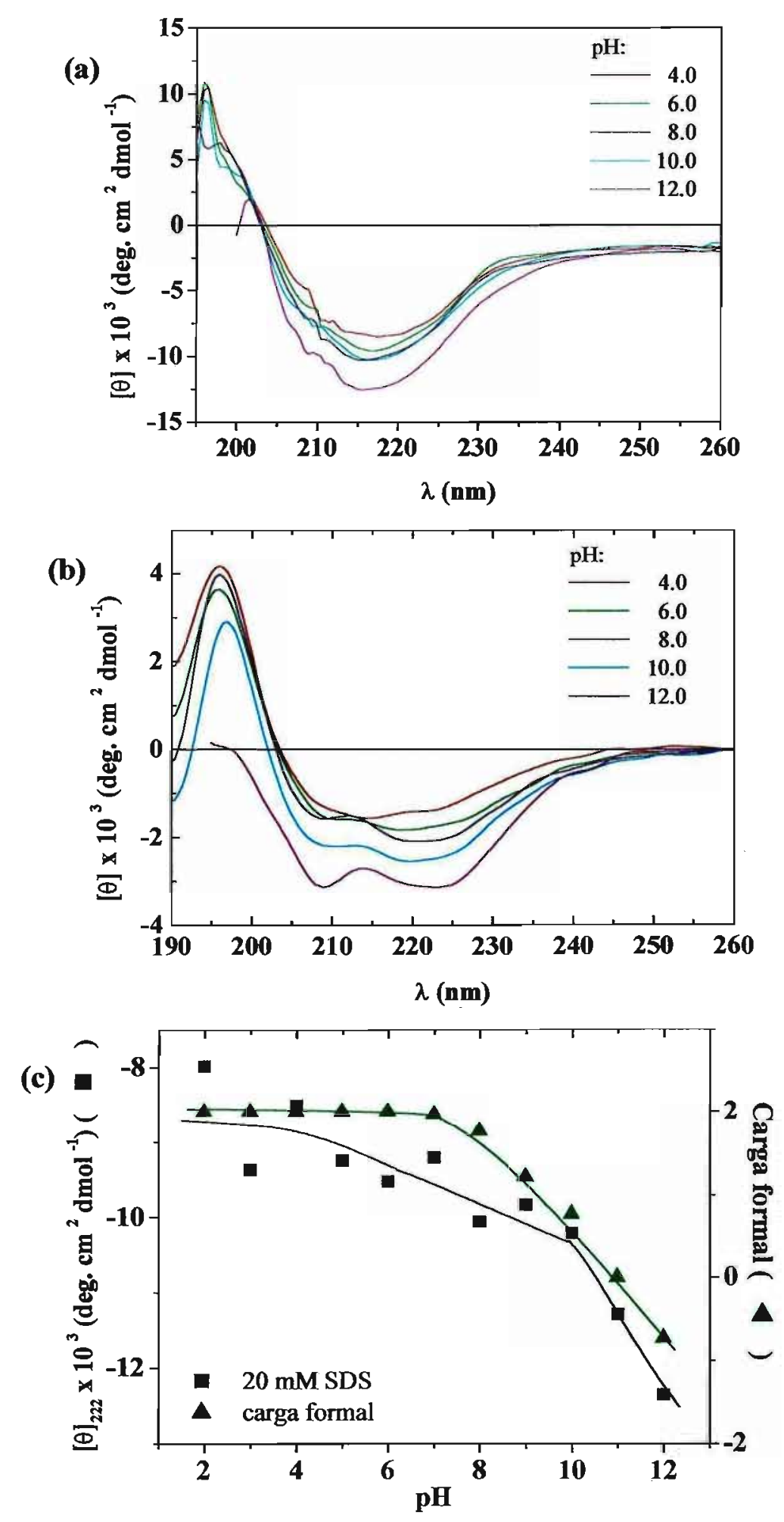


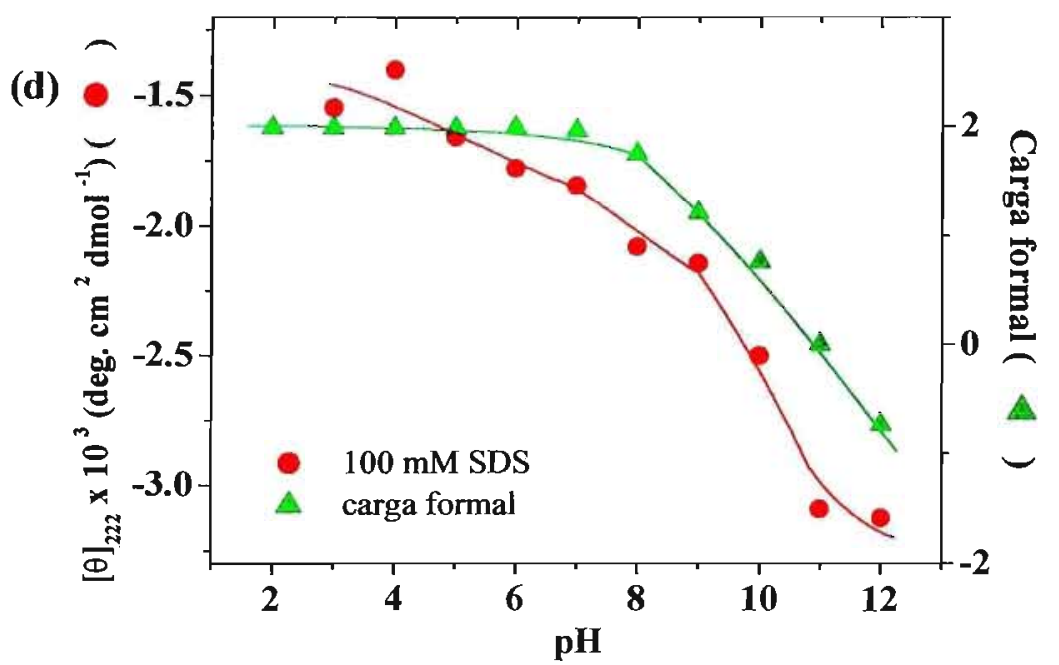

Figura 67 - Espectros de CD de um filme de $80 \mu \mathrm{M}$ de III suspenso na presença de uma solução aquosa de $20 \mathrm{mM}$ (a) e $100 \mathrm{mM}$ SDS (b) em função do pH. Variação da elipticidade molar em 222 nm e variação da carga líquida de II em função do pH (c) e (d). 
negativa torna-se um ombro e o comprimento de onda do segundo mínimo é deslocado para cerca de $216 \mathrm{~nm}$ em pH 12,0.

Em 100 mM SDS (Fig. 67b) os espectros de CD de III mostram que o peptídeo adota conformação $\alpha$-helicoidal, os quais apresentam uma banda positiva em torno de 195 $\mathrm{nm}$ e duas bandas negativas, uma ao redor de $209 \mathrm{~nm}$ e outra em cerca de $222 \mathrm{~nm}$.

As Figuras $67 \mathrm{c} 67 \mathrm{~d}$ mostram a variação de $[\theta]_{222}$ em função do $\mathrm{pH}$. Na presença de 20 mM SDS observa-se uma queda gradual da intensidade até $\mathrm{pH} 10,0$, acima desse $\mathrm{pH}$ a queda é mais acentuada. Em 100 mM SDS se observa um comportamento parecido, porém a diminuição de intensidade é mais intensa a partir de $\mathrm{pH} 9,0$. Em ambos os casos os resultados sugerem que houve diminuição do $\mathrm{pK}_{\mathrm{a}}$ dos grupos ionizáveis de III, provavelmente do grupo amino terminal e do grupo fenol.

O experimento de fluorescência (Fig. 68), mostra que ocorre um pequeno aumento da intensidade de fluorescência na amostra excitada em 275 nm (Fig. 68a e 68c). A intensidade do espectro de III só começa a diminuir acima de $\mathrm{pH} 8,0$, o que reflete a desprotonação da cadeia lateral da tirosina. Quando a amostra foi excitada em $292 \mathrm{~nm}$, observa-se um aumento progressivo da banda de emissão de tirosinato (Fig. 68b e 68c). Não foi observada a banda relativa à emissão de bitirosina em nenhum dos casos.

De modo geral, observou-se que suspensão de um filme dos peptídeos na presença de concentrações relativamente altas dos detergentes teve um efeito maior em promover a aquisição de $\alpha$-hélice do que em concentrações mais baixas.

\subsubsection{Estudos na presença de vesículas fosfolipídicas}

A conformação dos peptídeos derivados do LHR também foi estudada na presença de bicamadas lipídicas, tanto com carga líquida zero (POPC) quanto com carga líquida negativa (POPC:POPG, 9:1, mol:mol). Os experimentos foram feitos na presença de vesículas unilamelares grandes (LUVs), onde foi feita a mesma abordagem utilizada na presença de detergentes.

Num primeiro momento, adicionamos quantidades crescentes de lipídeos a uma solução aquosa dos peptídeos (método a). Em outro estudo, filmes dos peptídeos foram suspensos na presença das vesículas (método b).

Nos experimentos de CD e fluorescência não utilizamos concentrações de vesículas superiores a $0,75 \mathrm{mM}$ para minimizar o efeito do espalhamento de luz. 

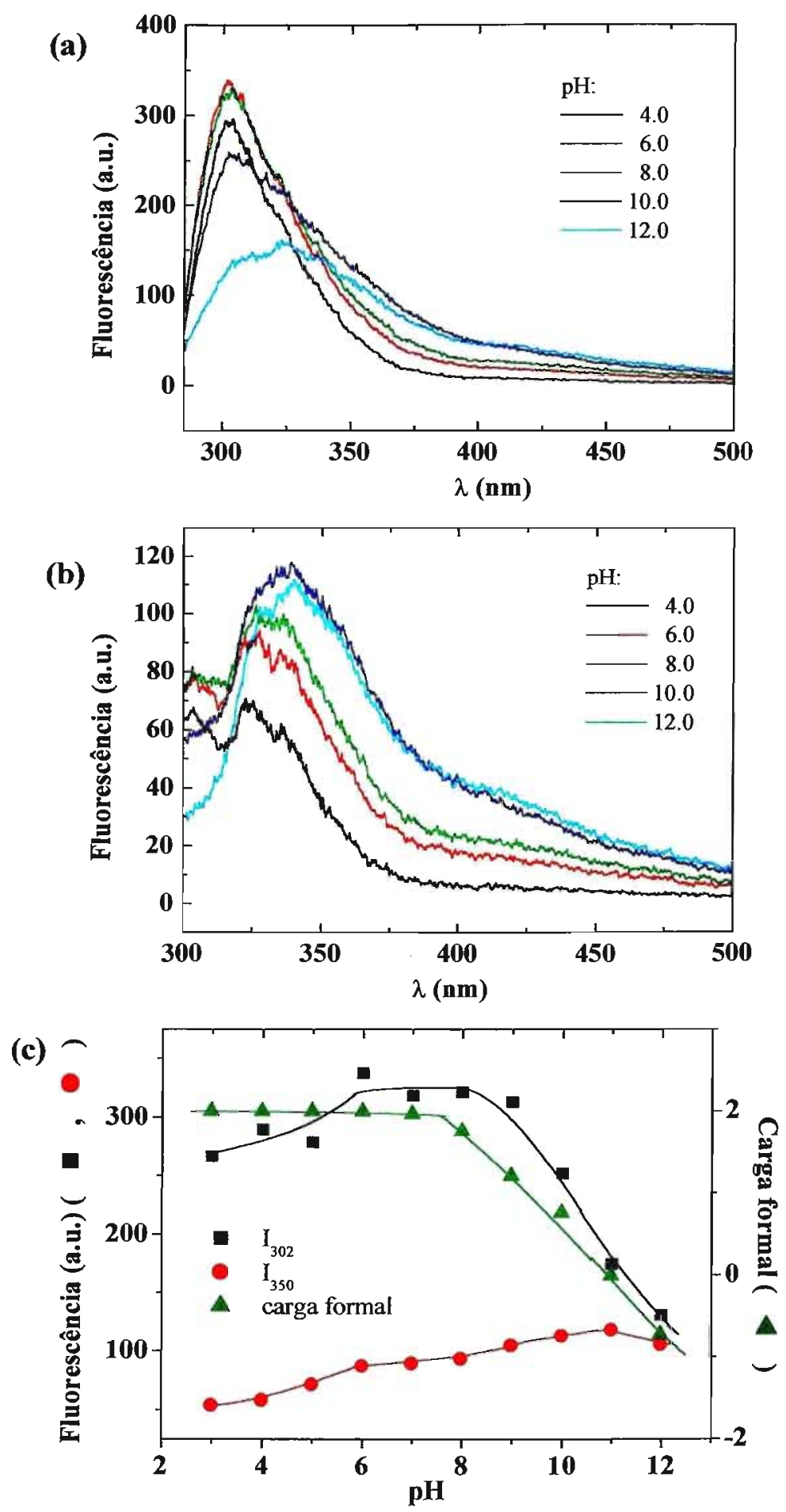

Figura 68 - Espectros de fluorescência de um filme de $30 \mu \mathrm{M}$ de III suspenso na presença de uma solução aquosa de 20 mM (a) e 100 mM SDS (b) em função do pH. Variação da intensidade de fluorescência em 302 e $350 \mathrm{~nm}$ e variação da carga líquida de III em função do $\mathrm{pH}(\mathrm{c})$. 


\subsubsection{Efeito do pH sobre I em presença de vesículas fosfolipídicas}

Na Figura 69, mostram-se os espectros de CD de I na presença de POPC em função do $\mathrm{pH}$ onde as amostras forma preparadas de acordo com o método a. Em $\mathrm{pH}$ 4,0 (Fig. 69a) o espectro de CD de I apresenta uma banda positiva com máximo em 201 $\mathrm{nm}$ e uma banda negativa com banda negativa centrada em $219 \mathrm{~nm}$ (Tabela 18). Com a adição de vesículas de POPC, a posição desses comprimentos de onda mudou pouco. Os espectros de CD de I nessas condições são indicativos de conformação em folha $\beta$.

Tabela 18 - Comprimento de onda máximo $\left(\lambda_{\max }\right)$ e mínimo $\left(\lambda_{\min }\right)$ nos espectros de CD de I na presença de concentrações crescentes de POPC em função do $\mathrm{pH}$.

\begin{tabular}{|c|c|c|c|c|c|c|}
\hline \multicolumn{7}{|c|}{$\lambda(\mathrm{nm})$} \\
\hline$[\mathrm{POPC}](\mathrm{mM})$ & \multicolumn{2}{|c|}{$\mathrm{pH} 4,0$} & \multicolumn{2}{|c|}{$\mathrm{pH} 7,0$} & \multicolumn{2}{|c|}{ pH 10,0} \\
\hline sem adição & $\begin{array}{c}\lambda_{\max } \\
201,0\end{array}$ & $\begin{array}{c}\lambda_{\min } \\
219,0\end{array}$ & $\begin{array}{c}\lambda_{\max } \\
202,0\end{array}$ & $\begin{array}{c}\lambda_{\min } \\
221,5\end{array}$ & $\begin{array}{c}\lambda_{\max } \\
200,5\end{array}$ & $\begin{array}{c}\lambda_{\min } \\
219,5\end{array}$ \\
\hline $0,02^{5}$ & 200,5 & 218,5 & 204,0 & 221,0 & 201,0 & 220,0 \\
\hline 0,05 & 201,0 & 218,5 & 202,0 & 221,5 & 200,5 & 220,5 \\
\hline 0,07 & 201,0 & 220,0 & 202,0 & 222,5 & 119,5 & 221,0 \\
\hline 0,10 & 201,0 & 219,0 & 201,0 & 221,0 & 200,5 & 220,0 \\
\hline 0,20 & 200,0 & 219,5 & 202,5 & 219,0 & 200,5 & 219,5 \\
\hline 0,50 & 200,5 & 220,5 & 201,5 & 219,5 & 202,0 & 219,5 \\
\hline 0,75 & 201,0 & 220,0 & 204,0 & 220,0 & 202,0 & 220,5 \\
\hline
\end{tabular}

Em pH 7,0 (Fig.69b) os espectros de CD de I em solução aquosa são indicativos de folha $\beta$ (Tabela 18). Com a adição de vesículas a posição do máximo da banda positiva de maneira geral continua centrada ao redor de $202 \mathrm{~nm}$ (Tabela 18), enquanto que para a banda negativa observa-se um pequeno deslocamento do mínimo para comprimentos de onda mais baixos, no entanto os resultados mostram que a conformação de I não mudou na presença de POPC.

Em pH 10,0 (Fig. 69c) foram observados resultados similares aos obtidos nos outros pHs. Em relação ao espectro em solução aquosa, a adição de POPC provocou uma diminuição significativa da intensidade da banda positiva. Nesse $\mathrm{pH}$, os espectros de CD de I tanto em solução aquosa quanto em presença de vesículas são indicativos de folha $\beta$.

A Figura 69d mostra a variação da elipticidade molar em $200 \mathrm{~nm}$ em função da concentração de vesículas. Observa-se que acima de $0,2 \mathrm{mM}$ de POPC em todos os pHs a intensidade varia pouco, o que sugere que a partir dessa concentração de vesículas I estaria praticamente todo ligado às vesículas. Nessa concentração de POPC, a proporção molar de lipídeo/peptídeo é de quase 3:1. 
(a)

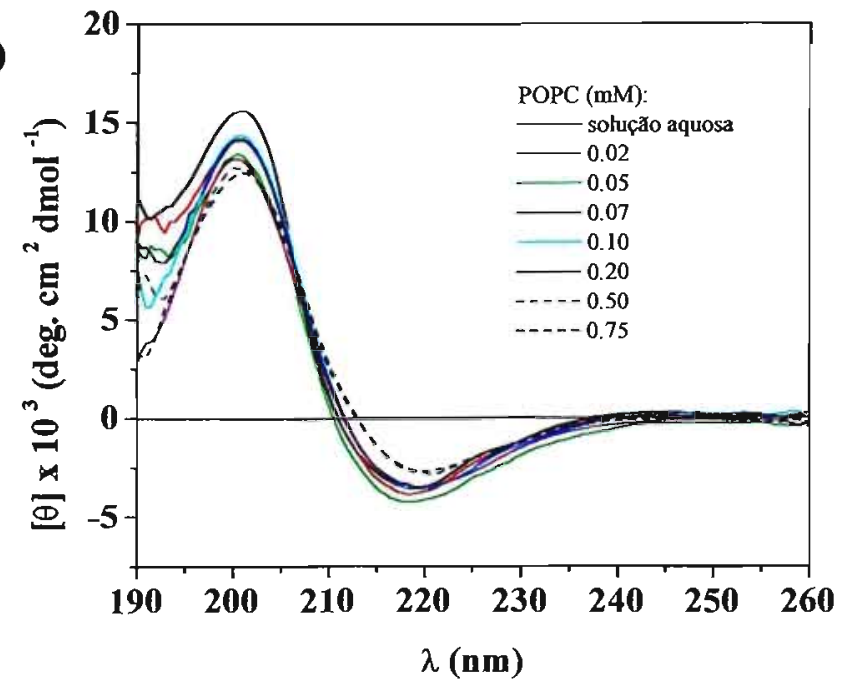

(b)

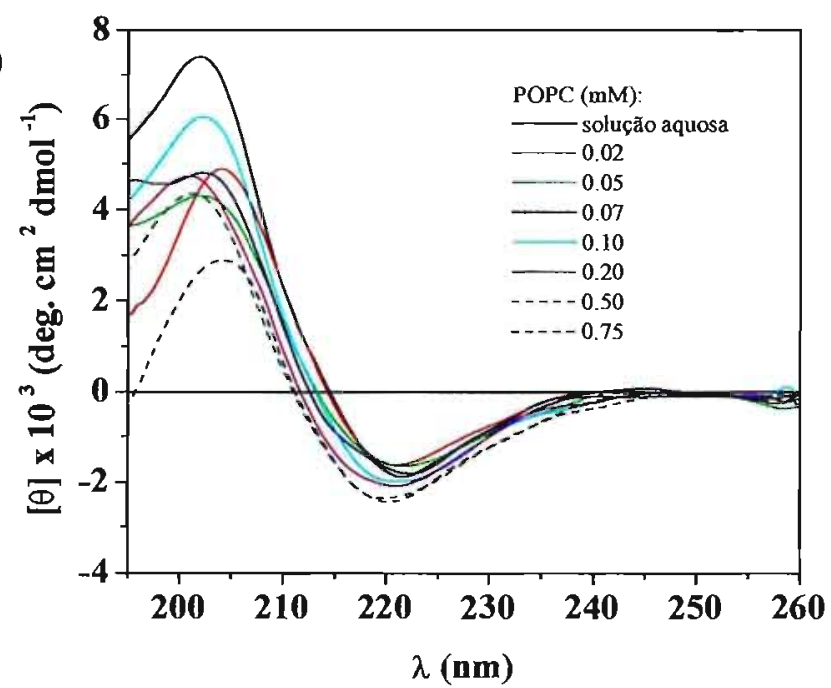

(c)

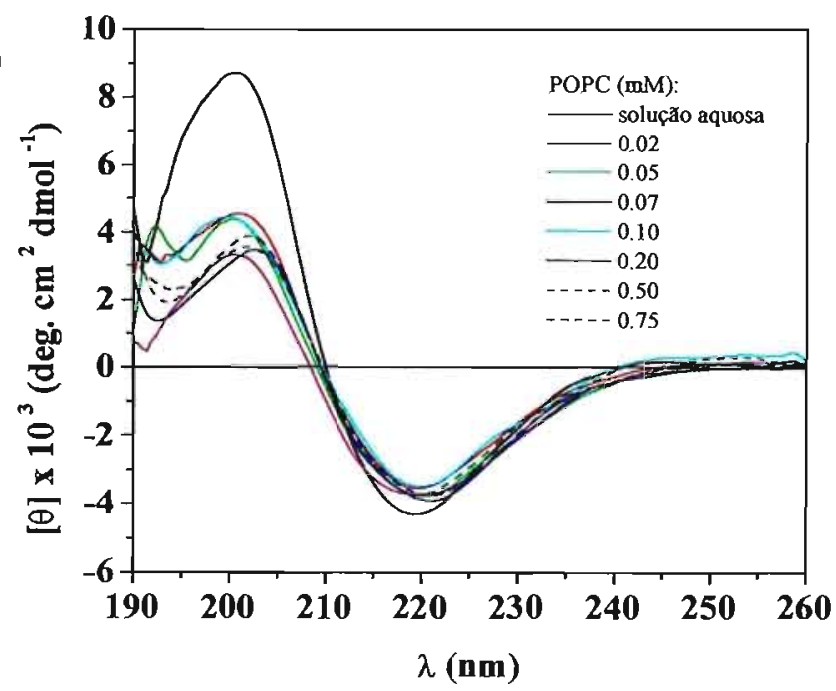




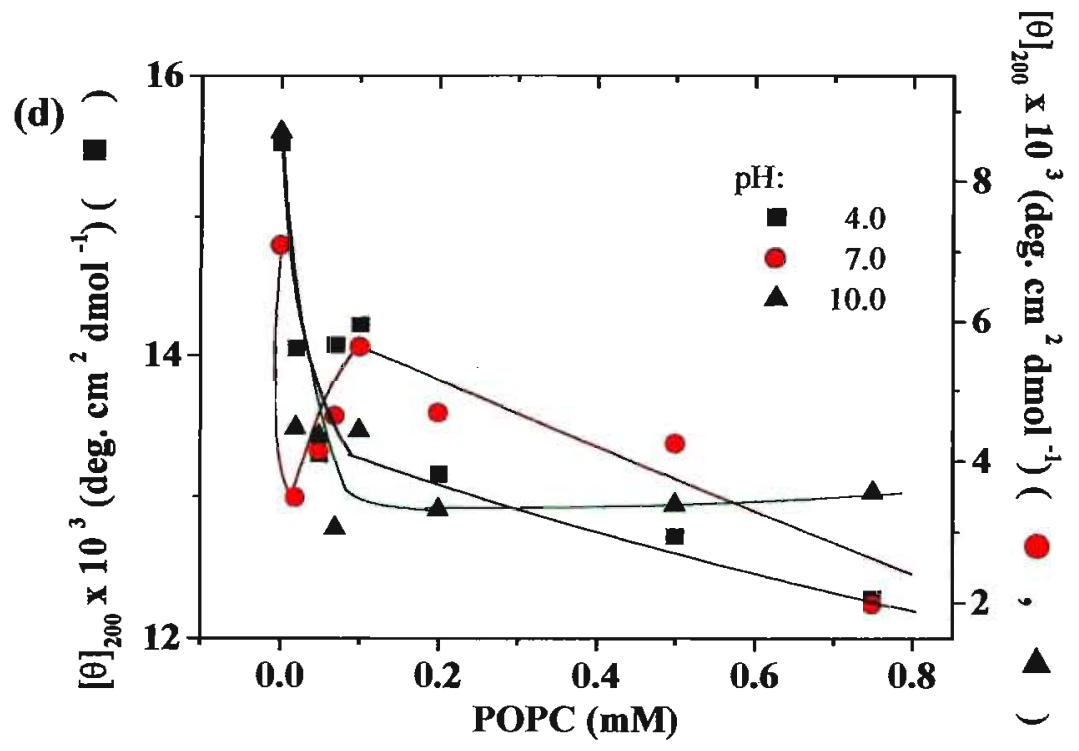

Figura 69 - Espectros de CD de $70 \mu \mathrm{M}$ de I na ausência e na presença de vesículas de POPC nos pHs 4,0 (a), 7,0 (b) e 10,0 (c). Variação da elipticidade molar dos espectros de CD de I em 200 nm em função da concentração de POPC (d). 
Na presença de vesículas de POPC:POPG em pH 4,0 (Fig. 70a) observa-se uma diminuição significativa da intensidade do espectro de $I$, principalmente da banda positiva, centrada ao redor de $201,5 \mathrm{~nm}$ (Tabela 19), que se deve provavelmente à interação de I com as vesículas. Os espectros de CD mostrados na Figura 70a são indicativos de folha $\beta$. Aparentemente I é capaz de interagir com as vesículas de POPC:POPG, porém não foram observadas mudanças conformacionais

Tabela 19 - Comprimento de onda máximo $\left(\lambda_{\operatorname{maxx}}\right)$ e mínimo $\left(\lambda_{\min }\right)$ nos espectros de CD de I na presença de concentrações crescentes de POPC:POPG em função do $\mathrm{pH}$.

\begin{tabular}{ccccccc}
\multicolumn{7}{c}{$\lambda(\mathrm{nm})$} \\
\hline$[\mathrm{POPC}](\mathrm{mM})$ & \multicolumn{2}{c}{$\mathrm{pH} \mathrm{4,0}$} & \multicolumn{2}{c}{$\mathrm{pH} \mathrm{7,0}$} & \multicolumn{2}{c}{$\mathrm{pH} \mathrm{10,0}$} \\
\hline & $\lambda_{\max }$ & $\lambda_{\min }$ & $\lambda_{\max }$ & $\lambda_{\min }$ & $\lambda_{\max }$ & $\lambda_{\min }$ \\
sem adição & 201,5 & 220,0 & 204,5 & 221,5 & 201,5 & 222,5 \\
0,02 & 203,0 & 221,0 & 204,5 & 222,0 & 201,5 & 221,0 \\
0,05 & 203,0 & 221,5 & 201,0 & 221,5 & 202,0 & 222,5 \\
0,07 & 203,0 & 221,0 & 203,0 & 221,5 & 203,5 & 221,5 \\
0,10 & 202,0 & 221,0 & 199,5 & 221,5 & 201,5 & 222,0 \\
0,20 & 201,5 & 221,0 & 200,0 & 221,5 & 202,5 & 221,5 \\
0,50 & 201,0 & 221,5 & 198,5 & 222,0 & 202,0 & 222,5 \\
0,75 & 201,0 & 221,5 & 198,5 & 222,0 & 200,5 & 220,5 \\
\hline
\end{tabular}

Em pH 7,0 (Fig.70b) observa-se que a intensidade da banda positiva no espectro de CD de I tende a aumentar e deslocar-se para comprimentos de onda mais baixos (Tabela 19), enquanto que a banda negativa tende a diminuir e sua posição permanece praticamente inalterada em torno de 221,5 nm. Em pH 10,0 (Fig. 70c), foram observadas poucas mudanças no espectro de I, observa-se apenas o achatamento da banda positiva centrada ao redor de $201 \mathrm{~nm}$

Ao observa-se à variação da elipticidade molar (Fig.70d) em função da concentração de vesículas nos três pHs observa-se que em todos os casos, principalmente nos pHs 7,0 e 10,0, a intensidade varia pouco acima de $0,2 \mathrm{mM}$ de vesículas, assim como observado na presença de POPC. Abaixo dessa concentração de vesículas existe provavelmente a contribuição de duas populações de peptídeo, uma em solução e outra que estaria ligada à bicamada.

A partir desses resultados, utilizamos outra abordagem para estudar a conformação de I. Um filme de I foi suspenso na presença de uma solução aquosa de 0,5 mM de vesículas (Fig. 71), o que representa uma proporção lipídeo/peptídeo em torno de 7:1. Nessa concentração I estaria praticamente todo ligado à membrana. Não utilizamos concentrações maiores de vesículas para evitar espalhamento de luz. 
(a)

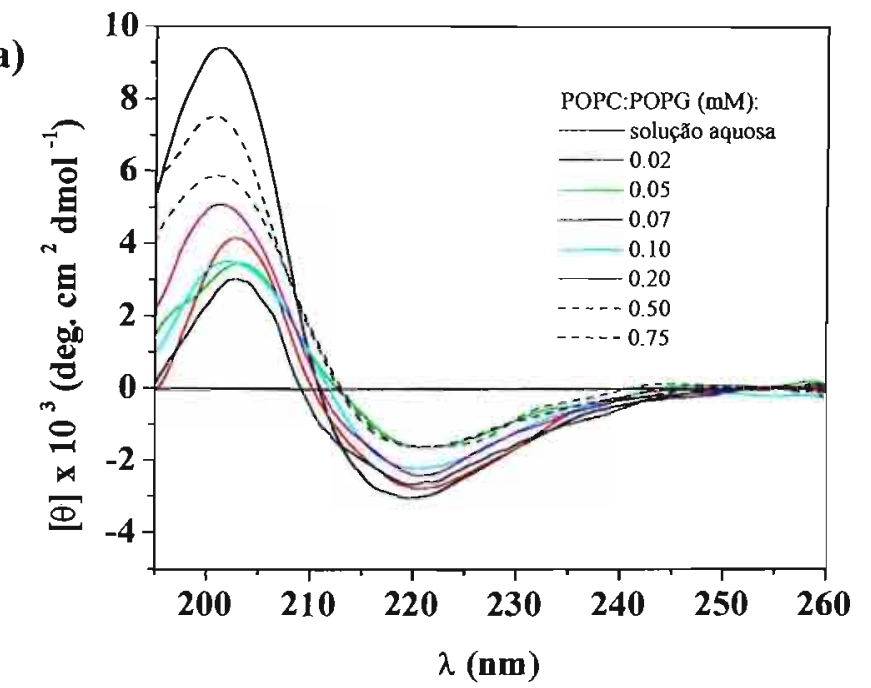

(b)

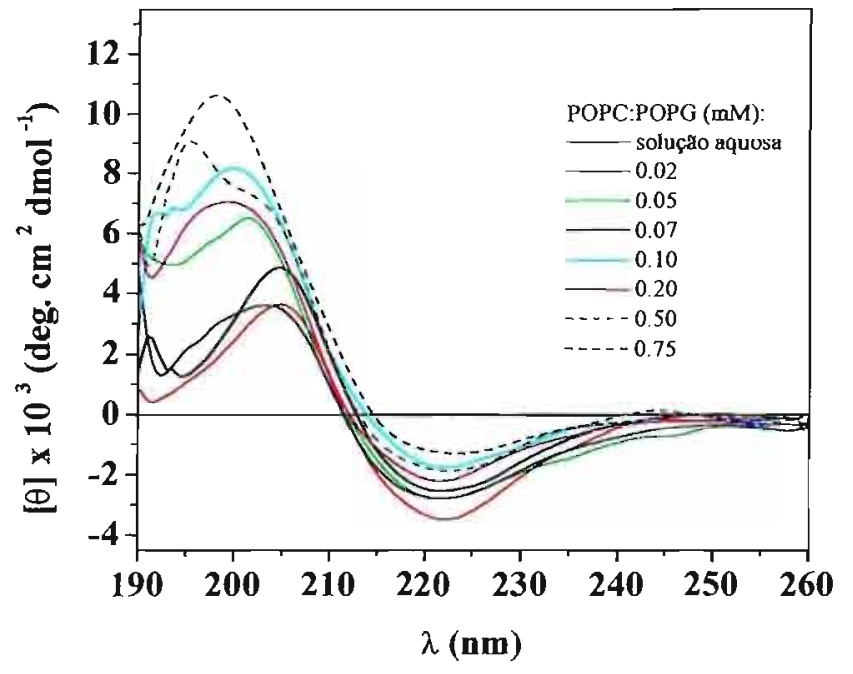

(c)

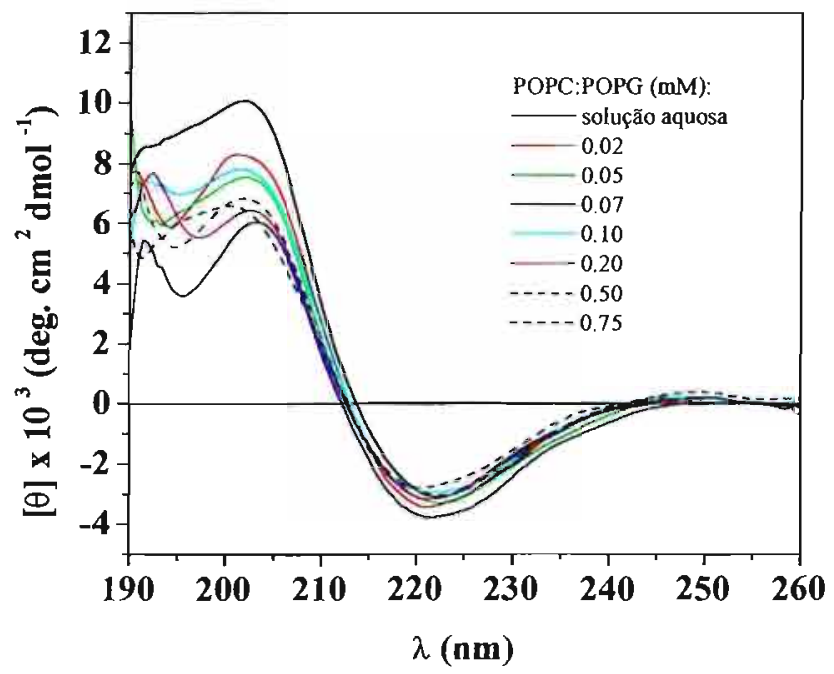




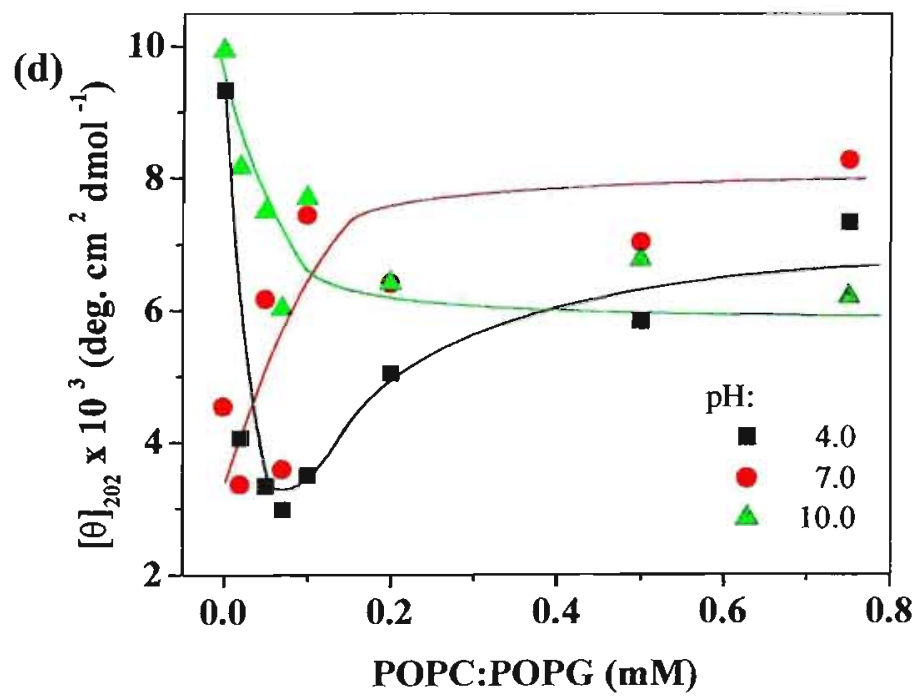

Figura 70 - Espectros de CD de $70 \mu \mathrm{M}$ de I na ausência e na presença de vesículas de POPC:POPG (9:1, mol:mol) nos pHs 4,0 (a), 7,0 (b) e 10,0 (c). Variação da elipticidade molar dos espectros de CD de I em 202 nm em função da concentração de POPC:POPG (d). 


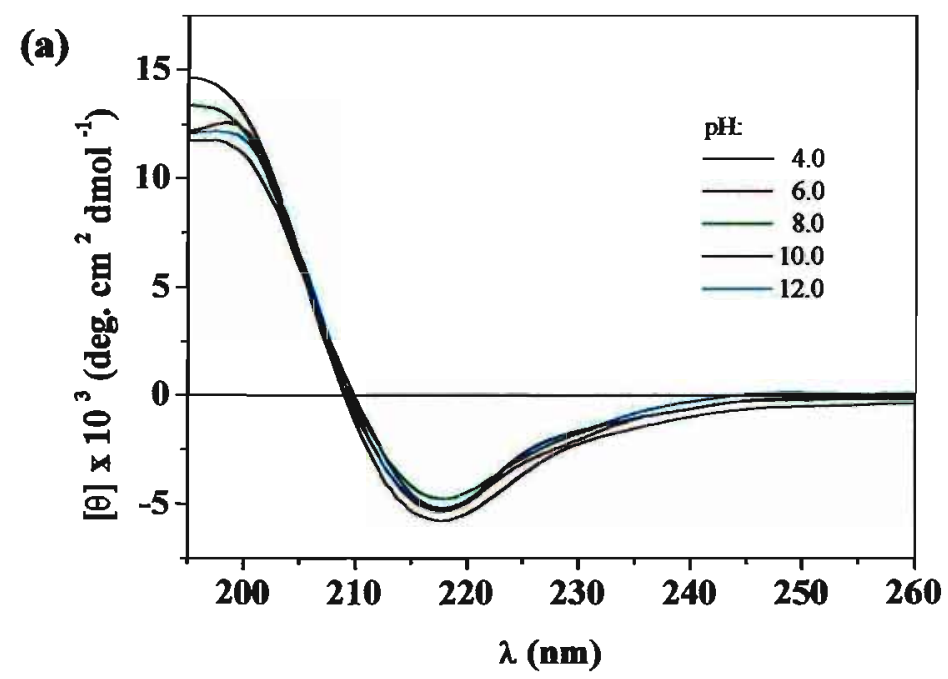

(b)

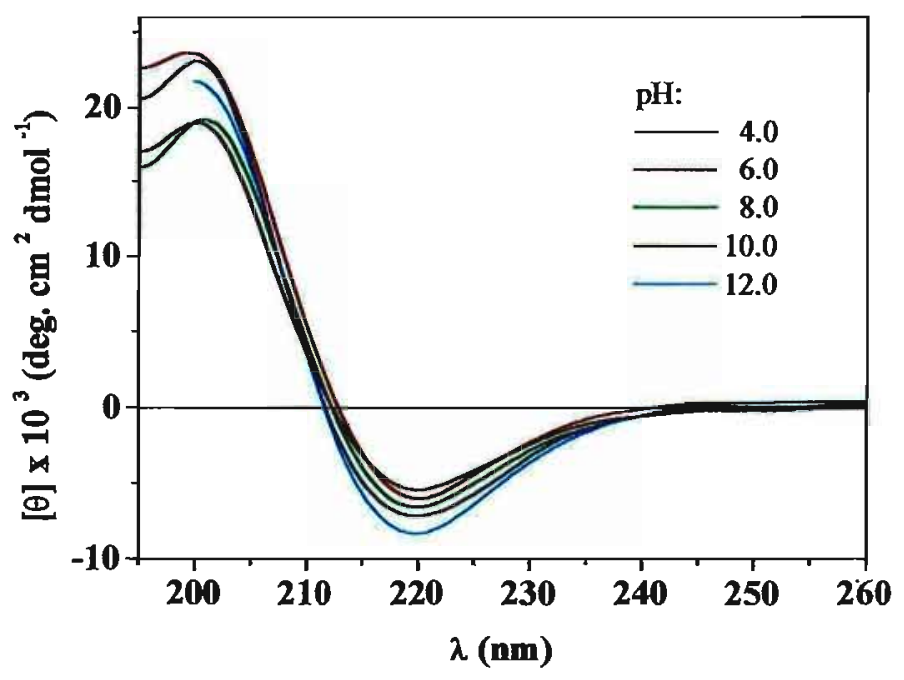

(c)

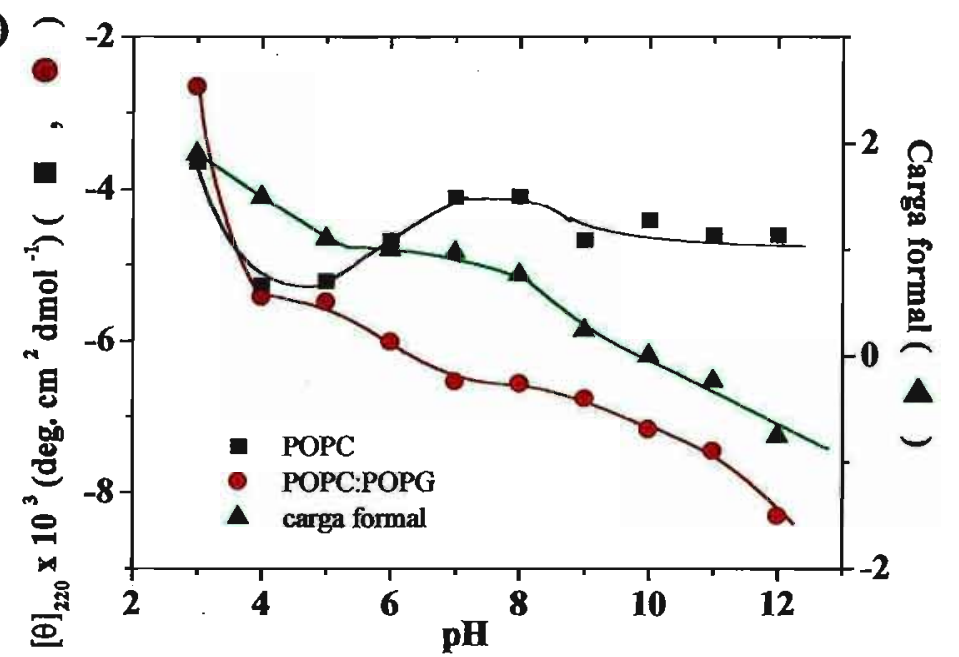

Figura 71 - Espectros de CD de um filme $60 \mu \mathrm{M}$ de I suspenso presença de vesículas de 0,5 mM de POPC (a) e na presença de 0,5 mM de POPC:POPG (9:1, mol:mol) (b) em função do pH. Variação da carga teórica de II e da elipticidade molar nos espectros de CD de I em $220 \mathrm{~nm}$ na presença de vesículas de POPC e de POPC:POPG (c). 
Na presença de 0,5mM POPC em pH 4,0 (Fig. 71a), o espectro de CD de I apresenta uma banda positiva com máximo ao redor de $195 \mathrm{~nm}$ e uma banda negativa com mínimo ao redor de $217 \mathrm{~nm}$, o que indica conformação em folha $\beta$. Com o aumento do $\mathrm{pH}$, não foram observadas mudanças na posição desses comprimentos de onda.

Na presença de vesículas com carga líquida negativa (Fig. 71b), os espectros de CD de I são parecidos com os obtidos em POPC, porém suas bandas encontram-se deslocadas para comprimentos de onda mais altos, o $\lambda_{\text {máx }}$ situa-se ao redor de $200 \mathrm{~nm}$ e o $\lambda_{\min }$ em torno de $220 \mathrm{~nm}$. Na presença de POPC:POPG I também adota uma folha $\beta$.

A Figura 71c mostra a variação da elipticidade molar em $220 \mathrm{~nm}$ na presença de $0,5 \mathrm{mM}$ de vesículas em função do $\mathrm{pH}$. Tanto no caso de POPC quanto de POPC:POPG é possível observar a desprotonação da cadeia lateral de Asp. No entanto, na presença de POPC não é possível ver claramente a titulação da cadeia lateral de Lys.

\subsubsection{Efeito do pH sobre II em presença de vesículas fosfolipídicas}

$\mathrm{O}$ espectro de $\mathrm{CD}$ de $\Pi$ em solução aquosa em $\mathrm{pH} 4,0$ é indicativo de conformação $\alpha$-helicoidal. Este espectro apresenta um mínimo ao redor de $207 \mathrm{~nm}$ e outro em torno de $220 \mathrm{~nm}$, além de uma banda positiva em torno de $192 \mathrm{~nm}$ (Tabela 20). Com a adição de POPC (Fig. 72a), observa-se um deslocamento desses mínimos para comprimentos de ondas mais baixos, os quais permanecem praticamente inalterados com a adição de quantidades maiores de POPC. Além disso, a banda positiva praticamente desaparece do espectro de CD de II. Esse resultado sugere que aumenta a contribuição de uma população com conformação ao acaso com a adição de POPC. Essa população encontra-se em equilíbrio com outra em $\alpha$-hélice.

Tabela 20 - Comprimento de onda máximo $\left(\lambda_{\max }\right)$ e mínimo $\left(\lambda_{\min }\right)$ nos espectros de CD de II na presença de concentrações crescentes de POPC em função do $\mathrm{pH}$.

\begin{tabular}{ccccccc}
\hline \multicolumn{7}{c}{$\lambda(\mathrm{nm})$} \\
\hline [POPC] $(\mathrm{mM})$ & \multicolumn{2}{c}{$\mathrm{pH} \mathrm{4,0}$} & \multicolumn{2}{c}{$\mathrm{pH} \mathrm{7,0}$} & \multicolumn{2}{c}{$\mathrm{pH} \mathrm{10,0}$} \\
\hline & $\lambda_{\max }$ & $\lambda_{\min }$ & $\lambda_{\max }$ & $\lambda_{\min }$ & $\lambda_{\max }$ & $\lambda_{\min }$ \\
sem adição & 192,0 & 207,$5 ; 220,0$ & 194,0 & 209,$5 ; 222,0$ & 193,0 & 209,$0 ; 218,5$ \\
0,02 & -- & 204,$5 ; 218,0$ & 194,0 & 210,$0 ; 222,0$ & 193,0 & 209,$0 ; 218,5$ \\
0,05 & -- & 204,$5 ; 218,0$ & 191,0 & 210,$0 ; 222,5$ & 191,0 & 208,$0 ; 218,5$ \\
0,07 & -- & 204,$5 ; 218,0$ & 192,0 & 210,$0 ; 222,5$ & 193,0 & 209,$0 ; 219,0$ \\
0,10 & -- & 204,$5 ; 218,0$ & 192,0 & 209,$5 ; 222,5$ & 191,0 & 209,$0 ; 218,5$ \\
0,20 & -- & 204,$5 ; 218,0$ & 192,0 & 209,$5 ; 222,5$ & 191,0 & 208,$0 ; 218,5$ \\
0,50 & -- & 204,$5 ; 218,0$ & 192,0 & 209,$5 ; 222,5$ & 191,0 & 208,$0 ; 218,5$ \\
0,75 & -- & 204,$5 ; 218,0$ & 192,0 & 209,$5 ; 222,5$ & 191,0 & 204,$5 ; 218,0$ \\
\hline
\end{tabular}



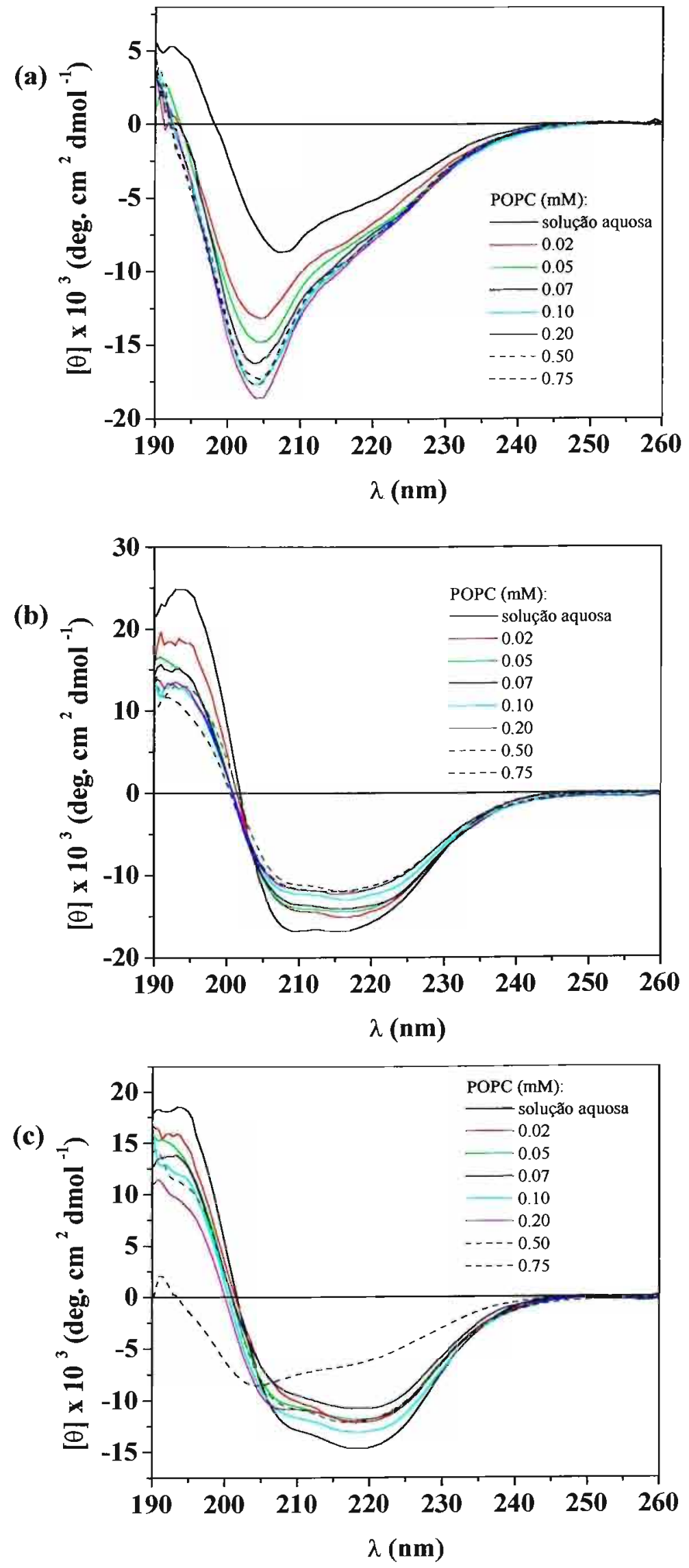


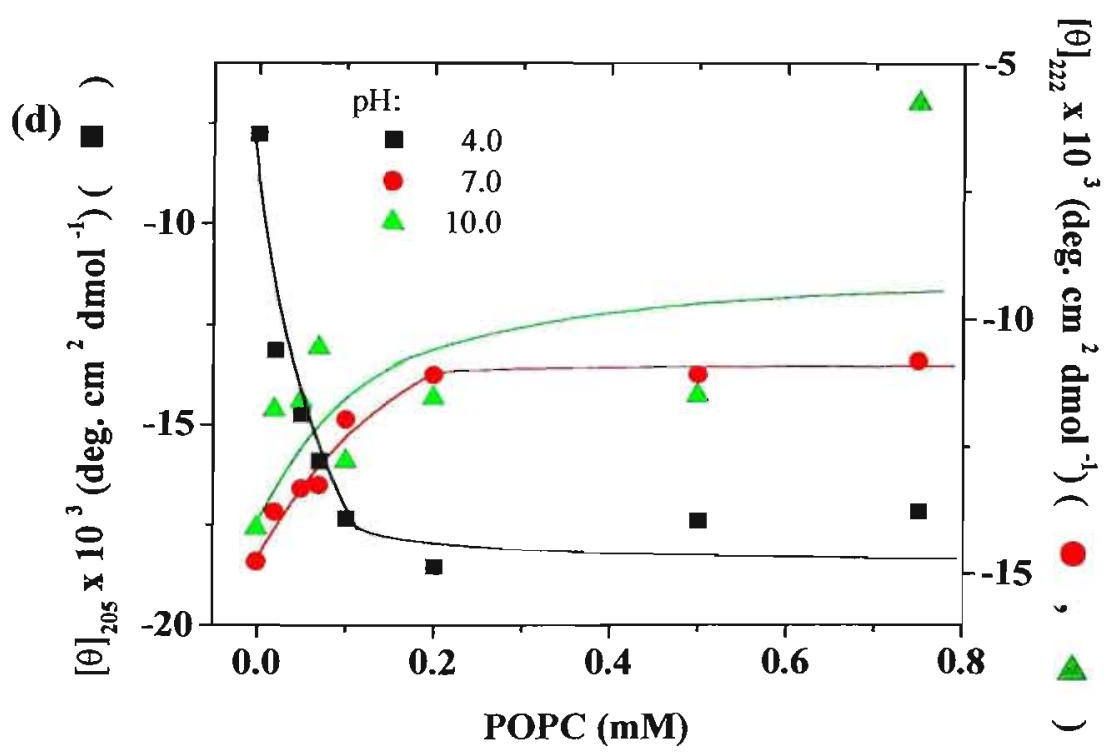

Figura 72 - Espectros de $\mathrm{CD}$ de $70 \mu \mathrm{M}$ de II na ausência e na presença de vesículas de POPC nos pHs 4,0 (a), 7,0 (b) e 10,0 (c). Variação da elipticidade molar dos espectros de CD de II em 205 e 222 nm em função da concentração de POPC (d). 
Em pH 7,0, o espectro de CD de II em solução aquosa apresenta uma banda positiva em torno de $194 \mathrm{~nm}$ e duas bandas negativas em torno de 209 e $222 \mathrm{~nm}$, o que mostra que II adquire conformação $\alpha$-helicoidal. Com a adição de POPC (Fig. 72b) as características dos espectros permanecem praticamente iguais, ocorrendo uma diminuição da intensidade do espectro que poderia ser causada pela interação com as vesículas de POPC.

Em pH 10,0 (Fig. 72c), também adquire conformação $\alpha$-helicoidal em solução, porém em relação a pH 7,0, a banda negativa centrada em 209 nm é menos intensa do a segunda banda negativa ao redor de $219 \mathrm{~nm}$. Com adição de POPC, também foi observada a diminuição da intensidade do espectro, sendo que as posições de seus máximos e mínimos permanece praticamente inalterada até $0,5 \mathrm{mM}$ POPC. Acima dessa concentração observa-se uma mudança significativa na forma do espectro, sendo que suas bandas deslocam-se para comprimentos de onda mais baixos. Essa mudança poderia estar relacionada com proporção mais alta de lipídeo/peptídeo.

De maneira geral, observa-se que acima de 0,2 $\mathrm{mM}$ de POPC II encontra-se praticamente todo ligado à membrana, o que ser visto pela pequena variação de elipticidade molar em $222 \mathrm{~nm}$ em função de POPC (Fig. 72d).

Na presença de POPC:POPG em pH 4,0 (Fig. 73a) inicialmente observa-se um aumento de intensidade da banda positiva centrada em $204 \mathrm{~nm}$ (Tabela 21), o que assim como observado na presença de POPC poderia indicar a contribuição de uma população ao acaso. Porém, com o aumento da concentração de vesículas observa-se um progressivo deslocamento desse mínimo para comprimento de ondas maiores, em torno de $206 \mathrm{~nm}$, e da banda positiva de $191 \mathrm{~nm}$ para $194 \mathrm{~nm}$. Observa-se também uma diminuição da proporção entre a primeira banda negativa e a segunda centrada em torno de $221 \mathrm{~nm}$. Acima de 0,5 mM POPC:POPG, esta se torna menos intensa do que a segunda. Esse resultado mostra a diminuição da população ao acaso com a adição de vesículas.

Em pH 7,0, assim como observado para POPC, II adota conformação $\alpha$ helicoidal na presença de vesículas de POPC:POPG (Fig. 73b). No entanto, observa-se uma progressiva diminuição da intensidade do espectro, o que indica diminuição do conteúdo de estrutura secundária. Em pH 10,0 a Figura 73c mostra uma mudança significativa no espectro de CD de II com o aumento da concentração de vesículas. Observa-se que a segunda banda negativa do espectro torna-se menos intensa do que a 

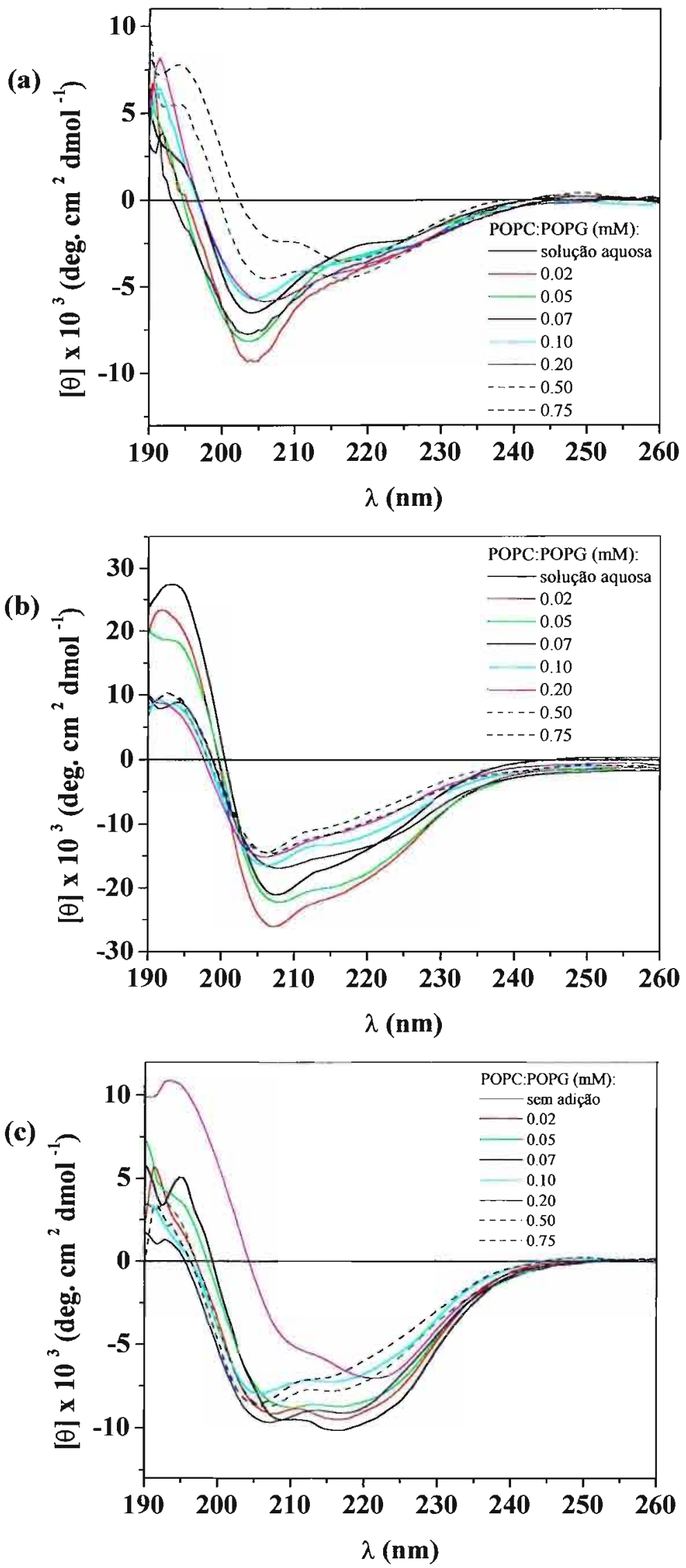


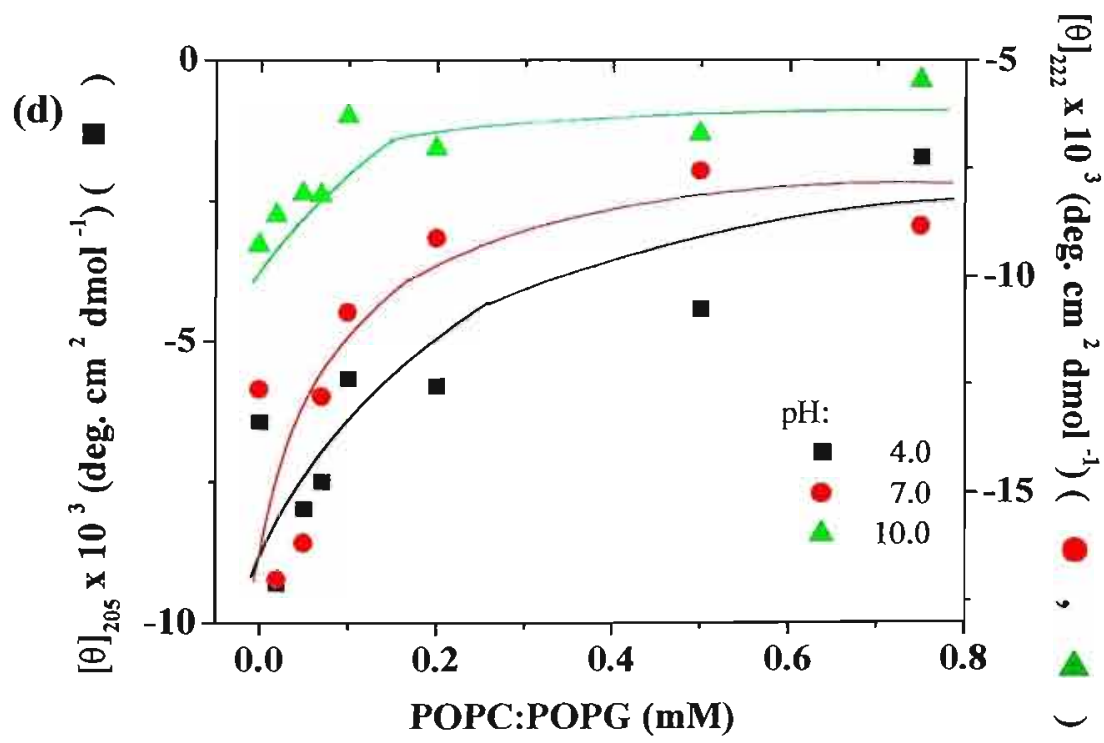

Figura 73 - Espectros de CD de $70 \mu \mathrm{M}$ de II na ausência e na presença de vesículas de POPC:POPG nos pHs 4,0 (a), 7,0 (b) e 10,0 (c). Variação da elipticidade molar dos espectros de CD de II em 205 e 222 nm em função da concentração de POPC:POPG (d). 
primeira centrada ao redor de $208 \mathrm{~nm}$. Esses espectros também mostram que II adquire uma $\alpha$-hélice na presença dessas vesículas. Em todos os pHs observou-se novamente que II encontra-se praticamente todo ligado acima de 0,2 $\mathrm{mM}$ de vesículas (Fig. 73d).

Tabela 21 - Comprimento de onda máximo $\left(\lambda_{\operatorname{máx}}\right)$ e mínimo $\left(\lambda_{\min }\right)$ nos espectros de CD de II na presença de concentrações crescentes de POPC:POPG em função do $\mathrm{pH}$.

\begin{tabular}{ccccccc}
\hline \multicolumn{7}{c}{$\lambda(\mathrm{nm})$} \\
\hline$[\overline{\mathrm{POPC}}](\mathrm{mM})$ & \multicolumn{2}{c}{$\mathrm{pH} 4,0$} & \multicolumn{2}{c}{$\mathrm{pH} 7,0$} & $\mathrm{pH} \mathrm{10,0}$ \\
\hline & $\lambda_{\max }$ & $\lambda_{\min }$ & $\lambda_{\max }$ & $\lambda_{\min }$ & $\lambda_{\max }$ & $\lambda_{\min }$ \\
sem adição & 191,0 & 204,$0 ; 223,0$ & 193,0 & 207,$5 ; 221,0$ & 192,0 & 209,$0 ; 216,5$ \\
0,02 & 191,0 & 204,$0 ; 221,0$ & 193,0 & 207,$5 ; 221,0$ & 192,0 & 208,$0 ; 216,5$ \\
0,05 & 191,0 & 204,$0 ; 221,0$ & 193,0 & 207,$5 ; 221,0$ & 192,0 & 210,$5 ; 217,0$ \\
0,07 & 191,0 & 204,$0 ; 221,0$ & 193,0 & 207,$5 ; 221,0$ & 192,0 & 207,$0 ; 217,5$ \\
0,10 & 191,0 & 204,$5 ; 221,0$ & 193,0 & 206,$0 ; 221,0$ & 192,0 & 205,$5 ; 216,0$ \\
0,20 & 191,0 & 206,$0 ; 221,0$ & 193,0 & 206,$0 ; 221,0$ & 193,0 & 211,$5 ; 221,5$ \\
0,50 & 194,0 & 206,$0 ; 218,0$ & 193,0 & 206,$0 ; 220,0$ & 192,0 & 207,$0 ; 216,0$ \\
0,75 & 194,0 & 207,$5 ; 218,0$ & 193,0 & 206,$0 ; 220,0$ & 192,0 & 205,$0 ; 214,5$ \\
\hline
\end{tabular}

A Figura 74 mostra os espectros de CD de um filme de II suspensos na presença de vesículas. No caso de POPC (Fig. 74a), observa-se que em pH 4,0 a presença de duas bandas ao redor de 200 e de $216 \mathrm{~nm}$. Esse espectro indica a contribuição de populações diferentes, uma estendida e outra estruturada. Com o aumento do $\mathrm{pH}$ observa-se o aparecimento de uma banda positiva ao redor de $200 \mathrm{~nm}$ e de uma segunda banda negativa acima de $225 \mathrm{~nm}$. Uma das possibilidades é de que esse peptídeo adote uma dobra $\beta$ na presença de POPC. Outra possibilidade é de que esse espectro seja o de uma $\alpha$-hélice, porém deslocado para o vermelho por causa do espalhamento de luz.

Na presença de POPC:POPG (Fig. 74b) os espectros de II são indicativos de uma estrutura em folha $\beta$. A forma do espectro não muda com o aumento do $\mathrm{pH}$, observa-se apenas o aumento de sua intensidade. A variação de elipticidade molar em $222 \mathrm{~nm}$ em função do $\mathrm{pH}$ (Fig. 74c) sugere que houve um abaixamento do $\mathrm{pK}_{\mathrm{a}}$ dos grupos ionizáveis de II na presença dos dois tipos de vesículas.

\subsubsection{Efeito do pH sobre III em presença de vesículas fosfolipídicas}

Em pH 4,0 o espectro de CD de III (Fig. 75a) em solução aquosa apresenta um máximo em $196 \mathrm{~nm}$ e um mínimo ao redor de 217 nm (Tabela 22). Com a adição de POPC observa-se a diminuição da intensidade da banda positiva, porém sem provocar deslocamento significativo da posição das bandas positiva e negativa. Os espectros de CD de III mostram que o peptídeo adota conformação em folha $\beta$ na presença de POPC. 
(a)

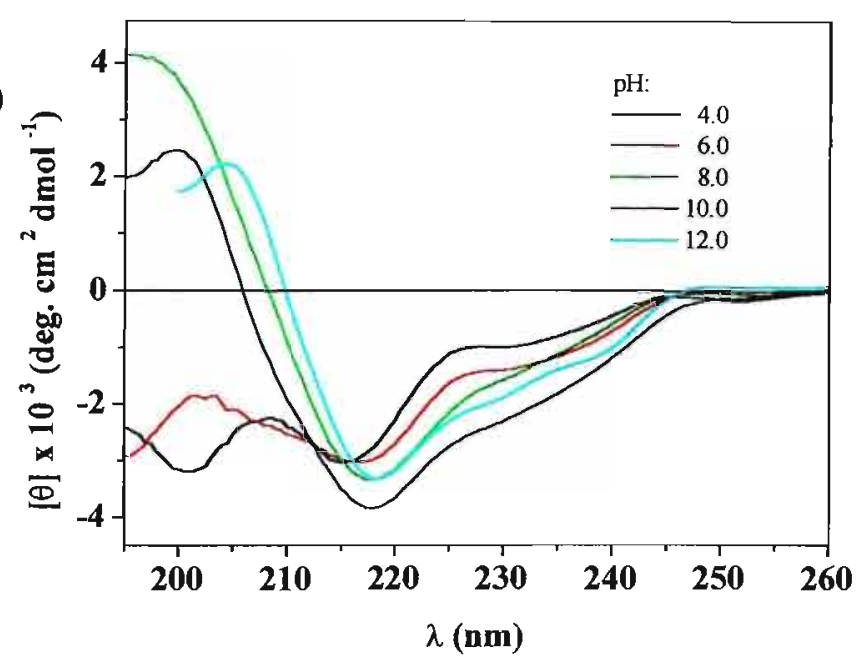

(b)

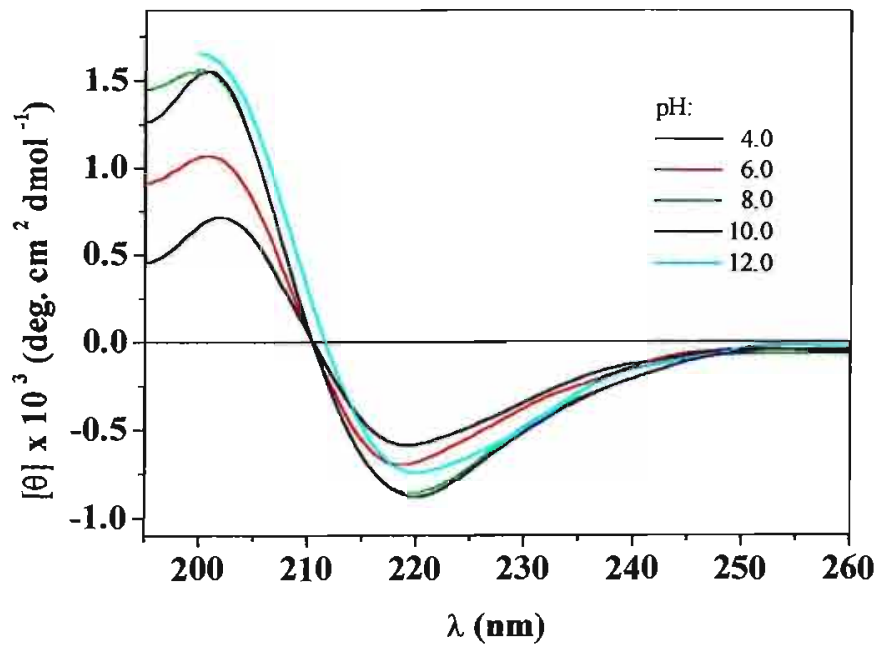

(c)

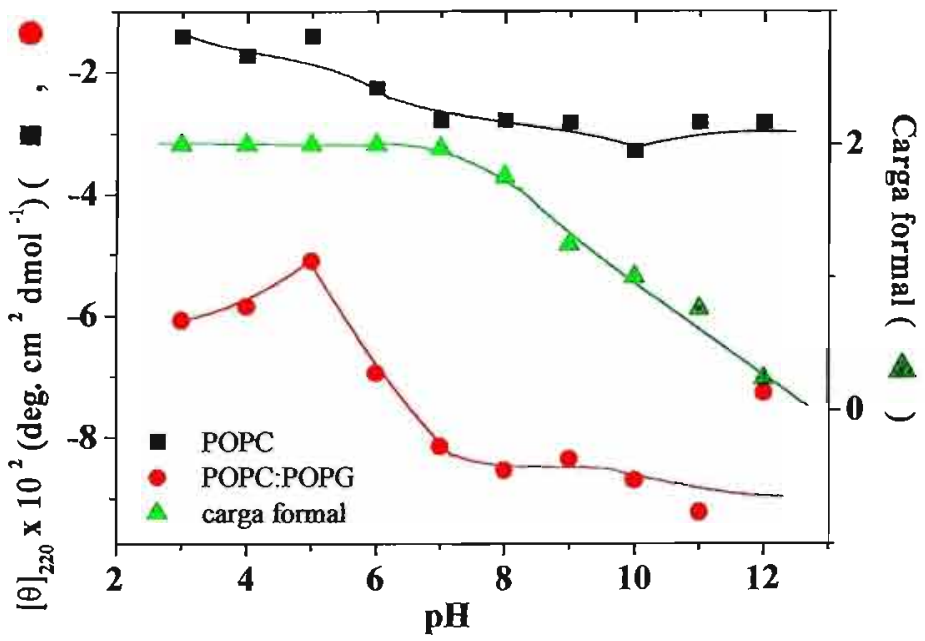

Figura 74 - Espectros de CD de $70 \mu \mathrm{M}$ II suspenso presença de 0,5 mM POPC (a) e na presença de 0,5 mM POPC:POPG $(9: 1, \mathrm{~mol}: \mathrm{mol})$ (b) em função do pH. Variação carga teórica de II e da elipticidade molar nos espectros de CD de II em 220 nm na presença de vesículas de POPC e de POPC:POPG (c). 

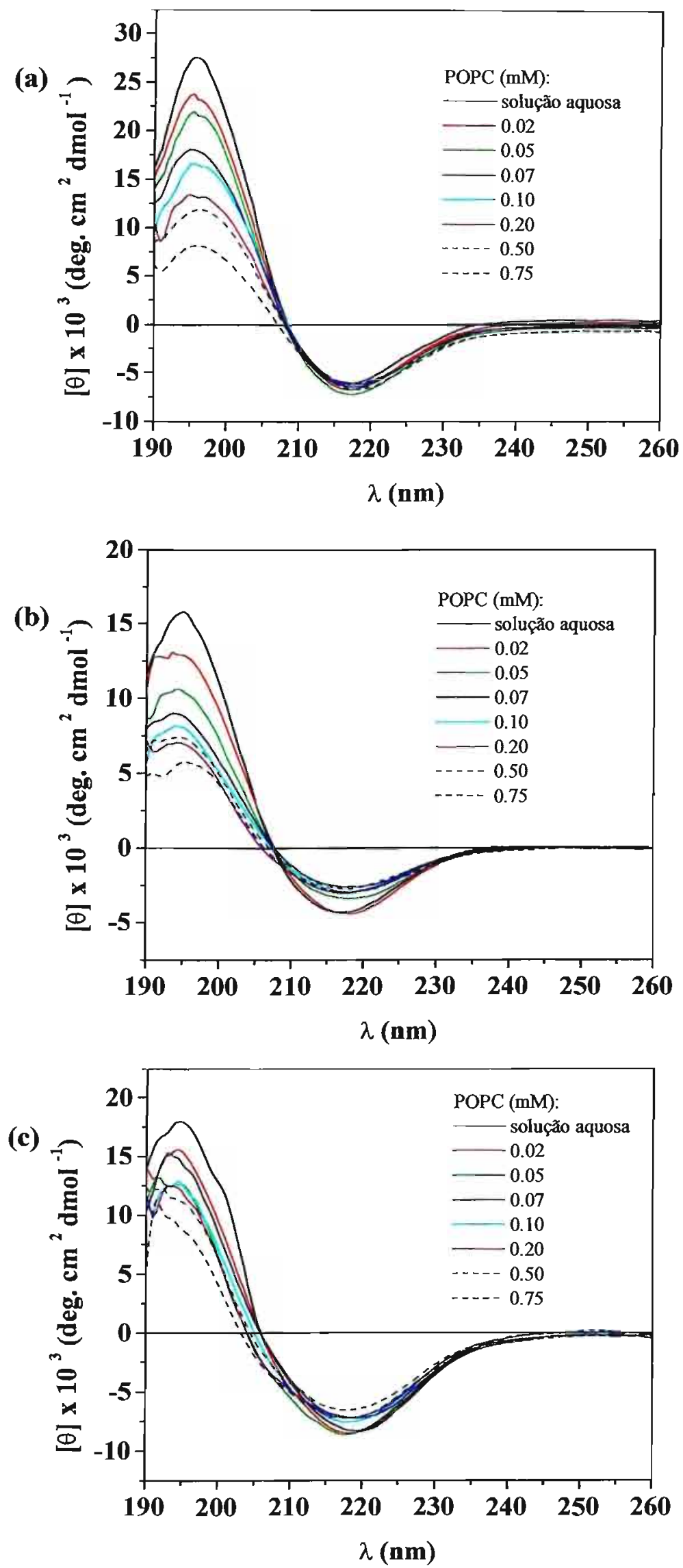


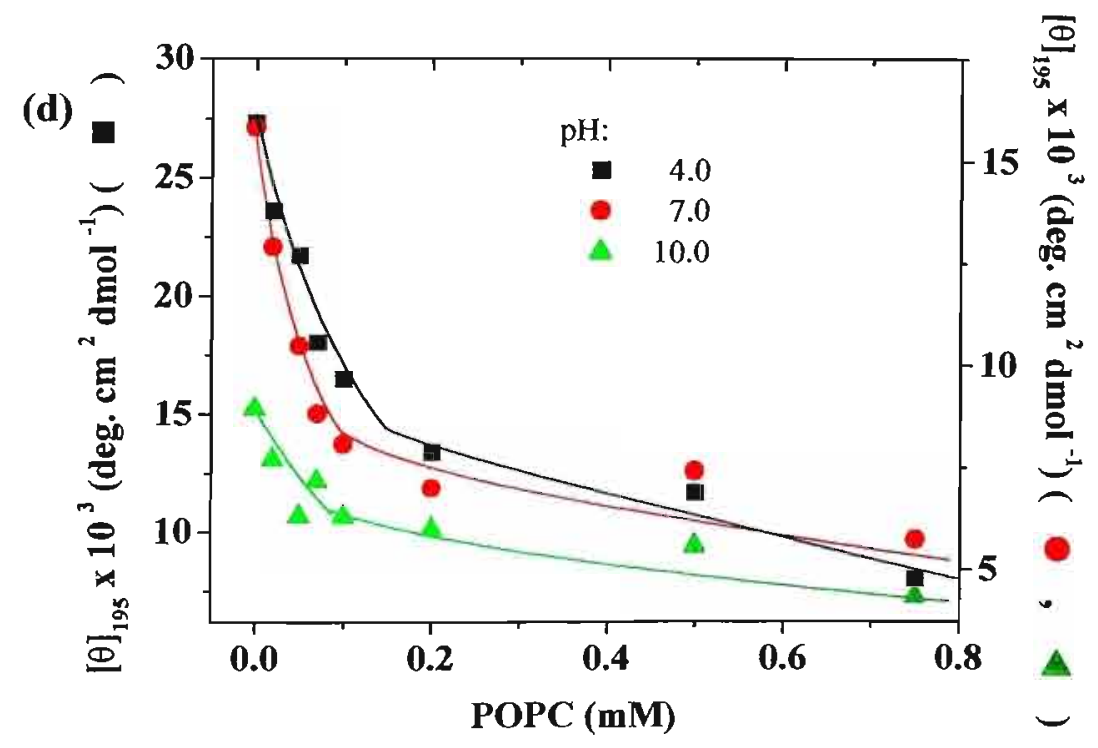

Figura 75 - Espectros de CD de $70 \mu \mathrm{M}$ de III na ausência e na presença de vesículas de POPC nos pHs 4,0 (a), 7,0 (b) e 10,0 (c). Variação da elipticidade molar dos espectros de CD de III em 195 nm em função da concentração de POPC (d). 
Em pH 7,0 e em pH 10,0 (Fig.75b e 75c) os espectros de CD em solução aquosa são similares ao observado em pH 4,0 (Fig.75a), sendo que ambos são indicativos de conformação em folha $\beta$. A adição de POPC não provocou mudanças significativas nas posições da banda positiva e negativa do espectro de CD (Tabela 22), o que indica que III também adota conformação em folha $\beta$ na presença de POPC. Observa-se em ambos os casos a diminuição da elipticidade molar em 195 nm (Fig. 75d), sendo que a diminuição é mais acentuada em pH 7,0 do que em pH 10,0. Observa-se que em todos os pHs a variação de elipticidade molar varia pouco acima de $0,2 \mathrm{mM}$ de vesículas, sendo que essa característica também foi observada para os peptídeos I e II.

Tabela 22 - Comprimento de onda máximo $\left(\lambda_{\operatorname{máx}}\right)$ e mínimo $\left(\lambda_{\min }\right)$ nos espectros de CD de III na presença de concentrações crescentes de POPC em função do $\mathrm{pH}$.

\begin{tabular}{ccccccc}
\hline \multicolumn{7}{c}{$\lambda(\mathrm{nm})$} \\
\hline [POPC] $(\mathrm{mM})$ & \multicolumn{2}{c}{$\mathrm{pH} \mathrm{4,0}$} & \multicolumn{2}{c}{$\mathrm{pH} \mathrm{7,0}$} & \multicolumn{2}{c}{$\mathrm{pH} \mathrm{10,0}$} \\
\hline & $\lambda_{\max }$ & $\lambda_{\min }$ & $\lambda_{\max }$ & $\lambda_{\min }$ & $\lambda_{\max }$ & $\lambda_{\min }$ \\
sem adição & 196,0 & 217,5 & 195,0 & 217,0 & 194,5 & 219,0 \\
0,02 & 196,0 & 217,5 & 194,0 & 217,5 & 194,5 & 218,0 \\
0,05 & 196,0 & 217,5 & 194,0 & 218,0 & 193,0 & 218,0 \\
0,07 & 196,0 & 217,5 & 194,0 & 217,5 & 193,0 & 219,0 \\
0,10 & 196,0 & 217,5 & 194,0 & 217,5 & 193,0 & 218,0 \\
0,20 & 196,0 & 217,5 & 194,0 & 217,5 & 193,0 & 218,0 \\
0,50 & 196,0 & 218,0 & 194,0 & 217,5 & 193,0 & 218,0 \\
0,75 & 196,0 & 218,0 & 195,0 & 217,5 & 193,0 & 218,0 \\
\hline
\end{tabular}

O experimento de fluorescência (Fig. 76) mostrou que III que em pH 4,0 (Fig. 76a) III possui um comportamento diferente em relação aos demais pHs. Nesse pH houve um pequeno aumento da intensidade de fluorescência até $0,05 \mathrm{mM}$ de vesículas. Acima dessa concentração a intensidade de fluorescência diminui (Fig. 76d). Nos pHs 7,0 e 10,0 (Fig. 76b e 76c) a adição de POPC provocou o aumento da intensidade de fluorescência; esse aumento é proporcionalmente maior para III em pH 10,0 (Fig. 76d). Essas diferenças podem estar relacionadas com a carga líquida do peptídeo nos diferentes pHs. Além disso, não foi observado acima de $0,2 \mathrm{mM}$ de vesículas a saturação da ligação como visto no experimento de CD. No entanto, deve-se ressaltar que a concentração de peptídeo utilizada no experimento de fluorescência é menor do que a utilizada em CD (30 e $70 \mu \mathrm{M}$ de III, respectivamente); portanto a proporção lipídeo/peptídeo é maior no primeiro caso.

$\mathrm{Na}$ presença de vesículas negativamente carregadas (Fig. 77), os espectros de $\mathrm{CD}$ em pH 4,0 (Fig. 77a) apresentam uma banda positiva ao redor de $198 \mathrm{~nm}$ e uma 

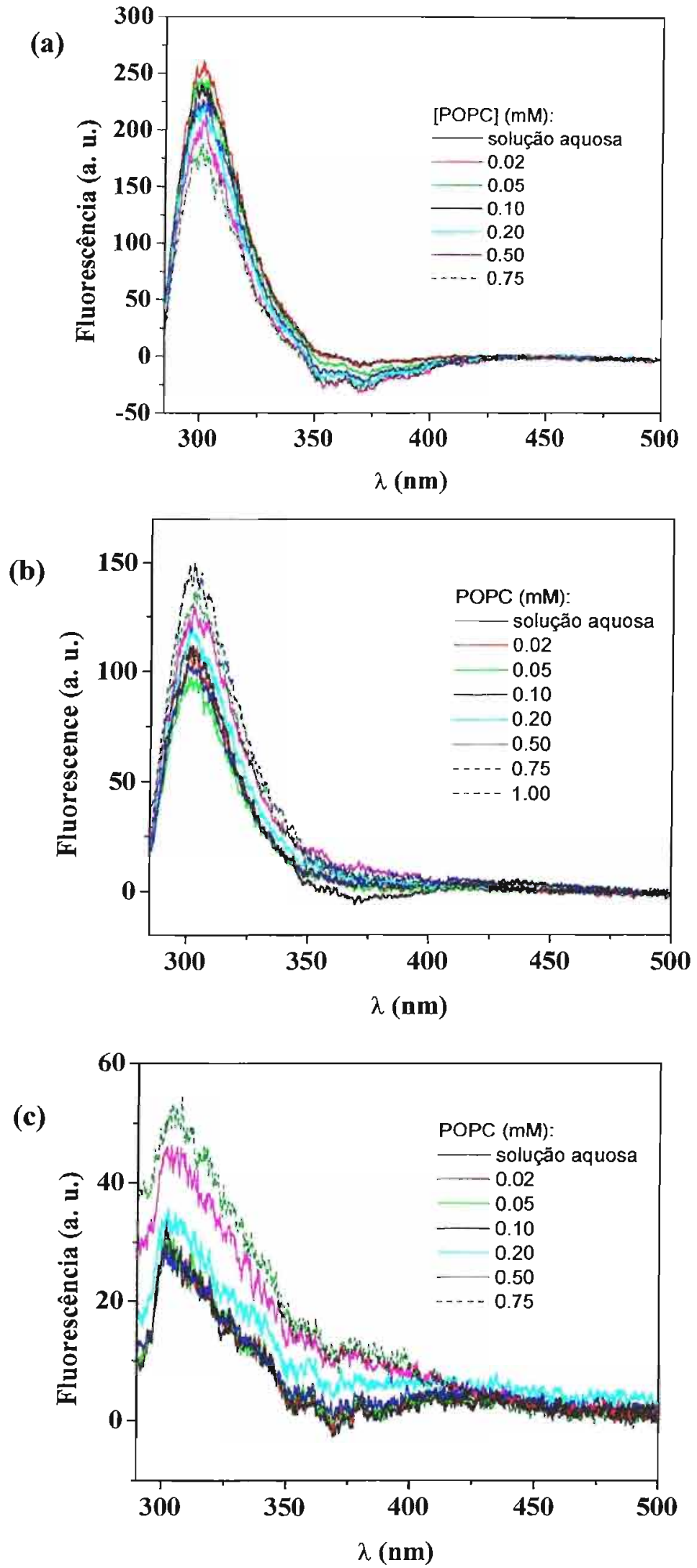


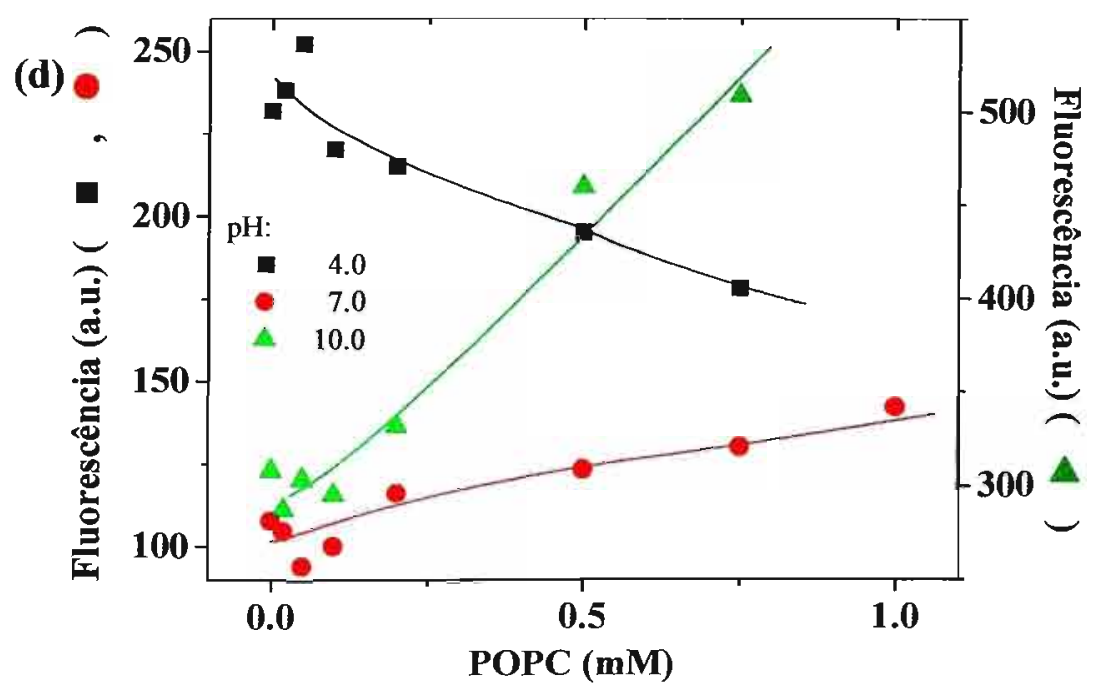

Figura 76 - Espectros de fluorescência de $30 \mu \mathrm{M}$ de III na ausência e na presença de vesículas de POPC nos pHs 4,0 (a), 7,0 (b) e 10,0 (c). Variação da intensidade de fluorescência em $302 \mathrm{~nm}$ nos espectros de III em função da concentração de POPC (d). 
(a)
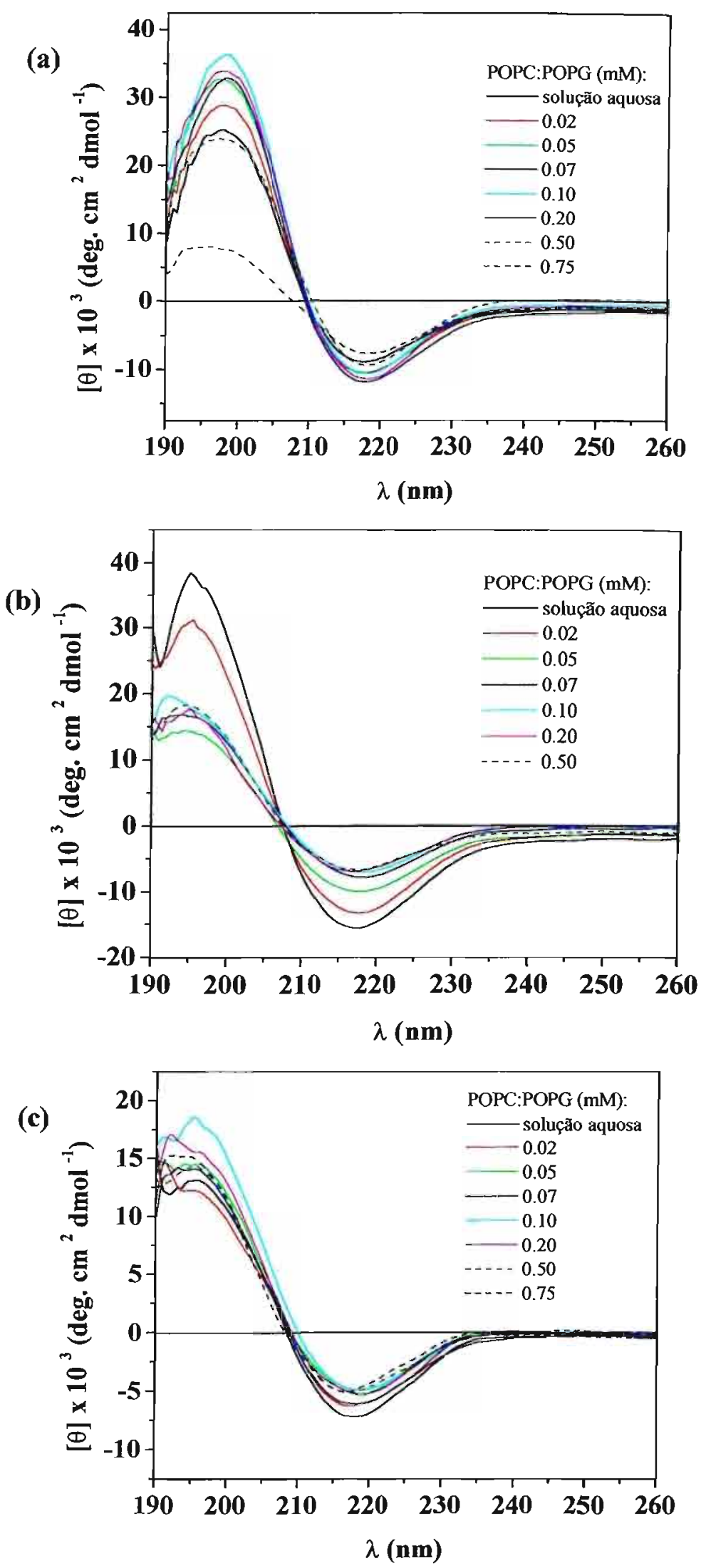


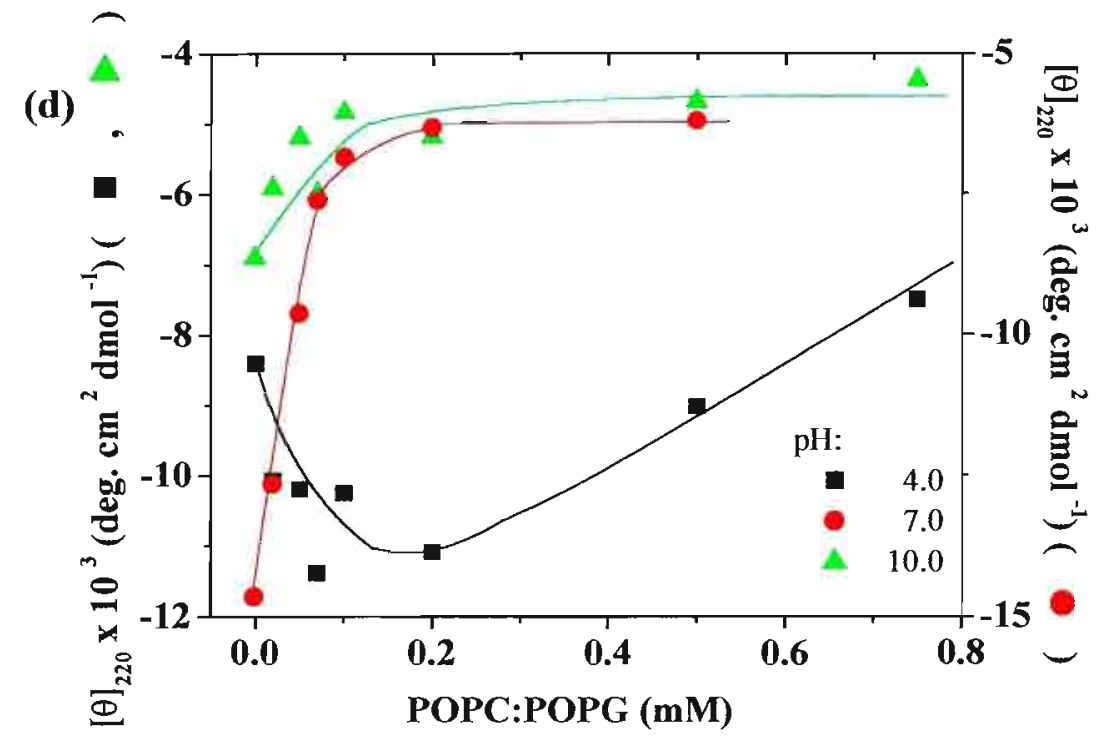

Figura 77 - Espectros de CD de $70 \mu \mathrm{M}$ de III na ausência e na presença de vesículas de POPC:POPG (9:1, mol:mol) nos pHs 4,0 (a), 7,0 (b) e 10,0 (c). Variação da elipticidade molar dos espectros de CD de III em $220 \mathrm{~nm}$ em função da concentração de POPC:POPG (d). 
banda negativa ao redor de $218 \mathrm{~nm}$ (Tabela 23). Observa-se um aumento da elipticidade molar de III até $0,10 \mathrm{mM}$ de vesículas, sendo que em seguida a intensidade do espectro começa a diminuir, o que pode estar relacionado com espalhamento de luz. Esse resultado sugere que III interage com as vesículas de POPC:POPG, porém os espectros de CD mostram que o peptídeo continua a adotar conformação em folha $\beta$.

Em pH 7,0 (Fig. 77b) observou-se uma diminuição significativa da intensidade do espectro assim que foram adicionadas vesículas de POPC:POPG, acima de 0,05 mM de vesículas os espectros encontram-se achatados e a intensidade do espectro varia pouco. A posição do máximo e mínimo nos espectros varia pouco, situando-se em torno de 195 e $218 \mathrm{~nm}$ (Tabela 23), o que sugere que III adquire conformação em folha $\beta$.

Tabela 23 - Comprimento de onda máximo $\left(\lambda_{\max }\right)$ e mínimo $\left(\lambda_{\min }\right)$ nos espectros de CD de III na presença de concentrações crescentes de POPC:POPG em função do pH.

\begin{tabular}{ccccccc}
\multicolumn{7}{c}{$\lambda(\mathrm{nm})$} \\
\hline [POPC] $(\mathrm{mM})$ & \multicolumn{2}{c}{$\mathrm{pH} \mathrm{4,0}$} & \multicolumn{2}{c}{$\mathrm{pH} \mathrm{7,0}$} & \multicolumn{2}{c}{$\mathrm{pH} \mathrm{10,0}$} \\
\hline & $\lambda_{\max }$ & $\lambda_{\min }$ & $\lambda_{\max }$ & $\lambda_{\min }$ & $\lambda_{\max }$ & $\lambda_{\min }$ \\
sem adição & 198,0 & 217,5 & 195,5 & 217,0 & 195,5 & 218,0 \\
0,02 & 198,0 & 218,0 & 195,5 & 217,5 & 195,0 & 217,0 \\
0,05 & 198,0 & 218,0 & 195,0 & 218,0 & 195,0 & 219,0 \\
0,07 & 198,5 & 218,0 & 195,0 & 218,0 & 195,0 & 218,5 \\
0,10 & 198,0 & 218,0 & 193,0 & 218,5 & 195,0 & 218,5 \\
0,20 & 198,0 & 218,0 & 195,0 & 217,0 & 194,0 & 219,0 \\
0,50 & 197,5 & 218,0 & 195,0 & 217,5 & 195,0 & 216,5 \\
0,75 & 196,0 & 218,5 & -- & -- & 193,5 & 217,0 \\
\hline
\end{tabular}

Em pH 10,0 (Fig. 77c) também foram observadas poucas mudanças nos espectros de CD com a adição de vesículas (Tabela 23), sendo que a elipticidade molar em $220 \mathrm{~nm}$ (Fig. 77d) varia pouco com a adição de POPC:POPG, acima de 0,1 mM de vesículas III parece estar todo ligado à membrana. Em pH 7,0 observou a saturação da ligação acima de 0,2 $\mathrm{mM}$ de vesículas, enquanto em $\mathrm{pH}$ 4,0 a elipticidade molar continuou a variar com a adição de POPC:POPG.

Por fluorescência (Fig. 78) também foi observado um comportamento diferente de III nos três pHs estudados. Em pH 4,0, observou-se um aumento contínuo da intensidade de fluorescência de III com a adição de vesículas (Fig. 78a e 78d), o que mostra que III liga-se à bicamada lipídica. Em pH 7,0 no entanto, a intensidade de fluorescência permanece praticamente inalterada com a adição de vesículas (Fig. 78b e 78d). Em pH 10,0, observa-se novamente um aumento da intensidade de fluorescência, 

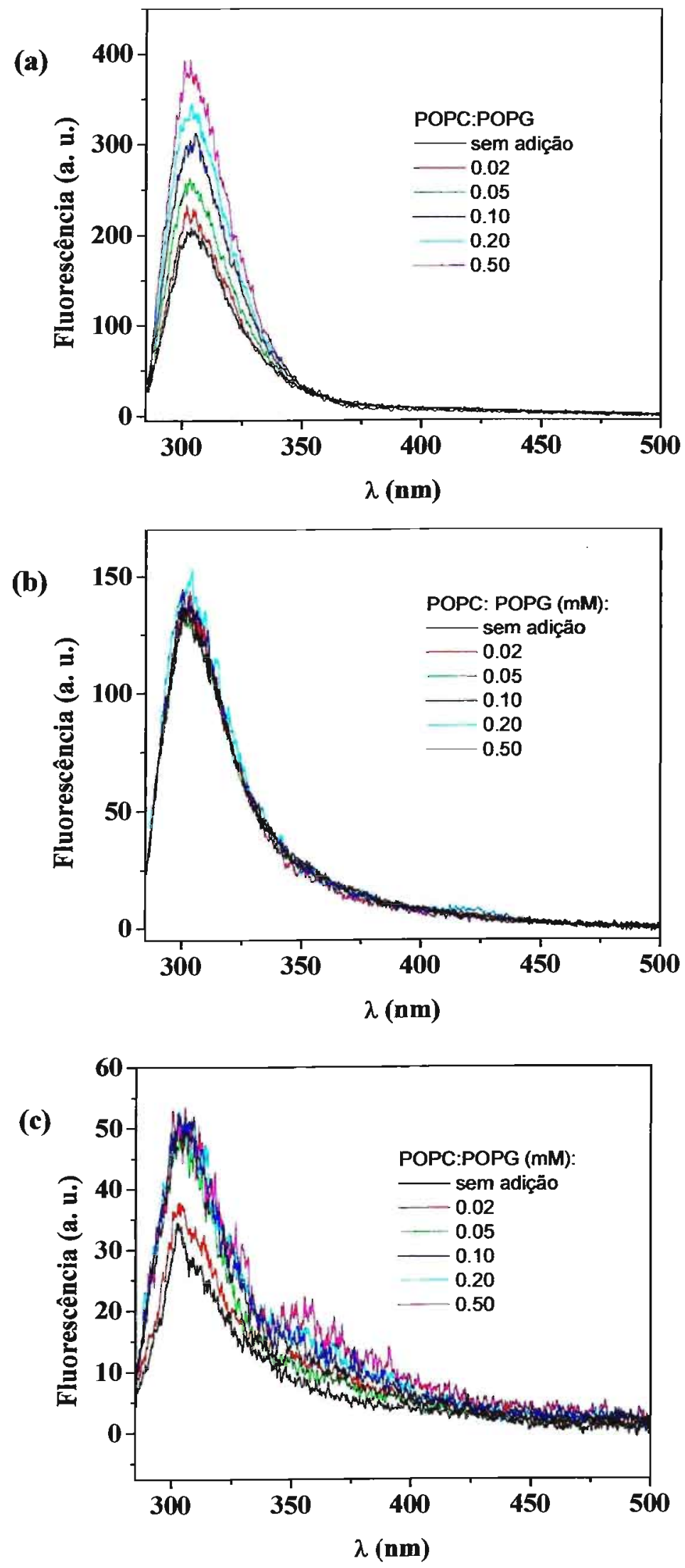


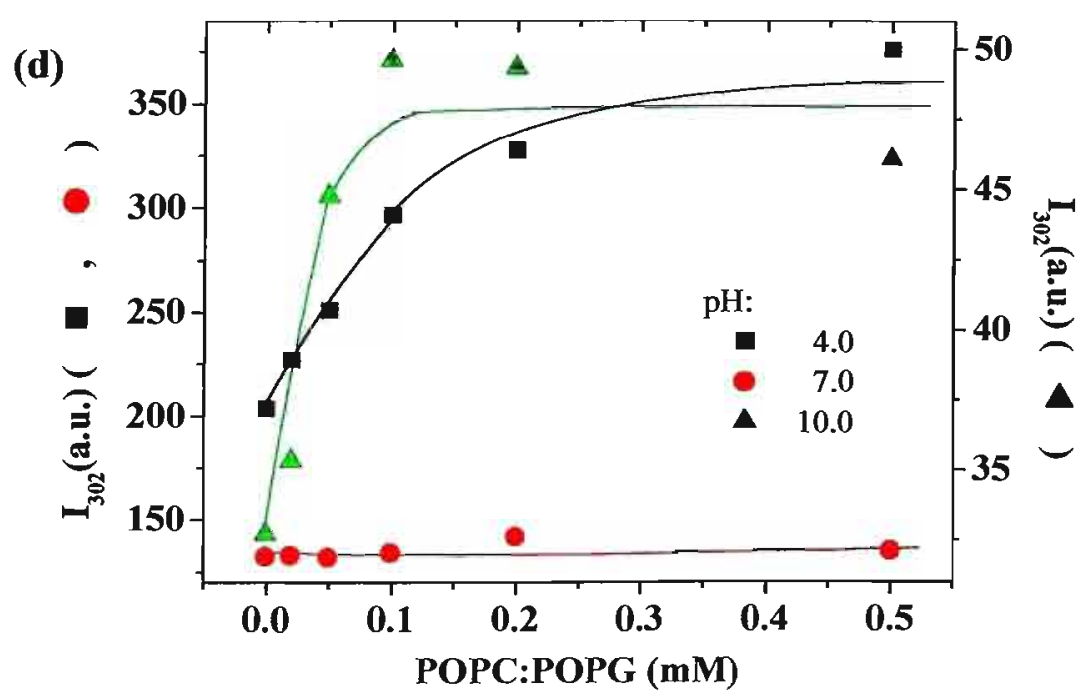

Figura 78 - Espectros de fluorescência de $30 \mu \mathrm{M}$ de III na ausência e na presença de vesículas de POPC:POPG (9:1, mol:mol) nos pHs 4,0 (a), 7,0 (b) e 10,0 (c). Variação da intensidade de fluorescência em $302 \mathrm{~nm}$ nos espectros de III em função da concentração de POPC:POPG (d). 
embora não tão gradual como em pH 4,0 (Fig. 78c e 78d). Provavelmente esse comportamento está relacionado com a carga líquida do peptídeo nos diferentes pHs.

A Figura 79 mostra os espectros de CD de um filme de III suspenso na presença de 0,5 mM de POPC (Fig. 79a) e de POPC:POPG (Fig. 79b) em função do pH. Na presença de POPC observou-se uma pequena diminuição da banda negativa do espectro. A Fig. 79 c e 79 d mostram a variação de $[\theta]_{222}$ de III na presença de vesículas e da carga teórica em função do $\mathrm{pH}$. Os resultados sugerem que pode ocorrido a diminuição do $\mathrm{pK}_{\mathrm{a}}$ dos grupos ionizáveis de III, possivelmente do grupo fenol do resíduo de Tyr e do grupo amino-terminal.

Os resultados de fluorescência (Fig. 80), mostram que tanto na presença de 0,5 $\mathrm{mM}$ de POPC (Fig. 80a) quanto na presença de 0,5 mM de POPC:POPG (Fig. 80b) houve um aumento inicial da intensidade de fluorescência até pH 5,5 no caso de POPC, e até pH 8,0 no caso de POPC:POPG (Fig. 80c). A variação inicial da intensidade de fluorescência pode estar refletindo a desprotonação do grupo fenol da Tyr no estado excitado. É interessante notar que foi possível observar a banda de emissão relativa a bitirosina, acima de $400 \mathrm{~nm}$, na presença de POPC:POPG em quase todos os $\mathrm{pHs}$, porém na presença de POPC essa banda foi observada apenas acima de $\mathrm{pH} 10,0$.

\subsubsection{Supressão da intensidade de fluorescência por acrilamida}

A intensidade de fluorescência do peptídeo III foi suprimida utilizando-se acrilamida como agente supressor. Os experimentos foram realizados com o peptídeo em solução aquosa e na presença de micelas de detergentes e de vesículas fosfolipídicas nos pHs 4,0, 7,0 e 10,0, onde as amostras foram preparadas segundo método a (ver Materiais e Métodos). A Tabela 24 mostra os valores de $K_{\text {SV }}$ obtidos nessas condições.

Tabela 24 - Constante de Stern-Volmer $\left(\mathrm{K}_{\mathrm{SV}}\right)$ para a supressão de intensidade de fluorescência de III por acrilamida em solução aquosa e na presença de membranas-modelo.

\begin{tabular}{ccccccc}
\hline \multicolumn{7}{c}{$\mathrm{K}_{\mathrm{SV}}\left(\mathrm{M}^{-1}\right)$} \\
\hline $\mathrm{pH}$ & $\begin{array}{c}\text { Solução } \\
\text { aquosa }\end{array}$ & HPS & LPC & SDS & POPC & POPC:POPG \\
4,0 & 9,0 & 4,7 & 6,8 & 2,2 & & \\
7,0 & 19,0 & 7,2 & 10,0 & 7,9 & 14,0 & 6,4 \\
10,0 & 10,0 & 5,7 & 9,0 & 5,0 & 13,0 & 5,3 \\
\hline
\end{tabular}

Comparando-se estes valores na ausência e na presença de membranas-modelo podemos ter uma idéia da acessibilidade do fluoróforo ao supressor. Os dados mostram que em solução aquosa os valores de $\mathrm{K}_{\mathrm{SV}}$ são parecidos em quase todos os pHs, sugerindo que III não sofre mudanças conformacionais que alterem a acessibilidade de 
(a)

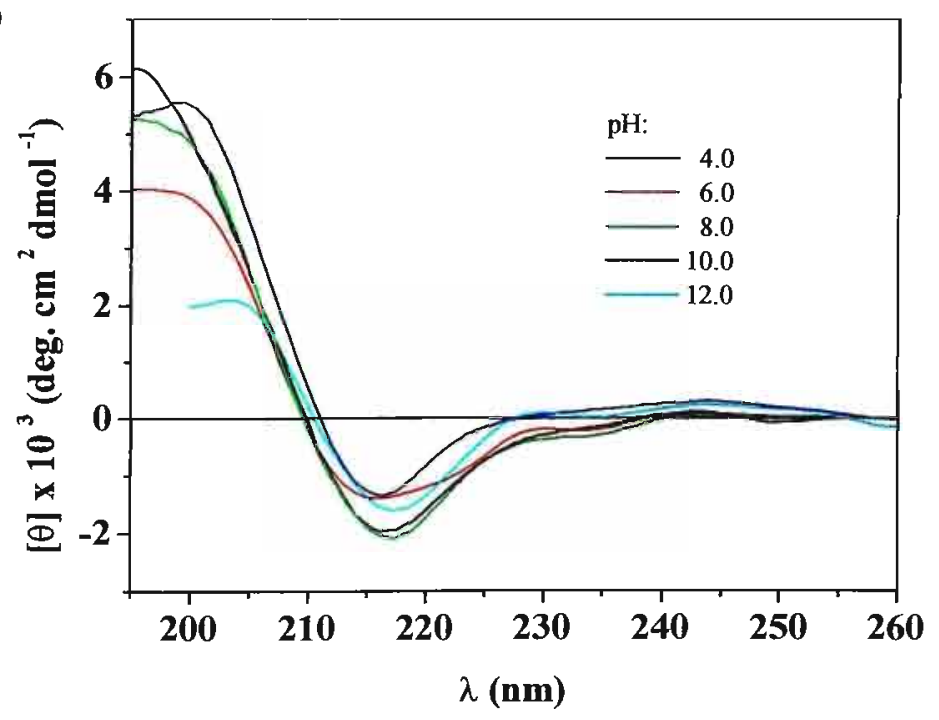

(b)
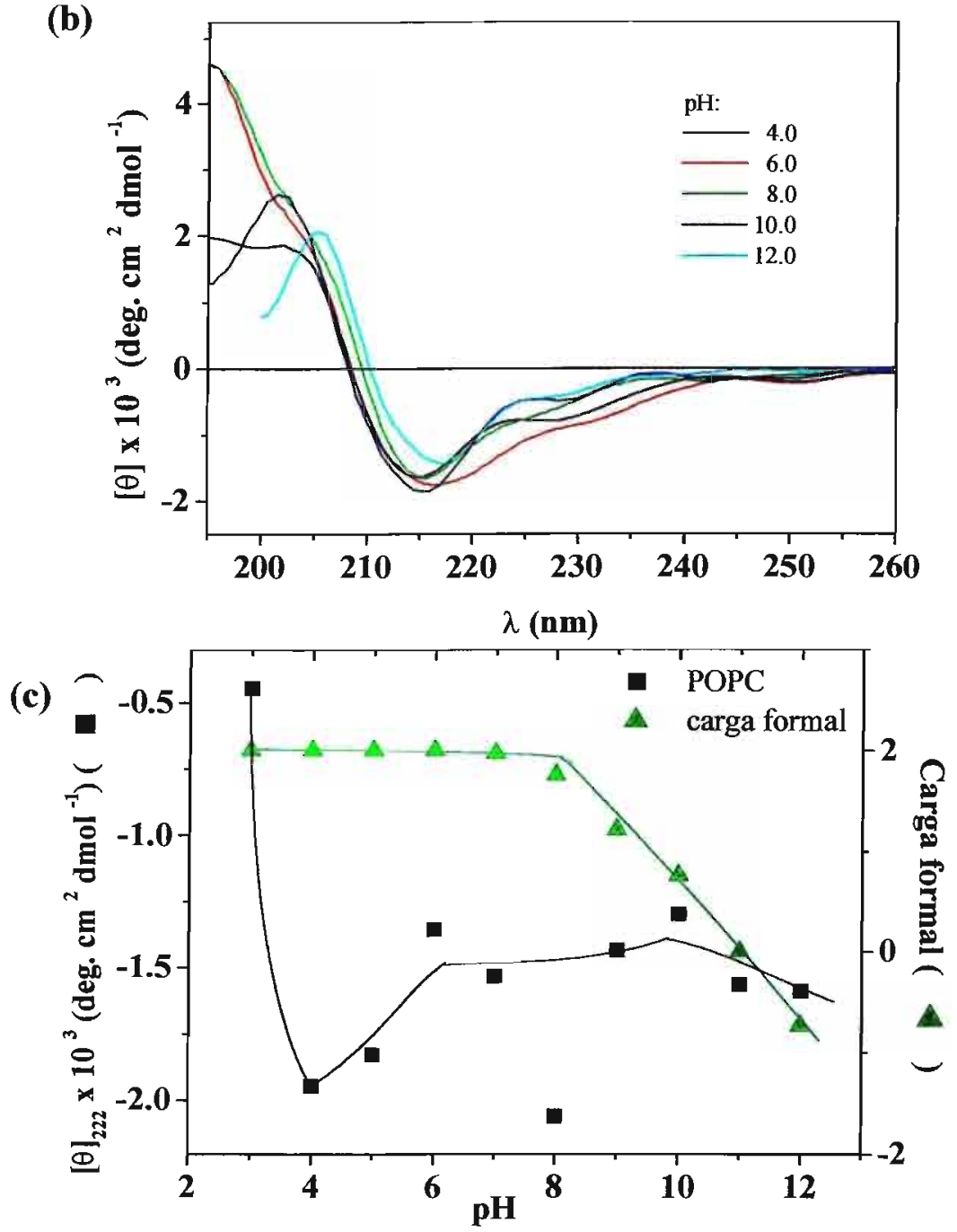


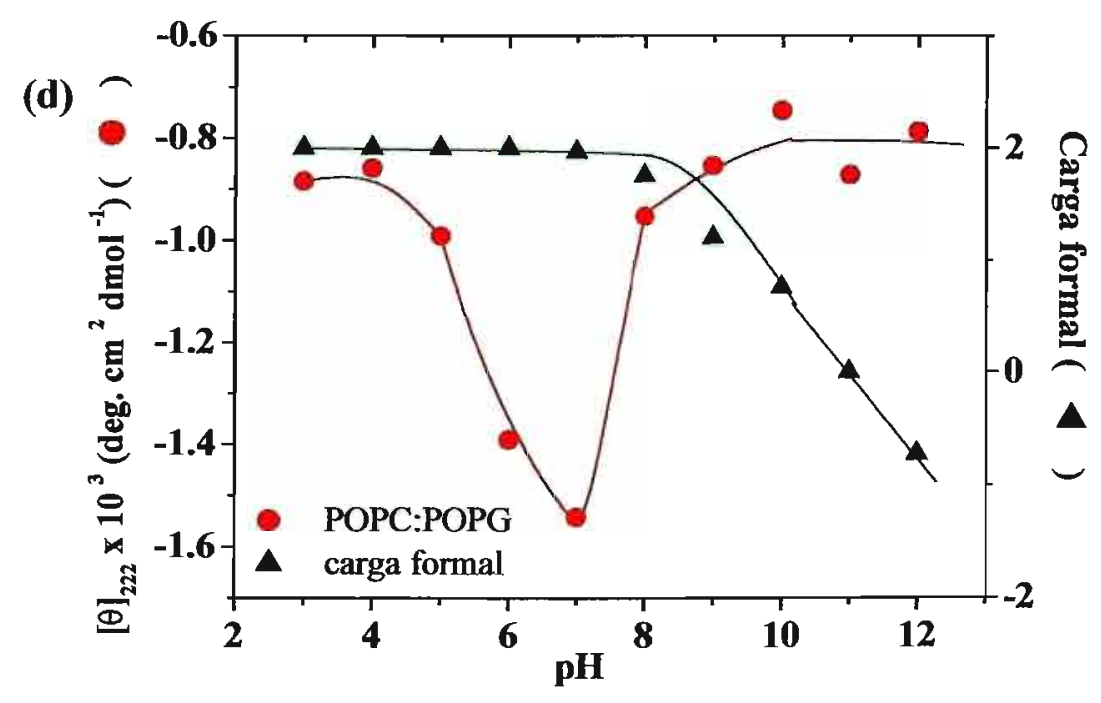

Figura 79 - Espectros de CD de $70 \mu \mathrm{M}$ de III suspenso presença de vesículas de 0,5 mM POPC (a) e de 0,5 mM POPC:POPG (9:1, mol:mol) (b) em função do pH. Variação carga teórica de III e da elipticidade molar dos espectros de CD de III em 222 nm na presença de vesículas POPC (c) e POPC:POPG (d). 
(a)

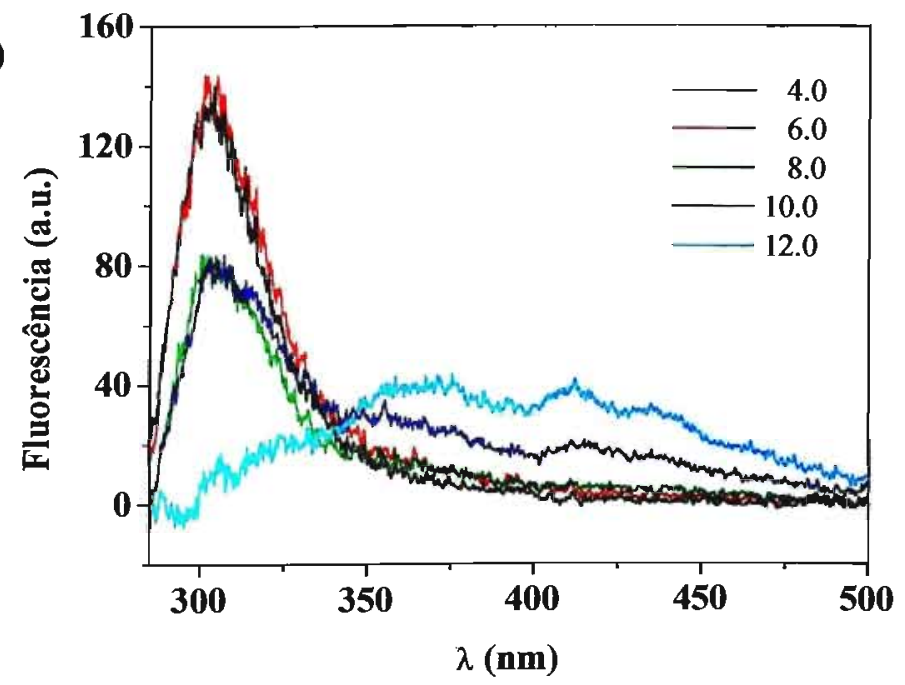

(b)

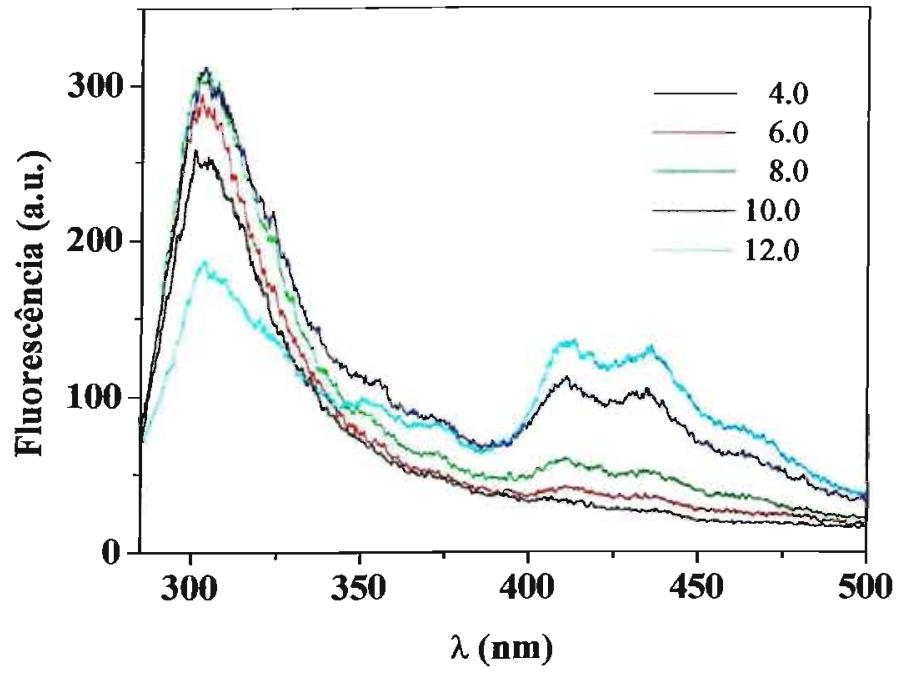

(c)

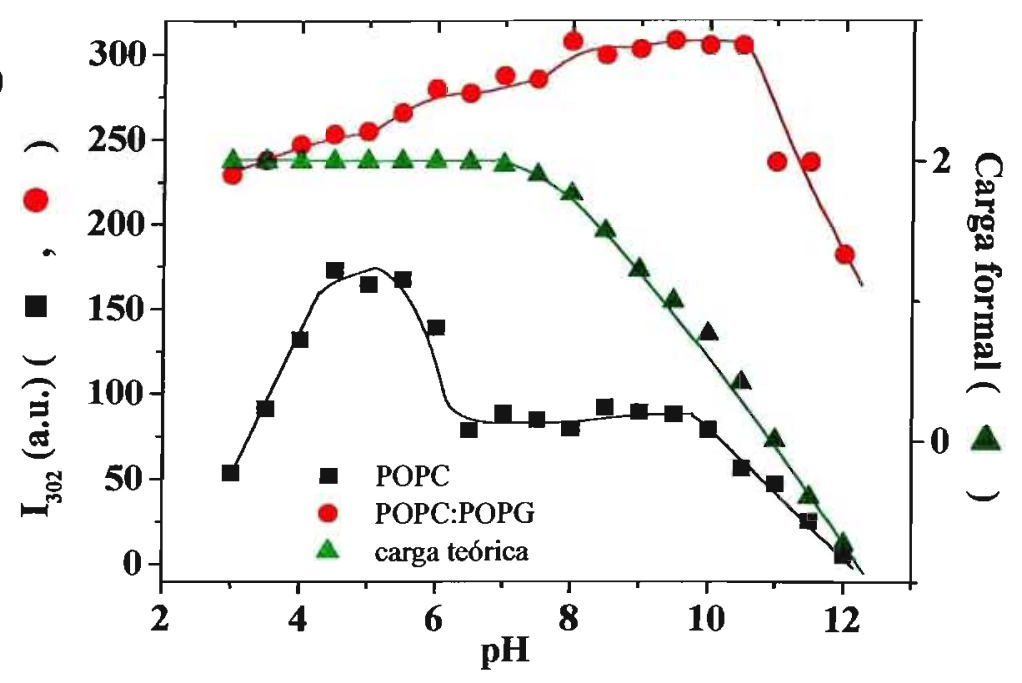

Figura 80 - Espectros de fluorescência de um filme de $30 \mu \mathrm{M}$ de III hidratado na presença de 0,5 mM de POPC (a) e de POPC:POPG 9:1 (b) em função do pH. Variação da carga teórica e da intensidade de fluorescência de III em $302 \mathrm{~nm}$ na presença de vesículas fosfolipídicas (c). 
Tyr nesses pHs. O valor maior obtido para $\mathrm{pH}$ 7,0 pode indicar que III esteja mais solúvel nesse $\mathrm{pH}$ e portanto, com Tyr mais acessível. Também é possível observar que em geral na presença de micelas o valor de $\mathrm{K}_{\mathrm{SV}}$ diminui, indicando que a acessibilidade de Tyr diminui quando III liga-se aos detergentes. Na presença de SDS a diminuição é maior do que na presença de HPS, o que sugere que Tyr está mais enterrada dentro das micelas de SDS do que em HPS. Na presença de ambos os detergentes, pode-se notar que em pHs ácidos o valor de $\mathrm{K}_{\mathrm{SV}}$ é menor do que em $\mathrm{pH} 7,0$ e 10,0, corroborando a idéia de que em pHs mais baixos III se liga com maior afinidade aos detergentes.

$\mathrm{Na}$ presença de vesículas os valores de $\mathrm{K}_{\mathrm{SV}}$ em $\mathrm{pH}$ 4,0 são maiores do que na presença de HPS e SDS, porém são comparáveis aos obtidos na presença de LPC. Com o aumento do $\mathrm{pH}$ se observar um aumento da acessibilidade do fluorórofo ao supressor na presença de POPC. Os valores obtidos são similares aos de III em solução aquosa. Isto sugere que III poderia permanecer na superfície da membrana.

$\mathrm{Na}$ presença de POPC:POPG observa-se o efeito inverso, os valores de $\mathrm{K}_{\mathrm{SV}}$ diminuem com o aumento do $\mathrm{pH}$. É possível que o grau de penetração do peptídeo nesse tipo membrana seja maior do que em POPC.

4.2. Estudo conformacional de CG e sua interação com fragmentos do receptor $A T_{1 A}$ de angiotensina II.

\subsubsection{Predições teóricas}

De acordo com predições teóricas pelo método desenvolvido por Rost et al. ${ }^{(217)}$, o fragmento correspondente ao CG (Fig. 81) possui alta propensão a adotar estrutura $\alpha$ helicoidal, principalmente em sua região $\mathrm{N}$-terminal. Esse resultado é compatível com o observado na literatura, a estrutura cristalina da proteína $\mathrm{G}$ indica que a porção $\mathrm{C}$ terminal da subunidade $\alpha$ adota esse tipo de estrutura secundária. No entanto, no cristal não foi possível resolver a estrutura dos últimos resíduos do C-terminal. O diagrama de roda helicoidal para CG (Fig. 82) indica que este fragmento não é capaz de adotar uma $\alpha$-hélice anfipática.

\subsubsection{Estudos em solução aquosa e na presença de TFE.}

As propriedades conformacionais do fragmento C-terminal da subunidade $\alpha$ da proteína $\mathrm{G}(\mathrm{CG})$ na presença de trifluoroetanol e em solução aquosa foram estudas em função do pH, temperatura em $\mathrm{pH}$ 4,0, e da força iônica nos pHs 2,5, 6,0 e 10,0. 


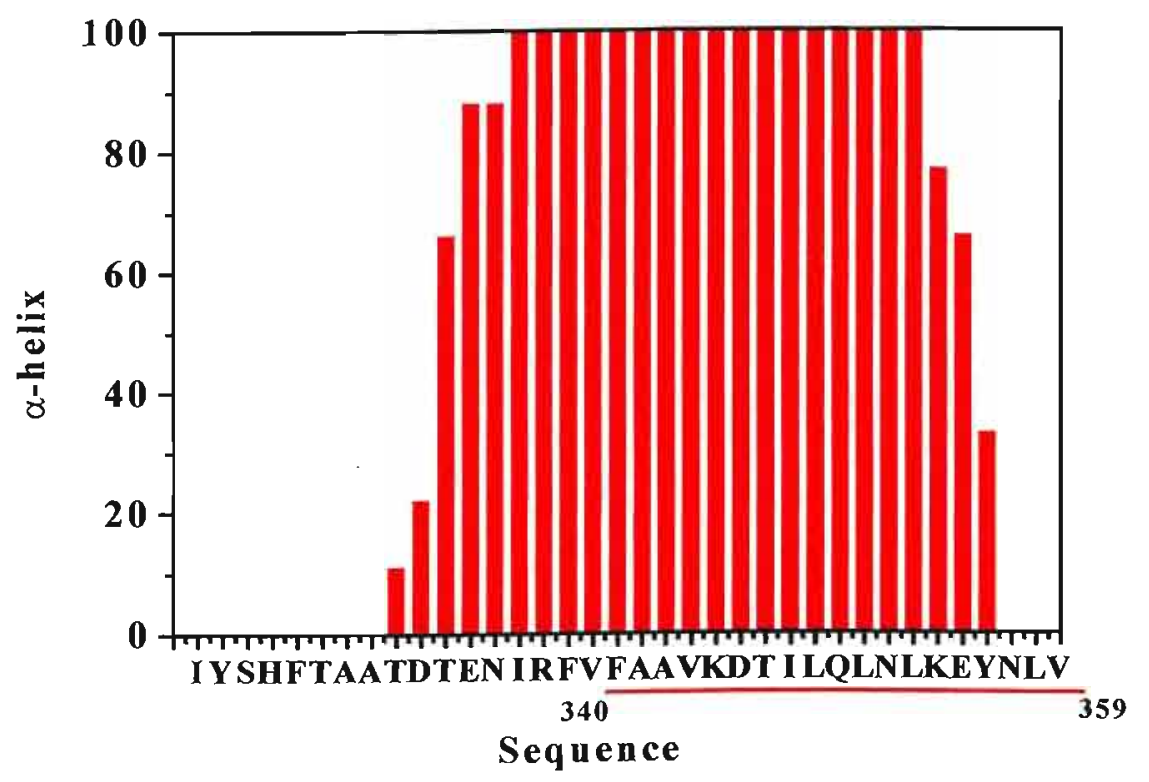

Figura 81 - Predição teórica do conteúdo helicoidal do domínio C-terminal da subunidade $\alpha$ da proteína $\mathrm{G}^{(218)}$.

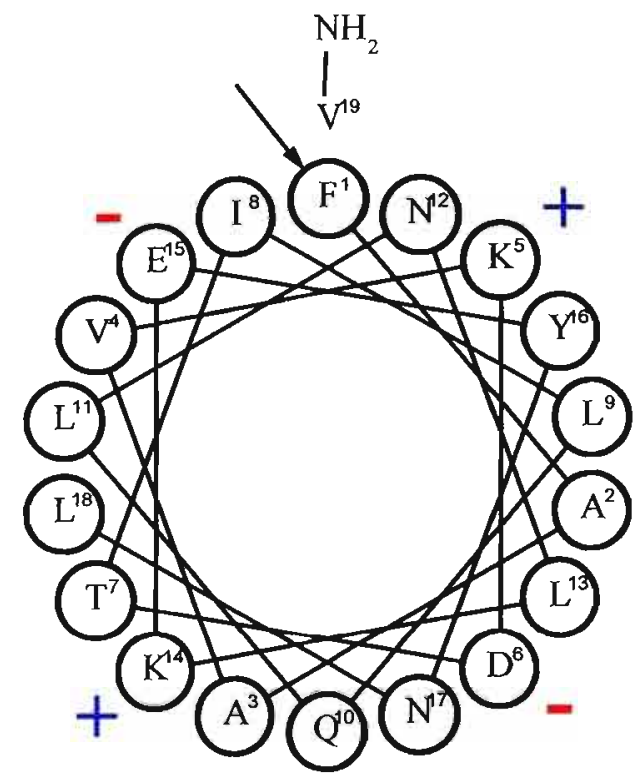

Figura 82 - Diagrama para uma roda helicoidal do CG de acordo com Schiffer e Edmundson ${ }^{(220)}$ 
Ao preparar-se uma solução estoque do peptídeo CG em meio aquoso, observouse que este agrega em altas concentrações. Dessa forma, a solução estoque desse peptídeo foi preparada em TFE.

\subsubsection{Efeito do trifluoroetanol}

A Figura 83a mostra os espectros de CG em função da concentração de TFE. Em solução aquosa em pH 4,0, CG apresenta um espectro com um mínimo centrado ao redor de $200 \mathrm{~nm}$ e uma outra banda negativa com mínimo ao redor de $220 \mathrm{~nm}$ (Tabela 25). Isso indica que nessa condição uma fração de CG encontra-se estruturada, contribuindo para o aparecimento da segunda banda positiva. Esse espectro pode ser visualizado melhor na Figura 83b, pois a adição de TFE causou o aumento significativo de elipticidade molar.

Tabela 25 - Comprimento de onda $(\lambda, \mathrm{nm})$ e seus respectivos valores de elipticidade molar

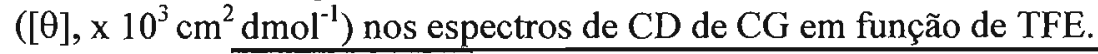

\begin{tabular}{ccccc}
\hline TFE (\%) & $\lambda_{\max }$ & {$[\theta]$} & $\lambda_{\min }$ & {$[\theta]$} \\
\hline 2 & -- & -- & 200 & $-9,88$ \\
& & & 221 & $-4,77$ \\
10 & 197 & 1,53 & 209 & $-5,43$ \\
& & & 218 & $-7,74$ \\
30 & 194 & 6,21 & 208 & $-8,14$ \\
& & & 219 & $-8,77$ \\
50 & \multirow{2}{*}{191} & 39,0 & 207 & $-28,2$ \\
& & & 221 & $-21,5$ \\
70 & \multirow{2}{*}{192} & 35,5 & 207 & $-27,2$ \\
& & & 222 & $-21,0$ \\
100 & \multirow{2}{*}{193} & 31,6 & 207 & $-28,2$ \\
& & & 221 & $-19,4$ \\
\hline
\end{tabular}

A partir de $10 \%$ TFE já é possível observar uma mudança conformacional significativa, com o aparecimento de uma banda positiva centrada em torno de $197 \mathrm{~nm}$. A partir de $40 \%$ TFE, CG adota estrutura $\alpha$-helicoidal, visto pela banda positiva em $197 \mathrm{~nm}$ e pelas bandas negativas em 207 e em $221 \mathrm{~nm}$. O aumento da intensidade em 222 nm (Fig. 83b) indica que CG é capaz de adquirir um conteúdo significativo de $\alpha$ hélice. Calculando-se o conteúdo de estrutura $\alpha$-helicoidal pelo método de Chen ${ }^{(214)}$, observa-se que CG atinge mais de $60 \%$ de $\alpha$-hélice em torno de $40 \%$ TFE (Tabela 26), que muda pouco em concentrações mais altas de TFE. Pelo método de Baldwin ${ }^{(215)}$, o conteúdo de $\alpha$-hélice obtido é maior, porém isso se deve à diferença entre os dois métodos. 


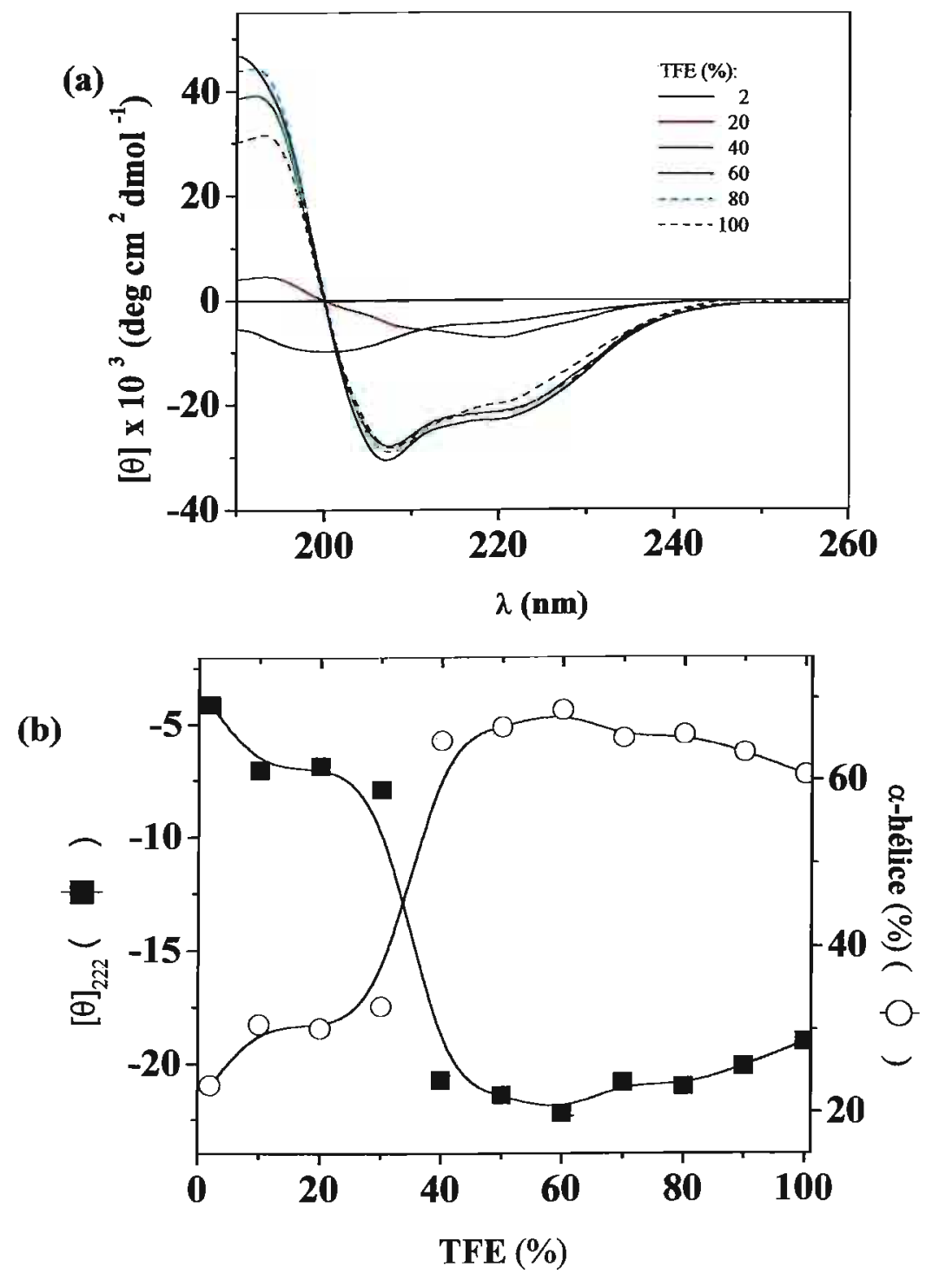

Figura 83 - (a) Espectros de CD de $70 \mu \mathrm{M}$ CG em função da concentração de TFE. (b) Variação de elipticidade molar ( $\boldsymbol{\square})$ e do conteúdo de $\alpha$-hélice segundo Chen et al ${ }^{(213)}$. (O) em função da concentração de TFE. 
Tabela 26 - Conteúdo $\alpha$-helicoidal para CG em função da concentração de TFE.

\begin{tabular}{ccc}
\hline \multicolumn{2}{c}{$\alpha$-hélice (\%) } \\
\hline TFE (\%) & Baldwin $^{\mathrm{a}}$ & Chen $^{\mathrm{a}}$ \\
0 & 31 & 23 \\
10 & 40 & 30 \\
20 & 40 & 30 \\
30 & 43 & 32 \\
40 & 72 & 64 \\
50 & 73 & 66 \\
60 & 74 & 68 \\
70 & 72 & 65 \\
80 & 71 & 65 \\
90 & 70 & 63 \\
100 & 68 & 60 \\
\hline
\end{tabular}

${ }^{a}$ Calculado pelos métodos de Chen ${ }^{(214)}$ e Baldwin ${ }^{(215)}$ conforme descrito em Materiais e Métodos.

Apesar do peptídeo encontrar-se agregado em altas concentrações em solução aquosa, a partir desse resultado pode-se concluir que quando CG está em um ambiente semelhante à vizinhança da membrana, este adota conformação $\alpha$-helicoidal.

Foi estudado ainda o efeito do TFE sobre a intensidade de fluorescência do CG (Fig. 84). Esperava-se que ao aumentar a quantidade de solvente orgânico, a intensidade de fluorescência aumentasse em virtude de um maior grau de monomerização do peptídeo. No entanto, foi observado o efeito inverso. Uma explicação possível para esse evento é que com o aumento de TFE a conformação adotada pelo peptídeo propicia uma interação maior do fluoróforo com o solvente, o que resulta num aumento dos processos de decaimento não radioativo.

É interessante notar que a queda da intensidade de fluorescência (Fig. 84b) corrobora o observado por CD (Fig. 83b); entre 10 e $30 \%$ TFE existe um patamar no gráfico de variação de $\mathrm{I}_{302}$, diminuindo significativamente logo em seguida. Por $\mathrm{CD}$, esse patamar ocorre entre 20 e 40 \% TFE. No entanto, no experimento de fluorescência utilizam-se concentrações menores, em torno de $30 \mu \mathrm{M}$. É possível que nessa faixa de concentração de TFE exista um equilíbrio entre populações, sendo que com a adição de maiores quantidades de TFE ocorre um aumento do conteúdo de estrutura secundária.

\subsubsection{Efeito da temperatura}

Na Figura 85a mostra-se o efeito da temperatura sobre a conformação do CG. O espectro de $\mathrm{CD}$ do peptídeo foi inicialmente adquirido à temperatura ambiente $\left(25^{\circ} \mathrm{C}\right)$ em solução aquosa a pH 4,0. Em seguida, abaixou-se a temperatura da amostra para 5 ${ }^{\circ} \mathrm{C}$. Os espectros posteriores foram adquiridos em intervalos de $5{ }^{\circ} \mathrm{C}$ até a temperatura de $40{ }^{\circ} \mathrm{C}$. Nesse intervalo foram observadas poucas mudanças na forma do espectro, no 


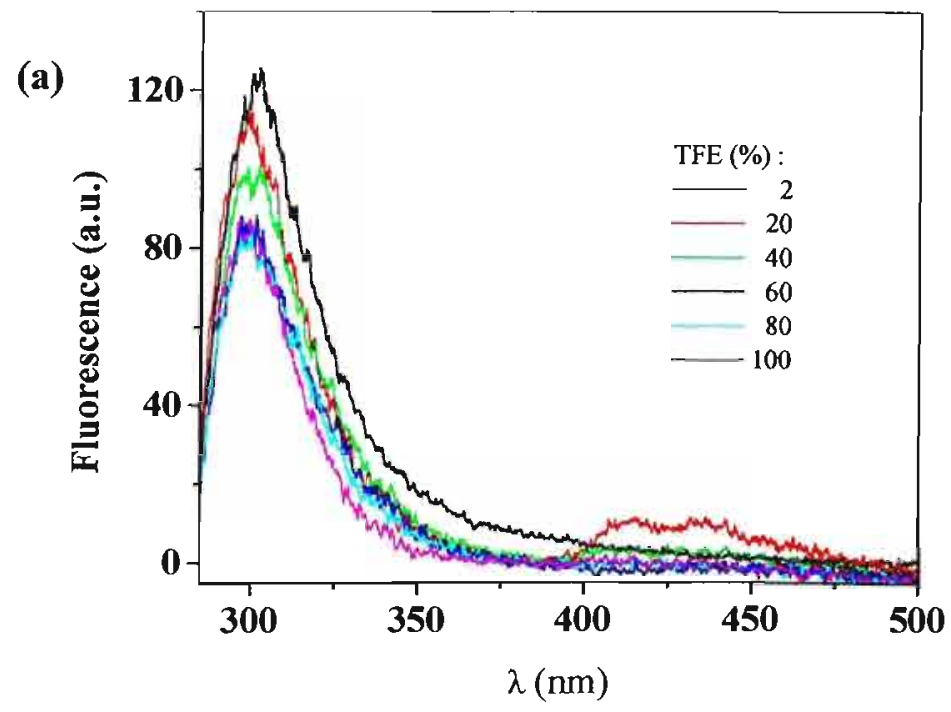

(b)

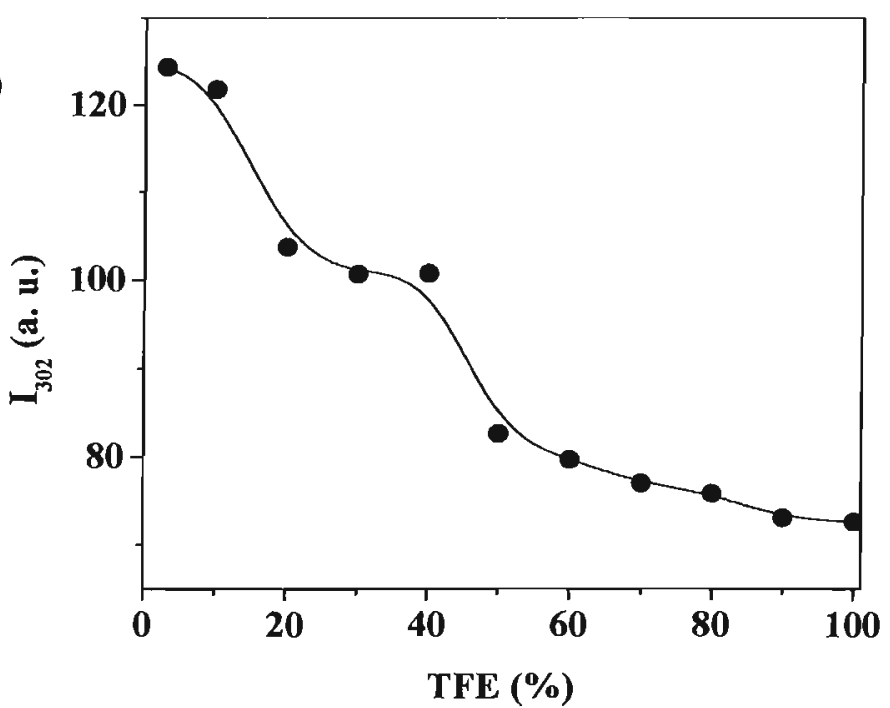

Figura 84 - Espectros de fluorescência (a) e variação da intensidade de fluorescência em $302 \mathrm{~nm}$ (b) de $30 \mu \mathrm{M}$ de CG em função da concentração de TFE. $\lambda_{\text {exc. }}=275 \mathrm{~nm}$. 
(a)

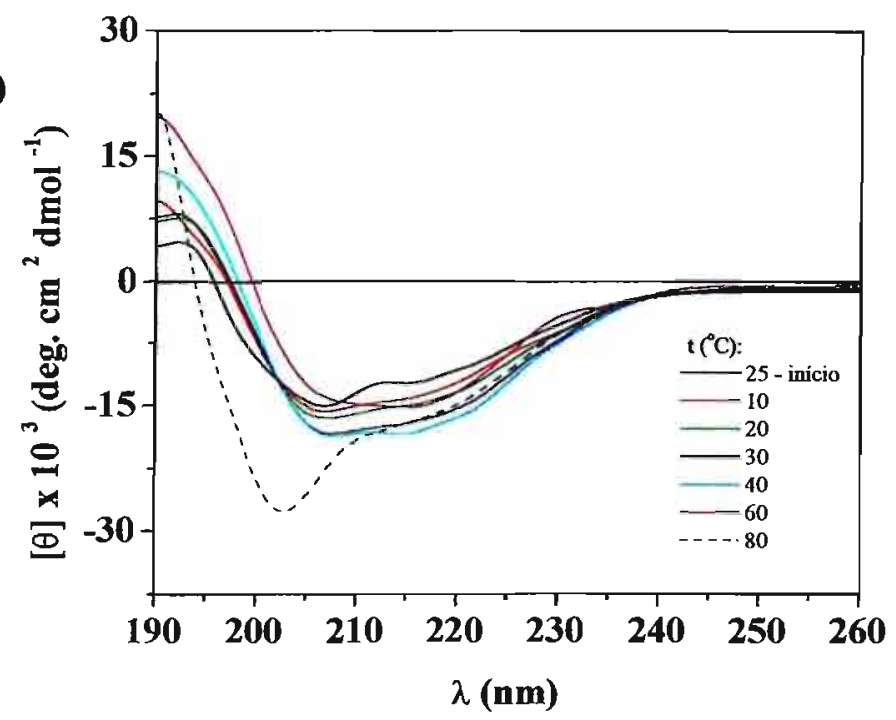

(b)

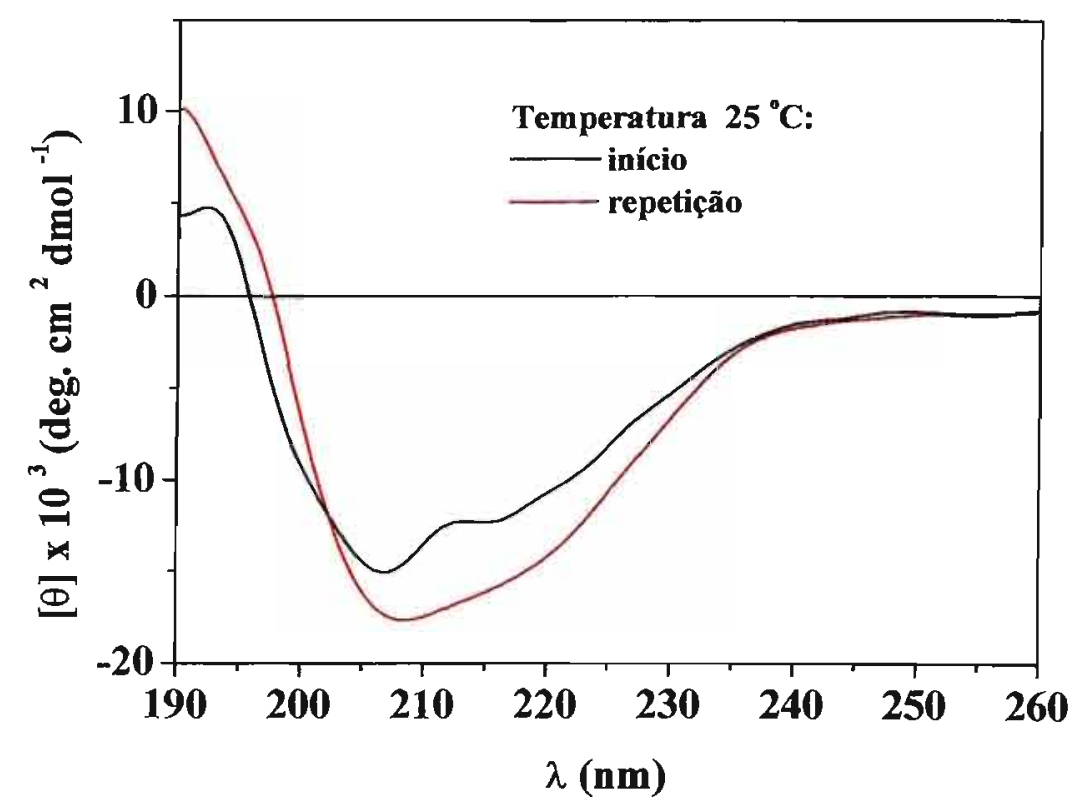

Figura 85 - Espectros de CD de $70 \mu \mathrm{M}$ de $\mathrm{CG}$ em função da temperatura (a) e a $25^{\circ} \mathrm{C}$ (b), $\mathrm{pH} \mathrm{4,0.}$ 


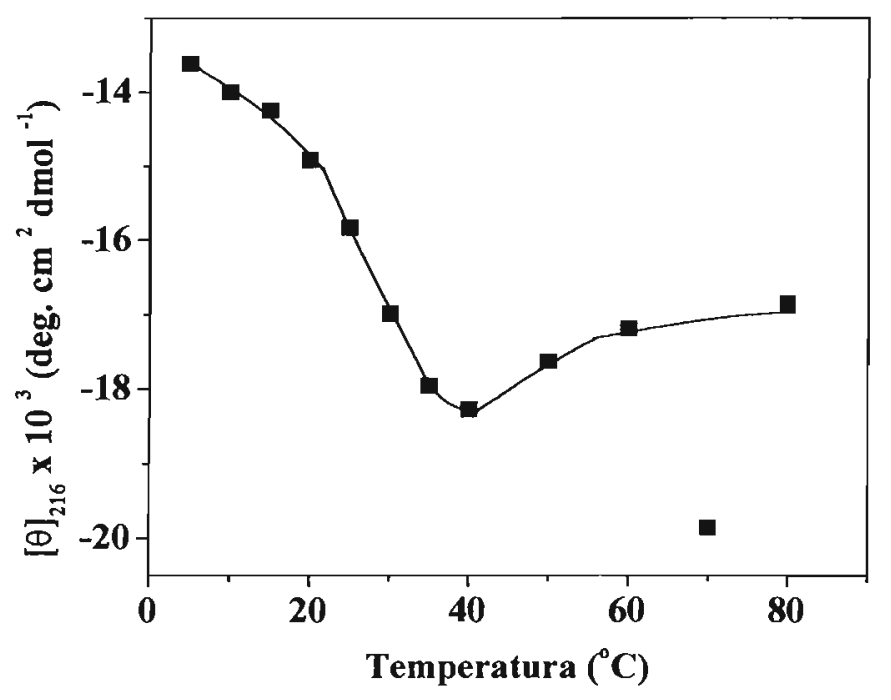

Figura 86 - Variação da elipticidade molar CG de $70 \mu \mathrm{M}$ em $216 \mathrm{~nm}$ em função da temperatura, $\mathrm{pH} 4,0$.

entanto ocorreu um aumento gradual da elipticidade molar, como mostrado na Figura 86. Ao aumentar-se a temperatura observa-se a diminuição de $[\theta]_{216}$ e uma mudança no espectro de $\mathrm{CD}$ em $70{ }^{\circ} \mathrm{C}$; a primeira banda negativa do espectro centrada em $206 \mathrm{~nm}$ desloca-se para ao redor de $203 \mathrm{~nm}$, o que sugere que o peptídeo nessa temperatura esteja menos agregado. $\mathrm{O}$ aumento posterior da temperatura não resultou em mudanças na forma do espectro.

Além disso, comparando-se o espectro inicial do peptídeo a $25{ }^{\circ} \mathrm{C}$ (Fig. 85b) no início do experimento e nessa mesma temperatura após ter abaixado a temperatura da amostra a $5{ }^{\circ} \mathrm{C}$, observa-se que houve histerese, pois os espectros apresentam diferenças significativas. Em virtude da dificuldade de solubilização do CG em solução aquosa, o abaixamento da temperatura poderia induzir agregação do peptídeo.

\subsubsection{Efeito da força iônica}

Para estudar o efeito do sal, foram feitas titulações do CG em três pHs diferentes em função de concentrações crescentes de $\mathrm{NaCl}$.

Em pH 2,5 (Fig. 87a), o espectro do peptídeo em solução na ausência de sal possui uma grande contribuição de um componente correspondente a uma conformação ao acaso, visto pela presença de uma banda negativa centrada ao redor de $204 \mathrm{~nm}$ (Tabela 27). A 

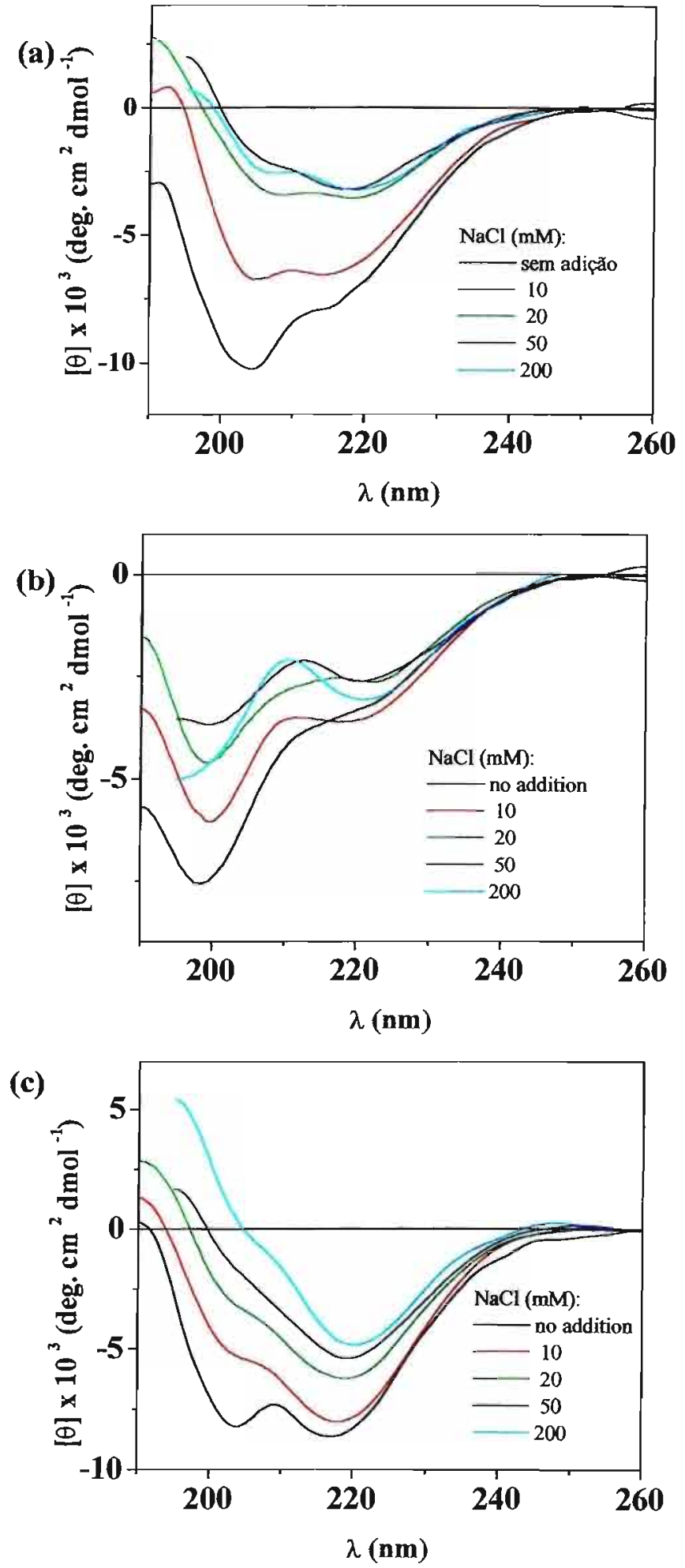

Figura 87 - Espectro de CD de $70 \mu \mathrm{M}$ de CG em função da força iônica. pH: 2,5 (a); 6,0 (b) e 9,0 (c). 
presença de outra banda negativa centrada ao redor de $215 \mathrm{~nm}$ também indica a presença de uma população estruturada. À medida que a força iônica aumenta, o sal deve blindar as cargas do peptídeo, possibilitando a aquisição de estrutura secundária, o que pode ser visto pelo deslocamento da posição da segunda banda negativa para comprimentos de onda mais altos; nessa condição os espectros podem ser atribuídos à dobra $\beta^{(221)}$. Em concentrações mais altas de sal, os espectros estão mais achatados, talvez devido a um aumento da agregação.

Em pH 6,0 (Fig. 87b), na ausência de sal, assim como em pH 2,5, o espectro do peptídeo tem um maior componente correspondente à estrutura ao acaso, apresentando um mínimo ao redor de $198 \mathrm{~nm}$ (Tabela 27). Com o aumento da força iônica, a intensidade do espectro na região entre 190 e $200 \mathrm{~nm}$ varia sem nenhuma tendência definida. Mesmo na presença de concentrações relativamente altas de sal, o espectro de CD de CG mostra que o peptídeo continua a adotar uma conformação flexível.

Tabela 27 - Posição do comprimento de onda máximo $\left(\lambda_{\max }\right)$ e mínimo $\left(\lambda_{\min }\right)$ nos espectros de $\mathrm{CD}$ de $\mathrm{CG}$ em presença de concentrações crescentes de $\mathrm{NaCl}$ em função do $\mathrm{pH}$.

\begin{tabular}{|c|c|c|c|c|c|c|}
\hline \multicolumn{7}{|c|}{$\lambda(\mathrm{nm})$} \\
\hline$[\mathrm{NaCl}](\mathrm{mM})$ & \multicolumn{2}{|c|}{$\mathrm{pH} \mathrm{2,5}$} & \multicolumn{2}{|c|}{$\mathrm{pH} \mathrm{6,0}$} & \multicolumn{2}{|c|}{$\mathrm{pH} 10,0$} \\
\hline & $\lambda_{\max }$ & $\lambda_{\min }$ & $\lambda_{\max }$ & $\lambda_{\min }$ & $\lambda_{\max }$ & $\lambda_{\min }$ \\
\hline sem adição & -- & 204,215 & -- & 198,221 & -- & 204,217 \\
\hline 1,0 & -- & 204,215 & -- & 197,222 & 190 & 204,217 \\
\hline 2,5 & -- & 205,214 & -- & 199,222 & 190 & 203,217 \\
\hline 5,0 & -- & 206,216 & -- & 202,219 & 190 & $203^{*}, 218$ \\
\hline 10 & -- & 205,215 & -- & 200,220 & 190 & $203^{*}, 218$ \\
\hline 20 & -- & 207,219 & -- & 199,222 & 190 & $202^{*}, 219$ \\
\hline 50 & -- & 208,219 & -- & 200,221 & 195 & $203^{*}, 219$ \\
\hline 100 & -- & 210,222 & -- & 201,222 & 195 & $204^{*}, 220$ \\
\hline 200 & -- & 208,219 & & 195,221 & 195 & $205^{*}, 220$ \\
\hline
\end{tabular}

*ombro

Em pH 9,0 (Fig. 87c), o espectro na ausência de $\mathrm{NaCl}$ possui duas bandas negativas ao redor de 204 e $217 \mathrm{~nm}$ (Tabela 27), cujas intensidades são parecidas. Nesse $\mathrm{pH}$, a contribuição de um componente mais estruturado no espectro é maior do que nos pHs anteriores. Com o aumento de sal, a primeira banda diminui bastante até se tornar apenas um ombro ao redor de $203 \mathrm{~nm}$, enquanto que a segunda banda tem a posição relativa de seu mínimo deslocada para o vermelho, para cerca de $220 \mathrm{~nm}$, indicando que o peptídeo passa a adotar uma conformação em dobra $\beta$.

Em todos os pHs, observou-se saturação do efeito do sal ao redor de $50 \mathrm{mM}$ $\mathrm{NaCl}$, vista pela variação de elipticidade molar em $205 \mathrm{~nm}$ (Fig. 88). 


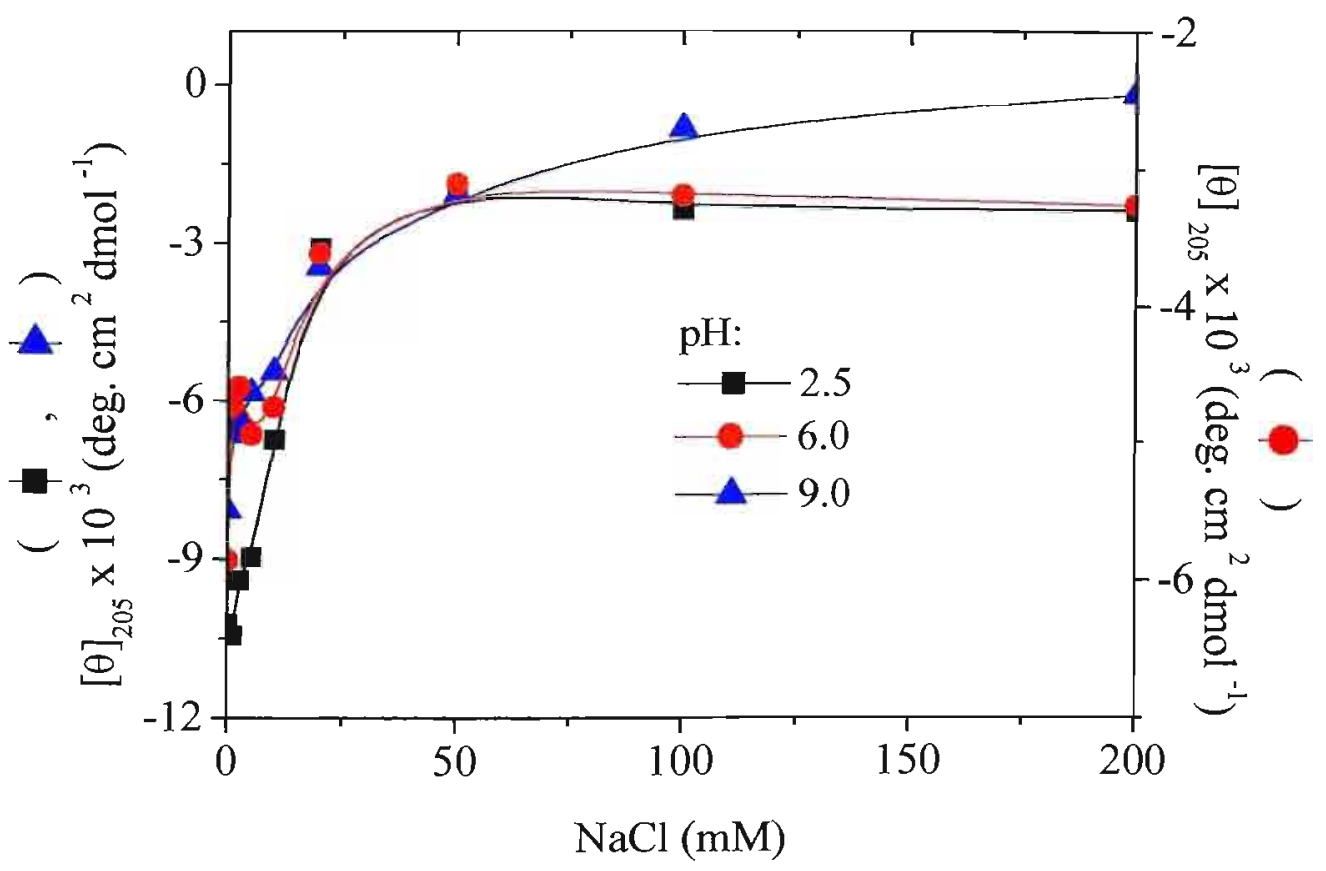

Figura 88 - Variação da elipticidade molar de $70 \mu \mathrm{M}$ de $\mathrm{CG}$ em função da força iônica.

\subsubsection{Efeito do $\mathrm{pH}$}

As propriedades conformacionais do $\mathrm{CG}$ em solução aquosa em função do $\mathrm{pH}$ foram estudadas por fluorescência e por CD. Este fragmento possui os seguintes grupos ionizáveis: Asp, Glu, Tyr e Lys, além do grupo amino-terminal. A Figura 89 mostra a variação da carga teórica desses resíduos e a carga líquida do peptídeo em função do $\mathrm{pH}$. Não foram levadas em consideração possíveis alterações dos $\mathrm{pK}_{\mathrm{a}} \mathrm{s}$ dos grupos ionizáveis das cadeias laterais.

Em solução aquosa (Fig. 90), o espectro de CD de CG indica que o peptídeo encontra-se parcialmente estruturado, apresentando um $\lambda_{\min }$ ao redor de $201 \mathrm{~nm}$ e outro ao redor de $220 \mathrm{~nm}$ em $\mathrm{pH} \mathrm{2,0.} \mathrm{Com} \mathrm{o} \mathrm{aumento} \mathrm{do} \mathrm{pH}$, observa-se o deslocamento desse primeiro mínimo para cerca de $204 \mathrm{~nm}$ e o aumento de intensidade da banda em $220 \mathrm{~nm}$, sendo que acima de $\mathrm{pH}$ 4,0 esta banda torna-se mais intensa do que a primeira, evidenciando uma mudança conformacional induzida pela mudança de pH. Essa mudança reflete provavelmente a desprotonação dos grupos ionizáveis da cadeia lateral de Asp e Glu, levando ao aumento do conteúdo de estrutura secundária. É possível notar o aumento do conteúdo de estrutura $\alpha$-helicoidal, como mostrado na Tabela 28.

Mesmo em pHs mais baixos CG possui um conteúdo significativo de estrutura secundária, acima de $20 \%$ de conteúdo $\alpha$-helicoidal. Em torno de pH 5,0 CG adota o máximo de $\alpha$-helicoidal, em torno de $50 \%$ segundo o método de Baldwin et al. ${ }^{(214)}$ e ao 


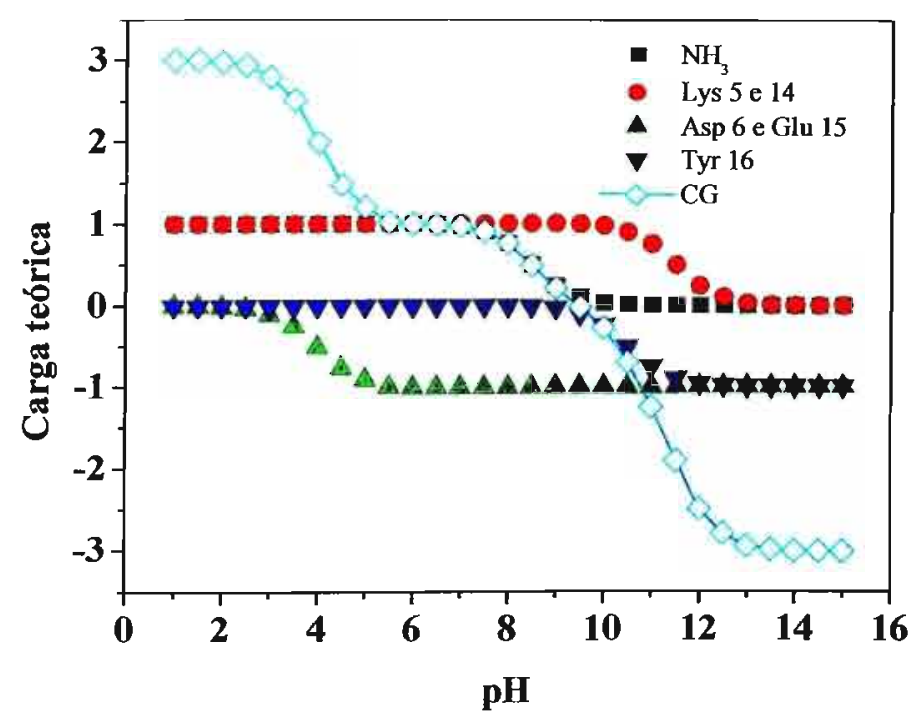

Figura 89- Variação da carga teórica dos aminoácidos presentes no CG e da carga formal do peptídeo em função do $\mathrm{pH}$. $\mathrm{pK}_{\mathrm{a}}$ : Asp, 4,0; Glu, 4,0; Tyr, 10,5; Lys, 11,0 e o grupo N-terminal, $8,5^{(223)}$.

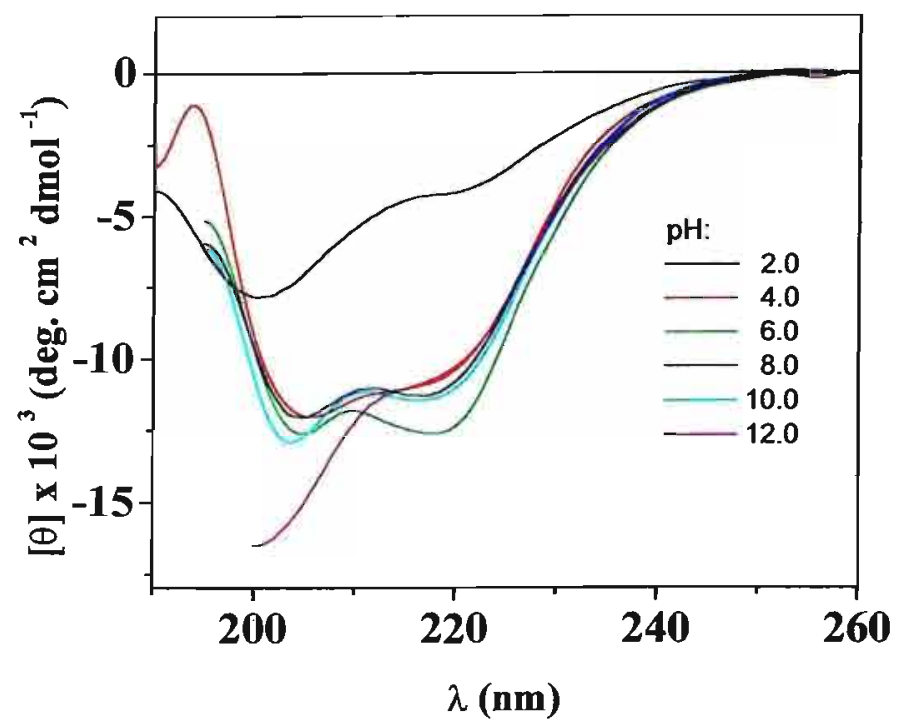

Figura 90 - Espectros de CD de $70 \mu \mathrm{M}$ de CG em solução aquosa em função do pH em ausência de tampão. 
redor de $40 \%$ segundo o método de Chen et al ${ }^{(213)}$. Acima desse $\mathrm{pH}$ o conteúdo de estrutura secundária mantém-se constante.

Tabela 28-Conteúdo $\alpha$-helicoidal para CG em função do $\mathrm{pH}$.

\begin{tabular}{ccc}
\hline \multicolumn{3}{c}{$\alpha$-hélice (\%) } \\
\hline pH & Baldwin $^{\mathbf{a}}$ & Chen $^{\mathbf{a}}$ \\
2,0 & 29 & 23 \\
2,5 & 30 & 24 \\
3,0 & 33 & 26 \\
3,5 & 39 & 29 \\
4,0 & 48 & 38 \\
4,5 & 51 & 41 \\
5,0 & 53 & 43 \\
6,0 & 52 & 42 \\
7,0 & 50 & 40 \\
8,0 & 49 & 39 \\
9,0 & 50 & 40 \\
10,0 & 49 & 39 \\
11,0 & 49 & 39 \\
12,0 & 48 & 38 \\
\hline
\end{tabular}

${ }^{a}$ Calculado pelos métodos de Chen ${ }^{(214)}$ e Baldwin ${ }^{(215)}$ conforme descrito em Materiais e Métodos.

A Figura 91 mostra a variação de [ $\theta]$ em 203 e 217 nm, em função do $\mathrm{pH}$, assim como a variação da carga teórica do peptídeo. Acompanhando-se a variação de elipticidade molar, principalmente em $217 \mathrm{~nm}$, é possível observar a titulação de Asp e Glu entre pH 2,0 e 5,0, assim como a titulação de Lys e do grupo amino terminal acima de pH 8,0.

Por fluorescência (Fig. 92), excitando-se a amostra em 275 nm (Fig. 92a), observase que a banda relativa ao espectro de emissão de tirosina, centrada ao redor de $301 \mathrm{~nm}$, a qual diminui com o aumento do $\mathrm{pH}$; em $\mathrm{pH} 11,0$ esta banda praticamente desaparece devido à desprotonação da tirosina.

Com o aumento do $\mathrm{pH}$, além da banda de emissão de fluorescência centrada em 302 $\mathrm{nm}$, aparecem outras duas bandas: uma ao redor de $350 \mathrm{~nm}$ e outra entre 400 e $450 \mathrm{~nm}$. A primeira, aparece a partir de $\mathrm{pH} \mathrm{8,0} \mathrm{e} \mathrm{é} \mathrm{resultado} \mathrm{da} \mathrm{emissão} \mathrm{de} \mathrm{tirosinato.} \mathrm{A} \mathrm{segunda} \mathrm{banda}$ aparece a partir de $\mathrm{pH}$ 4,0 e pode ser resultante da emissão de bitirosina. A presença dessa banda também pode ser vista como um indício de agregação de CG em pHs mais alcalinos.

A amostra também foi excitada em $292 \mathrm{~nm}$ (Fig. 92b), que corresponde ao comprimento de onda de excitação do tirosinato. Com o aumento do $\mathrm{pH}$ observa-se o aumento da intensidade de fluorescência de tirosinato; sendo que a mesma atinge um valor máximo em $\mathrm{pH}$ 10,0, diminuindo logo em seguida. Essa diminuição de intensidade pode 


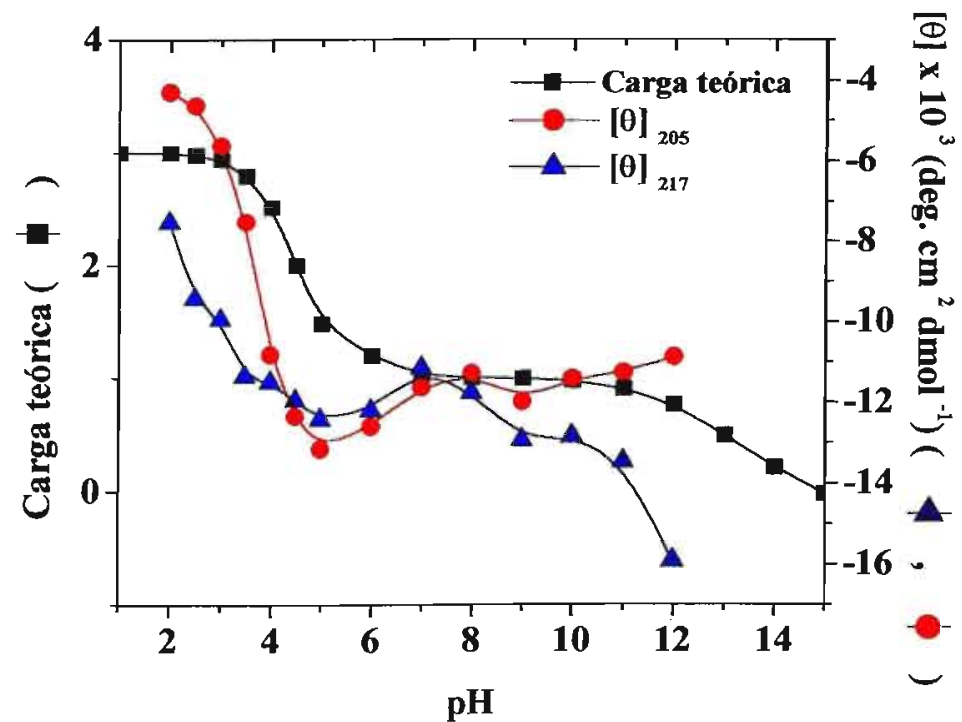

Figura 91 - Carga formal e elipticidade molar de CG em 205 e 217 nm em função do pH em solução aquosa. 

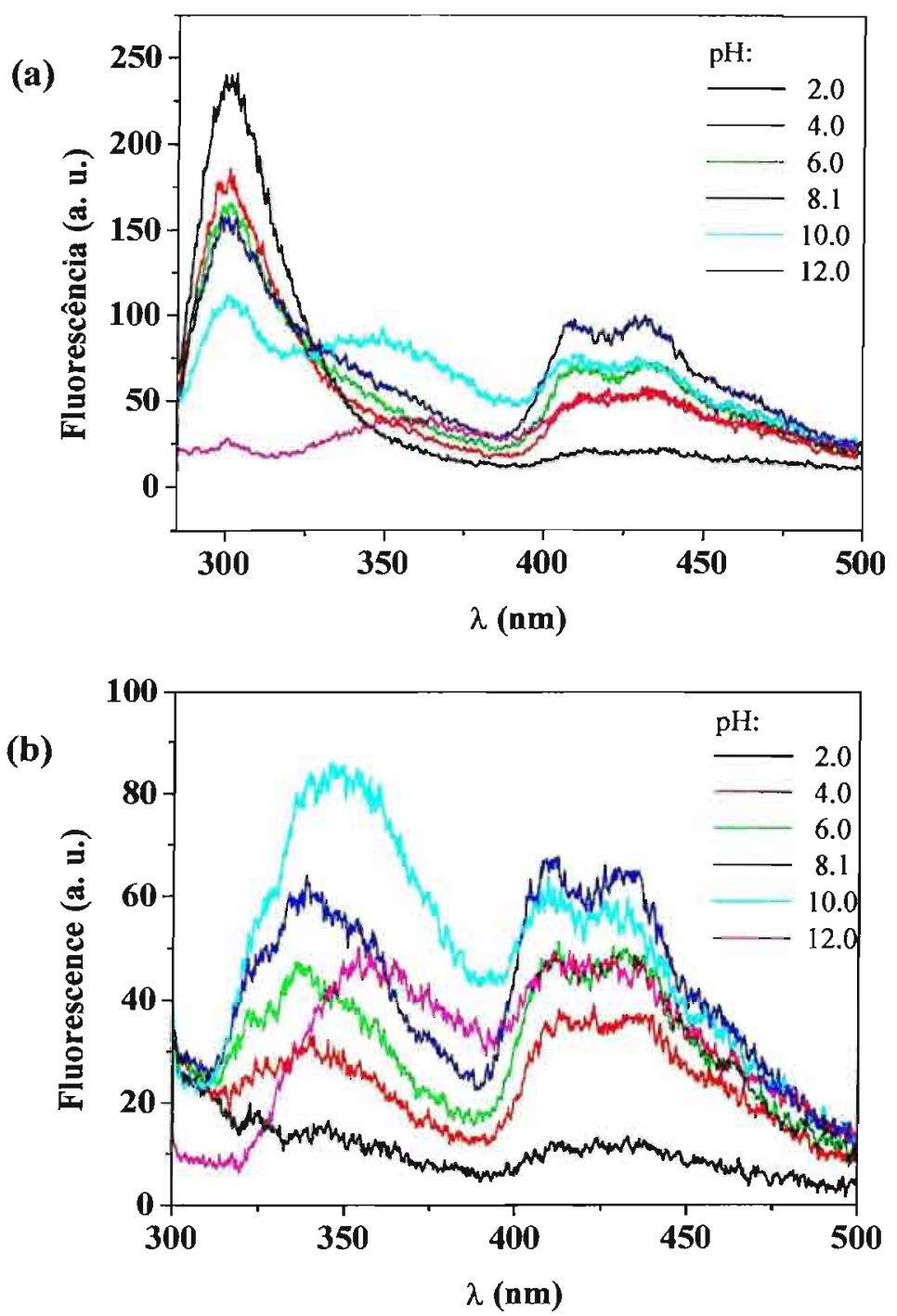

Figura 92 - Espectros de fluorescência de $30 \mu \mathrm{M}$ de CG em solução aquosa em função do pH em ausência de tampão. $\lambda_{\text {exc. }}=275$ (a) e 292 nm (b). 
ser devido a precipitação da amostra em pHs mais alcalinos, uma vez que nesses pHs foi observada a presença de pequenas partículas em solução. Nesse caso observou-se também a banda de emissão entre 400 e $450 \mathrm{~nm}$.

Comparando-se a variação da carga teórica com a variação da intensidade de fluorescência em 301 e $350 \mathrm{~nm}$ em função do pH (Fig. 93), observa-se que no primeiro caso a variação da intensidade é praticamente igual à variação da carga teórica.

\subsubsection{Estudos na presença de membranas modelo}

Um dos objetivos do estudo da conformação de CG na presença de membranasmodelo foi encontrar condições adequadas para investigar-se a interação de CG com fragmentos do receptor $\mathrm{AT}_{1 \mathrm{~A}}$ de angiotensina ПI. Uma vez que essa condição foi observada na presença de LPC, preferiu-se enfocar o estudo da interação ao invés de prosseguir com o estudo da conformação de CG na presença de vesículas fosfolipídicas. Dessa este capítulo enfoca apenas os estudos com detergentes.

\subsubsection{Estudos na presença de HPS.}

Em pH 2,5, os espectros CD (Fig. 94a) mostram poucas mudanças significativas. Os espectros, tanto na ausência como na presença de HPS, são característicos de uma estrutura flexível. Com a adição de detergente ocorre apenas um aumento de intensidade até $0,5 \mathrm{mM}$ HPS, e uma queda a partir de concentrações mais altas; a posição do $\lambda_{\min }$ da banda negativa centrada em $201 \mathrm{~nm}$ manteve-se praticamente constante (Tabela 29). Esses dados sugerem que CG se liga ao detergente, porém isto não resulta em mudanças conformacionais. A diminuição da intensidade do espectro pode ser devida ao espalhamento de luz a partir de concentrações relativamente altas do detergente.

Tabela 29 - Posição do comprimento de onda máximo $\left(\lambda_{\max }\right)$ e mínimo $\left(\lambda_{\min }\right)$ nos espectros de CD de CG em presença de concentrações crescentes de HPS em função do pH.

\begin{tabular}{ccccccc}
\hline \multicolumn{7}{c}{$\lambda(\mathrm{nm})$} \\
\hline [HPS] $(\mathrm{mM})$ & \multicolumn{7}{c}{$\mathrm{pH} \mathrm{2,5}$} & \multicolumn{2}{c}{$\mathrm{pH} \mathrm{6,0}$} & \multicolumn{2}{c}{$\mathrm{pH} \mathrm{10,0}$} \\
\hline & $\lambda_{\max }$ & $\lambda_{\min }$ & $\lambda_{\max }$ & $\lambda_{\min }$ & $\lambda_{\max }$ & $\lambda_{\min }$ \\
Sem adição & - & 201 & - & $202,222^{*}$ & -- & 200,220 \\
0.05 & - & 201 & - & $203,222^{*}$ & - & 200,219 \\
0.1 & - & 200 & - & $201,220^{*}$ & -- & $202^{*}, 221$ \\
0.5 & -- & 200 & - & $203,221^{*}$ & - & $203^{*}, 221$ \\
1.0 & - & 201 & - & $203,221^{*}$ & 190 & $204^{*}, 221$ \\
2.0 & -- & 201 & 190 & $204,220^{*}$ & 190 & $204^{*}, 221$ \\
\hline${ }^{*}$ ombro & & & & & &
\end{tabular}




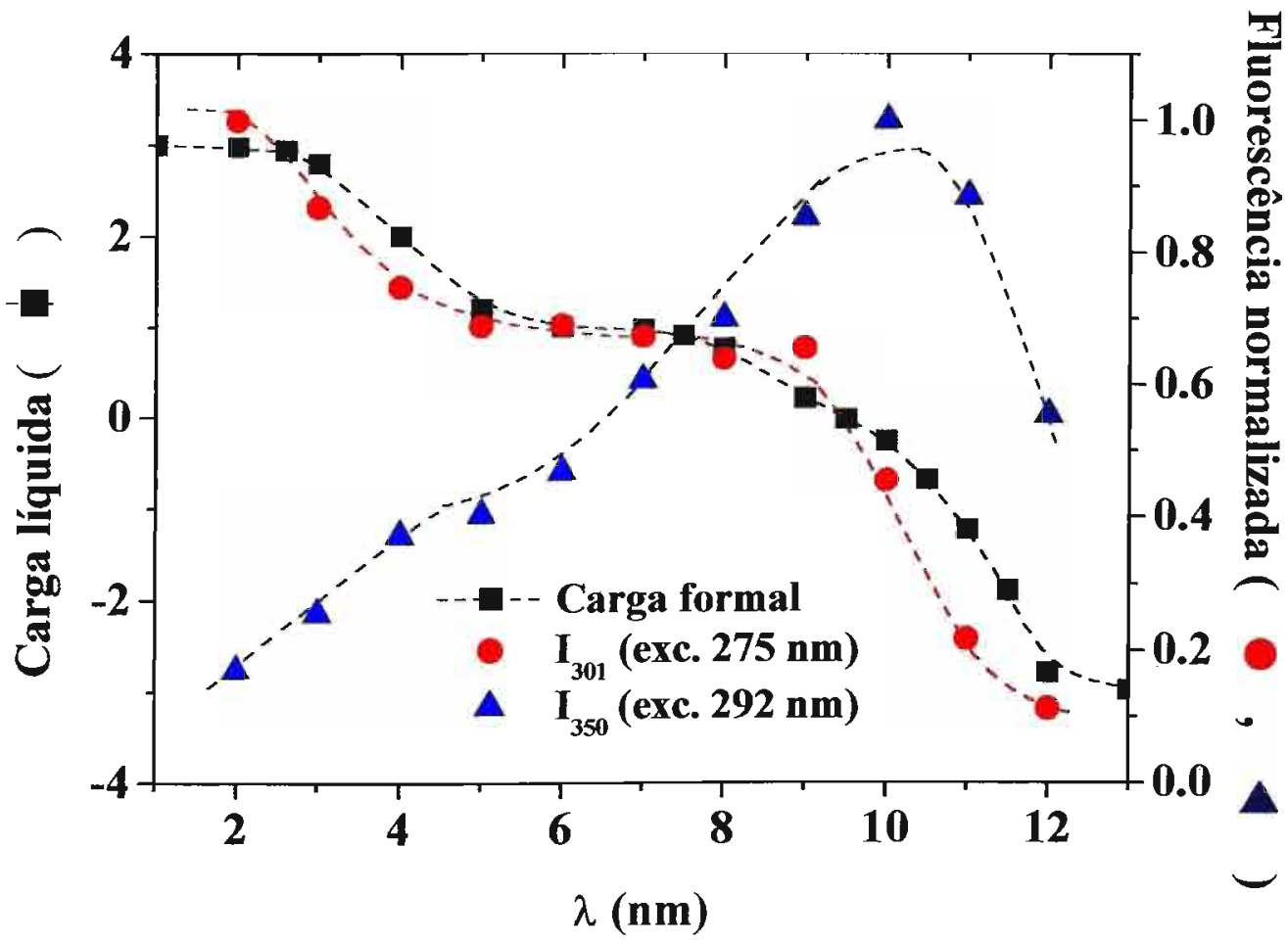

Figura 93 - Variação da carga formal e da intensidade de fluorescência de $30 \mu \mathrm{M}$ de $\mathrm{CG}$ em solução aquosa em função do pH na ausência de tampão. 
(a)

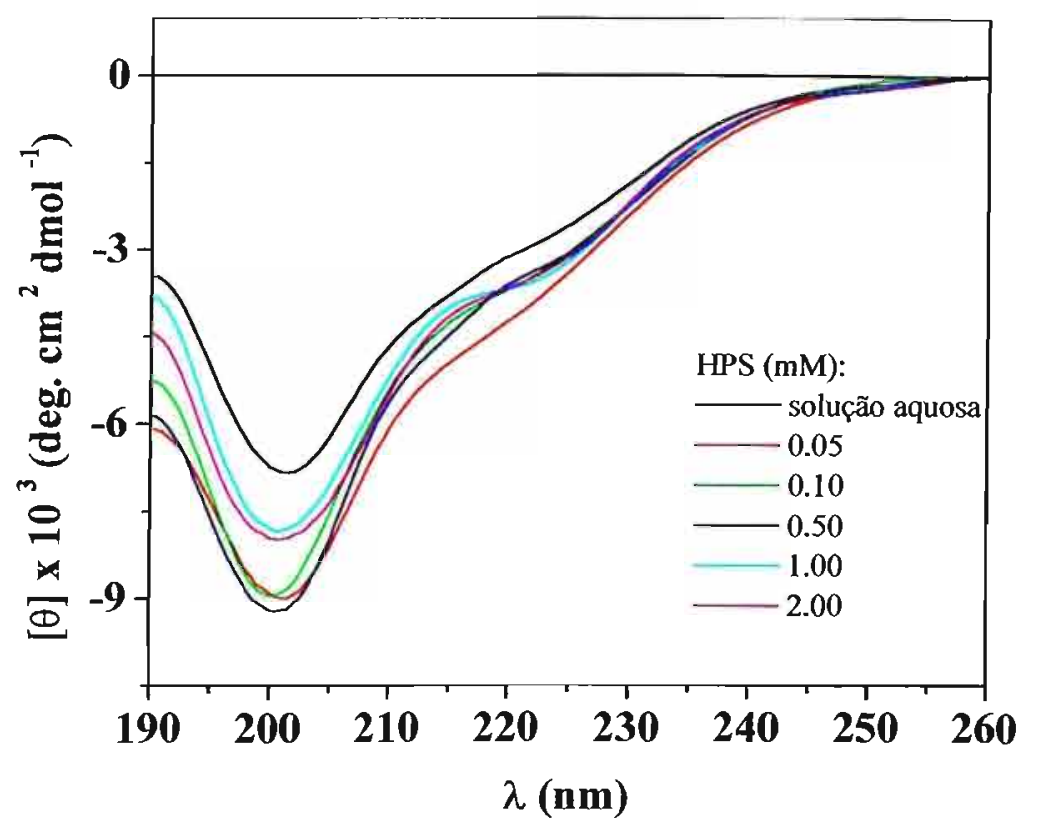

(b)

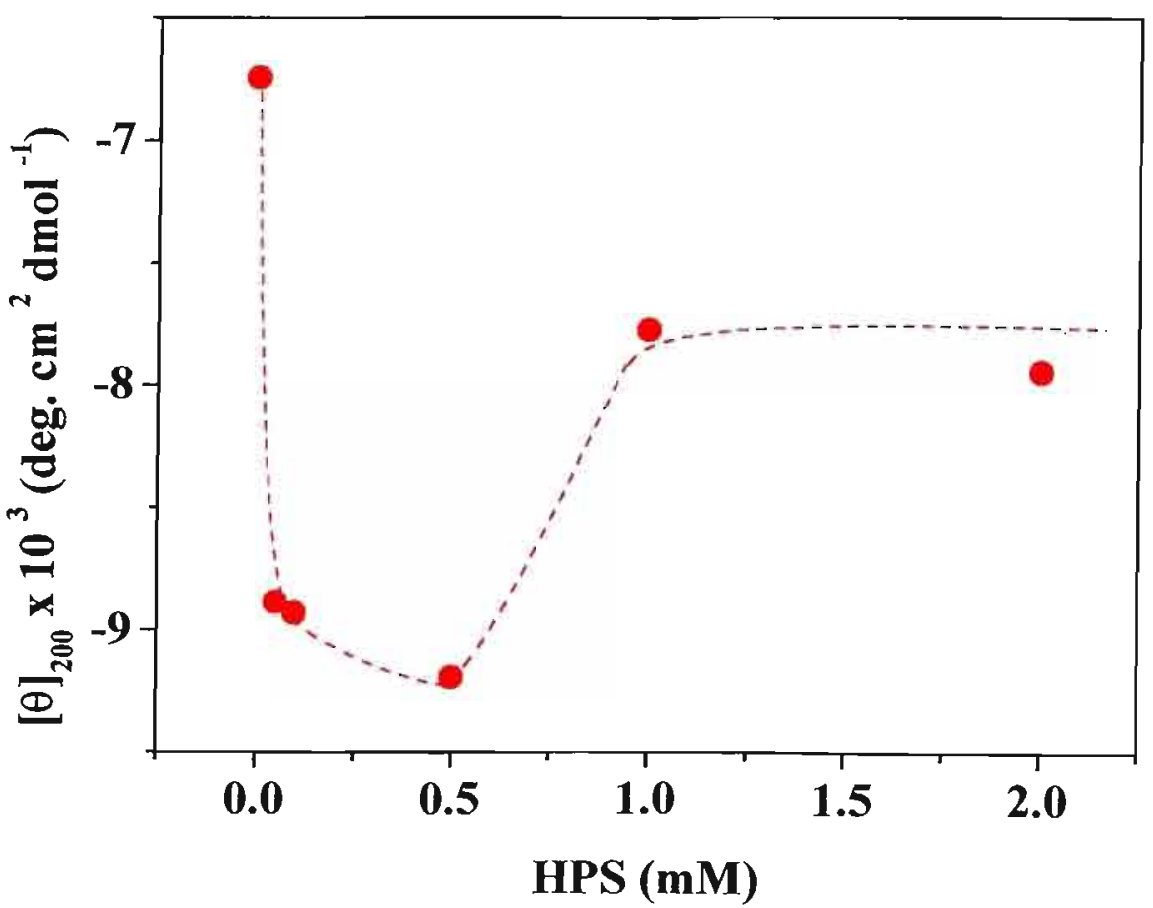

Figura 94 - Espectros de CD (a) e variação da elipticidade molar em $200 \mathrm{~nm}$ (b) de $70 \mu \mathrm{M}$ de CG em função da concentração de HPS, pH 2,5. 
Por fluorescência (Fig. 95), observa-se uma queda da intensidade de fluorescência com o aumento de HPS. Essa queda é acentuada nas primeiras adições do detergente (Fig. $95 \mathrm{~b}$ ), sendo que acima de 0,2 mM HPS, a variação é menos significativa. É possível que o peptídeo adote uma conformação tal que a cadeia lateral de outro aminoácido possa causar a supressão da intensidade de fluorescência de Tyr.

Em pH 6,0, obtiveram-se resultados relativamente semelhantes aos observados em pH 2,5 (Fig. 96); a forma dos espectros de CD (Fig. 96a) muda muito pouco com o aumento da concentração de detergente. Apenas na presença de $1 \mathrm{mM}$ HPS o espectro de CG apresenta uma mudança mais significativa; na presença de $2 \mathrm{mM}$ HPS observa-se o aparecimento de uma banda positiva centrada ao redor de $190 \mathrm{~nm}$ (Tabela 29). O espectro nessa condição indica que CG adota estrutura $\alpha$-helicoidal, no entanto a intensidade espectral é relativamente baixa. Outra possibilidade é que CG adote uma dobra $\beta$, pois foi observado na literatura que espectros parecidos com este foram atribuídos a esse tipo de estrutura secundária ${ }^{(221)}$. A intensidade de fluorescência na presença desse detergente mudou pouco em pH 6,0 (Fig. 97). A baixa afinidade por HPS pode estar relacionada com sua carga teórica.

Em pH 10,0, o espectro de CD do peptídeo em solução (Fig. 98) apresenta duas bandas negativas, a primeira ao redor de $200 \mathrm{~nm}$ (Tabela 29) e a segunda ao redor de 220 nm, cuja posição varia pouco com o aumento da concentração de detergente. Talvez existam pelo menos duas populações em solução nesse $\mathrm{pH}$, as quais poderiam ser responsáveis por essas duas bandas negativas.

Nesse $\mathrm{pH}$, os espectros de $\mathrm{CD}$ mostram que a adição de detergente induz mudanças conformacionais, ao contrário do observado nos pHs anteriores. Logo após a primeira adição de HPS, ocorre um aumento significativo da banda negativa em $220 \mathrm{~nm}$, a qual passa a ser mais intensa que a primeira. Com o aumento da concentração de HPS, a essa banda aumenta de intensidade, enquanto que a primeira tende a desaparecer, transformando-se em um ombro. Espectros de $\mathrm{CD}$ similares aos obtidos com $\mathrm{CG}$ foram atribuídos a dobras $\beta^{(208)}$. Assim nessa condição, é possível que o fragmento adote esse tipo de estrutura secundária. 
(a)

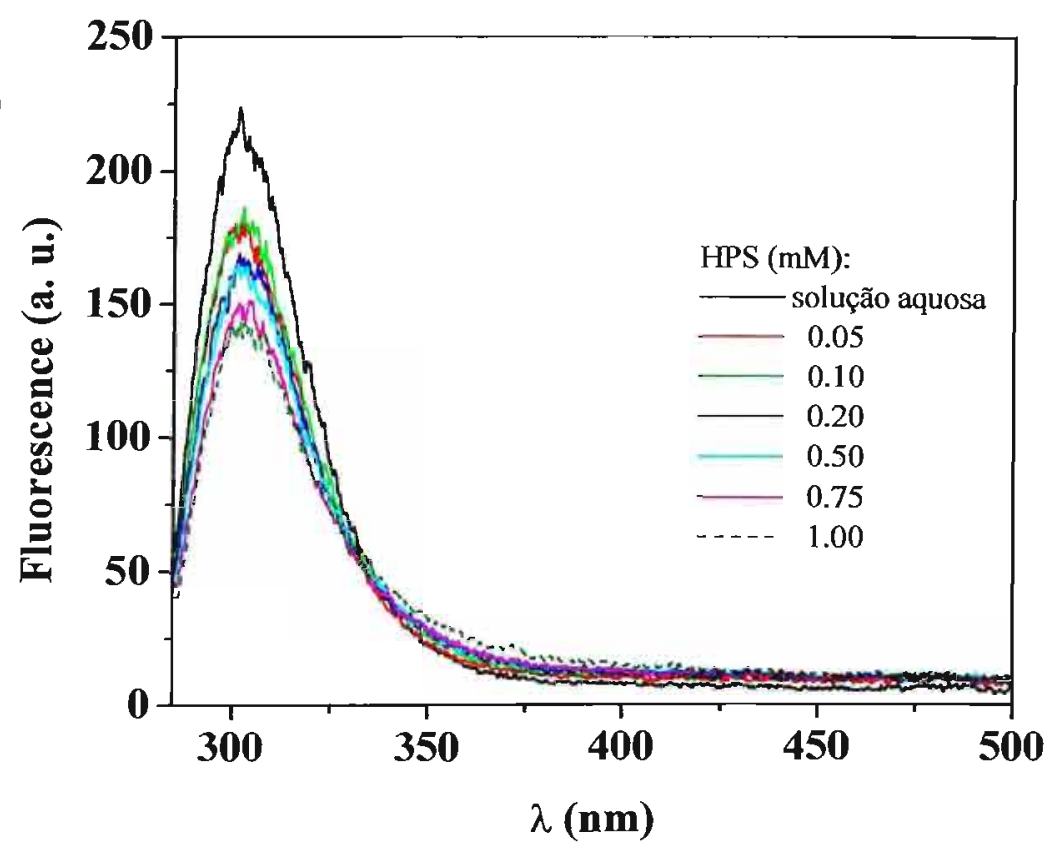

(b)

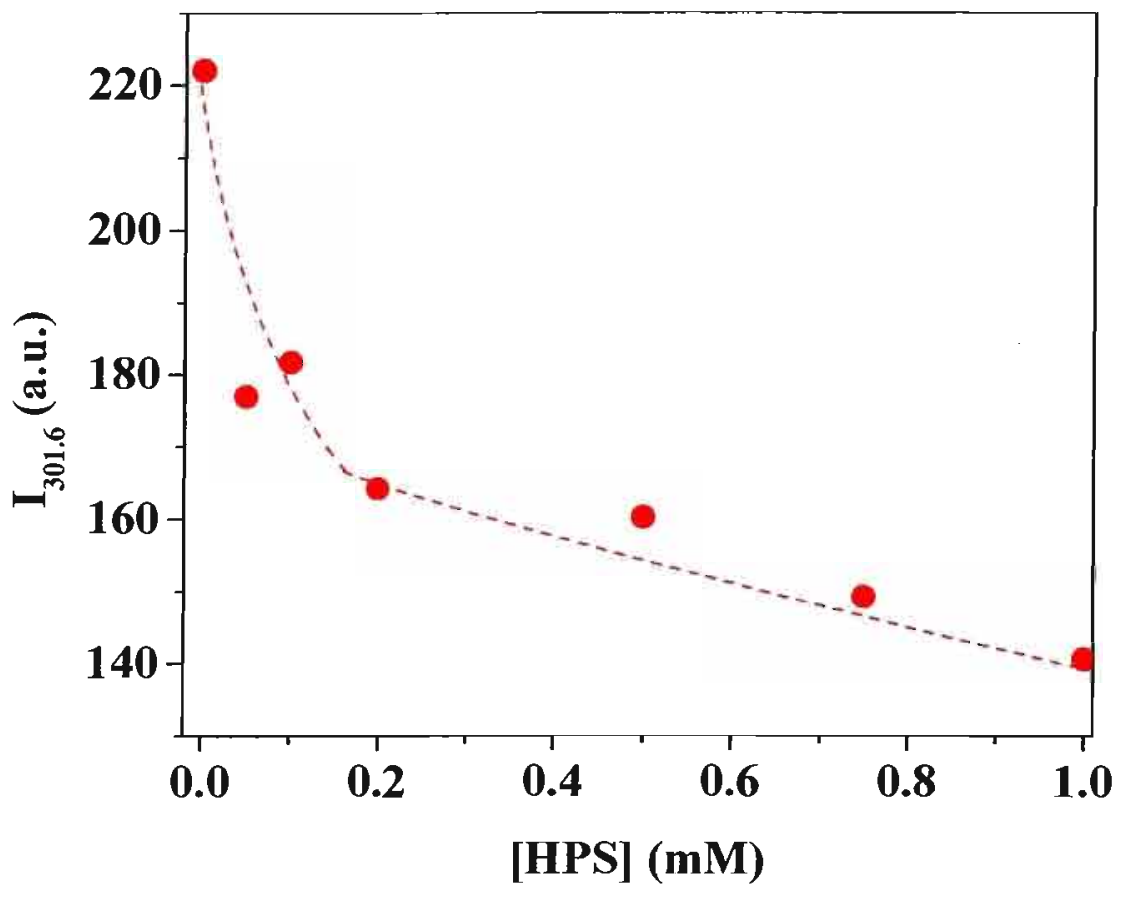

Figura 95 - Espectros de fluorescência (a) e variação da intensidade de fluorescência em $301,2 \mathrm{~nm}$ (b) de $30 \mu \mathrm{M}$ CG em função da concentração de HPS, pH 2,5. $\lambda_{\text {exc. }}=275 \mathrm{~nm}$. 
(a)
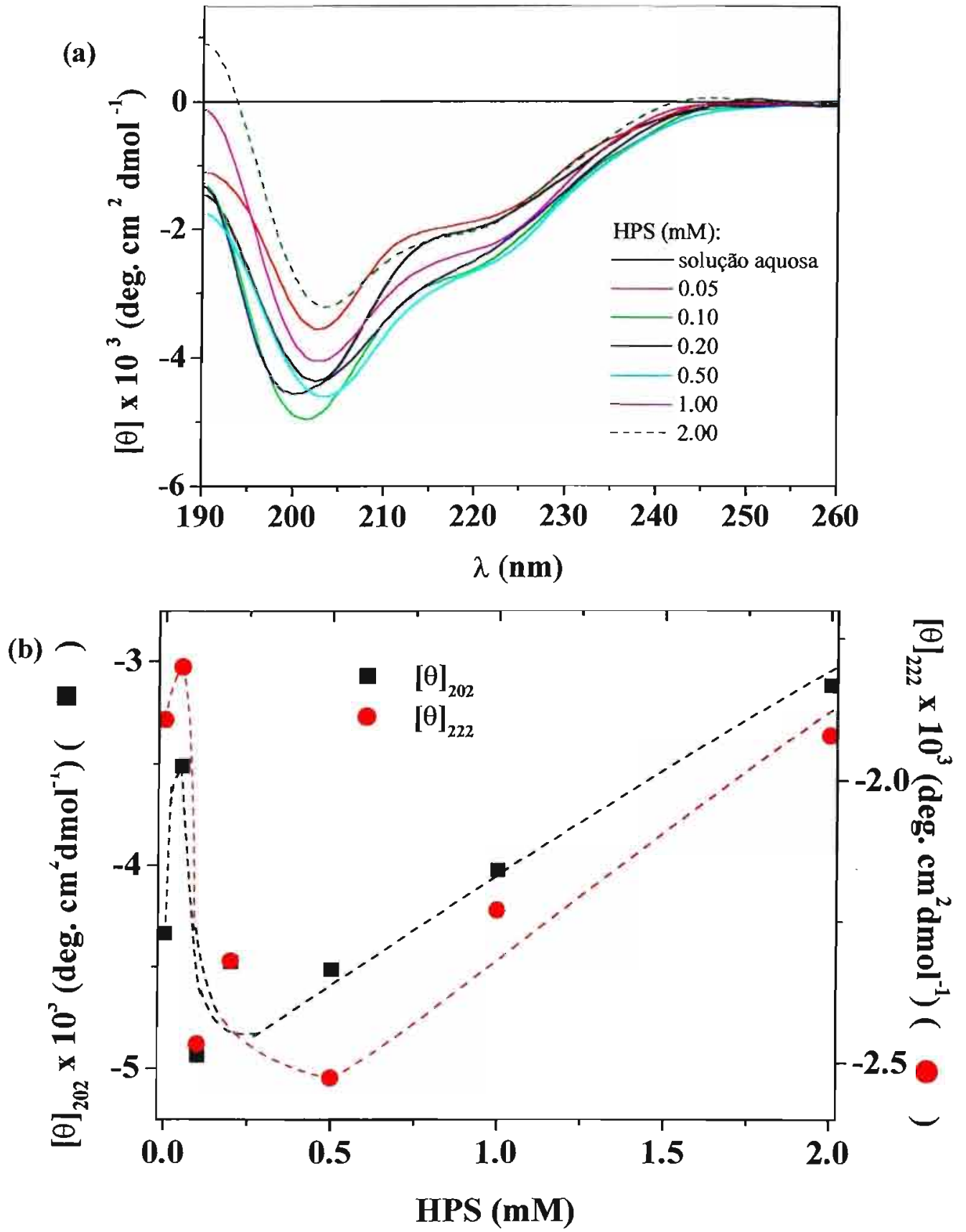

Figura 96 - Espectros de CD (a) e variação da elipticidade molar em 202 e 222 nm (b) de $70 \mu \mathrm{M}$ de CG em função da concentração de HPS, pH 6,0. 
(a)

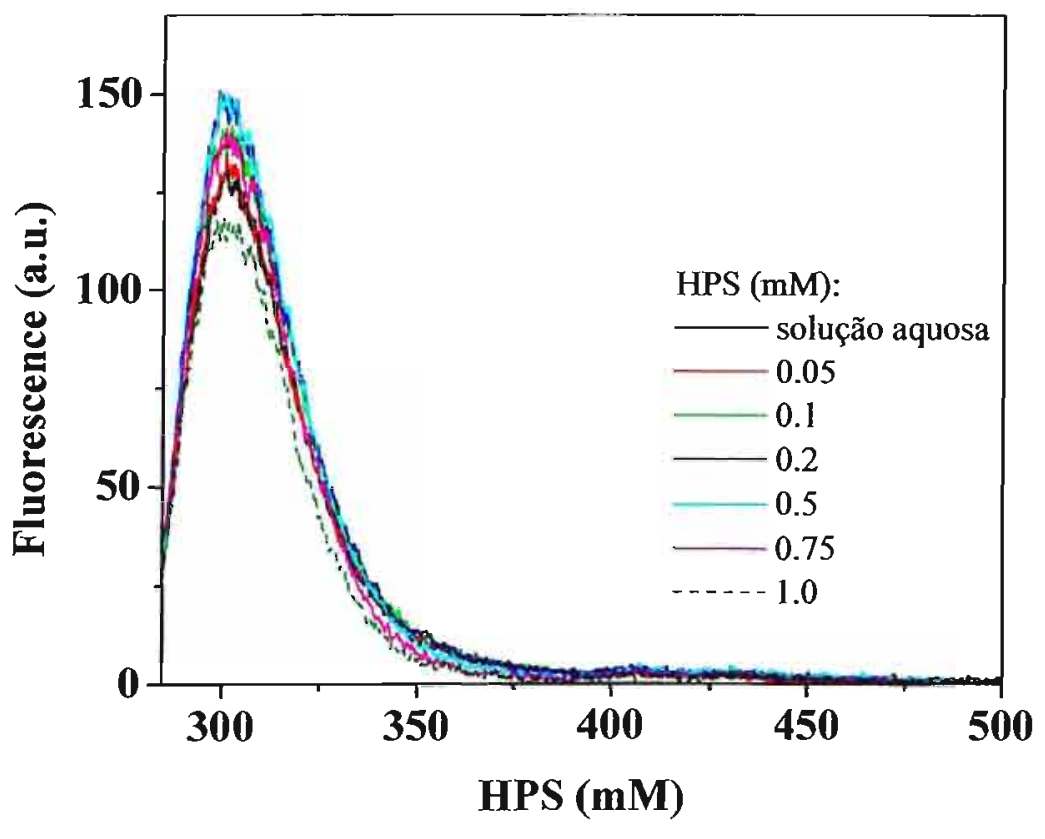

(b)

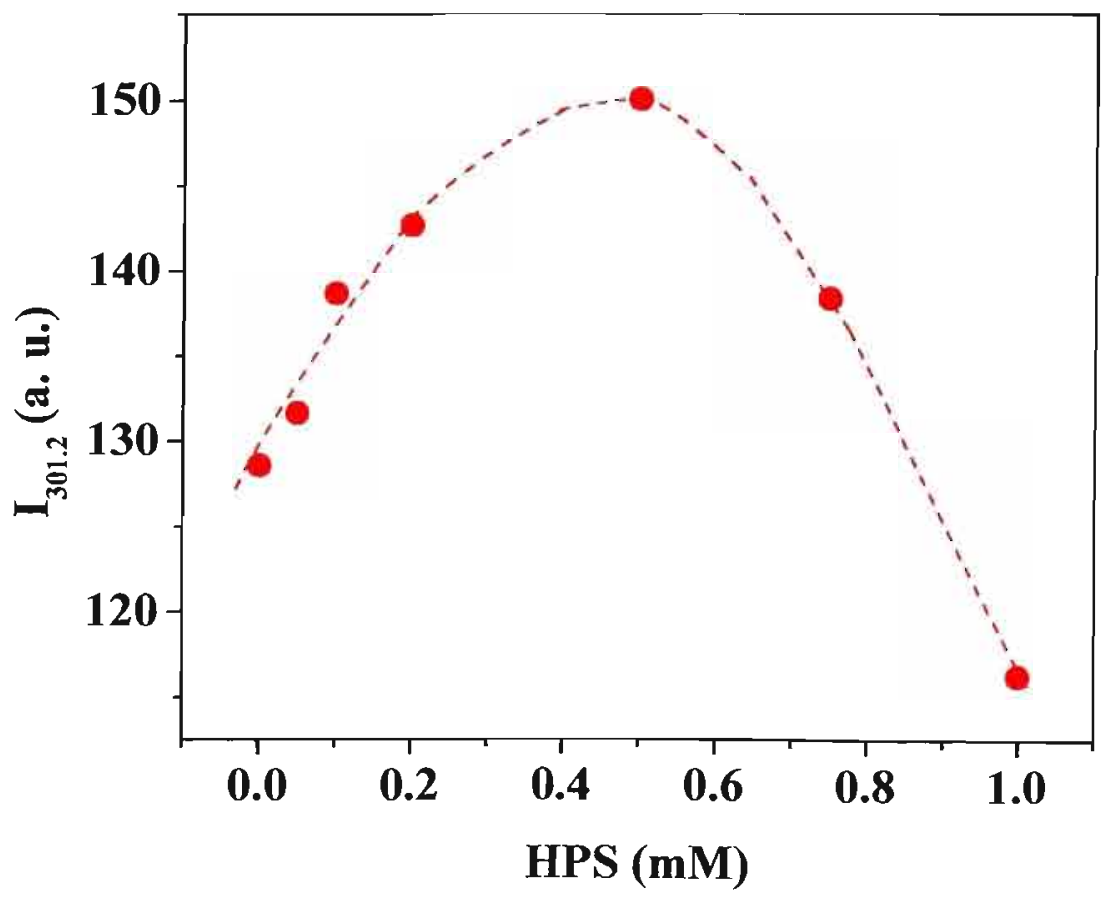

Figura 97 - Espectros de fluorescência (a) e variação da intensidade de fluorescência em $301,2 \mathrm{~nm}$ (b) de $30 \mu \mathrm{M}$ de CG em função da concentração de HPS, pH 6,0. $\lambda_{\text {exc. }}=275 \mathrm{~nm}$. 
(a)
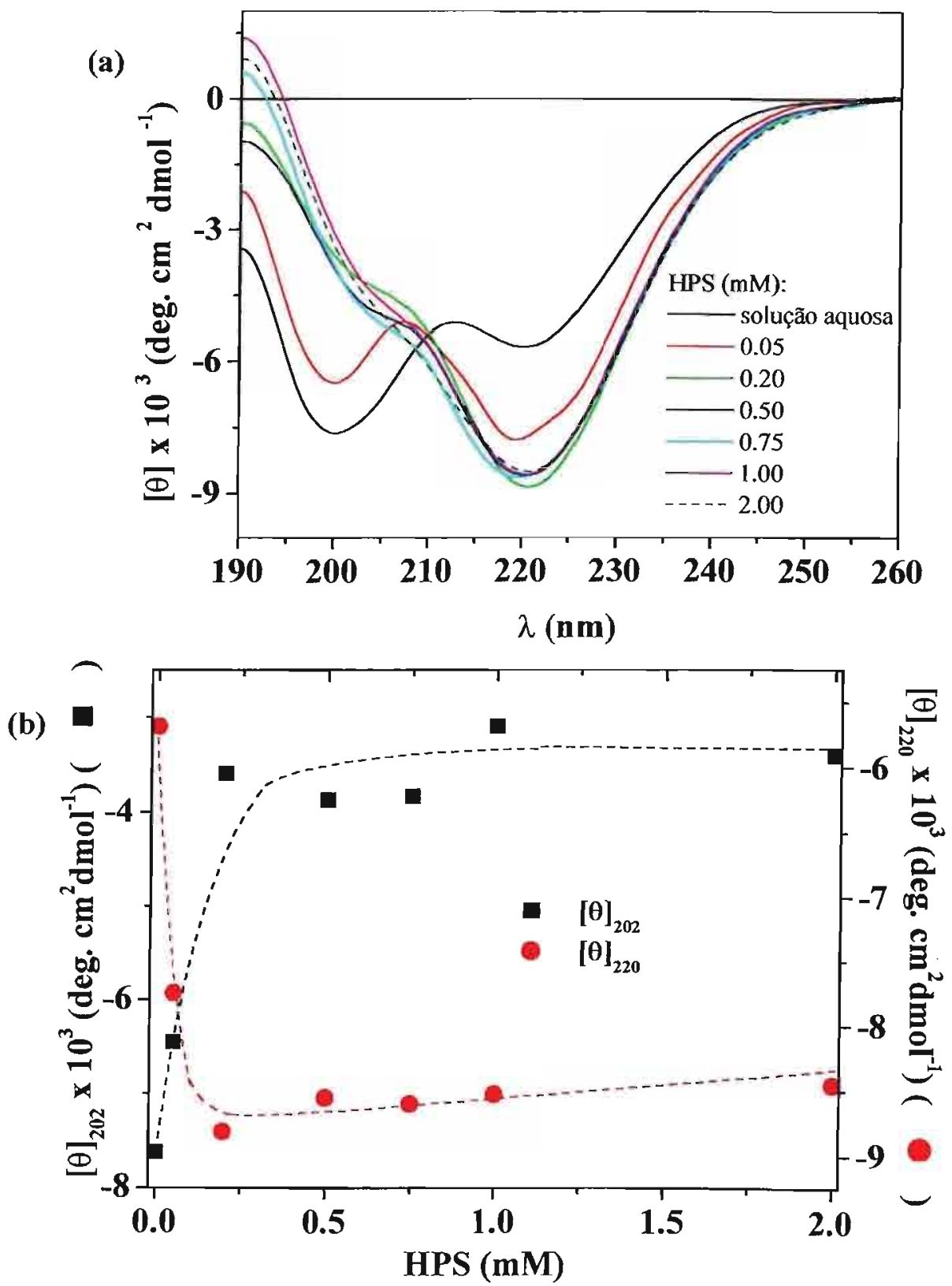

Figura 98 - Espectros de CD (a) e variação da elipticidade molar em 202 e 220 nm (b) de $70 \mu \mathrm{M}$ de CG em função da concentração de HPS, pH 10,0. 
Por fluorescência, excitando-se a amostra em 275 nm (Fig. 99), ao se adicionarem concentrações crescentes de HPS, ocorre um aumento constante da intensidade de fluorescência, o que indica que CG liga-se a HPS. Além disso, nesse pH ocorre a formação de tirosinato, cujo comprimento de onda de excitação é $292 \mathrm{~nm}$; normalmente seu espectro de emissão é pouco intenso devido ao baixo rendimento quântico do fenolato ${ }^{(215)}$. Ao excitar-se a amostra nesse comprimento de onda (Fig. 100), o espectro na ausência de HPS apresenta apenas uma banda pouco intensa, com máximo ao redor de $350 \mathrm{~nm}$. Com a adição de HPS, observa-se um aumento da intensidade de fluorescência dessa banda e também de uma banda de emissão ao redor de $302 \mathrm{~nm}$, que corresponde ao comprimento de onda de emissão do fenol.

É importante ressaltar que em nenhum $\mathrm{pH}$, principalmente nos mais alcalinos, foi observada uma banda relativa à emissão de bitirosina, o que indica que o peptídeo não agrega na presença desse detergente.

Para tentar estabelecer uma condição na qual o grau de agregação do peptídeo diminuísse, foi feito um filme de $\mathrm{CG}$, que foi hidratado na presença de altas concentrações de detergentes. Em seguida, estudou-se o efeito do $\mathrm{pH}$ nessas condições.

$\mathrm{Na}$ presença de $50 \mathrm{mM}$ HPS, os espectros de CD (Fig. 101a) na presença do detergente são diferentes do que o observado em solução aquosa, porém não sugerem que o peptídeo esteja monomérico. Apesar de alguns dos espectros serem parecidos com os de uma $\alpha$-hélice, os valores de elipticidade molar são relativamente pequenos e os mínimos das bandas negativas não se encontram na posições características de uma $\alpha$-hélice

Na Figura 101b comparam-se esses espectros com àqueles obtidos em solução aquosa nos pHs 2,0, 6,0 e 10,0. Há uma diferença significativa na forma dos espectros de $\mathrm{CD}$ nas duas condições. A variação da elipticidade molar em $215 \mathrm{~nm}$ em função do $\mathrm{pH}$ (Fig. 101c) não indica variação significativa do $\mathrm{pK}_{\mathrm{a}}$ do peptídeo quando comparado com sua carga teórica.

Por fluorescência (Fig. 102), a intensidade de fluorescência da amostra excitada em $275 \mathrm{~nm}$ (Fig. 102a) diminui gradualmente até pH 8,0, diminuindo mais abruptamente desse pH em diante, o que provavelmente reflete a desprotonação dos vários grupos ionizáveis do CG. Em pH 11,6, a banda relativa ao espectro de emissão da tirosina desaparece por completo. 
(a)

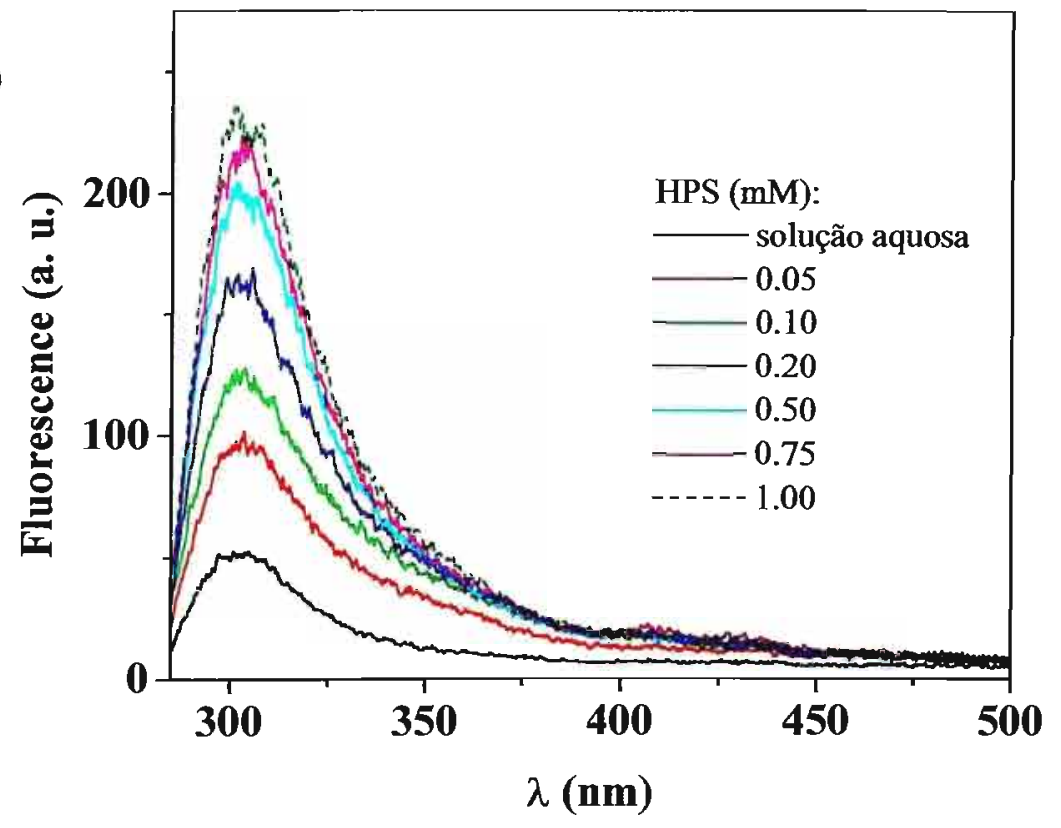

(b)

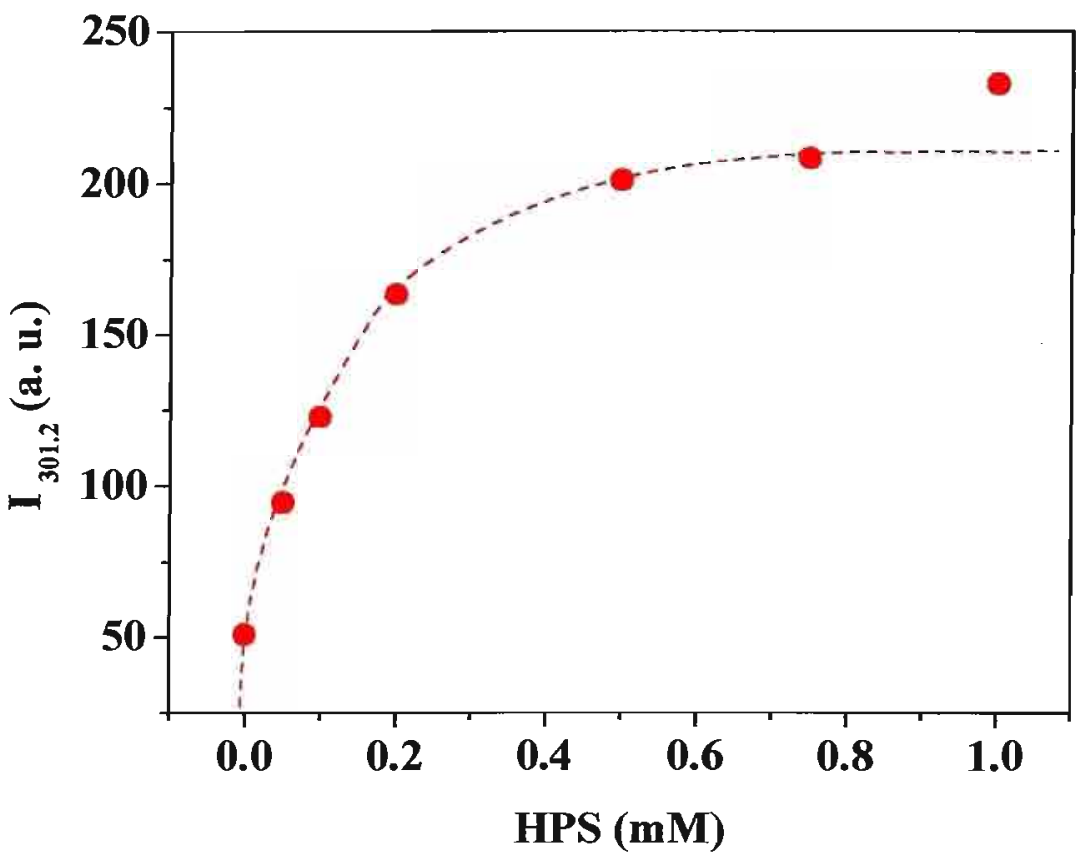

Figura 99 - Espectros de fluorescência (a) e variação da intensidade de fluorescência em $301,2 \mathrm{~nm}$ (b) de $30 \mu \mathrm{M}$ de CG em função da concentração de HPS, pH 10,0. $\lambda_{\text {exc. }}=275$ nm. 


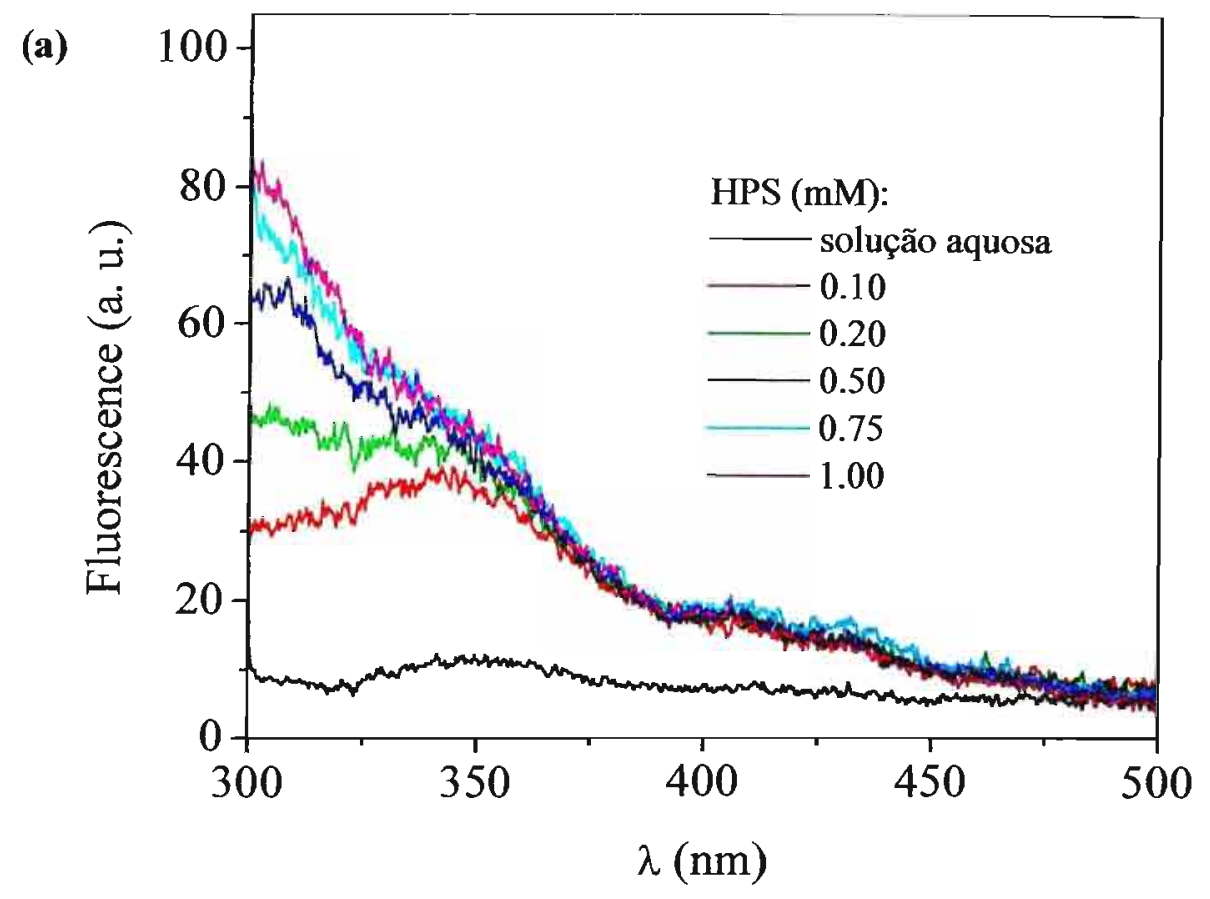

(b)

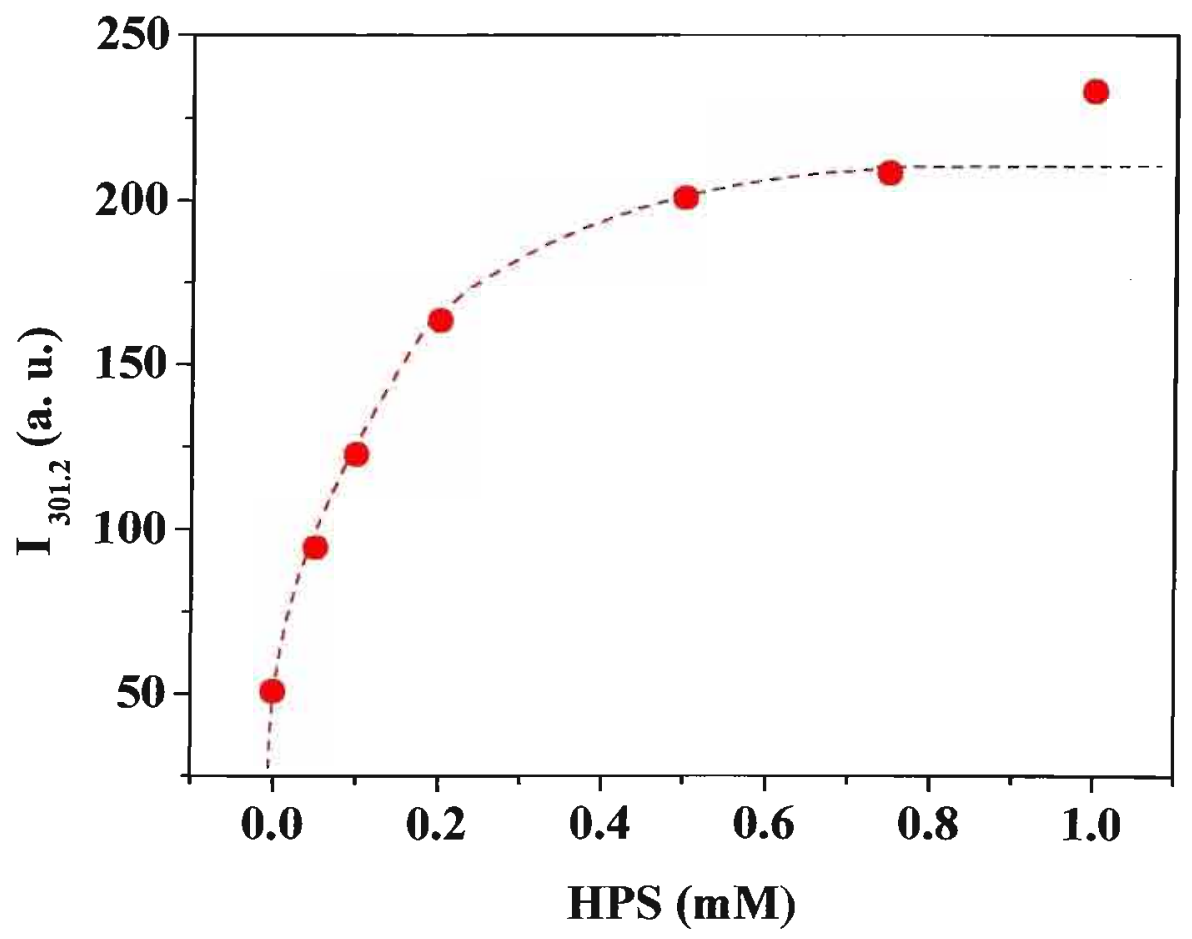

Figura 100 - Espectros de fluorescência (a) e variação da intensidade de fluorescência em $345 \mathrm{~nm}$ (b) de $30 \mu \mathrm{M}$ de CG em função da concentração de HPS, pH 10,0. $\lambda_{\text {exc. }}=292 \mathrm{~nm}$. 
(a)

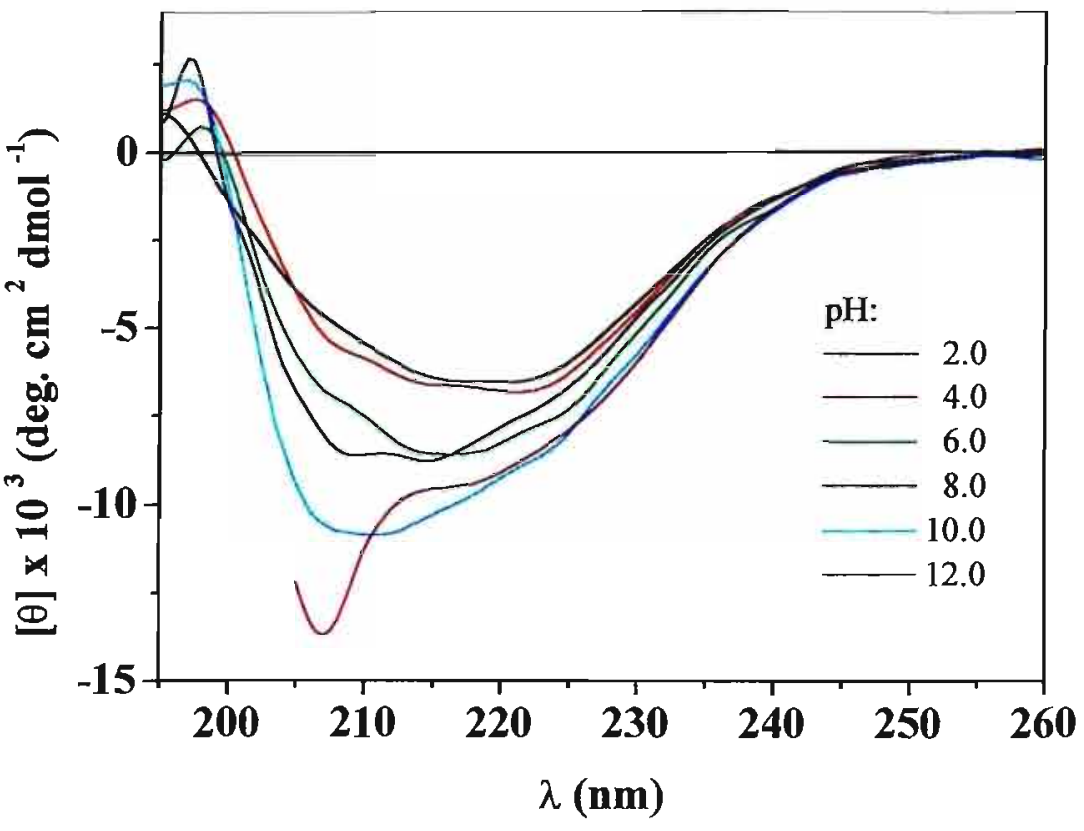

(b)

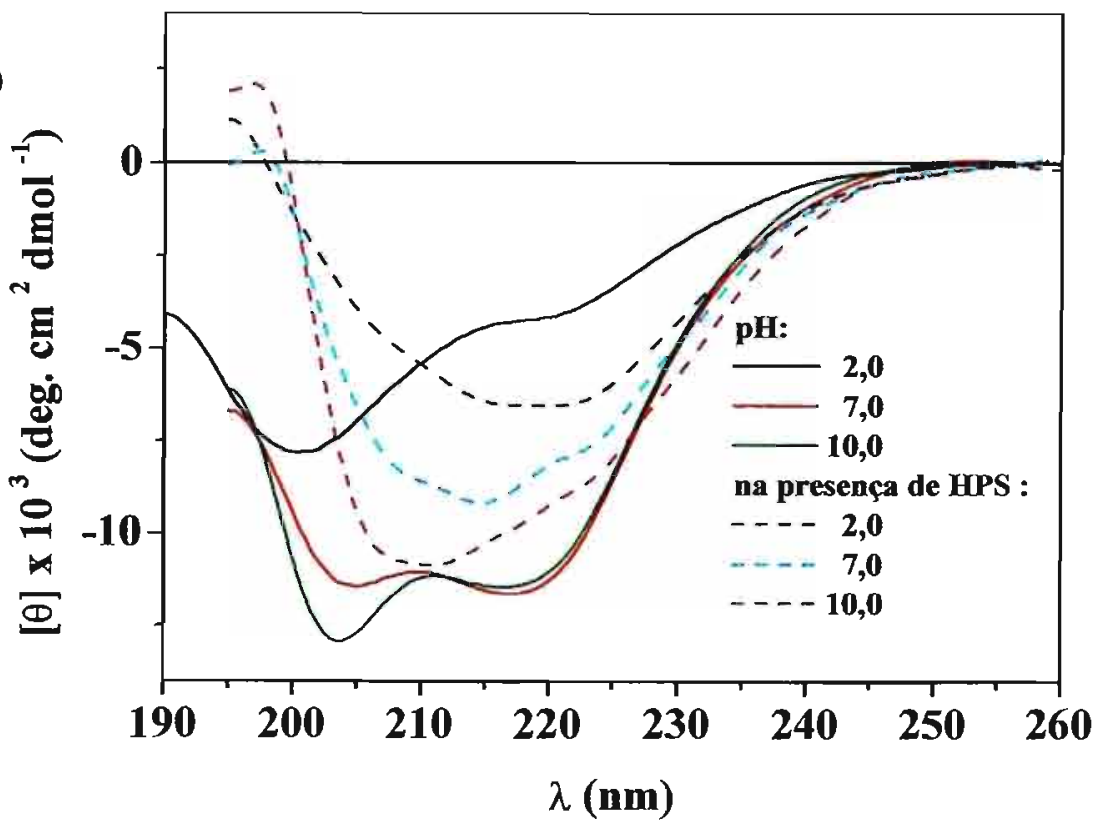


(c)

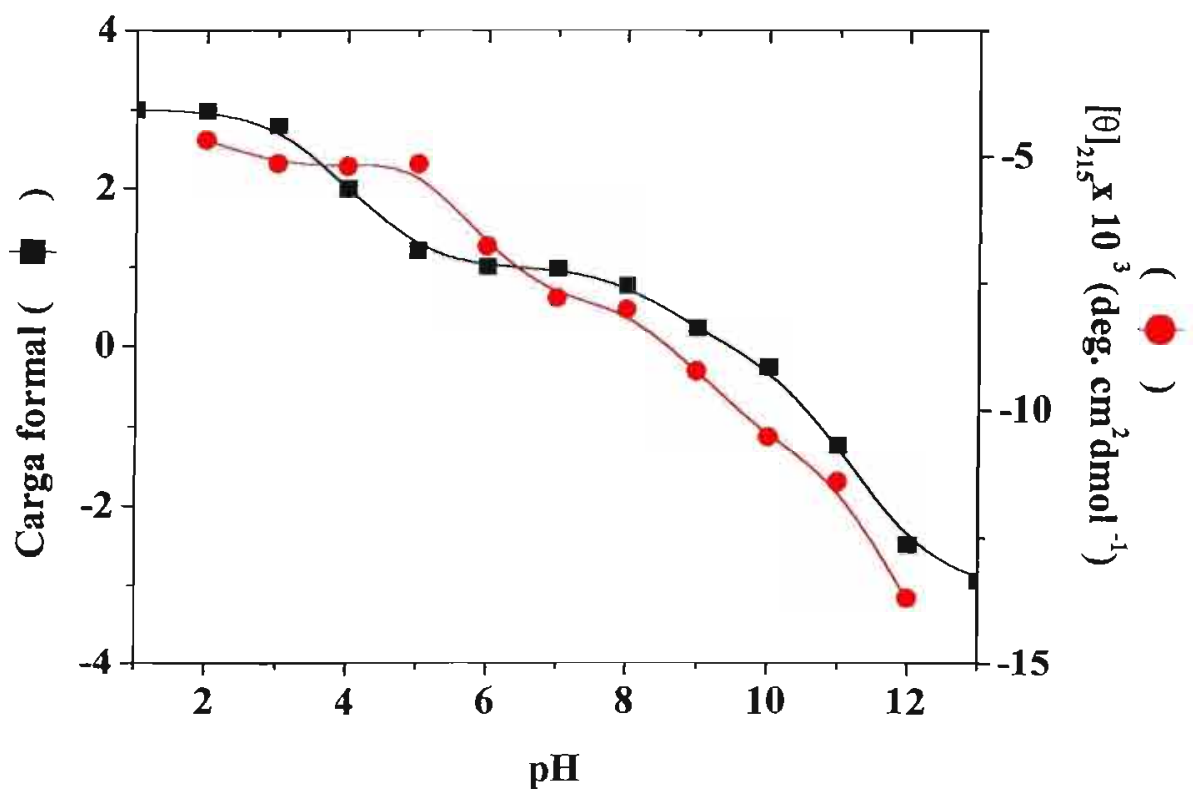

Figura 101 - Espectros de CD de um filme de $70 \mu \mathrm{M}$ CG hidratado na presença de $50 \mathrm{mM}$ HPS em função do pH (a). Comparação entre os espectros de CD de CG em função do $\mathrm{pH}$ em ausência epresença de HPS (b). Variação da elipticidade molar em $215 \mathrm{~nm}$ em função do $\mathrm{pH}$ em presença de HPS (c). 

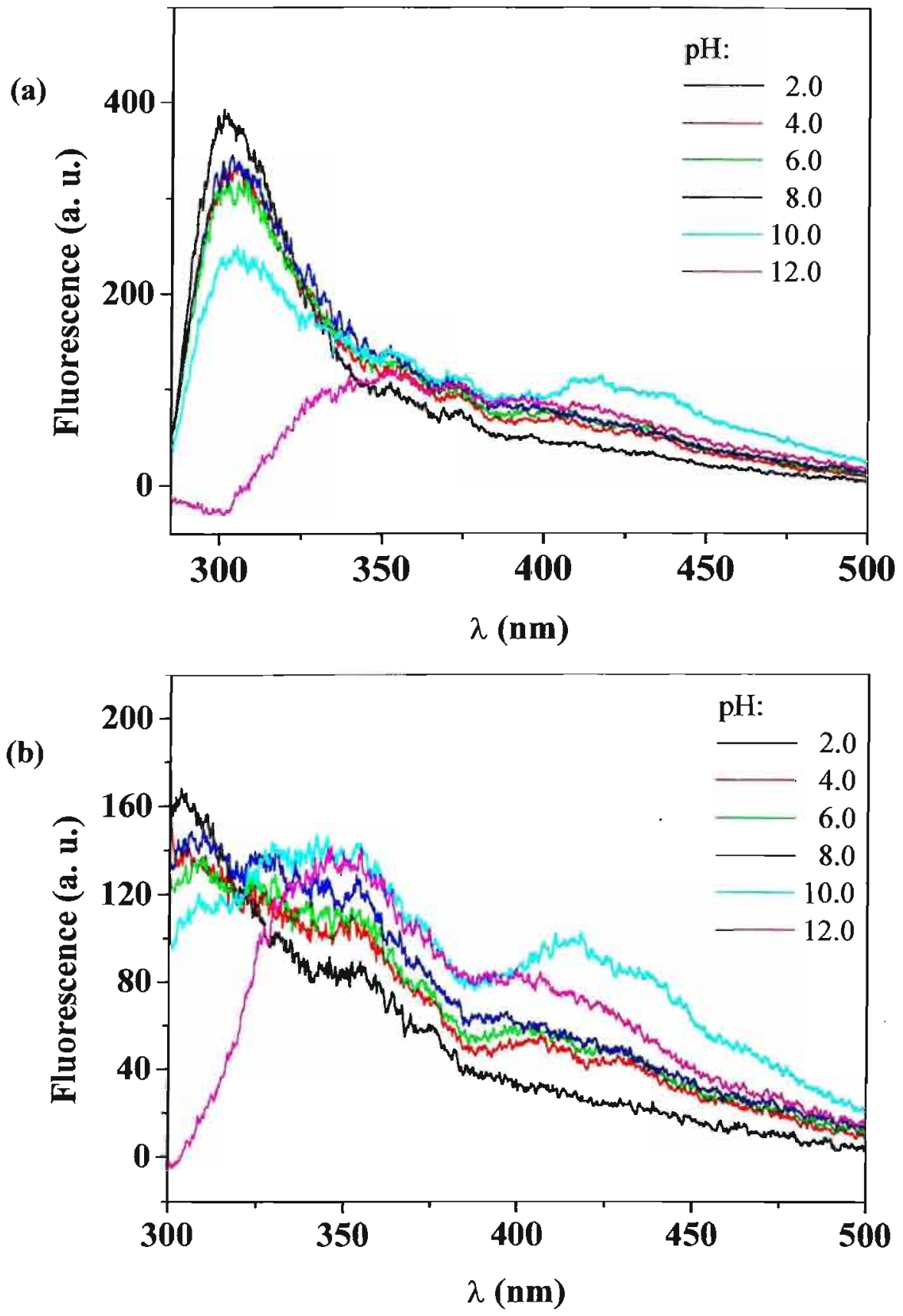

Figura 102 - Espectros de fluorescência de $30 \mu \mathrm{M}$ de CG hidratado na presença de 50 mM HPS em função do pH. $\lambda_{\text {exc. }}=275$ (a) e 292 nm(b) 
Excitando-se a amostra tanto em 275 ou $292 \mathrm{~nm}$, observa-se uma banda relativa à emissão de tirosinato. Quando a amostra é excitada em $275 \mathrm{~nm}$, essa banda só é significativa em torno de $\mathrm{pH} 10$. Na Fig 105b, contudo, essa banda aparece em pHs mais baixos, embora fraca.

Na Fig. 103 compara-se a variação da intensidade de fluorescência da amostra excitada tanto em 275 quanto em $292 \mathrm{~nm}$ com a variação da carga formal em função do pH. Em ambos os casos elas são diferentes da variação da carga formal, o que indica um deslocamento do $\mathrm{pK}_{\mathrm{a}}$ dos grupos ionizáveis. Esperar-se-ia que na presença de uma superfície zwitteriônica, os $\mathrm{pK}_{\mathrm{a}} \mathrm{s}$ de Asp, Glu e Tyr aumentem, enquanto que os $\mathrm{pK}_{\mathrm{a}} \mathrm{s}$ das lisinas e do grupo N-terminal diminuam. ${ }^{(222)}$

\subsubsection{Estudos na presença de LPC}

Para o CG em pH 2,5 (Fig. 104), os espectros de CD (Fig. 104a) mostram mudanças na forma do espectro com adições crescentes do detergente, principalmente acima de 0,5 $\mathrm{mM}$, ao contrário do observado com HPS.

$\mathrm{Na}$ ausência de LPC, o espectro de CG apresenta apenas uma banda negativa, centrada em $200 \mathrm{~nm}$ (Tabela 30). A partir de 0,2 mM LPC ocorre um deslocamento progressivo de $\lambda_{\min }$ para comprimentos de onda mais altos, sendo que na presença de concentrações maiores que $1 \mathrm{mM}$ de LPC, os espectros do peptídeo apresentam uma banda positiva e duas negativas; a primeira centrada em $205 \mathrm{~nm}$ e a segunda em $220 \mathrm{~nm}$. Esses resultados indicam que a interação de $\mathrm{CG}$ com o surfactante induz mudanças conformacionais. De fato, na presença de $10 \mathrm{mM}$ LPC, o espectro de CD de CG é indicativo de estrutura $\alpha$-helicoidal. No entanto, na presença de quantidades maiores de LPC, os espectros ficam mais alargados e achatados, o que pode ser devido ao espalhamento de luz. Em $30 \mathrm{mM}$ LPC, por exemplo, não é mais possível observar duas bandas negativas, somente uma banda alargada com mínimo ao redor de $210 \mathrm{~nm}$. Contudo, o espalhamento de luz provocado por altas concentrações do detergente poderia provocar a deformação do espectro de CD e ser responsável pelo alargamento da banda negativa.

Por fluorescência (Fig. 105), observa-se um aumento significativo da intensidade de fluorescência logo após a primeira adição de detergente, o que indica que o peptídeo tem grande afinidade pelo detergente. Acima de $5 \mathrm{mM} \mathrm{LPC}$, a intensidade de fluorescência 
(a)

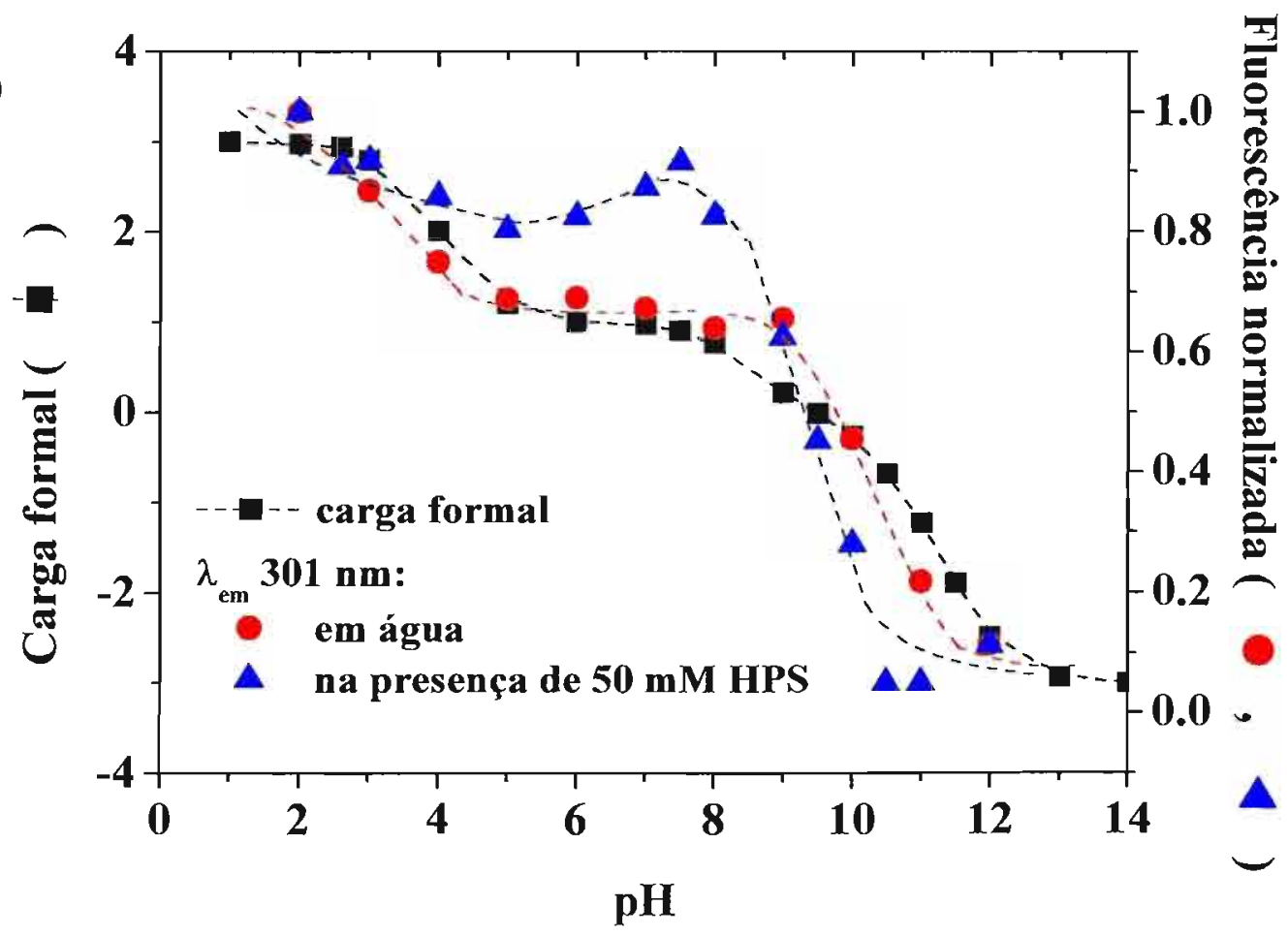

(b)

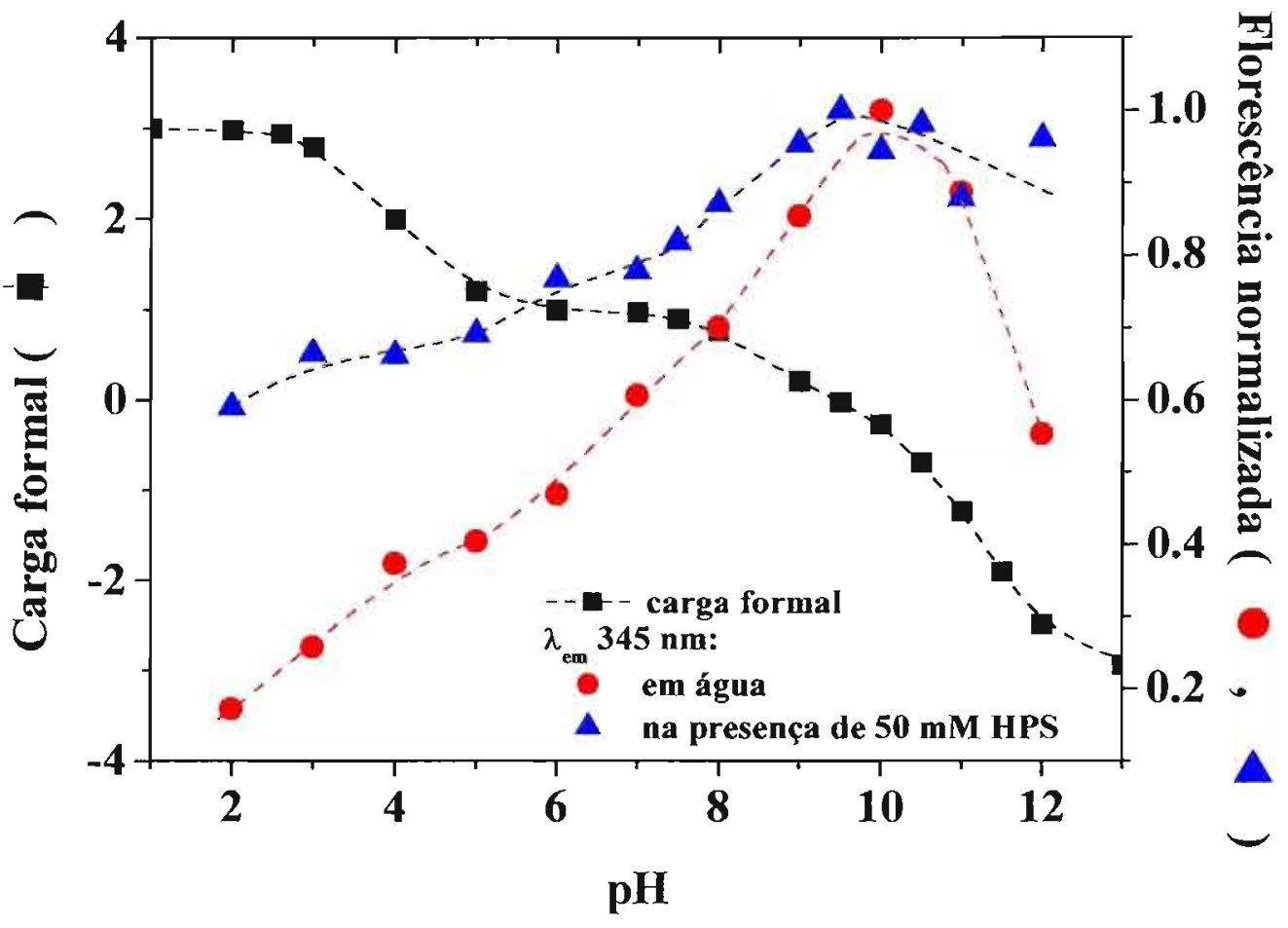

Figura 103 - Carga teórica e variação da intensidade de fluorescência de $30 \mu \mathrm{M}$ de CG em água e hidratado na presença de $50 \mathrm{mM}$ HPS em função do $\mathrm{pH}$. $\lambda_{\mathrm{em}}=301$ (a) e 345 nm (b). 
(a)

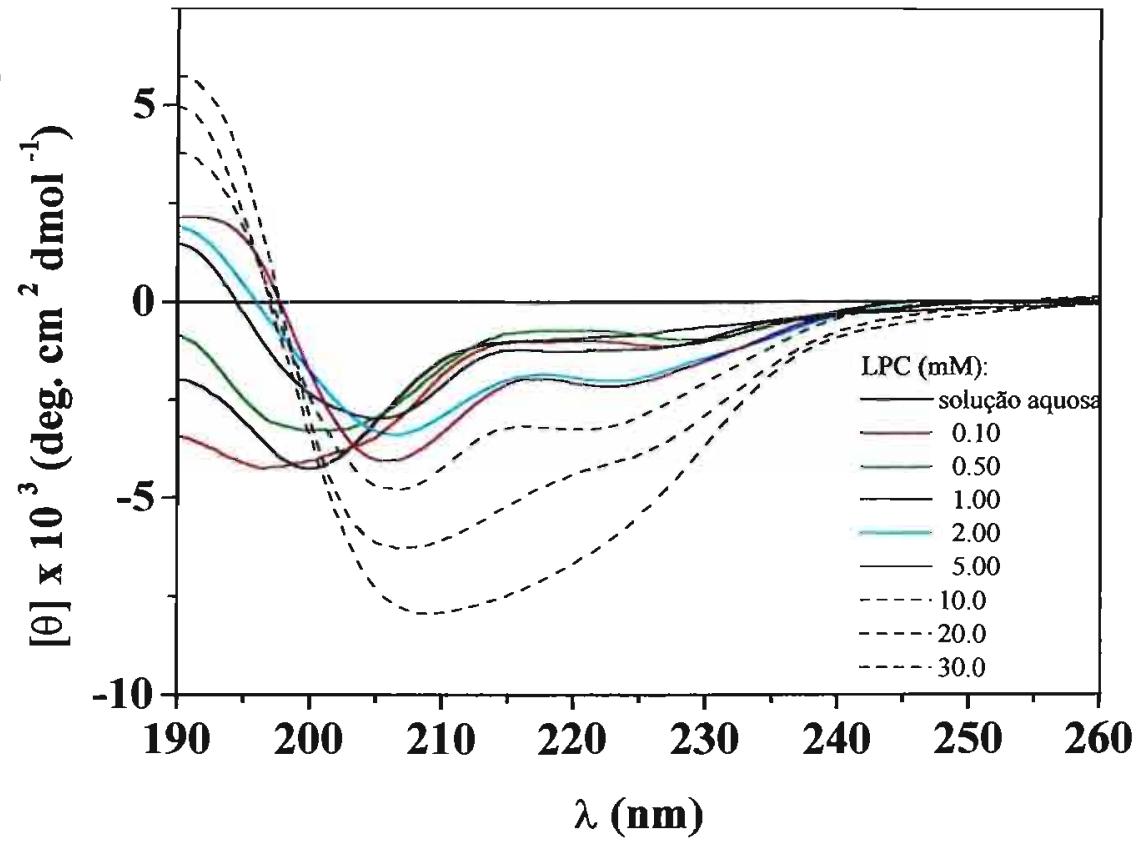

(b)

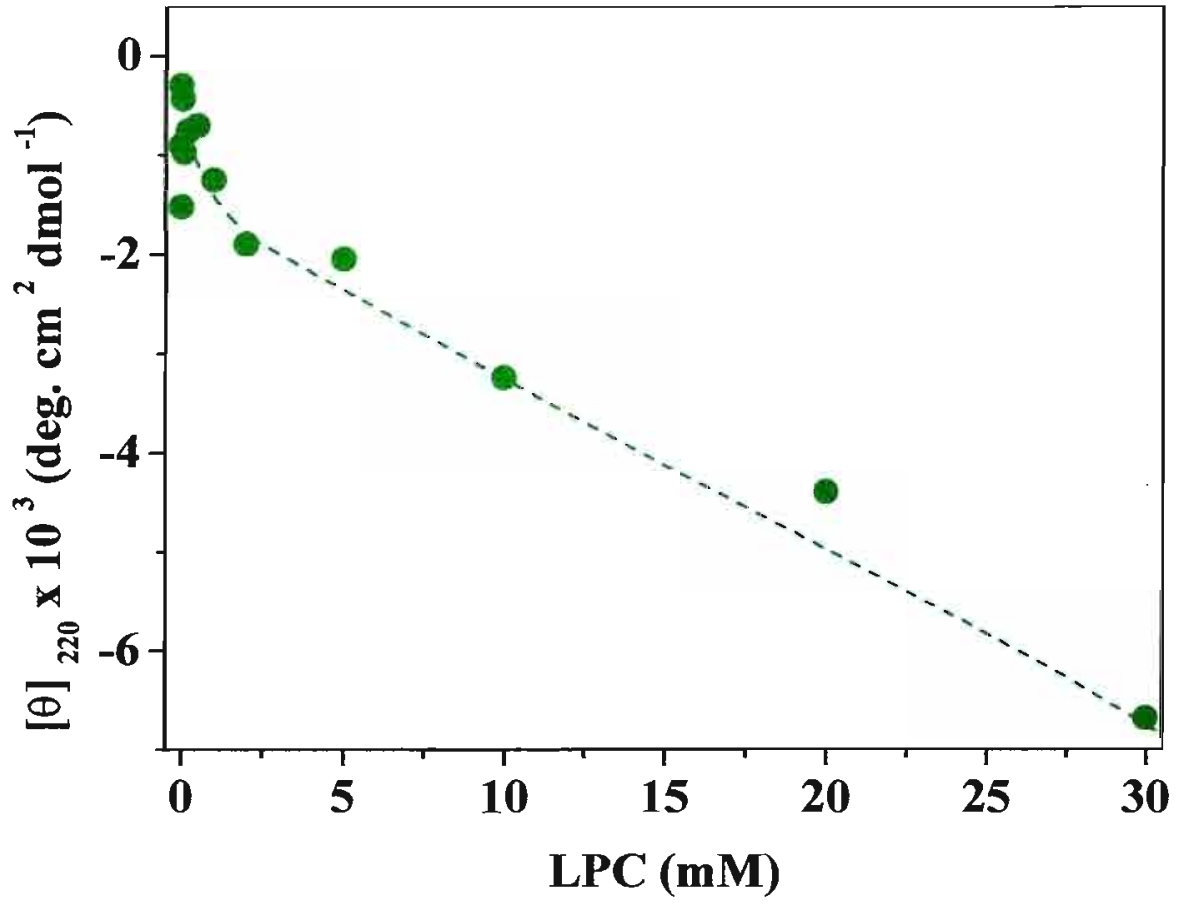

Figura 104 - Espectros de CD (a) e variação da elipticidade molar em $220 \mathrm{~nm}$ (b) de 70 $\mu \mathrm{M}$ de CG em função da concentração de LPC, pH 2,5. 


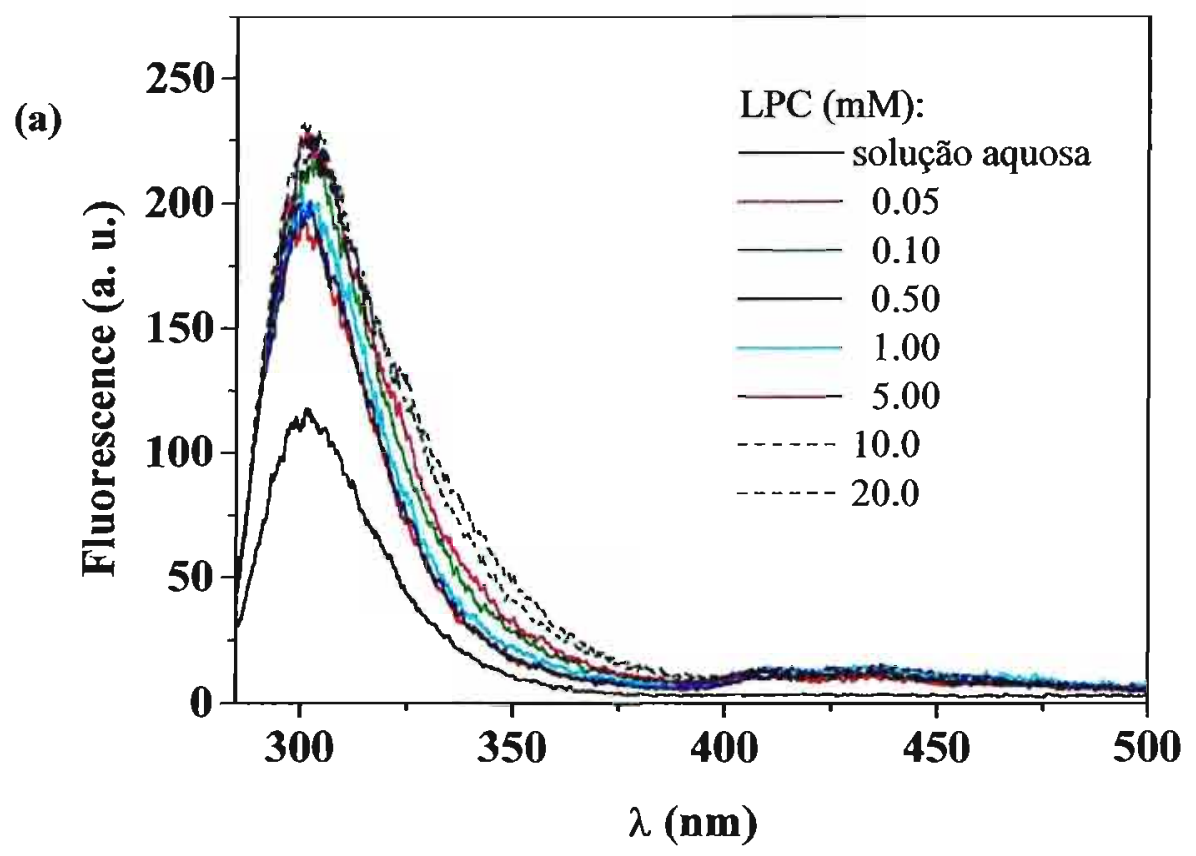

(b)

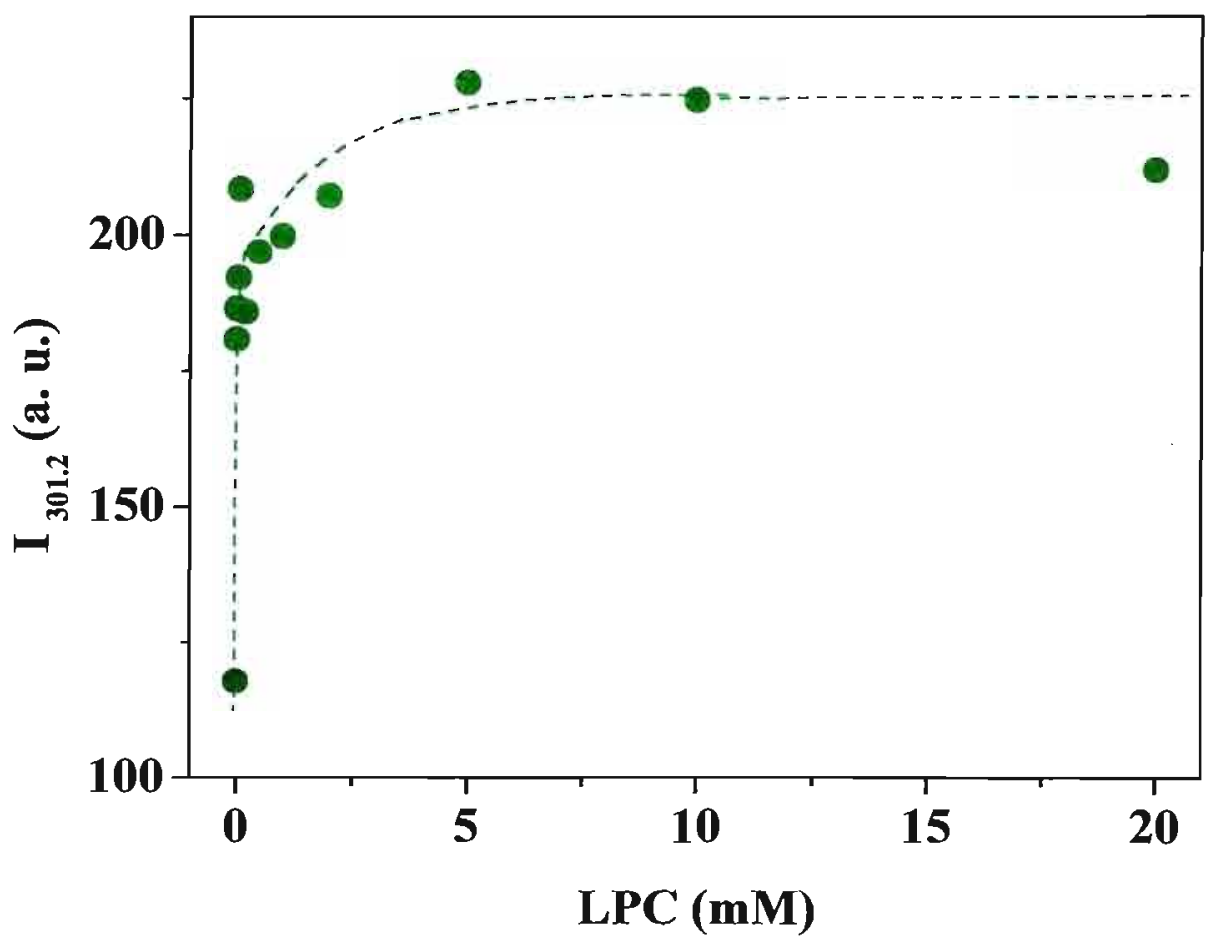

Figura 105 - Espectros de fluorescência (a) e variação da intensidade de fluorescência em $301,2 \mathrm{~nm}$ (b) de $30 \mu \mathrm{M}$ de CG em função da concentração de LPC, pH 2,5. $\lambda_{\text {exc. }}=$ $275 \mathrm{~nm}$. 
aumenta gradualmente (Fig. 105b), tendendo a se estabilizar, o que sugere que dessa concentração em diante o peptídeo já estaria praticamente todo ligado ao detergente.

Tabela 30 - Posição do comprimento de onda máximo $\left(\lambda_{\max }\right)$ e mínimo $\left(\lambda_{\min }\right)$ nos espectros de $\mathrm{CD}$ de CG em presença de concentrações crescentes de $\mathrm{L} P \mathrm{PC}$ em função do $\mathrm{pH}$.

\begin{tabular}{ccccccc}
\hline$[\mathrm{LPC}](\mathrm{mM})$ & \multicolumn{2}{c}{$\mathrm{pH} 2,5$} & \multicolumn{2}{c}{$\mathrm{pH} 6,0$} & $\mathrm{pH} \mathrm{10,0}$ \\
\hline & $\lambda_{\max }$ & $\lambda_{\min }$ & $\lambda_{\max }$ & $\lambda_{\min }$ & $\lambda_{\max }$ & $\lambda_{\min }$ \\
sem adição & -- & 201 & - & $201,216^{*}$ & - & 200,220 \\
0,01 & -- & $198,218^{*}$ & -- & 202,218 & - & $203^{*}, 219$ \\
0,02 & -- & 199 & - & 203 & - & $204^{*}, 219$ \\
0,05 & -- & 198 & -- & $204,219^{*}$ & -- & $205^{*}, 219$ \\
0,1 & -- & 197 & - & 205,219 & -- & $202^{*}, 219$ \\
0,2 & -- & 201 & - & 202 & - & $202^{*}, 219$ \\
0,5 & 190 & 205,223 & 190 & 207,219 & 190 & $202^{*}, 219$ \\
1,0 & 190 & 206,223 & 190 & 214 & 190 & $202^{*}, 219$ \\
5,0 & 192 & 206,223 & 190 & 207,218 & 190 & 219 \\
10 & 190 & 207,221 & 190 & 213 & 190 & 218 \\
20 & 190 & 207 & 190 & 213 & 190 & 217 \\
30 & 190 & 209 & 190 & 214 & 190 & 217 \\
\hline
\end{tabular}

Em pH 6,0 (Fig. 106), os espectros de CD também mostram que o CG se liga ao detergente e sofre mudanças conformacionais. A forma do espectro muda pouco até $10 \mathrm{mM}$ LPC. A partir daí, a intensidade do espectro aumenta consideravelmente e observa-se o surgimento de uma banda positiva acima de $195 \mathrm{~nm}$ (Tabela 30). Por fluorescência (Fig. 107), observa-se um aumento contínuo de intensidade com adição de LPC, porém de uma maneira mais gradual que em $\mathrm{pH}$ 2,5. Acima de 5mM (Fig. 107b) a intensidade de fluorescência varia pouco e assim como no $\mathrm{pH}$ anterior, tende a se estabilizar.

Em pH 10,0, os espectros de CD (Fig. 108) mudam de modo mais abrupto do que o observado no $\mathrm{pH}$ anterior. Na presença de concentrações baixas do detergente observa-se a presença de ombros no espectro de CD, centrados em torno de $202 \mathrm{~nm}$ (Tabela 30), os quais desaparecem a partir de $5 \mathrm{mM} \mathrm{LPC}$, sendo que dessa concentração de detergente em diante a banda negativa apresenta-se alargada. Com o aumento da concentração de LPC, também foi observado o aumento de intensidade de uma banda negativa centrada ao redor de $218 \mathrm{~nm}$ e o aparecimento de uma banda positiva pouco intensa. De modo geral parece que a LPC induz uma mudança conformacional de dobra $\beta$ para folha $\beta$, visto pelo aparecimento de uma banda positiva em torno de $191 \mathrm{~nm}$ e de uma banda negativa centrada ao redor de $218 \mathrm{~nm}$. 
(a)
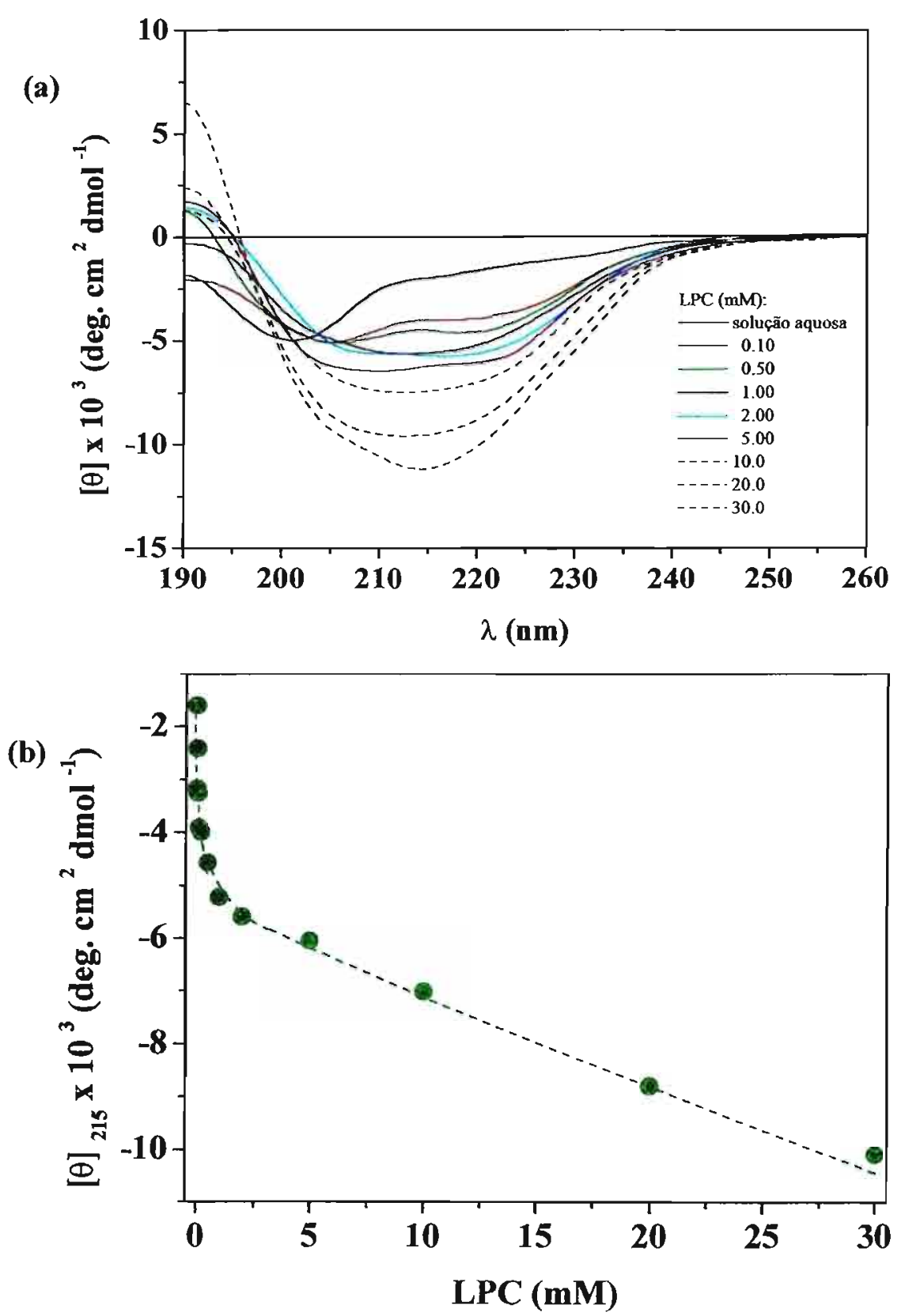

Figura 106 - Espectros de CD (a) e variação da elipticidade molar em $220 \mathrm{~nm}$ (b) de 70 $\mu \mathrm{M}$ de $\mathrm{CG}$ em função da concentração de LPC, pH 6,0 

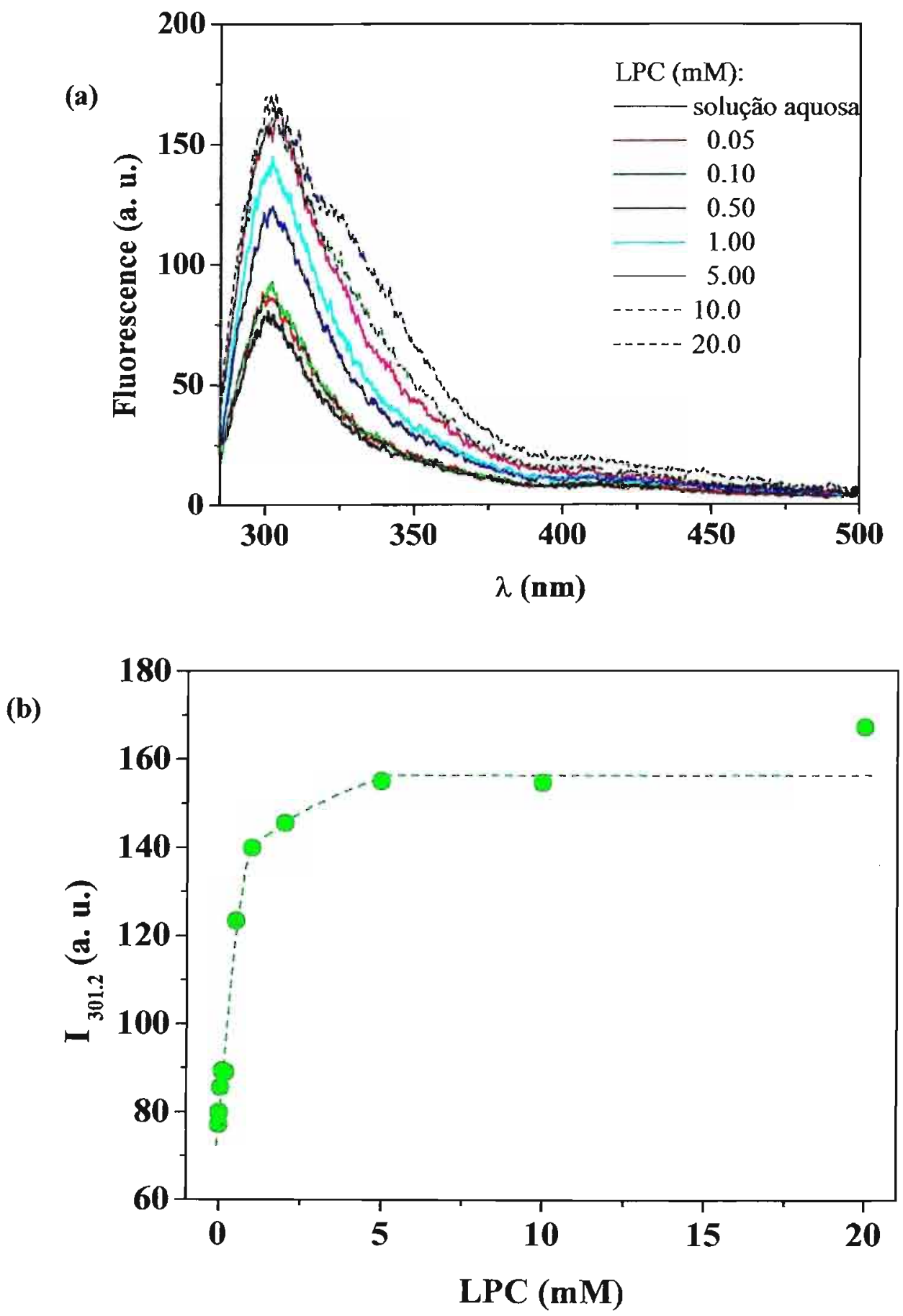

Figura 107 - Espectros de fluorescência (a) e variação da intensidade de fluorescência (b) de $30 \mu \mathrm{M}$ de CG em função da concentração de $\mathrm{LPC}, \mathrm{pH} 6,0 . \lambda_{\text {exc. }}=275 \mathrm{~nm}$. 
(a)
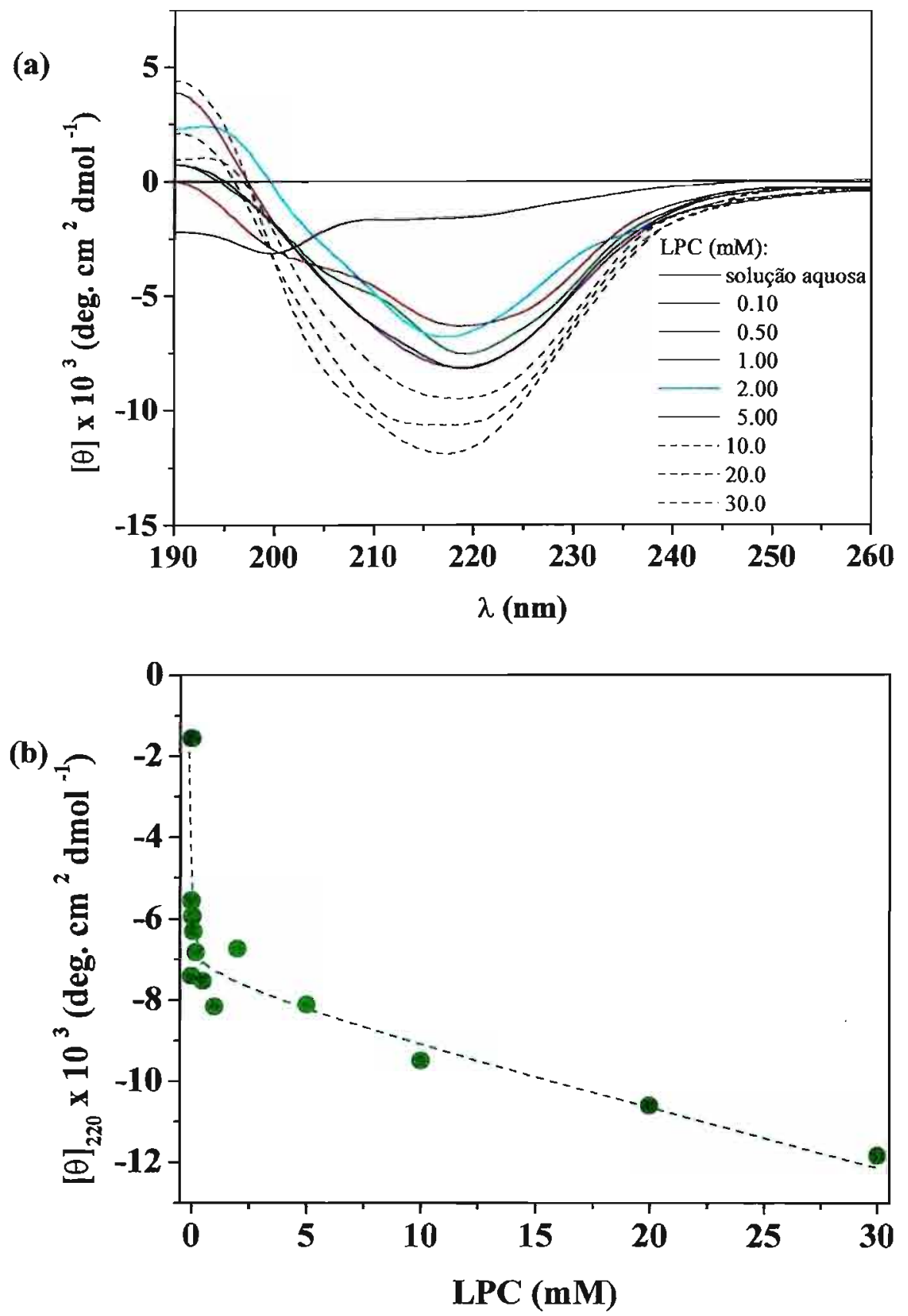

Figura 108 - Espectros de CD (a) e variação da elipticidade molar em $220 \mathrm{~nm}$ (b) de 70 $\mu \mathrm{M}$ de CG em função da concentração de LPC, $\mathrm{pH} 10,0$. 
Por fluorescência (Fig. 109), observa-se que em cerca de 2,5 mM LPC a variação intensidade de fluorescência tende a se estabilizar, o que sugere que abaixo dessa concentração o CG já estaria praticamente todo ligado. Também nesse $\mathrm{pH}$, aparece uma banda acima de $400 \mathrm{~nm}$, embora pouco nítida. Essa foi a única condição onde a banda de bitirosina apareceu.

Na presença de filmes de CG, os espectros de CD em presença de LPC (Fig. 110) apresentam uma intensidade significativamente maior do que observada para HPS; a elipticidade molar tanto da banda positiva quanto da banda negativa (Fig. 110b) do espectro aumenta continuamente com o incremento do $\mathrm{pH}$ até $\mathrm{pH} 11,0$, diminuindo logo em seguida. Nesse $\mathrm{pH}$, visualmente foi observada turbidez maior da solução, o que indica que houve precipitação. Os espectros também tem a forma parecida com a de uma $\alpha$-hélice, porém apresentam um mínimo abaixo de $220 \mathrm{~nm}$.

Na Figura 110b comparam-se os espectros de CD de CG na presença de filmes e em solução aquosa nos pHs 2,0, 7,0 e 10,0. A Figura mostra claramente que há um aumento significativo de intensidade na presença de LPC em relação à solução aquosa, principalmente em pHs mais altos, o que mostra que o fragmento possui grande afinidade pelo detergente. De modo geral, os espectros sugerem que as micelas de LPC tenham sido mais efetivas em promover a solubilização do CG do que na presença de HPS.

$\mathrm{Na}$ Figura 110c mostra-se a variação da elipticidade molar em $215 \mathrm{~nm}$ em função do $\mathrm{pH}$. Os resultados mostram uma alteração significativa do $\mathrm{pK}_{\mathrm{a}}$ do CG. Esse tipo de resultado não foi observado na presença de HPS. Isso pode sugerir que o grau de interação do peptídeo com o detergente tenha sido maior do que com HPS e também sugere que LPC tenha sido mais eficiente na diminuição do grau de agregação de CG.

Por fluorescência (Fig. 111), observa-se que a intensidade do espectro de emissão da tirosina (Fig. 111a) varia pouco até pH 10,5, diminuindo abruptamente daí em diante. Este fato fica mais nítido ao comparar-se a variação da intensidade de fluorescência em 301 $\mathrm{nm}$ com a variação da carga formal (Fig. 112), indicando alteração de $\mathrm{pK}_{\mathrm{a}} \mathrm{s}$ de grupos ionizáveis em presença do detergente. Por outro lado, a intensidade em $350 \mathrm{~nm}$ aumenta com o pH, como observado excitando a amostra em 292 nm (Fig. 112b). Por essa abordagem não foi possível observar nitidamente a presença de uma banda de emissão relativa a bitirosina. 
(a)

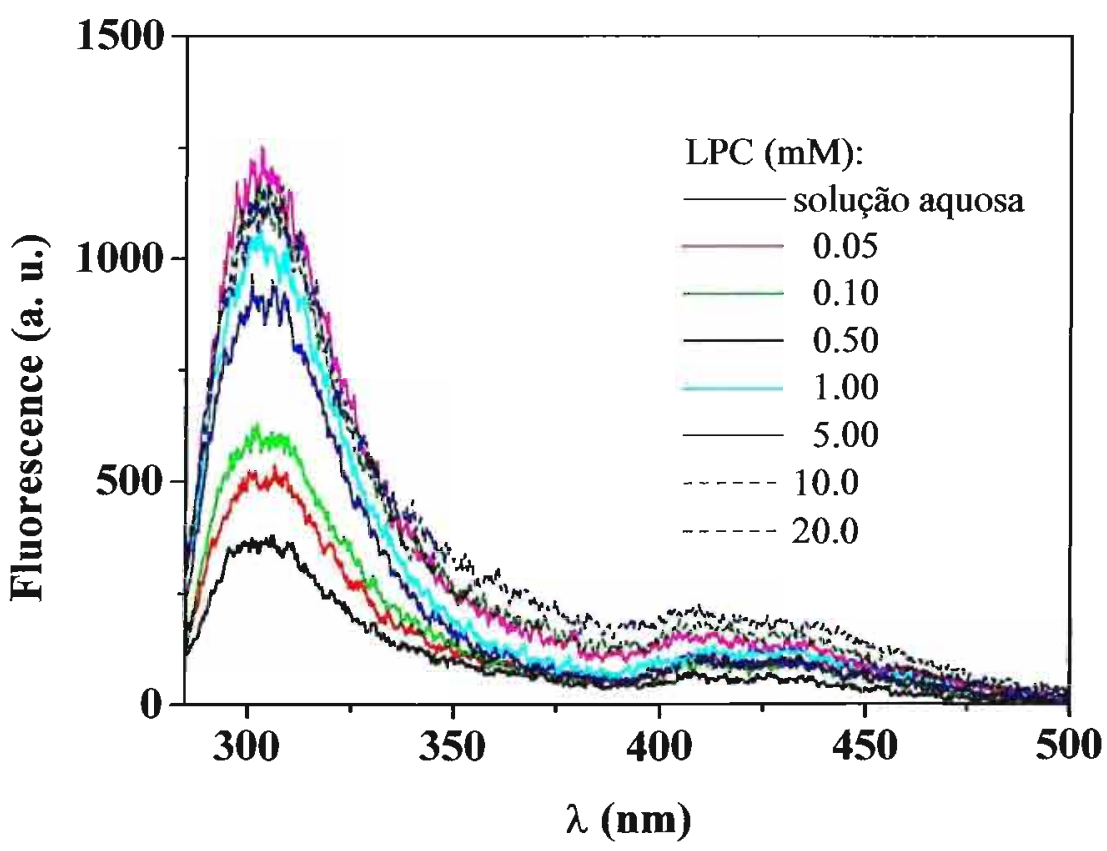

(b)

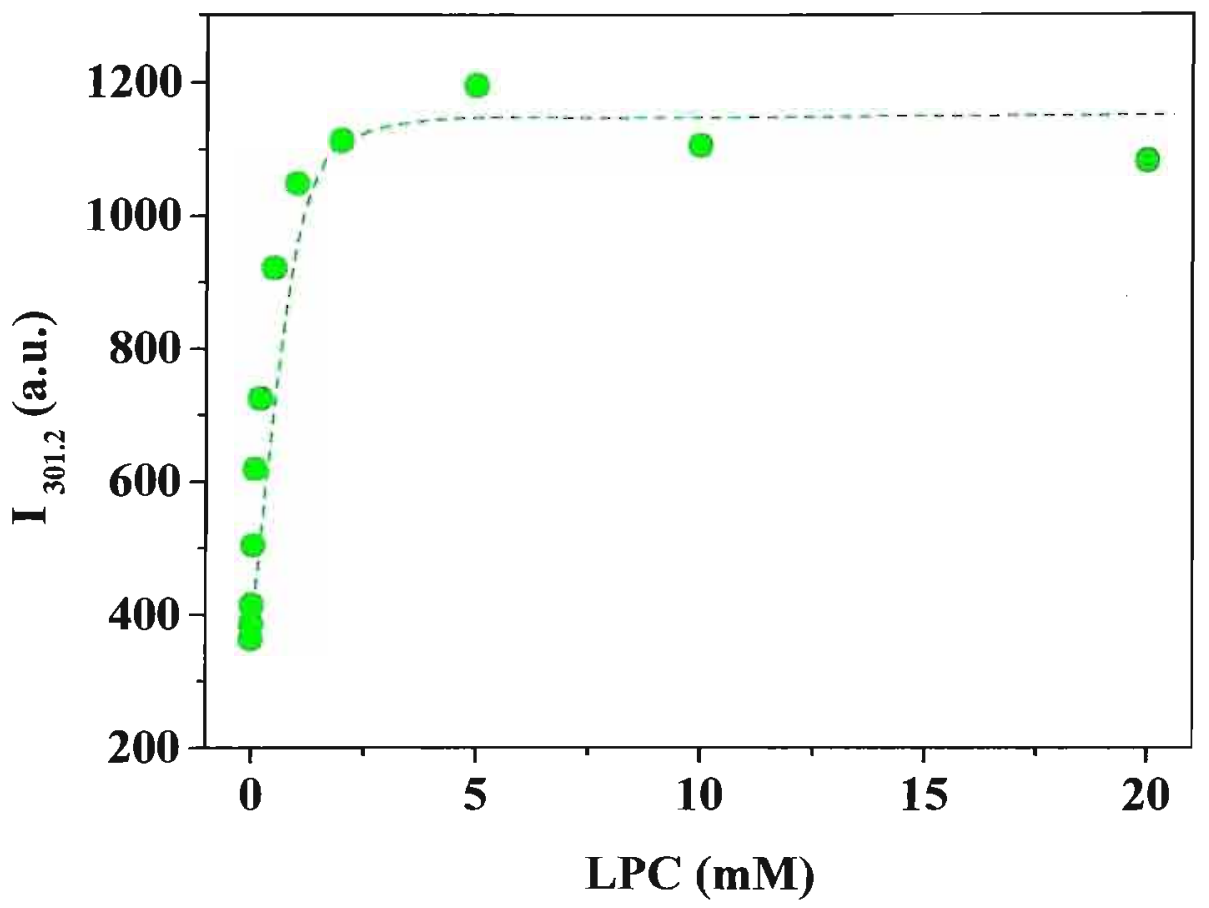

Figura 109 - Espectros de fluorescência (a) e variação da intensidade de fluorescência (b) de $30 \mu \mathrm{M}$ de CG em função da concentração de LPC, pH 10,0. $\lambda_{\text {exc. }}=275 \mathrm{~nm}$. 

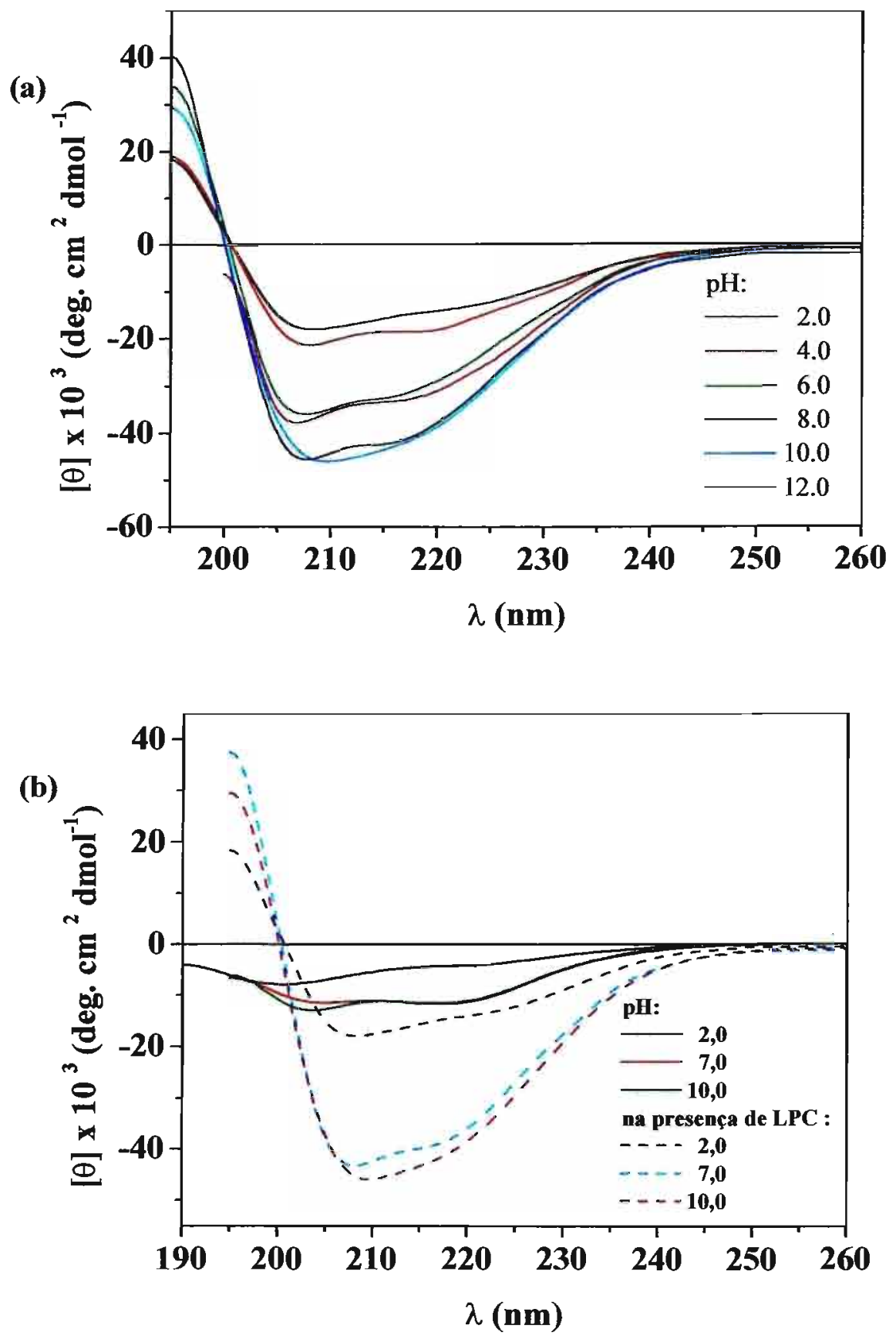
(c)

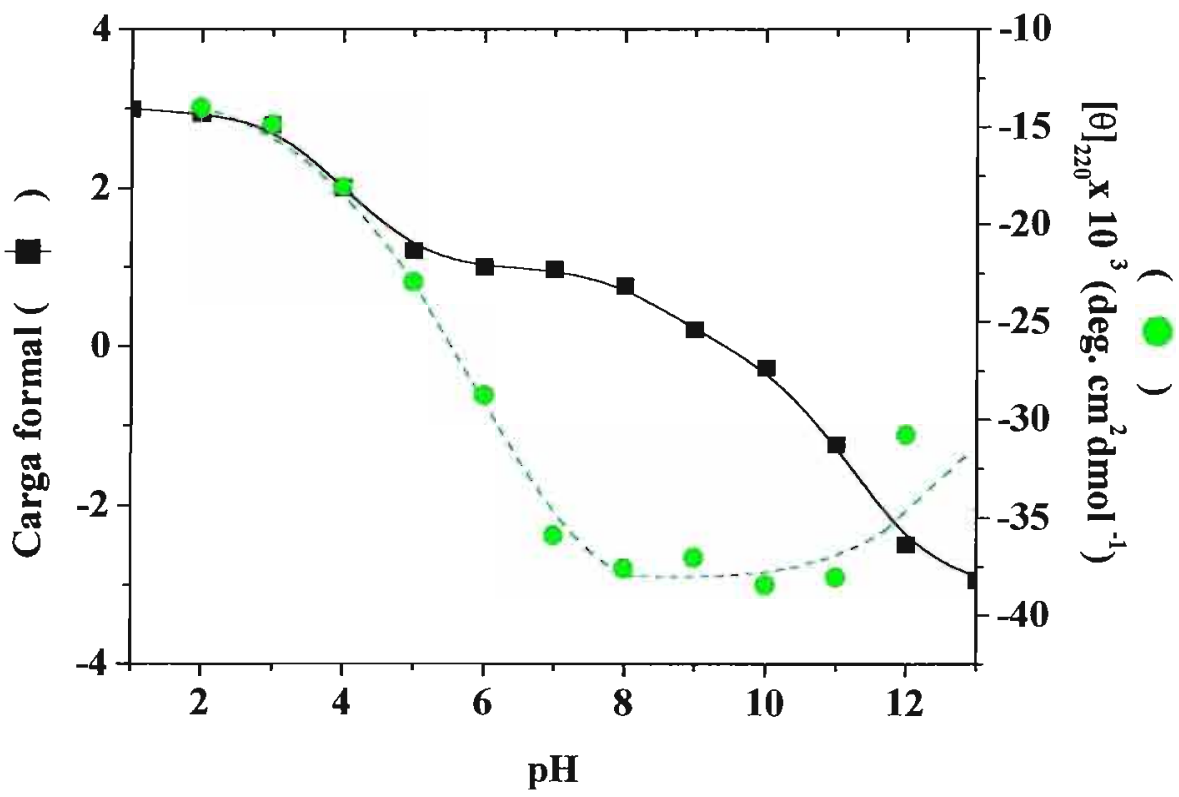

Figura 110 - Espectros de CD de um filme de $70 \mu \mathrm{M}$ CG hidratado na presença de $50 \mathrm{mM}$ LPC em função do pH (a). Comparação entre os espectros de CD de CG em solução aquosa e do filme de CG hidratado na presença de $50 \mathrm{mM}$ LPC (b). Variação da elipticidade molar em $215 \mathrm{~nm}(\mathrm{c})$. 
(a)
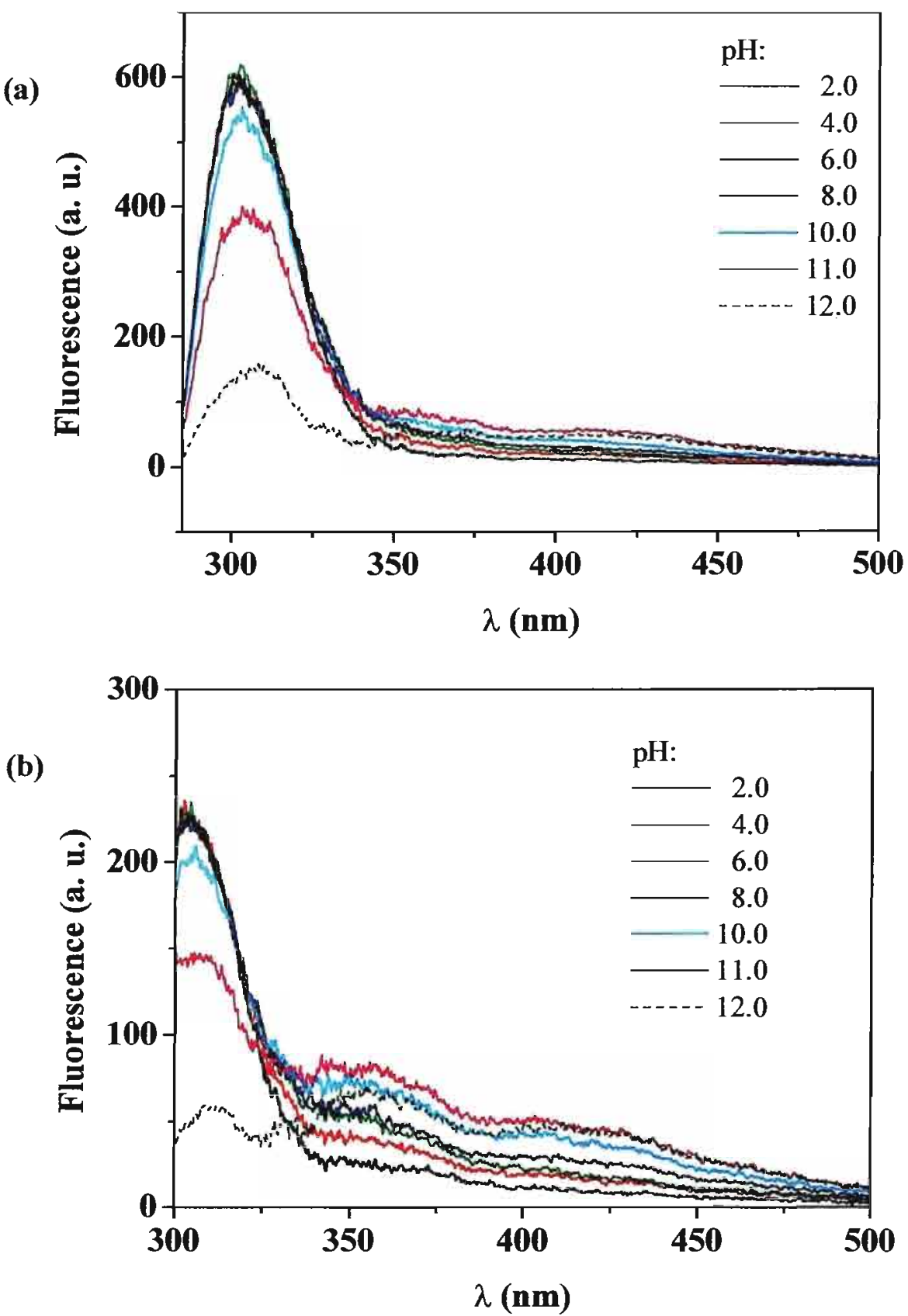

Figura 111 - Espectros de fluorescência de $30 \mu \mathrm{M}$ de CG hidratado na presença de $50 \mathrm{mM}$ LPC em função do pH. $\lambda_{\text {exc. }}=275$ (a) e $292 \mathrm{~nm}$ (b). 


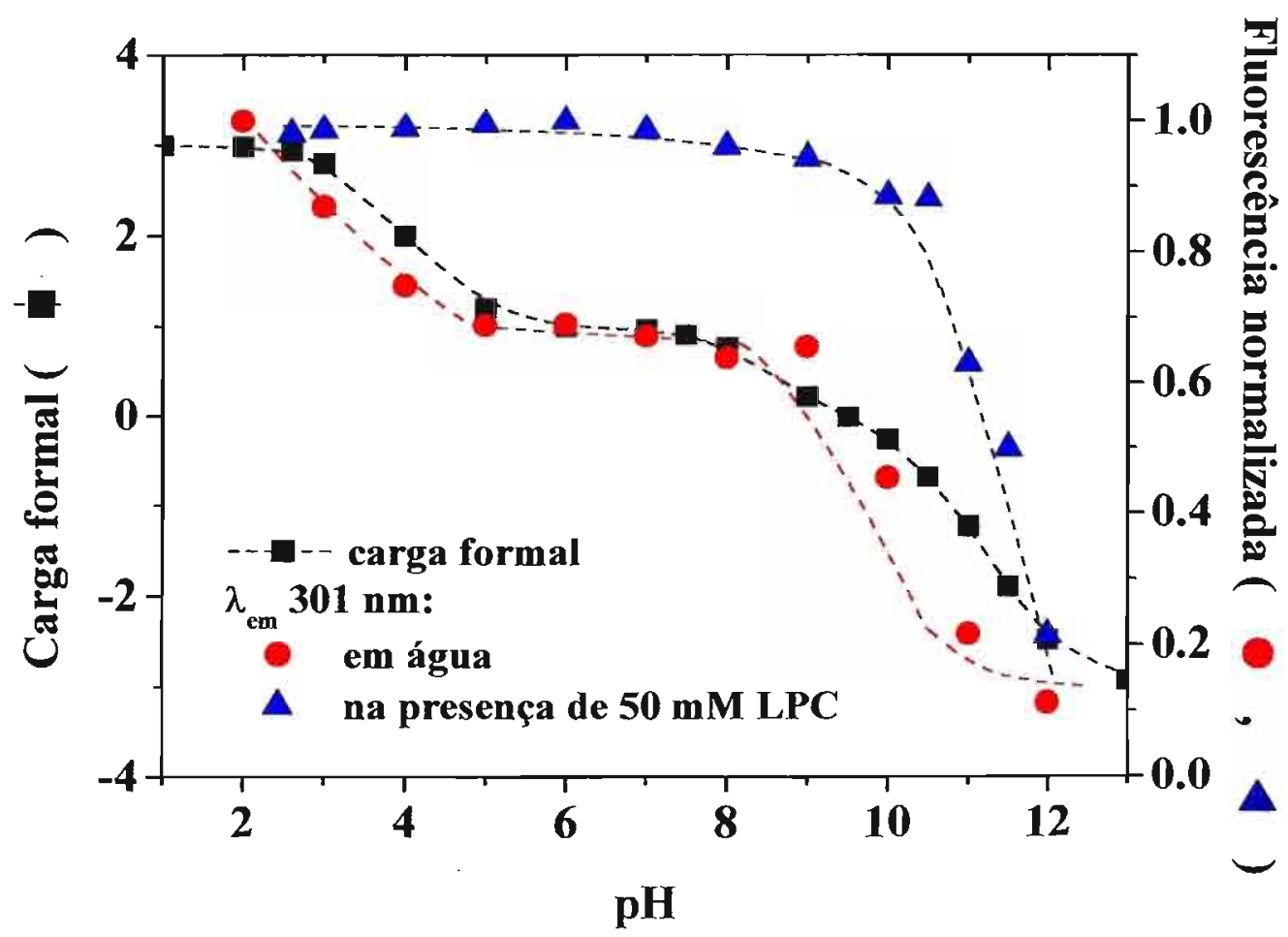

Figura 112 - Carga teórica e variação da intensidade de fluorescência de $30 \mu \mathrm{M}$ de CG em água e hidratado na presença de $50 \mathrm{mM} \mathrm{LPC} \mathrm{em} \mathrm{função} \mathrm{do} \mathrm{pH}$. $\lambda_{\mathrm{em}}=301 \mathrm{~nm}$. 


\subsubsection{Estudos na presença de SDS}

Na presença de SDS em pH 2,5, os espectros de CD (Fig. 113a) mostram que logo após a primeira adição de detergente, o espectro sofre uma significativa mudança conformacional, de estrutura ao acaso para folha $\beta$, o que mostra que o CG interage com monômeros de SDS. Com adições posteriores de SDS, a forma do espectro não muda significativamente, mesmo após a cmc do detergente $(\sim 8 \mathrm{mM}){ }^{(208)}$. A Tabela 31 mostra a posição dos máximos e mínimos dos espectros de CD na presença de SDS. Em pH 2,5, o $\lambda_{\min }$ desloca-se de $201 \mathrm{~nm}$ para $217 \mathrm{~nm}$, e aparece uma banda positiva ao redor de $192 \mathrm{~nm}$, o que reflete a mudança conformacional de $C G$ na presença do detergente. Observa-se também que a posição relativa desses comprimentos de onda não é alterada com o aumento da concentração de SDS, o que sugere que a conformação adotada por CG permanece estável mesmo acima da $\mathrm{cmc}$ do detergente.

Por fluorescência (Fig. 114), assim como o observado para o $\mathrm{CD}$, também se observa um grande aumento de intensidade. Acima de 0,5 mM SDS (Fig. 114b), a intensidade de fluorescência aumenta pouco, indicando que o CG já estaria praticamente todo ligado ao detergente abaixo da cmc.

Tabela 31 - Posição do comprimento de onda máximo $\left(\lambda_{\max }\right)$ e mínimo $\left(\lambda_{\min }\right)$ para CG na presença de SDS em função do pH.

\begin{tabular}{ccccccc}
\hline [SDS] $(\mathrm{mM})$ & \multicolumn{2}{c}{$\mathrm{pH} 2,5$} & \multicolumn{2}{c}{$\mathrm{pH} \mathrm{6,0}$} & \multicolumn{1}{c}{$\mathrm{pH} \mathrm{10,0}$} \\
sem adição & $\lambda_{\max }$ & $\lambda_{\min }$ & $\lambda_{\max }$ & $\lambda_{\min }$ & $\lambda_{\max }$ & $\lambda_{\min }$ \\
0,1 & -- & 201 & - & $202,221^{*}$ & -- & 203,220 \\
0,5 & 192 & 217 & 193 & $207^{*}, 219$ & - & 202,221 \\
1,0 & 192 & 217 & 194 & 219 & -- & 202,221 \\
5,0 & 192 & 217 & 190 & 218 & -- & $204^{*}, 221$ \\
10 & 191 & 217 & 190 & $207^{*}, 217$ & -- & 221 \\
15 & 191 & 217 & 194 & $207^{*}, 217$ & - & 218 \\
20 & 191 & 217 & 194 & $207^{*}, 217$ & -- & 219 \\
\hline
\end{tabular}

*ombro

Em pH 6,0, os espectros de CD (Fig. 115) mostram que o peptídeo adota conformação em folha $\beta$ na presença de SDS. A forma da linha do espectro muda com o aumento da concentração do detergente. Inicialmente, os espectros apresentam-se achatados. Acima da $\mathrm{cmc}$, a intensidade dos espectros, principalmente a banda positiva acima ao redor de $194 \mathrm{~nm}$, aumenta significativamente. Ocorre um progressivo 
(a)
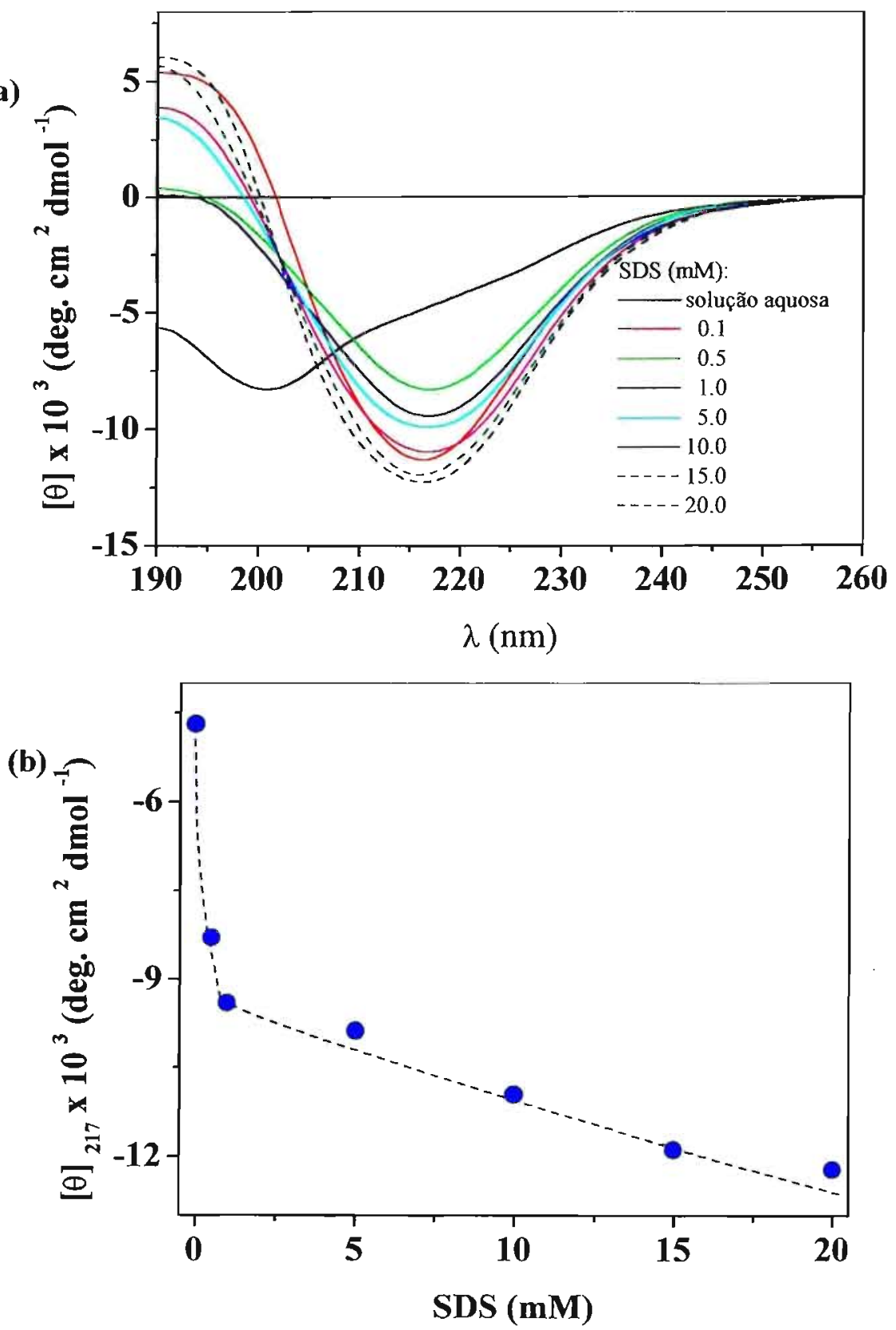

Figura 113 - Espectros de CD (a) e variação da elipticidade molar em 217 nm (b) de 70 $\mu \mathrm{M}$ de CG em função da concentração de SDS, pH. 2,5. 
(a)

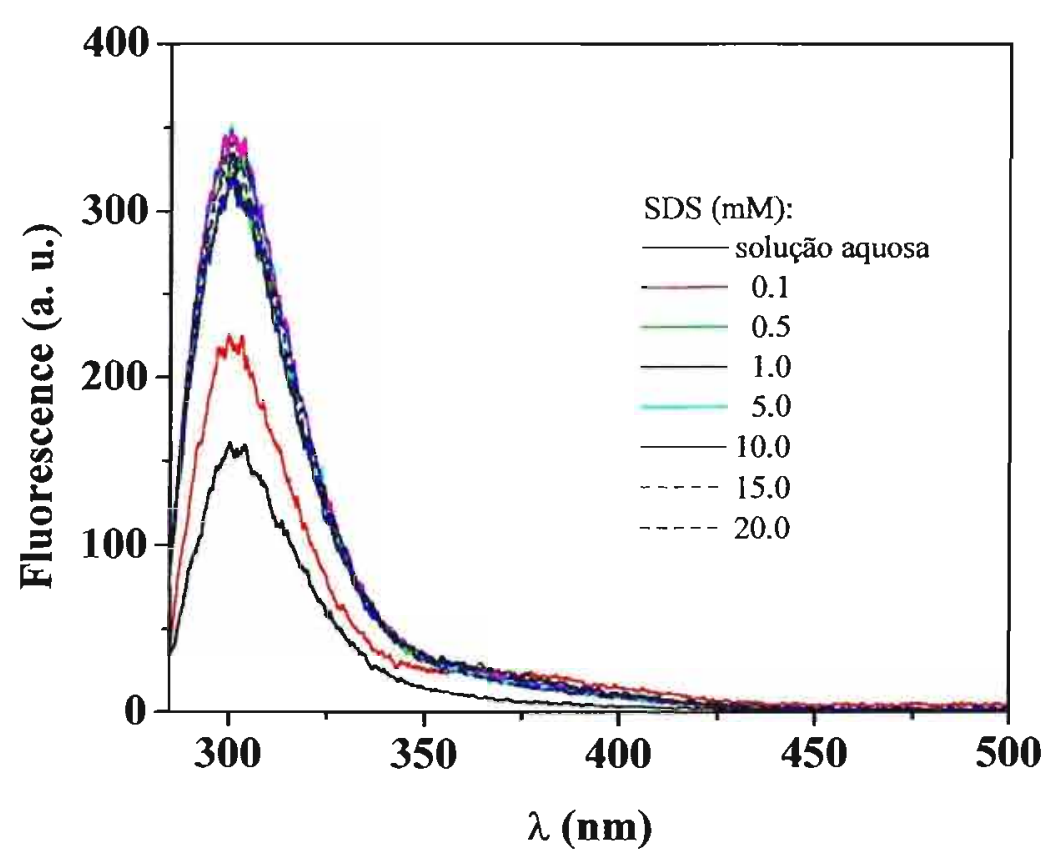

(b)

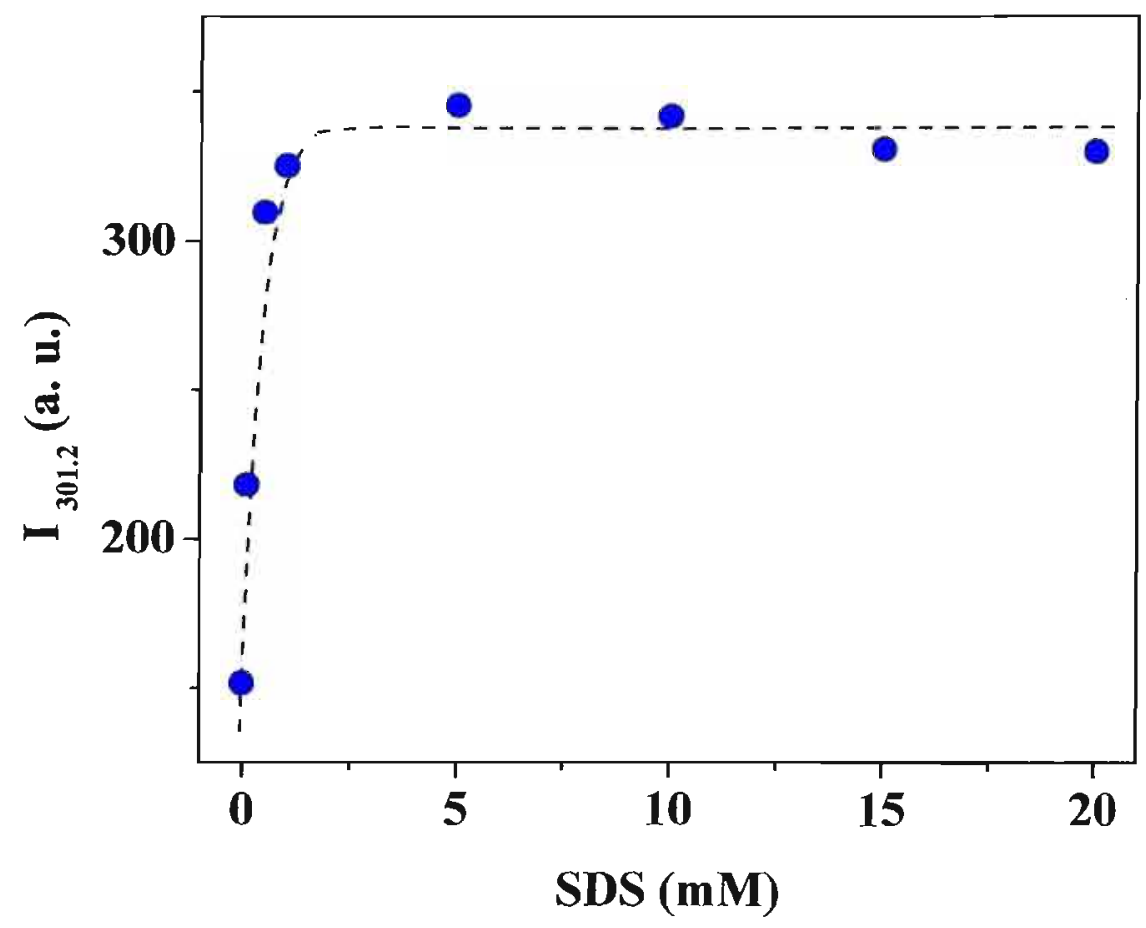

Figura 114 - Espectros de fluorescência (a) e variação da intensidade de fluorescência em $301,2 \mathrm{~nm}$ (b) de $30 \mu \mathrm{M}$ de CG em função da concentração de SDS, $\mathrm{pH} 2,5 . \lambda_{\text {exc. }}=275 \mathrm{~nm}$. 

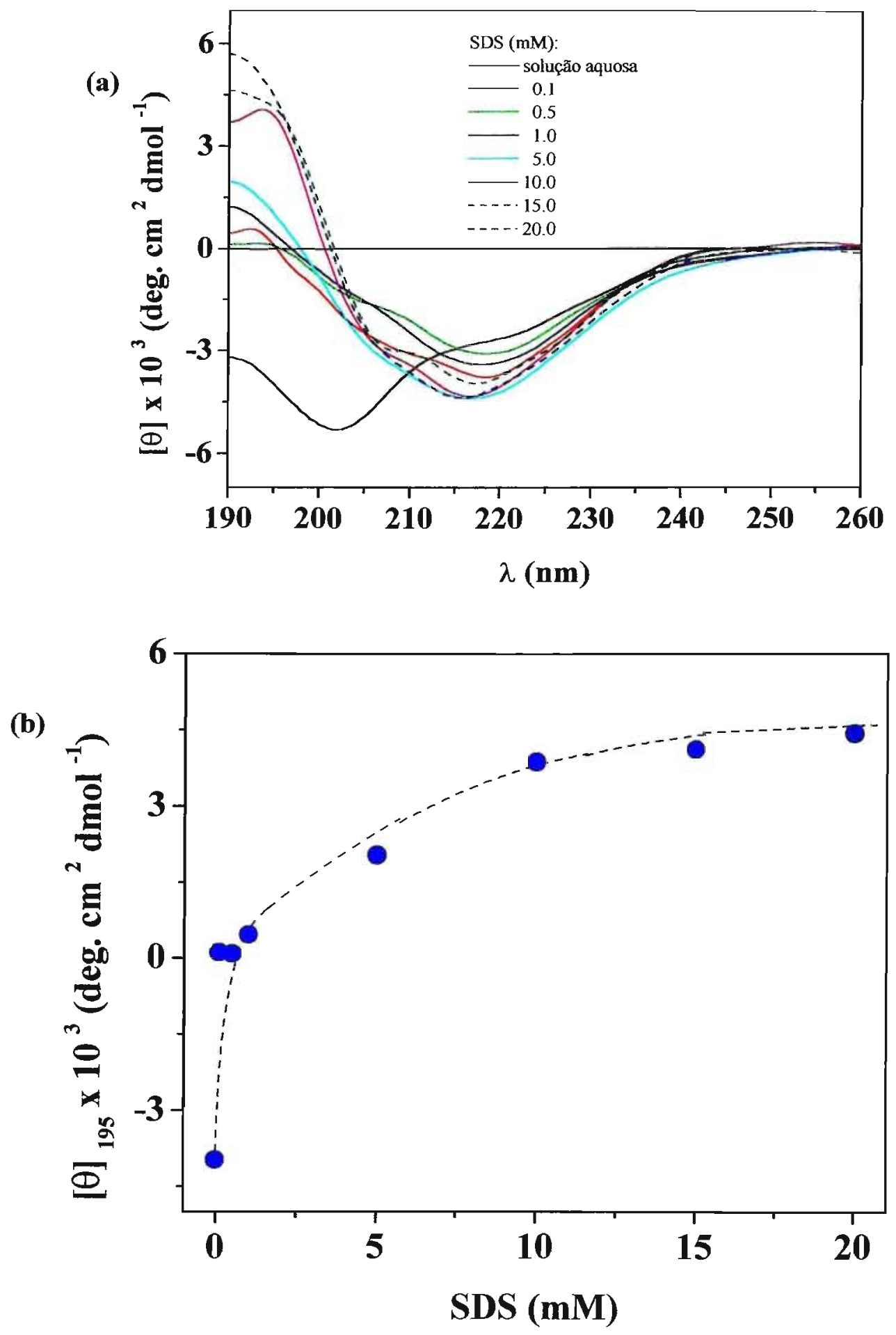

Figura 115 - Espectros de CD (a) e variação da elipticidade molar em 195 nm (b) de 70 $\mu \mathrm{M}$ CG em função da concentração de SDS, pH. 6,0. 
deslocamento do mínimo da banda negativa de 219 para $217 \mathrm{~nm}$ e o espectro passa a apresentar um ombro em torno de $207 \mathrm{~nm}$ (Tabela 31), o que sugere que o tipo de estrutura adquirido pelo peptídeo abaixo e acima da cmc é diferente.

Em pH 2,5 (Fig. 114) a intensidade de fluorescência aumenta de uma maneira mais abrupta do que em pH 6,0 (Fig. 116), provavelmente devido à grande atração eletrostática entre o peptídeo e o detergente no pH mais baixo. Em torno de 1mM SDS, CG parece estar totalmente ligado ao detergente, visto pela saturação da intensidade de fluorescência em torno de $301 \mathrm{~nm}$ no pH 6,0 (Fig 116b).

Em pH 10,0, o resultado obtido na presença de SDS (Fig. 117a) é parecido com o obtido neste mesmo pH na presença de HPS (Fig. 98a). O espectro em solução apresenta duas bandas negativas, uma em torno de $203 \mathrm{~nm}$ e outra em torno de $220 \mathrm{~nm}$ (Tabela 31). Com a crescente adição de SDS, a primeira banda desaparece progressivamente até se tornar um ombro, centrado ao redor de $204 \mathrm{~nm}$ enquanto que sobra apenas a segunda banda negativa. Bandas centradas ao redor desse comprimento de onda são atribuídas a dobras $\beta$ (221).

$\mathrm{Na}$ Figura 117c mostra-se a variação da elipticidade molar em função da concentração de SDS. Observa-se que em ambos os casos houve uma grande variação de intensidade logo após as primeiras adições de detergente, a qual se estabiliza acima de 5 $\mathrm{mM}$.

Por fluorescência, em pH 10,0 (Fig. 118), excitando-se a amostra em 275 nm ocorre um aumento considerável da intensidade de fluorescência até 5mM SDS (Fig. 118b), o que indica que o CG já estaria praticamente todo ligado nessa concentração.

Quando se efetuou a captação de um filme de CG na presença de $100 \mathrm{mM}$ SDS, assim como observado para HPS, os espectros de CD em função do pH (Fig. 119) são parecidos com os de uma $\alpha$-hélice, porém a intensidade dos espectros é relativamente baixa. Isto também pode ser observado na Figura 119b, ao comparar-se esses espectros com os obtidos em solução aquosa. É possível que nessas condições o peptídeo permaneça agregado. Também foi possível observar uma mudança de $\mathrm{pK}_{\mathrm{a}}$ de CG na presença de SDS (Fig. 119c).

Por fluorescência, ao contrário do observado na presença dos outros detergentes, observa-se uma banda de emissão na região de 400 a $450 \mathrm{~nm}$ ao excitar-se a amostra tanto 
(a)

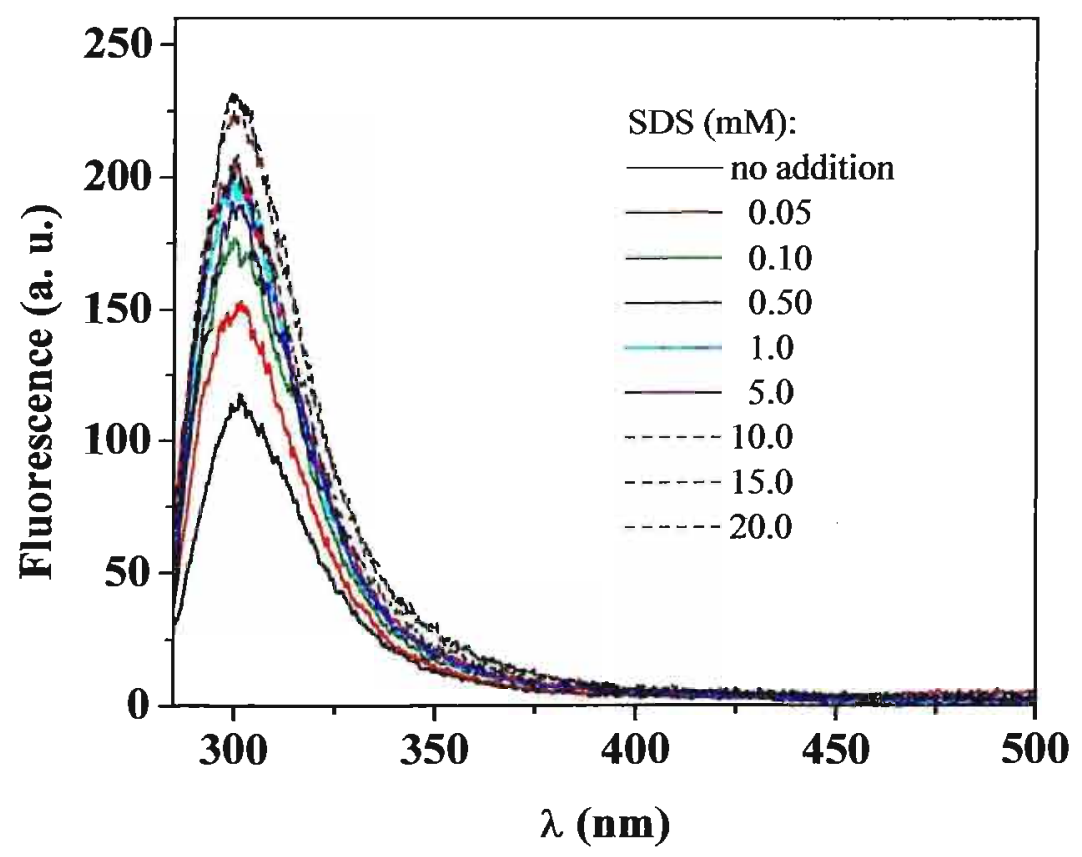

(b)

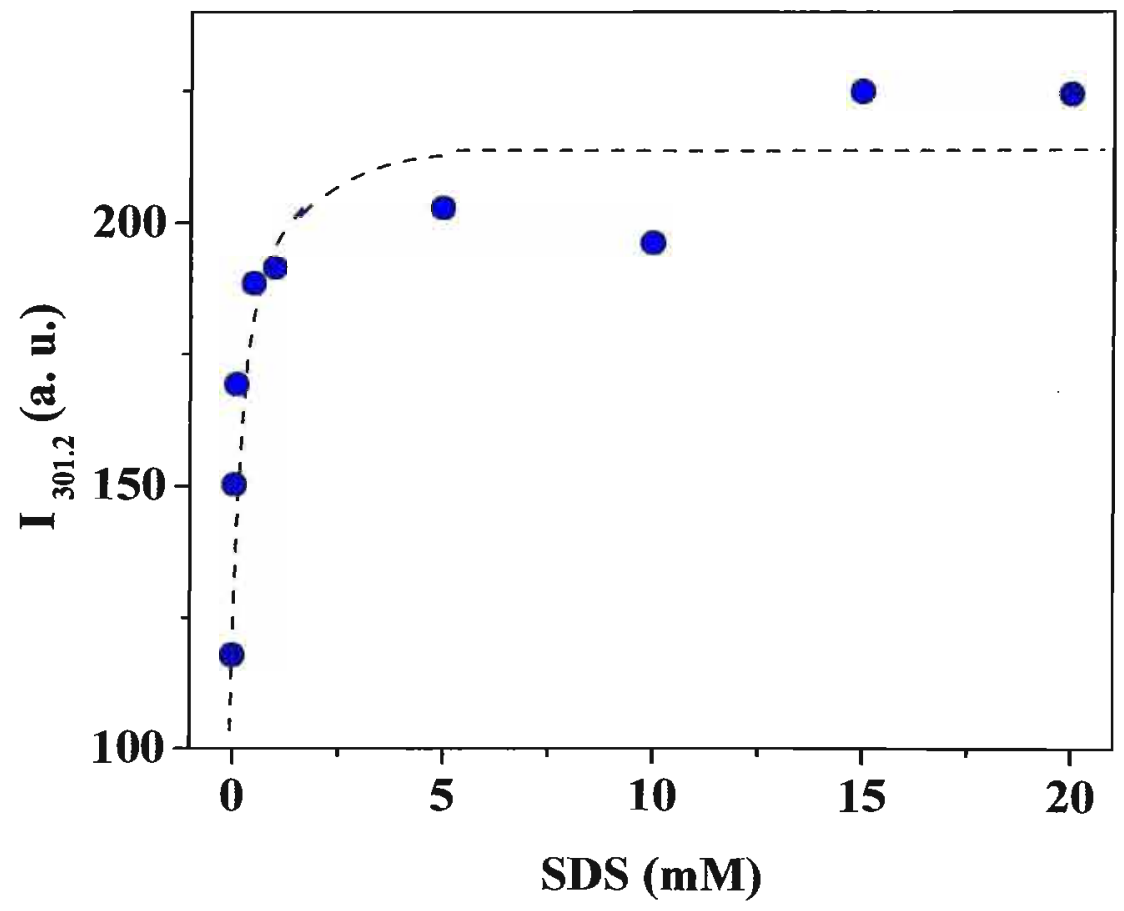

Figura 116 - Espectros de fluorescência (a) e variação da intensidade de fluorescência em 301,2 nm (b) de $30 \mu \mathrm{M}$ de CG em função da concentração de SDS, pH 6,0. $\lambda_{\text {exc. }}=$ $275 \mathrm{~nm}$. 
(a)
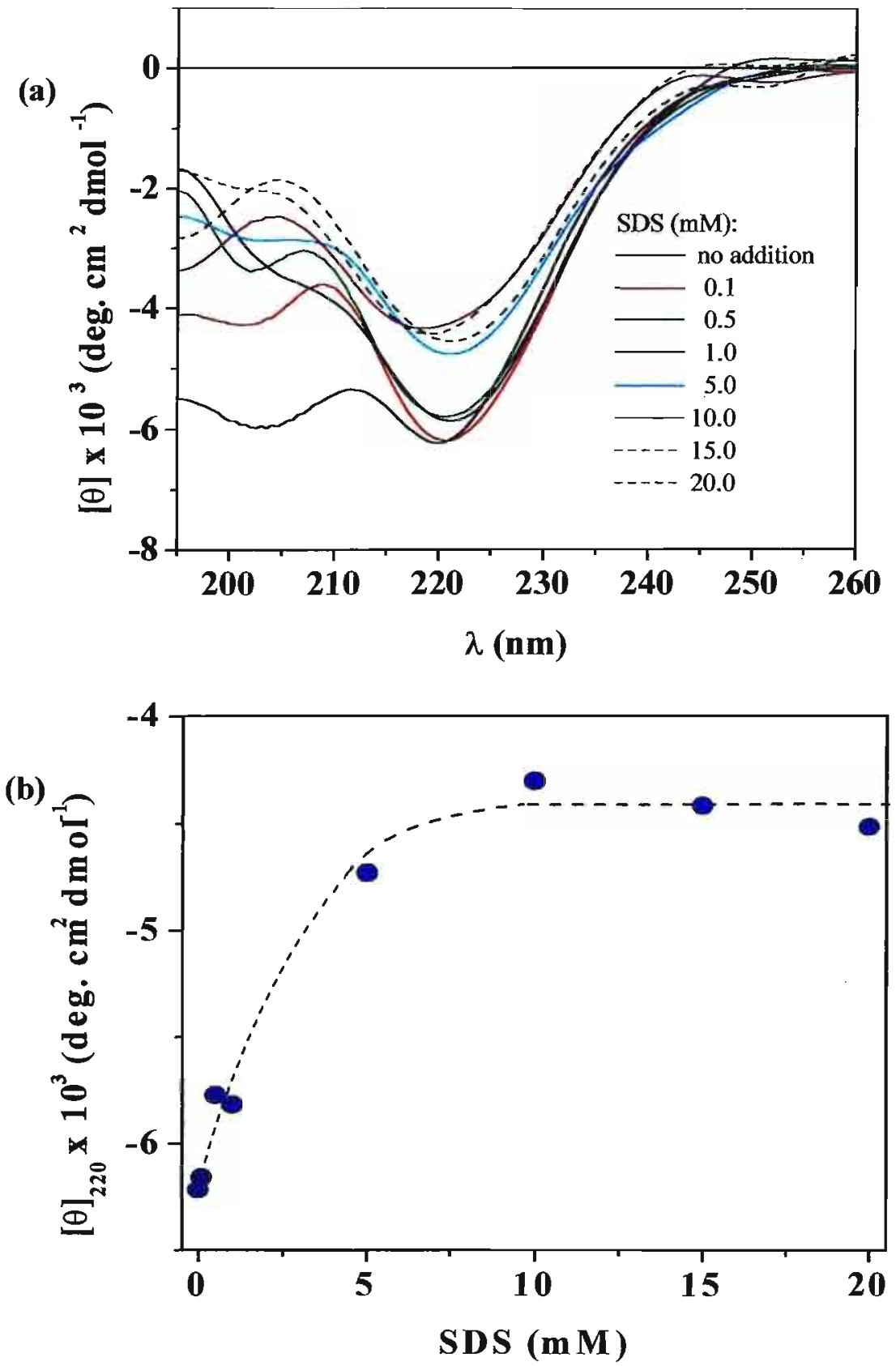

Figura 117 - (a) Espectros de CD de $70 \mu \mathrm{M}$ de CG em função da concentração de SDS, pH 10,0. (b) Variação da elipticidade molar em $220 \mathrm{~nm}$ em função da concentração de SDS. 
(a)

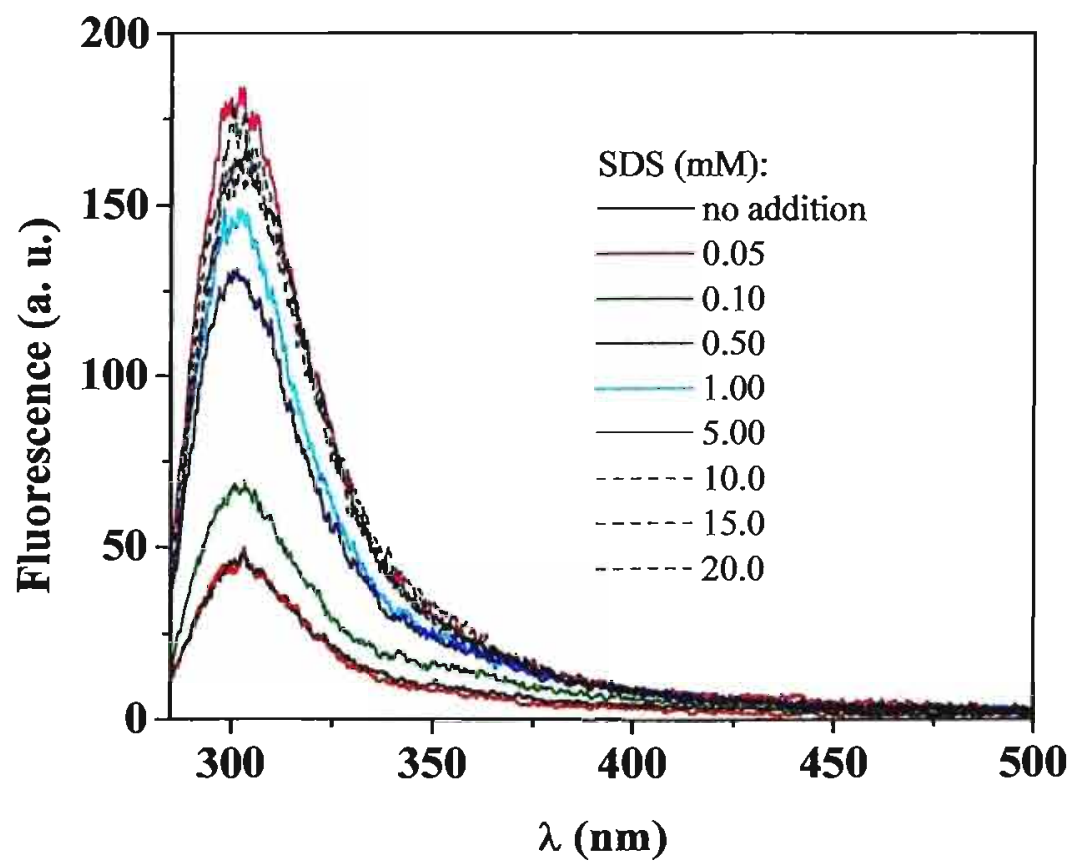

(b)

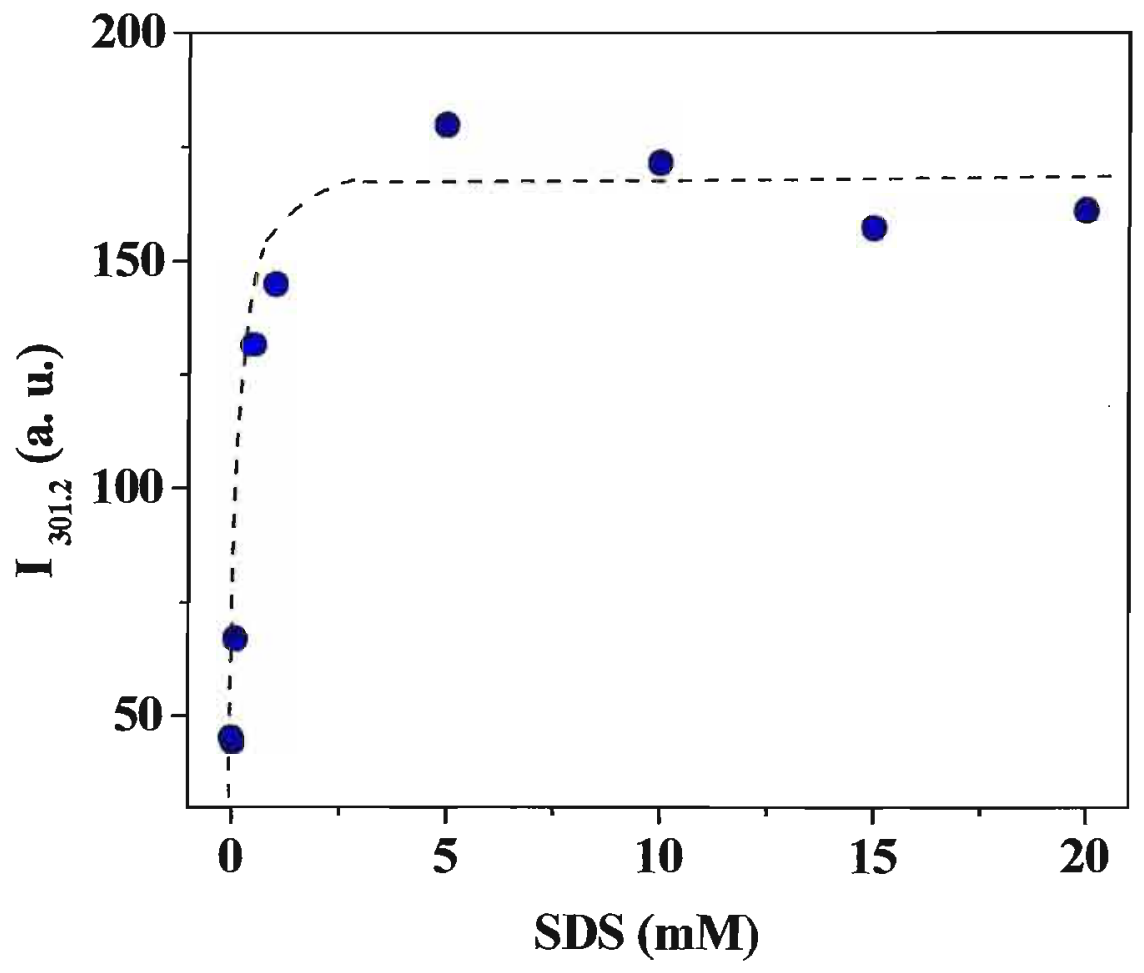

Figura 118 - Espectros de fluorescência (a) e variação da intensidade de fluorescência (b) de $30 \mu \mathrm{M}$ de CG em função de concentrações crescentes SDS, pH 10,0. $\lambda_{\text {exc. }}=275$ nm. 
(a)

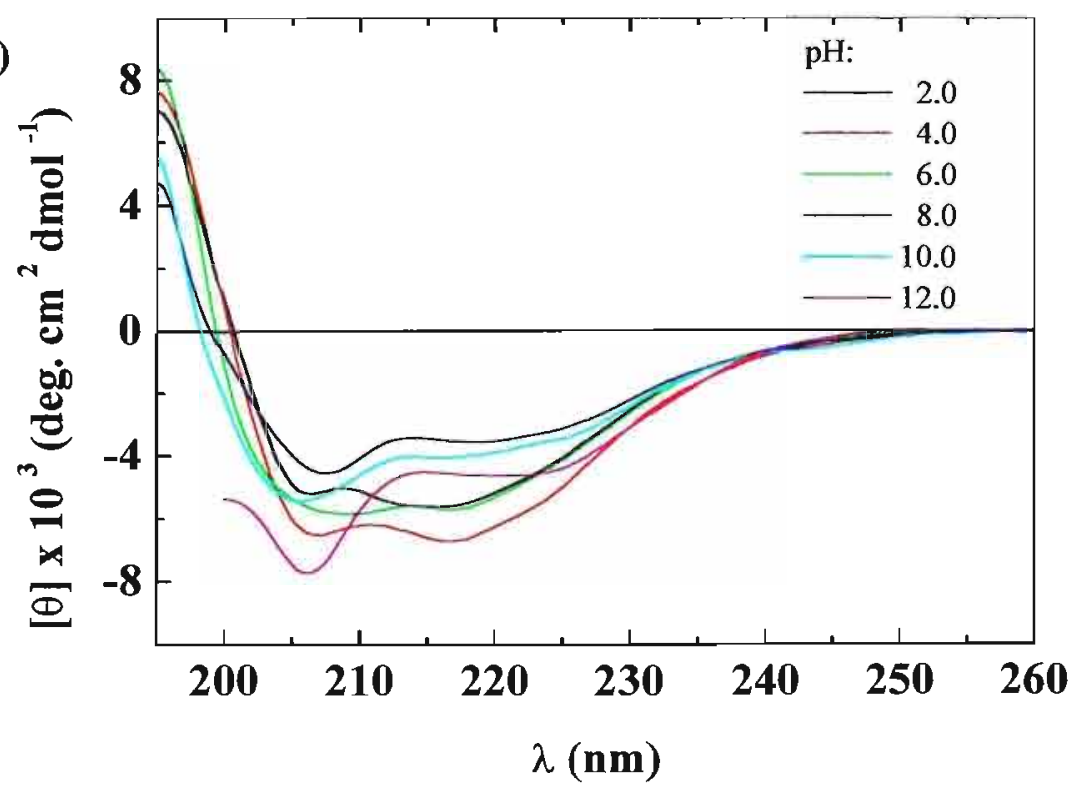

(b)

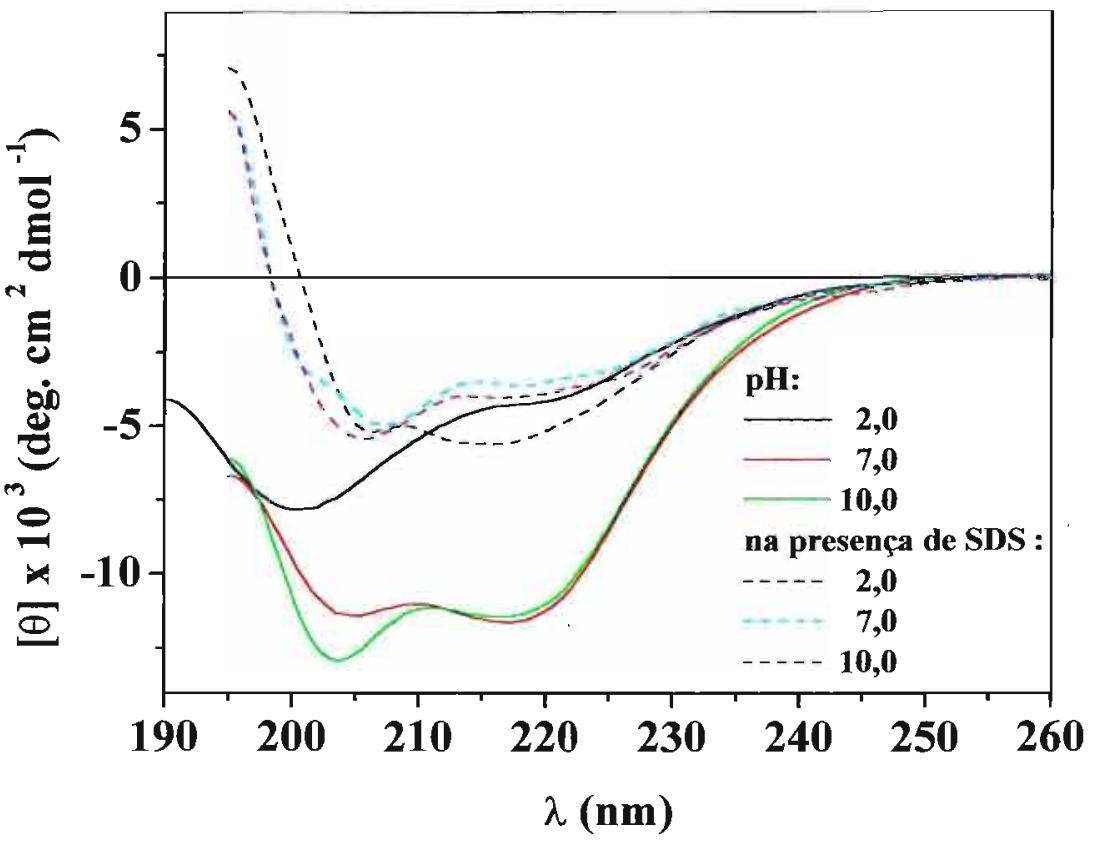




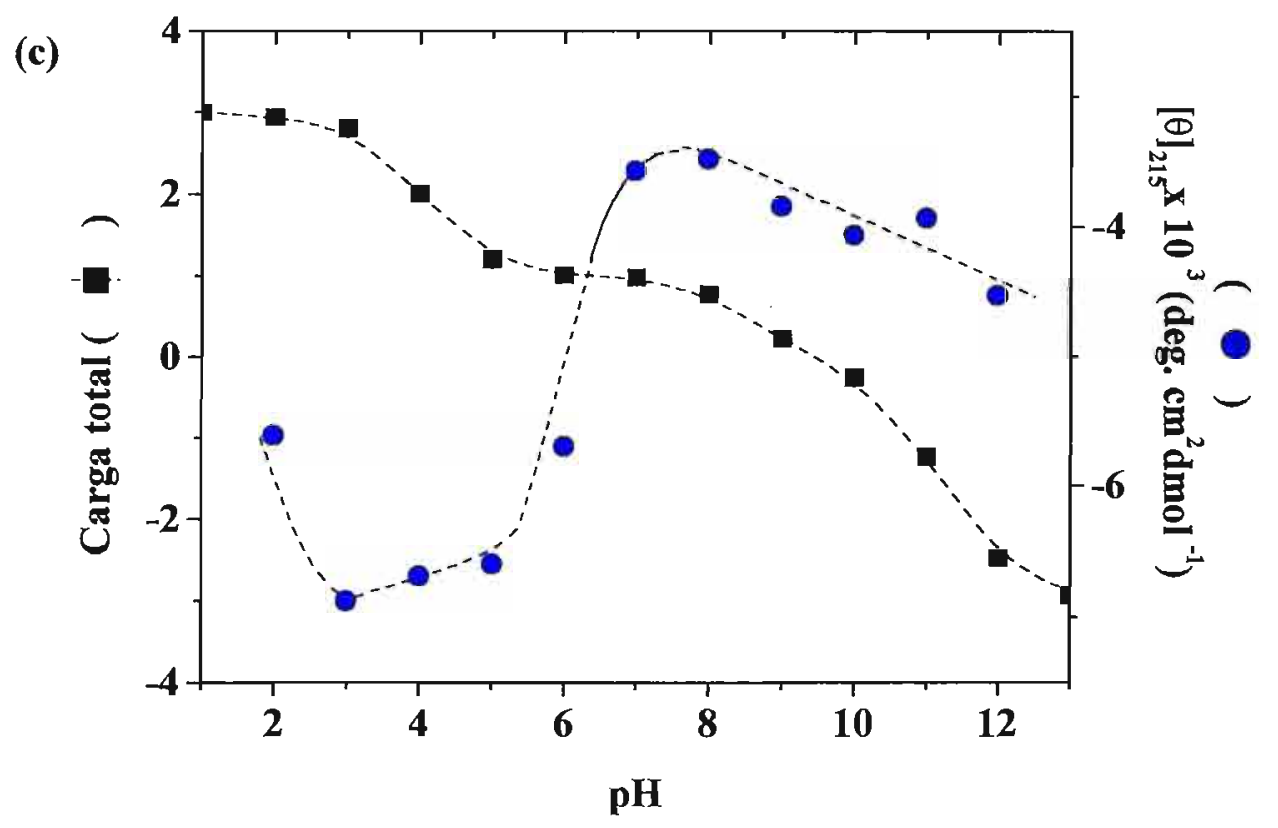

Figura 119 - Espectros de CD de um filme de $70 \mu \mathrm{M}$ de CG hidratado na presença de 100 mM SDS em função do pH (a). Comparação entre os espectros de CD de CG em solução aquosa e do filme de CG hidratado na presença de $50 \mathrm{mM}$ SDS (b). Variação da elipticidade molar em $215 \mathrm{~nm}$ (c). 
em 275 (Fig. 120a) como em 292 nm (Fig. 120b). A intensidade de fluorescência varia pouco até pH 6,0 (Fig. 121) e acima de pH 9,0 esta acompanha a variação da carga teórica.

\subsubsection{Supressão da intensidade de fluorescência}

Também foram realizados estudos de supressão da intensidade de fluorescência de CG por acrilamida em solução aquosa e na presença de detergentes, esses resultados estão mostrados na Tabela 32

Tabela 32 - Constantes de Stern-Volmer $\left(K_{S v}, M^{\prime}\right)$ para a supressão da intensidade de fluorescência de CG por acrilamida em solução aquosa e na presença de detergentes ${ }^{a}$

\begin{tabular}{|c|c|c|c|c|}
\hline \multicolumn{5}{|c|}{$\mathrm{K}_{\mathrm{SV}}\left(\mathrm{M}^{-1}\right)^{\mathrm{b}}$} \\
\hline $\mathrm{pH}$ & Solução aquosa & HPS & LPC & $\overline{\mathrm{SDS}}$ \\
\hline 2.5 & 19.6 & 7.5 & 2.5 & 5.6 \\
\hline 6.0 & 26.0 & 7.2 & 2.8 & 16.0 \\
\hline 10.0 & 11.0 & 11.0 & 5.7 & 14.6 \\
\hline
\end{tabular}

a ver Materiais e Métodos.

${ }^{b} \lambda_{\text {exc }}=275 \mathrm{~nm}$

Em solução aquosa, a supressão da intensidade de fluorescência é maior em pH 6,0 do que nos outros pHs, o que indica que o fluoróforo encontra-se mais exposto ao solvente nesse $\mathrm{pH}$. A adição de detergentes resultou em uma diminuição significativa da constante de Sten-Volmer, principalmente nos pHs 2,5 e 6,0 na presença de HPS e LPC. Com exceção de pH 2,5, o fluoróforo parece mais exposto ao supressor na presença de SDS. É possível que na presença desse detergente CG se localize mais na superfície da micela, em $\mathrm{pH} 10,0$ por exemplo, o grau de supressão é similar ao obtido em solução aquosa. Por outro lado, os resultados indicam que na presença de LPC o peptídeo parece penetrar mais profundamente na micela do que em relação aos outros surfactantes. De modo geral esses resultados corroboram os resultados de fluorescência e de CD que mostram que o CG ligase com grande afinidade aos detergentes, pricipalmente em $\mathrm{pHs}$ mais baixos.

\subsubsection{Agregação do $C G$}

Os resultados obtidos até o momento mostraram que em algumas condições como na presença de TFE e na presença de altas concentrações de LPC, o fragmento CG tende a adotar estrutura $\alpha$-helicoidal. Nas outras condições, é possível que a tendência a agregar do peptídeo o impedisse de adotar essa conformação. Dessa forma, resolvemos investigar algumas abordagens para tentar diminuir o grau de agregação de CG. 

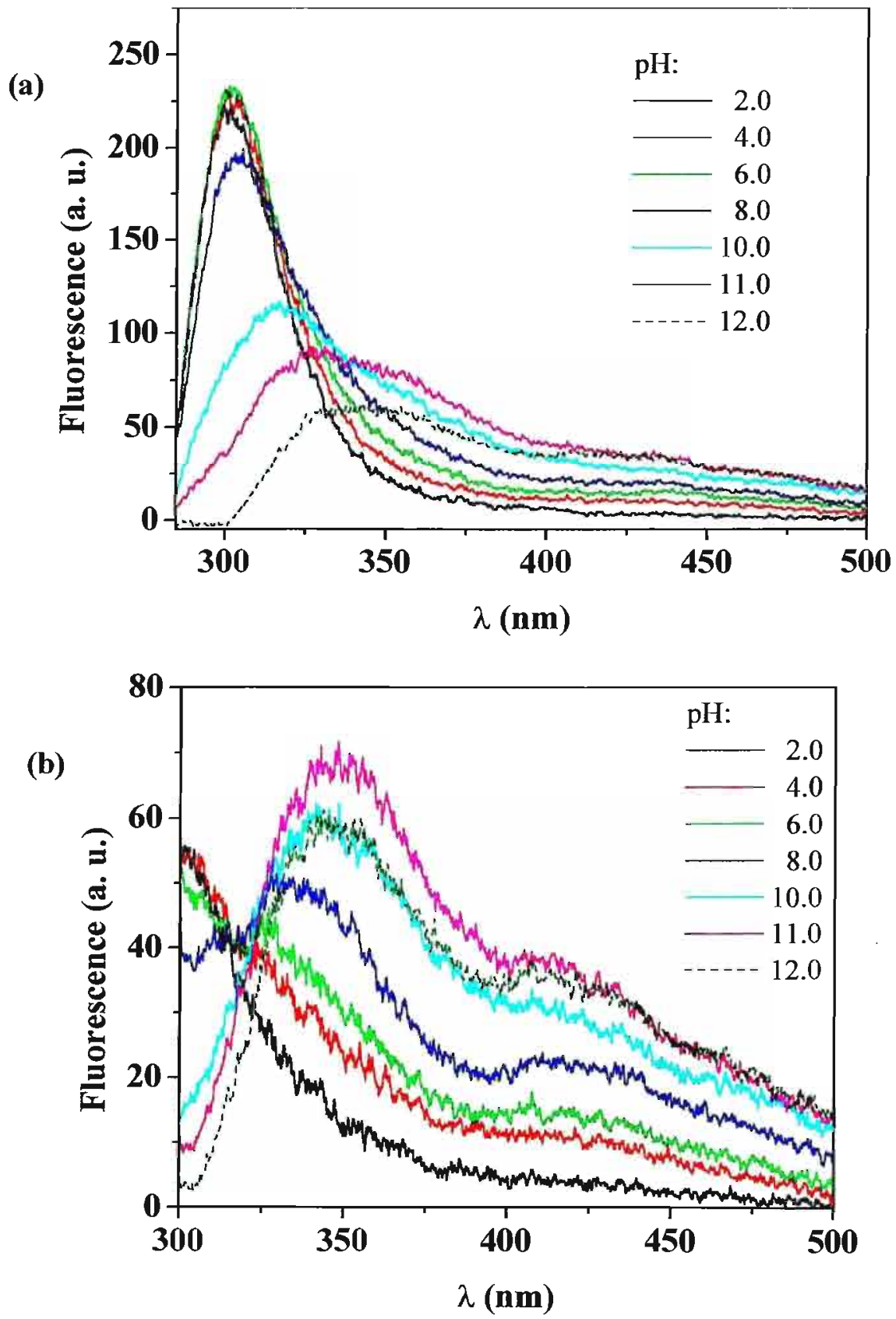

Figura 120 - Espectros de fluorescência de $30 \mu \mathrm{M}$ de CG hidratado na presença de 100 mM SDS em função do pH. $\lambda_{\text {exc. }}=275$ (a) e $292 \mathrm{~nm}$ (b). 
(a)

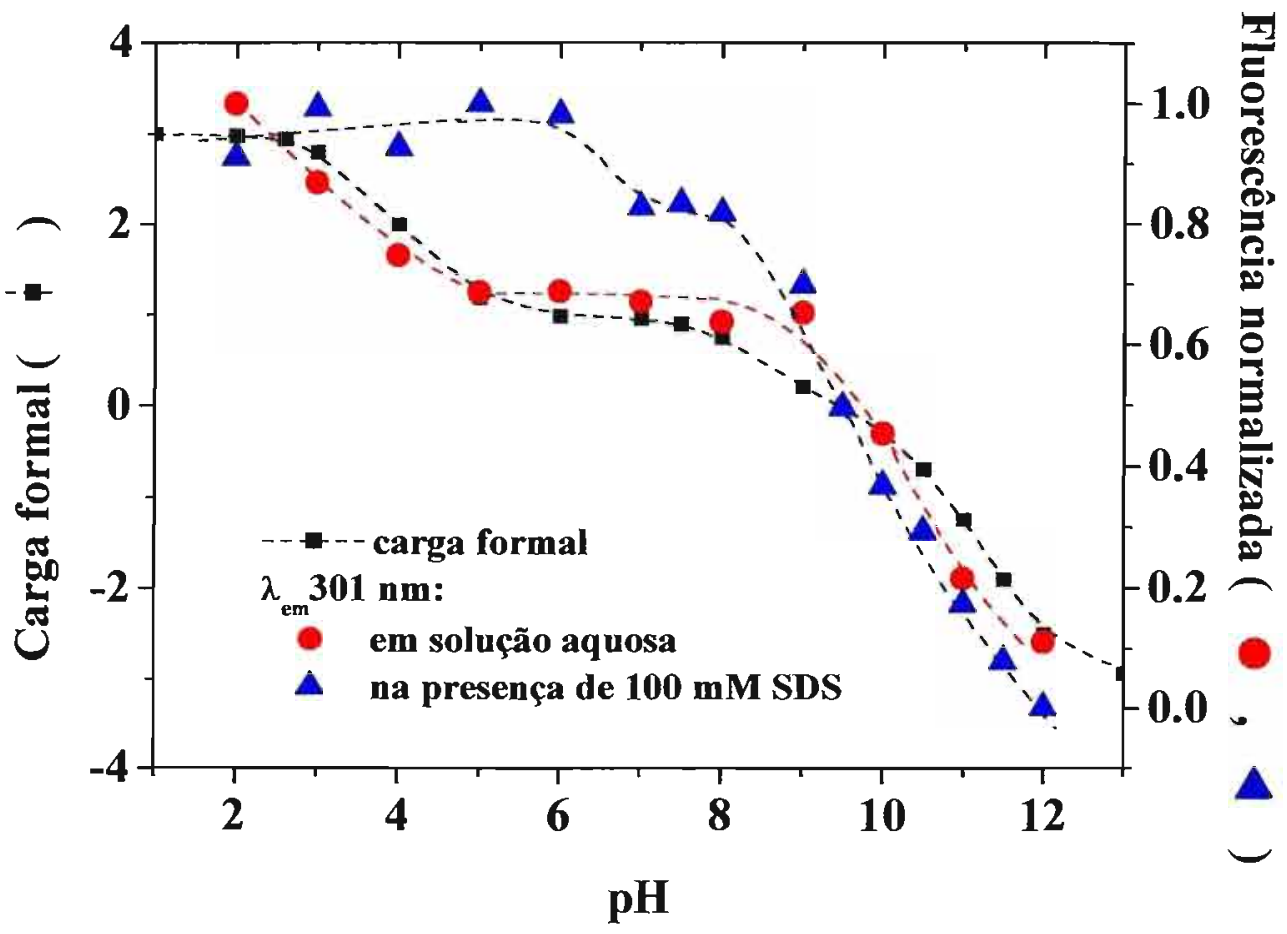

(b)

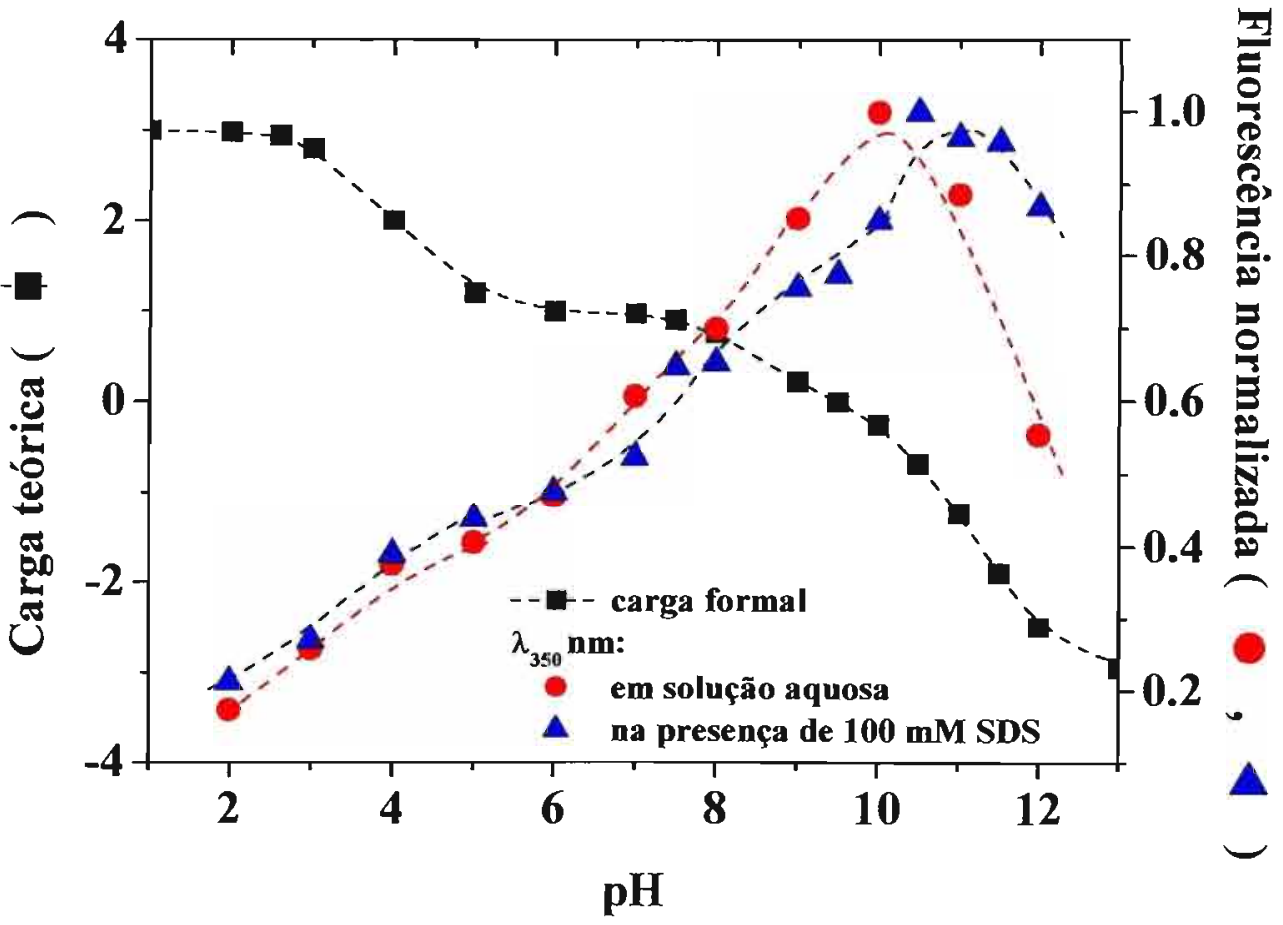

Figura 121 - Carga teórica e variação da intensidade de fluorescência de $30 \mu \mathrm{M}$ de $\mathrm{CG}$ hidratado na presença de $100 \mathrm{mM}$ SDS em função do $\mathrm{pH}$. $\lambda_{\mathrm{em}}=301$ (a) e $350 \mathrm{~nm}$ (b). 


\subsubsection{Efeito da uréia.}

Para comparação a Figura 122a apresenta o espectro de CD do peptídeo em solução aquosa, pH 7,0. Na Fig. 122b mostram-se os espectros de CD do CG na ausência e na presença de diferentes concentrações de uréia. Observa-se que acima de $2 \mathrm{M}$ de uréia a intensidade (Tabela 33) e a forma dos espectros varia pouco. A amostra foi preparada inicialmente em $6 \mathrm{M}$ de uréia e as outras concentrações foram obtidas a partir da diluição dessa amostra. Dessa forma, na presença de altas concentrações de uréia, o peptídeo deve ter perdido parte de sua estrutura secundária, a qual é recuperada, possivelmente induzida pela agregação, diminuindo-se a quantidade de uréia.

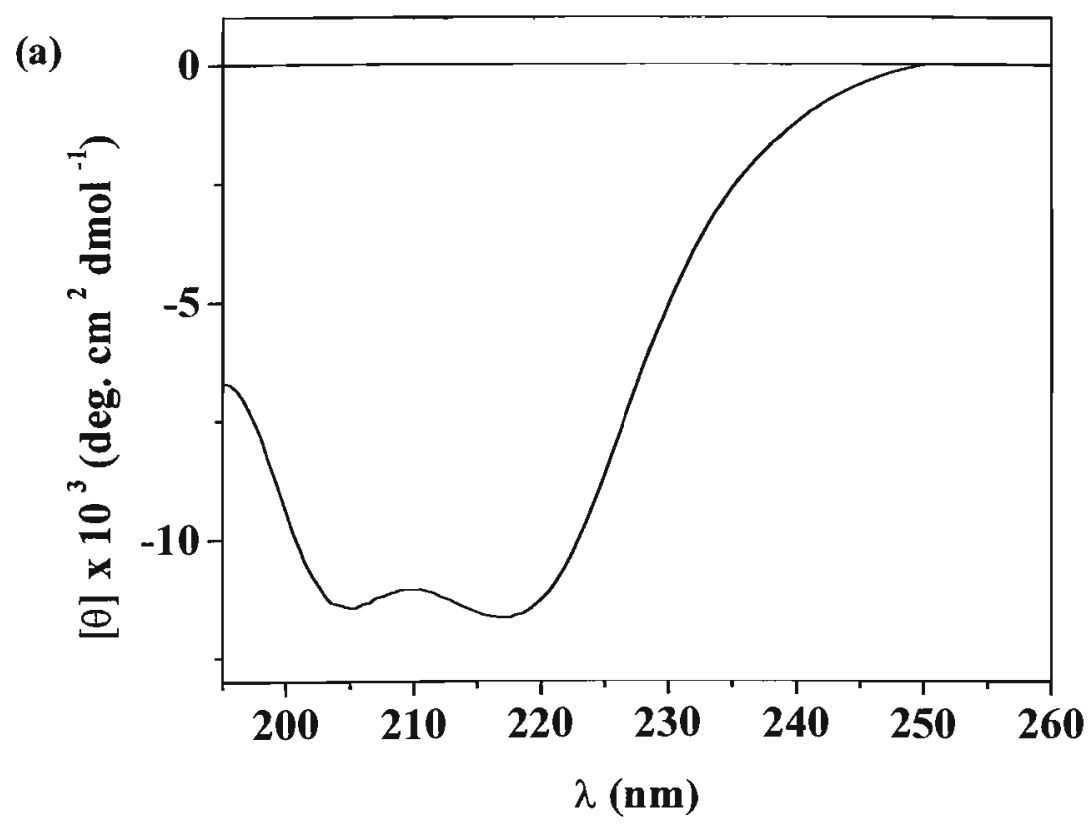


(b)
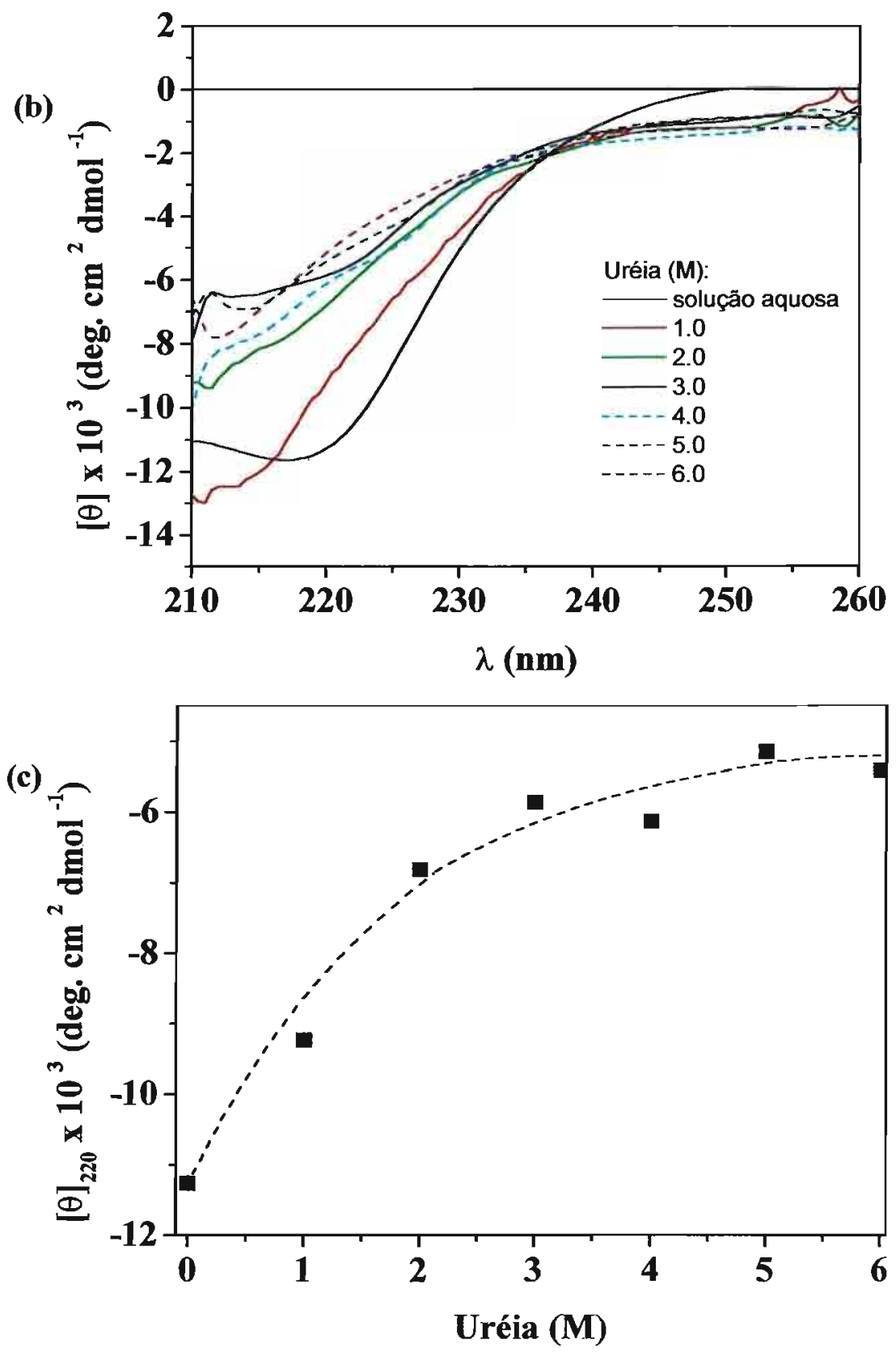

Figura 122 - (a) Espectro de CD de CG em solução aquosa em pH 7.0. (b) Espectros de $\mathrm{CD}$ de $\mathrm{CG}$ em função da concentração de uréia, $\mathrm{pH} 7,0$, a temperatura ambiente. (c) Variação da elipticidade molar nos espectros de CD de CG em $220 \mathrm{~nm}$. [CG] $=70 \mu \mathrm{M}$. 


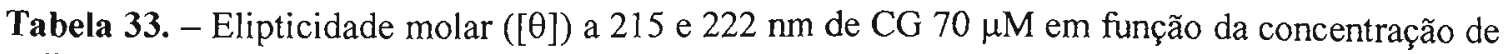
uréia, $\mathrm{pH} 7.0$

\begin{tabular}{ccc}
\hline Uréia $(\mathbf{M})$ & {$[\theta]_{215}$} & {$[\theta]_{222}$} \\
\hline 0 & -11524 & -10523 \\
1 & -12000 & -8138 \\
2 & -8149 & -6017 \\
3 & -6454 & -5438 \\
4 & -7713 & -5638 \\
5 & -6939 & -4519 \\
6 & -6847 & -4930 \\
\hline
\end{tabular}

\subsubsection{Efeito do $\mathrm{pH}$ e de detergentes.}

Outra abordagem para tentar promover a desagregação do $\mathrm{CG}$ foi elevar o pH de uma solução contendo o peptídeo para 11 e 12 e em seguida adicionar detergentes. Nesses pHs, imaginando-se que não há alteração dos $\mathrm{pK}_{\mathrm{a}} \mathrm{s}$ dos grupos ionizáveis, a carga liquida do peptídeo seria $-2,25$ e $-3,0$, respectivamente (Fig. 89). A repulsão eletrostática entre as cadeias laterais do peptídeo poderia inibir a agregação entre os monômeros do peptídeo.

Para efeito comparativo, além de adicionar o detergente à solução aquosa contendo o peptídeo (método a), também foi feito um filme deste (método b), o qual foi hidratado com soluções contendo os detergentes (ver Materiais e Métodos). Na Figura 123 mostramse os espectros de CD do CG em solução aquosa em pH 11,0 e na presença de HPS, LPC e SDS. Na Tabela 34 apresentam-se os valores dos mínimos de intensidade para cada espectro.

O espectro de CD em HPS 2 mM (Fig. 123a) da amostra preparada pelo método a é similar ao espectro em solução aquosa, com um mínimo centrado em 221,5 nm (Tabela 34), o que sugere que não houve mudanças conformacionais significativas induzidas pela ligação às micelas de HPS. Quando a amostra foi preparada pelo método $b$, o espectro de CD do CG evidencia um grande aumento da banda positiva e o aparecimento de um mínimo em 206 nm (Tabela 34).

$\mathrm{Na}$ presença de LPC $20 \mathrm{mM}$ (Fig. 123b), por ambos os métodos observam-se mudanças significativas em relação ao espectro de CD em solução aquosa. Pelo método a, o espectro de CD apresenta uma banda negativa larga, com mínimo em 217 nm (Tabela 
(a)

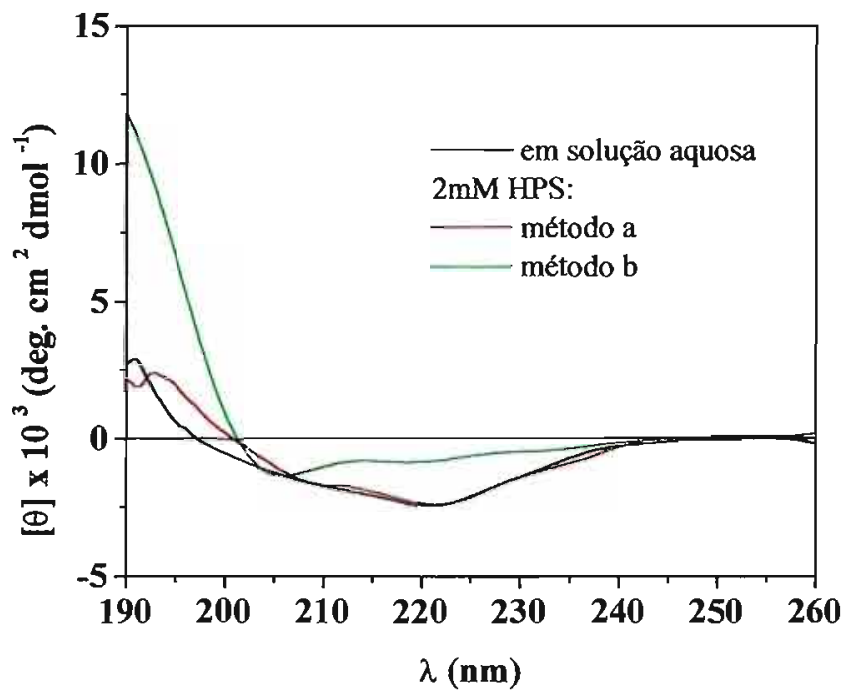

(b)

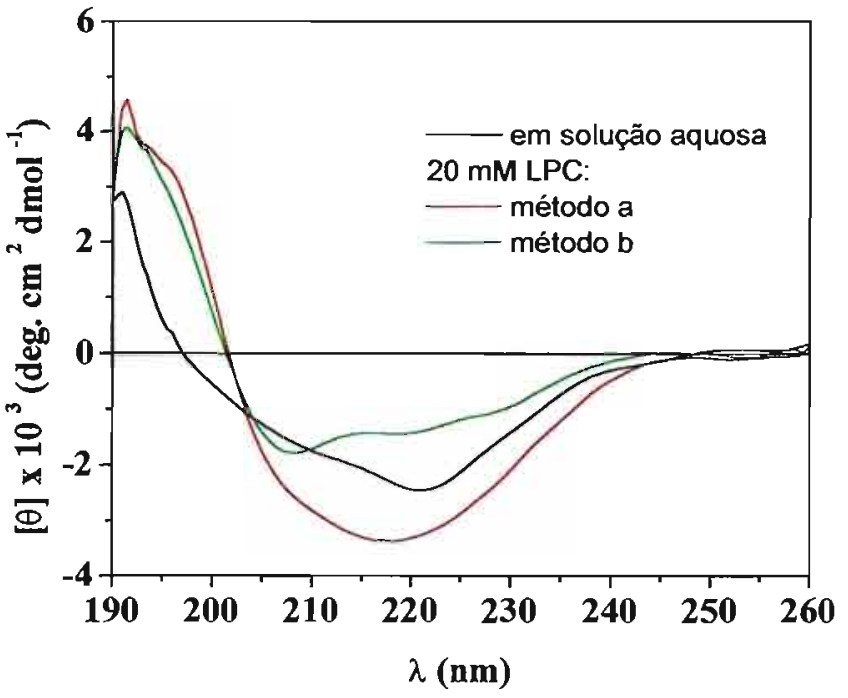

(c)

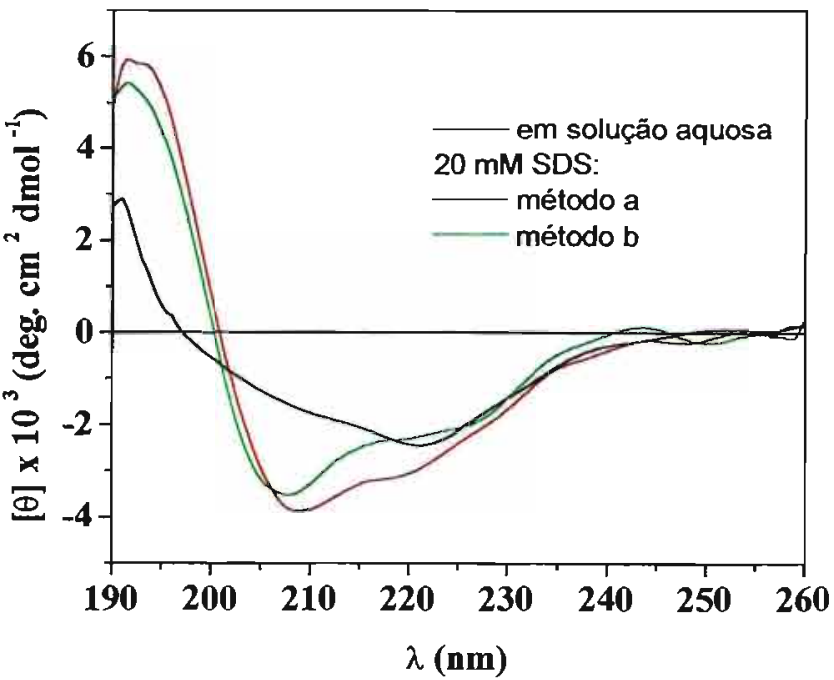

Figura 123 - Espectros de $\mathrm{CD}$ de $70 \mu \mathrm{M}$ de $\mathrm{CG}$ na presença de detergentes, $\mathrm{pH}$ 11,0. (a) $2 \mathrm{mM}$ HPS, (b) $20 \mathrm{mM}$ LPC e (c) $20 \mathrm{mM}$ SDS. As amostras foram preparadas de acordo com os métodos a e método b (ver Materiais e Métodos). 
34), sugestivo de estrutura $\beta$, enquanto que pelo método b, o mínimo é deslocado para $208,5 \mathrm{~nm}$ e o espectro de CD é sugestivo de estrutura $\alpha$-helicoidal.

Tabela 34. - Comprimento de onda mínimo $\left(\lambda_{\min }\right)$ dos espectros de CD de CG em solução aquosa e na presença de detergentes.

\begin{tabular}{|c|c|c|c|c|c|c|c|}
\hline \multirow[b]{2}{*}{$\mathrm{pH}$} & \multicolumn{6}{|c|}{$\lambda \min (\mathrm{nm})$} & \\
\hline & $\begin{array}{c}\text { Solução } \\
\text { aquosa }\end{array}$ & $2 \mathrm{mM}$ HPS & $\begin{array}{l}\text { Método a } \\
20 \mathrm{mM} \\
\text { LPC }\end{array}$ & $\begin{array}{c}20 \mathrm{mM} \\
\mathrm{SDS}\end{array}$ & $2 \mathrm{mM}$ HPS & $\begin{array}{c}\text { Método b } \\
20 \mathrm{mM} \\
\text { LPC }\end{array}$ & $\begin{array}{c}20 \mathrm{mM} \\
\text { SDS }\end{array}$ \\
\hline 11.0 & 221 & 221 & 217 & 209 & 206 & 208 & 207 \\
\hline 12.0 & 203 & 206 & 204 & 207 & 204 & 206 & 207 \\
\hline
\end{tabular}

* ver Materiais e Métodos.

Em SDS 20 mM (Fig. 123c), os espectros de CD obtidos de acordo com ambas as formas de preparação são semelhantes. Em relação ao espectro em solução aquosa, ocorre um deslocamento do mínimo de 221,5 nm para 209 (método a) e 207,5 nm (método b), apresentando características de estrutura $\alpha$-helicoidal. Em ambos os casos, os espectros indicam que o detergente foi capaz de diminuir o grau de agregação do peptídeo.

Em pH 12 (Fig. 124), os espectros de CD em HPS 2 mM (Fig. 124a) das amostras preparadas pelos métodos a e $\mathbf{b}$ apresentam características parecidas com o espectro em solução aquosa. A amostra preparada pelo segundo método apresenta um pequeno deslocamento do $\lambda_{\min }$ de 203 para $204.5 \mathrm{~nm}$ (Tabela 34), enquanto que a amostra preparada pelo primeiro apresenta deslocamento um pouco maior, de 203 para $206 \mathrm{~nm}$. Esses resultados sugerem que não são observadas mudanças conformacionais significativas.

Em LPC 20 mM (Fig. 124b), o espectro de CD preparado de acordo com o método a é muito parecido com o espectro em solução aquosa, enquanto que pelo método b o espectro evidencia um aumento de intensidade e um pequeno deslocamento da posição dos mínimo (Tabela 34), o que indica que pelo método b o CG foi capaz de incorporar-se melhor às micelas de LPC.

Ao contrário do observado em pH 11,0 (Fig. 123c), em pH 12,0 o espectro de CD de CG em SDS $20 \mathrm{mM}$ (Fig. 124c) pelo método a se mostra parecido com o espectro em solução aquosa, indicando que o CG não se liga às micelas de SDS, provavelmente devido à repulsão eletrostática entre o peptídeo, que nesse $\mathrm{pH}$ possui carga líquida negativa, e o detergente. Pelo método $\mathbf{b}$, foram observadas mudanças maiores em relação ao peptídeo em solução aquosa, sugerindo melhor incorporação à micela. 
(a)

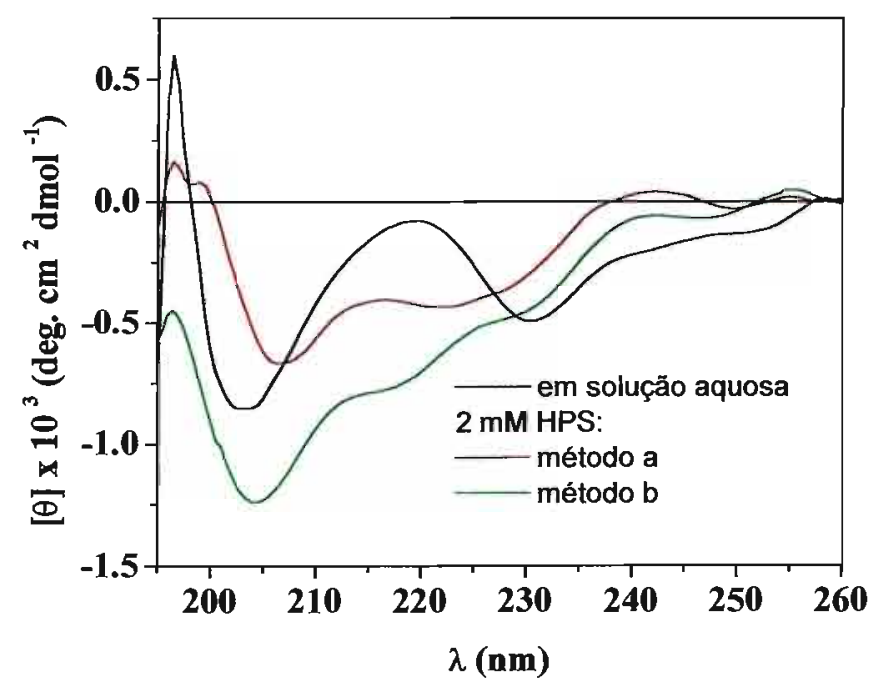

(b)

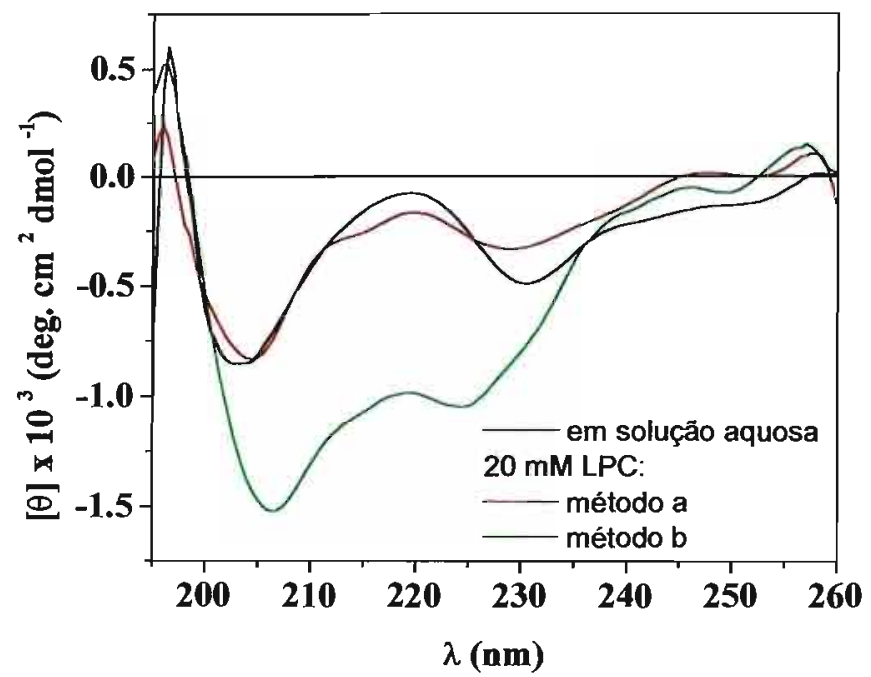

(c)

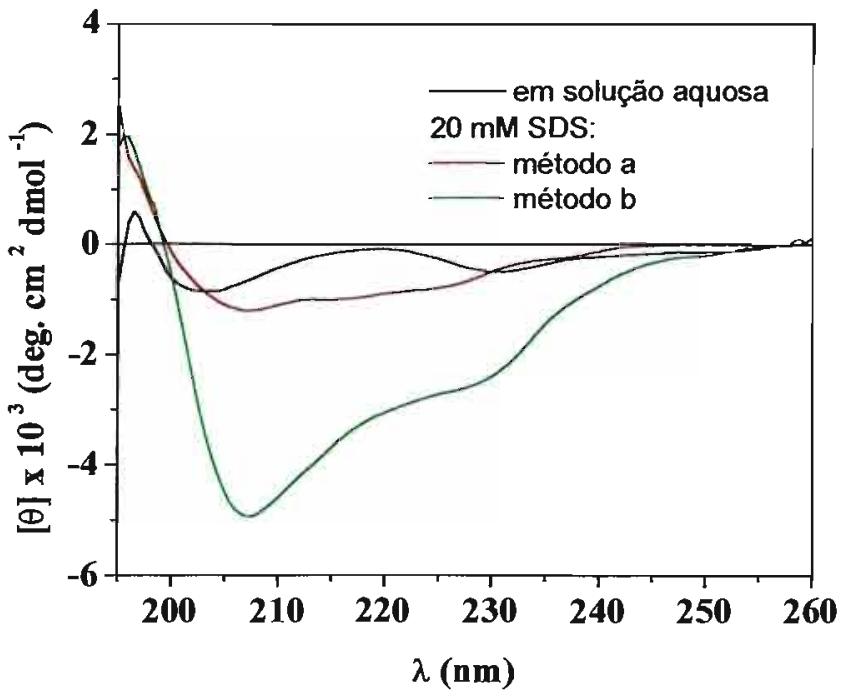

Figura 124 - Espectros de CD de $70 \mu \mathrm{M}$ de CG na presença de detergentes, pH 12,0. (a) HPS $2 \mathrm{mM}$, (b) LPC $20 \mathrm{mM}$ e (c) SDS $20 \mathrm{mM}$. As amostras foram preparadas de duas maneiras: os detergentes foram adicionados a solução aquosa contendo o peptídeo ou um filme do peptídeo foi hidratado na presença dos detergentes. 


\subsubsection{Interação entre $C G$ e fragmentos do receptor $A T_{l A}$ de angiotensina II.}

Uma das propostas deste trabalho é investigar a possível interação do fragmento Cterminal da subunidade $\alpha$ da proteína $\mathrm{G}$ com fragmentos do receptor $\mathrm{AT}_{\mathrm{IA}}$ de angiotensina II. Sabe-se que a região C-terminal e a segunda e a terceira alça citoplasmática do receptor estão envolvidas na interação com a proteína $\mathrm{G}^{(131,132)}$. A seguir apresentam-se resultados obtidos com o CG na presença dos fragmentos $f$-CT, i2 e Ni3 do receptor. Os experimentos foram feitos hidratando-se filmes dos peptídeos na presença de uma concentração baixa de LPC, de modo que a favorecer uma possível interação entre os fragmentos.

\subsubsection{Interação com $f$-CT}

A Figura 128 mostra os espectros de um filme de $f$-CT $100 \mu \mathrm{M}$ hidratado na presença de LPC $1 \mathrm{mM}$ em função do pH. Este peptídeo tem propensão a adquirir $\alpha$-hélice em solução aquosa com o aumento do $\mathrm{pH}^{(50)}$, bem como na presença de membranas modelo (Dra. T.A., tese de doutorado, 1998).

Os espectros de CD mostram que o peptídeo adquire estrutura em $\alpha$-hélice já em pH 2,0, a qual aumenta em pHs mais altos, atingindo um máximo em torno de $\mathrm{pH} 8,0$, visto pelos valores de elipticidade molar em $222 \mathrm{~nm}$ (Fig. 125c).

Os espectros de CG (Fig. 126) também indicam que o peptídeo adquire conformação $\alpha$-helicoidal na presença de LPC $1 \mathrm{mM}$. Inicialmente, em $\mathrm{pH}$ 2,0, o espectro de $\mathrm{CD}$ de $\mathrm{CG}$ indica uma predominância de estrutura ao acaso, contudo com o aumento $\mathrm{pH}$, o fragmento adquire um conteúdo maior de $\alpha$-hélice, atingindo um máximo em torno de $\mathrm{pH}$ 9,0 (Fig. 126b).

Em seguida foram adquiridos os espectros de CD de $f$-CT $100 \mu \mathrm{M}$ na presença de CG $100 \mu \mathrm{M}$ em LPC $1 \mathrm{mM}$ em função do $\mathrm{pH}$. Para comparação, foi feita a soma das intensidades dos espectros de $\mathrm{CD}$ de $f$-CT e de $\mathrm{CG}$, gerando um espectro teórico. A Figura 127 mostra os espectros de $f$-CT; CG; e o espectro teórico e experimental para $f$-CT na presença de $\mathrm{CG}$ em três pHs diferentes. Em todos os casos, a intensidade do espectro experimental foi maior do que o espectro teórico, o que sugere que os dois peptídeos interagem. 
(a)

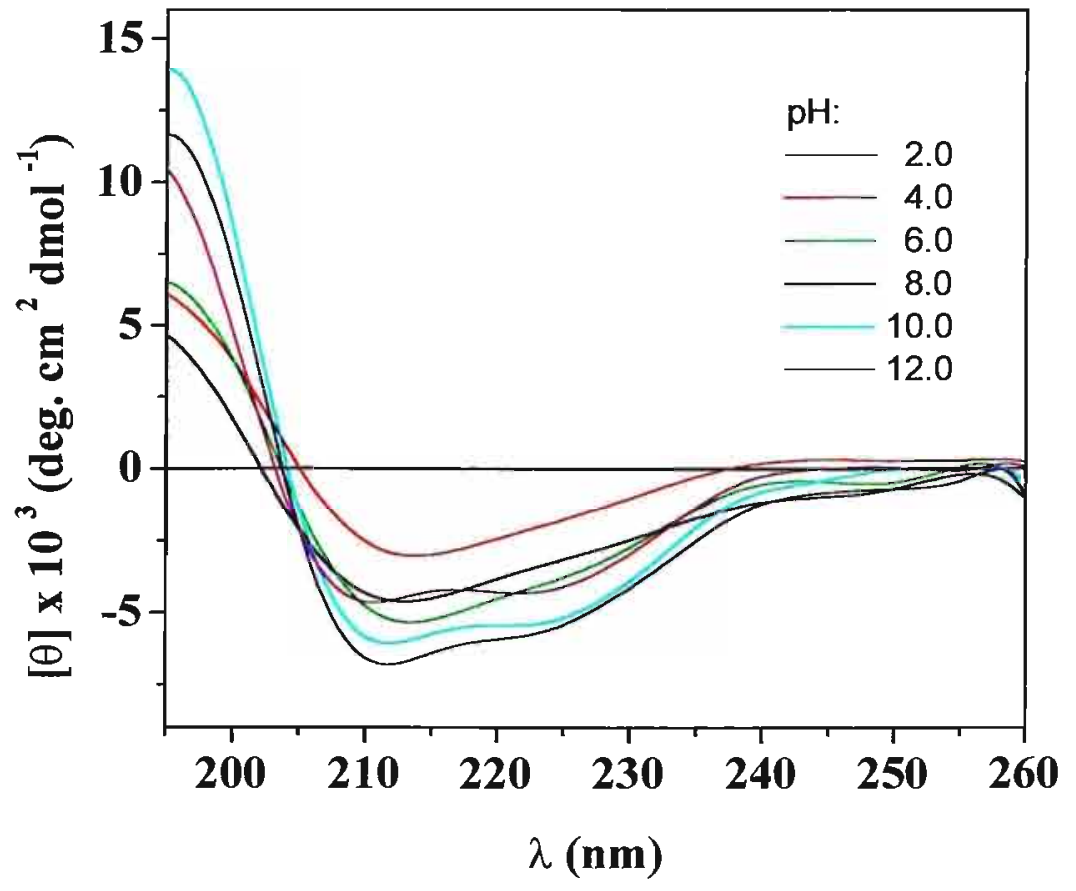

(b)

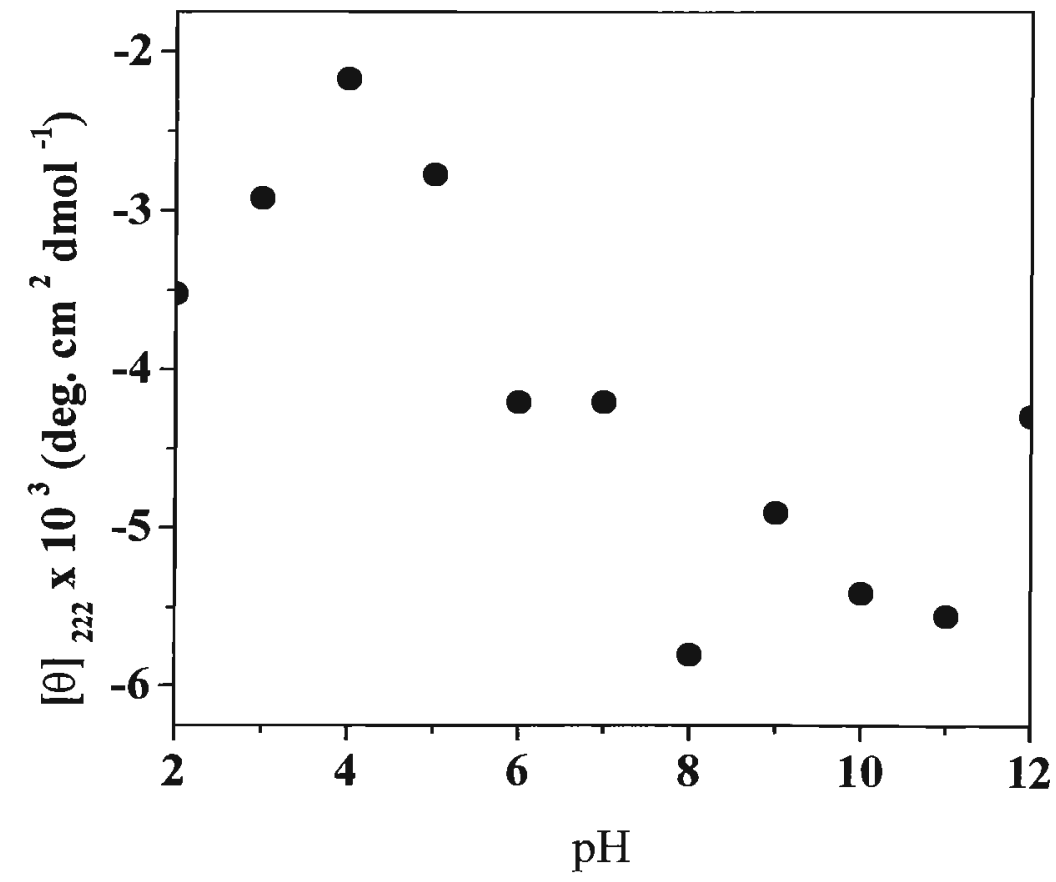

Figura 125 - (a) Espectros de CD de $f$-CT $100 \mu \mathrm{M}$ em função do pH. (b) Elipticidade molar em $222 \mathrm{~nm}$ em função do $\mathrm{pH}$. 
(a)

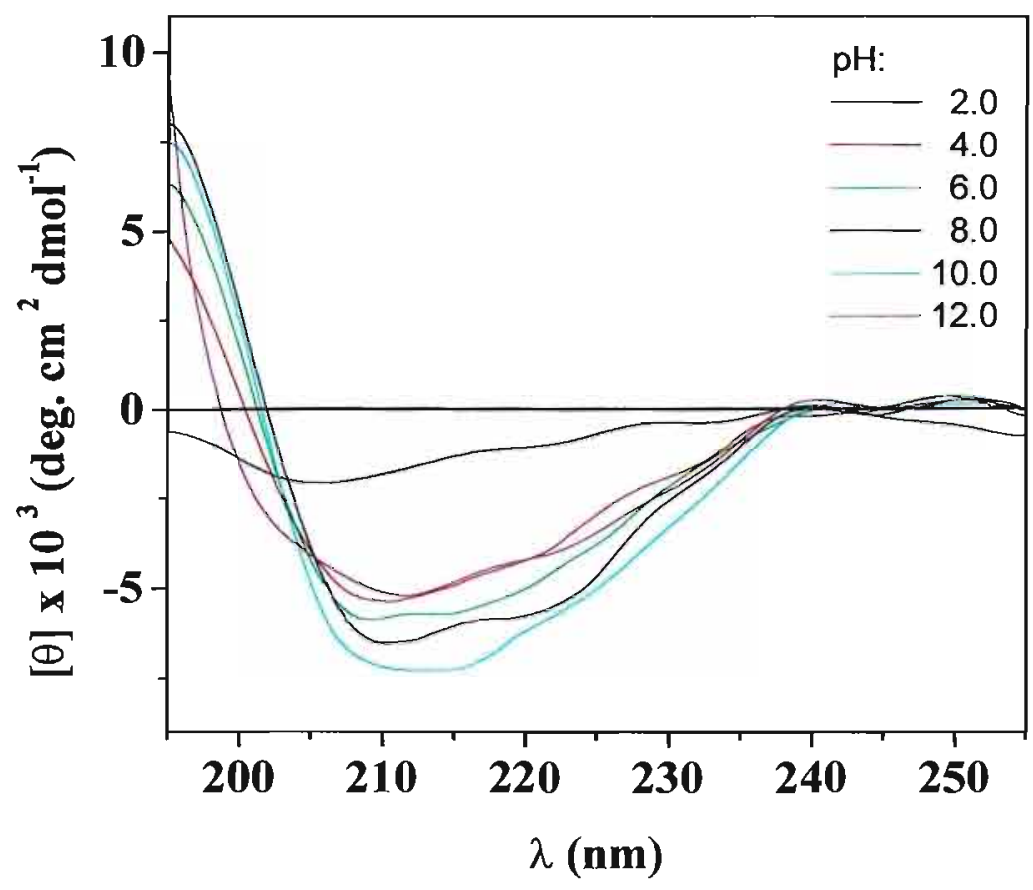

(b)

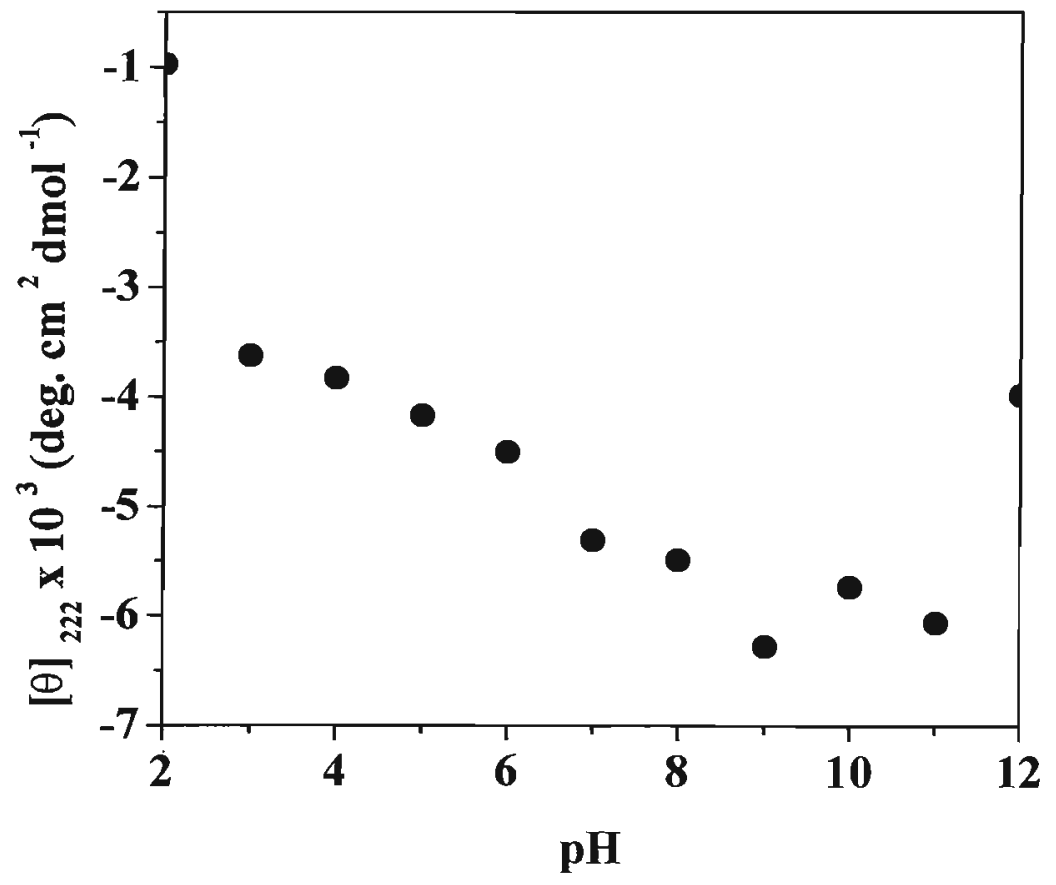

Figura 126 - (a) Espectros de CD de CG $100 \mu \mathrm{M}$ em função do pH. (b) Elipticidade molar em $222 \mathrm{~nm}$ em função do $\mathrm{pH}$. 
(a)

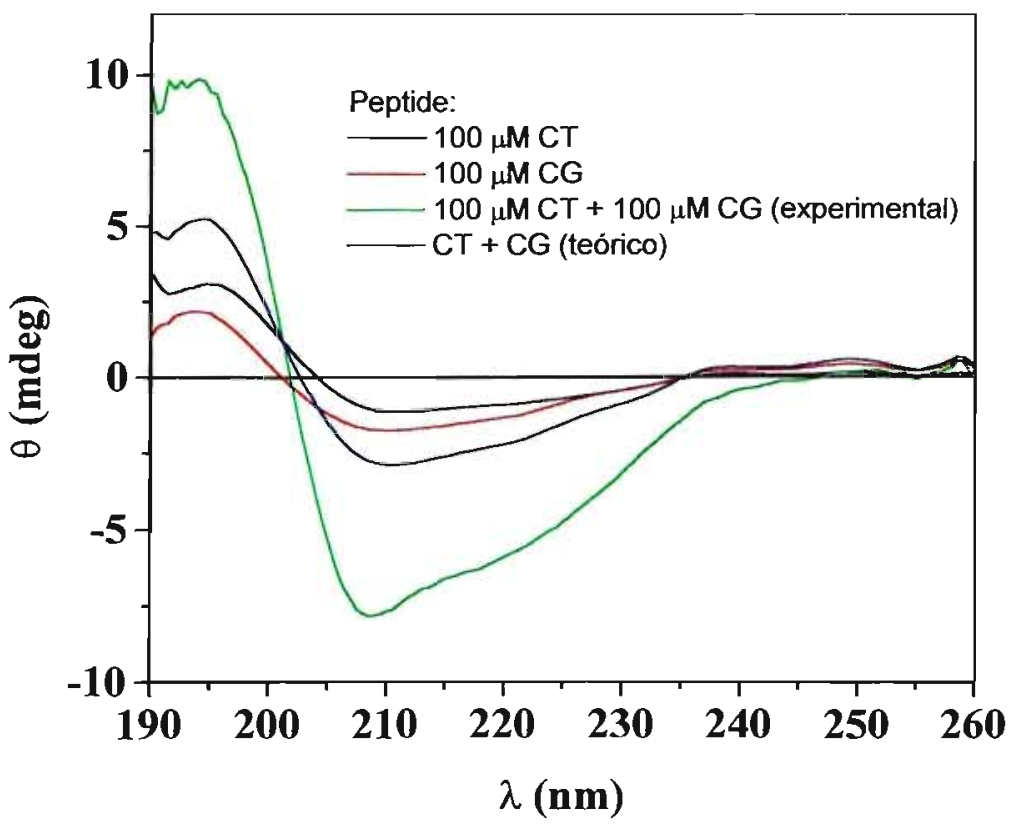

(b)

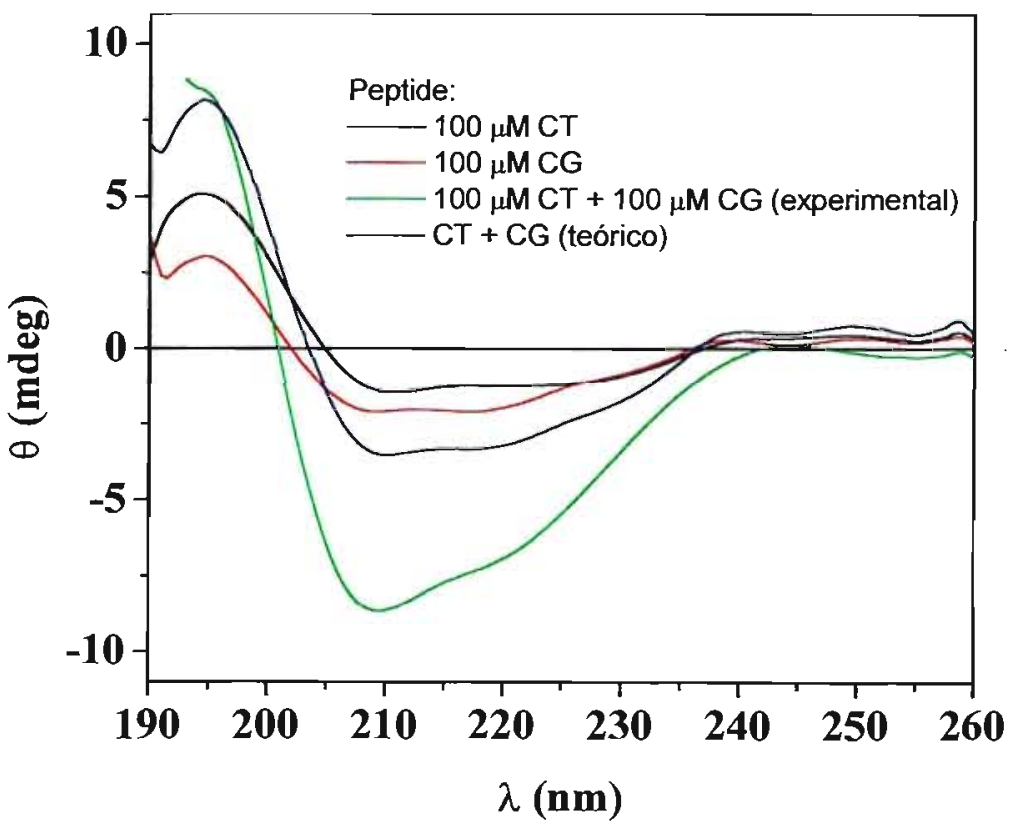




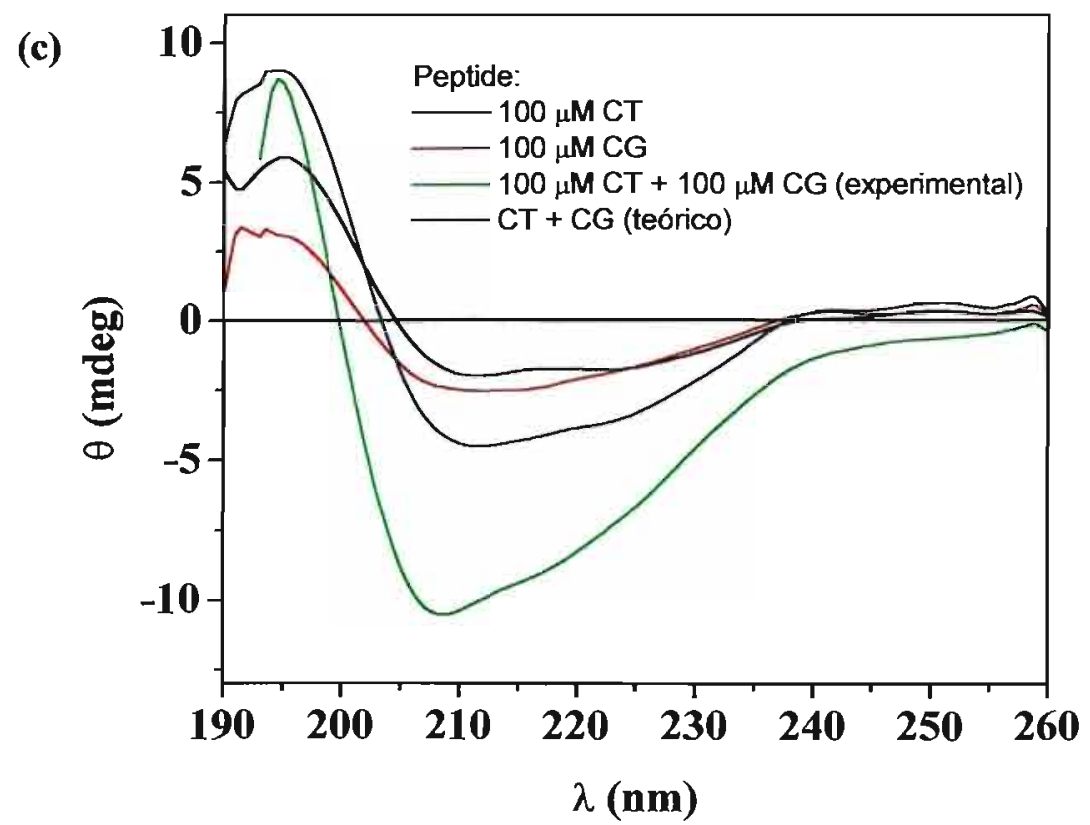

Figura 127 - Espectros de CD de $f$-CT, CG e de $f$-CT na presença de CG em LPC $1 \mathrm{mM}$. pH: 4,0 (a), 7,0 e 10,0 (c). 
A Tabela 35 mostra os comprimentos de onda mínimos para cada espectro nos pHs 4,0, 7,0 e 10,0. Na presença dos dois peptídeos, há um pequeno deslocamento do mínimo em relação ao espectro teórico, principalmente nos pHs 4,0 e 10,0.

Tabela 35. - Comprimento de onda mínimo $\left(\lambda_{\min }\right)$ dos espectros de CD de $f$-CT, $\mathrm{CG}, f-\mathrm{CT}+\mathrm{CG}$ em LPC $1 \mathrm{mM}$, em função do $\mathrm{pH}$. [peptídeo] $=100 \mu \mathrm{M}$.

\begin{tabular}{ccccc}
\hline \multicolumn{5}{c}{$\lambda_{\min }$} \\
\hline $\mathrm{pH}$ & $f$-CT & $\mathrm{CG}$ & $f$-CT $+\mathrm{CG}$ & $f$-CT $+\mathrm{CG}$ \\
& & & teórico & experimental \\
4.0 & 211,0 & 210,5 & 210,5 & 208,5 \\
7.0 & 210,5 & 209,5 & 210,0 & 209,5 \\
10.0 & 211,5 & 211,0 & 211,5 & 208,5 \\
\hline
\end{tabular}

Para visualizar melhor a diferença na forma dos espectros, estes foram normalizados de acordo com sua intensidade em 208 nm (Fig. 128). É possível observar que existe uma diferença significativa entre a forma do espectro experimental e teórico, principalmente em pHs mais altos.

A Tabela 36 mostra a razão entre $[\theta]_{208} /[\theta]_{222}$ obtida dos espectros de CD de cada peptídeo e dos espectros teórico e experimental de $f$-CT + CG. Em pH 4,0 a razão entre o espectro teórico é similar ao do espectro experimental. No entanto em pHs mais altos há uma diferença significativa entre ambos, o que também sugere a interação entre os peptídeos.

Tabela 36. - Razão entre $[\theta]_{208} /[\theta]_{222}$ obtida a partir dos espectros de $\mathrm{CD}$ de $f$-CT, $C G, f-C T+$ CG em LPC $1 \mathrm{mM}$, em função do $\mathrm{pH}$. [peptídeo] $=100 \mu \mathrm{M}$.

\begin{tabular}{|c|c|c|c|c|}
\hline & & {$[\theta]_{208} /[\theta]_{222}$} & & \\
\hline $\mathrm{pH}$ & $f$-CT & CG & $\begin{array}{c}f-\mathrm{CT}+\mathrm{CG} \\
\text { teórico }\end{array}$ & $\begin{array}{l}f-\mathrm{CT}+\mathrm{CG} \\
\text { experimental }\end{array}$ \\
\hline 4.0 & 1,18 & 0,44 & 1,33 & 1,36 \\
\hline 7.0 & 0,97 & 1,17 & 1,09 & 1,31 \\
\hline 10.0 & 0,89 & 1,20 & 1,05 & 1,37 \\
\hline
\end{tabular}

\subsubsection{Interação com $i 2$}

Na presença de LPC 1 mM, o peptídeo i2 (Fig. 129) apresenta inicialmente estrutura ao acaso. Até $\mathrm{pH}$ 6,0 praticamente não há variação de intensidade (Fig. 129b). Com o aumento do $\mathrm{pH}$ a intensidade aumenta continuamente entre os $\mathrm{pHs} 6,0$ e 11,0 , refletindo a 
(a)

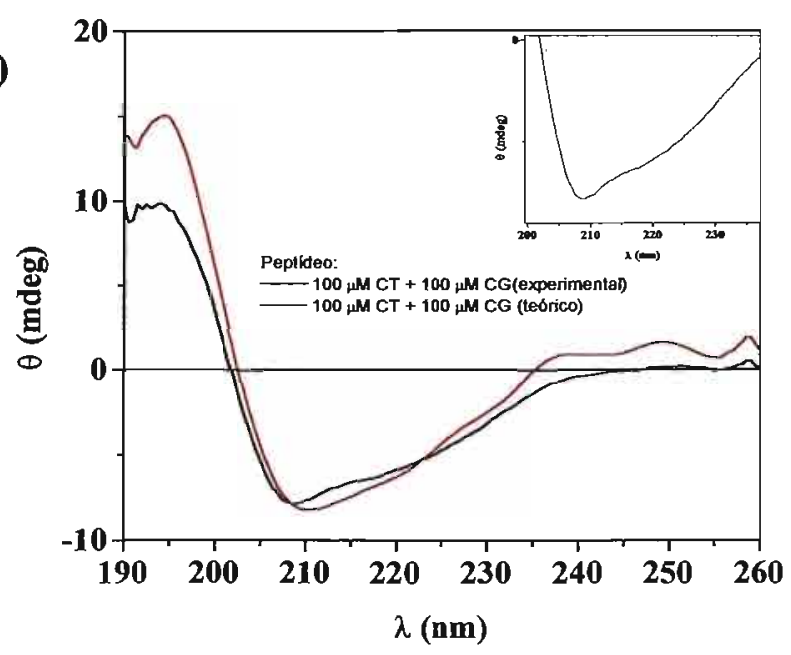

(b)

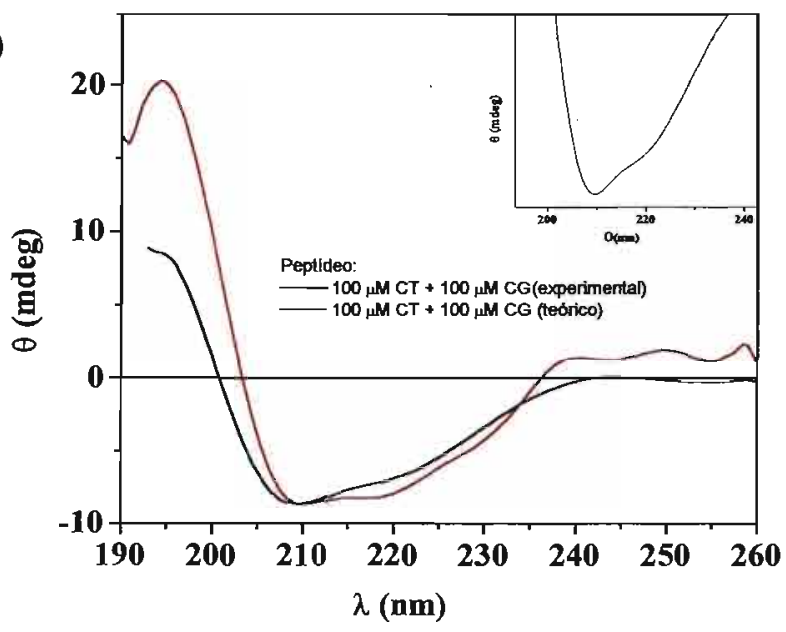

(c)

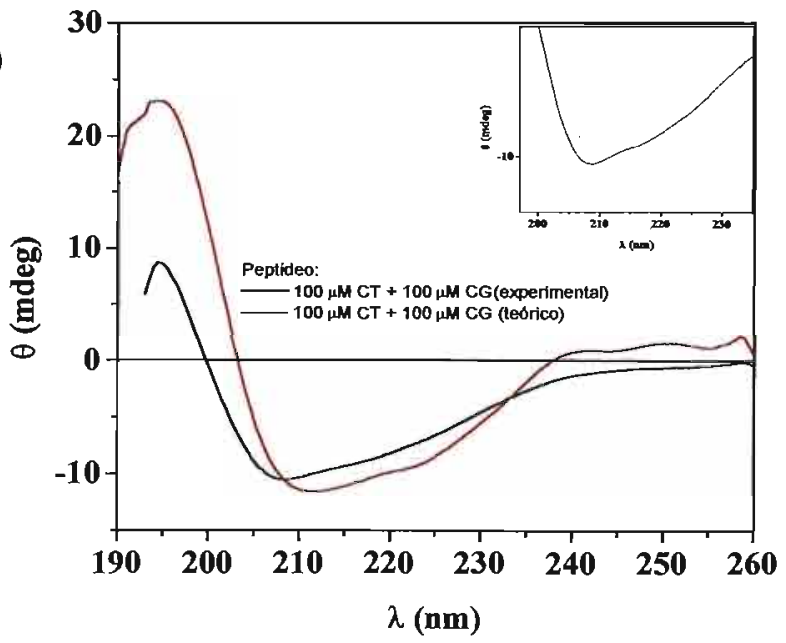

Figura 128 - Espectros experimental e teórico de $f$-CT+CG em LPC 1 mM. pH: 4,0 (a), 7,0 e 10,0 (c). Os espectros foram normalizados pelo valor de elipticidade molar em 208 nm. 
(a)

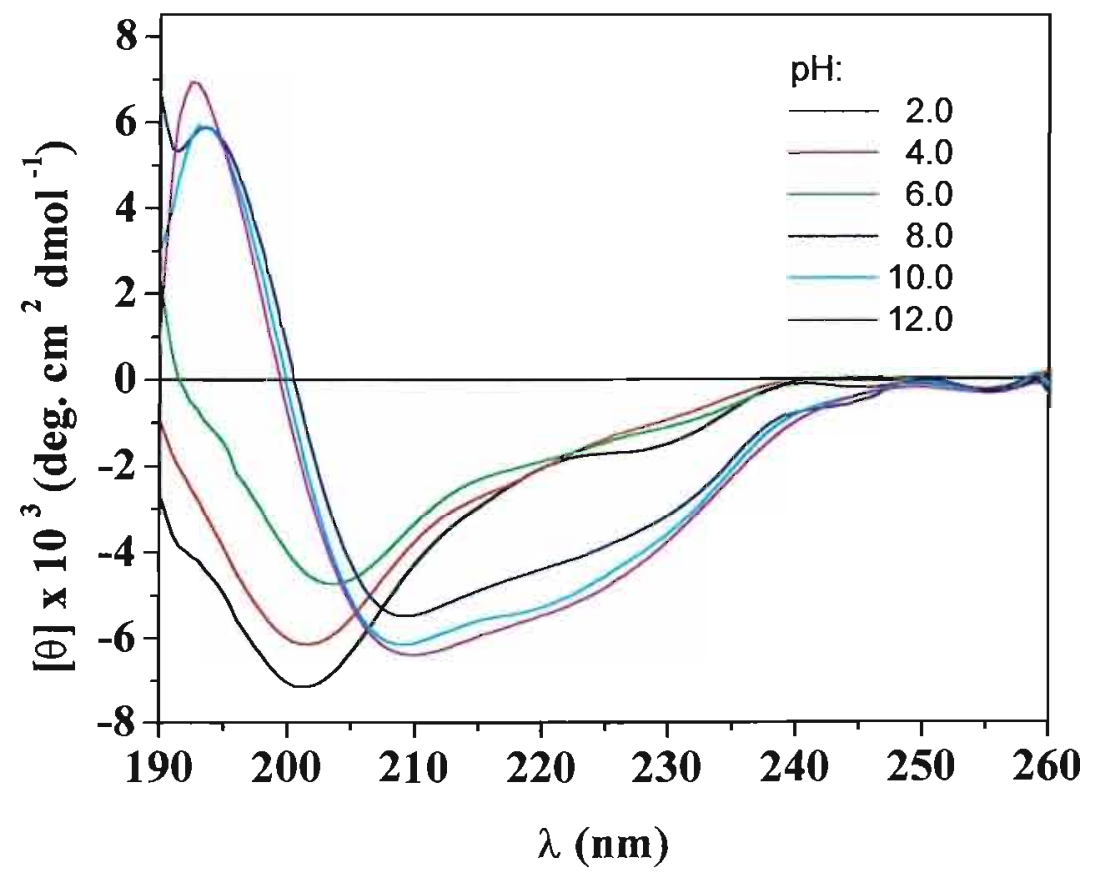

(b)

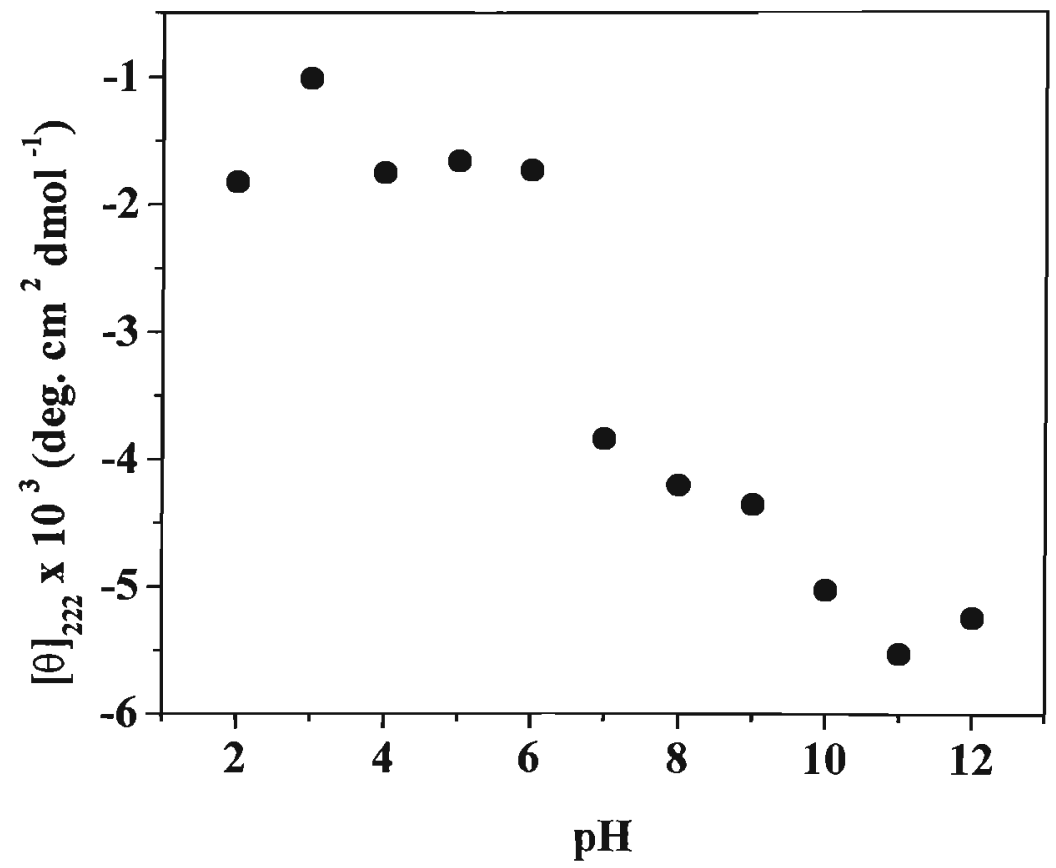

Figura 129 - (a) Espectros de CD de i2 $100 \mu \mathrm{M}$ em função do pH. (b) Elipticidade molar em $222 \mathrm{~nm}$ em função do $\mathrm{pH}$. 
desprotonação dos grupos ionizáveis. Nessa faixa de $\mathrm{pH}$, os espectros de $\mathrm{CD}$ (Fig. 132b) mostram que a conformação do peptídeo muda de ao acaso para $\alpha$-hélice. Estes dados estão de acordo com os encontrados em estudos realizados no nosso grupo com esse peptídeo. (Dr. Cláudio S. Shida, trabalhos não publicados)

Na Figura 130 mostram-se os espectros de i2, CG e de i2 + CG em LPC $1 \mathrm{mM} \mathrm{em}$ três pHs diferentes. Assim como observado no item anterior para o $f$-CT, os espectros experimentais do CG na presença de i2 apresentam intensidade maior do que o espectro teórico obtido pela soma dos espectros dos peptídeos separados.

A Tabela 37 apresenta os valores dos comprimentos de onda mínimos para cada espectro nos pHs 4,0, 7,0 e 10,0. As diferenças observadas entre o espectro teórico e o espectro experimental são relativamente pequenas; a maior diferença é observada em pH 4,0 , provavelmente devido à contribuição do espectro de i2 que neste $\mathrm{pH}$ apresenta conformação ao acaso.

Tabela 37. - Comprimento de onda mínimo $\left(\lambda_{\min }\right)$ dos espectros de CD de i2, CG, i2 + CG em LPC $1 \mathrm{mM}$, em função do $\mathrm{pH}$. [peptídeo] $=100 \mu \mathrm{M}$.

\begin{tabular}{ccccc}
\hline & \multicolumn{3}{c}{$\lambda_{\min }$} & \\
\hline $\mathrm{pH}$ & $\mathrm{i} 2$ & $\mathrm{CG}$ & $\begin{array}{c}\mathrm{i} 2+\mathrm{CG} \\
\text { teórico }\end{array}$ & $\begin{array}{c}\mathrm{i} 2+\mathrm{CG} \\
\text { experimental }\end{array}$ \\
4.0 & 201,5 & 210,5 & 206,0 & 207,5 \\
7.0 & 208,5 & 209,5 & 209,0 & 209,0 \\
10.0 & 208,5 & 211,0 & 210,0 & 209,0 \\
\hline
\end{tabular}

Comparando-se os espectros normalizados (Fig. 131), observa-se que a forma dos espectros é parecida nos pHs 7,0 e 10,0 . A razão entre $[\theta]_{208} /[\theta]_{222}$ apresenta diferenças significativas em pH 4,0, que como mencionado deve-se a contribuição de i2. Apesar disso, a diferença significativa de intensidade entre os espectros teórico e experimental pode ser sugestiva de que haja interação entre esses dois fragmentos. 
(a)

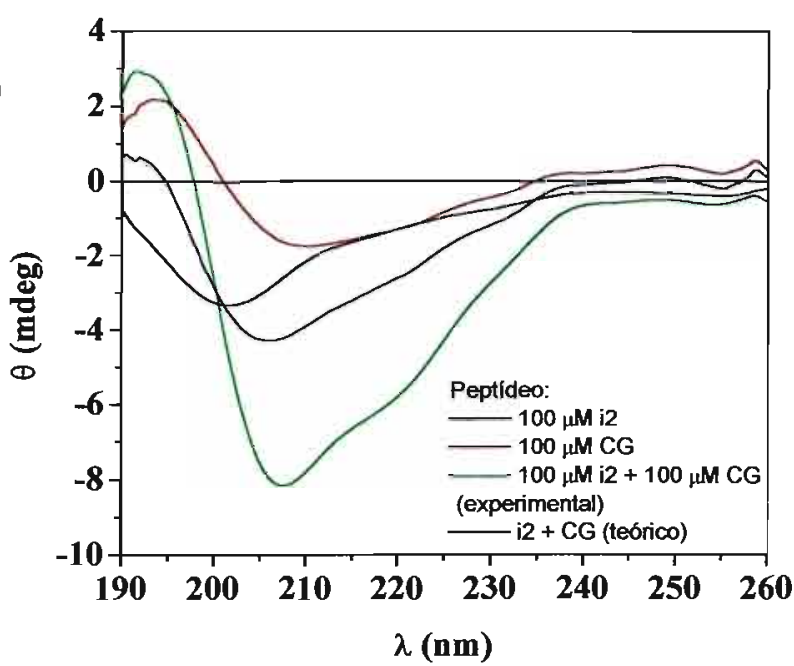

(b)

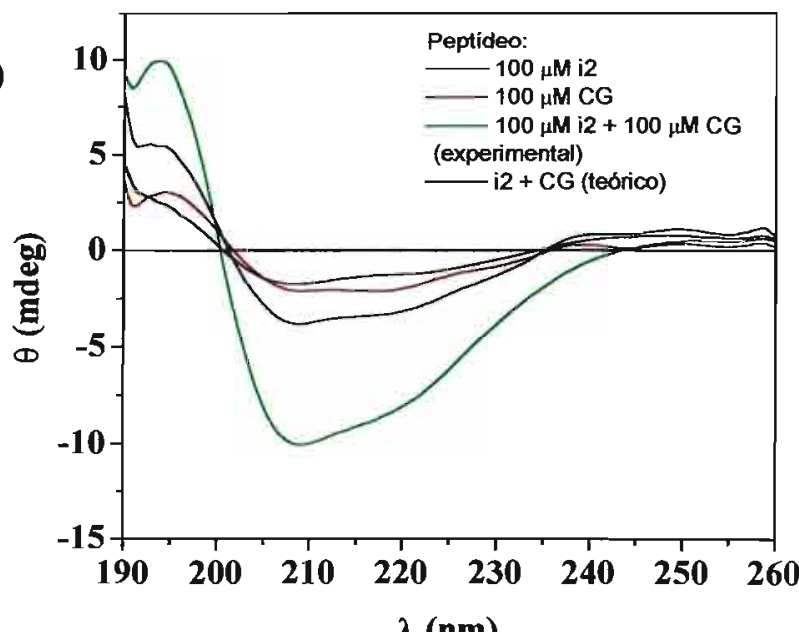

(c)

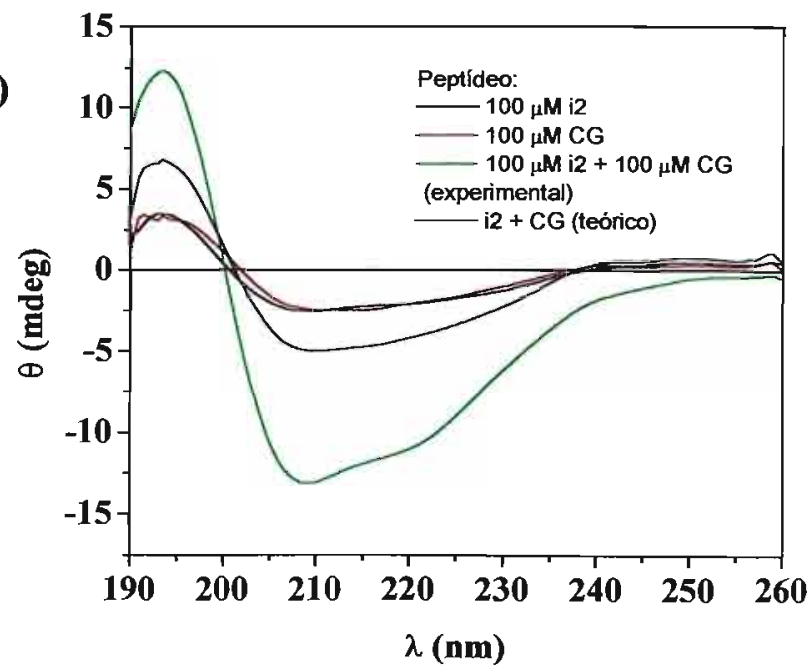

Figura 130 - Espectros de CD de i2, CG e de i2 na presença de CG em LPC $1 \mathrm{mM}$. pH: 4,0 (a), 7,0 e 10,0 (c). 
(a)

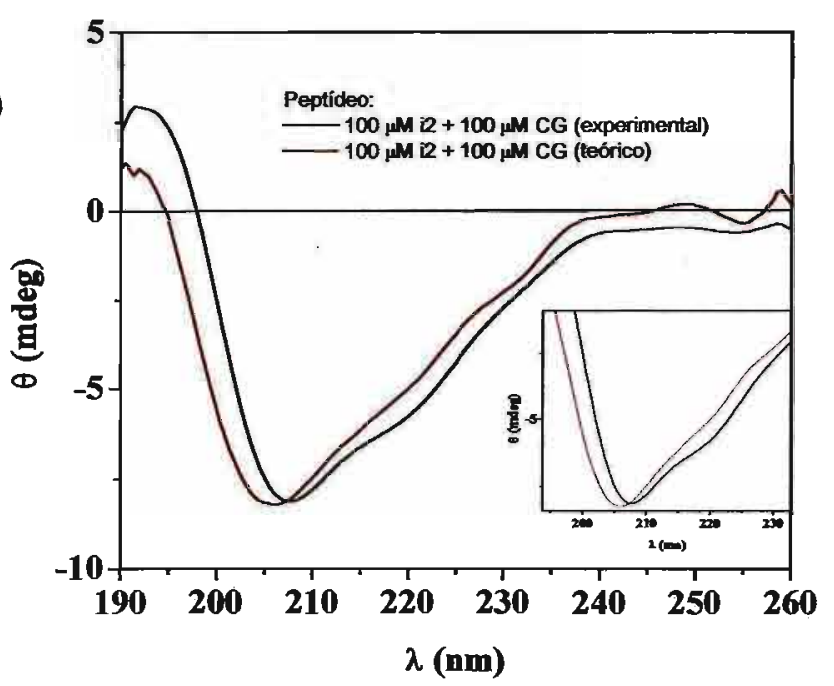

(b)

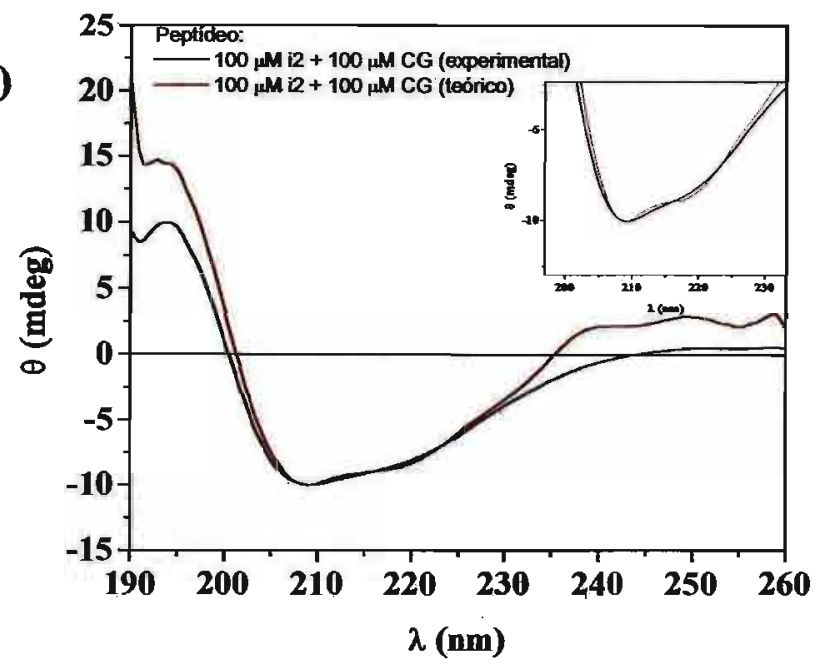

(c)

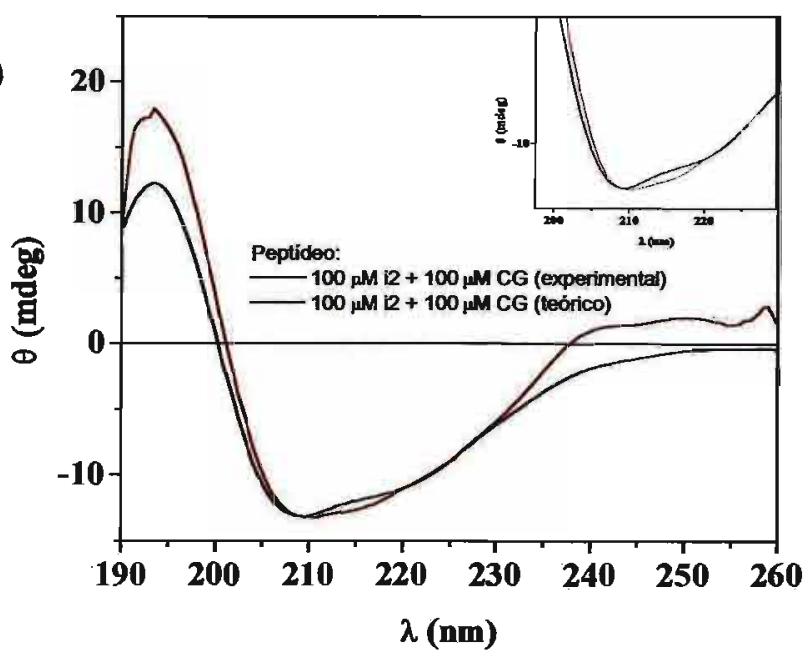

Figura 131 - Espectros experimental e teórico de i2 + CG em LPC 1 mM. pH: 4,0 (a), 7,0 e 10,0 (c). Os espectros foram normalizados pelo valor de elipticidade molar em $208 \mathrm{~nm}$. 
Tabela 38. - Razão entre $[\theta]_{208} /[\theta]_{222}$ obtida a partir dos espectros de CD de $i 2, \mathrm{CG}$, i2 + CG em $\mathrm{LPC} 1 \mathrm{mM}$, em função do $\mathrm{pH}$. [peptídeo] $=100 \mu \mathrm{M}$.

\begin{tabular}{ccccc}
\hline \multicolumn{5}{c}{$[\theta]_{208}[\theta]_{222}$} \\
\hline $\mathrm{pH}$ & $\mathrm{i} 2$ & $\mathrm{CG}$ & $\mathrm{i} 2+\mathrm{CG}$ & $\mathrm{i} 2+\mathrm{CG}$ \\
& & & teórico & experimental \\
4.0 & 2,15 & 0,44 & 1,79 & 1,53 \\
7.0 & 1,47 & 1,17 & 1,29 & 1,34 \\
10.0 & 1,26 & 1,20 & 1,24 & 1,23 \\
\hline
\end{tabular}

\subsubsection{Interação com $\mathrm{Ni3}$}

Em solução aquosa o peptídeo Ni3 (Fig. 132) em pH 2,0 apresenta uma banda negativa em torno de $202 \mathrm{~nm}$ e outra em torno de $221 \mathrm{~nm}$; o espectro de CD indica que o espectro de CD possui um conteúdo baixo de estrutura $\alpha$-helicoidal. Com o aumento do $\mathrm{pH}$, o conteúdo de $\alpha$-hélice também aumenta, principalmente a partir de 6,0.

O espectro de CD do filme de $100 \mu \mathrm{M}$ Ni3 (Fig. 133) na presença de $1 \mathrm{mM} \mathrm{LPC}$ mostra que o peptídeo nessa condição adota estrutura $\alpha$-helicoidal. $O$ espectro apresenta intensidade significativamente maior do que o CG na mesma condição, esse fato está relacionado com a solubilidade maior de CG em solução aquosa. Em todos os pHs observase que o espectro de $\mathrm{CD}$ teórico de Ni3 na presença de CG possui intensidade maior do que o espectro experimental, o que se deve a contribuição de Ni3 na construção do espectro teórico. Esse resultado indica que nesse caso também houve interação entre CG e Ni3.

Na Tabela 39 apresenta-se a posição do comprimento de onda mínimo dos espectros de CD da Figura 133. A posição do $\lambda_{\min }$ do espectro experimental apresenta um deslocamento pequeno em relação ao espectro teórico, porém essa diferença é relevante.

Tabela 39 - Comprimento de onda mínimo $\left(\lambda_{\text {min }}\right)$ dos espectros de CD de Ni3, CG, Ni3 + CG em $\underline{L P C} 1 \mathrm{mM}$, em função do pH. [peptídeo] $=100 \mu \mathrm{M}$.

\begin{tabular}{ccccc}
\hline pH & \multicolumn{4}{c}{$\lambda_{\min }$} \\
& $\mathrm{Ni3}$ & $\mathrm{CG}$ & $\mathrm{Ni3}+\overline{\mathrm{CG}}$ & $\begin{array}{c}\mathrm{Ni} 3+\mathrm{CG} \\
\text { experimental }\end{array}$ \\
4,0 & 203,0 & 210,5 & 209,0 & 207,5 \\
7,0 & 205,0 & 209,5 & 209,5 & 207,0 \\
10,0 & 207,5 & 211,0 & 209,0 & 207,0 \\
\hline
\end{tabular}


(a)

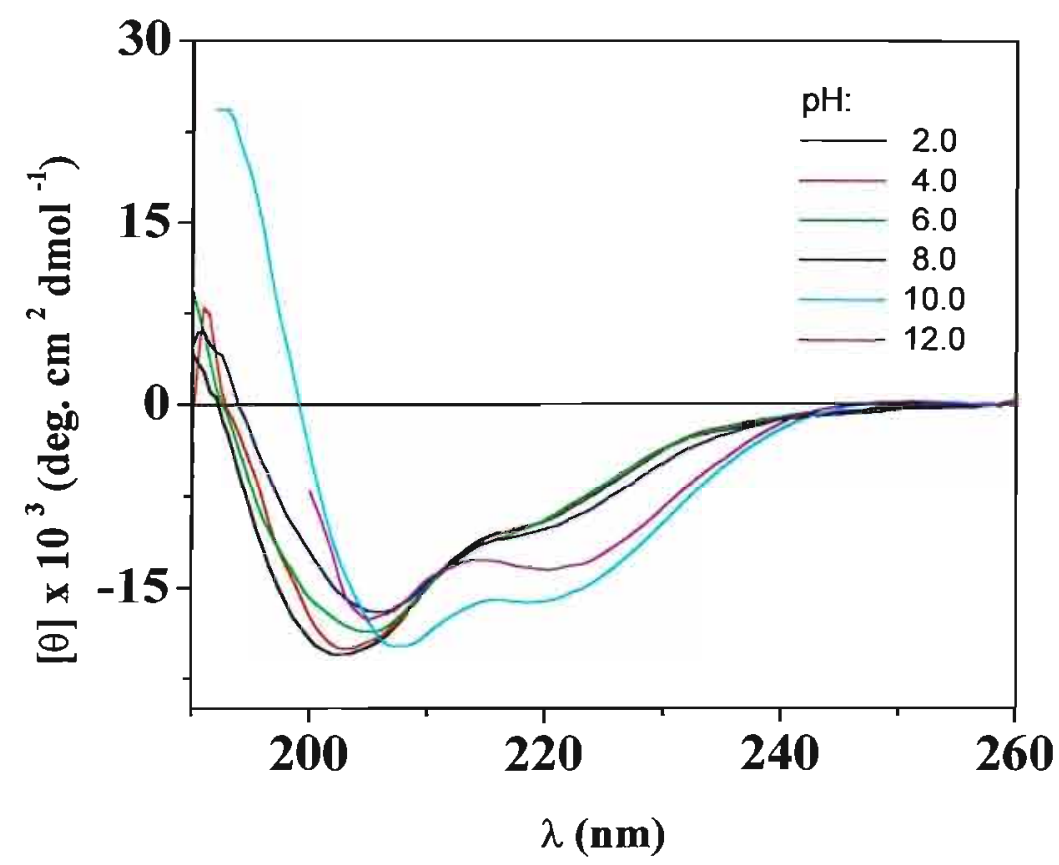

(b)

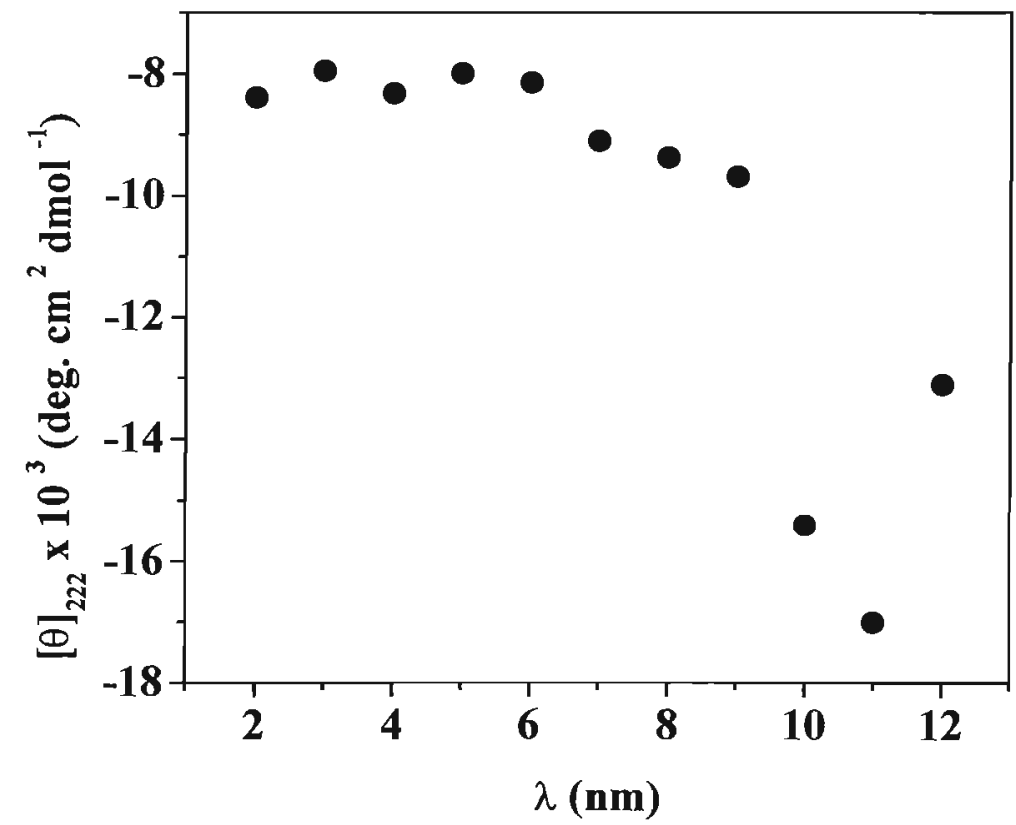

Figura 132 - (a) Espectros de CD de Ni3 $100 \mu \mathrm{M}$ em função do pH. (b) Elipticidade molar em 222 nm em função do pH. 
(a)

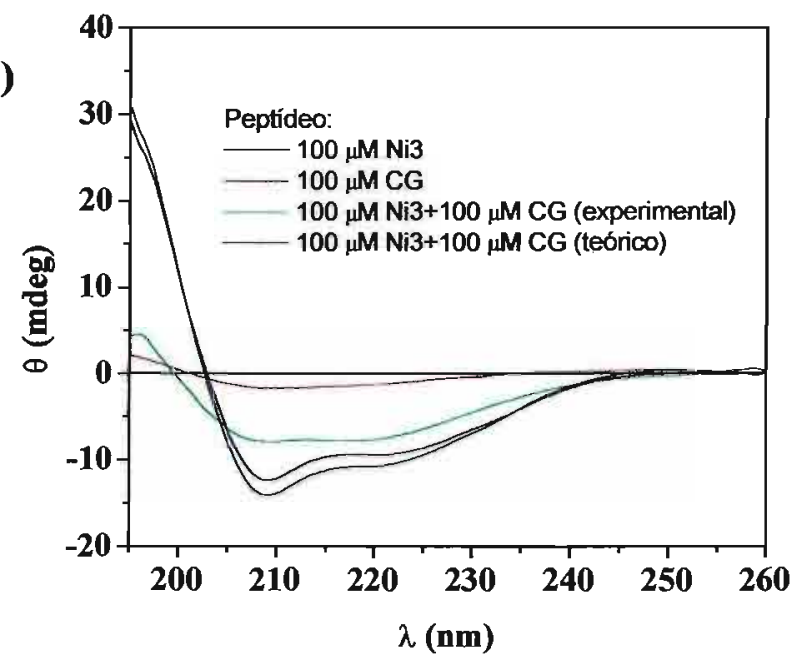

(b)

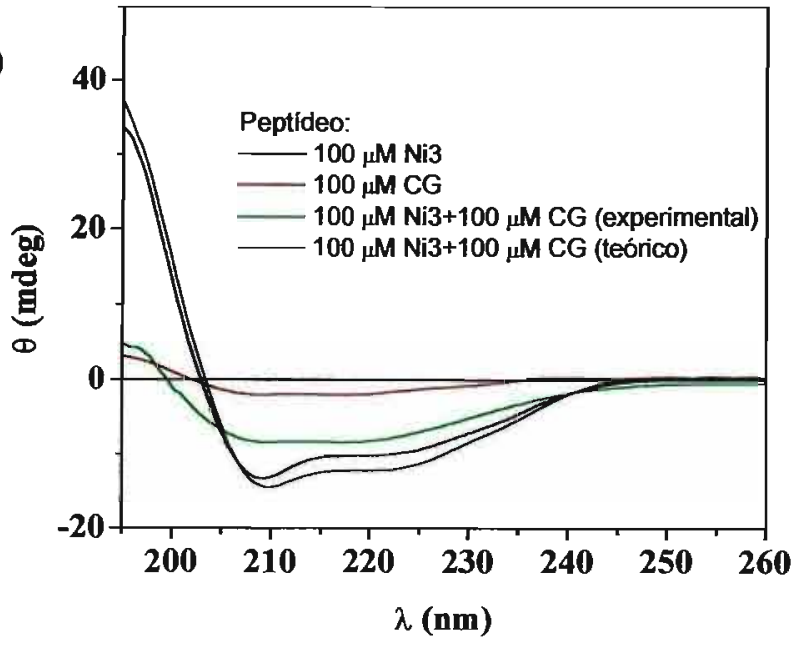

(c)

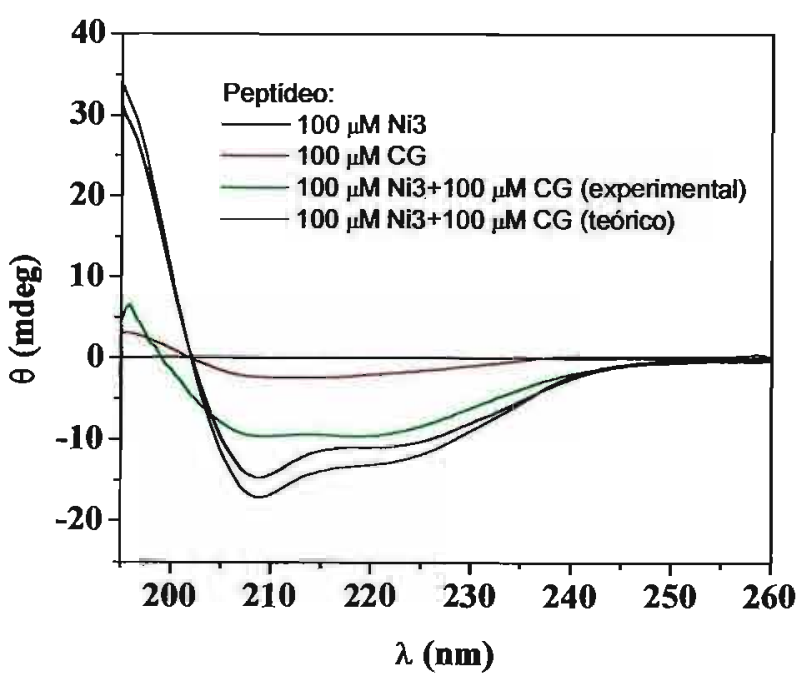

Figura 133 - Espectros de CD de Ni3, CG e de Ni3 na presença de CG em LPC $1 \mathrm{mM}$. pH: 4,0 (a), 7,0 e 10,0 (c). 
Comparando-se os espectros normalizados de Ni3 na presença de CG, observa-se neste caso uma grande diferença na forma entre os dois espectros (Fig. 134). Isso também pode ser observado na Tabela 40, onde nota-se uma diferença significativa na razão entre $[\theta]_{208} /[\theta]_{222}$ nos pHs 4,0 e 10,0 . Esse resultado também sugere que os dois peptídeos interagem na presença de LPC.

Tabela 40. - Razão entre $[\theta]_{208} /[\theta]_{222}$ obtida a partir dos espectros de CD de Ni3, CG, Ni3 + CG em LPC $1 \mathrm{mM}$, em função do pH. [peptídeo] $=100 \mu \mathrm{M}$.

\begin{tabular}{ccccc}
\hline \multicolumn{5}{c}{$[\theta]_{208} /[\theta]_{222}$} \\
$\mathrm{pH}$ & $\mathrm{Ni3}$ & $\mathrm{Ni3}+\mathrm{CG}$ & $\mathrm{Ni3}+\mathrm{CG}$ \\
& & & teórico & experimental \\
4,0 & 1,28 & 0,44 & 1,30 & 1,06 \\
7,0 & 1,28 & 1,17 & 1,11 & 1,03 \\
10,0 & 1,32 & 1,20 & 1,30 & 1,02 \\
\hline
\end{tabular}


(a)

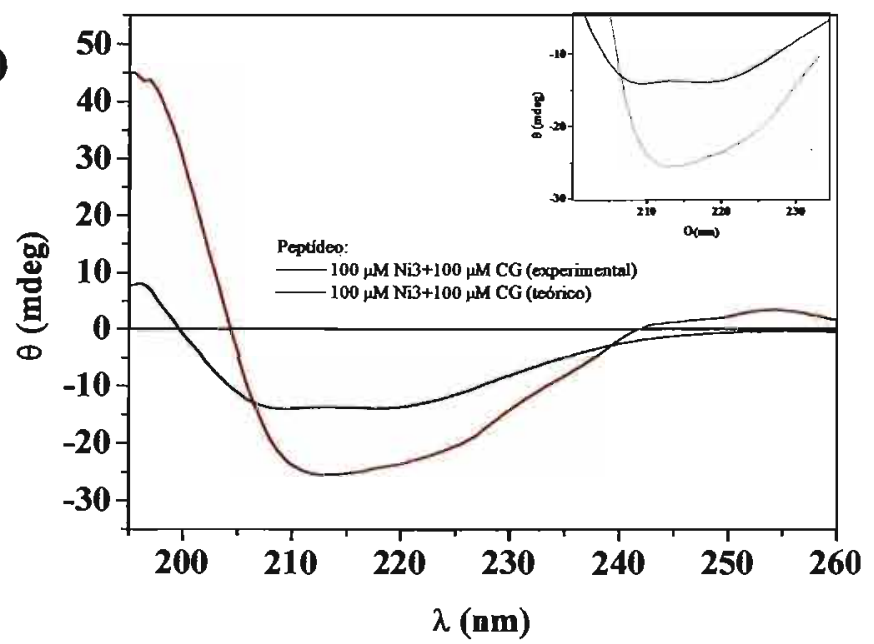

(b)

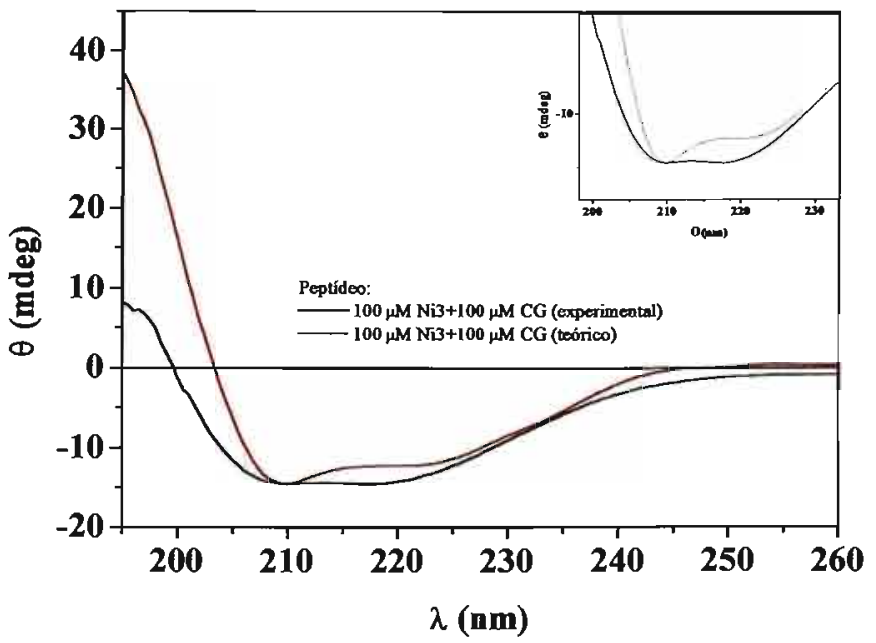

(c)

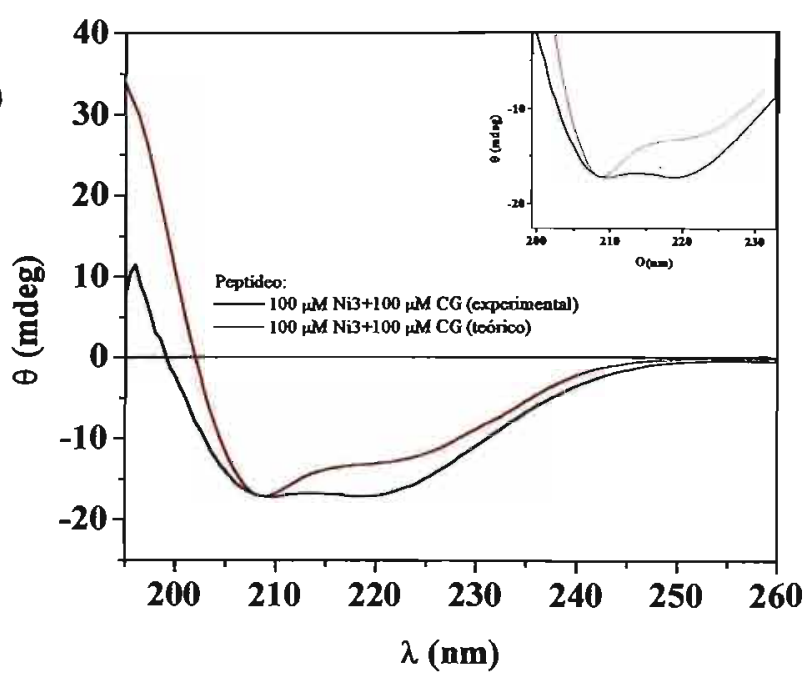

Figura 134 - Espectros experimental e teórico de Ni3 + CG em LPC 1 mM. pH: 4,0 (a), 7,0 e 10,0 (c). Os espectros foram normalizados pelo valor de elipticidade molar em 208 $\mathrm{nm}$. 


\section{Discussão}

Nesse trabalho enfocou-se o estudo conformacional de domínios do LHR e da subunidade $\alpha$ da proteína G. Esses fragmentos, principalmente os do LHR, possuem uma quantidade significativa de resíduos hidrofóbicos e como resultado, observou-se que os peptídeos possuem tendência a agregar em solução aquosa. Dessa forma, essa característica predominou sobre a conformação predita para os fragmentos. Em virtude disso, procuramos estudar do ponto de vista físico-químico a conformação desses peptídeos na presença de TFE, em solução aquosa em função do $\mathrm{pH}$, da temperatura, de uréia e no caso de $\mathrm{CG}$, da força iônica. As propriedades conformacionais desses fragmentos também foram estudadas na presença de membranas modelo.

No último caso, propusemos uma nova abordagem, a suspensão de filmes dos peptídeos na presença de soluções aquosas de membranas modelo. A comparação dos resultados obtidos por essa metodologia com os resultados obtidos adicionando-se quantidades crescentes de detergentes ou vesículas a uma solução aquosa do peptídeo, revelou resultados bem interessantes, que nos mostraram que em muitos casos, quando em um ambiente propício, os peptídeos adotaram a conformação predita teoricamente, o que já havia sido observado na presença de TFE. A abordagem do emprego de filmes, da forma como foi apresentada nesse trabalho, é inédita na literatura até o presente momento.

Acreditamos que o estudo de fragmentos de proteína continua a ser uma proposta válida. Os peptídeos apresentados aqui possuem baixa solubilidade, porém como já mencionado na introdução, esse enfoque se mostrou importante para investigar a estrutura e função de diversas proteínas ${ }^{(26-28)}$. Na literatura ${ }^{(43-67)}$, incluindo trabalhos do nosso próprio grupo, os resultados obtidos ajudaram a entender melhor o mecanismo de transdução de sinal. Mesmo em relação a fragmentos transmembranares, grupos como o de Naider et al. ${ }^{(64-67)}$ mostraram a importância de se estudar domínios de GPCRs. Deve-se ter em mente que, entre os GPCRs, apenas no caso da rodopsina foi possível obter um modelo de alta resolução a partir de sua estrutura cristalina ${ }^{(5)}$. Os resultados obtidos a partir do estudo conformacional de fragmentos desse e de outros receptores podem contribuir para refinar os modelos teóricos para os outros receptores. $\mathrm{O}$ próprio grupo de Naider et al. ${ }^{(64-67)}$ observou que alguns dos fragmentos 
transmembranares não adotam conformação $\alpha$-helicoidal nem mesmo em TFE. É possível que isso também seja verdade para outros receptores.

A partir dos dados obtidos nesse trabalho, procuramos quando possível, correlacionar os resultados obtidos com uma possível relevância biológica. Essa discussão é apresentada adiante.

\subsection{Fragmentos da TM6 LHR}

\subsubsection{Estudo conformacional dos peptideos derivados da TM6 do hLHR}

Nesse trabalho, estudou-se um fragmento derivado da porção $\mathrm{N}$-terminal da TM6 do hLHR e dois peptídeos análogos, envolvidos com a síndrome FMPP. Através do estudo físico-químico desses peptídeos, procurou-se identificar possíveis alterações conformacionais causadas pela substituição de $\mathrm{Asp}^{578}$ por Gly e Tyr e eventualmente, correlacionar tais mudanças com seu papel biológico.

Os peptídeos estudados são relativamente curtos, contém apenas 11 aminoácidos, e possuem uma porcentagem significativa de aminoácidos hidrofóbicos, o que diminui sensivelmente sua solubilidade em solução aquosa. Além disso, todos os fragmentos são amidados em seu C-terminal, o que também contribui para diminuir sua solubilidade em água. Experimentalmente, observamos que os peptídeos agregam em solução aquosa em altas concentrações, sendo que soluções estoques desses peptídeos tiveram que ser preparadas em TFE.

Apesar disso, esperávamos inicialmente que em condições que mimetizassem o ambiente encontrado pelos peptídeos na membrana, estes adquirissem conformação $\alpha$ helicoidal, uma vez que os mesmos correspondem a fragmentos de hélices transmembranares. Dessa forma estudamos a conformação desses fragmentos na presença de TFE e de modelos de membrana. No entanto, somente em algumas condições os espectros obtidos indicaram conformação $\alpha$-helicoidal.

Uma dessas condições foi na presença de TFE. Este solvente tem sido utilizado como agente indutor de estrutura secundária, como $\alpha$-hélices, dobras $\beta$ e folhas $\beta$. No entanto, o mecanismo pelo qual o TFE induz ou estabiliza a estrutura secundária de peptídeos ainda não foi completamente elucidado ${ }^{(230,231)}$. Foi observado que o TFE é capaz de formar estruturas do tipo clatrato dependendo de sua concentração, cujo tamanho varia de 5 a $10 \AA^{(230)}$. Nesses clusters a concentração local de TFE pode ser muitas vezes maior do que no seio da solução. Em vista disso, Reiersen et al. ${ }^{(230)}$ 
propuseram que essas estruturas possuem um papel relevante no processo de indução de estrutura secundária, onde o TFE atua como agente caotrópico. Segundo este grupo, os clusters removem moléculas de água da camada de solvatação em torno do peptídeo, dessa forma o TFE forma uma matriz em volta deste, o que promove interações entre seus resíduos; essas interações propiciam aquisição ou a estabilização da estrutura secundária.

Em outro trabalho, Roccatano et al. ${ }^{(231)}$ através de modelagem molecular mostraram que moléculas de TFE agregam ao redor de peptídeos. Esse evento remove moléculas de água e impede a formação de pontes de hidrogênio com a mesma, além de fornecer um ambiente com constante dielétrica baixa o suficiente para favorecer a formação de pontes de hidrogênio intra-moleculares.

Conforme a concentração de TFE aumenta, a composição e o tamanho desses clusters variam. Segundo Reiersen et al. ${ }^{(230)}$, este fato poderia ser responsável pelo fato do TFE induzir mudanças conformacionais ao redor de $50 \%$ TFE.

De fato, os resultados obtidos com os fragmentos derivados do LHR mostraram que em concentrações relativamente baixas de TFE (Fig. 15, seção 4.1.2.1), entre 10 e $20 \%$, a forma do espectro de CD muda pouco. Em $20 \%$ TFE os espectros dos peptídeos II e III (Fig. 15b e 15c) mudam pouco em relação aos adquiridos em solução aquosa. $\mathrm{O}$ espectro de I apresenta uma banda positiva com dois ombros, o que pode ser interpretado como o resultado da contribuição de populações com conformações diferentes. Nessa faixa de concentração, o conteúdo de estrutura $\alpha$-helicoidal calculado segundo o método de Chen et al. ${ }^{(214)}$ e de Baldwin et al. ${ }^{(215)}$ é relativamente baixo (Tabela 4).

No entanto, acima de $40 \%$ TFE os espectros de CD desses fragmentos mostram que todos os peptídeos adquiriram conformação $\alpha$-helicoidal. $\mathrm{O}$ aumento do conteúdo de TFE deve minimizar o contato dos resíduos hidrofóbicos dos peptídeos com a água, o que facilita a aquisição de $\alpha$-hélice. Deve-se ressaltar porém que o conteúdo de estrutura $\alpha$-helicoidal chega no máximo a $40 \%$ em $100 \%$ TFE, que é relativamente baixo. Os fragmentos estudados são curtos, possuem apenas 11 resíduos, o que pode afetar a aquisição desse tipo estrutura secundária. Porém, é importante observar que em um ambiente que mimetiza aquele encontrado na membrana em termos de polaridade todos os peptídeos adquirem conformação em $\alpha$-hélice conforme predito teoricamente (Fig. 14). Comparando-se os três fragmentos, observa-se que III adquire o maior 
conteúdo de estrutura $\alpha$-helicoidal (Tabela 4), o que também está de acordo com os resultados de predição teórica .

Chou e Fasman ${ }^{(232)}$ elaboraram uma escala que prediz a propensão de cada aminoácido em adotar um tipo de estrutura secundária, seja $\alpha$-hélice, folha ou dobra $\beta$. Essa escala foi feita levando-se em conta a freqüência com que um determinado aminoácido é encontrado em proteínas cuja estrutura é conhecida. Segundo essa escala resíduos como Gly e Pro não favorecem a aquisição de estrutura $\alpha$-helicoidal. No entanto, essa escala toma como base proteínas globulares que são solúveis em solução aquosa; porém esses resíduos, além de aminoácidos como Val, Phe, Leu e Ile, aparecem freqüentemente em TMs de proteínas de membrana ${ }^{(233)}$.

A conformação $\alpha$-helicoidal é o motivo estrutural preferido de segmentos transmembranares. Dessa forma, é possível que esses resíduos tenham um papel relevante na aquisição desse tipo de estrutura. Deber et al. ${ }^{(234)}$ mostraram que resíduos como Gly, Ile e Val favorecem a aquisição de estrutura $\alpha$-helicoidal no ambiente da membrana. Os autores desenvolveram uma escala que mostra a propensão de cada resíduo em promover a aquisição de estrutura $\alpha$-helicoidal. A Tabela 40 mostra a propensão de cada resíduo que constituí os fragmentos I, II e III em adquirir conformação $\alpha$-helicoidal segundo a escala de Chou-Fasman e em um fragmento transmembranar, o que também pode ser visto na Figura 135. Observa-se que os fragmentos possuem um porcentagem alta de resíduos com propensão a adotar estrutura $\alpha$-helicoidal em um ambiente com baixa polaridade, como o encontrado na presença de membranas, sendo que o resíduo de Gly possui maior helicidade do que Asp ou Tyr.

Tabela 40 - Preferência conformacional dos aminoácidos presentes nos fragmentos derivados

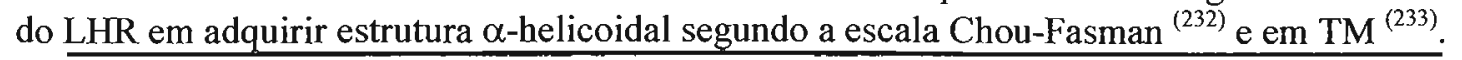

\begin{tabular}{ccc}
\hline Aminoácido & $\mathrm{P}_{\mathrm{a}}$ (Chou-Fasman) & $\mathrm{P}_{\mathrm{a}}(\mathrm{TM})$ \\
\hline Ala & 1,41 & 1,86 \\
Asp $^{\mathrm{a}}$ & 0,99 & 0,06 \\
Gly $^{\mathrm{b}}$ & 0,43 & 1,36 \\
Ile & 1,09 & 2,69 \\
Leu & 1,34 & 2,53 \\
Lys & 1,23 & 0,08 \\
Met & 1,30 & 1,26 \\
Phe & 1,16 & 1,63 \\
Thr & 0,76 & 0,70 \\
Tyr $^{\mathrm{c}}$ & 0,74 & 0,39 \\
\hline
\end{tabular}

${ }^{a}$ Peptídeo I, ${ }^{b}$ Peptídeo II, ${ }^{c}$ Peptídeo III 
Os resultados apresentados neste trabalho mostraram que na presença de vesículas fosfolipídicas (seção 4.1.4), tanto com carga líquida zero (Fig. 72) e com carga líquida negativa (Fig. 73), o análogo II, que possui o resíduo de Gly no lugar de Asp, adota conformação $\alpha$-helicoidal, enquanto que os peptídeos I (Fig. 69 e 70) e III (Fig. 75 e 76) adquirem folha $\beta$. Apesar de I e III adotarem conformação em folha $\beta$, variação da elipticidade molar e da intensidade de fluorescência no caso de III (Fig. 76 e 77) com o aumento da concentração de vesículas nos pHs estudados (4,0, 7,0 e 10,0) mostra que esses peptídeos também interagem com as vesículas. Observa-se que o peptídeo II em solução aquosa em alguns pHs (Fig. 20, seção 4.1.2.4), como pH 7,0, adota conformação em $\alpha$-hélice. Em pHs mais baixos, os espectros de CD de II indicam que existe um equilíbrio de populações, tanto ao acaso como $\alpha$-helicoidal. Esse resultado mostra que II é mais solúvel do que os outros peptídeos em solução aquosa, o que pode contribuir para a aquisição de uma $\alpha$-hélice na presença de bicamadas lipídicas.

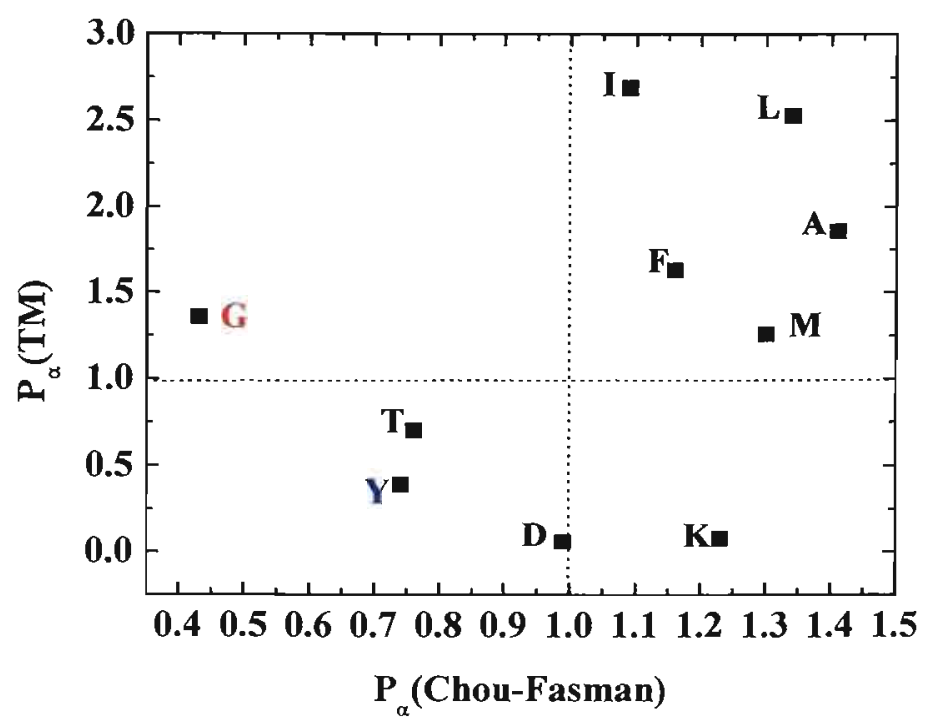

Figura 135 - Propensão em adquirir conformação $\alpha$-helicoidal $\left(\mathrm{P}_{\alpha}\right)$ para resíduos presentes nos fragmentos do LHR segundo a ocorrência dos resíduos em proteínas globulares (solúveis), determinada por Chou-Fasman, comparada com a ocorrência em proteínas transmembranares (TM).

Além da hidrofobicidade, o tamanho dos peptídeos também é um fator relevante que contribui para o baixo conteúdo de estrutura $\alpha$-helicoidal. Na literatura, Ding et al. (235) ao estudar fragmentos de tamanhos diferentes da TM2 do fator $\alpha$, que é um GPCR de Saccaromyces cerevisiae, observaram que não só a composição dos fragmentos é 
importante para a aquisição de estrutura $\alpha$-helicoidal, mas também que o tamanho desses peptídeos é capaz de influenciar no tipo de estrutura secundária adquirida. Esse grupo mostrou que em solução aquosa e na presença de $50 \%$ TFE um fragmento da TM2 que contém 10 aminoácidos possui forte tendência à agregação e adota folha $\beta$, enquanto que fragmentos maiores eram capazes de adotar conformação $\alpha$-helicoidal.

Em solução aquosa os espectros de CD dos peptídeos I e III em função do pH (Fig. 19 e 21, respectivamente, seção 4.1.2.4) mostram que os mesmos adquiriram conformações diferentes . O peptídeo I (Fig. 19) e o mutante III (Fig. 21) apresentaram espectros indicativos de estrutura $\beta$ (folha ou dobra $\beta$ ), como pode ser visto pelas características de cada espectro de CD; embora apenas a posição dos mínimos seja diferente para cada fragmento (Tabela 6). Em alguns pHs o fragmento III apresenta uma banda positiva desproporcionalmente maior do que a banda negativa.

As diferenças entre I e III podem ser atribuídas ao resíduo de Tyr no lugar do resíduo de $\mathrm{Asp}^{578}$, que possui cadeia lateral mais volumosa do que Asp, o que pode levar a adoção de uma conformação diferente em relação ao peptídeo nativo. Além disso, o experimento de fluorescência revelou a presença de uma banda relativa a emissão de bitirosina (Fig. 22), o que pode ser um indício de que essa substituição pode favorecer interações inter-moleculares entre os monômeros de III e facilitar o processo de agregação do peptídeo. Na presença de modelos de membrana observou-se em alguns casos (seção 4.1 .3 e 4.1.4) que essa banda diminuiu ou estava ausente.

Foi possível observar através de CD a titulação dos grupos ionizáveis dos peptídeos em função do pH. No caso do peptídeo I (Fig. 19) observa-se um grande aumento da intensidade do espectro à medida que o $\mathrm{pH}$ aumenta de 3,0 para 6,0, o que provavelmente reflete a titulação do resíduo de Asp.

Nessa mesma faixa de $\mathrm{pH}$, o mesmo efeito foi observado para III (Fig. 21), embora este fragmento não possui nenhum grupo ionizável nesses pHs. Esse fato sugere que pode ter ocorrido o abaixamento do $\mathrm{pK}_{\mathrm{a}}$ de um de seus grupos ionizáveis, possivelmente o grupo N-terminal ou o grupo fenol da Tyr. $\mathrm{O}$ experimento de fluorescência (Fig. 22) mostra a diminuição de intensidade de fluorescência com o aumento do $\mathrm{pH}$. No entanto, é possível que a queda inicial da intensidade de fluorescência reflita outro evento, a desprotonação da Tyr no estado excitado, que possui $\mathrm{pK}_{\mathrm{a}}$ em torno de $4,0^{(216)}$. 
No intervalo entre os $\mathrm{pHs} 6,0$ e 9,0 para I e III e de $\mathrm{pH}$ 8,0 para II observa-se um progressivo achatamento do espectro de $\mathrm{CD}$ de todos os peptídeos. Em $\mathrm{pHs}$ mais alcalinos foi possível observar em solução a formação de fibras para os três fragmentos. Nesses pHs a desprotonação do grupo amino-terminal e também grupo $\varepsilon-\mathrm{NH}_{2}$ da Lys acaba por diminuir a solubilidade desses peptídeos, na medida em que sua carga formal diminui (Fig. 18); em conseqüência disso ocorre um aumento do grau de agregação dos peptídeos, que resulta na formação dessas fibras.

É interessante notar que quando estudamos o efeito da temperatura sobre esses peptídeos (Fig. 16, seção 4.1.2.2) observou-se que a solução tornou-se mais límpida, embora os espectros de CD tenham sido pouco afetados pelo aumento da temperatura. Ao final do experimento, quando a temperatura da amostra diminui para temperatura ambiente, observou-se visualmente em todos os casos a formação de agregados fibrosos. Embora os espectros de CD tenham mudado pouco, esse resultado indica que o aumento de temperatura aumentou a solubilidade dos peptídeos.

Uma das alternativas para estudar a conformação desses peptídeos seria adicionar em suas extremidades resíduos polares para aumentar sua solubilidade. Outra opção, publicada na literatura pelo grupo de Schulz et al. ${ }^{(219)}$ foi estudar a conformação de um fragmento que compreende a porção C-terminal da i3 e a TM6 do hLHR, resíduos 560-583, em solução aquosa e na presença de TFE. Seus resultados mostraram por CD que esse fragmento adota conformação $\alpha$-helicoidal na presença de $50 \%$ TFE. O NMR mostrou que o trecho desse fragmento que adota uma $\alpha$-hélice, nessas mesmas condições, corresponde a porção N-terminal da TM6, enquanto que a porção do peptídeo que corresponde ao C-terminal da i3 possuí estrutura mais flexível. Segundo esses resultados, a TM se estende para o citossol, incorporando alguns resíduos da porção C-terminal da i3. Esses dados são corroborados pela estrutura cristalina da rodopsina ${ }^{(5)}$. Apesar de não ter sido comentado pelos autores, os espectros de CD mostram claramente que em solução aquosa o peptídeo tende a formar agregados. Schulz et al. ${ }^{(219)}$ também discutem o papel de $\mathrm{Asp}^{564}$, localizado na i3 do hLHR, como um aminoácido capaz de estabilizar a TM, pois o resíduo seria um motivo de capeamento de hélices (helix-capping motif).

Para tentar aumentar o grau de solubilidade dos peptídeos, também investigamos o efeito de uréia sobre os mesmos (seção 4.1.2.3). Os resultados mostraram que apenas em altas concentrações $(\sim 6 \mathrm{M})$ a uréia exerce algum efeito sobre o grau de agregação 
dos peptídeos (Fig. 17). Assume-se que o efeito desnaturante da uréia deve-se à sua capacidade de quebrar a estrutura da água. No entanto, Wallqvist et al. ${ }^{(236)}$ através de um estudo de dinâmica molecular contestaram esse mecanismo; segundo esses autores a uréia em altas concentrações (na faixa de 6-8 M) adsorve sobre os resíduos hidrofílicos de um peptídeo ou proteína, o que induz a repulsão entre os mesmos e provoca sua exposição, sendo que esse evento provoca a desestabilização da estrutura nativa. No caso dos peptídeos, nem mesmo aquecendo-os na presença de $6 \mathrm{M}$ uréia foi possível diminuir significativamente o grau de agregação (dados não mostrados). É possível que a interação entre os resíduos hidrofóbicos sejam tão forte que mesmo em altas concentrações a eventual adsorção de uréia sobre os resíduos hidrofóbicos não seja efetiva.

\subsubsection{Estudos na presença de membranas modelo}

Estudamos a interação de I, II e III com detergentes (seção 4.1.3) e com vesículas fosfolipídicas (seção 4.1.4). Conforme discutido acima, esses peptídeo são constituídos por aminoácidos que possuem propensão significativa a adotar conformação $\alpha$-helicoidal em um ambiente similar ao da membrana biológica.

O grupo de Wimley et al. ${ }^{(237)}$ calculou para cada aminoácido individualmente a energia livre de transferência da água para dois sistemas, POPC e n-octanol. Esses valores foram calculados com base nas escalas de hidropaticidade de cada aminoácido. Utilizando esses valores, calculamos esse parâmetro para os peptídeos I, II e III (Tabela 41). Como pode ser observado, com exceção do peptídeo I em pH 4,0, todos os fragmentos possuem uma tendência significativa em se translocar para meios com baixa de constante dielétrica. Isso corrobora as predições para TFE mostradas na Figura 135 e na Tabela 40.

Tabela 41 - Energia livre de transferência $(\Delta \mathrm{G})$ da água para a interface de POPC (wif) e para n-octanol (woct) para os peptídeos derivados do LHR.

\begin{tabular}{ccccccc}
\hline & \multicolumn{3}{c}{$\mathrm{POPC}$} & \multicolumn{3}{c}{$\mathrm{n}$-octanol } \\
\hline & \multicolumn{3}{c}{$\Delta \mathrm{G}_{\text {wif }}\left(\mathrm{kcal} \mathrm{mol}^{-1}\right)$} & \multicolumn{3}{c}{$\Delta \mathrm{G}_{\text {woct }}\left(\mathrm{kcal} \mathrm{mol}^{-1}\right)$} \\
\hline $\mathrm{pH}$ & $\mathrm{I}$ & II & III & I & II & III \\
$4,0^{*}$ & $-1,00$ & $-2,20$ & $-3,17$ & $-0,14$ & $-2,63$ & $-4,49$ \\
7,0 & $-2,30$ & $-2,20$ & $-3,17$ & $-3,35$ & $-2,63$ & $-4,49$ \\
10,0 & $-2,30$ & $-2,20$ & $-3,17$ & $-3,35$ & $-2,63$ & $-4,49$ \\
\hline
\end{tabular}


Dessa forma, nossa expectativa era de que os peptídeos fossem capazes de interagir com detergentes e vesículas fosfolipídicas e que essa interação fosse capaz de promover a aquisição de estrutura $\alpha$-helicoidal por parte dos mesmos.

Como já mencionado, os resultados obtidos mostram que os peptídeos são capazes de interagir com as membranas-modelo, porem na maioria dos casos não adotam conformação $\alpha$-helicoidal.

Na presença de HPS (seção 4.1.3.1) observa-se de maneira geral que o peptídeo adota conformação em folha $\beta$ na presença de HPS em todos os pHs estudados (Fig. 24, 25 e 26). De modo geral, os resultados mostraram que acima de 0,5 mM de HPS I encontra-se praticamente todo ligado ao detergente, porém não sofre mudanças conformacionais significativas.

Foi observado que o peptídeo II é capaz de interagir melhor com HPS em pHs mais altos (Fig. 28 e 29). Em pH 4,0 (Fig. 27) sua conformação permanece ao acaso, embora a intensidade de seu espectro aumente com a adição de detergente. Em todos os pHs II parece estar completamente ligado ao detergente.

Os efeitos mais significativos de HPS foram observados para o análogo $\mathrm{III} \mathrm{em}$ pH 4,0 (Fig. 30) onde se observa um deslocamento progressivo de sua banda positiva para comprimentos de onda menores (Tabela 11) e um aumento de intensidade. $O$ experimento de fluorescência (Fig. 33) também mostra que III é capaz de interagir com o detergente, principalmente em $\mathrm{pH} 4,0$ e 10,0. O CD não mostra claramente essa interação em pH 10,0, porém a concentração de peptídeo utilizada no experimento de fluorescência é menor $(30 \mu \mathrm{M})$ do que no $\mathrm{CD}(70 \mu \mathrm{M})$, o que pode facilitar a interação com detergente. Em concordância com o CD, os resultados de fluorescência (Fig. 34) mostram que acima de 0,2 mM HPS III estaria praticamente todo ligado ao detergente.

De um modo geral, os peptídeos parecem ter maior afinidade por LPC (seção 4.1.3.2) do que por HPS. A LPC possui cmc significativamente menor do que HPS (7 $\mu \mathrm{M}$ e $50 \mu \mathrm{M}$, respectivamente), o que pode facilitar a interação com os peptídeos.

Os resultados indicaram que acima de 1mM LPC em pH 4,0 e 7,0 (Fig. 35 e 36) I estaria praticamente todo ligado ao detergente, enquanto que em $\mathrm{pH} 10,0$ acima de 5 mM LPC (Fig.37) a intensidade do espectro de I continua a aumentar, o que indica que o peptídeo continua a se ligar ao detergente. A interação maior com LPC nos pHs 4,0 e 7,0 pode estar relacionada com sua carga líquida. 
$\mathrm{O}$ análogo II também possui afinidade significativa por LPC em todos os pHs estudados (Fig. 38, 39 e 40). As mudanças mais significativas na conformação de II foram observadas nos pHs 4,0 (Fig. 38) e 7,0 (Fig. 39). O espectro de CD acima de 20 mM LPC apresenta dois mínimos, o primeiro abaixo de $203 \mathrm{~nm}$ e o segundo em torno de $220 \mathrm{~nm}$ (Tabela 13). Esse espectro não é característico de conformação $\alpha$-helicoidal. Uma das possibilidades seria que nessa condição II adote conformação em dobra $\beta^{(208)}$. Os espectros de CD indicam II parece estar praticamente todo ligado acima de $5 \mathrm{mM}$ LPC em todos os pHs

Com relação ao peptídeo III, os resultados de fluorescência (Fig. 45) mostram que este fragmento estaria todo ligado ao detergente acima de $10 \mathrm{mM}$ LPC. Por CD (Fig. 41, 42 e 43) em todos os pHs foram observadas mudanças conformacionais pouco significativas, geralmente um deslocamento da banda positiva do espectro para comprimentos de onda mais baixos (Tabela 14). Em pH 7,0 e 10,0 (Fig. 44) observa-se um grande incremento da banda de emissão do tirosinato em $350 \mathrm{~nm}$.

$\mathrm{Na}$ presença de SDS, as mudanças mais significativas nos espectros de CD de I foram observadas em $\mathrm{pH} 10,0$ (Fig. 48), onde se observa um deslocamento da banda positiva do espectro (Tabela 15). Nos outros pHs (Fig. 46 e 47) observa-se um pequeno aumento de intensidade.

Os espectros de $\mathrm{CD}$ do análogo II mostram que este interage mais com $o$ detergente me pH 4,0 e 7,0 (Fig. 49 e 50) do que em pH 10,0 (Fig. 51). Em pHs mais baixos $\Pi$ tende a adotar conformação em folha $\beta$, enquanto que em $\mathrm{pH} 10,0$ os espectros de $\mathrm{CD}$ poderiam atribuídos tanto a folha $\beta$ e dobra $\beta^{(221)}$. Em todos os $\mathrm{pHs}$, II parece estar praticamente todo ligado a SDS.

Também foi observado que III possui afinidade significativa por SDS. Os resultados de fluorescência (Fig. 55 e 56) mostram que acima de 1,0 mM de SDS III parece estar totalmente ligado ao detergente. Os espectros de CD um comportamento um pouco diferente. Em pH 4,0 (Fig. 52) os resultados corroboram o observado por fluorescência, no entanto em pH 7,0 (Fig. 53) e em pH 10,0 (Fig. 54) a elipticidade molar pára de aumentar acima de $15 \mathrm{mM}$ e de $20 \mathrm{mM}$ SDS, respectivamente. Em pH mais altos, a interação eletrostática entre o análogo III e o detergente é provavelmente menor, uma vez que a carga líquida do peptídeo diminui devido à desprotonação do grupo amino terminal e da cadeia lateral de Lys. 
Para estudar a conformação dos peptídeos na presença de detergentes também utilizamos outra abordagem, a suspensão de filmes dos peptídeos na presença de soluções aquosas dos detergentes (seção 4.1.3.4). Pensamos que ao ressuspender um filme dos peptídeos, as moléculas destes seriam capazes de se penetrar mais facilmente no detergente, o que poderia aumentar a probabilidade de aquisição de estrutura $\alpha$ helicoidal. Os experimentos foram feitos na presença de altas concentrações de detergente e das concentrações mais altas atingidas quando da titulação do detergente.

Essa metodologia se mostrou efetiva apenas na presença de concentrações altas do detergente. No caso do peptídeo I, apenas na presença de $100 \mathrm{mM}$ de SDS (Fig. 56) os espectros são indicativos de $\alpha$-hélice. Por outro lado, os mutantes $\Pi$ e III parecem adotar conformação $\alpha$-helicoidal apenas presença de HPS e de SDS (Fig. 57, 59, 60 e 66 ), enquanto que na presença de LPC os espectros continuam sendo indicativos de folha $\beta$ (Fig. 58 e 63).

Por fluorescência (Fig. 62, 65 e 68), na maioria dos pHs na presença dos detergentes, não foi observada a banda relativa à emissão de bitirosina, o que pode sugerir que os monômeros de III são capazes de se inserir nas micelas do detergentes.

Como mencionado anteriormente, nas presença de vesículas fosfolipídicas (seção 4.1.4), no entanto, tanto pelo método a (solução) quanto pelo método b (filmes), os espectros de CD de I e III mostram que os fragmentos adotam folha $\beta$, enquanto que II adota conformação $\alpha$-helicoidal.

Os espectros de CD de I mostram que na presença de POPC (Fig. 69) e de POPC:POPG (Fig. 70) na maioria dos pHs observa-se uma diminuição da intensidade da banda positiva, o que indica que I interage com as bicamadas. Apesar disso os espectros de CD não indicaram mudanças conformacionais significativas.

Quanto ao peptídeo II (Fig. 72 e 73), em todos na presença de vesículas em todos os pHs o peptídeo adquire um conteúdo significativo de $\alpha$-hélice, o que pode estar relacionado com o fato de que II é mais solúvel em solução aquosa do que os demais peptídeos.

O mutante III apresenta um comportamento parecido com o observado com o peptídeo I. Na presença de POPC (Fig. 75) observa-se a diminuição progressiva da intensidade do espectro com o aumento da concentração de vesículas, enquanto na presença de POPC:POPG (Fig. 77) os espectros de CD de III mostram variação significativa da intensidade do espectro nos pHs 4,0 e 7,0. 
Também utilizamos a abordagem de filmes para estudar a conformação dos peptídeos (Fig. 71, 74 e 79). Para todos os fragmentos observou-se a aquisição de conformação em folha $\beta$, mesmo para o peptídeo II (Fig. 74) que em solução na presença de vesículas adotou conformação $\alpha$-helicoidal. É possível que nesse caso os peptídeos não tenham sido capazes de se penetrar na membrana.

No caso do peptídeo III foi possível realizar experimentos de supressão da intensidade de fluorescência por acrilamida. Esses experimentos foram feitos em solução e na presença de modelos de membrana (seção 4.1.5, Tabela 24). Observa-se que no caso de POPC, a acessibilidade do fluoróforo ao supressor é parecida com àquela obtida em solução aquosa, o que corrobora em parte os experimentos descritos acima. No entanto, na presença de membranas com carga líquida negativa, a acessibilidade ao supressor diminui significativamente, o que indica que nesse caso o peptídeo foi capaz de penetrar na bicamada. Embora esses resultados tenham sido obtidos para III, pode-se especular que o comportamento dos outros seja parecido. Com relação aos detergentes, na presença de SDS foi observado o menor grau de exposição ao supressor.

Esses resultados permitem especular que além da hidrofobicidade, o tamanho do fragmento também pode influir no grau de penetração deste na membrana. Alguns estudos têm sido mostrados na literatura correlacionando a extensão do fragmento e a conformação adotada na presença de membranas. Schulz et al. ${ }^{(219)}$, além dos estudos feitos em TFE, também estudaram a conformação de peptídeos de tamanhos diferentes derivados da TM2 de um GPCR na presença de vesículas fosfolípídicas. Seus resultados mostraram que apenas os peptídeos com 22, 26 e 35 resíduos foram capazes de formar $\alpha$-hélice, enquanto que um peptídeo com 10 resíduos adota conformação do tipo folha $\beta$.

\subsubsection{Possíveis implicações biológicas}

Observamos que os três peptídeos estudados apresentam propriedades conformacionais diferentes em vários meios estudados. A substituição de $\mathrm{Asp}^{578}$ por Glu pode romper interações que sejam importantes para manter o receptor em sua forma nativa. Em vários estudos $(140,155,161)$ foi proposto que esse resíduo seria capaz de interagir com resíduos localizados em outras hélices, como dois resíduos de Asn localizados na TM7 do hLHR. Além disso foi proposto que a TM6 faz contatos com a TM5 e possivelmente a TM3 ${ }^{(140,155,161)}$. A substituição por Gly poderia mudar a 
orientação relativa da TM6 e poderia expor ao citossol uma porção da TM6 que estaria localizada na membrana no receptor nativo. Schultz et al. ${ }^{(219)}$ mostram que a porção Cterminal da i3 adota conformação $\alpha$-helicoidal e propõem que esta seria uma estensão da TM6. A troca de Asp por Gly poderia facilitar a exposição de resíduos localizados na membrana e dessa forma disparar mudanças conformacionais que resultam na ativação da proteína $G$, levando à ativação constitutiva do receptor e causando FMPP. De fato, observamos experimentalmente que II possui propriedades conformacionais significativamente diferentes de I.

Com relação ao peptídeo III, esse peptídeo em solução também apresenta estrutura $\beta$, no entanto os espectros de CD do filme desse peptídeo em detergente mostraram uma propensão maior em adquirir espectros sugestivos de estrutura $\alpha$ helicoidal. Pearstein et al. ${ }^{(161)}$ propõem que essa mutação leva a constitutiva devido à reorientação das hélices causada pela acomodação de um aminoácido que possui uma cadeia lateral mais volumosa do que Asp. No entanto, o fato desse mutante estimular a via de $\mathrm{IP}_{3}$ e não só a adenilato ciclase não foi bem explicado. Uma possibilidade é que a ativação constitutiva provocada por esse resíduo poderia ser resultado de novas interações com resíduos em outras TMs. Apesar das estruturas obtidas por modelagem molecular darem novas pistas sobre o mecanismo de ativação constitutiva do hLHR, é possível que para a elucidação do mesmo seja necessária a resolução da estrutura cristalina do receptor e mesmo de alguns mutantes. Esse advento seria de grande ajuda não só para entender os eventos desencadeados pela ativação constitutiva do LHR, mas também para outros GPCRs e seria de grande importância para o desenvolvimento de novas abordagens farmacológicas para as patologias causadas por essas mutações.

Outro fato relevante é que a agregação dos peptídeos observada experimentalmente pode ter um papel biológico. Foi observado que os GPCRs são capazes de formar dímeros ou oligômeros ${ }^{(238)}$. Observou-se experimentalmente que o LHR forma dímeros transientes ${ }^{(238)}$. É possível que a TM6 seja um local importante para a dimerização do receptor e que a mutação de um aminoácido dessa TM interfira nesse processo, levando à ativação constitutiva. Dessa forma podemos especular que os fragmentos estudados constituem potenciais sítios de dimerização do receptor. 


\subsection{CG e sua interação com fragmentos do receptor $A T_{I A}$ de angiotensina $I I$}

\subsubsection{Estudos em solução aquosa e na presença de TFE}

Antes de enfocar uma possível interação do CG com o domínio C-terminal do receptor de angiotensina II (CT), procurou-se estudar o comportamento do peptídeo em solução e na presença de membranas modelo. A predição teórica (Fig. 81, seção 4.2.1) mostrou que este fragmento tem propensão a adotar conformação $\alpha$-helicoidal em solução. Em solução aquosa, verificamos que o espectro de CD de CG em pH 4,0 indica a presença de um equilíbrio entre populações, com a contribuição de uma população ao acaso, vista pelo mínimo ao redor de $200 \mathrm{~nm}$ e outra estruturada, com múnimo ao redor de 220 nm. (Fig. 83, seção 4.2.2.1).

Nas estruturas cristalinas de $G_{\alpha}$ não foi possível observar os 10 últimos resíduos do C-terminal, o que foi atribuído flexibilidade dessa região ${ }^{(138,239)}$. Hamm et al. ${ }^{(239)}$ resolveram por NMR a estrutura de um peptídeo sintético correspondente a porção Cterminal de $\mathrm{G} \alpha$ da transducina $\left(\mathrm{G}_{\mathrm{t} \alpha}\right.$, IKENLKDCGLF, resíduos 340-350), ligado ao receptor tanto em sua forma nativa como inativa. A estrutura desse fragmento mostrou que os últimos quatro resíduos formavam uma dobra $\beta$ tipo II'. Segundo os autores, a presença do resíduo de $\mathrm{Gly}^{347}$ é essencial para a formação desse tipo de dobra. A presença de uma dobra na porção terminal de $\mathrm{G}_{t \alpha}$ também foi observada pelo grupo de Kisselev et al. ${ }^{(138)}$, quando este encontra-se ligado à rodopsina; em solução, o mesmo grupo observou por que $\mathrm{G}_{\mathrm{t} \alpha}$ possui conformação ao acaso. No caso de $\mathrm{CG}$ também observamos que o peptídeo encontra-se ao acaso em solução aquosa em pHs baixos (Fig. 87).

Com relação ao CG (FAAVKDTILQLNLKEYNLV, resíduos 341-359), na posição correspondente ao resíduo de $\mathrm{Gly}^{348}$ existe o resíduo de $\mathrm{Asn}^{357}$, dessa forma CG não poderia adotar o tipo de dobra $\beta$ descrito acima. Segundo Hamm et al ${ }^{(239)}$. a presença dos resíduos de Glu ${ }^{355}$ e Asn ${ }^{357}$, que são conservados na família $G_{\alpha q}$ e à qual CG pertence, levaria a formação de uma dobra $\beta$ tipo VIII.

Pode-se observar na Figura 81 que a propensão à aquisição de estrutura $\alpha$ helicoidal diminui significativamente na porção C-terminal, sendo que para os três últimos resíduos a propensão é nula. Essa região corresponde justamente aos resíduos que fariam parte da dobra $\beta$. Na mesma Figura é possível observar que a região que possui maior propensão à aquisição de estrutura $\alpha$-helicoidal corresponde à região $\mathrm{N}$ - 
terminal do CG. Kisselev et al. ${ }^{(138)}$ observaram que quando $\mathrm{G}_{\mathrm{t} \alpha}$ liga-se ao receptor a conformação do peptídeo muda de ao acaso para $\alpha$-helicoidal; seus resultados indicam que a $\alpha$-hélice compreende os resíduos 325 a 346 (Fig. 7). No CG essa região corresponde à porção N-terminal do peptídeo.

Nossos resultados mostraram que $\mathrm{CG}$ adquire um conteúdo significativo de estrutura $\alpha$-helicoidal na presença de TFE, (seção 4.2.2.1, Figura 83 e Tabela 26), chegando a cerca de $70 \%$. Utilizando-se essa estimativa, pode-se inferir que dos dezenove resíduos de $\mathrm{CG}$, aproximadamente seis não fariam parte da $\alpha$-hélice. Como mencionado acima, tanto o grupo de Hamm et al. ${ }^{(239)}$ quanto o de Kisselev et al. ${ }^{(138)}$ mostraram que os quatro últimos resíduos fazem parte da dobra $\beta$, dessa forma podemos especular que o conteúdo $\alpha$-helicoidal obtido na presença de TFE é consistente com os resultados mostrados por NMR. A partir do espectro de CD em altas concentrações de TFE não é possível dizer se existe ou uma dobra $\beta$ na porção $C$-terminal de $C G$, porém os resultados discutidos acima deixam em aberto essa possibilidade.

Em função do pH (seção 4.2.2.4, Fig. 90) também observamos que o CG tende a adquirir maior conteúdo de estrutura secundária com o aumento do $\mathrm{pH}$. O conteúdo de estrutura $\alpha$-helicoidal aumenta de menos de $30 \%$ em pH 2,0 (Tabela 28) para valores que variam de $50 \%$ segundo Baldwin et al. ${ }^{(215)}$ a $40 \%$ segundo Chen et al. ${ }^{(214)}$ acima de $\mathrm{pH} 5,0$. Os espectros de $\mathrm{CD}$ em todos os pHs, continuam a indicar um equilíbrio de populações. Aparentemente a desprotonação dos resíduos de Asp e Glu (Fig. 91 e 93), que possuem $\mathrm{pK}_{\mathrm{a}}$ em torno de 4,0, é importante para o aumento do conteúdo de estrutura secundária. Em seu ambiente fisiológico, é possível que esses resíduos estejam desprotonados e que isso contribua para a aquisição da conformação na qual o CG seja capaz de interagir com o receptor. Wess et al. ${ }^{(240)}$ mostraram que os resíduos de Asp e Glu são importantes para o acoplamento da proteína $\mathrm{G}$ com o receptor. Esse grupo expressou receptores que interagem com $\mathrm{G}_{q}$, como o receptor $\mathrm{m} 3$ muscarínico e o receptor V1a de vasopressina, na presença de mutantes $G_{\alpha s}$ que contém resíduos da porção C-terminal de $\mathrm{G}_{\alpha q}$. Eles observaram em um dos mutantes que a substituição de Glu por Asn aumentou o acoplamento da proteína $\mathrm{G}_{\mathrm{s}}$ com o receptor.

Em solução aquosa, observamos por fluorescência (Fig. 92) de pH 4,0 em diante uma banda de emissão de uma banda acima de $400 \mathrm{~nm}$ que pode ser atribuída a bitirosina. A presença dessa banda pode ser uma evidência de interação inter-molecular entre as moléculas de CG à medida que ocorre a desprotonação dos resíduos carregados 
do peptídeo. Em solução aquosa, também havíamos observado com o aumento da força iônica e aumento da concentração que CG tende a agregar. No primeiro caso, observamos que o CG é sensível à concentração de sal (Fig. 87); os espectros de CD mostraram que a adição de quantidades relativamente pequenas de sal provoca mudanças significativas na conformação de $\mathrm{CG}$, que indicam que $\mathrm{CG}$ agrega na presença de $50 \mathrm{mM} \mathrm{NaCl}$ (Fig. 88). Por causa da agregação de CG, levantamos a possibilidade de que o CG formasse um coiled-coil em solução aquosa, porém foi observado que para formar um coiled-coil estável, um peptídeo deve ter pelo menos 28 resíduos ${ }^{(241)}$. Uma das possibilidades de interação entre as moléculas de CG seria como disposto na Figura 136, onde o resíduo de Lys $^{345}$ de um monômero poderia interagir com o resíduo de $\mathrm{Asp}^{346}$ de outro monômero e o resíduo de $\mathrm{Glu}^{355}$ poderia interagir com o resíduo de Lys $^{353}$.
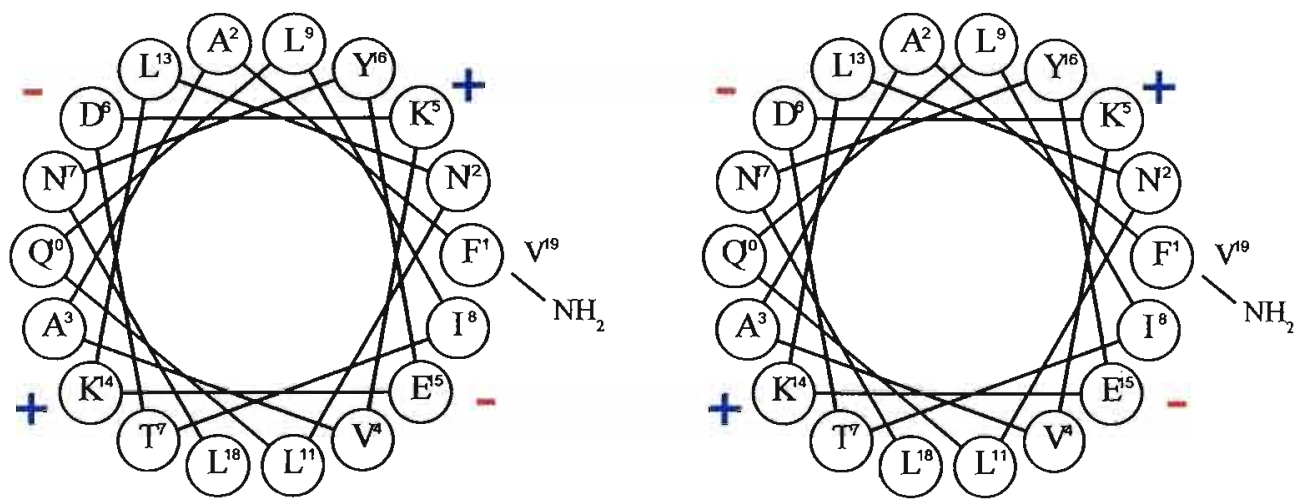

Figura 136 - Diagrama de roda helicoidal do CG de acordo com Schiffer e Edmundon, onde se mostra a interação entre dois monômeros de CG orientados paralelamente.

Outra abordagem para investigar o grau de agregação de CG foi investigar o efeito da temperatura (seção 4.2.2.2, Fig. 85) e de concentrações crescentes de uréia (seção 4.2.5.1, Fig. 122). Observamos que a conformação de CG muda pouco com o aumento de temperatura, apenas em temperaturas relativamente altas foi possível observar uma mudança significativa no espectro de $C D$, ocorrendo um aumento da banda positiva centrada ao redor de $204 \mathrm{~nm}$. Também foi possível observar um pequeno aumento da elipticidade molar em $216 \mathrm{~nm}$ com o aumento da temperatura (Fig. 86). No caso de uréia, observamos mudanças significativas no espectro de CD acima de $1 \mathrm{mM}$ uréia, o que sugere que essa agente é capaz aumentar a solubilidade de CG. 


\subsubsection{Estudos na presença de detergentes}

Também estudamos a interação entre o CG e detergentes (seção 4.2.3). $\mathrm{Na}$ presença de HPS, foi observado tanto por CD (Fig. 98 e 99) como por fluorescência que CG possui maior afinidade pelo detergente em $\mathrm{pH} 10,0$. Em $\mathrm{pHs}$ mais baixos, os espectros de CD indicam maior contribuição de estrutura ao acaso (Fig. 94 e 96) Os resultados de fluorescência nesses pHs (Fig. 95 e 97) indicam que CG é liga-se ao detergente. Em pH 10,0, no entanto, os espectros de CD (Fig. 98) a diminuição da banda negativa centrada acima de $200 \mathrm{~nm}$ (Tabela 29), a qual transforma-se em um ombro a partir de 0,20 mM HPS. Também é possível observar o aumento de intensidade da segunda banda negativa centrada ao redor de $220 \mathrm{~nm}$. Esse espectro pode ser atribuído a uma dobra $\beta^{(221)}$. De modo geral, os resultados de fluorescência e CD indicam que acima de $0,5 \mathrm{mM}$ HPS o peptídeo está praticamente todo ligado ao detergente.

Na presença de LPC (seção 4.2.3.2) foi observado que o CG apresenta grande afinidade pelo detergente. Em todos os pHs foram observadas mudanças significativas no espectro de CD (Fig. 104, 106 e 108) de CG induzidas pela ligação do peptídeo ao detergente. De modo geral, os espectros de CD nessa condições são indicativos de dobra $\beta$. Apenas em pH 10,0, na presença de concentrações altas de LPC $(\sim 10 \mathrm{mM})$, os espectros são indicativos de folha $\beta$. Os resultados de fluorescência (Fig. 105, 107 e 109) sugerem que acima de $1 \mathrm{mM}$ LPC CG está praticamente todo ligado a LPC.

Na presença de SDS (seção 4.2.3.3) observou que CG é capaz de interagir com SDS, porém a conformação adquirida variou conforme o $\mathrm{pH}$ da solução. Em pH 2,5 (Fig. 113), o aumento da concentração de detergente induz a mudança de uma conformação ao acaso para folha $\beta$. Em pH 6,0 (Fig. 115) o peptídeo passa adotar conformação em dobra $\beta$, enquanto em pH 10,0 (Fig. 117), os espectros indicam a presença de diferentes populações. Aparentemente, CG liga-se completamente a SDS abaixo de $1 \mathrm{mM}$ nos pHs 2,5 e 6,0 (Fig. 114b e 116b) e de 5 mM SDS em pH 10,0 (Fig. $118 b)$.

Também utilizamos a abordagens de filmes para estudar a conformação de CG. Os espectros de CD de CG parecem indicar conformação $\alpha$-helicoidal na presença de todos os detergentes (Fig. 101, 110 e 119), principalmente na presença de LPC (Fig. 110) e SDS (Fig. 119).

Também calculamos a energia livre de transferência de CG para POPC e noctanol (Tabela 42), calculados conforme descrito anteriormente. Esses cálculos 
sugerem que CG possui uma forte preferência em permanecer em um ambiente polar, principalmente em pHs baixos. No entanto, conforme descrito acima, nossos resultados mostram o contrário, CG é capaz de interagir com modelos de membrana. Isto está de acordo com resultados da literatura que mostram que fragmentos de alças externas e citossólicas de GPCRs são capazes de interagir com membranas modelo ${ }^{(43-61)}$.

Tabela 42 - Energia livre de transferência $(\Delta \mathrm{G})$ da água para a interface de POPC (wif) e para n-octanol (woct) para CG ${ }^{(237)}$.

\begin{tabular}{ccc}
\hline & POPC & n-octanol \\
\hline $\mathrm{pH}$ & $\Delta \mathrm{G}_{\text {wif }}\left(\mathrm{kcal} \mathrm{mol}^{-1}\right)$ & $\Delta \mathrm{G}_{\text {woct }}\left(\mathrm{kcal} \mathrm{mol}^{-1}\right)$ \\
\hline $4,0^{*}$ & 2,81 & 7,79 \\
7,0 & $-0,52$ & 1,06 \\
10,0 & $-0,52$ & 1,06 \\
\hline
\end{tabular}

Além disso, os resultados de supressão de fluorescência de CG (Tabela 32, seção 4.2.4) mostram valores de $\mathrm{K}_{\mathrm{sv}}$ significativamente menores na presença de detergentes do que em solução aquosa, principalmente nos pHs 2,5 e 6,0, o que mostra que além de se ligar aos detergentes, CG também capaz de penetrar nas micelas. Em pH 10,0, a supressão da intensidade de fluorescência na presença de detergentes é comparável com àquela observada em solução aquosa, o que indica que nesse caso é possível que CG permaneça na superfície da micela.

\subsubsection{Interação do CG com fragmentos do receptor $A T_{I A}$ de angiotensina II.}

$\mathrm{Na}$ literatura vários grupos têm procurado estudar a interação entre a proteína $\mathrm{G}$ e seu respectivo receptor. Uma gama enorme de trabalhos mostrou que as regiões i2, i3 e a porção C-terminal de vários receptores são importantes para o acoplamento e ativação da proteína $\mathrm{G}$.

Os estudos discutidos acima nos ajudaram a elaborar um modo para investigar a interação entre o $\mathrm{CG}$ e peptídeos derivados do receptor $\mathrm{AT}_{1 \mathrm{~A}}$ de angiotensina II. Resolvemos utilizar a abordagem de filmes, onde filmes dos peptídeos foram ressuspensos na presença de uma solução aquosa de $1 \mathrm{mM}$ LPC (seção 4.2.6). Imaginamos que ao proceder dessa forma, as moléculas dos dois peptídeos seriam captadas pela micela do detergente ao mesmo, o que poderia favorecer a interação entre ambos.

Nesses estudos, geralmente investiga-se a interação entre fragmentos sintéticos da proteína $\mathrm{G}$ com o receptor, ou fragmentos do receptor com a proteína G. Em alguns casos, como já mencionado, foi possível determinar por NMR a conformação de um 
fragmento sintético correspondente a $\mathrm{G}_{\mathrm{t \alpha}}$ ligado tanto à forma inativa como à forma nativa do receptor ${ }^{(138)}$; esses estudos ajudaram a fornecer detalhes sobre a interação receptor/proteína G. A abordagem apresentada neste trabalho, onde se procurou observar a interação entre fragmentos sintéticos de um GPCR com um peptídeo sintético de sua respectiva proteína $G$ é inédita na literatura.

Conforme discutido na seção 5.2.1, a parte distal do C-terminal de $\mathrm{G}_{\alpha}$ é importante para o acoplamento com o receptor ${ }^{(138,240-242)}$. Além de Wess et al. ${ }^{(240)}$, Graber et al. ${ }^{(242,243)}$ também mostraram através de mutações que os últimos cinco resíduos do C-terminal de Ga são importantes para o acoplamento da proteína G com o receptor muscarínico. Essa região forma uma dobra $\beta$, conforme discutido acima (seção 5.2.1). Pin et al. ${ }^{(243,244)}$ também mostraram que a posição -3 e $-4(-1$ corresponde ao último resíduo) em $\mathrm{G}_{\alpha}$ é importante para o acoplamento com o receptor de glutamato. Em $G_{i \alpha} e G_{t \alpha}$ a posição -4 corresponde ao resíduo de Cys, enquanto que em $G_{q \alpha}$ essa posição corresponde ao resíduo de Tyr. Segundo Yamamoto et al. ${ }^{(245)}$ esse resíduo de tirosina é fosforilado e esse evento é importante para o acoplamento com o receptor. No mesmo trabalho, o grupo de Pin et al. ${ }^{(246)}$ também propõe que as $\alpha$-hélices $\alpha 4$ e $\alpha 5$, assim como a alça L9 e a folha $\beta 6$ também fazem parte do sítio de ligação ao receptor.

Nesse trabalho investigamos a interação entre CG e fragmentos correspondentes a porção C-terminal ( $f$-CT), Ni3 e i2 do receptor $\mathrm{AT}_{1 \mathrm{~A}}$. Os espectros de $\mathrm{CD}$ sugerem em todos os casos a interação entre CG e os fragmentos do receptor de angiotensina, principalmente com o $f$-CT e com Ni3. Porém resta ainda responder como seria essa interação.

Vários estudos demonstraram que a região proximal do domínio C-terminal dos GPCRs é importante para o acoplamento com a proteína $\mathrm{G}^{(134,189-193)}$. No caso do receptor $\mathrm{AT}_{1 \mathrm{~A}}$ de angiotensina II. Griendling et al. ${ }^{(134)}$ observaram que um fragmento sintético do C-terminal correspondente aos resíduos 304-316 era capaz de ativar a proteína G. Inagami et al. observaram que a região YFL, resíduos 312-314, é essencial para o acoplamento com $\mathrm{G}_{\mathrm{q}}$. Sakmar et al. ${ }^{(247)}$ mostraram que um fragmento sintético correspondente ao C-terminal da rodopsina foi capaz de inibir a ativação de $\mathrm{G}_{\alpha}$ pela rodopsina, onde os resíduos $\mathrm{Asn}^{310}, \mathrm{Lys}^{311}$ e Gln ${ }^{312}$ são importantes para o acoplamento com o receptor. Esse trabalho também mostrou que peptídeos correspondentes a i 2 e a i3 da rodopsina eram capazes de interagir diretamente com $\mathrm{G}_{\mathrm{t} \alpha}$. 
Vários estudos demonstraram que a i3 de GPCRs é importante para o acoplamento com a proteína $\mathrm{G}^{(134,239)}$. Wess et al. ${ }^{(240)}$ mostraram que para o receptor m3 muscarínico, a porção N- e C-terminal da i3 possui resíduos importantes para o acoplamento com $\mathrm{G}_{\mathbf{q}}$, como o resíduo de $\mathrm{Tyr}^{254} \mathrm{em} \mathrm{Ni3}$. No caso do receptor $\mathrm{AT}_{1 \mathrm{~A}}$ de angiotensina II, Griendling et al. ${ }^{(134)}$ mostraram que um fragmento sintético correspondente a Ni3 era capaz de ativar a proteína. Através de estudos com receptores quiméricos, Clauser et al. ${ }^{(199)}$ também mostraram que a porção C-terminal da i3 é importante para a seletividade e acoplamento com o receptor. Segundo Simon et al. ${ }^{(248)}$ os resíduos a porção compreendida pelos resíduos $\operatorname{Tyr}^{217}$ a $\mathrm{Val}^{219}$ no receptor $\alpha_{1}$ adrenérgico é importante para o acoplamento com $\mathrm{G}_{\mathrm{q}}$.

Com relação a i2, Coughlin et al. demonstraram que a i2 é importante para o acoplamento do receptor de trombina com $G_{q}$. Wess et al. ${ }^{(240)}$ mostraram que os resíduos $\operatorname{Ser}^{168}, \operatorname{Arg}^{171}, \operatorname{Arg}^{176}$ e $\operatorname{Arg}^{183}$ são importantes são críticos para a ligação com a proteína G. Segundo Pin et al. ${ }^{(246)}$, a posição central da i2 é responsável pelo reconhecimento de $G_{\alpha}$, especialmente com o resíduo na posição - 4, que em $C G$ corresponde a $\mathrm{Tyr}^{356}$. Miyazaki et al. ${ }^{(249)}$ mostraram que mutações dos resíduos de $\mathrm{Asp}^{125}$, $\mathrm{Arg}^{126}$, $\mathrm{Tyr}^{127}$ e $\mathrm{Met}^{134}$ por Ala ou Gly no receptor $\mathrm{AT}_{1 \mathrm{~A}}$ de angiotensina impediram seu acoplamento com $\mathrm{G}_{\mathrm{q}}$.

Com base nessas informações esquematizamos uma figura onde hipotetizamos as regiões de contato entre o $\mathrm{CG}$ e os fragmentos do receptor $\mathrm{AT}_{1 \mathrm{~A}}$ de angiotensina $\mathrm{II}$, mostrada na Figura 137. Nele apresentamos o diagrama de roda helicoidal de CG e dos outros peptídeos.

No caso de $f$-CT, este peptídeo corresponde aos resíduos 300-320 do receptor $\mathrm{AT}_{1 \mathrm{~A}}$, que portanto contém a região YFL descrita acima. Os espectros de CD mostraram que tanto o $f$-CT como o CG são capazes de adotar conformação $\alpha$-helicoidal na precença de LPC em todos os pHs estudados (Fig. 127). Ao investigarmos a interação entre esses dois peptídeos, observamos que os espectros de CD téorico e experimental de CG na presença de $f$-CT são significativamente diferentes em todos os pHs (Fig. 127), assim como a forma dos espectros (Fig. 128), o que sugere que os dois fragmentos interagem na presença de LPC.

Observando-se o diagrama de roda helicoidal de $f$-CT (Figura 137), observa-se que esse peptídeo é capaz de formar uma $\alpha$-hélice anfipática. De fato, em sua tese de doutoramento, a Dra. Thelma A. Pertinhez observou por NMR que o peptídeo adquire 
essa conformação na presença de TFE ${ }^{(48)}$. Também foi observado que a conformação de $f$-CT muda de ao acaso para $\alpha$-helicoidal como o aumento do $\mathrm{pH}$ e da força iônica (T.A. Pertinhez, tese de doutoramento, 1998), sendo que acima de $\mathrm{pH} 8,0$, o peptídeo agrega. Observou-se também que o peptídeo agrega com o aumento da concentração.

(a) $\mathrm{CG}$
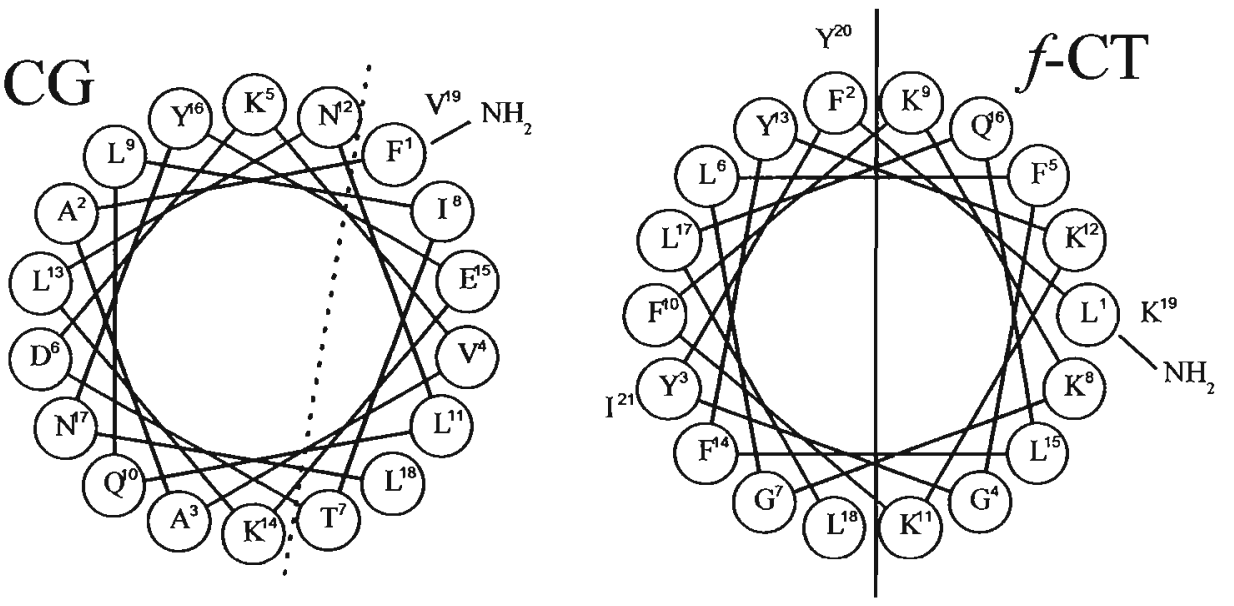

(b) $\mathrm{CG}$
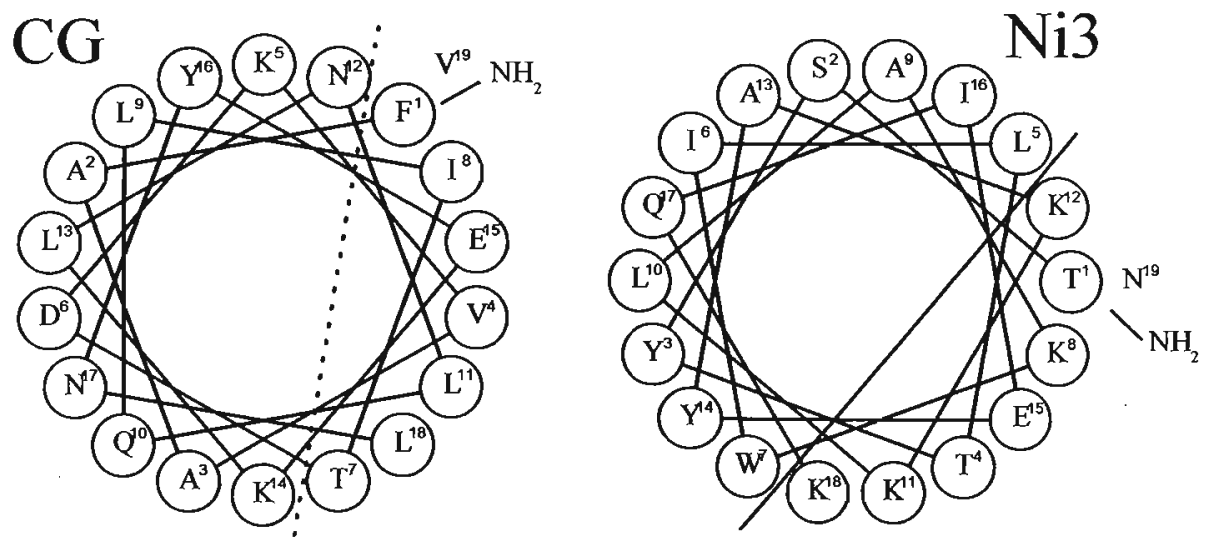

(c) $\mathrm{CG}$
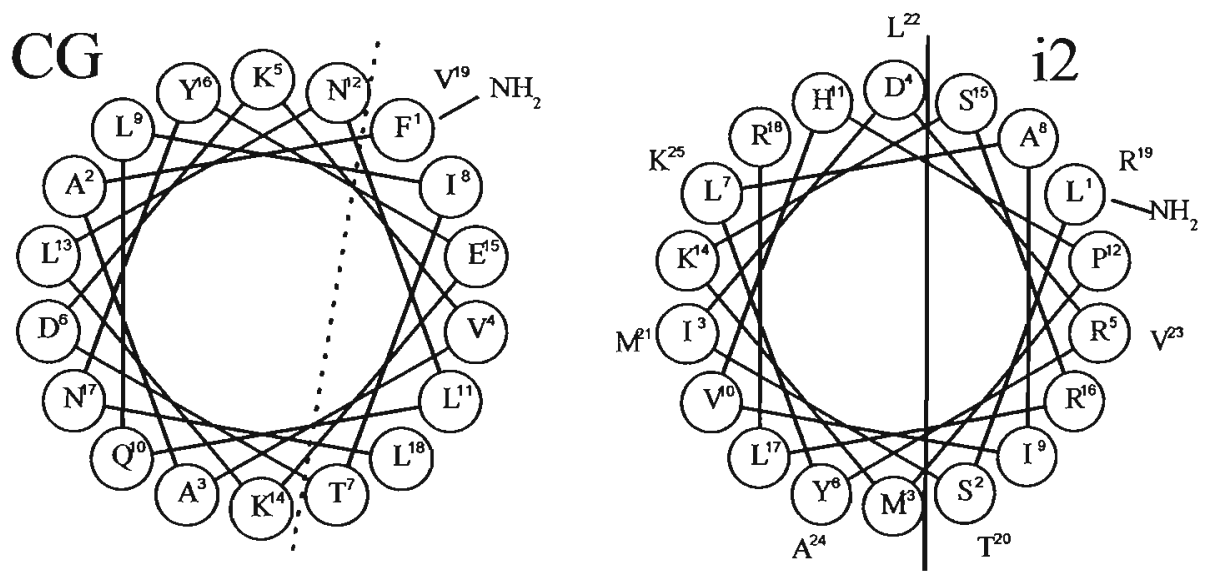

Figura 137 - Diagrama de roda helicoidal de acordo com Schiffer e Edmundon ${ }^{(220)}$ de CG com $f$-CT (a), com Ni3 (b) e com i2 (c). 
Uma das possibilidades seria que a face apolar da $\alpha$-hélice anfipática formada por $f$-CT interagisse com a face do CG a direita da linha tracejada na figura, essa regiões contém muitos dos resíduos descritos acima com sendo importantes para a interação receptor/proteína G. A disposição dos resíduos polares carregados em CG poderia atrapalhar interação com $f$-CT. No entanto, Weiss et al. ${ }^{(240)}$ observaram a substituição de $\mathrm{Asp}^{346}$ em $\mathrm{G}_{\mathrm{t} \alpha}$ por alanina não afeta o acoplamento com a rodopsina. A posição correspondente em CG é ocupada pelo resíduo de $\mathrm{Glu}^{355}$. Fahmy ${ }^{(250)}$ mostra para um peptídeo correspondente a porção C-terminal de $\mathrm{G}_{\mathrm{t} \alpha}$ que os resíduos de $\mathrm{Glu}^{342}$ e $\mathrm{Asp}^{346}$ permanecem protonados quando o esse fragmento interage com a rodopsina. Pode-se especular que o aumento do $\mathrm{pK}_{\mathrm{a}}$ do resíduo de $\mathrm{Glu}^{355}$ poderia facilitar a interação de CG $\operatorname{com} f$-CT.

Com relação a Ni3 Em solução que o conteúdo de $\alpha$-helicoidal de Ni3 aumenta com o pH (Fig.132). também observamos que o peptídeo adota uma $\alpha$-hélice na presença de LPC (Fig. 133). Na Figura 142b observa-se que Ni3 é capaz de formar uma $\alpha$-hélice anfipática. A Dra. T.A. Pertinhez durante seu doutorado observou por NMR que Ni3 forma uma $\alpha$-hélice anfipática estável na presença de $70 \% \mathrm{TFE}^{(49)}$.

Nossos resultados sugerem que CG é capaz de interagir com Ni3 na presença de LPC, visto pelas diferenças significativas na no espectro teórico e experimental de $\mathrm{Ni} 3$ na presença de CG (Fig.130). Na Figura 134 é possível observar uma grande diferença entre a forma dos espectros teórico e experimental em todos os pHs. Assim como discutido para $f$-CT, existe a possibilidade de que a face apolar de Ni3 interaja com CG.

Quanto à i2, a forma dos espectros teórico e experimental é similar em muitos pHs; no entanto, devido a grande diferença de intensidade entre esses dois espectros, acreditamos que os dois fragmentos são capazes de interagir em solução.

Em solução aquosa em pHs ácidos, o espectro de CD de i2 indica que o peptídeo encontra-se predominantemente ao acaso (Fig. 129). Com o aumento do $\mathrm{pH}$, observa-se o aumento do conteúdo $\alpha$-helicoidal, principalmente acima de $\mathrm{pH} \mathrm{8,0}$. Na presença de LPC, o espectro de CD de i2 indica uma mistura de uma população ao acaso e outra estruturada (Fig. 130a); nos outros pHs, o espectro de CD de i2 é indicativo de estrutura $\alpha$-helicoidal. Em nosso laboratório, o Dr. Cláudio S. Shida (trabalhos não publicados) observou por CD que i2 é capaz de formar uma $\alpha$-hélice na presença de membranas modelo com carga líquida negativa. 
Na literatura propõe-se que os fragmentos estudados nesse trabalho façam parte do sítio de ligação entre o receptor e a proteína $\mathrm{G}^{(138,249,251)}$. Kisselev et al. ${ }^{(138)}$ propõe que esse sítio seja formado pela i2 e i3, sendo que o C-terminal não faz parte do sítio, porém faz contato com a i3 mantendo-a na conformação adequada para a interação com a proteína G. Segundo Yokomizo et al. ${ }^{(252)}$ ao estudar o receptor B4 de leucotrienos propôs que o CT desempenha um papel importante na mudança conformacional sofrida pelo receptor quando este passa para o estado de baixa afinidade após a ativação da proteína G. Os resultados obtidos por Pin et al. ${ }^{(246)}$ também os levaram a concluir que o CT, i2 e i3 façam parte do sítio de ligação com a proteína G.

Os resultados mostrados nesse trabalho sugerem a interação entre CG e os fragmentos do receptor $\mathrm{AT}_{1 \mathrm{~A}}$ de angiotensina $\mathrm{II}$. No entanto, falta ainda investigar a especificidade dessa interação, o que poderia ser feito através do estudo com "scrambled peptides", onde a posição relativa dos aminoácidos na seqüência do peptídeo é alterada aleatoriamente. 


\section{Conclusões}

\section{1. $L H R$}

Apesar da baixa solubilidade dos peptídeos em solução aquosa, observou-se que esses fragmentos, que diferem apenas por um aminoácido, possuem propriedades conformacionais diferentes em vários sistemas estudados, o que pode ter uma relação com a propriedade biofísica do receptor inteiro de sofrer ativação constitutiva.

A metodologia de ressupenssão de filmes dos peptídeos e os estudos em TFE mostraram que quando estes fragmentos encontram-se em um ambiente mais próximo daquele encontrado na membrana biológica, estes tendem a fornecer espectros de CD sugestivos de conformação $\alpha$-helicoidal, o que é corroborado pelo fato de que na literatura foi observado que um peptídeo que compreende a região C-terminal da i3 e a TM6 possui estrutura em $\alpha$-hélice em $50 \% \mathrm{TFE}^{(219)}$.

\subsection{CG e interação com os peptídeos do receptor $A T_{1}$}

O presente trabalho mostrou que a conformação de CG é sensível ao $\mathrm{pH}$ e à força iônica, tendendo a agregar na presença de concentrações relativamente pequenas de sal.

Tanto CG como os peptídeos do receptor $\mathrm{AT}_{1}$ (i2, Ni3 e $f$-CT) foram capazes de interagir com membranas modelo, em particular, micelas de LPC, adquirindo conformação $\alpha$-helicoidal. Os estudos de CD mostraram que CG interage com os três peptídeos e que o conteúdo de $\alpha$-hélice aumenta muito em conseqüência da interação.

Nossos resultados sugerem que a região C-terminal da subunidade $\alpha$ da transducina (proteína $\mathrm{G}$ acoplada à rodopsina) é capaz de interagir com regiões i2, Ni3 e $f$-CT do receptor $\mathrm{AT}_{1}$ da angiotensina. 


\section{Bibliografia}

1. Horn F, Bettler, E., Oliveira, L., Campagne, F., Cohen, F.E. e Vriend, G. (2003) "GPCRDB information system for G protein-coupled receptors". Nucleic Acids Res. 31, 294-297.

2. Neves, S.R., Ram, P.T. e Iyengar, R. (2002) "G-protein pathways". Science 296, 1636-1639.

3. Wess, J. (1998) "Molecular basis of receptor/G-protein-coupling selectivity". Pharmacol. Ther. 80, 231-264.

4. Gether, U. (2000) "Uncovering the molecular mechanisms involved in activation of G-protein coupled receptors". Endocrine Reviews 21, 90-113.

5. Palczewski, K., Kumasaka, T., Hori, T., Behnke, C.A., Motoshima, H., Fox, B.A., LeTrong, I., Teller, D.C., Okada, T., Stenkampe, R.E., Yamamoto, M. e Miyano, M. (2000) "Crystal structure of rhodopsin: a G protein-coupled receptor". Science 289, 739-745.

6. Henderson, R., Baldwin, J.M., Ceska, T.A., Zemlin, F., Beckmann, E. e Downing, K.H. (1990) "Model for the structure of bacteriorhodopsin based on high resolution elctron cry-microscopy”. J. Mol. Biol. 213, 899-929.

7. Hilbert, M.F., Trumpp-Karlmeyer, S., Bruinvels, A., Hoflack, J. (1991) "Threedimensional models of neurotransmitter G-binding protein coupled receptors". Mol. Pharmacol. 40, 8-15.

8. Trumpp-Karlmeyer, S., Hoflack, J., Bruinvels, A. e Hilbert, M.F. (1992) “Modeling of G-protein coupled receptors: application to dopamine, adrenaline, serotonin, acetylcholine, and mammalian opsin receptors" J. Med. Chem. 35, 3448-3462.

9. MaloneyHuss, K. e Lybrand, T.P. (1992) "Three dimensional structure for the $\beta_{2}$ adrenergic receptor protein based on computer modeling studies". J. Mol. Biol. 225, 859-871.

10. Cronet, P., Sander, C. e Vriend, G., (1993) "Modeling of transmembrane seven helix bundles". Protein Eng. 6, 59-64.

11. Albert A.D. e Yeagle, P.L. (2002) "Strcutural studies on rhodopsin". Biochim. Biophys. Acta 1565, 183-195.

12. Schertler, G.F.X., Villa, C. e Henderson, R. (1993) "Projection structure of rhodopsin". Nature 362, 770-772. 
13. Unger, V.M. e Schertler, G.F. (1995) "Low resolution structure of bovine rhodopsin determined by electron cryo-microscopy". Biophys. J. 68, 1776-1786.

14. Krebs, A., Villa, C., Edwards, P.C. e Schertler, G.F. (1998) "Characterisation of an improved two-dimensional p22121 crystal from bovine rhodopsin”. J. Mol. Biol. 282, 991-1003.

15. Pebay-Peroula, E., Rummel, G., Rosenbusch, J.P. e Landau, E.M. (1997) "X-ray structure of bovine rhodopsin at $2.5 \AA$ from microcrystals grown in lipidic cubic phases". Science 277, 1676-1681.

16. Baldwin, J.M. (1993) "The probable arrangement of the helices in G protein coupled receptors". EMBO J.12, 1693-1703.

17. Unger, V.M., Hargrave, P.A., Baldwin, J.M. e Schertler, G.F. (1997) “Arrangement of rhodopsin transmembrane $\alpha$-helices". Nature 389, 203-206.

18. Baldwin, J.M, Schertler, G.F. e Unger, V.M. (1997) "An alpha-carbon template for the transmembrane helices in the rhodopsin family of G protein-coupled receptors". J. Mol. Biol. 272, 144-164.

19. Liu, J., Schoneberg, T., van Rhee, M. e Weiss, J. (1995) "Mutational analysis of the relative orientation of the transmembrane helices I and VII in G protein-coupled receptors". J. Biol. Chem. 270, 19532-19539.

20. Mizobe, T., Maze, M., Lam., V., Suryanarayana, S. e Kobilka, B.K. (1996) "Arrangement of transmembrane domains in adrenergic receptors. Similarity to bacteriorhodopsin". J. Biol. Chem. 271, 2387-2389.

21. Elling, C.E. e Schwartz, T.W. (1996) "Connectivity and orientation of the seven helical bundle in the tachykinin NK-1 receptor probed zinc site engeneering". EMBO J. 15, 6213-6219.

22. Zeng, F.Y., Hopp, A., Soldner, A. e Wess, J. (1999) "Use of a disulfide bond crosslinking strategy to study the muscarinic receptor structure and mechanisms of activation. J. Biol. Chem. 274, 16629-16640.

23. Javitch, J., Fu, D., Chen, J. e Karlin, A. (1995) "Mapping the binding-site crevice of the dopamine D2 receptor by the substituted-cysteine accessibility method". Neuron 14, 825-831.

24. Filipek, S., Teller, D.C., Palczewski, K. e Stenkamp, R. (2003) "The crystallographic model of rhodopsin and its use in studies of other G proteincoupled receptors". Annu. Rev. Biophys. Biomol. Struct. 32, 375-397. 
25. Visiers, I., Braunheim, B.B. e Weinstein, H. (2000) "Prokink: a protocol for numerical evaluation of helix distortions by proline". Protein Eng. 13, 603-606.

26. Singer, D.S. e Singer, M.F. (1976) "Studies on the interaction of H1 histone with superhelical DNA: characterization of the recognition and binding of H1 histones". Nucleic Acids Res. 3, 2531-2547.

27. Hartman, P.G., Chapman, G.E., Moss, T. e Bradbury, E.M., (1977) "Studies on the role and mode of operation of the lysine-rich histone $\mathrm{H} 1$ in eukaryote chromatin. The three structural regions of histone $\mathrm{H} 1$ molecule". Eur. J. Biochem. 77, 45-51.

28. Rashin, A.A. (1981) "Location of domain in globular proteins". Nature 291, 85-87.

29. Vita, C., Dalzoppo, D. e Fontana, A. e Rashin, A.A. (1984) "Independent folding of the carboxy-terminal fragment 228-316 of thermolysin". Biochemistry 23, 55125519.

30. Dalzoppo, D., Vita, C. e Fontana, A. (1985) "Folding of thermolysin fragments. Identification of the minimum size of a carboxyl-terminal fragment that can fold into a stable native-like structure". J. Mol. Biol. 182, 331-340.

31. Conejero-Lara, F., De Fillippis, V., Fontana, A. e Mateo, P.L. (1994) "The thermodynamics of the unfolding of an isolated protein subdomain. The 255-316 Cterminal fragment of thermolysin". FEBS Lett. 344, 154-156.

32. Rico, M., Jimenez, M.A., Gonzalez, C., De Fillippis, V. e Fontana, A. (1994) "NMR solution structure of the C-terminal 255-316 of thermolysin: a dimer formed by subunits having the native structure". Biochemistry 33, 14834-14847.

33. Ishizaka, M., Ohshima, Y. e Yanagawa, H. (2001) "Protein anatomy: structure and function of peptide fragments corresponding to the secondary structure units of barnase". J. Biochem. 129, 971-977.

34. Honda, S., Kobayashi, N., Munekata, E. e Uedaira, H. (1999) "Fragment reconstitution of a small protein: folding energetics of the reconstituted immunoglobulin binding domain B1 of streptococcal protein G". Biochemistry 38, 1203-1213.

35. Therien, A.G. e Deber, C.M. (2002) "Oligomerization of a peptide derived from the transmembrane region of the sodium pump gamma subunit: effect of the pathological mutation G41R". J. Mol. Biol. 322, 583-550.

36. Ben-Efraim, I., Bach, D. e Shai, Y. (1993) "Spectroscopic and functional characterization of the putative transmembrane segment of the minK potassium channel". Biochemistry 32, 2371-2377. 
37. Challou, N., Goormaghtigh, E., Cabiaux, V., Conrath, K. e Ruysschaert, J.M. (1994) "sequence and structure of the membrane -associated peptide of glycophorin $\mathrm{A}$ ". Biochemistry 33, 6902-6910.

38. Kahn, T.W. e Engelman, D.M. (1992) "Bacteriorhodopsin can be refolded from two independently stable transmembrane helices and the complementary five-helix fragment". Biochemistry 31, 6144-6151.

39. Nicastro, G., Peri, F., Franzoni, I., de Chiara, C., Sartor, G. e Spisni, A. (2003) "Spin-labeled extracellular loop from a seven-transmembrane helix receptor: studies in solution and interaction with model membranes". J. Pept. Sci. 9, 229-243.

40. Salinas, R.K., Shida, C.S., Pertinhez, T.A., Spisni, A., Nakaie, C.R., Paiva, A.C.M. e Schreier, S. (2002) "Trifluoroethanol and binding to model membranes stabilize a predicted turn in a peptide corresponding to the first extracellular loop of the angiotensin II AT $\mathrm{AA}_{1 \mathrm{~A}}$ receptor". Biopolymers 65, 21-31.

41. Piserchio, A., Bisello, A., Rosenblatt, Chorev, M., Mierke, D.F. (2000) "Chracterization of parathyroid hormone/receptor interactions: structure of the first extracellular loop". Biochemistry 39, 8153-8160.

42. Yeagle, P.L., Salloum, A., Chopra, A., Bhawsar, N., Ali, L., Kuzmanovski, G., Alderfer, J.I. e Albert, A.D. (2000) "Structures of the intradiskal loops and the amino terminus of the G-protein receptor, rhodopsin". J. Pept. Res. 55, 455-465.

43. Arshava, B., Liu, S.F., Jiang, H., Breslav, M., Becker, J.M., Naider, F. (1998) "Structure of segments of a G protein-coupled receptor: CD and NMR analysis of Saccharomyces cerevisiae tridecapeptide pheromone receptor". Biopolimers 46, 343-357.

44. Pellegrini, M., Bisello, A., Rosenblatt, M., Chorev, M. e Mierke, D.F. (1998) "Binding domain of human parathyroid hormone receptor: from conformation to function". Biochemistry 37, 12737-12743.

45. Pertinhez, T.A., Nakaie, C.R., Paiva, A.C.M. e Schreier, S. (1997) "Spin-labeled extracellular loop from a seven transmembrane helix receptor: studies in solution and interactions with model membranes". Biopolimers 42, 821-829.

46. Strader, C.D., Fong, T.M., Tota, M.R., Underwood, D.M. e Dixon, R.A.F. (1994) "Structure and function of G protein-coupled receptors". Annu. Rev. Biochem. 63, 101-132. 
47. Krishna, A.G., Menon, S.T., Terry, T.J. e Sakmar, T.P. (2002) "Evidence that helix 8 acts as a membrane-dependent conformational switch". Biochemistry 41, 82988309.

48. Franzoni, L., Nicastro, G., Pertinhez, T.A., Tato, M. C.R., Paiva, A.C., Schreier, S. e Spisni, A. (1997) "Structure of the C-terminal fragment 300-320 of the rat angiotensin II $\mathrm{AT}_{1 \mathrm{~A}}$ receptor and its relevance with respect to G-protein coupling". J. Biol. Chem. 272, 9734-9741.

49. Franzoni, L., Nicastro, G., Pertinhez, T.A., Oliveira, E., Nakaie, C.R., Paiva, A.C., Schreier, S. e Spisni, A. (1999) "Structure of two fragments of the third cytoplasmatic loop of the rat angiotensin $\mathrm{AT}_{1 \mathrm{~A}}$ receptor: implications with respect to receptor activation and G-protein selection and coupling". J. Biol. Chem. 274, 227235.

50. Pertinhez, T.A., Krybus, R., Cilli, E.M., Paiva, A.C.M., Nakaie, C.R., Franzoni, L., Sartor, G., Spisni, A. e Schreier, S. (2002) "Conformational flexibility of three cytoplasmatic segments of the angiotensin II $\mathrm{AT}_{1 \mathrm{~A}}$ receptor: a circular dichroism and fluorescence study. J. Pept. Sci. 8, 23-35.

51. Yeagle, P.L., Alderfer. J.L. e Albert, A.D. (1997) "Three-dimensional structure of the cytoplasmatic face of the G protein-coupled receptor rhodopsin". Biochemistry 36, 9649-9654.

52. Yeagle, P.L., Alderfer. J.L., Salloum, A.C., Ali, L. e Albert, A.D (1997) "The first and second cytoplasmatic loopsof the G-protein receptor, rhodopsin, independently form beta-turns". Biochemistry 36, 3864-3869.

53. Yeagle, P.L., Alderfer. J.L. e Albert, A.D. (1996) "Structure determination of the fourth cytoplasmatic loop and carboxyl terminal domain of bovine rhodopsin". Mol. Vis. 29, 2-12.

54. Yeagle, P.L., Alderfer. J.L. e Albert, A.D. (1995) "Structure of the third cytoplasmaticloop of bovine rhodopsin". Biochemistry 34, 14621-14625.

55. Langen, R., Cai, K., Altenbach, C., Khorana, H.G. e Hubell, W.L. (1999) "Structural features of the C-terminal domain of bovine rhodopsin: a site-directed spin-labeling study". Biochemistry 38, 7918-7924.

56. Altenbach, C., Cai, K., Khornana, H.G. e Hubell, W.L. (1999) "Structural features of the light-dependant changes in sequence 306-322 extending from helix VII to the palmitoylation sites in rhodopsin: a site-directed spin-labeling study". Biochemistry 38, 7931-7937. 
57. Altenbach, C., Klein-Seethraman, J., Hwa, J., Khorna, H.G. e Hubell, W.L. (1999) "Structural features and light-dependant changes in the sequence 59-75 connecting helices I and $\Pi$ in rhodopsin: a site-directed spin-labeling”. Biochemistry 38, 79457949.

58. Altenbach, C., Yang, K, Farrens, D.L., Farahbakhsh, Z.T., Khorna, H.G. e Hubell, W.L. (1996) "Structural features and light-dependant changes in the cytoplasmatic interhelical E-F loop region of rhodopsin: a site-directed spin-labeling study". Biochemistry 35, 12470-12478.

59. Farahbakhsh, Z.T., Ridge, K.D., Khorna, H.G., Hubell, W.L. (1995) “Mapping light-dependant structural changes in the cytoplasmatic loop connecting helices $\mathrm{C}$ and D in rhodopsin: a site-directed spin-labeling study". Biochemistry 34, 88128819.

60. Jung, H., Windhaber, R., Palm, D. e Schnakerz, K.D. (1996) “Conformation of a $\beta$ adrenoreceptor-derived signal transducing peptideas inferred by circular dichroism and 'H-NMR spectroscopy" Biochemistry 35, 6399-6405.

61. Pellegrini, M., Royo, M., Chorev, M. e Mierke, D.F. (1996) “Conformational characterization of a peptide mimetic of the third intracellular loop of the G-protein coupled parathyroid hormone/parathyroid hormone related protein receptor". Biopolymers 40, 653-666.

62. Oliveira, E., Miranda, A., Albericio, F., Andreu, D., Schreier, S., Paiva, A.C.M., Nakaie, C.R., and Tominaga, M. (1999) "Structure analysis of the second transmembrane segment of the rat bradykinin receptor in solution and micelles by $\mathrm{CD}$ and fluorescence spectroscopy". In "Peptide Science - present and future" (Shimonishi, Y., Ed.) Kluwer Academic Publishers, The Netherlands, pp. 583-585.

63. Grijalba, M.T., Schreier, S., Oliveira, E., Nakaie, C.R., Miranda, A., Tominaga, M., and Paiva, A.C.M. (2000) "Conformational studies of a detergent-bound transmembrane segment of the rat bradykinin receptor". In "Peptides for the New Millennium " (Fields, G.B., Tamm, J.P., and Barany, G., Eds.). Kluwer Academic Publishers, Dordrecht, The Netherlands, pp. 385-386.

64. Xie, H., Ding, F.X., Schreiber, D., Eng, G., Liu, S., Arshava, B, Arevalo, E., Becker, J.M. e Naider, F. (2000) "Synthesis and biophysical analysis of transmembrane domains of a Saccharomyces cerevisiae G Protein-coupled receptor". Biochemistry 39, 15462-15474. 
65. Ding, F.X., Xie, H., Arshava, B, Becker, J.M. e Naider, F. (2001) "ATR-FTIR study of the structure and orientation of transmembrane domains of Saccaromyces cerevisiae alpha mating factor receptor in phospholipids". Biochemistry 40, 89458954.

66. Valentine, K.G., Liu, S.F., Marassi, F.M., Veglia, G., Opella, S.J., Ding, F.X., Wang, S.H., Arshava, B., Becker, J.M. e Naider, F. (2001) "Structure and topology of a peptide segment of the 6th transmembrane domain of the Saccharomyces cerevisae alpha-factor receptor in phospholipid bilayers". Biopolymers 59, 243-256.

67. Arshava, B., Taran, I., Xie, H., Becker, J.M. e Naider, F. (2002) "High resolution NMR analysis of the seven transmembrane domains of a heptahelical receptor in organic-aqueous medium". Biopolymers 64, 161-176.

68. Chopra, A., Yeagle, P.L., Alderfer, J.A. e Albert, A.D. (2000) "Solution structure of the sixth transmembrane helix of the G-protein-coupled receptor, rhodopsin". Biochim. Biophys. Acta 1463, 1-5.

69. Mirzadegan, T., Benkö, G., Filipek, S. e Palczewski, K. (2003) "Sequence analyses of a G-protein-coupled receptors: similarities to rhodopsin". Biochemistry 42, 27592767.

70. Archer, E., Maigret, B., Escrieut, C., Pradayrol, L. e Fourmy, D. (2003) "Rhodopsin crystal: new template yielding realistic models of G-protein-coupled receptors?" TIPS 24, 36-40.

71. Sakmar, T.P (2002) "Structure of rhodopsin and the superfamily of seven-helical receptors: the same and not the same". Curr. Opin. Cell Biol. 14, 189-195.

72. Meng, E.C. e Bourne, H.R. (2001) "Receptor activation: what does the rhodopsin structure tell us?" Trends. Pharmacol. Sci. 22, 587-593.

73. Ji, T.H, Grossmann, M. e Ji, I. (1998) “G protein-coupled receptors. I. Diversity of receptor-ligand interactions". J. Biol. Chem. 273, 17299-17302.

74. Kobilka, B. (1992) "Adrenergic receptors as models for G-protein receptors". Annu. Rev. Neurosci. 15, 87-114.

75. Savarese, T.M. e Fraser, C.M. (1992) "In vitro mutagenesis and the search for structure-function relationships among G protein-coupled receptors". Biochem. J. 283, 1-19.

76. Strader, C.D., Fong, T.M., Graziano, M.P. e Tota, M.R. (1995) "The family of G protein-coupled receptors". FASEB J. 9, 745, 754. 
77. Tota, M.R. e Strader, CD. (1990) "Characterization of the binding domain of the beta-adrenergic receptor with the fluorescent antagonist carazolol". J. Biol. Chem. 265, 16891-16897.

78. Hjorth, S.A., Schambye, H.T., Greenlee, W.J. e Schwartz, T.W. (1994) "Identification of peptide binding residues in the extracelllular domains of the $\mathrm{AT}_{1}$ receptor". J. Biol. Chem. 269, 30953-30959.

79. Feng, Y.H., Noda, K., Saad, Y., Liu, X.P., Hussein, A. e Karnik, S.S. (1995) “The docking of $\mathrm{Arg}^{2}$ of angiuotensin II with $\mathrm{Asp}^{281}$ of $\mathrm{AT}_{1}$ receptor is essential for full agonism". J. Biol. Chem. 270, 12846-12850.

80. Heerding, J.N., Yee, D.K., Jacobs, S.L. e Fluharty, S.J. (1997) "Mutational analysis of the angiotensin II type 2 receptor: contribution of conserved extracellular aminoacids". Regul. Pept. 72, 97-103.

81. Walker, P., Munoz, M., Martinez, R. e Peitsch, M.C. (1994) “Acidic residues in extracellular loops of the human-Y1 neuropeptide- $Y$ receptor are essential for ligand binding”. J. Biol. Chem. 269, 2863-2869.

82. Leong, S.R., Kabakoff, R.C. e Hebert, C. (1994) “Complete mutagenesis of the extracellular domain of interleukin-8 (IL-8) type A receptor indentifies charged residues mediating $\Pi$ L-8 binding and signal transduction". J. Biol. Chem. 269, 19343-19348.

83. Cotte, N., Balestre, M.N., Phalipou, S., Hibert, M., Manning, M., Barberis, C. e Moulliac, B. (1998) "Identification of residues responsible for the selective binding of peptide antagonists and agonists in the V2 vasopressin receptor". J. Biol. Chem. 273, 29462-29468.

84. Davidson, J.S., Assefa, D., Pawson, A., Davies, P., Hapgood, J., Becker, I., Flanagan, C., Roeske, R. e Millar, R. (1997) "Irreverssible activation of the gonadotropin-releasing hormone receptor by photoaffinity cross-linking: localization of attachment site to Cys residue in N-terminal segment". Biochemistry 36, 12881-12889.

85. Yamano, Y., Ohyama, K., Kikyo, M., Sano, T., Nakagomi, Y., Inoue, Y., Nakamura, N., Morishima, I., Guo, D.F., Hamakubo, T. e Inagami, T. “Mutagenesis and the molecular modeling of the rat angiotensin $\Pi$ receptor $\left(\mathrm{AT}_{1}\right)$ ". (1995) J. Biol. Chem. 270, 14024-14030.

86. Monnot, C., Bihoreau, C., Conchon, S., Curnow, K.M., Corvol, P. e Clauser, E. (1996) "Polar residues in the transmembrane domains of the type 1 angiotensin II 
receptor are required for binding and coupling. Reconstitution of the binding site by co-expression of two deficient mutants". J. Biol. Chem. 271, 1507-1513.

87. Befort, K., Tabbara, L., Kling, D., Maigret, B. e Kieffer, B.L. (1996) "Role of aromatic transmembrane residues of the $\delta$-opioid receptor in ligand recognition". $J$. Biol. Chem. 271, 10161-10168.

88. Fathy, D.B., Mathis, S.A., Leeb, T. e Leeb-Lundberg, L.M. (1998) "A single in the third transmembrane domains of the $\mathrm{B} 1$ and $\mathrm{B} 2$ bradykinin receptors is adjacent to and discriminates between the C-terminal residues of subtype-selective ligands". $J$. Biol. Chem. 273, 12210-12218.

89. Nagayama, Y., Russo, D., Wadsworth, H.L., Chazenbalk, G.D. e Rapoport, B. (1991) "Eleven amino acids (Lys-201 to Lys-211) and 9 amino acids (Gly-222 to Leu-230) in the human thyrotropin receptor are involved in ligand binding". J. Biol. Chem. 266, 14926-14930.

90. Nagayama, Y., Wadsworth, H.L., Chazenbalk, G.D., Russo, D., Seto, P. e Rapoport, B. (1991) “Thyrotropin-luteinizing hormone/chorionic gonadotropin receptor extracellular domain chimeras as probes for the thyrotropin receptor function". Proc. Natl. Acad. Sci. USA 88, 902-905.

91. Moyle, W.R., Bernard, M.P., Myers, R.V., Marko, O.M. e Strader, C.D. (1991) “ leutropin/beta-adrenergic receptor chimeras bind choriogonadotropin and adrenergic ligands but are not expressed at the cell surface". J. Biol. Chem. 266, 10807-10812.

92. Thomas, D., Rozell, T.G., Liu, X. e Segaloff, D.L. (1996) “Mutational analysis of the extracellular domain of the full-length lutropin.choriogondotrpin receptor suggest leucine rich repeats 1-6 are involved in hormone binding". Mol. Endocrinol. 10, $760-768$.

93. Osuga, Y., Kudo, M., Kaipia, A., Kobilka, B.K. e Hsueh, A.J.W. (1997) “ Derivation of functional antagonists using $\mathrm{N}$-terminal extracellular domain of gonadotropin and thyrotropin receptors". Mol. Endocrinol. 11, 16590-1668.

94. Dufau, M.L. (1998) “The luteinizing hormone receptor”. Annu. Rev. Physiol. 60, 461-496.

95. Samama, P., Cotecchia, S., Costa, T. e Lefkowitz, R.J. (1993) “A mutation-induced activated state of the $\beta_{2}$-adrenergic receptor: extending the ternary complex model." J. Biol. Chem. 268, 4625-4636.

96. Leff, P. "The two-state model of receptor activation". Trends. Pharmacol. Sci. 16, 89-97. 
97. Lefkowitz, R.J., Cotecchia, S., Samama, P. e Costa, T. (1993) "Constitutive activity of receptors coupled to guanine nucleotide regulatory proteins". Trends. Pharmacol. Sci. 14, 303-307.

98. Rittano, D., Werge, T.M. e Costa, T. (1997) "A mutation changes ligand selectivity and transmmebrane signaling preference of neurokinin-1 receptor". J. Biol. Chem. 272, 7646-7655.

99. Waelbroeck, M. (2001) “Activation of guanosine $5^{\prime}-\left[\gamma^{35}\right.$ S-triphosphate binding through $M_{1}$ muscarinic receptors in transfected chinese hamster ovary cell membranes: 2. Testing the "two-states"model of receptor activation". Mol. Pharmacol. 59, 886-893.

100. Mhaouty-Kodja, S., Barak, L.S., Scheer, A., Abuin, L., Diviani, D., Caron, M.G. e Cotecchia, S. (1999) "Constitutively active $\alpha_{1 b}$ adrenergic receptor mutants display different phosphorylation and internalization features". Mol. Pharmacol. 55, 339-347.

101. Gether, U., Lowe III, J.A. e Schwartz, T.W. (1995) "Tachykinin non-peptide antagonists: binding domain and molecular mode of action". Biochem. Soc. Trans. 23, 96-102.

102. Schwartz, T.W., Gether, U., Schambye, H.T. e Hjorth, S.A. (1995) “Molecular mechanism of action of non-peptide ligands for peptide receptors". Curr. Pharm. Design 1, 325-342.

103. Scheer, A., Fanelli, F., Costa, T., De Benedetti, P.G. e Cotecchia, S. (1996) "Constitutively active mutants of the $\alpha_{1 b}$ adrenergic receptor: role of higly conserved polar aminoacids in receptor activation. EMBO J. 15, 3566-3578.

104. Allen, L.F., Lefkowitz, R.J., Caron, M.G. e Cotecchia, S. (1991) "G-protein coupled receptor genes as protooncogenes: constituvely activating mutation of the $\alpha_{1 b}$ adrenergic receptor enhances mitogenesis and tumorigenicity." Proc. Natl. Acad. Sci. USA 88, 11354-11358.

105. Kjelsberg, M.A., Cotecchia, S., Ostrowski, J., Caron, M.G. e Lefkowitz, R.J. (1992) "Constitutive activation of the $\alpha_{1 b}$ adrenergic receptor by all aminoacids substitutions at a single site. Evidence for a region which constrains reeptor activation." J. Biol. Chem. 267, 1430-1433. 
106. Shenker, A., Laue, L., Kosugi, S., Merendino, J.J., Minegishi, T. e Cutler, G.B. (1993) "A constitutively activating mutantion of the luteinizing hormone receptor in familial male precocious puberty". Nature 365,652-654.

107. Parma, J., Duprez, L., Van Sande, J., Cochaux, P., Gervy, C., Mockel, J., Dumont, J. e Vassart, G. (1993) "Somatic mutations in thyrotropin receptor gene hyperfunctioning thyroid adenomas". Nature 365, 649-651.

108. Kudo, M., Osuga, Y., Kobilka, B.K. e Hsueh, A.J.W. (1996) "Transmembrane regions $\mathrm{V}$ and $\mathrm{VI}$ of the luteinizing hormone receptor are require for constitutive activation by a mutation in the third intracellular loop". J. Biol. Chem. 271, 2247022478 .

109. Spalding, T.A., Burstein, E.S., Henderson, S.C., Ducote, K.R. e Brann, MR. (1998) "Identification of a ligand-dependant switch within a muscarinic receptor". $J$. Biol. Chem. 273, 21563-21568.

110. Dube, P. e Konopka, J.B. (1998) "Identification of a polar region in transmembrane domain 6 that regulates the function of the $G$ protein-coupled $\alpha$ factor receptor". Mol. Cell. Biol. 18, 7205-7215.

111. Han, M., Smith, S.O. e Sakmar, T.P. (1998) "Constitutive activation of opsinby mutation of methionine 257 on transmembrane helix 6." Biochemistry 37, 82538261.

112. Groblewski, T., Maigret, B., Larguier, R., Lombard, C., Bonnafous, J.C. e Marie J. (1997) "Mutation of Asn111 in the third trasnmembrane domain of the AT1A angiotensin $I I$ receptor induces its cosntitutive activation". J. Biol. Chem. 272, $1822-$ 1826.

113. Porter, J.E., Hwa, J. e Perez, D.M. (1996) "Activation of the $\alpha_{1 b}$ adrenergic receptor is initiated by disruption of an interhelical salt bridge constraint. J. Biol. Chem. 271, 28318-28323.

114. Rasmussen, S.G., Jensen, A.D., Liapakis, G., Ghanouni, P., Javitch, J.A. e Gether, U. (1999) "Mutation of a highly conserved aspartic acid in the $\beta 2$ adrenergic receptor: constitutive activation, strucutral instability, and conformational rearrangement of transmembrane segment 6". Mol. Pharmacol. 56, 175-184.

115. Ballesteros, J., Kitanovic, S., Guarnieri, F., Davies, P., Fromme, B.J., Konvicka, K., Chi, L., Millar, R.P., Davidson, J.S., Weinstein, H. e Seafon, S.C. (1998) "Functional microdomains in G-protein coupled-receptors. The conserved arginine- 
cage motif in the gonadotropin-releasing hormone receptor". J. Biol. Chem. 273, 10445-10453.

116. Lu, Z.L., Curtis, C.A., Jones, P.G., Pavia, J. e Hulme, E.C. (1997) "The role of aspartate-arginine-tyrosine triad in the $\mathrm{ml}$ muscarinic receptor: mutations of aspartate 122 and tyrosine 124 decrease receptor expression but do not abolish signaling". Mol. Pharmacol. 51, 234-241.

117. Arnis, S., Fahmy, K., Hofmann, K.P. e Sakmar, T.P. (1994) "A conserved carboxylic acid group mediates light-dependant proton uptake and signaling by rhodopsin". J. Biol. Chem. 269, 23879-23881.

118. Scheer, A., Fanelli, F., Costa, T., De Benedetti, P.G. e Cotecchia, S. (1997) “The activation process of the alphalB-adrenergic receptor: potencial role of protonation and hydrophobicity of higly conserved aspartate". Proc. Natl. Acad. Sci. USA. 94, 808-813.

119. Garcia-Quintana, D., Francesch, A., Garriga, P., de Lera, A.R., Padros, E. e Manyosa, J. (1995) "Fourier transform infrared spectroscopy indicates a major conformational rearrangement in the activation of rhodopsin". Biophys. J. 69, 1077 1082.

120. Salamon, Z., Wang, Y., Brown, M.F., Macleod, H.A. e Tollin, G. (1994) "Conformational changes in rhodopsin probed by surface plasmon resonance spectroscopy". Biochemistry 33, 13706-13711.

121. Lin, S.W. e Sakmar, T.P. (1996) "Specific trytophan UV-absorbance changes are probes of the transition of rhodopsin to its active state". Biochemistry 35, 11149 11159.

122. Clapham, D.E. e Neer, E.J. (1997) "G protein $\beta \gamma$ subunits". Annu. Rev. Pharmacol. Toxicol. 37, 167-203.

123. Neer, E.J. (1995) "Heterotrimeric G proteins: organizers of transmembrane signals". Cell 80, 249-257.

124. Rens-Domiano, S. e Hamm, H.E. (1995) "Structural and function relationships of heterotrimeric G-proteins". FASEB J. 9, 1059-1066.

125. Hamm, H.E. (1998) "The many faces of G protein signaling". J. Biol. Chem. 273, 669-672.

126. Clapham, D.E. (1996) "The G-protein nanomachine". Nature 379, 297-298. 
127. Wall, M.A., Coleman D.E., Lee E., Iniguez-Lluhi, J.A., Posner, B.A., Gilman, A.G. e Sprang, S.R. (1995) "The structure of the G protein heterotrimer $G_{i} \alpha_{1} \beta_{1} \gamma_{2}$ ". Cell 83, 1047-1058.

128. Lambright, D.G., Sondek, J., Bohm, A., Skiba, N.P., Hamm, H.E. e Sigler, P.B. (1996) "The $2.0 \AA$ crystal structure of a hetrotrimeric G protein". Nature 379, 311 319.

129. Sondek, J., Bohm, A., Lambright, D.G., Hamm, H.E. e Sigler, P.B. (1996) "Crystal structure of a G protein $\beta \gamma$ dimmer at $2.1 \AA$ resolution". Nature 379, 369374.

130. Wedegaertner, D., Wilson, P.T e Bourne, H.R. (1995) "Lipid modifications of trimeric G proteins". J. Biol. Chem. 270, 503-506.

131. Dohlman, H.G., Thorner, J., Caron, M.C. e Lefkowitz, R.J. (1991) "Model systems for the study of seven transmembrane receptors". Annu. Rev. Biochem. 60 , 653-688.

132. Wess, J. (1997) “G protein-coupled receptors: molecular mechanisms involved in receptor activation and selectivity of G-protein recognition". FASEB J. 11, 346354.

133. Burstein, E.S., Spalding, T.A. e Brann, M.R. (1998) "The second intracellular loop of the m5 muscarinic receptor is the switch which enables G-protein coupling”. J. Biol. Chem. 273, 24322-24327.

134. Kai, H., Alexander, R.W., Ushio-Fukai, M., Lyons, P.R., Akers, M. e Griendling, K.K. (1998) "G protein binding domains of the angiotensin II $\mathrm{AT}_{1 \mathrm{~A}}$ receptors mapped with synthetic peptides selected from the receptor sequence". Biochem. J. 332, 781-787.

135. Farrens, D.L., Altenbach, C., Yang, K., Hubbell, W.L. e Khorana, H.G. (1996) "Requirement of rigid-body motion of transmembrane helices for light activation of rhodopsin". Science 274, 768-770.

136. Gether, U., Lin, S., Ghanouni, P., Ballesteros, J.A., Weinstein, H. e Kobilka, B. K. (1997) "Agonists induce conformational changes in transmembrane domains III abd Vi of the $\beta 2$ adrenergic receptor". EMBO J. 16, 6737-6747.

137. Iiri, T., Farfel, Z. e Bourne, H. (1998) "G protein diseases furnish a model for the turn-on switch". Nature 394, 35-38. 
138. Kisselev, O. G., Kao, J., Ponder, J. W., Fann, Y. C., Gautam, N. e Marshall, G. R. (1998) Proc. Natl. Acad. Sci. U.S.A. 95, 4270-4275

139. Aris, L., Gilchrist, A., Rens-Domiano, S., Meyer, C., Schatz, P.J., Dratz, E.A., Hamm, H.E.(2001) "Structural requirements for the stabilization of metarhodopsin $\Pi$ by the $\mathrm{C}$ terminus of the alpha subunit of transducin". J. Biol. Chem. 276, 23332339.

140. Ascoli, M., Fanelli, F. e Segaloff, D.L. (2002) "The lutropin/choriogonadotropin receptor, a 2002 perspective". Endocrine Reviews 23, 141-174.

141. Xie, Y.B., Wang, H. e Segaloff, D.L. (1990) "Extracellular domain of lutropin/choriogonadotropin receptor expressed in transfected cells binds choriogonadotropin with high affinity". J. Biol. Chem. 265, 21411-21414.

142. Braun, T., Schofield, P.R. e Sprengel, R. (1991) "Amino-terminal leucine rich repeats in gonadotropin receptors determine hormone selectivity". EMBO J.10, 1885-1890.

143. Thomas, D.M. e Segaloff, D.L. (1994) "Hormone binding properties and glycosilation pattern of a recombinant form of the extracellular domain of the LH.CG receptor expressed in mammalian cells". Endocrinology 135, 1902-1912.

144. Nakamura, K. Liu, X. e Ascoli, M. (1999) "The rate of internalization of the gonadotropin receptors is greatly affected by the origin of the extracellular domain". J. Biol. Chem. 274, 25426-25432.

145. Tapanaiene, J.S, Bo, M., Dunkel, L., Billig, H., Perlas, E., Boime, I. e Hsueh, AJ.W. (1993) "Deglycossylation of the human luteinizing hormone receptor does not affect ligand binding and signal transduction". Endocrine 1, 219-225.

146. Davis, DP, Rozell, T.G., Liu, X. e Segaloff, D.L. (1997) “The six N-linked carbohydrates of the lutropin/choriogonadotropin receptor are not absolutely required for correct folding, cell surface expression, hormone binding or signal transduction". Mol. Endocrinol. 11, 550-562.

147. Moyle, W.R., Campbell, R.K., Myers, R.V., Bernard, M.P., Han, Y. e Wang, X. (1994) “Co-evolution of ligand receptor pairs". Nature 368, 251-255.

148. Zhang, F.P., Kero, J. e Huhtaniemi, I. (1998) "The unique exon 10 of the human luteinizing hormone receptor is necessary for the expression of the receptor protein at the plasma membrane in the human luteinizing hormone receptor, but deleterious when inserted in the human follicle-stimulating hormone receptor". Mol. Cell Endocrinol. 142, 165-174. 
149. Nakabayashi, K., Kudo, M., Kobilka, B. e Hsueh, A.J.W. (2000) "Activation of the luteinizing hormone receptor following substitution of Ser277 with selective hydrophobic residues in the ectodomain hinge region". J. Biol. Chem. 275, 3026430271.

150. Zeng, H., Phang, T., Song, Y.S., Ji, I. e Ji, T.H. (2001) "The role of the hinge region of the luteinizing hormone receptor in hormone interaction and signal generation". J. Biol. Chem. 276, 3451-3458.

151. Alvarez, C.A., Narayan, P., Huang, J. e Pret, D. (1999) "Characterization of a region of the lutropin receptor extracellular domain near transmembrane helix 1 that is important in ligand-mediated signaling". Endocrinology 140, 1775-1782.

152. Fernandez, L.M. e Puett, D. (1996) "Lys ${ }^{583}$ in the third extracellular loop of the lutropin/choriogonadotropin receptor is critical for signaling”. J. Biol. Chem. 271, 925-930.

153. Ryu, K., Gilchrist, R.I., Ji, I. e Kim, S.T.H.J. (1996) "Exoloop 3 of the luteinizing hormone/chorionic gonadotropin receptor”. J. Biol. Chem. 271, 73017304.

154. Ryu, K., Kim, S., Beauchamp, J., Tung, C.S., Isaacs, N.W., Ji, I. e Ji, T.H. (1998) "Modulation of high affinity hormone binding. Human choriogonadotropin binding to the exodomain of the receptor is influenced by exoloop 2 of the receptor". J. Biol. Chem. 273, 6285-6291.

155. Abell, A.M. e Segaloff, D.L. (1997) "Evidence for the direct involvement of transmembrane region 6 of the lutropin/choriogonadotropin receptor in activating $\mathrm{G}_{\mathrm{s}}$ ". J. Biol. Chem. 272, 14586-14591.

156. Schulz, A., Schöneberg, T., Paschke, R., Schultz, G., Gudermann, T. (1999) "Role of the third intracellular loop for the activation of gonadotropin receptors". Mol. Endocrinol. 13, 181-190.

157. Angelova, K., Narayan, P., Simon, J.P. e Pret, D. (2000) "Funtional role of transmembrane heilx 7 in the activation of the heptahelical lutropin receptor". Mol. Endocrinol. 14, 459-471.

158. Cotecchia, S., Exum, S., Caron, M.G. e Lefkowitz, R. (1990) "Regions of the $\alpha_{1}$ adrenergic receptor involved in coupling to phosphatidylinositol hydrolysis and enhanced sensivity of biological function". Proc. Natl. Acad. Sci. USA 87, 28962900. 
159. Laue, L., Chan, W-Y., Hsueh, A.J.W., Kudo, M., Hsu, S.Y., Wu, S-M., Blomberg, L. e Cutler Jr., G.B. (1995) "Genetic heterogeneity of constitutively activating mutations of the human luteinizing hormone receptor in familial malelimited precocious pubery". Proc. Natl. Acad. Sci. USA. 92, 1906-1910.

160. Cohen, G.B., Yang, T., Robinson, P.R. e Oprian, D.D. (1993) "Constitutive activation of opsin: influence of charge at position 134 and size at position 296". Biochemistry 32, 6111-6115.

161. Lin, Z., Shenker, A. e Pearlstein, R. (1997) "A model of lutropin/choriogonadotropin receptor: insights into the structural and functional effects of constitutively activating mutations". Protein Eng. 10, 501-510.

162. Kosugi, S., Mori, T. e Shenker, A. (1996) "The role of $\mathrm{Asp}^{578}$ in maintaining the inactive conformation of the human lutropin/choriogonadotropin receptor". J. Biol. Chem. 271, 31813-31817.

163. Fanelli, F. (2000) "Theorethical study on mutation-induced activation of the luteinizing hormone receptor". J. Mol. Biol. 96, 1333-1351.

164. Shinozaki, H., Fanelli, F., Liu, X., Butterbrodt, J., Nakamura, K. e Segaloff, D.L. (2001) "Pleiotropic effects of substitutions of a highly conserved leucine in transmembrane helix III of the human lutropin/choriogonadotropin receptor with respect to constitutive activation and hormone responsiveness". Mol. Endocrinol. $15,972-984$.

165. Kosugi, S., Mori, T. e Shenker, A. (1998) "An anionic residue at position 564 is important for maintaining the inactive conformation of the human lutropin/choriogonadptropin receptor". Mol. Pharmacol. 53, 894-901.

166. Sheikh, S.P., Zvyaga, T.A., Lichtarge, O., Sakmar, T.P. e Bourne, H.R. (1996) Rhodopsin activation blocked by metal ion-binding sites linking transmembrane helices C and F". Nature 383, 347-350.

167. Abell, A.N., McCormick, D.J. e Segaloff, D.L. (1998) "Certain activating mutations within helix 6 of the human luteinizing hormone receptor may be explained by alterations that allow trnasmembrane regions to activate $\mathrm{G}_{\mathrm{s}}$ ". Mol . Endocrinol. 12, 1857-1869.

168. Gudermann, T., Birnbaumer, M., Birnbaumer, L. (1992) "Evidence for dual coupling of the murine luteinizing hormone receptor to adenyly cyclase and phosphoinositide breakdown and $\mathrm{Ca}^{2+}$ mobilization". J. Biol. Chem. 267, 44794488. 
169. Gudermann, T., Nichols, C., Levy, F.O., Birnbaumer, M. e Birnbaumer, L. (1992) " $\mathrm{Ca}^{2+}$ mobilization by the LH receptor expressed in Xenopus oocytes independent of $3^{\prime}, 5^{\prime}$-cyclic adenosine monophosphateformation: evidence of parallel activation of two signaling pathways". Mol. Endocrinol. 6, 272-278.

170. Rajagopalan-Gupta, R., Rasenick, M. e Hunzicker-Dunn, M. (1997) "Luteinizing hormone/choriogonadotropin-dependant, cholera toxin-catalized adenosine 5'-diphosphate(ADP)-ribosylation of the long and short forms of $\mathrm{G}_{\mathrm{s}} \alpha$ and pertussis toxin-catalyzed ADP-ribosylation of $\mathrm{G}_{\mathrm{i}} \alpha$ ". Mol. Endocrinol. 11, 538-549.

171. Rajagopalan-Gupta, R., Lamm, M.L.G., Mukherjee, S., Rasenick, M. e Hunzicker-Dunn, M. (1998) "Luetinizing hormone/choriogonadotropin receptormediated activation of hetrotrimeric guanine nucleotide binding proteins in ovarian follicular membranes". Endocrinology 139, 4547-4555.

172. Herrlich, A., Kuhn, B., Grosse, R., Schmid, A., Schultz, G. e Gudermann, T. (1996) "Involvement of $G_{s}$ and $G_{i}$ proteins in dual coupling of the luteinizing hormone receptor to adenylyl cyclase and phospholipase C". J. Biol. Chem. 271, 16764-16772.

173. Kühn, B. e Gudermann, T. (1999) “The luteinizing hormone receptor activates phospholipase $\mathrm{C}$ via preferencial coulping to $\mathrm{G}_{\mathrm{i} 2}$ ". Biochemistry 38, 12490-12498.

174. Touyz, R.M. e Schiffrin, E.L. (2000) "Signal transduction mechanisms mediating the physiological and pathophysiological actions of angiotensin II in vascular smooth muscle cells". Pharmacol. Rev. 52, 639-672.

175. Chang, R.S. e Lotti, V.J. (1990)"Two distinct angiotensin II receptor binding sites in rat adrenal revealed by new selective nonpeptide ligands". Mol. Pharmacol. 37, 347-351.

176. Lokuta, A.J., Cooper, C., Gaa, S.T., Wang, H.E., e Rogers, T.B. (1994) "Angiotensin II stimulates the release of phospholipid-derived second messengers through multiple receptor subtypes in heart cells". J. Biol. Chem. 269, 4832-4838.

177. Griendling, K.K., Lassègue, B., Murphy, T.J. e Alexander, R.W. (1994) "Angiotensin II receptor pharmacology". Adv. Pharmacol. 28, 269-304.

178. Chiu, A.T., Roscoe, W.A., McCall, D.E. e Timmermans, P.B.M.W.M. (1991) "Angiotensin II-1 receptors mediate both vasoconstrictor and hypertrophic responses in rat aortic muscles cells". Receptor 1, 33-40. 
179. Sasamura, H., Hein, L. Kueger, J.E., Pratt, R.E., Kobilka, B.K. e Dzau, V.J. (1992) "Cloning, characterization, and expression of two angiotensin receptor $\left(\mathrm{AT}_{1}\right)$ isoforms from the mouse genome". Biochem. Biophys. Res. Commun. 185, 253-259.

180. Murphy, T.J., Alexander, R.W., Griendling, K.K., Runde, M.S. e Bernstein, K.E. (1991) "Isolation of a cDNA encoding the vascular type-1 angiotensin II receptor". Nature 351, 233-6.

181. Schwartz, T.W. (1996) "Molecular structure of G protein-coupled receptors". In Textbook ofreceptor pharmacology (J.C. Foreman e T. Johansen, Eds.) CRC Press, New York, pp 65-84.

182. Thomas, W.G., Motel, T.J., Kule, C.E., Karoor, V. and Baker, K.M. (1998) "Phosphorylation of the angiotensin II $\left(\mathrm{AT}_{1 \mathrm{~A}}\right)$ receptor carboxy terminus: a role in receptor endocytosis". Mol. Endocrinol. 12, 1513-1524.

183. Thomas, W.G. (1999) "Regulation of aniotensin II type 1 (AT $)$ receptor function". Regulatory Peptides 79, 9-23.

184. Noda, K, Saad, Y. e Karnik, S.S. (1995) "Interaction of $\mathrm{Phe}^{8}$ of angiotensin II with Lys ${ }^{199}$ and $\mathrm{His}^{256}$ of $\mathrm{AT}_{1}$ receptor in agonist activation”. J. Biol. Chem. 270, 28511-28514.

185. Tese de doutorado de Cláudio Miguel da Costa Neto. "Bases moleculares da ativação do receptor de angiotensina II". Unifesp 1997.

186. Balmforth, A.J., Lee, A.J., Warburton, P., Donnelly, D. e Ball, S.G., (1997) "The conformation change responsible for $\mathrm{AT}_{1}$ receptor activation is dependent upon two juxtaposed asparagines residues ontransmembrane helices III and VII". J. Biol. Chem. 272, 4245-4251.

187. Marie, J., Maigret, B., Joseph, M.P., Larguier, R., Nouet, S., Lombard, C. E Bonnafous J.C. (1994) " $\mathrm{Tyr}^{292}$ in the seventh transmembrane domain of the $\mathrm{AT}_{1 \mathrm{~A}}$ angiotensin $\Pi$ receptor is essential for its coupling to phospholipase C". J. Biol. Chem. 269, 20815-20818.

188. Hunyady, L., Ji, H., Zhang, M., Gaborik, Z., Mihalik, B. e Catt, K.J. (1998) "Dependence of $\mathrm{AT}_{1}$ angiotensin receptor function on adjascent asparigine residues in the seventh transmembrane helix". Mol. Pharmacol. 54, 427-434.

189. Franke, R.R., Konig, B., Sakmar, T.P., Khorana, H.G. e Hofmann, K.P. (1990) "Rhodopsin mutants that bind but fail to activate transducin". Science 250, 123-125. 
190. Ohyama, K., Yamano, Y., Chaki, S., Kondo, T. e Inagami, T. (1992) "Domains for G-protein coupling in angiotensin II receptor type 1: studiesby site-directed mutagenesis". Biochem. Biophys. Res. Commun. 189, 677-683.

191. Chaki, S., Guo, D-F., Yamano, Y., Ohyama, K., Tani, M., Mizukoshi, M., Shirai, H. e Inagami, T. (1994) "Role of carboxy tail of rat angiotensin II type 1A receptor in agonist-induced internalization of the receptor". Kidney Int. 46, $1492-$ 1495.

192. Caili, W., Jayadev, S. e Escobedo, J.A. (1995) "Identification of of a domain in the angiotensin II type 1 receptor determining $\mathrm{G}_{\mathrm{q}}$ coupling by the use of receptor chimeras". J. Biol. Chem. 270, 16677-16682.

193. Shirai, H., Takahashi, K., Katada, T. e Inagami, T. (1995) "Mapping of G protein coupling sites of angiotensin II type 1 receptor". Hypertension 25, 726-730.

194. Thomas, W.G., Baker, K.M., Motel, T.J., e Thekkumkara, T.J. (1995) "Angiotensin II receptor endocytosis involves two distinct regions of the cytoplasmatic tail. A role for residues on the hydrophobic face of a putative amphiphatic helix". J. Biol. Chem. 270, 22153-22159.

195. Inoue, Y., Nakamura, N. e Inagami, T. (1997) "A review of mutagenesis studies of angiotensin II type I receptor, three dimensional receptor model in search of agonist and antagonist binding site hypothesis of a receptor activation mechanism". J. Hypertension 15, 703-714.

196. Okamoto, T. e Ishimoto, I. (1992) "Detection of G-protein activator regions in M4 subtype muscarinic, cholinergic, and $\alpha_{2}$-adrenergic receptors based upon characteristics in primary structure". J. Biol. Chem 267, 8342-8346.

197. Oliveira, L., Paiva, A.C.M. e Vriend, G. (1999) "A low resolution model for the interaction of G proteins with G protein-coupled receptors". Protein Eng. 12, 10871095.

198. Wang, C., Jayadev, S. e Escobedo, J.A. (1995) "Identification of of a domain in the angiotensin $I I$ type 1 receptor determining $G_{q}$ coupling by the use of receptor chimeras". J. Biol. Chem. 270, 16677-16682.

199. Conchon, S., Barrault, M.B., Misery, S., Corvol, P. e Clauser, E. (1997) "The Cterminal third intracellular loop of the rat $\mathrm{AT}_{1 \mathrm{~A}}$ angiotensin receptor plays a key role in G protein coupling specificity and transduction of the mitogenic signal". J.Biol.Chem. 272, 25566-25572. 
200. Sano, T, Ohyama, K., Yamano, Y., Nakazawa, S., Kikyo, M., Shirai, H., Blank, J.S., Exton, J.H. e Inagami, T. (1997) “A domain for G protein coupling in carboxy tail of rat angiotensin $\Pi$ receptor type 1A". J. Biol. Chem. 272, 23631-23636.

201. Denker, B.M., Schimdt, C.J. e Neer, E.J. (1992) "Promotion of the GTPliganded state of the Go alpha protein by deletion of the C terminus". J. Biol. Chem 267, 9998-10002.

202. Probst, W.C., Snyder, L.A., Schuster, D.J., Brosius, J. e Sealfon, S.C. (1992) "Sequence alignment of the G protein-coupled receptor superfamily". DNA Cell Biol. 11, 1-20.

203. Ohyama, K., Yamano, Y., Sano, T., Nakagomi, Y., Wada, M. e Inagami, T. (2002) "Role of the conserved DRY motif on G protein activation of rat angiotensin I receptor type 1A" Biochem. Biophys. Res. Commun. 292, 362-367.

204. Merrifield, R.B. (1963) "Solid-phase peptide synthesis. 1.Synthesis of a tetrapeptide". J. Am. Chem. Soc. 85, 2149.

205. Stewart, J.M. e Young, J.D. (1984) "Solid phase synthesis" Pierce Chemical Co., Rockford, USA.

206. Mukerjee, P. e Mysels, K.J. (1971) Critical Micelle Concentration of Aqueous Surfactant Systems, NSRDS-NBS36, National Standard Reference Data Systems., Washington, D. C.

207. Naydenova, S., Lalchev, Z., Petrov, A.G. e Exerowa, D. (1990) "Pure and mixed lipid black foam films as models of memebrane fusion". Eur. Biophys. J. 59, 343-347.

208. Catálogo Sigma Chemical Co., (1997), 1792.

209. Creighton, T.E. " The folded conformations of globular proteins" in Proteinsstructure and molecular properties, W.H. Freeman and Co., cap. 6, pág. 256.

210. Mulkerrin, N.G. (1996) em "Spectroscopic Methods for determining Protein Structure in Solution “ (H. A. Havel, Ed.) V.C.H. Publishers, Inc., New York, pp. 527.

211. Basch, H., Robin, M. B. e Kuebler, N. A. J. (1967) "Eletronic states of the amide group". J. Chem. Phys. 47, 1201-1210.

212. Hozwarth, G. e Doty, P. J. (1966) "The ultraviolet circular dichroism of polypeptides" J. Am. Chem. Soc. 87, 218-228.

213. Greenfield, N. e Fasman, G. D. (1969)" Computed circular dichroism spectra for the evaluation of protein conformation". Biochemistry 8, 4108-4116. 
214. Chen, Y.H., Yang, J.T. e Chau, K.C. (1974) "Determination of the helix and beta form of proteins in aqueous solution by circular dichroism". Biochemistry 13, 33503359.

215. Rohl, C.A. e Baldwin, R.L. (1995) Methods Enzymol. 294, 1-26.

216. Lakowics, J. R. (1983) em “Principles of Fluorescence Spectroscopy" Plenum Press, New York.

217. Eftink, M. R. (1991) in “Methods of Biochemical Analysis" (C. H. Suelter, Ed.), John Wiley \& Sons, Inc., New York, vol. 35, pp. 127-205.

218. Rost, B. e Sander, C. (1993) "Prediction of protein secondary structure at better than $70 \%$ accuracy". J. Mol. Biol. 232, 584-599.

219. Schulz, A., Bruns, K., Henklein, P., Krause, G., Schubert, M., Gudermann, Wray, V., Schultz, G. e Schöneberg, T. (2000) "Requirement of specific intrahelical interactions for stabilizing the inactive conformation of glycoprotein hormone receptors". J. Biol. Chem. 275, 37860-37869.

220. Schiffer, M. e Edmundson, A.B. (1967) "Use of helical wheels to represent the structures of proteins and to identify segments with helical potential". Biophys $J$. 7, 121-135.

221. Perczel, A. e Hollósi, M., (1996) "Turns", em Circular Dichroism and the Conformational Analysis of Biomolecules, (Gerald D. Fasman Ed.), Plenum Press, New York, cap.9, pp 285-380.

222. Lee, A.G. e Schreier, S. (1993) "Entrapment of Drugs and Other Materials" in Liposome Technology, Vol. II, (G. Gregoriadis, Eds.), CRC Press, cap 1, pp 1-25.

223. Vöet, D. e Vöet, J.G. (1995) Biochemistry, John Wiley \& Sons Inc., New York, $2^{\mathrm{a}}$ ed., pp 58-59.

224. Tilstra, L. e Mattice, W.L. (1996) "The $\beta$-sheet-coil transition of polypeptides, as determined by circular dichroism", em Circular Dichroism and the Conformational Analysis of Biomolecules, (Gerald D. Fasman Ed.), Plenum Press, New York, cap.9, pp 285-380.

225. Zhou, N.E., Kay, C.M., e Hodges, R.S. (1992) "Synthetic model proteins. Positional effects of interchain hydrophobic interactions on stability of two stranded a-helical coiled coils". J. Biol. Chem. 267, 2664-2670.

226. Lehrer, S.S. e Fasman, G.D. (1967) "Ultraviolet irradiation effects in poly-Ltyrosine and model compounds. Identification of bityrosine as a photoproduct". Biochemistry 6, 757-767. 
227. Jochek, H. I. e Miller, S. I. (1966) "Photocleavage of phenoxyphenols and bromophenols". J. Am. Chem Soc. 88, 3273-3281.

228. Musso, H. (1963) Angew. Chem. 2, 723-735.

229. Baptista, M.S. e Politi, M.J. (1991) "Dipole oriented anion binding and exchange in zwitterionic micelles". J. Phys. Chem. 95, 5936-5942.

230. Reiersen, H. e Rees, A.R. (2000) “ Trifluoroethanol may form a solvent matrix for assisted hydrophobic interactions between peptide side chains ". Protein Eng. 13, 739-743.

231. Roccatano, D., Colombo, G., Fioroni, M. e Mark, A.E. (2002) "Mechanism by which 2,2,2-trifluoroethanol/water mixtures stabilize secondary-structure in peptides: A molecular dynamics study". Proc. Natl. Acad. Sci. USA 99, 121791284.

232. Chou, P.Y. e Fasman, G.D. (1978) "Prediction of secondary structure of proteins from their amino acid sequence". Adv. Enzymol. Relat. Areas Mol. Biol. 47, 45-148.

233. Liu-L.P. e Deber, C.M. (1998) "Uncoupling hydrophobicity and helicity in transmembrane segments: $\alpha$-helical propensities of the aminoacids in non-polar environments". J.Biol.Chem. 273, 23645-23648.

234. Deber, C.M., Liu-L.P. e Wang, C. (1999) "Perspective: peptide as mimetic of transmembrane segments in proteins". J. Peptide Res. 54, 200-205.

235. Wallqvist, A., Covell, D.G. (1998) " Hydrophobic interactions in aqueous urea solutions with implications for the mechanism of protein denaturation". J. Am. Chem. Soc. 120, 427-428.

236. Ding, F.X., Schreiber, D., VerBerkmoes, N.C., Becker, J.M. e Naider (2002) "The chain length dependence of helix formation of second tranmembrane domain of G Protein-coupled receptor of Saccharomyces cerevisiae". J. Biol. Chem. 277, $14483-4492$

237. White, S.H. e Wimley, W.C. (1999) "Membrane protein folding and stability: physical principles". Annu. Rev. Biophys. Biomol. Struct. 28, 319-365.

238. Brady, A.E. e Limbird, L.E. (2002) "G protein coupled receptor interacting proteins: emerging rolesin localization and signal transduction". Cell. Sig. 14, $297-$ 309. 
239. Dratz, E.A., Furstenau, J.E., Lambert, C.G., Thireault, D.L., Rarick, H., Schepers, T., Pakhlevaniants, S. e Hamm, H.E. (1993) "NMR structure of a receptor-bound G-protein peptide". Nature 363, 276-281.

240. Kostenis, E., Conklin, B.R., Wess, J. (1997) "Molecular basis of receptor/G protein coupling selectivity studied by coexpression of wild type and mutant $\mathrm{m} 2$ muscarinic receptors with mutant $\mathrm{G}$ alpha(q) subunits". Biochemistry 36, 1487 1495.

241. Hodges, R. S., Saund, A.K., Chong, P.C.S., St.Pierre, S.A. e Reid, R.E. (1981) "Synthetic model for two-stranded alpha-helical coiled-coils-Design, synthesis, and characterization of an 86-residue analog of tropomyosin". J. Biol. Chem. 256, 12141224.

242. Slessareva, J.E. e Graber, S.G. (2003) "Reconstitution reveals additional roles for $\mathrm{N}$ - and C-terminal domains of $\mathrm{G}$ (alpha) in muscarinic receptor coupling". Biochemistry 42, 7552-7560.

243. Slessareva, J.E., Ma, H., Depree, K.M., Flood, L.A., Bae, H., Cabrera-Vera, T.M., Hamm, H.E. e Graber, S.G. (2003) "Closely related G-protein-coupled receptors use multiple and distinct domains on G-protein alpha-subunits for selective coupling". J. Biol. Chem. 278, 50530-50536..

244. Blahos, J., Mary, S., Perroy, J., de Colle, C., Brabet, I., Bockaert, J. e Pin, J.P. (1998) "Extreme $\mathrm{C}$ terminus of $\mathrm{G}$ protein alpha-subunits contains a site that discriminates between Gi-coupled metabotropic glutamate receptors". J. Biol. Chem. 273, 25765-25769.

245. Blahos, J., Fischer, T., Brabet, I., Stauffer, D., Rovelli, G., Bockaert, J. e Pin, J.P. (2001) "A novel site on the Galpha -protein that recognizes heptahelical receptors". J. Biol. Chem. 276, 3262-3269.

246. Umemori, H., Inoue, T., Kume, S., Sekiyama, N., Nagao, M., Itoh, H., Nakanishi, S., Mikoshiba, K., and Yamamoto, T. (1997) "Activation of the G Protein Gq/11 Through Tyrosine Phosphorylation of the alpha Subunit". Science 276, 1878-1881

247. Havlickova, M., Blahos, J., Brabet, I., Liu, J., Hruskova, B., Prezeau, L. e Pin, J.P. (2003) "The second intracellular loop of metabotropic glutamate receptors recognizes C termini of G-protein alpha-subunits". J. Biol. Chem. 278, 3506335070 . 
248. Marin, E.P., Krishna, A.G., Zvyaga, T.A., Isele, J., Siebert, F. e Sakmar, T.P. (2000) "The amino terminus of the fourth cytoplasmic loop of rhodopsin modulates rhodopsin-transducin interaction”. J. Biol. Chem. 275, 1930-1936.

249. Wu, D., Jiang, H. e Simon, M.I. (1995) "Different alpha 1-adrenergic receptor sequences required for activating different $\mathrm{G}$ alpha subunits of $\mathrm{Gq}$ class of $\mathrm{G}$ proteins" J. Biol. Chem. 270, 9828-9832.

250. Shibata, T., Suzuki, C., Ohnishi, J., Murakami, K. e Miyazaki, H. (1996) "Identification of regions in human angiotensin receptor type 1 responsible for Gi and $\mathrm{Gq}$ coupling by mutagenesis study". Biochem. Biophys. Res. Commun. 218, 383-389.

251. Fahmy, K. (1998) "Binding of transducin and transducin-derived peptides torhodopsin studied by total attenuated reflection-transformed infrared difference spectroscopy". Biophys. J. 75, 1306-1316.

252. Okuno, T., Ago, H., Terawaki, K., Miyano, M., Shimizu, T. e Yokomizo T. (2003) "Helix 8 of the leukotriene B4 receptor is required for the conformational change to the low affinity state after G-protein activation”. J. Biol. Chem. 278, 41500-41509. 